\title{
FOUR CENTURIES OF THE
}

\section{PANAMA CANAL}

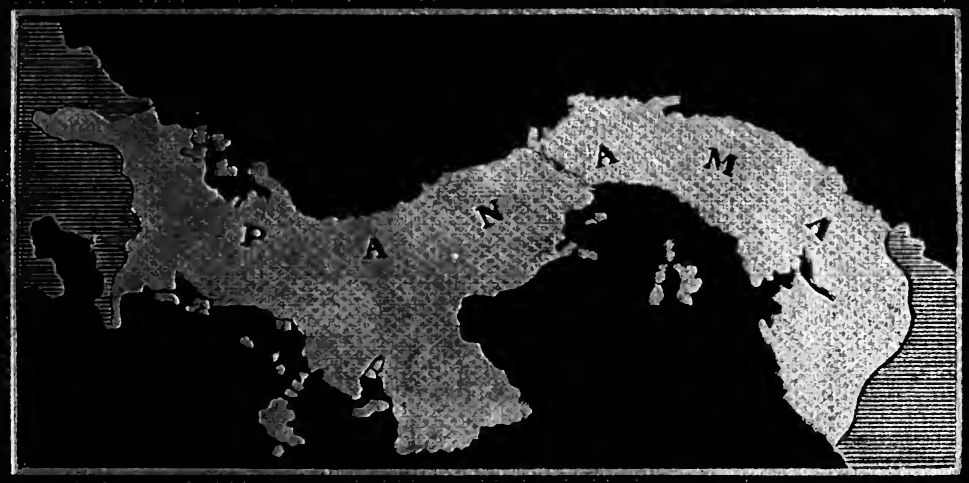

WLUS FLETCHER JOHNSON 

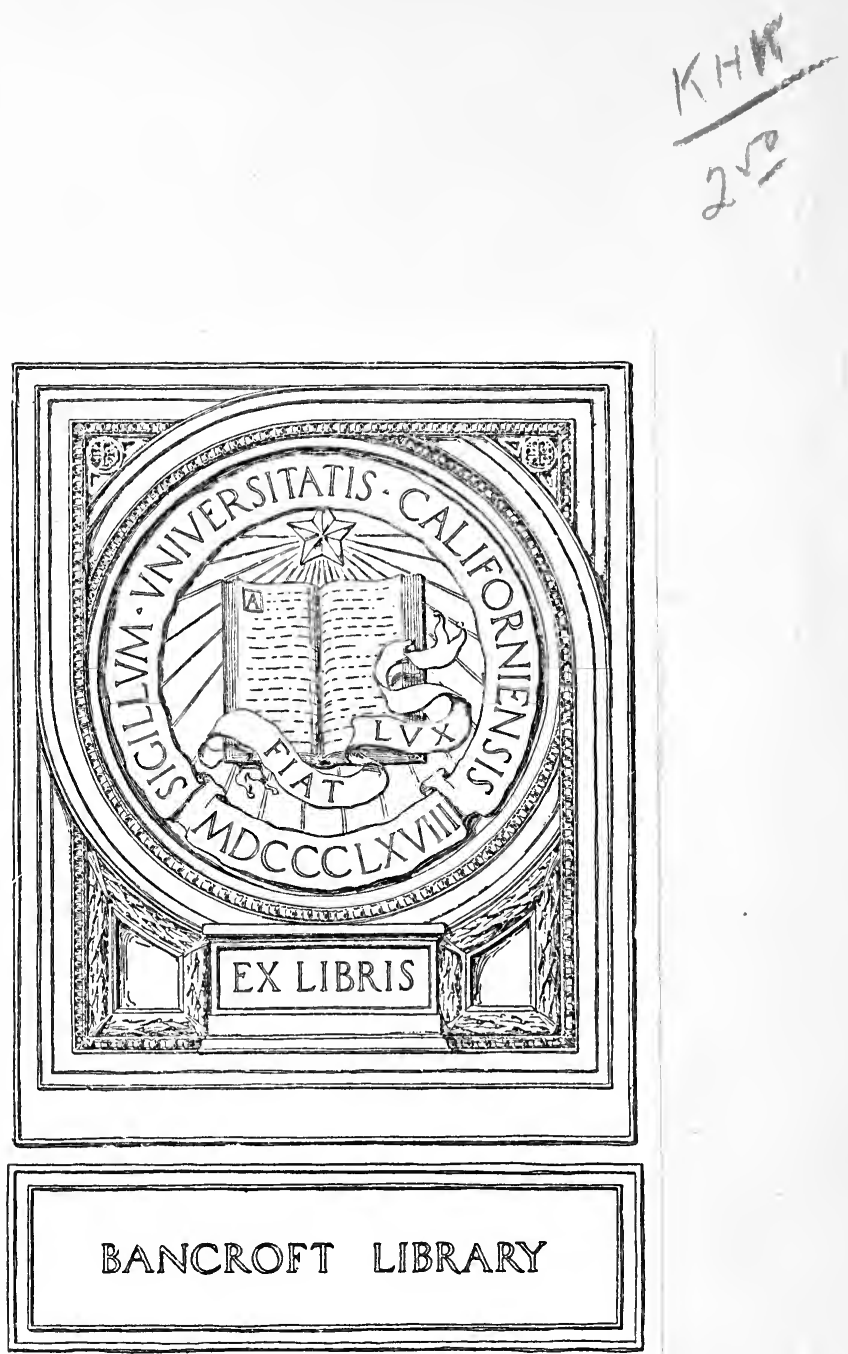



\section{Digitized by the Internet Archive in 2007 with funding from \\ Microsoft Corporation}





\section{FOUR CENTURIES OF THE PANAMA CANAL}




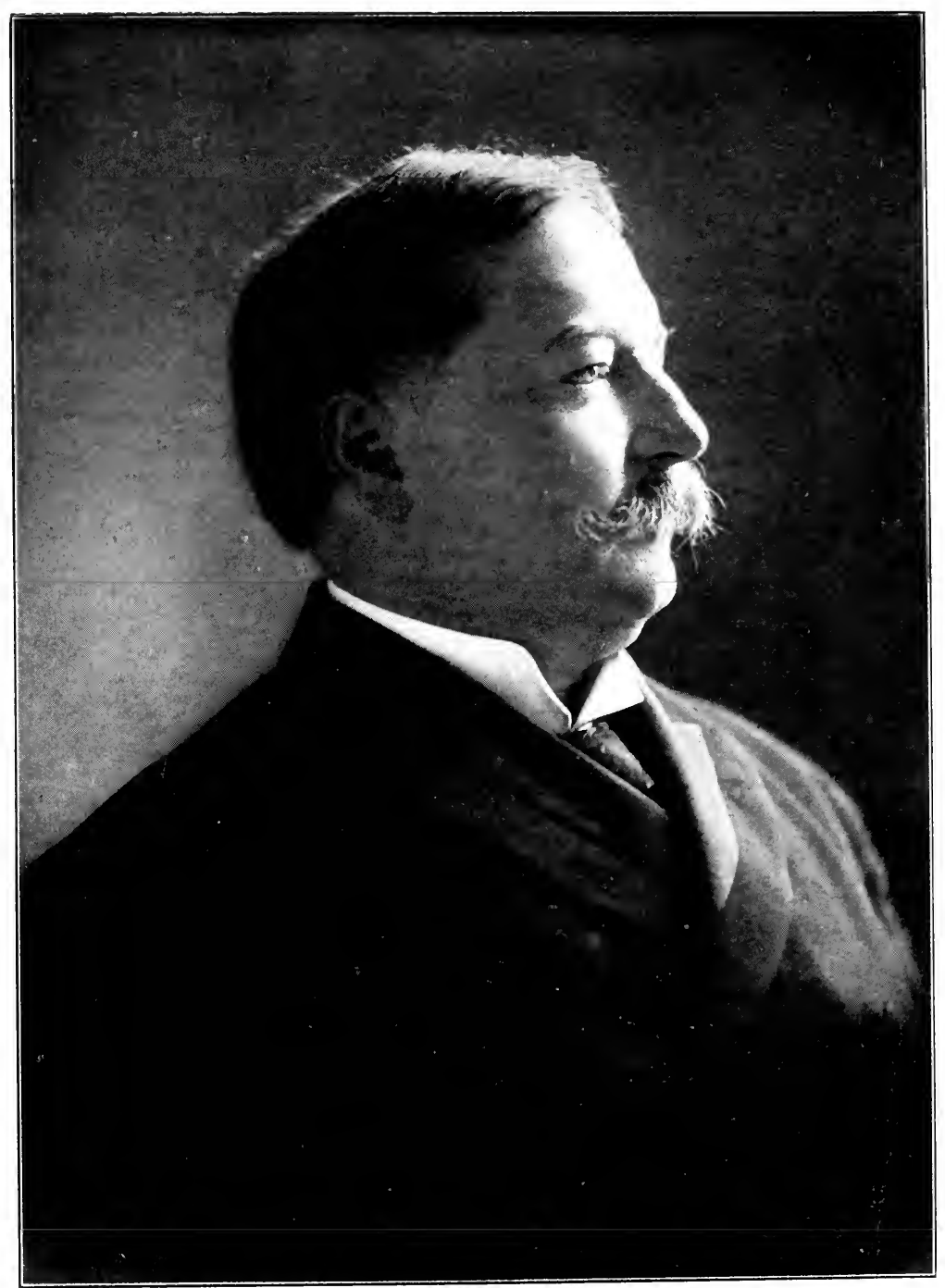

Vaughan \& Keith, Photo.

WILLIAM H. TAFT,

United States Secretary of War. 


\title{
FOUR CENTURIES OF THE PANAMA CANAL
}

\author{
BY \\ $1851-1931$ \\ WILLIS FLETCHER JOHNSON, A.M., I.H.D. \\ AUthor of 'a CENTURY OF EXPansion," etc.
}

WITH MAPS AND ILLUSTRATIONS

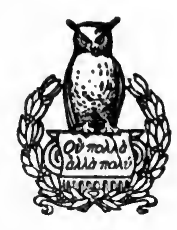

NEW YORK

HENRY HOLT AND COMPANY

1906 


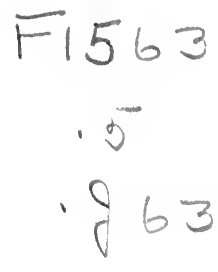

COPYRIGHT, 1906 BY HENRY HOLT AND COMPANY

Published November, 1906 


\section{5}

\section{Bencroft Librag}

TO

\section{WILLIAM H. TAFT,}

SECRETARY OF WAR, JURIST, ADMINISTRATOR, DIPLOMAT, AND, UNDER THE PRESIDENT, CHIEF BUILDER OF THE PANAMA CANAL; IN SINCERE THOUGH INADEQUATE COMMEMORATION OF ESTEEMED

FRIENDSHIP AND INVALUABLE AID;

THIS VOLUME IS GRATEFULLY

AND AFFECTIONATELY DEDI-

CATED BY THE AUTHOR. 


\section{PREFACE}

I shall try in this book to tell the story of the Panama Canal, and incidentally that of Panama itself so far as the latter is necessary to the completeness of the former. It will be impossible for me to do so with any great elaboration of detail. The vastness of the topic forbids it; unless indeed this single volume were to be multiplied into many. The story is more than four centuries long, and it implicates, literally, mankind from China to Peru. Any one of half a dozen of its phases might well monopolise a volume. But I shall hope to give in these pages some account of all the really salient and essential features of the story, and especially to make clear the relationships of cause and effect among them, and to show how, by virtue of a somewhat devious train of incidents and circumstances leading from Christopher Columbus to Theodore Roosevelt, this country, in opportunity and privilege, in authority and responsibility, has become at Panama the "heir of all the ages." It will also be impossible for me to give much detailed description of the Isthmian country, of its conditions of resources, soil, and climate, of its people, or of the technical features of the canal and its auxiliary works. To each of half a dozen such topics, also, a volume might well be given. If I touch upon these more lightly and briefly than upon historical matters, that will be because this is to be a history rather than a descriptive treatise.

It is now more than a quarter of a century since I became, as a student of affairs and as a writer upon them, interested in the chief proposals and problems of Isthmian transit. Ferdinand de Lesseps had then achieved his splendid success at Suez, and was beginning his grandiose but fatuous undertaking at Panama; an American company was 
planning the final and fruitless essay at Nicaragua; and James B. Eads was elaborating for Tehuantepec the most ambitious scheme of his engineering genius. In those projects, applied to routes which had been selected by Cortez, I became absorbed, and in all the years since that time I have striven to keep myself in touch with them, as long as two of them lasted, and with the one triumphant survivor down to the present. It was also my privilege, through the courtesy of the Government of the United States, and especially of its Secretary of War, the Hon. William H. Taft, to spend some time at Panama and there to study historical data, political and social conditions, and the various problems of the canal enterprise, under exceptionally favourable conditions of authority and intimacy, at what was probably the most important formative period thus far in the career of the Isthmian Republic and of our relations to it. The result will be found in this volume, in which I shall embody information acquired through personal investigation at Panama as well as in Washington and New York, and through inquiry of authoritative sources at Paris and Bogotá-the five cities, in four lands and three continents, in which the modern history of Panama and the Panama Canal has been chiefly made.

Much more might be said, not only than I shall have space to say, but also than it would be fitting for me to say. Much has been imparted to me which is of indispensable value to me in preparing this work, in directing me to other data, and in enabling me to judge correctly among diverse opinions and reports, but which confidence forbids me to reveal. I am deeply indebted, for information, opportunity, and aid, to Dr. Amador, the President of Panama, and to his son, Dr. R. A. Amador, the Panaman Consul-General in New York; to Dr. Arosemena, then First Designate of Panama; to Señor Obaldia, the Panaman Minister, and to Señor C. C. Arosemena, the Secretary of Legation, at Washington; to Señors J. A. Arango, Tomas Arias, Ramon M. Valdes, and other gentlemen at Panama; to the lamented John Hay, 
then Secretary of State; to Mr. William H. Taft, Secretary of War; to Mr. F. B. Loomis, then Assistant Secretary of State; to Mr. John Barrett, then American Minister, and to Mr. Joseph Lee, then Secretary of Legation, at Panama; to Mr. Charles E. Magoon, then counsel to the Canal Commission and since Governor of the Canal Zone; to Rear-Admiral John A. Walker, then Chairman of the Canal Commission; to Mr. John F. Wallace, then Chief Engineer of the Canal; to Colonel William C. Gorgas, Chief of the Sanitary Staff of the Canal Zone; to Mr. William Nelson Cromwell, Counsel to the French Panama Canal Company; and to many others. I desire also to make grateful acknowledgments to the Editors of The Forum magazine and of The Tribune newspaper, of New York, for permission to use in this volume portions of various articles contributed by me to the pages of those publications.

With all its shortcomings,-which I sincerely trust no reader will realise as keenly as the writer,-this book will be offered to the public with a hope that it will in some measure, by suggesting inquiry and stimulating study as well as by imparting information, increase appreciation and right knowledge of an undertaking which is not only the greatest in our history but also the greatest of its kind in the history of the world, and which is to be completed not only for the immeasurable advantage of the American nation but also for the promotion of the welfare of all mankind.

Willis Fletcher Johnson.

NEW YoRK, October, 1906. 


\section{CONTENTS}

\section{Chapter I \\ THE QUEST OF COLUMBUS}

PAGE

Columbus's Aim not to Find a New Continent but to Find a Water Highway from Europe to Asia-Theories of the World from Aristotle to Toscanelli-Some Ante-Columbian AdventuresThe Alleged Letter and Map of Toscanelli-The Reports of Marco Polo and Mandeville-Thinae-Columbus in Quest of the Land of the Great Khan-His Identification of America with Asia-The "Garden of Eden"-Origin of the Legend of the Strait-Isthmian Explorations of His Fourth Voyage-The Map of Waldseemüller-Persistence of Columbus's Delusion . .

\section{Chapter II}

\section{THE SECRET OF THE STRAIT}

The Quests of Ojeda and Bastidas-La Cosa and Vespucci-First Colonies on the Gulf of Darien-Pizarro and Enciso-The Advent of Balboa-Rivalry with Enciso-Discovery of the Pacific Ocean-Pedrarias Davila and His Deviltries-The First Ships in the South Sea-Judicial Murder of Balboa-Founding of Panama-The Pearl Islands-Explorations at Nicaragua and Tehuantepec-Work of De Soto and His Colleagues-The Voyage of Magellan-Cortez and the Mythical Strait-First Proposal of a Canal-Alvaro de Saavedra Ceron-Four Rival Canal Routes in the Time of Cortez-Decree of Charles V-Reversed by Philip II-Advent of the English Freebooters-Morgan the Buccaneer-Sharpe and Wafer-William Paterson's Colonial Enterprise-Explorations of Condamine and Ulloa . .

\section{Chapter III}

\section{EARLY PLANS AND RIVALRIES}

Humboldt's Observations and Recommendations-Nine Canal Routes across the Americas-Discussions of Panama and Darien-The "Secret of the Strait" again-Goethe's Remarkable Prophecies- 
Rise of American Interest in the Canal Scheme-The First PanAmerican Congress-The First Nicaragua Canal Company-A French Franchise at Panama-Question of the Level of the Two Seas-Various American Expeditions to Nicaragua-Interest of the French Government-Humboldt's Renewed SuggestionsLouis Napoleon's Schemes at Nicaragua . . . . .

\section{Chapter IV}

\section{THE CLAYTON-BULWER EPISODE}

Origin of the British Claims in Central America-The Mosquito Indians and Their Kings-Planting of British Colonies-Controversies with Spain-Rapid Expansion of Belize and Mosquitia -The Bay Islands-Aggressions upon Nicaragua-The American Migration to California-Treaty with New Granada-Enterprises at Nicaragua-Hise's Treaty-Squier's Treaty-Seizure of Tigre Island-The Recommendations of Abbott LawrenceNegotiation of the Clayton-Bulwer Treaty-Its Provisions-Dissatisfaction with Its Terms-Walker the Filibuster-The British Treaty with Nicaragua . . • . . . . . .

\section{Chapter V}

\section{SOME FUTILE SCHEMES}

Felix Belly and His Concessions-Effective Protest of the United States-End of Louis Napoleon's Schemes-The Tehuantepec Route-Rival Explorations at Panama-Persistent Efforts of Frederick Kelly to Find a Route-A Sea-Level Canal Considered -Renewal of French Enterprises-The Proposed Chiriqui Colony-Surveys of Lull and Menocal-Gradual Development of American Policy-The Dickinson-Ayon Treaty with Nicaragua -Seward's Proposal of a "Canal Zone"-Grant's First Enunciation of the Policy of "an American Canal"-The First Interoceanic Canal Commission and Its Surveys-The Nicaragua Route Selected-The Clayton-Bulwer Treaty in the Way-More French Schemes at Panama-Wyse's Survey and De Lesseps's Scheme-Call for an International Engineering Congress . •

Chapter Vi

\section{“CONSULE LESSEPS"}

The International Congress of 1879-Dominated by De LessepsIts Composition and Organisation-The Committee on Choice 
of Route-Panama Approved-American Opposition to the French Plans-Organisation of a Nicaragua Canal CompanyDe Lesseps's Visit to Washington-Hayes's Message-Advanced Ground Taken by the American Government-De Lesseps's Change of Tactics-The "American Committee" and Its WorkThe Tehuantepec Ship Railroad Project-Blaine's Futile Diplomacy-The American Policy Stated-Controversy over the Clayton-Bulwer Treaty-Abrogation Proposed-Blaine's Discomfiture at the Hands of Granville-Frelinghuysen's Continuation of the Controversy-An Impasse-Inauguration of De Lesseps's Undertaking-“Le Grand Français"-Blundering and Plundering-Failure and Bankruptcy of the Panama Company-Tragic End of De Lesseps-Confirmation of the American Policy . •

\section{Chapter VII}

\section{WHY THE FRENCH FAILED}

Profligacy in Finance-"Forty-Seven Miles of 'Graft'"-How the Money was Wasted and Stolen-Snow-Shovels at Panama!Extortions of Colombian Administration-A Real Estate Transaction-Improving a Providential Opportunity-What We Escaped by Establishing the Canal Zone-French Neglect of Sanitation-Mismanagement of Hospitals-Too Many Experiments with Machinery-Imperfect Surveys-Improper Disposition of Material-Errors for Americans to Avoid . .

\section{Chapter VIII}

\section{NICARAGUA OR PANAMA?}

Efforts of the French to Reorganise Their Scheme-Extension of Their Franchise-Formation of the New Panama Canal Company-The Technical Committee and Its Report-American Activity at Nicaragua-The Frelinghuysen-Zavala TreatyCleveland's Attempted Reversal of American Policy-Chartering of the Maritime Canal Company-Its Construction Company -Work at Nicaragua-Embarrassment and Failure of the Company-A Long Campaign in Congress-Various Proposals for Government Aid at Nicaragua-The Ludlow and Walker Canal Commissions-The Grace-Eyre-Cragin Syndicate-The Voyage of the Oregon-An Impressive Object-Lesson-A Triangular Fight-Final Discomfiture of the Maritime Canal CompanySeeking Abrogation of the Clayton-Bulwer Treaty-The First Hay-Pauncefote Treaty-The Second and Successful Hay. 
Pauncefote Treaty-Report of the Third Canal CommissionNicaragua Favoured-Desperation of the Panama CompanyNegotiations for Sale at Panama-Change of the Commission's Report-Resolution of the Pan-American Congress-The Final Struggle at Washington-Enactment of the Spooner Bill

\section{Chapter IX}

\section{NEGOTIATIONS WITH COLOMBIA}

Validity of the French Company's Sale of Its Property to the United States-Seeking a Treaty with Colombia-Terms of the Preliminary Protocol-Bad Condition of Colombian Finances-A Covetous Plan of Colombian Politicians-German Interest in the Isthmus-Efforts to Defeat the American Project-Rebellion at Panama-Intervention by the United States-Colombian Protest -Departure of Señor Concha-The Hay-Herran NegotiationsTerms of the Treaty-Colombia's Attitude toward It-Election of a New Colombian Congress-President Marroquin in Control-Attempts to Extort Blackmail from the French Company-Anxiety in Paris-Colombian Plans for Delay-Lapsing of the Treaty-Adjournment of the Colombian Congress . . 130

\section{Chapter $X$}

\section{THE PANAMA REVOLUTION}

The Story of Colombia's Dealings with the Isthmus-Bolivar's Achievement of Independence-Panama's Union with New Granada-Revolt against the Bogotá Government-Herrera's Revolution-Isthmian Independence Restored-Federal Union again-Bad Faith of a Packed Congress-Separation Proposed - Mosquera's Promises of Reform-Reorganisation of the Federal System-“Organised Anarchy"-The Conquest of Panama"The Milch Cow of the Confederation"-Nuñez and His Coup'T'Etat-Repudiation and Despotism-"Ratification" of a New Constitution-Marroquin's Description of Colombia-Panama's Warning to Bogotá-Dr. Amador-The Colombian Reply-J. A. Arango's Revolutionary Plans-Captain Beers's Mission-Organising a Revolution-The Junta-Dr. Amador's Mission to the United States-Appeal to William Nelson Cromwell— "Shadowed" by a Colombian Spy-“Desanimado"-Bunau-Varilla's Opportune Arrival-"Esperanzas"-At the State DepartmentSecretary Hay's Frank Talk-Dr. Amador's Return to Panama-Arrival of the Nashville at Colon-The Day Set-Arrival of the Colombian Army-Conduct of General Huertas-"Spar- 
ring for Time" at Panama-"Do It Now !"-Arrest of Colombian Generals-Action of the Gunboats-Declaration of Panaman Independence-Organisation of a Provisional GovernmentSoldiers Stranded at Colon-United States Protection of Panama-Departure of the Colombian Troops-Recognition of the New Republic-Colombian Protests-Mission of General ReyesHis Extraordinary Proposal-Constitutional Progress at Panama 150

\section{Chapter XI}

\section{AMERICAN POLICY IN PANAMA}

Criticisms of American Action-Justification of Our Policy-The Orders to American Ships-Treaty Rights and Obligations-Propriety of Recognising Panama-The Domestic Obligations of the President-Legal Obligations to Colombia-Annals of Isthmian Outbreaks-Colombia's Inability to Govern Panama-Protection of Isthmian Transit-A Covenant that "Ran with the Land"-Equity to Colombia-Colombia's Own Inequity-No Analogy with Our Civil War-Law and Equity to Other Nations-No Dog-in-the-Manger Policy-"International Eminent Domain"-Good Faith of the American Policy . . . 187

\section{Chapter XII \\ THE REPUBLIC OF PANAMA}

The Constitutional Convention-Adoption of a Constitution-Salient Features of that Instrument-The Legislature-The ExecutiveThe Judiciary-Miscellaneous Provisions-Organisation of the Permanent Government-A Non-Partisan Régime-The FlagCoinage-An Endowed Republic-The Canal Treaty-Diplomatic Relations with the United States-Area and Bounds of the Republic-Its Physical Features-Description of the CoastsChiriqui Lagoon-Colon-The Bay of Panama-The Pearl Islands-Principal Cities of the Republic-The Line of the Railroad and Canal-Features of the Canal Route-Earthquakes-The Climate-Temperature-Humidity-Tropical Conditions at Their Best . . . . . . . . .

\section{Chapter XIII}

\section{AN ANTI-REVOLUTIONARY EPISODE}

Development of Partisanship-Inclinations toward Military Revolutions-General Huertas's Demand for the Resignation of 
Cabinet Ministers-An Amazing Letter-Threatening the President-Appeal to the American Legation-Mr. Lee's Discreet Advice-A Significant Reminder-Keeping the Peace on a Holiday-General Huertas's "Order of the Day"-Another Railing Letter-A Critical Review of the Army-Action and Advice of the American Minister-Warships in the Harbour and Marines in the Suburbs-Resignation of General Huertas-Disbandment of the Army-The Crisis Safely Passed . . . . .

\section{Chapter XIV}

\section{A MISSION OF READJUSTMENT}

Panaman Discontent with an American Executive Order-The Postal and Customs Services Involved-Diplomatic CorrespondenceSecretary Taft's Mission-Pensacola and Its Memories-Reception at Panama-American Intentions Promptly Stated-Diplomatic Conferences-A Notable Banquet-American and Panaman Speechmaking-Excursion to the Pearl IslandsAnnouncement of the Result of the Negotiations-The New Executive Order-Gratification of the Panamans-Secretary Taft's Address to the People-Interest in President Roosevelt's Reëlection-Net Result of the Mission-Permanence of the Settlement

\section{Chapter XV}

\section{ISTHMIAN POLITICS}

The Old Colombian Spirit not Dead-Dr. Porras and the Revolution -The Rise of a Partisan Opposition-Dr. Porras's Citizenship Impeached-Railings against the Court's Judgment-Memorial of the Liberal Directorate to Secretary Taft-A Bitter Arraignment of the Panaman Government-Inquiries as to the Intentions of the United States-Exaggerations of Partisan Campaign Utterances-A Conservative Reply-American Policy Well Defined

\section{Chapter XVI}

\section{BEGINNING THE WORK}

The Canal the Thing-Its Construction at last Assured-Delusions Concerning the "Mighty Mountain Wall" of the CordillerasNo Barrier to a Sea-Level Canal-What We Secured from the French Company-The First Canal Commission-The President's 
Orders-Government of the Canal Zone-Organisation of the Commission-Governor Davis's Proclamation-Engineering Work -Wallace Made Chief Engineer-Organisation of His StaffThoroughness of the Preliminary Surveys-The Gatun, Bohio, and Gamboa Dams-The Culebra Cut-New Steam-ShovelsFour Plans of Construction Considered-The Sea-Level Plan Decidedly Favoured-Plans of Philippe Bunau-Varilla, Lindon W. Bates, and Cassius E. Gillette-Arguments in Favour of a Sea-Level Cut-The Questions of Earthquakes, the Chagres, Cost, and Time

\section{Chapter XVII}

\section{REORGANISATION}

Dissatisfaction with the Commission-Too Much Red Tape and Delay-Recommendations for Reorganisation-Failure of Congress to Act-The President's Action-A New Commission Formed-The Executive Committee-The President's Rules for the Conduct of the Commission-A Promise of Increased Efficiency-The Question of Purchasing Supplies in the Cheapest Market-Secretary Taft's Business-like Policy-Protests of the "Stand-Patters"-Purchase of All the Panama Railroad Stock by the Government-Mr. Bristow's Report on Traffic-Chief Engineer Wallace's Resignation-Its Circumstances and CausesInterview between Messrs. Taft and Wallace--Their Statements about It-A Painful Episode-Appointment of John F. Stevens as Chief Engineer-The Board of Consulting Engineers-The President's Instructions-Two Reports on Plan of ConstructionThe Majority for a Sea-Level Canal-The Chief Engineer's Report-Action of the Canal Commissioners and the Secretary of War-The President's Recommendation for a High-Level Lock Canal-The Final Decision by Congress . . . . 297

\section{Chapter XVIII}

\section{THE FIGHT WITH FEVER}

Progress of Medical Science-Vital Statistics of the French Canal Company-Reappearance of Yellow Fever at Panama-Demoralisation of the American Colony-Neglect of Precautions-Mistakes of Our Government-Vigorous Action Taken by Governor Magoon-Some Orders that Meant Business-Difficulties in the Way of Sanitation-Thorough Inspection and DisinfectionThe War against Mosquitoes-Admirable Work of Colonel 
Gorgas-Gradual Suppression of the Disease-Its Complete Elimination-A Reward Offered for the Reporting of a Case - Healthfulness of Panama Compared with Other PlacesSocial Improvements-The Problem of Feeding the Workmen -Governor Magoon's Commissary System-Suppression of Gambling-The Eight-Hour Law and the Civil Service . . 326

\section{Chapter XIX \\ STULTILOQUENTIA}

The Tribe of Gifted Hopkins Not Extinct-A Political Propagandist at Bogotá-Seeking a Mare's Nest on the Isthmus-Adding to the Joy of Nations-A Misinterpreted Metaphor-Foolish Complaints at Culebra-A Sample of Descriptive Balderdash-A Libel upon the Isthmus and Its People-Poultney Bigelow's Encyclopædic Researches in Twenty-Eight Hours and Ten Minutes-The Facts in the Case-Mr. Stevens's Comprehensive Contradictions-Governor Magoon's Effective Reply-Probable Animus of Mr. Bigelow's Outbreak-His Railings to Aliens against the American Army-President Roosevelt on False Accusers

\section{Chapter XX}

\section{THE NEXT THING}

The Task at Panama Well Begun-Need of Considering the FuturePlan of the Canal and Auxiliary Works-The Question of Labour-A Great Army of Workmen Needed-Permanent Colonists also Needed-Can the Two be Combined?-Permanent Chinese Immigration Undesirable-Negro Colonisation to be Deprecated-Russians and Boers Suggested but not AvailableThe Country Unsuited to American Labour-Possibility of Securing Spanish and Italian Workingmen-Chinese Contract Labour as a Last Resource, to be Sent Back when the Work is DoneAmerican Relations with the Panaman Government and PeopleSensitiveness of the Isthmians-Tact the Supreme Desideratum of Americans in Dealing with Southern Neighbours-The Point of View-Panama to Remain Panaman, and not to be Made American-No More "Damned Greasers" than "Damned Yankees"-Need of Radical Improvement in Our Trade Methods-The Future of Isthmian Sanitation _ . $\quad$ - . 3 


\section{Chapter XXI}

\section{PANAMA}

PAGE

Some Fascinating Memories-The Approach by Way of ColonA Dismal Spot-Beauties and Splendours of Isthmian Landscapes-Fertile but Little Cultivated Lands-Agricultural and Other Possibilities-Scenes in the Villages-The Streets of Panama as They Were-The Parks and Buildings-The Old Sea Wall-The Seamy Side of Panama-Vice-Absence of Drunkenness-An "Orgy" at State Expense-Open-Air Concerts-A Sunday in Panama-Business and Shopping-The Thrifty Landlord-Cab Fares and Hotel Bills-Traditions of "Graft"Courteous and Cultivated Society-A Cosmopolitan MenuPanama as a World's Highway-Some Suggestive Measurements-A Prophetic Vision

\section{APPENDICES}

I. The New Granadan Treaty of 1846 . $\quad$. 391

II. The Clayton-Bulwer Treaty . • • • • • . 393

III. The Hay-Pauncefote Treaty . • . • • • . . 398

IV. The Spooner Bill .

V. Panama's Declaration of Independece • • • • . 405

VI. The Hay-Bunau Varilla Treaty . . . . . 408

VII. The Governor's Proclamation to the Canal Zone . . 419

VIII. The First Administrative Order • . . • . . 423

IX. The Panaman Protest . . . . . . • . . 426

X. The Revised Executive Order • • • • . . $\quad .430$

XI. Data of Existing Ship Canals • • • • • • • 436

INDEX $• \quad \cdot \quad \cdot \quad \cdot \quad \cdot \quad \cdot \quad \cdot \quad \cdot \quad \cdot \quad \cdot \quad \cdot \quad .443$ 


\title{
ILLUSTRATIONS
}

\author{
PORTRAITS
}

The Hon. William H. Taft

Founders of the Republic of Panama $\quad$. $\quad . \quad$. . . . . 164

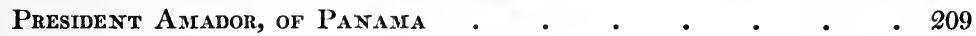

The Hon. Joseph Lee . • . . . . . . . . . 242

The Hon. John Barrett . . . . . . . . . . 248

The Hon. Charles E. Magoon . . . . . . . . . 330

\section{VIEWS}

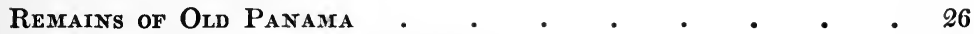

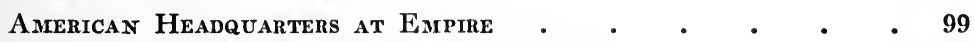

Hospital on Axcon Hill, Panama . . . . . . . 104

LANDSCAPE FROM GoLd HILL . . . . . . • . 281

The Culebra Cut .

Canal Administration Buindng, Panama • • • • • 353

Old-Thme Cabins, Empire . . . . . • . • • . 371

Typical Village Street, Empire • • • • • • • • • 373

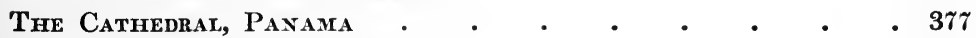

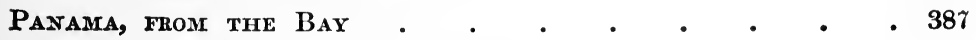

\section{MAPS}

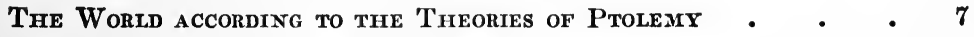

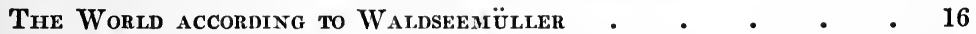
Various Proposed Isthmian Canal Routes . . . . . . 41 The Republic of Panama . . . . . . . . . . 216 The Panama Canal Route . . . . . . . . . . 228 Map Contrasting Trade Routes by Way of Panama and Patagonia 385 


\section{FOUR CENTURIES OF THE PANAMA CANAL}

\section{CHAPTER I}

\section{THE QUEST OF COLUMBUS}

THe design of Spanish adventurers in the fifteenth century is being fulfilled by American engineers in the twentieth century. That, in epitome, is the story of the Panama Canal, as it came vividly to mind during a recent visit to the Isthmus. There were present on that historic ground the associates and agents of President Roosevelt, and there were also those whose family names were on the rolls of Columbus's and Balboa's companies, and some whose ancestors probably came to the American shores with those discoverers. Such meeting of the representatives of the new and the old was suggestive, and it recalled the fact that Columbus was the practical founder of the Panama Canal enterprise, which, after four centuries of delay, President Roosevelt has undertaken to complete. Columbus was the first to propose a water highway from Europe to Asia, westward, by way of the Atlantic. It was such a highway that he sought, and not the new world which he actually found. The preColumbian voyages and explorations of the Northmen had given Europe no knowledge of America, and down to the time of the illustrious Genoese, Europe stood, figuratively, with its face toward Asia, and with its back turned toward the "Sea of Darkness," as the Atlantic was often called. So Columbus had no thought of finding a new continent, and no notion that one existed; nor indeed did he ever fully realise that he had found one. The lands which he dis- 
covered he regarded to the end of his life as merely some outlying islands or fringes of the Asian continent, and as impediments or obstacles to be passed by in some way, in order to reach the mainland empire of Cathay. His theory was not that such a land as America existed, but that by crossing the Atlantic Ocean he would come directly to the shores of China and Japan; for he clung to the old fallacy that whatever was not Europe or Africa must be Asia. (Isidore of Seville had taught more than eight centuries before, concerning the globe: "Divisus est autem trifarie; e quibus una pars Asia, altera Europa, tertia Africa.")

It is true that his theory had been held by others, long before. Aristotle, Seneca, and Pliny had written the belief that one might reach the Indies of Asia in a few days by sailing westward from Spain. Strabo had put upon record the same theory, adding that Menelaus, after the fall of Troy, sailed past the Pillars of Hercules, around Africa, and so reached India. It is not impossible that some adventurous navigators in those early days had actually crossed the Atlantic, and, like Columbus, had mistaken America for Asia. Hanno of Carthage is, not incredibly, declared by Pliny to have sailed around Africa to Arabia, thus anticipating the plans of Henry the Navigator and the achievements of Vasco da Gama. Antonio Galvano, the Portuguese historian, citing Berosius, Gonsalvo Ferdinand de Oviedo, and Pliny, tells us that "in the six hundred and fiftieth year after the Flood there was a king in Spain named Hesperus, who in his time, as it is reported, went and discovered as far as Cape Verde, and the Island of St. Thomas, whereof he was Prince; and Gonsalvo Ferdinand de Oviedo affirmeth that in his time the Islands of the West Indies were discovered, and called somewhat after his name, Hesperides; and he allegeth many reasons to prove it, reporting particularly that in forty days they sailed from Cape Verde unto those Islands." Again, upon the authority of Aristotle ("Lib. de Mirandis in Natura Auditis"), Galvano relates: 
"In the year 590 before the incarnation of Christ, there went out of Spain a fleet of Carthaginian merchants, upon their own proper costs and charges, which sailed toward the west through the high seas, to see if they could find any land; and they sailed so far that they found at last the islands which we now call the Antilles and New Spain; which Gonsalvo Ferdinand de Oviedo saith were then dis: covered; although Christopher Columbus afterwards, by his travel, got more exact knowledge of them and hath left us an evident notice where they be. But all these historians which wrote of these Antilles before, as of doubtful and uncertain things, and of places undiscovered, do now plainly confess the same to be the country of New Spain."

Coming down to a much later date, the same scribe tells us that "in the year 1344, King Peter, the fourth of that name, reigning in Aragon, the chronicles of his time report that one Don Lewis, of Cerda, grandson of Don Juan of Cerda, craved aid of him to go and conquer the Canary Islands, standing in 28 degrees of latitude to the north, because they were given to him by Pope Clement the Sixth, who was a Frenchman; by which means, in those days, there grew a great knowledge of those islands in all Europe, and particularly in Spain; for such great Princes would not begin nor enterprise things of such moment, without great certainty. . . . About this time also," continues our author, "the Island of Madeira was discovered by an Englishman named Macham; who, falling out of England into Spain, with a woman of his, was driven out of his direct course by a tempest, and arrived in that island and cast anchor in that haven which is now called Machico, after the name of Macham. And because his lover was then seasick, he went on land with some of his company; but in the meantime his ship weighed, and put to sea, leaving him behind; which accident occasioned his lover to die of grief. Macham, who was passionately fond of her, erected a chapel, or hermitage, in the island, to deposit her remains, naming it Jesus Chapel, and engraved on the stone of her tomb both their names and the occasion that brought them there. 
After this he made himself a boat out of a tree (trees being there of a great circumference), and went to sea in it, with those men of his company that were left with him, and fell in with the coast of Africa, without sail or oar. The Moors, among whom he came, took it for a miracle, and presented him to the King of the country, who, also admiring the accident, sent him and his company to the King of Castile. In the year 1395, King Henry III reigning in Castile, the information Macham gave of this island and also of the ship wherein he went thither, moved many of France and Castile to go and discover it and the Great Canary." Still later, in 1428, "it is written that Don Peter, the King of Portugal's eldest son, who was a great traveller, went into England, France, Germany, and from thence to the Holy Land and other places; and came home by Italy, taking Rome and Venice in his way; from whence he brought a map of the world which had all the parts of the world and the earth described. The Strait of Magellan was called in it The Dragon's Tail. . . ." Who was the author of this extraordinary map, and what became of it, are unknown. There are many other chronicles of early voyages to the Canary and Madeira Islands, and of voyages along the African Coast, even to and around the Cabo de Bona Speranza, or Cape of Good Hope.

One of the most important steps toward the enterprise of Columbus was taken in $\mathbf{1 2 4 5}$ and 1253. In the former year Friar John, of Plano Carpini, was sent by Pope Innocent IV as a missionary to the Great Khan, and in the latter year William of Rubruquis, a monk, was sent by King Louis (St. Louis) of France on a similar errand. These pious and observant men learned much from the Chinese whom they met about their empire of Khitai, or Cathay, and especially that at the east it bordered upon a great sea. This was the first definite information to that effect which Europe had received since classical times, and it set philosophers and geographers to thinking. Since Europe fronted upon an ocean at the west, and Asia fronted upon an ocean at the 
east, it seemed probable-nay, it seemed certain-that those oceans were one and the same, and by sailing due west from Europe the eastern shore of Asia would be reached. But though this theory was thus revived and discussed in the thirteenth century, it was not for two hundred years adopted as a rule of action; and, with all these preliminaries, it seems to be pretty well established that in the latter part of the fifteenth century there was only one man who practically believed in a westward waterway from Europe to the Indies, or who was sufficiently earnest in his belief to put it to the test.

It was about 1474 that the great enterprise was definitely conceived. Columbus was then at Lisbon, upon the very brink of the unexplored Atlantic. For aid and encouragement in his scheme he is said to have entered into correspondence with his countryman, Paolo Toscanelli. Whether he really did so or not, whether the famous map and letter of Toscanelli were what they were said to be or were mere forgeries, and indeed whether Columbus had, in advance of his first voyage, any definite scientific theory, are questions immaterial to the present argument, which need not be considered here. The recent researches and writings of Mr. Harrisse, Mr. Vignaud, and their contemporaries have thrown much light upon the early career of Columbus, and have placed it in a somewhat different aspect from that familiar to readers of Irving and other early historians. It is sufficient for our purpose to note that grave doubt has been thrown upon the whole story of Toscanelli's aid and encouragement to Columbus, but to note, also, that whatever be the truth of that matter, the theory and the aim of Columbus's venture remain indisputable; and they are all with which this writing is concerned.

According to the old story, then, Toscanelli, a Florentine and one of the foremost geographers of his time, sent to Columbus two documents, priceless for information. One was a map which he had prepared, partly according to the theories of Ptolemy, but somewhat more according to the 
reports of Marco Polo. The other'was a copy of a letter which Toscanelli is said to have written to Ferdinand Martinez, or Martins, of Lisbon, in answer to some questions which King Alfonso V of Portugal had asked. The map was a map of the world, showing the eastern coast of Asia to be at the western side of the Atlantic Ocean, about 4,000 miles west from Europe. The northern part of China was called Cathay, and the southern part Mangi, or Mangu. Off the coast were two great islands, one of which, Cipango, or Zipangu, may be identified with Japan, and the other, Antilla (which had been mentioned by Aristotle), corresponding with Formosa. There was also some indication of the Philippine Archipelago. The letter to Martinez was an explanation of the map and an argument of the practicability of sailing from Lisbon due west to China, a distance, as Toscanelli believed, of only 4,000 miles; for King Alfonso had asked whether in Toscanelli's opinion the Indies and China could be reached by sailing across the Atlantic more readily than by circumnavigating Africa. In after years Arias Perez Pinzon, son of Martin Alonzo Pinzon, the fellowvoyager of Columbus, testified that he and his father had seen in Rome, in the Vatican library, a manuscript written by a historian "contemporary with Solomon," in which it was set forth that by sailing due westward from the Pillars of Hercules a distance of 95 degrees of longitude, one might reach the "Land of Cipango," a country equal in size to Europe and Africa united. The identity of that alleged manuscript has not been certainly determined. That it was of Solomon's time seems most improbable. That it was the work of Marco Polo is by no means impossible, or even improbable. The chief interest of it, if Pinzon's report was true, is that it seems to have hinted at a new continent, instead of merely the eastern part of Asia, and that it makes the distance from Spain to Cipango about the same as that which Toscanelli and Columbus reckoned-their figures being 120 degrees from the Azores to Thinae, the latter being probably a considerable distance west of Cipango. It 


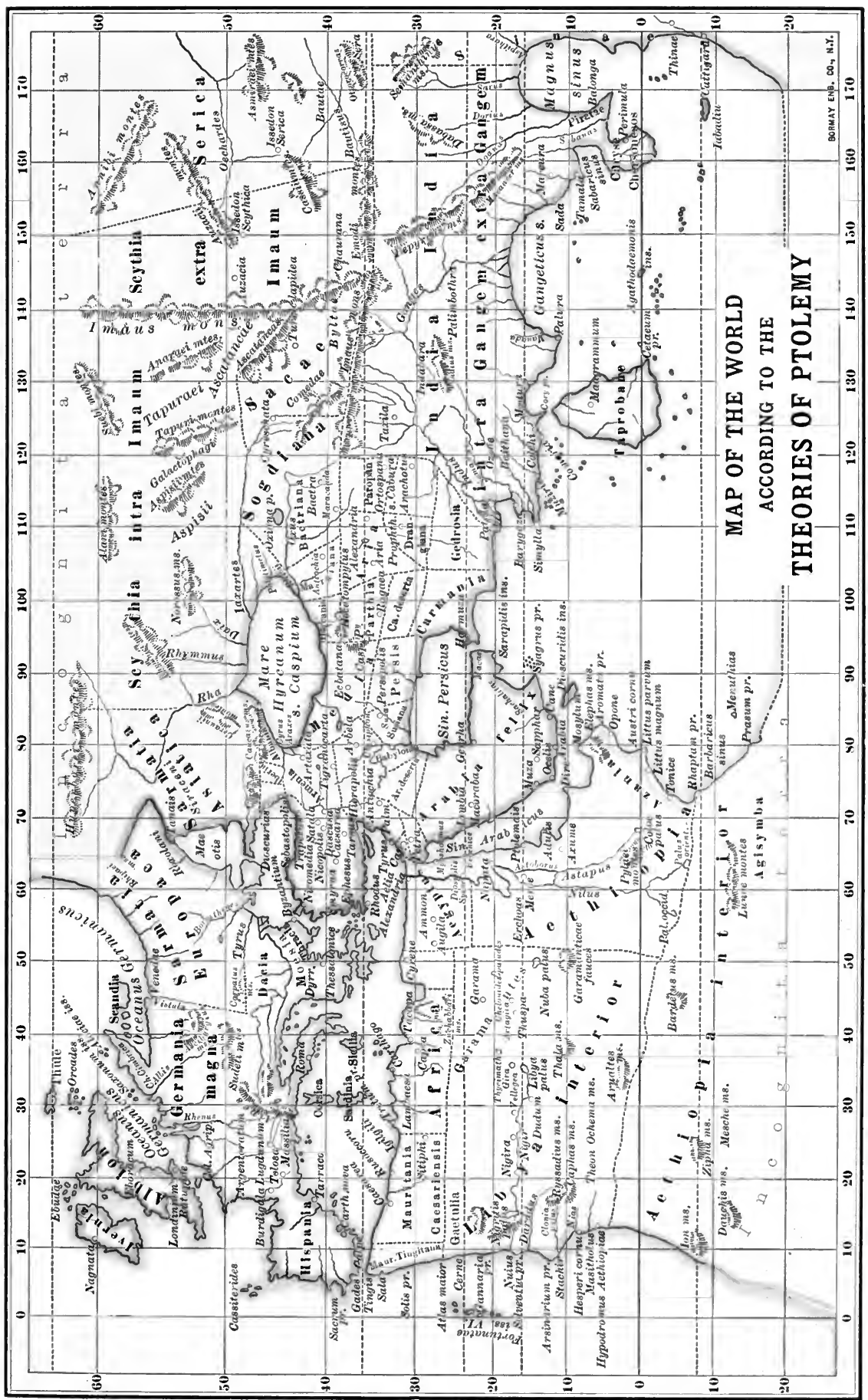




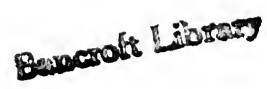


may be noted, by the way, that 95 degrees of longitude westward from the Pillars of Hercules bring us a little beyond the extreme western shore of the Gulf of Mexico.

These geographical details of the Pacific coast of Asia are said to have been derived by Toscanelli chiefly from the reports of Marco Polo and Sir John Mandeville-travellers who were once ignorantly denounced, as was Herodotus, as great liars, but who have since been vindicated, as he was, in their remarkable and substantial accuracy. Aristotle had mentioned Antilla, from sources of information which seem to have been lost soon after his time. Ptolemy knew nothing of Asia further east than Thinae, if indeed he can be said to have known anything of that legendary place. Just what or where Thinae was is matter of conjecture. It may have been a province of China, or China itself. It may have been the old Chinese capital of Si-Ngan, in Shen-Si, in east longitude $109^{\circ}$; or Tai-Yuan, in Shan-Si, in east longitude $112^{\circ} 30^{\prime}$; or yet Lo-Jang, in east longitude $113^{\circ}$. Ptolemy, following Herodotus, put it in what is now east longitude $150^{\circ}$, and two or three degrees south of the equator; that is to say, in the Pacific Ocean northeast of New Guinea. That was only one of many similar inaccuracies. Thus he placed the mouth of the Ganges midway between Hainan and Luzon; the Golden Chersonesus just northwest of New Guinea; the great island of Taprobane (Ceylon) west of Sumatra and the Malay Peninsula; and the Chinese city of Sera, now Cha-Ngan, which really is in east longitude $110^{\circ}$, he put in east longitude $147^{\circ}$, or in the Pacific Ocean east of Japan.

Ptolemy, moreover, supposed Asia and Africa to be connected at the south as well as at Suez, and the Indian Ocean to be an inland sea resembling the Mediterranean. According to his mind, beyond the Golden Chersonesus, or Malay Peninsula, lay a great gulf, which we know as the Gulf of Siam. Its further shore, instead of ending at Cape Cambodia, he carried southward, making it continuous with Borneo and the western end of Australia, and then, about 
20 degrees south of the equator, brought it due westward so as to join Africa at Zanzibar or Mozambique. How access was had to this inland Indian Ocean from the Atlantic does not appear, though, as we have seen, Aristotle, Seneca, Pliny, and others had held that there was such access. Of the southern shore of the land south of the Indian Ocean, and of the eastern shore of the land east of the Gulf of Siam, Ptolemy professed no knowledge.

Of course this over-extension of the Asian continent eastward correspondingly restricted the remaining space in the circuit of the globe, between the east coast of Asia and the west coast of Europe; and this error in reckoning was further exaggerated by under-estimating the size of the earth itself. Perversely enough, the discovery of facts in some measure increased the error. For Marco Polo and Mandeville, in the thirteenth and fourteenth centuries, explored the remainder of the Asian continent, clear to the Pacific coast, and confirmed the reports of Friar John of Plano Carpini and William of Rubruquis in describing its frontage upon a great ocean, which was forthwith assumed to be the Atlantic. As they showed Thinae to be far inland from that coast, it was assumed that the Asian continent extended much further eastward than the longitude which had been attributed to Thinae, and that there was therefore only a small part of the earth's circle left between Asia and Europe.

In constructing his scheme of geography, then, Toscanelli clung to the old error of supposing there to be only one ocean; and the still greater error of vastly underestimating the distance across it from Europe westward to China. Ptolemy had known the world, or had thought he did, from Thinae in the east to the Canary Islands in the west, and the Portuguese under Henry the Navigator had advanced knowledge westward to the Azores and the Cape Verde Islands. Working from these data, Toscanelli divided the circuit of the globe into 360 degrees, subdivided into 24 hours of 15 degrees each. Then he reckoned that the distance from Thinae to the Azores was 16 of the 24 hours, or 240 of the 
360 degrees, or two-thirds of the circumference of the globe. There remained, then, between the Azores and Thinae, going westward, only eight hours or 120 degrees, or one-third the circumference of the globe. Moreover, as Thinae was a considerable distance inland from the eastern coast of Asia, there was thus left between Asia and Europe room for only a comparatively narrow ocean, about the actual width of the Atlantic. He is said to have written to Columbus in $\mathbf{1 4 7 4}$ that from Lisbon westward to Quisai-now Hang-Chowthen the capital of China, was only 6,500 miles. Practically, Toscanelli eliminated the American continents and the Pacific Ocean, and vastly exaggerated the extension of Asia toward the east, putting the eastern coast of Asia near where the western coast of America is. These incorrect estimates prevailed for a long time. Antonio Galvano, writing as late as 1555, and reviewing all the records of his predecessors, said :

"I gather by all the precedent discoveries that the whole earth is in circuit 360 degrees, and to every degree ancient writers allow seventeen leagues and a half, which amount to 6,300 leagues; yet I take it that every degree is just seventeen leagues. However it be, all is discovered and sailed from the east to the west, almost even as the sun compasseth it; but from the south to the north there is great difference; for towards the north pole there is discovered no more than 77 or 78 degrees, which come to 1,326 leagues, and towards the south pole there is discovered from the equinoxial to 52 or 53 degrees, that is, to the Strait Magellan passed through, which amounts to about 900 leagues; and putting both these said sums together, they amount to about 2,026 leagues. Now, take so many out of 6,300 leagues, there remaineth as yet undiscovered, north and south, above the space of 4,000 leagues."

Accepting Toscanelli's erroneous reckoning of the width of Asia, Columbus estimated that he would reach China and Japan at just about the distance from Spain, and in just about the longitude, in which he actually found America. With the legends of Atlantis, St. Brandan, and the Ișland 
of the Seven Cities, we need not now concern ourselves. Columbus appears to have put no faith in them. His aim was to reach the Indies, to wit, Cathay, Mangi, Cipango, and Antilla, and to do so by means of an unbroken waterway westward across the Atlantic. In this it was providential that he did make the error which we have noted concerning the distance, for he would scarcely have ventured to set out upon a supposed journey of more than 12,000 miles across an unknown sea.

This aim appeared in almost every part of his great work. When he set forth on his first voyage in 1492, he carried, according to his subsequent statement, letters from the sovereigns of Leon and Castile to the Great Khan of Tartary. In his Journal, on the very opening page, he recorded that he was being sent to India, to "a Prince who is called the Great Khan," and that he was about to sail westward, on and on, until he should "arrive at the Indies." There was not a word nor a thought about the seeking of a new continent. His maps and charts indicated the coasts of Europe and Africa, from the British Isles to Guinea, and, directly opposite them, in the same latitude, at the west side of the Atlantic Ocean, the coast of Asia, with Cathay at the north and Mangi at the south, and with Cipango lying almost exactly where Florida really was. Toward Cipango he directed his course, and kept it so well that he arrived at the Bahamas, off the Florida coast. It was a part of his mission to convert the Great Khan of Tartary to Christianity, wherefore he called the first island he reached San Salvador, the Land of the Holy Saviour, and, supposing it to be a part of the Indies, he called the inhabitants Indians. When the natives spoke of the mainland lying north and west, he assumed it to be Cathay, and when they told of a greater island at the south, called Cuba, he supposed it to be Cipango. Sailing southward among the Bahamas, he thought himself among the Philippines, or other Asian islands described by Marco Polo, and on reaching Cuba he had no doubt that it was Cipango. When, however, Marco 
Alonzo Pinzon reported to him that the natives were speaking of a place called Cubanacan, he identified that name with Kublai Khan, and assumed that he was on the mainland of Cathay, and about only 100 leagues from the capital of the Great Khan. This practice of confusing native names in the American islands with those in Asia of which he had heard, was continued, with further misleading results. Thus, when he heard the island of Santo Domingo called Quisqueya, he identified it with Quisai, the Chinese metropolis mentioned by Marco Polo; and when the natives named the place as Cibao he supposed that name to be a corruption of Cipango. Constantly, as Lamartine observed, the phantom of Asia interposed itself between Columbus and America, to rob him, for a chimera, of a great reality. Finally, on his return from this voyage, Columbus explicitly reported to the King of Portugal that he had not been to any of the African lands claimed by that monarch, but to Cipango and to India; the Spanish sovereigns addressed him as "Viceroy and Governor of the Islands discovered in the Indies"; and the general supposition in Europe was that he had reached the eastern coast of Asia, and that Cuba was a part of the mainland of Cathay. The letter of Columbus to Ferdinand and Isabella, reporting the result of his voyage, was entitled a "letter . . . concerning the Islands discovered in the Indian Sea," or, "the Islands of India beyond the Ganges," and in the opening passages of that letter Columbus said: "On the 33rd day . . I I came to the Indian Sea."

This delusion was not corrected but rather confirmed by his second voyage. He then explored the many islands of the Caribbean Sea, and believed himself to be among the 7,440 islands near Cipango, described by Marco Polo, who probably referred to Formosa and the Loo Choos, or possibly the Philippines. Marco Polo, following Aristotle's nomenclature, had named an island in that region Antilla, whence Columbus - or else Peter Martyr - gave to these islands the name of the Antilles. Thence Columbus revisited Cuba, 
skirting its southern coast for a long distance. Natives assured him that nobody had ever travelled so far as its western extremity, wherefore he was confirmed in his belief that it was indeed the mainland of Asia. Again the native nomenclature led him into self-deception, for hearing of a province named Mangon, he unhesitatingly identified it with the Mangi of Marco Polo. When he was told it was inhabited by people with tails, who wore long garments to conceal those appendages, he found in that report further confirmation of his belief; for he recalled that Sir John Mandeville had mentioned the alleged existence of such a tribe in Asia. Thus encouraged, he kept on, expecting to reach the Golden Chersonesus, or Malay Peninsula, and thus circumnavigate the world, returning to Europe by way of the Indian Ocean. He in fact went as far as the Bay of Philippina, or Cortez, and then turned back, still confident in his belief that Cuba was Cathay, and that Hispaniola, or Santo Domingo, was Cipango. Nor did he learn the truth on his third voyage, but instead added to his stock of errors. Directing his course further southward than before, in order to ascertain whether the people of equatorial Asia (which he supposed South America to be) were like those of Africa, he reached the Island of Trinidad, and the coast of Venezuela. He correctly judged the land at the south and west of the Gulf of Paria to be part of a great continent, though he persisted in the error of supposing it to be either Asia or a continent lying just south of Asia. But he cherished the extraordinary notion that it occupied the "highest part of the globe," and was the seat of the Garden of Eden, and that the great torrent of fresh water which flowed into the Gulf of Paria proceeded from the fountain which fed the Tree of Life!

The fourth and last voyage of Columbus was dominated by the same erroneous conceptions, and was in addition marked with the beginning of that quest for the "Secret of the Strait" which so greatly occupied the attention of his successors for many years, and which has scarcely yet been 
wholly relinquished. Says the historian and explorer Galvano, citing Gomara:

"In this same year, 1502, Christopher Columbus entered the fourth time into his discovery, with four ships, at the command of Don Ferdinand, to seek the Strait which, as they said, did divide the land from the other side. . . . They went first to the Island of Hispaniola, to Jamaica, to the river Azua, to the Cape of Higueras, to the Islands Gamares, and to the Cape of Honduras, that is to say, the Cape of the Depths. From thence they sailed towards the east, unto the Cape Gracias á Dios, and discovered the province and river of Veraguas, and Rio Grande, and others which the Indians called Hiemra; and from thence he went to the River of Crocodiles, which is now called Rio de Chagres, which hath its springs near the South Sea, within four leagues of Panama, and runneth into the North Sea; and so he went unto the island which is called Isla de Bastimentos, that is, the Isle of Victuals; and then to Porto Bello, that is, the Fair Haven; and so unto Nombre de Dios, and to Rio Francisco, and so to the Haven of Retreat; and then to the Gulf of Cabesa Cattiva, and to the Islands of Caperosa; and, lastly, to the Cape of Marble, which is 200 leagues upon the coast; from thence they began to turn again to the Island of Cuba."

Thus is the story briefly told by the old historian, with some terminology strange to modern ears. To paraphrase the narrative, and to amplify it in the light of other knowledge, we may say that, being refused entrance to the harbours of Hispaniola, Columbus directed his course westward, passing completely by Cuba without realising the fact and its significance, and reached Roatan, the Bay Islands, and the coast of Honduras. There, on the mainland of Central America, he found native tribes more civilised than any he had seen before, and accordingly assumed that at last he was approaching the capital of the Great Khan. The mainland of Honduras he believed to be continuous with Cuba and to be Cochin China, the southeastern part of Asia ; and he supposed that if he went northward he would presently reach that south coast of Cuba, along which he had sailed on his 
second voyage, and would thus be compelled to return eastward. Thus, to our lasting regret, he was deterred from going on to Yucatan and visiting that country while it was yet in the glories of Mayan civilisation. Instead, he turned southward, to seek the Golden Chersonesus, and to go home to Europe by way of the Strait of Malacca, which he believed was to be found somewhere between Honduras and Venezuela-between Cochin China, Cathay, and Mangi at the north, and the Garden of Eden at the south. That "Secret of the Strait" thereafter engaged his chief attention. He rounded Cape Gracias á Dios, and so went down the Mosquito Coast, along Costa Rica, to the Chiriqui Lagoon, and along the coast of Veraguas, the western part of the Caribbean coast of Panama. There he reckoned that he was only ten days' journey from the mouth of the Ganges River. The natives told him he was nearing what they called "a narrow place between two seas." They meant, of course, a narrow strip of land, the Isthmus of Panama. But Columbus, always believing that which he wished to be true, confidently assumed it to be a narrow strip of water-the much desired Strait. No such Strait appearing, however, he pressed on to the eastward along the Panama coast, entering the Bay of Limon and the mouth of the Chagres River. On November 2, 1502, he entered the Bay of Porto Bello, east of Colon, and thence proceeded to Nombre de Dios. Finally at El Retrete, on December 5, he abandoned for a time the quest of the Strait in that direction and turned back to the westward, to explore more carefully the coast of Panama along which he had already sailed. He spent the winter there, chiefly on the coast of Veraguas, which, because of its gold mines, he firmly believed to be a part of the Golden Chersonesus. He vainly sought to plant a permanent colony on the Belen River. At the end of April he set out again in quest of the Strait. Reaching the Mulatas Islands, near Point Blas, he identified them with a part of Mangi, or southeastern Asia. Past them he proceeded as far as the entrance to the Gulf of Darien, and then, instead of entering it and exploring its 
waters and shores, the very native habitat of the Legend of the Strait, he turned northward and eastward, and on May 1 started back for Hispaniola, never again to approach the mainland of the American continent.

Thus he ended his career under the same delusion which had marked its beginning, and left his actual aim unaccomplished, though in the unconscious fulfilment of a far greater aim. He died in the unshaken belief that he had reached the Asian coast, and in ignorance of his real discovery of a thitherto unknown continent, and without finding the mythical Strait for which he sought. He had indeed "builded better than he knew." In his will he reaffirmed the error he had cherished, declaring that "It pleased the Lord Almighty that in the year 1492 I should discover the Continent of the Indies and many islands, among them Hispaniola, which the Indians call Ayte and the Monicongos, Cipango." It was not until 1508, two years after his death, that Cuba was circumnavigated, and thus found not to be a part of the mainland; though it may be that Amerigo Vespucci, in $1497-8$, practically achieved that enterprise without realising its significance, by sailing around the Gulf of Mexico from Yucatan to Florida.

It is true that upon the Admiral's coat-of-arms was placed the well-merited inscription, "A Castilla y a Leon, Nuevo mundi dio Colon"-To Castile and Leon, Columbus gave a New World. But it is not certain that Columbus himself was the author of that inscription, or of the phrase "New World." Peter Martyr seems to have been the first to speak of the lands discovered by Columbus as the "New World," in a letter written by him in 1494, while Amerigo Vespucci, in 1503, was probably the first to use the phrase in a published book; but Vespucci cherished the same delusions that Columbus did. Writing to Lorenzo de Medici, on July 18, 1500, after his voyage to America, he reported that about a month before he had "arrived from the Indies;" of the Venezuelan and Colombian coast, which he had explored, he said he had concluded that "this land was a continent, which might be 
bounded by the eastern parts of Asia, this being the commencement of the western part of the continent;" he spoke of having discovered "a very large country of Asia;" and he promised in his next voyage to discover "the Island of Taprobane, between the Indian Ocean and the Gulf of the Ganges." Orontius Finæus, in 1531, upon a geographical globe, indicated Florida as the eastern coast of Asia, and Mexico, Central America, and South America as an enormous peninsula extending south and east from the continent of Asia.

Centuries afterward, the illustrious scientist, Alexander von Humboldt, in his "Personal Narrative," spoke of the oldest existing map of America as that of John Ruysch; a map of the world, annexed to a Roman edition of Ptolemy in 1508. "We there," said Humboldt, "find Yucatan and Honduras figured as an island, by the name of Culicar. There is no Isthmus of Panama, but a passage, which permits of a direct navigation from Europe to India. The great southern island bears the name of Terra de Parias." That map was dated two years after the death of Columbus, and probably embodied the best conception of American geography which he and his contemporaries had been able to form.

Since Humboldt's time, however, there has come to light another map, of an earlier date. This is a map of the world drawn by Martin Waldseemüller (also known as Ilacomilus, or Hylacomylus, his own translation of his name into Greek), in 1507. This map follows in general the theories of Ptolemy, but of course shows much that was unknown to that earlier geographer. It is especially interesting in connection with the subject now in hand, for the reason that it indicates North America and South America as entirely separate continents, with a broad seaway between them, connecting the Atlantic with the Pacific. The North American continent is called on it Parias, and the southern continent bears the name of America. This map apparently accompanied a little Latin book, written by Waldseemüller and published in April, 1507, in which it was suggested that the New World 


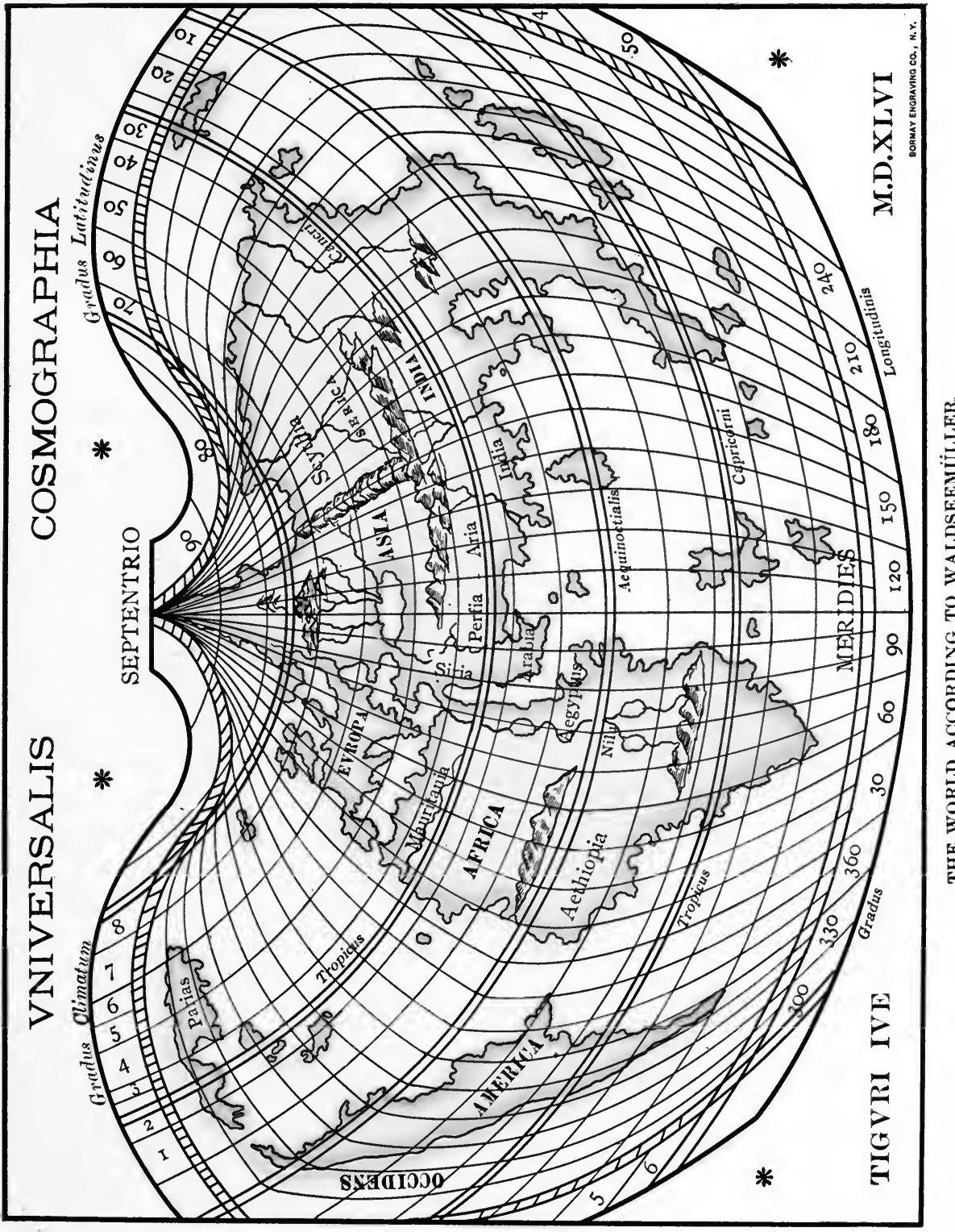


Sivenaros bistaty 
should be named for Amerigo Vespucci. "Quarta orbis pars, quam quia Americus invenit Amerigen, quasi America terram, sive American, nuncupare licet;" or, "the fourth part of the world, which it is proper to call America, or American Land, since Amerigo discovered it." Again, in another chapter: "Alia quarta pars per Americum Vesputium, ut in sequentibus audietur, inventa est: quare non video, cur quis jure vetet ab Americo inventore sagacis ingenii viro Amerigen, quasi Americi terram, sive Americam, dicendam;" or, "the other fourth part (of the world) was discovered, as will appear in what follows, by Amerigo Vespucci; wherefore I do not see why any one can lawfully object to its being called the Land of Amerigo, or America, after Amerigo or Americo, the man of genius who discovered it by his sagacity." (It will be recalled that Amerigo Vespucci is said to have accompanied Ojeda to the Isthmus of Panama in 1499, and to have been the first European to set foot upon Terra Firma, as the mainland of the American continent was then called.)

Nevertheless, the error of his conceptions and of his conclusions in no way detracts from the glory of Columbus. He went to seek a new road to a known continent. Instead, he found two hitherto unknown continents, and to their colonised inhabitants in after centuries he left the lesser work of creating by artifice the water highway which he had sought, but which he had sought in vain because nature had failed to create it. 


\section{CHAPTER II}

\section{THE SECRET OF THE STRAIT}

Columbus sought the "Secret of the Strait." He was not, however, the first European to visit the American Isthmus. Galvano, deriving his authority from Gomara, records that "in the year 1502, one Alfonso Ojeda went to discover Terra Firma, and followed his course till he came to the Province of Uraba. The next year following also one Rodrigo Bastidas, of Seville, went out with two caravels. . . . They took their course toward the west to Santa Martha, and Cape de la Vela, and to Rio Grande, or the Great River; and they discovered the haven of Zamba, the Coradas, Carthagena, and the islands of St. Bernard, of Baru, and Islas de Arenas; and went forward unto Isla Fuerta, and to the point of Caribana, standing at the end of the Gulf of Uraba, where they had sight of the Farallones, standing on the other side, hard by the river of Darien; and from Cape de la Vela unto this place are two hundred leagues, and it standeth in nine degrees and two parts of latitude." There are other records bearing upon these adventures, and it is difficult to determine with confidence the true story.

According to some, Alfonso, or Alonzo, de Ojeda landed at Darien as early as 1499; having with him as his pilots Amerigo Vespucci and Juan de Cosa, the latter being the Biscayan navigator and cartographer who was the owner and master of the Santa Maria and the companion of Columbus on his first voyage. The weight of testimony, however, inclines to the belief that in that voyage Ojeda and his famous comrades visited only the coast of Venezuela and did not go west of Cape Gallinas, and that we should give the credit of discovering the mainland of the Isthmus to another, who has 
been called "Spain's noblest and best conquistador." Rodrigo de Bastidas, a native of Seville, sailed from Cadiz in October, 1500, with La Cosa, and, passing by Hispaniola and the other islands of the West Indies, was probably the first of all Europeans to reach the American Isthmus, at or near Porto Bello. Thence he skirted the coast, southward and eastward, entering the Gulf of Darien, or the Gulf of Uraba, as far as the mouth of the Atrato River, and going along the Colombian coast as far as Cape Gallinas, at the extremity of the Goajira Peninsula, and the entrance of the Gulf of Venezuela and thence striking off on a tangent for Hispaniola. The object of that voyage was partly to get pearls and gold, but more to find the "Secret of the Strait," the entrance to that fabled passageway from ocean to ocean of which there were innumerable traditions among the natives from California to Peru, and of which you may still hear confident reports among the Indians of San Blas, and the natives in the Valley of the Atrato. Bastidas, then, was the pioneer at Panama, two years in advance of Columbus. His quest was unsuccessful, but it inspired Columbus himself to follow him, and many others. In 1505, from May to December, La Cosa and Amerigo Vespucci diligently explored the Gulf of Darien and ascended the Atrato River about 200 miles, in quest of a passageway to India; and two years later they went thither again, not for the Strait but for gold, of which they found much. Indeed, the profits of the voyage were so great that they made a second visit to the same region in 1507 , this time seeking gold rather than the Strait. In 1506 came Juan Diaz de Solis, and Vincente Yañez Pinzon, the latter the commander of the Nina on Columbus's first voyage; who in 1497-8 had sailed with Amerigo Vespucci from Yucatan to Florida. They reached Juanaja, the easternmost of the Bay Islands, and sighted the mainland near Truxillo, and thence surveyed the coast westward and northward almost to Yucatan. Two years later they were sent again on the same errand, but turned southward and followed the South American coast as far as the Rio de la Plata. It may be a cause of 
passing wonder that they did not enter the mouth of the Amazon, and ascend that river, supposing it to be the much sought Strait.

The next important name on the roll is that of Alfonso, or Alonzo, de Ojeda, already mentioned, one of the most brilliant and gallant of the cavaliers of Spain, and the hero of a thousand thrilling tales. Having shown his exceptional efficiency as a commander at St. Thomas, he was in 1508 appointed Governor of what is now the Caribbean coast of Colombia. The King of Spain, in shameful disregard of the rights of Diego Columbus, divided that region into two provinces, with a line of demarcation running north and south through the Gulf of Uraba. All eastward from that line, to Cabo de la Vela, he called Nueva Andalusia, or New Andalusia, and made Ojeda its governor, while all westward, to Cabo Gracias á IDios, he called Castilla del Oro, or Golden Castile, and appointed as its governor Diego de Nicuesa, or Niquesa. In 1509 these governors set out for their provinces, with instructions to press diligently the search for the "Secret of the Strait." Concerning them, we may again quote Galvano:

"In the year 1508, one Alfonso de Ojeda, with the favour of Don Ferdinand, purposed to go to Terra Firma, to conquer the Province of Darien. He went forth at his own charges, and discovered the Firm Land, where it is called Uraba, which he named Castilla del Oro, that is, Golden Castile, because of the gold which they found among the sand along the coast; and they were the first Spaniards that did this. Alfonso de Ojeda went first from the Island of Hispaniola and the City of San Domingo, with four ships and three hundred soldiers, leaving behind him the bachelor Enciso, who afterwards compiled a book of these discoveries. And after him there also went a ship with victuals, ammunition, and one hundred and fifty Spaniards. He went on land to Carthagena; but there the people of the country took, slew, and ate seventy of his followers; whereupon he grew very weak. . . . In the year 1508, one Diego de Niquesa prepared seven ships in the Port of Beate, to go to Veraguas, and carried in them almost eight hundred men. When he 
came to Carthagena, he found there Alfonso de Ojeda, much weakened by his former loss; but then they joined together, and went on land, and avenged themselves on the people. In this voyage Diego de Niquesa went and discovered the coast called Nombre de Dios, and went unto the Sound of Darien, and called it Puerto de Misas, which is upon the River Pito. When they were come unto Veraguas, he went on shore with his army, his soldiers being out of hope to return to Hispaniola. Alfonso de Ojeda began a fortress in Caribana against the Caribbees; which was the first town the Spaniards builded on the firm land; and in Nombre de Dios they builded another, and called it Nuestra Señora de la Antigua. They builded also the town of Uraba. And there they left for their captain and lieutenant one Francisco Pizarro, who was there much troubled. They builded other towns also whose names I here omit. But these captains had not that good success which they hoped for."

Nicuesa died at sea. La Cosa was among those of Ojeda's men who were slain by the savages. Ojeda also died, leaving as his successor in command Francisco Pizarro, an Estremaduran adventurer, formerly a swineherd, and afterward the conqueror of Peru. Pizarro, despairing of accomplishing much on the Gulf of Darien, was actually abandoning the enterprise and leaving the place when he met Martin Fernandez de Enciso coming to him with succour. Enciso had been a partner of Ojeda, and, beside being a competent adventurer and administrator, was one of the ablest cosmographers of his time, and wrote in 1519 "Suma de Geografia," the first Spanish book ever published about America. With this aid and encouragement Pizarro returned to his place.

There now came npon the scene the most important figure of all. This was an impoverished Hidalgo of Estremadura, by name Vasco Nuñez de Balboa. He had gone to the Isthmian coast in 1500, with Bastidas, and thence to Hispaniola. While Bastidas was arrested and imprisoned by Bobadilla, Balboa settled down as a farmer, at which occupation he had little success. Finally, overwhelmed with debts, he fled from his creditors concealed in a cask, which was put 
aboard one of Enciso's ships, and was thus conveyed to San Sebastian, which was the seat of Pizarro's government on the Gulf of Darien. There he got Enciso recognised as the successor of Diego de Niquesa as Governor of Castilla de Oro, and with Enciso founded the colony and city of Santa Maria del Antigua on the west coast of the Gulf, at the mouth of the Darien River, near the Atrato River. Balboa had visited those regions before, with Bastidas and La Cosa, and was thus better informed about it than the others; and he advised the building of the town on the west shore of the Gulf, because he knew the natives there were more friendly than those on the east shore, who had made such havoc with Ojeda's party. He himself became Alcalde of the town; and then presently quarrelled with Enciso, overthrew his government, and arrested him and sent him back to Spain. Enciso appears to have been a man of overbearing disposition, with whom it was difficult for any one to remain on friendly terms. Balboa owed him no thanks, either, although he had made his escape from his creditors on one of Enciso's ships; for Enciso was not privy to that trick, but was angry when he learned of it, and was with difficulty restrained from marooning Balboa on a desert island where he would have perished miserably.

Thus Balboa became Governor of Castilla del Oro, getting a commission from the Royal Treasurer at Hispaniola; he married the daughter of Careta, a powerful native prince of Darien, and made an alliance with Comogre, another native prince; and was on the high road to distinction. Enciso, however, on arriving in Spain got the ear of the King, and poured into it a tale which, in spite of the excuses of Balboa's friend Zamudio, moved His Majesty to send for Balboa to return to Spain and to explain his extraordinary conduct. This was awkward. It would be impossible to give a satisfactory explanation, and Balboa would probably be removed from the governorship which he had usurped, and perhaps be cast into prison. In this desperate predicament Balboa determined to do, if possible, some great deed which 
would command the favour of the King-or perish in the attempt. He had heard from the chieftain Comogre and other natives various tales of a great water lying not far to the south and west, and also of a land where gold was so abundant that people made bowls and cups of it, instead of pottery. The reference was, of course, to the Pacific Ocean and Peru. He shrewdly assumed that if he could discover those regions, the King would overlook that irregular episode with Enciso. Accordingly he organised an expedition for the purpose. He sailed, on September 1, 1513, for Coiba, on the coast of the Gulf of Darien, between Punto Tiburon and Caledonian Bay, with a company of 290 men. Leaving half of his force with the ships, and securing 100 Indian guides and bearers, he started inland on September 6. Privations and difficulties were great in those savage jungles and progress was slow. But at last, on September 25,

\section{- "With eagle eyes}

He stared at the Pacific,- - and all his men

Looked at each other with a wild surmise,Silent, upon a peak in Darien."

He was still some distance from that new-found sea, but thereafter more rapid progress toward it was made. On September 29 he reached the shore, strode into the water, and proclaimed possession of it in the name of the King of Spain. It was the day of St. Michael, wherefore he named the water the Golfo de San Miguel, or Gulf of St. Michael, as it is called to this day. He had by happy chance crossed the Isthmus at its very narrowest part, by the route long afterwards surveyed for a canal and known as the Caledonian Canal route-the shortest route but not at the lowest level. He spent some time exploring the coast, and saw afar the beautiful Pearl Islands in the Bay of Panama. "He embarked himself," says Galvano, "against the will of Chiapes, who was lord of that coast, who wished him not to do so because it was very dangerous for him. But he, desirous to have it known that he had been upon those seas, went for- 
ward, and came back again to land in safety, and with great content, bringing with him good store of gold, silver, and pearls, which they there took." The "seas" upon which he sailed were the Gulf of St. Michael. He landed upon the northern shore of that gulf, and secured the friendship of a powerful chief of that region, named Tumaco, or Tumaccus.

Balboa then returned to his capital, and, instead of proceeding to Spain in answer to the royal summons, he sent thither an account of his great achievement. He had not hoped too much for its effect. The King, appreciative and grateful, reckoned that the man was doing too profitable a work to be interrupted by coming home to Spain to answer Enciso's charges, so he sent him word to stay where he was, not merely as Governor but also as Adelantado of the new coast and lands he had discovered.

Unfortunately, however, Balboa's messenger did not reach Spain until after the King had despatched the infamous Pedrarias Davila to the Isthmus to supersede him and to hurry him to Spain. "In the year 1514," says Galvano, citing Peter Martyr, "and in the month of May, there went out of St. Lucar, one Pedro Arias de Avila, at the command of Don Ferdinand. He was the fourth Governor of Castilla del Oro, or Golden Castile, for so they named the countries of Darien, Carthagena, and Uraba, and that country which was newly conquered. He carried with him his wife, the Lady Elizabeth, and 1,500 men, in seven ships; and the King appointed Vasco Nuñez de Balboa Governor of the South Sea, and of that coast." Pedro Arias de Avila is variously known in history as Pedrarias Davila and as Pedrarias. There are now some most estimable people living in Panama who bear the name of Arias, for whose sake we shall do well not to identify them more than we can help, through similarity of name, with that "Timour of the Indies;" wherefore let him be disguised as Pedrarias. He was one of the worst of the early conquistadors, having little real ability to counterbalance his infernal cruelties and wickednesses, the best thing about him being his old age, which made his days 
comparatively few in the land which he cursed. Oviedo reckoned that on the Day of Judgment Pedrarias would have to confront the souls of $2,000,000$ of his murdered victims. Probably this was an exaggeration, but it is noteworthy that not one reputable historian of his time attempted to defend the character and career of the man.

Pedrarias reached Santa Maria del Antigua and at once arrested Balboa. The presiding judge was Gaspar de Espinosa, a just man, and Balboa was acquitted. Thereafter a bitter conflict prevailed between Balboa and Pedrarias, which was much intensified by Balboa's manly refusal to repudiate his Indian wife and marry a daughter of Pedrarias -an arrangement which the Bishop of Darien proposed as a means of ending the quarrel. However, an apparent truce was in time made and then Balboa proceeded with great plans for the exploration of the shores of the Pacific, which he called the South Sea, and especially for reaching the "Golden Land" of Peru. He recrossed the Isthmus in 1516, starting from Aclas, a new port on the Caribbean side, and some say he carried with him overland four brigantines which he launched into the Pacific, while others say he carried only the tools and materials for constructing two ships. We need not concern ourselves as to the choice between the tales. Either attributes to him a marvellous achievement for those days. With these, the first ships which ever sailed those waters, he took possession of the Pearl Islands, and then was about to start for Peru, of which latter country he, instead of Pizarro, should have been the discoverer and conqueror. But during the delay caused by waiting for some supplies, he was approached by a treacherous messenger from Pedrarias, who persuaded him to stop and return to Aclas, where he was put through a mockery of a trial, and beheaded. The captain of the soldiers who arrested him under the orders of Pedrarias was his old comrade, Francisco Pizarro.

Thus perished, in 1517, the man who first crossed the American Isthmus and reached the eastern shore of the Pacific-a wise statesman, a brave soldier, a daring and 
resourceful explorer; a man of unconquerable determination, of great gifts of leadership, and, for those times, of considerable humanity. Even his flight from Hispaniola, and his conduct toward Enciso, seem petty faults by the side of the glaring iniquity of his murderer. However, it is to be recorded that Pedrarias, fearing he was to be dismissed from his governorship, in 1519 founded the city of Panama-not the present city, but the old one, a few miles away, which was destroyed by Henry Morgan, the Welsh buccaneer, in 1671 , and of which now scarcely a trace remains, save a picturesque old church tower. He also continued the search for the Strait, surveyed the coast from a little below the Tuyra River up to Costa Rica, and first heard of Lake Nicaragua, which was said to connect directly with both seas and thus to form the Strait for which he was seeking.

Galvano attributes to Pedrarias, also, the discovery and conquest of the Pearl Islands in the Bay of Panama, which have been ascribed to Balboa. "In the beginning of the year 1515," he says, apparently on the authority of Peter Martyr, and also of Gomara, "the Governor, Pedro Arias de Avila, sent one Gaspar Morales with 150 men unto the Gulf of St. Michael, to discover the islands of Tararequi, Chiapes, and Tumaccus. There was a Cacique, Balboa's friend, which gave him many canoes or boats made of one tree, to row in, wherein they passed unto the Island of Pearls; the lord whereof resisted them at their coming to land. But Chiapes and Tumaccus did pacify him, in such order that the captain of the isle had them come unto his house, and made much of them, and received baptism at their hands, naming him Pedro, after the Governor's name; and he gave unto them, for this, a basket full of pearls, weighing an hundred and ten pounds; whereof some were as big as hazel nuts ; of $20,25,26$, or 31 carats, and every carat is four grains. There was given for one of them one thousand two hundred ducats." Pizarro, by the way, was with Morales on this expedition.

In that same year, 1515, Pedrarias also sent Gonsalvo de Badajos and Louis de Mercado, with one hundred and thirty 


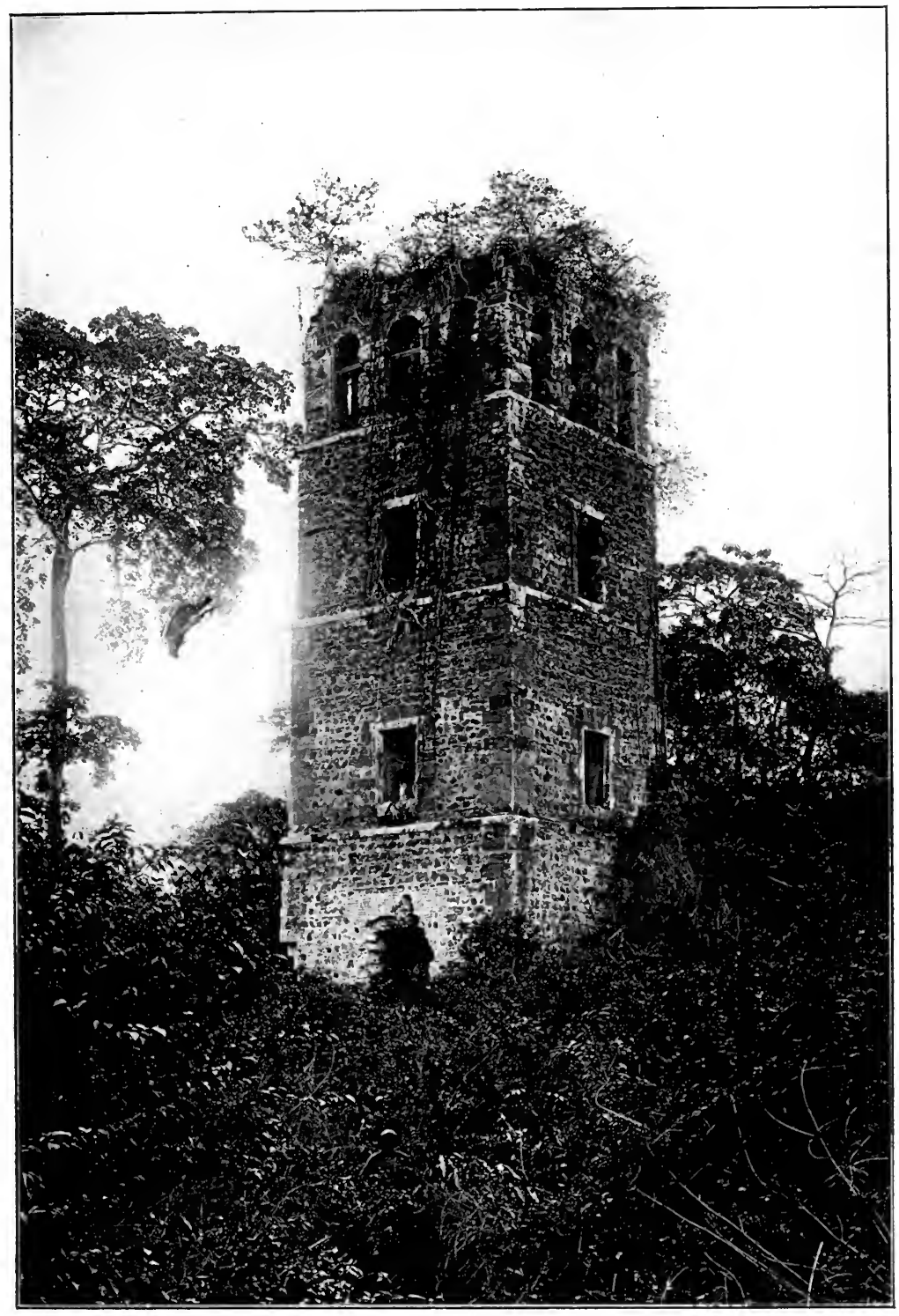

Calm, Photo.

THE REMAINS OF OLD PANAMA. 


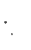


men, to make further explorations of the Isthmian regions. They went by sea from Darien to Nombre de Dios, and thence, with Indian guides, struck southward along the coast. They found much gold, and captured forty negro slaves who had apparently escaped from Portuguese masters, for Peter Martyr tells us they were branded with hot irons according to the Portuguese practice of those times. After a long march, however, the expedition came to grief at the hands of a native Cacique, named Parisa, who killed or captured nearly all of them. Thereupon Pedrarias sent out his son, Juan Arias de Avila, to inflict revenge upon the natives and to continue the explorations. Juan went westward to Cape de Guerra, and thence to Punta de Borico and to Cape Blanco. "They discovered 250 leagues, as they affirm," says Galvano, "and peopled the city of Panama."

Among those who worked under or with Pedrarias in his explorations were Gonzalez Gomez Espinosa, whose relative, the judge Gaspar Espinosa, supplied the funds for the conquest of Peru, and whose name is now conspicuously and most honourably borne in Panama; Fernando Ponce, Bartholomew Hurtado, and Gonsalvo de Badajos. A contemporary, but by no means a colleague, was his own kinsman, Gil Gonzalez Davila (de Avila). The last named, a man of fine character and high ability, arrived at the Isthmus in $\mathbf{1 5 1 7}$ with a commission to explore the west coast. Pedrarias wanted a monopoly of the undertaking himself, and accordingly refused to provide him with ships for the purpose, whereupon Gil took his two caravels apart at Porto Bello, carried them across the Isthmus, rebuilt them, and launched them into the Pacific; thus practically repeating Balboa's feat. This was in 1522. Gomara records that he "armed four ships in the Island of Tararequi, standing in the South Sea, with intent to discover the coast of Nicaragua, and especially a strait or passage from the South Sea into the North Sea."

He went up the Pacific Coast as far as the Bay de Salinas, and then went inland and discovered the great lake of which 
reports had been heard; his pilot, Andrea Niño, meantime going along the coast as far as Tehuantepec, vainly seeking the mysterious Strait. The principal native chieftain of that region, with whom Gil made a treaty, was named Nicarao, wherefore the Spaniards called the lake Nicaro Agua, or Nicaragua - the Sea of Nicarao. It was not until three years later, in the year 1525, however, that it was ascertained that this lake and the smaller Lake Managua, while connected with the Caribbean Sea by a river, were in no way connected with the Pacific, and therefore gave no solution of the "Secret of the Strait." There were ancient legends, which indeed survive to this day, among the natives of Central America, that once a waterway existed across that region, by way of the San Juan River, Lake Nicaragua, and Lake Managua, to the Bay of Fonseca, and that it was closed up by volcanic action.

Worthy of note in passing, too, are various others who in that time sought the "Secret of the Strait." Francisco Hernandez de Cordova, Hernando de Soto (afterward the discoverer of the Mississippi River), Christopher Morantes, and Lopez Ochoa, in 1517, explored the coast of Yucatan and the Gulf of Campeachy; and Juan de Grijalva in 1518 continued those explorations along the Mexican coast as far as Tampico; and Alvarez de Pineda made the circuit of the Gulf of Mexico. It was on the same errand, "to find a shorter route to Cathay," that France sent Giovanni da Verrazzano and Jacques Cartier, who explored the coasts further north from Hatteras to Labrador. Had it not been for the quest of the mythical Strait, there might have been no French colony planted in Canada. Meantime, the famous explorer Magellan joined in the search, sailing southward, and was of them all alone successful. He did indeed find a strait, and the only strait existing across the American continents; but that waterway, which bears his name, was much too remote in the far south to satisfy those who were seeking a short cut to the East Indies. The search at Darien therefore was continued, and was presently taken up by another 
famous man, to whom Keats, in the familiar lines already quoted, ascribed the great achievement of Balboa.

Hernando Cortez was, like Balboa, an impoverished nobleman of Estremadura. He went to Hispaniola in 1504, thence to Cuba, and in 1518 to Mexico, where his marvellous achievements easily gave him rank as the greatest of all the Spanish conquerors, and as second in fame to only Columbus himself among the discoverers and explorers of America. After the conquest of Mexico and Central America, he was in $\mathbf{1 5 2 3}$ directed by Charles $\mathrm{V}$ to engage in the quest of the Strait, and he entered upon that work with characteristic zeal. Already he had heard in Mexico of the Strait and had in 1520 tried to get from Montezuma information concerning it. Montezuma had pleaded ignorance, but had provided Cortez with maps and guides, with the aid of which Cortez had sent Diego Ordaz to explore the Huasacualco River, which Cortez called Quacalco and which is now known as the Coatzacoalcos. In 1521 Gonzalo de Sandoval had completed the conquest of the Isthmus of Tehuantepec, and had ascertained that no Strait existed in that region, though the Huasacualco River was utilised as a part of an overland route from the Atlantic to the Pacific.

But in 1523 Cortez was still hopeful of discovering the elusive Strait, and, what was more to the purpose, he was convinced of the desirability and the practicability of creating such a Strait if one were not found to exist. To find a way or make one was his strenuous rule. How intent he was, and how important he deemed the quest, were shown in a letter which he wrote to the King in 1524, saying that he had determined to send five ships upon the strait-seeking errand, and expected the enterprise would cost him more than ten thousand pesos in gold; a heavy expense, yet one which he would gladly incur, because, he said, "If the Strait is found, I shall hold it to be the greatest service I have yet rendered. It would make the King of Spain master of so many lands that he might call himself the Lord of the whole world." He also sent out a fleet to search the Pacific Coast 
for that end of the Strait, with orders to keep on southward until it reached the scene of Magellan's discovery, while those on the Caribbean side were to examine the coast all the way northward to Labrador. "Thus," said the conqueror of Mexico, "on the one side or the other I shall not fail to solve the secret." He spoke in the same letter to Charles V of California and other lands on the Pacific Coast, as of great value and well worth exploring; "but," he added, "being well aware of the great desire of your Majesty to know the secret of this Strait, and of the great advantage the crown would derive from its discovery, I postpone all other schemes and interests, some of them of the highest moment, to pursue this object alone."

"In this year 1524," says Galvano, quoting the "General History" and "Conquest of Mexico" of Gomara, "Cortez sent one Christopher de Olid with a fleet of the Island of Cuba, to receive the victuals and ammunition which Alonzo de Contreras had prepared, and to discover and people the country about Cape de Higueras and the Honduras; and to send Diego Hurtado de Mendoza by sea, to search the coast from thence even unto Darien, to find out the Strait which was thought to run into the South Sea, as the Emperor had commanded. He sent also two ships from Fanuco, to search along the coast unto Florida. He commanded also certain brigantines to search the coast from Zacatullan to Panama. This Christopher de Olid made a league with Diego Velasquez against Cortez. He took Gil Gonzalez de Avila prisoner, and killed his nephew and the Spaniards that were with him, and showed himself an enemy to Cortez, who had spent in that expedition 30,000 Castellans of gold to pleasure him." The treason of Christopher de Olid and the hostility of Pedrarias compelled Cortez to turn his attention away from the Strait. In 1532, however, he sent Diego Hurtado de Mendoza from Acapulco 200 leagues down the Pacific Coast, without making any important discovery.

At about this time, indeed, men began to doubt the existence of a natural waterway, and to consider the practicabil- 
ity of constructing an artificial one. The pioneer in this ambitious scheme, after Cortez himself, appears to have been Alvaro de Saavedra Ceron, who had been a follower of Balboa, and later became one of the most faithful and efficient lieutenants of Cortez, whose cousin he was. He was a brother of the Ferdinand de Saavedra who was at the head of the colony founded by Cortez at Truxillo, in 1525. As early as 1517, Gomara tells us, he turned his attention to the secret of the Strait. Doubting the existence of a natural strait, he recalled the narrowness and low elevation of the Isthmus at Panama, where he had been with Balboa. In 1529, according to Galvano, he prepared plans for the construction of a canal at that point, and was about to lay them before the King of Spain when death ended his promising career.

It is related that Cortez, learning that Magellan's ships had passed through the Patagonian Strait into the Pacific Ocean, sent three ships to join that expedition and to go with it to the Moluccas, and open up navigation between Mexico and the East Indies. "There went as Governor in those ships, one Alvaro de Saavedra Ceron, cousin to Cortez, a man fit for that purpose." Saavedra reached the Moluccas in 1528, and in June of that year set out to return to Mexico, but was detained at the Island of Tidore until the next year. In 1529 he again essayed to return. He visited Papua and the Marquesas Islands, and then "perceiving that the time and weather were then somewhat better for his purpose, made sail toward the Firm Land and city of Panama, where he might unload the cloves and merchandise which he had, that so in parts it might be carried four leagues to the river of Chagres, which they say is navigable, running out into the North Sea not far from Nombre de Dios, where the ships ride which come out of Spain; by which ways all kinds of goods might be brought unto them in shorter time and with less danger than to sail around the Cape of Bona Speranza. For, from Molucea unto Panama, they sail continually between the tropics and the line; but they never found wind to 
serve that course, and therefore they came back again to Molucca very sad, because Saavedra died by the way; who, if he had lived, meant to have opened the land of Castilla del Oro and New Spain from sea to sea. Which might have been done in four places, namely, from the Gulf of San Miguel to Uraba, which is 25 leagues; or from Panama to Nombre de Dios, being 17 leagues distance; or through Xaquator, a river of Nicaragua, which springeth out of a lake three or four leagues from the South Sea and falleth into the North Sea. The other place is from Tehuantepec through a river to Verdadera Cruz, in the Bay of Honduras, which might also be opened in a strait. Which if it were done, then they might sail from the Canaries unto the Moluccas, under the climate of zodiac, in less time and with much less danger than to sail about the Cape of Bona Speranza or by the Strait of Magellan, or by the northwest. And yet if there might be found a strait there, to sail into the Sea of China, as it hath been sought, it would do much good."

Thus, according to Gomara and Galvano, at this early date the four major canal routes, so much discussed and surveyed in our own time, were indicated: Darien, Panama, Nicaragua, and Tehuantepec; and the superiority of one of them over the routes by the Cape of Good Hope, by the Strait of Magellan, and by the problematic North West Passage, was appreciated. Meantime, it is of curious interest to observe, there arose at the very outset the long maintained rivalry between Panama and Nicaragua for the location of the canal. While Saavedra was planning at Panama, Pedrarias turned for a time from the congenial work of torturing and massacring the natives of Nicaragua, and of reducing a population of $2,000,000$ to 200,000 , and sent his lieutenant Estete to establish an overland traffic route from the lakes to the Pacific, and also to survey a route for a canal. It does not appear, however, that any definite plans for such a canal were at that time made, and happily in 1530 Pedrarias died.

Charles V continued earnestly and urgently in his desire 
and his efforts for a waterway across the Isthmus, and in 1534 directed Andagoya, the Governor of Costa Firme, as the Panama region was then called, to make surveys in the valley of the Chagres River and elsewhere, to determine the most practicable route. That functionary seems to have been, in that matter at least, an unworthy successor of Balboa and Cortèz, for he showed no stomach for the undertaking and soon declared it to be quite impossible. Others were more resolute and optimistic. The historian Gomara, in his official "History of the Indies," dedicated to Charles V, in 1551, unhesitatingly declared a canal to be practicable at any of the four places named by Galvano. He recognised the obstacles, but refused to regard them as insurmountable. "There are mountains," he wrote, "but there are also hands. Give me the resolve, and the task will be accomplished. If determination is not lacking, means will not fail; the Indies, to which the way is to be made, will furnish them. To a King of Spain, seeking the wealth of Indian commerce, that which is possible is also easy." But not even with this eloquent encouragement was Charles $\mathrm{V}$ able to effect the enterprise, but he was compelled to leave it as unfinished business to his successor.

Philip II at first took up the matter hopefully. In $\mathbf{1 5 6 7}$ he sent an engineer, Batista Antonelli, to survey the Nicaragua route, but got from him as a result an unfavourable report, of difficulties too great to be overcome. Soon after this, however, he reversed his policy. The difficulties reported by Antonelli discouraged him, the rising power of the English at sea made him fear lest he should not be able to control the canal if one were constructed, and finally the reactionary bigotry which so completely dominated him and dwarfed his statesmanship led him to conclude-according to the Jesuit historian, José de Acosta-that it would be contrary to the Divine Will to unite two oceans which the Creator of the world had separated, and that to attempt so impious a deed would surely provoke some appalling catastrophe. Accordingly he not only abandoned all schemes for 
a canal, but he forbade the making of them, decreed that no canal should be constructed, and imposed the penalty of death upon any one who should make known, or should attempt to seek, a better route across the Isthmus than the overland trail from Porto Bello to Panama; especially interdicting attempts on the Mandingo or Atrato River. Mr. W. L. Scruggs, in his "History of the Colombian and Venezuelan Republics," quotes an official document, written in 1743, by Dionysius Alceda, Governor of Panama, in which reference was made to this prohibition of navigation of the Atrato River, "owing to the facility it affords for passing from the Atlantic to the Pacific Ocean," and which positively declared that "this passage was effected in the year 1679 by the arch pirates John Guartem, Edward Blomar, and Bartholomew Charles."

There was indeed cause for Philip to fear the maritime might of England. The Islands and the Peninsula were nominally at peace. But English privateers, freebooters, and buccaneers began to harry the treasure fleets of Spain. About 1570 they became such a terror in the Caribbean that Spanish trade was practically driven from the Isthmus to the roundabout route through the Strait of Magellan. Then in 1579 Francis Drake went to the latter scene and played havoc with the Spanish ships in the South Sea, so that a return to the Isthmian route was deemed advisable; Nicaragua, however, being chosen instead of Panama. In those times there was no thought of canal building, and the task of holding the overland trail against the freebooters was sufficient to tax the power and ingenuity of Spain. For a generation the plan of an Isthmian waterway slumbered and slept; to be revived in 1616, when Philip III directed Diego Ferdinand de Velasco, Governor of Castilla del Oro, to make surveys for a canal by way of the Gulf of Darien and the Atrato River-the very route which Philip II had most forbidden. Velasco's report has been lost to the world, and its nature is unknown, but its results were nothing.

The pernicious activities of the freebooters and buccaneers 
were meantime maintained, and an actual state of war between England and Spain added to the embarrassments of the latter. In 1655 the English seized the Island of Jamaica, and vigorous efforts were made to establish an English foothold in Central America. Wallace indeed had established himself in Belize, as early as 1638. Other settlements were made on the coasts of Honduras and Nicaragua, and a party of adventurers under Edward David went up the San Juan River, stormed Fort San Carlos, sacked Leon, and explored the shores of Lake Nicaragua. Thus for the first time the English were led to realise the magnitude of that sheet of water and its potential value as part of a transit route from sea to sea. From that time dated the persistent English attempts to get control of Nicaragua.

The Spanish rebuilt Fort San Carlos, only to have it again attacked by a second English expedition. Then, in a desperate effort to baffle the English, a Spanish engineer, Fernando de Escobedo, determined to make the San Juan River more difficult for them to navigate. He accordingly opened the southern branch of that river, the Rio Colorado, through which to divert some of the waters of the main stream. In that mad enterprise he succeeded beyond expectation, and the result in time was the ruin of the good natural harbour at Greytown. The freebooters no longer ventured to go up the river, but they blockaded its mouth, and when, in 1685, L'Olonnais entered the Bay of Fonseca, and thence marched to Granada, and sacked it, the Nicaraguan route as a highway of commerce became for a time a thing of the past.

Nor did the British neglect the lower Isthmus, of Panama and Darien. That worst of all buccaneers, the Welshman Sir Henry Morgan, in 1671 seized and sacked Porto Bello, and then marched across the Isthmus and did the same infernal work at Panama, so effectively that the city was never rebuilt on the old site. In that nameless tragedy Spanish commerce across that Isthmus was all but destroyed, and it received its death blow nine years later, when another British freebooter, Captain Sharpe, landed in Caledonian Bay, 
marched over to the Tuyra River, and destroyed the town of Villa Maria. But this latter expedition had a still more important result than such harrying of the Spaniards. One of Sharpe's companions was Lionel Wafer, an ambitious, if not an entirely trustworthy, observer. On his return to England, he reported that in that part of the Isthmus there was no mountain range at all. There were only detached hills, among which were broad, low valleys, extending across the narrow Isthmus from sea to sea.

This report attracted the attention of that extraordinary man, William Paterson, of Scotland, the founder of the Bank of England, and he, about 1694, conceived the grandiose scheme of planting on the Isthmus of Darien a British colony, which should, in his own words, secure for Great Britain "the keys of the universe, enabling their possessors to give laws to both oceans, and to become the arbiters of the commercial world." Thus did this canny Scot repeat the glowing estimates of Cortez and Gomara. He energetically set about the execution of the project. "The Company of Scotland Trading to Africa and the Indies" was organised by him, and was incorporated by the Scotch Parliament. A large party of colonists was recruited, and sailed from Leith, 1,200 strong, on July 26, 1698. It arrived at the Isthmus on November 4, and established itself at Puerto Escoces, or Scotch Port, in Caledonian Bay, founding the "cities" of New Edinburgh and New St. Andrews, near the site of Pedrarias's Aclas, where Balboa was put to death. Unfortunately for the enterprise, the situation chosen was a most unhealthful one, the English and Dutch East India Companies were bitterly and effectively opposed to it, and exerted much political and commercial influence against it, the English and Dutch colonists in the West Indies were forbidden to trade with the new company, and the Spaniards and Indians were openly hostile. In June, 1699, the discouraged colonists abandoned the place and departed, but two months later were succeeded by another company. The latter had scarcely got settled on shore when word came that 
a Spanish force at Tubacanti, on the Santa Maria River, was preparing to attack it in concert with a fleet. The colonists hastened to anticipate the attack with a march against the Spaniards, whom they defeated and dispersed, but on returning to their "city" they found themselves confronted by a Spanish fleet too strong to be successfully resisted. Accordingly they evacuated and abandoned the place, in April, 1700 .

That was the end of the whole enterprise, save that the names of Caledonian Bay and Puerto Escoces remained upon the map, and that Paterson, after personal survey of the Isthmus, was led to record his conviction of the practicability of a canal. In his "Central America in 1701," he wrote that if such interoceanic communication were established, through its ports would flow at least two-thirds of the commerce of the East Indies, amounting to not less than $\$ 150$,000,000 a year; while the time and expense of the voyage to China and Japan, and the richest parts of the East Indies, would be lessened by more than one-half, and the consumption of European commodities in those countries would soon be more than doubled and thereafter would be yearly increased. There is interesting food for speculation in the reminder that Paterson's enterprise was undertaken only a few years before the union of England and Scotland, which occurred in 1707, and in the inquiry of what might have happened had that union been effected before his undertaking, or had his venture been postponed until after the union. In such case, it is to be assumed, there would have been no effective English opposition to his colony, but on the contrary it would have received earnest support from English commerce and from the English army and navy. With such support, it would probably have been successful. The Isthmus of Panama would have become an English colony, and generations ago an Isthmian canal might have been successfully constructed under the British flag.

With the final collapse of Paterson's enterprise, the whole scheme of an Isthmian canal practically lapsed for a century. 
Charles Maire de la Condamine, the astronomer, was sent by the French government in $\mathbf{1 7 3 5}$ to measure an arc of the meridian on the plain of Quito, and on his return in 1740 he addressed the French Academy of Sciences in behalf of a canal at Nicaragua, which he declared to be quite practicable. He was accompanied across the Isthmus by Don George Juan, and by Don Antonio de Ulloa, the distinguished Spanish scientist and statesman who was afterward governor of Louisiana in 1764 ; but competent as the expedition was, it appears to have made only most superficial examinations of the ground. During the latter half of the eighteenth century a few sporadic and futile essays were made to select a route. Augustin Cramer and Miguel del Corral surveyed the Tehuantepec route, and Ysasi, Muestro, and Alexandre the Nicaragua route, but their labours were fruitless. The illustrious Horatio Nelson led an expedition to Nicaragua in 1780 , to seize the lakes and control the interoceanic route, but did little more than permanently impair his own health. The next year Manuel Galisteo surveyed the Nicaragua route and reported to the Spanish government that it would be impossible to construct a canal from the lakes to the Pacific. In 1788 a Spanish engineer officer, Manuel Milla, was sent by his government over the Caledonian Bay route, which Sharpe and Wafer had traversed long before, and which Paterson had surveyed. His report was even more favourable than Wafer's had been and must be regarded as grossly exaggerating the ease with which a canal could be constructed there. The native tribes were so troublesome, however, as to keep the Spanish government from making any further efforts in that region. Moreover, both war and science were preparing to open an entirely new era in the history of the Isthmus and of interoceanic trade. 


\section{CHAPTER III}

\section{EARLY PLANS AND RIVALRIES}

W ITH the opening years of the nineteenth century a new era in Isthmian exploration and in canal schemes was begun. Its foremost pioneer was the great scientific genius Alexander von Humboldt, who spent the years from 1799 to 1804 in Mexico (then still called New Spain), Central America, and the northwestern states of South America. His scientific researches were of incalculable value, but none of them surpassed in interest and suggestion his observations upon the feasibility and desirability of constructing an artificial waterway between the Atlantic and Pacific oceans. In his "Political Essay on New Spain" he described the Central American Isthmus, the "barrier against the waves of the Atlantic," as having been for many ages "the bulwark of the independence of China and Japan." Only by making a navigable channel across that Isthmus, he believed, could "any great changes be effected in the political state of Eastern Asia." Such an undertaking was "calculated to immortalise a government occupied with the true interests of humanity." Of the practicability of it he had no doubts. No fewer than nine routes were considered by him, for waterways between the two oceans. The first, beginning at the north, involved the Mississippi, Missouri, Peace, and Columbia rivers, with a passage over the "Stony" or Rocky Mountains, which latter, he was informed, were in some places as much as 3,520 feet high ! The second was by way of the RioBravo, or Rio Grande del Norte, in Mexico, and the Rio Colorado, entering the Gulf of California. The third was at the Isthmus of Tehuantepec, Mexico, making use of the Coatzacoalcos River. The fourth was at Nicaragua, where 
the great lakes appeared to him to offer special facilities for navigation, as did also the San Juan River. He appears to have known, as he certainly should have known, that the San Juan River flows from the lakes to the Caribbean Sea, though strangely enough one of his maps of that region indicates it as flowing into the lakes, and a separate river, the Colorado, flowing into the Caribbean, with a mountain range between them.

The fifth route was that at Panama, from the City of Panama to Venta de Cruces, at the head of navigation on the Chagres River, near Obispo and Gamboa, on the present railroad and canal route. To this he devoted most attention of all. "That canal," he said, "would have to pass through a hilly tract, of the height of which we are completely ignorant. . . . It is very astonishing that in crossing the Isthmus neither La Condamine nor Don George Juan and Ulloa had the curiosity to observe their barometer, for the sake of informing us what is the height of the most elevated point on the route. . . However, it appears beyond a doubt that we find the principal Cordillera, or, rather, a range of hills that may be regarded as a prolongation of the Andes of New Granada, between Cruces and Panama. It is from them that the two oceans are said to be discernible at the same time, which would only require an absolute height of 290 metres. However, Lionel Wafer complains that he could not enjoy this interesting spectacle. He assures us that the hills are separated by valleys which allow free course for the passage of the rivers. If this be true, we might believe in the possibility of a canal from Cruces to Panama, of which the navigation would be interrupted by only a very few locks." The 290 metres, or 951 feet, suggested by Humboldt, was really more than three times the actual height of the loftiest hill on the route ultimately selected for the Panama Canal.

After further consideration of the Panama route, Humboldt continued: "It appears to me that the expectation of a canal of seven metres in depth and from 22 to 28 metres in 


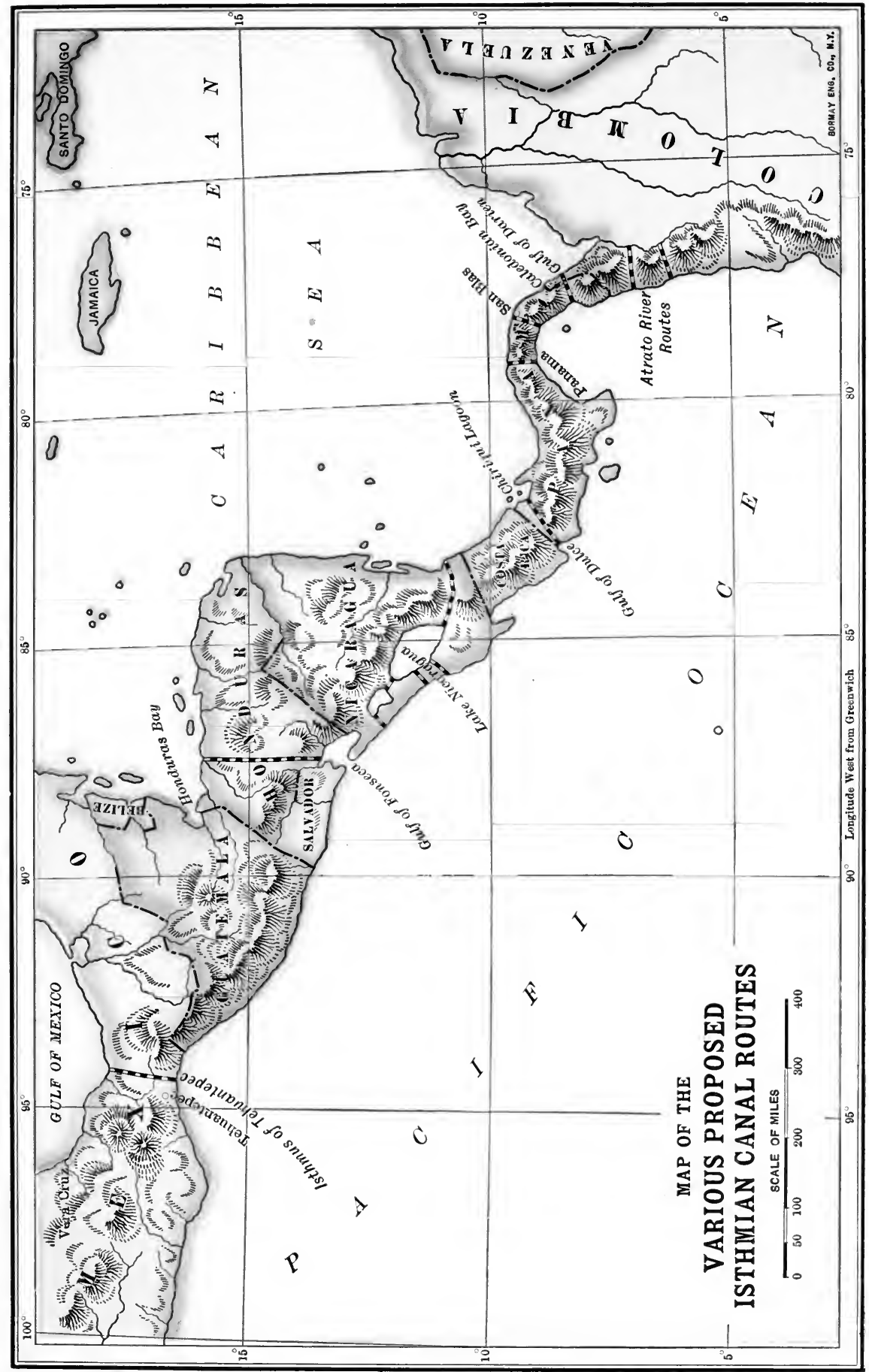


-

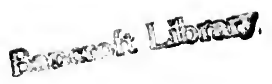


breadth, which, like a passage or strait, should go from sea to sea and admit the vessels which sail from Europe to the Indies, ought to be completely abandoned. The elevation of the ground would force the engineer to have recourse either to subterraneous galleries, or to the system of sluices; and the merchandises destined to pass the Isthmus of Panama could only thereafter be transported in flat-bottomed boats unable to keep the sea. . . . Supposing, then, that this canal were cut, the greatest number of these vessels would probably continue their voyage round Cape Horn. . . . It would be otherwise with the products of Western America, or with the goods sent from Europe to the coast of the Pacific Ocean. These would cross the Isthmus at less expense and with less danger." But he urged as most desirable good roads for camel traffic at Tehuantepec and at Panama.

Humboldt's sixth route for a canal was that from Cupica, on the Pacific, by way of the Napipi and Atrato rivers to the Gulf of Darien. "We might almost say," he wrote, "that the ground between Cupica and the mouth of the Atrato is the only part of all America in which the chain of the Andes is entirely broken"-in which he was much in error. It will be observed that he ignored the Caledonian and Mandingo routes, although on one of his maps the Bay of Mandingo is so enormously exaggerated in size as to make the Isthmus at that point scarcely more than one-third its width at Panama. His seventh route revived the old legend of the "Secret of the Strait," in the form already cited in the records quoted by Mr. Scruggs. This route was through the Ravine of Raspadura, uniting the sources of the Noanama or San Juan, and the Quito, Andagega, Zitara, and Atrato rivers. "A monk, curé of the village of Novita," wrote Humboldt, "employed his parishioners to dig a small canal in the Ravine de la Raspadura, by means of which, when rains are abundant, canoes loaded with cacao can pass from sea to sea. This interior communication has existed since 1788, unknown in Europe." The eighth route was by way of the Rio Callaga, in Peru, across the Andes to the headwaters of the Amazon. 
The ninth was from the Gulf of St. George across Patagonia. Five of these routes, the second, third, fourth, fifth, and sixth, were seriously considered and commended by him, as worthy of practical and immediate investigation. To him they all seemed about equally desirable. "They are," he wrote in his "Personal Narrative," "at the centre of the New Continent, at an equal distance from Cape Horn and the Northwest Coast. . . . Opposed to each, on the same parallel, are the seas of China and India, an important circumstance in latitudes where the trade winds prevail. All are easily entered by vessels coming from Europe and the United States."

The observations and conclusions of Humboldt gave inspiration upon the same theme to another great genius, John Wolfgang Goethe. In the record of his "Conversations with Eckermann and Soret," under date of February 21, 1827, it is related:

"He spoke much, and with admiration, of Alexander von Humboldt, whose work on Cuba and Colombia he had begun to read, and whose views as to the project for making a passage through the Isthmus of Panama appeared to have a particular interest for him. 'Humboldt,' said Goethe, 'has, with a great knowledge of his subject, given other points where, by making use of some streams which flow into the Gulf of Mexico, the end may perhaps be better attained than at Panama. All this is reserved for the future and for an enterprising spirit. So much, however, is certain, that if they succeed in cutting such a canal that ships of any burden and size can be navigated through it from the Mexican Gulf to the Pacific Ocean, innumerable benefits will result to the whole human race, civilised and uncivilised. But I should wonder if the United States were to let an opportunity escape of getting such a work into their own hands. It may be foreseen that this young State, with its decided predilection to the West, will, in thirty or forty years, have occupied and peopled the large tract of land beyond the Rocky Mountains. It may, furthermore, be foreseen that along the whole coast of the Pacific Ocean, where nature has already formed the most capacious and secure harbours, important commercial towns will gradually arise, for the furtherance of a 
great intercourse between China and the East Indies, and the United States. In such a case it would be not only desirable but almost necessary that a more rapid communication should be maintained between the Eastern and Western shores of North America, both by merchant ships and men-ofwar, than has hitherto been possible with the tedious, disagreeable, and expensive voyage around Cape Horn. I therefore repeat that it is absolutely indispensable for the United States to effect a passage from the Mexican Gulf to the Pacific Ocean: and I am certain that they will do it. . . . I should like to see another thing,-a junction of the Danube and the Rhine, but this undertaking is so gigantic that I have grave doubts of its completion, particularly when I consider our German resources. And, thirdly and lastly, I should wish to see England in possession of a canal through the Isthmus of Suez. Would I could live to see these three great works! It would well be worth the trouble to last some fifty years more for the very purpose!"

Both of these illustrious men erred as prophets: Humboldt in saying that only by cutting the Isthmus could the political status of Eastern Asia be changed, and Goethe in thinking the Danube-Rhine canal more remote and doubtful than the Isthmian: though we must regard with admiration the latter's forecast of the American occupation of the Pacific Coast and the demand for an Isthmian canal as a connecting link between our east and west coast lines, as well as his suggestion of British possession of the Suez Canal.

At a date between the exploration of Humboldt and the prophecies of Goethe, however, statesmen and engineers began to busy themselves with practical schemes for canal construction. In 1814 the Spanish Government, feeling its need of doing something to restore the waning prestige of Spain and to renew its failing hold upon its American colonies, decreed the construction of an Isthmian canal. Before any steps could be taken to make the decree effective, however, the Central and South American provinces declared and established their independence. The first to do so was the Colombian confederation, which comprised Venezuela (the present republic of that name), Quito (the present republic 
of Ecuador), and New Granada (the present republic of Colombia). These provinces, under the lead of Miranda and Bolivar, began their struggle for independence in 1811, and in 1821 their efforts were crowned with success. A year later, in 1822, the Isthmian provinces of Panama and Veraguas (the present republic of Panama) followed the example, asserted their independence, and allied themselves with New Granada. The Central American provinces came next. In 1821 the independence of Guatemala was proclaimed and the other provinces joined the movement the next year. For a time Mexico, under the Emperor Iturbide, tried to annex them, but upon Iturbide's defeat by Santa Anna in 1823 the five republics-Guatemala, Honduras, Salvador, Nicaragua, and Costa Rica-became independent and formed a short-lived federal union.

Very soon thereafter the governments of those countries began in their turn to urge the construction of a canal. The first Central American envoy to the United States, Antonio José Canaz, in 1825, immediately upon his arrival at Washington, addressed a written communication to the American Government, inviting it to participate with Central America in the enterprise and in the advantages which its execution would produce, and to that end to enter into a treaty which would perpetually secure the possession of the canal to the two nations. Our Secretary of State, Henry Clay, was doubtless in sympathy with this proposal, but could scarcely commit the Government to it offhand. He therefore assured Señor Canaz "of the deep interest taken by the Government of the United States in an undertaking so highly calculated to diffuse an extensive influence on the affairs of mankind," and instructed Mr. Williams, the United States envoy to Central America, to investigate the matter and to report all possible data concerning the practicability of constructing a canal at Nicaragua. At the same time commissioners from New Granada were in Washington, asking the United States to participate in the first Pan-American Congress, at Panama, in June, 1826. Fearing that Congress would discuss 
the question of human slavery, and would adopt resolutions in favour of emancipation, the United States Senate adopted a resolution to the effect that this country should not be represented there, save in a diplomatic way, and should not enter into any alliance with Central and South American States. Mr. Clay nevertheless officially declared to the envoys that the question of a canal might properly be discussed at the Congress, and that such a canal, if ever it should be constructed, would be of interest to all the world, while its greatest benefits would accrue to this continent.

In 1825 the Congress of the United States of Central America ordered the construction of a canal at Nicaragua, and gave to a promoter named Beniski a concession for the enterprise. This concession was afterwards transferred to an American company, known as the Central American and United States Atlantic and Pacific Canal Company, among the members of which were De Witt Clinton, the builder of the Erie Canal; Monroe Robinson, President of the Bank of the United States; and Stephen Van Rensselaer and A. H. Palmer, of New York City. A second scheme was the outcome of the Congress of Panama, and was organised by General Werweer, of Belgium, who endeavoured to organise a Nicaragua Canal Company. He secured from the Nicaragua Government, in 1829, a canal concession for the King of Holland, and a monopoly of the coasting trade. This latter provision was offensive to the Monroe Doctrine, and threatened unpleasant complications; but the revolution in the Netherlands and the secession of Belgium, the next year, caused the whole project to be abandoned.

A third scheme was fathered by Simon Bolivar, then President of New Granada, who gave to a Frenchman, Baron Thierry,-a picturesque adventurer, who had got some halfsavage Maoris to elect him "King of New Zealand,"-a franchise for a canal at Panama. The next year, finding Thierry was unable to proceed with the work, Bolivar undertook it himself. His two officers, Lloyd, a British engineer, and Falcmar, a Swedish captain, surveyed the route, but 
made the curious error of reporting that there was three feet difference between the mean levels of the two oceans. This error was generally accepted as a fact, and was enlarged upon, until it was widely believed that the Pacific Ocean was from 10 to 20 feet higher than the Caribbean Sea. The LloydFalcmar route was, however, on the whole singularly well chosen, and was afterwards substantially adopted for the Panama Railroad. This error concerning the level of the two oceans was not original with or confined to Lloyd and Falcmar. Many years before Humboldt had referred to the "vulgar opinion" existing in every age and clime, that of two seas, separated by an isthmus, one was invariably higher than the other. Strabo mentioned that in his time the Gulf of Corinth was believed to be higher than the Egean Sea, and that thus it would be dangerous to make a canal across that isthmus. In America, Humboldt recalled, the South Sea or Pacific Ocean had long been supposed to be higher than the Caribbean. This theory had been combated by Don George Juan, however, who found the barometric readings the same at Panama and at the mouth of the Chagres River. A French engineer, on the other hand, had reported that the Red Sea was 38 feet higher than the Mediterranean. Humboldt's own observations made him believe that if there was a difference between the Pacific and the Caribbean, it could not possibly be more than from 19 to 22 feet, but he did not believe, as he afterward declared, that there was any difference at all.

Another interesting speculation of Humboldt's related to the possible effects which the construction of an Isthmian canal at tide level might have upon the currents of the ocean. "We cannot doubt," he said, "that if the Isthmus of Panama were once burst, the current of rotation, instead of ascending toward the Gulf of Mexico and issuing through the Bahama Channel, would follow the same parallel from the coast of Paria to the Philippine Islands. The effect of this opening, or new strait, would extend much beyond the Banks of Newfoundland, and would either occasion the disappear- 
ance or diminish the celerity of the Gulf Stream." But such a result could not follow the construction of a canal with locks, and probably would not follow the construction of one at sea level on account of its small size.

That the United States should become interested in the Isthmian canal project was, as Goethe observed, natural and inevitable. Henry Clay, the Secretary of State, as we have remarked, in 1826 ordered an official survey of the Nicaragua route, and in the next three or four years several canal schemes were put forward in this country to no avail. The United States Senate in $\mathbf{1 8 3 5}$ adopted a resolution for the construction of a canal at Nicaragua, and President Jackson sent Charles Biddle to the Isthmus to make surveys and negotiations; but Biddle, instead of visiting Nicaragua, went to Panama, and privately secured Thierry's concession, whereupon he was repudiated by the United States Government, and the whole business lapsed. Next the United States of Central America took up the work again, President Morazan sending two engineers, Bailey and Bates,-the former having been the agent of an English corporation,- - to survey the Nicaragua route, but the chief result was a twelve years' war with the Mosquito Indians, and the dissolution of the Central American Government ended the enterprise.

Horatio Allen, the engineer of the Croton Aqueduct, in New York, in 1837 aroused American interest in the scheme, and got Mayor Aaron Clark, of New York City, and other leading citizens of New York and Philadelphia to prepare a plan for the Nicaragua Canal, and to present a memorial to Congress on the subject, in January, 1838. In this memorial it was asked that the Central American States, the United States, and all the great powers of Europe, should unite in opening a ship canal across the Isthmus, and that the United States should at once begin the preliminary surveys. The outcome of this was the adoption of a non-committal resolution by Congress, simply expressing deep interest in the project. Captain Edward Belcher, in 1838, made 
explorations at Nicaragua, and proposed a canal with its Pacific outlet in the Bay of Fonseca. In 1839 the United States Government sent John L. Stephens on a confidential mission to Central America to do the work which Biddle had failed to do. He recommended the construction of a canal on the Nicaragua route, and estimated its cost at $\$ 25,000,000$, but added that the country was at that time too unsettled and revolutionary for capital to risk investment in it.

In the political chaos which then prevailed, various wild schemes were launched. Guatemala sent ecclesiastical envoys to Rome, to get the Pope to patronise the canal scheme. New Granada gave vast concessions to a French speculative scheme, whose promoters professed to have found, by Morel's surveys, a route between Porto Bello and Panama with no elevation above 10 1-2 metres. This preposterous fiction was pushed by Messrs. Salomon \& Co., until Guizot, for Louis Philippe, sent Napoleon Garella to find out the truth. He reported that the elevation of the lowest pass was more than 115 metres. At about this time Nicaragua and Honduras also tried, through a French promoter, to get French capital interested in their routes.

In time the French Government became further interested in the matter, and upon the strength of the surveys made by Garella and Courtines was inclined to attempt the construction of a canal at Panama, which should have 25 locks, be navigable by vessels of 600 tons only, and cost $\$ 40,000,000$. In support of this scheme Guizot read in the French Chamber of Deputies, on June 10, 1843, a letter which Baron von Humboldt had written, on August 1, 1842, to Salomon, the French promoter already mentioned. In this letter Humboldt referred to the advice which he had formerly given to the British Embassy at Paris, that a competent engineer should be sent to explore the various routes across the Isthmus, and expressed regret at the failure to act upon his advice. "I am," he wrote, "sorry to learn that you are no further advanced in your interesting undertaking than you 
were when I had the pleasure of seeing you in my last visit to Paris. Twenty-five years have now elapsed since the project of a communication between the two oceans, either by the Isthmus of Panama, the Lake of Nicaragua, or the Isthmus of Cupica, has been proposed and discussed topographically; but nothing toward realising this project has even yet been begun. I should have thought that the English Embassy might have found the means of inspiring confidence by proposing to send a scientific engineer to study the valley between the two seas along which the canal might be cut to the western part of the port of Chagres. Be persuaded that those persons who make use of the authority of my name to support the idea that the two seas are not on a level, do so only in order to excuse themselves from engaging in the undertaking."

In 1844, Francisco Castellon, of Nicaragua, disgusted with the unsettled political state of Central America, went to France as a Nicaraguan envoy, to try to persuade Louis Philippe to establish a protectorate over Nicaragua, and to undertake the construction of a canal. The King paid little attention to him, but Louis Napoleon Bonaparte, then a State prisoner in the fortress of Ham, became deeply interested in the scheme. That "man of destiny" began to regard it, because of the old concession to Baron Thierry, as properly a French enterprise, and while yet in prison secured from the Nicaraguan Government, in 1846, a concession and franchise for a company to construct the "Canale Napoléon de Nicaragua." So interested was he in the scheme that he informed the French Government of it and begged to be released from prison, in order that he might carry it out. $\mathrm{He}$ promised that if he were released he would proceed to America, and trouble France no more, but the Government refused to grant his request. In the same year, however, he escaped from Ham, and went to London, where he published a pamphlet on the subject of an Isthmian Canal, advocating a route in Nicaragua by way of the San Juan River and the two lakes, to Realejo. In this he said: 
"The geographical position of Constantinople rendered her the Queen of the ancient world. Occupying, as she does, the central point between Europe, Asia, and Africa, she could become the entrepot of the commerce of all these countries, and obtain over them immense preponderance; for in politics, as in strategy, a central position always commands the circumference. This is what the proud city of Constantine could be, but it is what she is not, because, as Montesquieu says, 'God permitted that the Turks should exist on earth, as a people most fit to possess uselessly a great empire.' There exists in the New World a State as admirably situated as Constantinople, and we must say up to this time as uselessly occupied. We allude to the State of Nicaragua. As Constantinople is the centre of the ancient world, so is the town of Leon the centre of the New, and if the tongue of land which separates its two lakes from the Pacific Ocean were cut through, she would command by virtue of her central position the entire coast of North and South America. The State of Nicaragua can become, better than Constantinople, the necessary route of the great commerce of the world, and is destined to attain an extraordinary degree of prosperity and grandeur. France, England, and Holland have a great commercial interest in the establishment of a communication between the two oceans, but England has, more than the other powers, a political interest in the execution of this project. England will see with pleasure Central America becoming a powerful and flourishing State, which will establish a balance of power by creating in Spanish America a new centre of active enterprise, powerful enough to give rise to a feeling of nationality, and to prevent, by backing Mexico, any further encroachments from the north."

This essay attracted much attention in Great Britain and elsewhere in Europe. But two years later the revolution in France gave its author his opportunity to become President and to plot for the establishment of the Second Empire, and the canal was forgotten by him in those larger ambitions. 


\section{CHAPTER IV}

\section{THE CLAYTON-BULWER EPISODE}

In order fully to understand the British claims in Central America, we must turn back nearly two and a half centuries. In the middle of the seventeenth century British freebooters established themselves at various points on the coast of Honduras and Nicaragua, where they presently, in order to secure Government countenance and protection, abandoned their piratical ways and became bona fide colonists, developing a large trade in the fine lumber and dyewoods which there abounded. In 1670 a treaty between Great Britain and Spain confirmed all the British in and about the West Indies forever in possession of all the lands they then actually held. The Spanish Government two years later declared that this applied only to those in Jamaica and other islands, and not to those on the mainland, whom it regarded as freebooters and pirates, while the British Government insisted that it did apply to the lumber colonists of Honduras and Nicaragua.

There was on the Nicaragua coast a tribe of Indians known as the Moscoes, of a good-natured and easy-going disposition. Early in the seventeenth century it received from British adventurers a certain mixture of Caucasian blood, and to this was added a strain of negro blood from the refugees from a wrecked Dutch slave ship. The hybrid race which was thus produced, of Indian, negro, and Caucasian amalgamation, proved most prolific, and soon occupied the entire coast from the Guayape or Patuca to the San Juan River. The name Moscoe was transformed into Mosquito and the people were called Mosquito Indians and their country the Mosquito Coast. About the time of the treaty of 1670, 
the chief of this tribe, Oldman by name, was persuaded by the British settlers to proclaim himself King, and an ally of the King of England. According to some, he actually visited England, and was received by Charles II. Thus in "Churchill's Voyages" we read that "he, the King, says that his father, Oldman, King of the Mosquito men, was carried over to England soon after the conquest of Jamaica, and there received from his brother King a crown and commission, which the present Old Jeremy still keeps safely by him; which is but a cocked hat and a ridiculous piece of writing that he should kindly use and relieve such straggling Englishmen as should choose to come that way, with plantains, fish, turtle, etc."

Upon his death in 1686, Oldman was succeeded by his son Jeremy, who the next year went to Jamaica, to beg the British Government to take him and his "kingdom" under the protection of the British Crown. The Governor seems to have regarded the application with suspicion and disfavour, and not to have granted Jeremy's request. Says Sir Hans Sloane: "One King Jeremy came from the Mosquitoes (an Indian people near the provinces of Nicaragua, Honduras, and Costa Rica) ; he pretended to be a King there, and came from the others of his country to beg the Duke of Albemarle, Governor of Jamaica, his protection, and that

- he would send a governor thither with power to war on the Spaniards and pirates. This he alleged to be due to his country from the Crown of England, who had in the reign of King Charles II submitted itself to him. The Duke of Albemarle did nothing in this matter." The British settlers on the Mosquito Coast held their ground, however, and some years later sent Jeremy to Jamaica again, to renew the request for protection. This time he was a little more successful. The British Governor went so far as to make a private agreement with him, under which the Governor was to support the "King" with money and arms, and the "King" was to lend the Governor a company of fifty men to capture runaway slaves in Jamaica. This compact was ratified by 
the Jamaica Assembly, and was thereafter regarded as a practical recognition of the sovereignty of the Mosquito King.

The next step toward British rule in Central America was taken in 1739-40, when efforts were made to rouse the Mosquitoes and other Indians to join the British in the war against Spain, and British fleets operated on the Mosquito Coast and also along the Pacific coast of Nicaragua. British troops were landed in the Mosquito territory, British forts were built, and a British "Superintendent" became practically the ruler of the land, though the Mosquito "King" retained the outward form of sovereignty. Under the Treaty of Aix-la-Chapelle, which ended the war, no definite disposition was made of the Mosquito territory, and the British remained in possession of their holdings there, as before, in defiance of the Spanish protests. When the Seven Years' War was begun, in 1754, the British Government offered to relinquish all its holdings and claims on the mainland to Spain, if the latter would join Great Britain against France. Spain declined this offer, and allied herself with France, and in consequence the British retained possession of the Mosquito Coast colonies, and this possession was confirmed by the Treaty of Paris, in 1763, which in addition gave British subjects the right to cut trees and engage in the lumber trade not only on the Mosquito Coast but anywhere along the eastern shore of Central America, though it also provided for the demolition of all the forts which the British had erected.

In 1775 the British colonists in the Mosquito country, numbering nearly 500, with twice as many slaves, and with extensive cotton and other plantations in addition to the lumber trade, were organised as a dependency of Jamaica, with a Superintendent, a Council of Government, and a Court of Common Pleas. In this the Spanish Government apparently acquiesced, until war arose again between the two countries in 1779 , when an attempt was made to expel the British colonists. In return the British Government 
sent thither a fleet, which protected the colonists, and then a second fleet under Horatio Nelson (already referred to in Chapter II), to seize the San Juan River and the lakes, and thus extend British rule across the country from the Caribbean to the Pacific. The latter enterprise failed, and the British colonists were in time driven from all points except the Mosquito Coast. At the end of the war, in the Treaty of Versailles, Great Britain formally abandoned her claim to sovereignty on the mainland, and retained nothing but the privilege of cutting and shipping lumber in Belize (now British Honduras), and it was expressly stipulated that this should in no wise derogate from the Spanish rights of sovereignty over that territory. The British settlements on the Bay Islands and the Mosquito Coast were to be entirely abandoned.

This last agreement, however, was not fulfilled. The British made no pretence, even, of withdrawing, and the Spanish made no attempt to compel them to do so, save to protest against their remaining. A little later, in 1786, a new convention was made, under which the Spanish greatly enlarged the area in Belize in which the British might cut timber, while the British government agreed "to give the most positive orders" for the evacuation of all other regions by British subjects, and, if they disregarded the orders, to withhold from them all succour or protection, and to "disavow them in the most solemn manner." Even in Belize, where they had lumber rights, the British were not to establish any agricultural plantations, or any manufactures, or to make any permanent settlements. Despite this, many British colonists remained on the Bay Islands and the Mosquito Coast, and held their ground against various efforts of the Spanish to expel them. Some time after the end of the Napoleonic wars, the Treaty of 1786 was practically disregarded by the British, and the British settlements were confirmed in their former status.

It would be difficult to tell just when or in what form the British pretensions and aggressions were thus renewed. 
James Buchanan, the United States Minister to England, in January, 1854, in a "statement for the Earl of Clarendon," discussed this question:

"At what period, then, did Great Britain renew her claims to the country of the Mosquitoes, as well as the continent in general, and the islands adjacent, without exception? It certainly was not in 1801, when, under the Treaty of Amiens, she acquired the Island of Trinidad from Spain, without any mention whatever of further acquisitions in America. It certainly was not in $\mathbf{1 8 0 9}$, when she entered into a treaty of alliance, offensive and defensive, with Spain, to resist the Emperor Napoleon in his attempt to conquer the Spanish monarchy. It certainly was not in 1814, when the commercial treaties, which had previously existed between the two powers, including, it is presumed, those of 1783 and 1786 , were revised. On all these occasions there was no mention whatever of any claims of Great Britain to the Mosquito protectorate, or to any of the Spanish-American territories which she had abandoned. It was not in 1817 and 1819, when acts of the British Parliament distinctly acknowledged that the British settlement at Belize was 'not within the territory and dominion of His Majesty' but was merely a 'settlement for certain purposes, in the possession and under the protection of His Majesty;' thus evincing a determined purpose to observe with the most scrupulous good faith the treaties of 1783 and 1786 with Spain."

Steps toward the reassertion of British claims were taken, however, with or without authority, as early as 1816. The "Crown Prince" of the Mosquito Indians, George Frederick, and his half-brother, Robert, were taken by British settlers to Belize, and thence to Jamaica, to be educated and also to be subjected to British influences. Upon the death of his father, George Frederick was taken back to the Mosquito Coast in a British warship, and was formally crowned and enthroned as "King of the Mosquito Shore and Nation." He soon got killed in a drunken brawl, and was succeeded by Robert, who showed himself more friendly to the Spanish of Nicaragua than to the British, and was accordingly deposed. A negro, named George Frederick, was put into his 
place, but he, proving unsatisfactory to the British, was in turn arbitrarily displaced in favour of another negro, called Robert Charles Frederick, who was taken to Belize, dressed in a British army officer's uniform, and crowned King of the Mosquito Coast. This was in April, 1825. He was then taken back to his "kingdom" for a time, but, his reign giving little satisfaction to the British, he was soon practically exiled to Belize and was kept there for the rest of his life. In his place Patrick Walker, the private secretary of the British Superintendent of Belize, was established as a sort of regent at Bluefields, where he renamed the country "Mosquitia" and established a purely British administration.

Since there seemed little prospect of extending the British power northward, the sovereignty of Mosquitia was next declared to extend southward as far as Boca del Toro, on the Chiriqui Lagoon, in Panama, and there thus loomed large a scheme of British rule in Central America from Yucatan to Darien. This scheme was promoted by the dissolution of the Central American union and by the weakness of the separate States which succeeded it. In 1835 a Legislative Assembly was formed in Belize, the name of that country was changed to "British Honduras," its boundaries were much enlarged, and it was declared to be a British possession entirely independent of any Central American State. The Bay Islands and Mosquitia were similarly declared to be independent of Honduras and Nicaragua, and the British Government was asked to recognise them as Crown Colonies.

Before acting upon these strenuous proposals of its agents, the British Government sent special commissioners to investigate matters, and also a naval force to protect its colonists and to compel Nicaragua to acknowledge the independence of Mosquitia, not as a British colony but as a native kingdom allied with Great Britain. Guatemala, Nicaragua, and New Granada protested against these acts and proposals, while Costa Rica acquiesced in them. The United States was for some time silent and inactive. It was too busy with its plans for the spoliation of Mexico to pay much 
attention to what was going on so far southward. Moreover, it had not yet acquired a great territory on the Pacific Coast with which it needed to have intercourse by way of the Isthmus. Great Britain therefore went on unchecked and almost unchallenged, under Lord Palmerston's vigorous leadership. War was waged against Nicaragua, with the result that British control was established on the San Juan River, and Nicaragua was compelled formally to relinquish forever to the Mosquito King all her rights in that region. It needed only the subsequent British seizure of Tigre Island in the Bay of Fonseca, off the Pacific coast of Nicaragua, to make the British conquest and control of that Isthmus complete.

It was not until matters had gone thus far that the United States was roused to action, and even then it was aroused not so much by resentment at Great Britain's aggression as by the desire and the need of securing a line of communication with those Pacific Coast possessions which it was seizing from Mexico. The best route from New York to California was by way of the Isthmus of Panama, and in order to secure the use of that route the United States made in 1846-at the beginning of the Mexican war and long before the discovery of gold in California-a treaty with the Republic of New Granada, which was destined to have a profound and far-reaching effect upon all further Isthmian Canal schemeś. (See Appendix I.) Under that treaty the United States secured the exclusive right of transit across the Isthmus of Panama, including all routes in the country between the Chiriqui Lagoon and the Atrato River, and in return undertook to maintain the neutrality of such routes and of any lines of traffic which might be established on that Isthmus, and also the sovereignty of the Isthmian territory against any attack by alien powers. Under this treaty American capitalists promptly proceeded to the construction of a railroad across the Isthmus, from Aspinwall (now Colon), on the Caribbean coast, to Panama, on the Pacific Coast, which was opened for traffic in 1855 , and which has ever 
since proved one of the most important factors in the whole problem of interoceanic commerce.

Nor was the traditional rivalry of Nicaragua lacking. In March, 1849, New York capitalists organised the "Compania de Transito de Nicaragua," and made a contract with the Nicaraguan Government for the construction of a canal; and later in the same year Cornelius Vanderbilt and others organised the American Atlantic and Pacific Ship Canal Company, absorbed into it the "Compania de Transito de Nicaragua," and in 1851, under the name of the Accessory Transit Company, established a transit route across Nicaragua, with steamboats on the river and lakes and coach and truck lines for the remainder of the way. This was for years a much frequented route of interoceanic travel, but in time was overcome and destroyed by the superior facilities of the Panama Railroad route:

Diplomacy next began to dominate the scene, and not to the advantage or the credit of America. The British seizure of the Mosquito Coast and the San Juan River, and the British designs upon the Bay of Fonseca, were so great a menace to existing American interests at Nicaragua and to all prospect of extending them that much commercial and popular indignation was excited in the United States. In response to this President Polk and his Secretary of State, James Buchanan, sent Elijah Hise in 1849 as a special envoy to Nicaragua to see what was being done and what needed to be done. Conceiving it to be his duty to uphold the principles of the Monroe Doctrine, and regarding the treaty concluded with New Granada three years before as a precedent which it would be proper to follow, Mr. Hise soon concluded a treaty with Nicaragua, giving the United States or its citizens the exclusive right to construct a transit way, railroad or canal, across the Isthmus of Nicaragua, and to control it and guard it with fortifications; and in return giving to Nicaragua an American guarantee of the inviolability of her territorial sovereignty.

It was substantially an application to Nicaragua of the 
principles which had just been applied to Panama. But there was this radical difference between the two cases: Great Britain was not directly interested in Panama, while she was very directly interested in Nicaragua. In almost every clause Mr. Hise's treaty ignored, traversed, or defied the pretensions and ambitions of Great Britain in that region. So the Washington Government, which had no stomach for a direct conflict with a great power, flatly repudiated him and all his doings, on the ground that he had exceeded his instructions; which was true enough, seeing that he had been sent down there practically without any instructions at all. In his place, President Taylor and his Secretary of State, John M. Clayton,-who had succeeded Polk and Buchanan while Hise was in Nicaragua,- - sent E. G. Squier to the Isthmus, with instructions to negotiate with Nicaragua for an "equal right of transit for all nations through a canal which should be hampered by no restrictions." In addition he was bidden to be careful "not to involve this country in any entangling alliances, or any unnecessary controversy."

Mr. Squier went to work with zeal and with discretion, and in September, 1849, secured from Nicaragua a favourable concession for a canal, in behalf of the Company already mentioned, which had been organised that year by Cornelius Vanderbilt. But he also, moved by much the same spirit that had animated Mr. Hise, made a treaty with Nicaragua, guaranteeing the neutrality of the canal and the sovereignty of Nicaragua over the territory traversed by the canal and over the ports at its terminals. This, again, was practically a challenge to Great Britain, since she was already asserting her sovereignty, or at least her control, over much of the line of the canal, and over its Caribbean terminus. The British answer came promptly. Honduras, the owner of Tigre Island in the Bay of Fonseca, was pressed for immediate payment of an old British claim, the obvious intent of Great Britain being to seize the Island in default of settlement. To prevent this, Mr. Squier hastened to make a treaty with Honduras, under which Tigre Island and certain lands on 
the shore of the Bay of Fonseca were practically ceded to the United States. This was on September 28, 1849. On October 16, following, a British fleet appeared in the Bay of Fonseca, and took forcible possession of Tigre Island in the name of the British Government. Mr. Squier at once protested against such seizure of what he regarded as the property of the United States, and ordered the British to evacuate within a week; which they declined to do.

This awkward and menacing situation was disposed of at Washington by the negotiation of one of the most famous and most criticised treaties in American history. It is probable that a much different course would have been followed, had it not been for some very necessary political considerations. President Taylor and Secretary Clayton were Whigs. But there was a Democratic majority in the Senate, which would have to pass upon any treaty which might be made. It was therefore necessary to do something which would meet the approval of the political opponents of the administration. Mr. Clayton entered into negotiations with the British Minister at Washington, Mr. Crampton, and offered practically to recognise British control on the Mosquito Coast, provided Great Britain would not make that control an obstacle to the construction and maintenance of a neutral canal. To this the British Minister and British Government assented. The American Minister to England, Abbott Lawrence, however, after an elaborate investigation of the matter, declared that the British claim of a protectorate over the Mosquito territory had no foundation in history, law, or justice, and argued that it should be abandoned, or at any rate that Great Britain should relinquish all claim to or control of the Caribbean terminal of the proposed canal. Unfortunately the Washington Government did not support Mr. Lawrence in this contention, but proceeded, over his head, with negotiations in which the independence of the Mosquito territory from Nicaragua, and also its "close political connection" with Great Britain, were practically conceded. Sir Henry Bulwer was then sent as 
British Minister to Washington, and work upon the draft of a treaty was begun by him and Mr. Clayton.

It was while this work was in progress that news came of the British seizure of Tigre Island, and the Democratic majority in the Senate, quite willing and perhaps eager to embarrass the Whig administration, demanded the immediate consideration of Mr. Squier's treaties with Nicaragua and Honduras, and asked the President for all letters and papers relating thereto. This request was refused, "on grounds of public policy," because such disclosure of documents might embarrass important negotiations then pending; and then, in order to strengthen that argument for refusal, Mr. Clay. ton urged Sir Henry Bulwer to conclude the treaty at once. Sir Henry suggested as a preliminary that the United States Government should disavow and cancel Mr. Squier's treaty with Honduras and his acquisition of Tigre Island, in return for which the British Government would disavow and undo its agent's seizure of that Island. This was done, and there. upon the famous Clayton-Bulwer treaty was concluded, signed, sent to the Senate, and ratified. (See Appendix II.)

It provided that neither the United States nor Great Britain should exclusively control the Nicaragua canal or build any fortifications along it; that neither should ever take possession of, fortify, colonise, or exercise dominion or protection over any part of Central America; that they should mutually guard the safety and neutrality of the proposed canal, and should invite all other nations to do the same; that both should give aid and support to any satisfactory company which would construct the canal; and that thus a general principle should be established for application to all Isthmian canals or railroads, at Panama or Tehuantepec as well as at Nicaragua. On the face of it this seemed a splendid thing, and the treaty was generally applauded. But there was something d€, per than the face of it. Even before the treaty was ratified, the British Government informed the United States that it did not interpret the provisions of the treaty as applicable to the existing British 
settlement in Honduras "or its dependencies,"-to wit, the Bay Islands and the Mosquito coast. In other words, Great Britain was to be confirmed in all her disputed claims in Central America, and was thus to be enabled to do to a great extent the very things the treaty forbade the United States to do.

In this Mr. Clayton practically acquiesced, and so the treaty, which was signed on April 18,.1850, was ratified on July 5,1850 . The treaties negotiated by Messrs. Hise and Squier were cancelled, and the Clayton-Bulwer treaty became the supreme law of the land.

Meantime various schemes of canal construction arose, only to be defeated by the circumstances established by this very treaty whose ostensible object was to promote the enterprise. The Republic of Costa Rica had Andreas Oersted, a Danish engineer, in 1847, survey a Nicaragua canal route which instead of running to the Bay of Fonseca should reach the Pacific through Costa Rican territory. Stephen Bailey proposed another route in the same general region. Immediately after the ratification of the Clayton-Bulwer treaty, Colonel O. W. Childs, a distinguished American canal engineer, was sent to Nicaragua, where he laid out an entirely new route, having its Pacific terminus at Brito. His plans were approved by the War Department at Washington, and also by British official engineers, and formed the basis of the actual attempt which was made in after years to construct a canal in Nicaragua. But all these enterprises were hampered and frustrated by political considerations. Friction and disputes arose between the United States and Great Britain over the interpretation and application of the Clayton-Bulwer treaty. Great Britain intrigued with Costa Rica and opened the way for a boundary dispute between that country and Nicaragua. Presently, the republics of Salvador, Nicaragua, and Honduras united in a federal league, while Guatemala and Costa Rica remained aloof, the latter almost openly hostile to the combination. 
President Pierce and his Secretary of State, William L. Marcy, took up the controversy with Great Britain, sending Solon Borland as a special agent to Central America and James Buchanan as Minister to England, with instructions to insist upon such construction of the Clayton-Bulwer treaty as would require Great Britain to withdraw from the Mosquito Coast. This demand Lord Clarendon, the British Foreign Minister, met with a flat refusal, to which he added that the British Government would not recognise the Monroe Doctrine as international law, and would not consent to be questioned further by the United States concerning her original rights in Central America. The American answer to this should have been immediate notice of abrogation of the Clayton-Bulwer treaty. Instead, our Government contented itself with bombarding, in the interest of Cornelius Vanderbilt's company, the British-Mosquito settlement of Greytown, at the mouth of the San Juan River.

Then Walker, the filibuster, began in 1855 his nefarious operations in Nicaragua, and affairs in all that part of America became chaotic. In Honduras some further work was done toward establishing satisfactory interoceanic transit. A British concern known as the Honduras Interoceanic Railway Company was organised in 1854, and secured a concession for its route across that country. Diplomatic complications ensued, however, among Honduras, Great Britain, and the United States, with the result that by 1857 all plans and operations were practically shelved. There followed some futile diplomatic passages between Great Britain and the United States, in which abrogation of the Clayton-Bulwer treaty was threatened by this country, but was not effected; and then Great Britain made a highly profitable series of treaties with various Central. American States, taking advantage of the facts that Walker's filibustering had aroused much prejudice against the United States in those countries, and that the United States was, moreover, too much concerned with its own domestic troubles 
and impending civil war to pay much attention to its southern neighbours.

The climax of these diplomatic achievements of Great Britain was the negotiation, in 1860 , of a treaty with Nicaragua, in which Great Britain, with an appearance of much magnanimity, agreed to abandon her protectorate over the Mosquito Coast, and to hand the whole of that region back to Nicaragua, in return for which Nicaragua was to acknowledge the validity of the claims which were thus relinquished. In fact the British withdrawal was only nominal, and the sovereignty restored to Nicaragua was the merest shadow, for it was stipulated that if Nicaragua attempted to make her sovereignty fully effective Great Britain should have the right to intervene under a title whose validity and sufficiency Nicaragua had now herself admitted. 


\section{CHAPTER V}

\section{SOME FUTILE SCHEMES}

While Great Britain and the United States were wrangling over their ill-made treaty, another French essay was made in Nicaragua. Louis Napoleon had temporarily abandoned his canal scheme in favour of his imperial coupd'état, but he took it up again during the Anglo-American deadlock following the ratification of the Clayton-Bulwer treaty, in a way which caused some concern. At the time of Walker's filibustering operations, one Felix Belly, an enthusiastic French adventurer and promoter, organised a company for the construction of a canal along Oersted's route, through Nicaragua and Costa Rica. He played strongly upon local sentiment in those countries by exploiting the evils of Walker's raids, publicly declaring that thitherto all the official agents of the United States in Nicaragua had been accomplices and auxiliaries of Walker and other filibusters; and in order to protect Nicaragua from any more such outrages he proposed that the canal, if not, indeed, the whole country, should be placed under the protection of the European powers which had just guaranteed the integrity of the Turkish empire, to wit, France, Great Britain, and Sardinia. Working with shrewd pertinacity along such lines, Belly persuaded the Nicaraguan and Costa Rican governments to adjust their boundary disputes, and then, in May, 1858, to grant him a canal concession for ninety-nine years on the Oersted route. He was to have all the privileges which had been enjoyed by the American Atlantic and Pacific Canal Company, and in addition that of stationing two French warships in Lake Nicaragua. At this the United States Government was aroused, and it warned Nica- 
ragua that such stationing of French warships in the lake would not be tolerated, and insisted that the rights already granted to American citizens must be respected. Mr. Cass, the American Secretary of State, writing to Mr. Mason, the American Minister to France, spoke plainly as follows, his words being intended for the French Government:

"The general policy of the United States concerning Central America is familiar to you. We desire to see the Isthmian routes opened and free for the commerce and intercourse of the world, and we desire to see the States of that region well governed and flourishing and free from the control of all foreign powers. The position we have taken we shall adhere to, that this country will not consent to the resubjugation of those States, or to the assumption and maintenance of any European authority over them. The United States have acted with entire good faith in this whole matter. They have done all they could to prevent the departure of illegal military expeditions with a view to establish themselves in that region, and at this time measures are in progress to prevent the organisation and departure of another, which is said to be in preparation. Should the avowed intention of the French and British governments be carried out and their forces be landed in Nicaragua, the measure would be sure to excite a strong feeling in this country, and would greatly embarrass the efforts of the Government to bring to a satisfactory close these Central American difficulties which have been so long pending."

In the face of that strong and statesmanlike assertion of American principles and purposes, the French and British governments paused, and Nicaragua quickly reversed her untenable attitude. Belly and his schemes were swept aside, and in March, 1861, the Central American Transit Company, directed by William $\mathrm{H}$. Webb, of New York, received a franchise for the old monopoly of navigation on the San Juan River and Lake Nicaragua. The French menace was not, however, past. Louis Napoleon would not openly support Belly in his schemes, but he presently took them up on his own account. He was already deeply involved in schemes for the practical conquest of Mexico and the crea- 
tion of a French Empire in America, and he conceived the design of extending his aggression southward so as to secure the Nicaraguan Isthmus and the site of the future interoceanic canal. To this end he sent Michael Chevalier, a distinguished French engineer, to survey a route and to obtain a concession for a canal at Nicaragua, in which errand Chevalier was successful. Unfortunately for the imperial intriguer, however, the civil war in America came to an end, and the United States Government was thus enabled to vindicate the Monroe Doctrine by practically driving the French out of Mexico. For a few years longer Napoleon clung to his Nicaragua canal scheme, but could do nothing with it before the German war of 1870 brought his career to an end. Meantime, in 1869, the Nicaragua transportation line which had been established by Cornelius Vanderbilt twenty years before was abandoned, and its almost worthless franchise was sold to an Italian corporation, which held it for twenty years and then resold it to the ill-fated American Maritime Canal Company.

Some attention was also paid, from time to time, to the Tehuantepec route. Thus in 1842 Don José de Garay, a Mexican promoter, sent Gaetano Moro, an Italian engineer, to survey the Mexican Isthmus for a railroad or a canal route, and secured a concession from President Santa Anna. The route adopted was intended for both a railroad and a canal, the latter to be fifty miles long and provided with locks. At the end of the war between Mexico and the United States, President Polk offered to double the $\$ 15,000,000$ indemnity to be paid by the United States under the treaty of Guadelupe Hidalgo, if the Mexican Government would cede to this country the exclusive right of way across the Isthmus of Tehuantepec. This offer was declined, the Mexican Government expecting Garay to fulfil his plans, which he failed to do. Instead, he sold out his concession to a syndicate of New York capitalists, and after the Gadsden treaty in $\mathbf{1 8 5 3}$ the Mexican Government confirmed to the United States the privileges it had granted to Garay, for a Tehuantepec rail- 
road. There was still, however, too much ill-will in Mexico against the United States for capitalists to risk important investments in that country, and moreover the Panama railroad was being pushed to completion; wherefore the Tehuantepec scheme was abandoned, to be revived many years later by Captain James B. Eads, with his imposing project of a ship railway, and finally to be carried to completion in the twentieth century by a British company under the lead of Sir Weetman Pearson, in the construction of a fine railroad with ample shipping terminals, a work calculated to be a not insignificant rival of the Panama railroad and canal.

More and more, however, both European and American attention was recalled to and centred upon the Panama route, and other possible routes on the lower Isthmus. There arose in that region a sharp rivalry between Great Britain and the United States. This had its origin in 1850, when Dr. Edgar Cullen, of Dublin, residing at Bogotá, laid before the Royal Geographical Society of London a most favourable report upon the Caledonian Bay route. Lord Palmerston, flushed with his Clayton-Bulwer triumph, and expecting great things in Nicaragua, paid no attention to it, but practical business men in London assumed a more favourable attitude. A corporation was formed, which sent out Lionel Gisborne, an engineer, to make surveys. The local Indian tribes drove him away from the Caledonian Bay region, and he went to Panama. There he began surveys, but had more trouble with the natives, and finally went home with his work unfinished. He made a favourable report upon the Panama route, declaring that the greatest height of land to be overcome was only 150 feet above sea level, a statement which attracted much attention in England and on the continent. Meantime Dr. Cullen secured from the New Granadan Government at Bogotá a concession for a canal on the Caledonian Bay route, and declined the earnest entreaties of a French company to be permitted to share in the enterprise.

These things aroused the apprehension of James Bu- 
chanan, then American Minister to England, and he urged the United States Government to do something to counteract them. Accordingly, Lieutenant Isaac C. Strain, of the United States Navy, was sent to Caledonian Bay with a surveying party. Marching inland, he found mountains from 1,000 to 3,500 feet high in the way of a canal, which he regarded as practically insurmountable obstacles. He thereupon returned to the coast, discouraged, and there met Gisborne's party and a French surveying party. Joining forces with the former, he returned inland and made his way across the Isthmus, with great difficulty and with complete confirmation of his first unfavourable impressions. Thus, as he said, he "dispersed a magnificent and dangerous fallacy" -the fallacy originated in $\mathbf{1 6 8 0}$ by Sharpe and Wafer.

The Caledonian Bay route was thereupon abandoned. The several Atrato routes were next considered. We have already referred to the legends of a natural waterway in that region (quoted by Mr. Scruggs from Governor Alceda), and of the canal dug by a priest in $\mathbf{1 7 8 8}$ in the Raspadura Ravine (cited and credited by Humboldt). It was further said that in 1799 the attention of the French Government had been called to the Raspadura canal by a French pilot, and that in 1820 a ship's boat had been taken from ocean to ocean by that route. Moreover, Humboldt, as the result of personal observations and inquiries, had declared that no chain of mountains or even ridge of partition existed in that region. If these reports were true, it seemed that there was the most promising route for a canal. In order to determine their truth or falsity Frederick Kelly, an American capitalist, in 1851, sent J. C. Trautwine, one of the engineers of the Panama Railroad, to explore the Atrato valley. The result was that the story of the priest's canal in the Ravine of Raspadura was pronounced to be entirely fanciful. Two more surveying parties were sent to the same general region by Mr. Kelly in 1853, with unsatisfactory results. A fourth, sent in $\mathbf{1 8 5 4}$ to the Atrato-Truando route, made more favourable reports. Mr. Kelly then went to England and France and aroused 
there some interest in his researches and plans, but failed to attain any practical results.

In 1857 President Buchanan sent to the Atrato region Lieutenants Nathaniel Michler, U. S. A., and T. A. Craven, U. S. N., to make surveys. The former made a favourable report, declaring that a canal could be constructed at that point, at a cost of $\$ 134,000,000$. Lieutenant Craven, on the other hand, condemned the entire scheme as quite impracticable. Again, Mr. Kelly asked Colonel Totten, U. S. A., the chief engineer of the Panama railroad, his opinion concerning a canal at Panama, and especially concerning one at sea level. Colonel Totten replied that a sea-level canal was impracticable, that any canal that was cut there would necessarily have ten or twelve locks, and that it was by no means certain that the Chagres River could be controlled by any engineering device. From these discouragements Mr. Kelly, who was one of the most resolute and unsparing of canal promoters, in 1863 turned to the San Blas route as a last resort. That route was at that date almost unknown, the formidable San Blas Indians, who down to this day keep all strangers out of their country, having prevented explorations and surveys. A party was sent thither by Mr. Kelly, but the Indians would not permit anything like a thorough survey. Enough was ascertained, however, to convince the explorers that a tunnel seven miles long would be necessary, and on their return they so reported. At this Mr. Kelly reluctantly, but finally, gave up the whole enterprise.

Lieutenant Strain's exposure of the Caledonian Bay fallacy did not discourge some enthusiastic French promoters, who in 1861 had further surveys made there by M. Bourdiol, working from the Pacific coast. He did not succeed in crossing the Isthmus, but reported that it was entirely feasible to make a canal there, and that the extreme elevation of land on the route was only 144 feet. M. Airian, a French resident of Bogotá, also made survers, and reported that there was no mountain range in that region, but only scattered hills, and that the extreme elevation was only 161 feet. A 
third Frenchman, M. de Puydt, professed to have discovered another route, near by, with an elevation of only 101 feet, and backed up his report with some old Spanish documents and a map which had been found in Madrid. Two properly equipped surveying parties were thereupon sent to that region. One was sent by a speculative company, and it professed to find a satisfactory Atrato-San Miguel route with an extreme elevation of 190 feet. The other, sent by the Compagnie Génerale Transatlantique, reported that it would be practically impossible to construct a canal in that place.

Nor was the other end of the Panama Isthmus neglected. The great Chiriqui Lagoon, adjoining the Costa Rica border, on the Caribbean coast, appeared to furnish an advantageous starting place for a canal, and in 1859-60 President $\mathrm{Bu}$ chanan had surveys made there, though not so much for a canal as for a railroad and for a naval and coaling station. A Chiriqui Improvement Company was formed in the United States, and secured valuable concessions. At the outbreak of the Civil War the enterprise languished, but in 1862 President Lincoln planned to purchase the rights of the company and to establish there a great colony of emancipated negroes. The employment of the negroes in the army and elsewhere caused, however, the abandonment of this scheme.

After the Civil War renewed attention was given to the canal project. Rear-Admiral Davis, U. S. N., in 1866-67 made a strong report against the Childs route in Nicaragua, and in favour of a canal at Panama. Following this, in 1869, the United States made a treaty with Colombia (the new name of New Granada) for the construction by this country of a canal at Panama, which was to be, as afterward explained, "an American canal under American control," but the Senate of the United States refused to ratify the treaty when it was submitted by President Johnson, and the submission of a similar treaty by President Grant in 1870 met with the same deplorable fate. In 1872-73 the United States had surveys made of several routes, the report 
upon Nicaragua, made by Commander E. P. Lull and Lieutenant A. G. Menocal, being the most favourable. This so encouraged the Nicaraguan Government to expect the speedy construction of a canal by the United States that in 1877 it refused a concession to Ferdinand de Lesseps who, flushed with his great success at Suez, was looking to America for new isthmuses to conquer.

More and more diplomacy entered into the problem, and it became evident that there would have to be a strong assertion of the American policy and of American rights. In 1856 Secretary Marcy had announced his intention of asking other nations to join in guaranteeing the neutrality of the Panama route. Secretary Seward in 1862, in the midst of the perplexities and complications of the Civil War, was for a time inclined to follow that unworthy precedent, and went so far as to make overtures to the British and French governments to that end. On both these occasions, however, it should be noted, the provocation to such action was found in serious disorders on the Isthmus. A better policy was enunciated by Mr. Seward in 1866, when the return of peace had given him a more free hand in dealing with foreign affairs. He then suggested the purchase of Tigre Island from Honduras as a coaling station, and hinted at the abrogation of the Clayton-Bulwer treaty, or the declaration that it had already become void, on the ground that its object, the construction of a canal, had not been accomplished nor even attempted. Mr. Charles Francis Adams, our Minister to England, however, deprecated any further controversy with Great Britain at that time, wisely realising how great a controversy with that country was already on hand, in the Alabama claims. The matter of abrogating the Clayton-Bulwer treaty was therefore not pressed.

In 1868 the highly important Dickinson-Ayon treaty was made with Nicaragua, under which this country securedthough not exclusively - the right of way for a canal across that country. In return, the United States was to guarantee 
the neutrality of the canal, under the supreme sovereignty of Nicaragua, and was to ask other nations to join in the guarantee. Mr. Seward also attempted to make a new treaty with Colombia in 1869, under which the United States should have exclusive rights in the canal to be constructed there. In time of war the canal was not to be open to enemies of the United States, and there was to be a twenty-mile "Canal Zone" under the neutral guarantee of this country. This treaty was negotiated but failed of ratification. It was nevertheless an indication of the change of official and popular sentiment which was taking place in this country.

Finally, the true and ultimate American doctrine was enunciated by President Grant-that of "an American canal under American control," though this exact phrase was put forth by President Hayes. "I regard it," said President Grant, in 1869, "as of vast political importance to this country that no European government should hold such a work." Later, in a notable article in the North American Review, in February, 1881, he wrote these golden words:

"In accordance with the early and later policy of the government, in obedience to the often expressed will of the American people, with a due regard to our national dignity and power, with a watchful care for the safety and prosperity of our interests and industries on this continent, and with a determination to guard against even the first approach of rival powers, whether friendly or hostile, on these shores, I commend an American canal, on American soil, to the American people."

It was in pursuance of the policy expressed by him in 1869 that in that year he appointed an Interoceanic Canal Commission. This body consisted of General A. A. Humphreys, the Chief of Engineers of the United States Army; C. P. Patterson, Superintendent of the Coast Survey; and Rear-Admiral Daniel Ammen, the Chief of the Bureau of Navigation of the United States Navy. Under the directions of this very competent commission, four important surveys were promptly undertaken. The first, under Com- 
mander T. O. Selfridge, U. S. N., proceeded to the Isthmus of Darien. It carefully examined the Caledonian Bay route, confirmed the unfavourable reports of Strain, and finally pronounced that route impracticable. The same expedition then went to the San Blas route and examined it far more thoroughly than any preceding party had done, in the end reporting that it, too, was impracticable. The next year, 1871, Commander Selfridge led his men to the valley of the Atrato River, and there surveyed two routes. One of these, the Atrato-Tuyra, he pronounced impossible. The other, the Atrato-Napipi route, to Chiri-Chiri Bay, impressed him favourably, and he made a report recommending its adoption.

The second party, under Captain R. W. Shufeldt, went in the fall of 1870 to the Mexican Isthmus of Tehuantepec and carefully surveyed it. The resulting report was to the effect that a canal at that point was practicable, but was not advisable because of the great expense of constructing it. The third party was under the direction of Captain Chester Hatfield. It went in. 1872 to Nicaragua and investigated the principal routes which had been suggested there. Of these it rejected Oersted's as impractical, or at least undesirable, and recommended Childs's. Another surveying party, under Captain E. P. Lull and Lieutenant A. G. Menocal, followed in the same region and with the same result, advocating the construction of a canal on Childs's route, with its Pacific terminal at Brito. The fourth survey was effected by Messrs. Lull and Menocal at Panama, on the route from Panama to the Bay of Limon. The report was to the effect that a canal with locks might be constructed there, but that the Chagres River made a sea-level canal impossible.

Upon receiving these reports, the Interoceanic Canal Commission hesitated to decide among them, and ordered some further surveys to be made. It sent a special surveying party, composed of Major Walter MacFarland and Captain W. H. Heuer, U. S. A., engineers, and Professor Henry Mitchell of the U. S. Coast Survey, to examine the Nica- 
ragua and Darien routes. Messrs. Lull and Menocal were sent to San Blas, and confirmed Selfridge's unfavourable report. Lieutenant Frederick Collins was detailed to examine the Atrato-Napipi route, and reported that a canal there would cost more than fifty per cent. more than Selfridge had estimated. At last, at the end of 1875, the Commission had secured all available data, and on February 7, 1876, it made a unanimous report to President Grant in favour of the Nicaragua route, from Greytown to the San Juan River, to Lake Nicaragua, through the Rio del Medio and Rio Grande valleys, to Brito, on the Pacific Coast.

This report was received as practically conclusive. It was evident, however, that if it was to be adopted and a canal was to be built at Nicaragua according to President Grant's policy of exclusive American control, the ClaytonBulwer treaty must be modified or abrogated. The Secretary of State, Hamilton Fish, therefore began tentative negotiations with Great Britain to that end, and at the same time he opened negotiations with Nicaragua for a canal treaty. In neither case was anything practical effected, and President Grant's administration closed with the canal project apparently as far from realisation as ever. It left, however, to the succeeding administration of President Hayes an invaluable legacy of plans and sound policy.

Meantime the French were at work again. In the winter of 1874-75 an adventurer named Gorgoza appeared at Bogotá, representing himself as the agent of a French company which was ready to undertake the construction of a canal. In that capacity he secured a hearing before the Colombian Congress, which was quite ready to listen to any scheme that promised to put money into its treasury. M. Gorgoza positively asserted that in 1868 he had himself solved the "Secret of the Strait" by making the passage from sea to sea in a boat, by way of the Atrato River. This achievement, he said, he had reported to Commander Selfridge, when the latter was surveying that region for the United States Government, but Selfridge had simply laughed 
at him for his pains. It is quite possible, indeed probable, that this latter story was true. There is little doubt that if Gorgoza did tell the story of his marvellous voyage, Selfridge laughed at him; for Gorgoza solemnly declared that he had been accompanied on the trip by two other men, one of whom had since died, while he really could not remember who the other was.

On the strength of this cock-and-bull story, however, Gorgoza secured a concession for a canal, which he took back to Paris in triumph in the fall of 1876. This moved a lot of "Old Imperialists," who still hoped to effect a Bonapartist restoration, to organise a speculative corporation called "La Société Civile Internationale du Canal Interocéanique," for the promotion of canal schemes on the lower Isthmus. At the head of it were Lieutenant Lucien Napoleon Bonaparte Wyse, and his brother-in-law, General Étienne Turr. Count Ferdinand de Lesseps, the builder of the Suez Canal, was also interested in it, and on his advice Lieutenant Wyse went to the Isthmus and explored Gorgoza's Atrato-Tuyra route, which he found impracticable. A modification of it, however, from the Tuyra River to Acanti Bay, commended itself to him and he reported in its favour. De Lesseps was not pleased with it, and on his urging Wyse again, in 1877, went to the Isthmus, with Lieutenant Armand Reclus-a member of the famous family of that name, of geographers and scientists. They first examined the San Blas route, and found it impracticable, and then Wyse's Acanti route, which seemed no better, Wyse himself confessing it to be quite hopeless.

As a last resort, therefore, they proceeded to Panama. There Reclus undertook a survey of the route, while Wyse hastened to Bogotá, and persuaded the Government to give him a concession for a canal anywhere on the Isthmus, provided he or his company could make satisfactory terms with the Panama Railroad Company. Wyse, on his part, covenanted to organise a construction company within two years, and to complete the canal within twelve years thereafter. 
From Bogotá he went to Nicaragua and devoted his attention to defeating in the Legislature of that country a bill giving a concession there to a rival French company. Thence he came to New York, and made a bargain with the Panama Railroad Company. Finally he returned to Paris, in August, 1878, and laid his plans before De Lesseps and the Société Civile. Reclus, meantime, had done little more at Panama than to walk across the Isthmus along the line of the railroad, but on the strength of that achievement he too returned to Paris in 1878, and made an authoritative and favourable report upon the Panama route. Thereupon the Société Civile decided to adopt that route, the canal to be cut at sea level, with a tunnel four and a half miles long. The Atrato-Tuyra, the Acanti, and the San Blas routes were still talked about, but only as foils to that at Panama. Finally, announcement was made that an International Engineering Congress would be held in Paris in 1879, under the presidency of De Lesseps, to consider and definitely pass upon the whole question. It is interesting to observe that the "Old Imperialists" thus promoted and committed themselves to a canal at Panama, of which Louis Napoleon had written in 1848 that it "could cross only a country which was marshy, unwholesome, desolate, and uninhabitable, which would afford a passage of thirty miles through stagnant waters and barren rocks, yielding no spot of ground fitted for the growth of a trading community, for sheltering fleets, or for the development and interchange of the produce of the soil." 


\section{CHAPTER VI \\ "CONSULE LESSEPS"}

The International Engineering Congress, or International Scientific Congress, as it has been variously called, was assembled at the call of Count Ferdinand de Lesseps, in Paris, on May 15, 1879. It consisted of 136 delegates, offcial and unofficial. The majority of them-seventy-fourwere Frenchmen, as was not unnatural, and were friends and supporters of De Lesseps. Indeed, the whole body was most favourably disposed toward that distinguished man, who had at Snez achieved in the face of enormous difficulties a success beyond even the loftiest flights of his own imagina. tion. Eleven members were from the United States. Of these, only two were officially commissioned by the American Government, to wit, Rear-Admiral Ammen and Lieutenant Menocal, and they were carefully instructed not to commit the United States in any way to support or approval of the decisions of the Congress. Other American members, who attended in an unofficial capacity, on De Lesseps's invitation, were Nathan Appleton, of Boston, a close friend of De Lesseps; Cyrus W. Field, and Commander Selfridge.

Whether the Congress was or was not a "packed" body, with a predetermined programme, is a question which probably never can be satisfactorily answered. De Lesseps and his friends earnestly protested that it was not. Many American and British observers with equal positiveness declared that it was, and the latter opinion probably prevails and will continue to prevail the more widely. One thing is certain, from the record, that it was a great misnomer to call it an "Engineering" or a "Scientific" congress. It was nothing of the sort. It was a speculative gathering. Of the $\mathbf{1 3 6}$ 
members, only forty-two were engineers or geographers. The majority were politicians, financiers, speculators, and "promoters." That fact gave much colour to the charge that it was a "packed" body, and the proceedings of the Congress did not dispel that impression.

Ferdinand de Lesseps himself presided, and appointed a number of committees, the most important of which, and the only one which we need consider, was that on the choice of route. It consisted of fifty-four members, and was believed to have been chosen by De Lesseps to ratify his own judgment in favour of the Panama route. Its American members were Commander Selfridge and Lieutenant Menocal. It spent some time in consideration of the various routes. De Lesseps was outspoken in favour of the WyseReclus route, at Panama, which was, as he said, to go up the Chagres River, then "under the Cordillera by means of an immense tunnel," afterward abandoned in favour of a cut, and then down the Rio Grande to the Pacific; at sea level all the way. Mr. Appleton still clung to the San Blas route, as the shortest, despite its forbidding length of tunnel. Commander Selfridge advocated his Atrato route, at Darien.

If this committee was "packed," the fact did not at once appear. In fact, at first it seemed decidedly hostile to the Panama route, on the ground that it was much more costly than that at Nicaragua. To meet and dispose of this objection, Lieutenant Wyse modified his plans so as to provide for a canal with locks, which would be cheaper than one at sea level. This, however, would deprive the Panama route of its one great advantage over all others, and it was argued that if there must be locks, a lock canal at Nicaragua was preferable to one at Panama. The partisans of De Lesseps began, however, to make it clear that despite their apparent hesitation at first, they were resolved to report in favour of Panama. A number of the committee, including the Americans, the English, and some French engineers, withdrew from the proceedings in disgust. Then the remainder of the committee quickly adopted a resolution in 
favour of Panama, and submitted it to the whole Congress, or to all that was left of the latter body. When it came to a vote, only 98 of the 136 delegates recorded themselves. Of these, seventy-five, an overwhelming majority, were in favour of Panama. But of these seventy-five, only nineteen were engineers, only five were practising engineers, and only one had ever set foot upon the Isthmus of Panama. In such fashion did this "scientific" congress decide this momentous question. But it served its purpose. On October 20, following, the Universal Interoceanic Canal Company was organised and incorporated by De Lesseps in Paris, under Wyse's concession of May 18, 1878, the Société Civile having already sold out to him its rights.

Public reports of these doings, and especially the official reports of Messrs. Ammen and Menocal, aroused American interest in the French scheme, and moved both Houses of Congress to apprehension, and to resentment against what threatened to be an infringement upon the Monroe Doctrine. American enterprise also busied itself with counter schemes. A Provisional Interoceanic Canal Company was organised, for the purpose of constructing a canal at Nicaragua, among its members being Captain S. L. Phelps, Rear-Admiral Ammen, General George B. McClellan, Lieutenant A. G. Menocal, and Messrs. Levi P. Morton, George W. Riggs, and Hugh J. Jewett. Lieutenant Menocal was commissioned to go to Nicaragua to secure a concession, which he did, the condition being that the company should begin work within two years from May 22, 1880, the time being afterward extended to September 30, 1884. There also arose some distrust of De Lesseps's scheme and some reaction against him in France itself, on account of which he deemed it desirable to do something spectacular, which would appeal to the imagination and arouse enthusiasm. He accordingly went to Panama in the fall of 1879, and "inaugurated" the canal scheme in a showy fashion. In February, 1880, he reported that the plans of the canal were perfected. It was to be a tide-level canal, twenty-eight feet 
deep, costing $\$ 132,000,000$, and under a European guarantee of neutrality. Then he came to the United States, was entertained at a great public banquet at Delmonico's in New York on March 1, and proceeded to Washington to try to conciliate the Government-an impossible task. President Hayes had been profoundly impressed by Grant's resolute American canal policy, and committed himself unreservedly to its maintenance. He received De Lesseps courteously, but on March 8 , just after their interview, he sent to the Senate a message in which he said:

"I deem it proper to state briefly my opinion as to the policy of the United States with respect to the construction of an interoceanic canal by any route across the American Isthmus. The policy of this country is a canal under American control. The United States cannot consent to the surrender of this control to any European powers. If existing treaties between the United States and other nations, or if the rights of sovereignty or property of other nations, stand in the way of this policy,-a contingency which is not apprehended,- - suitable steps should be taken by just and liberal negotiations to promote and establish the American policy on this subject, consistently with the rights of the nations to be affected by it. The capital invested by corporations or citizens of other countries in such an enterprise must, in a great degree, look for protection to one or more of the great powers of the world. No European power can intervene for such protection, without adopting measures on this continent which the United States would deem wholly inadmissible. If the protection of the United States is relied upon, the United States must exercise such control as will enable this country to protect its national interests and maintain the rights of those whose private capital is embarked in the work.

"An interoceanic canal across the American Isthmus will essentially change the geographical relations between the Atlantic and Pacific coasts of the United States, and between the United States and the rest of the world. It will be the great ocean thoroughfare between our Atlantic and our Pacific shores, and virtually, a part of the coast line of the United States. Our mere commercial interest in it is larger than that of all other countries, while its relation to 
our power and our prosperity as a nation, to our means of defence, our unity, peace, and safety, are matters of paramount concern to the people of the United States. No other great power would, under similar circumstances, fail to assert a rightful control over a work so closely and vitally affecting its interest and welfare.

"Without urging further the grounds of my opinion, I repeat, in conclusion, that it is the right and the duty of the United States to assert and maintain such supervision and authority over any interoceanic canal across the isthmus that connects North and South America as will protect our national interests. This, I am quite sure, will be found not only compatible with, but promotive of, the widest and most permanent advantage to commerce and civilisation."

It will be worth while to pause for a moment in our narrative and to note in detail some of the terms of this admirable declaration; especially since the present policy and conduct of our Government have been ignorantly or heedlessly criticised as a new and dangerous departure. Nothing that Theodore Roosevelt has said or done concerning the Panama Canal has surpassed by one jot or tittle the policy enunciated by Rutherford B. Hayes nearly a quarter of a century before. Mr. Hayes proposed a canal under sole and exclusive American control. No European power was to be admitted to even the smallest share in it. If European capitalists invested their money in the enterprise, they must look to the United States alone for protection. Moreover-and this is the climax of the matter-no existing treaties, and no rights of property or of sovereignty of other nations, were to be permitted to stand in the way of our assertion of such control. If the Clayton-Bulwer treaty was in the way, it must be abrogated. If any foreign power had secured concessions or property rights on the Isthmus, it must surrender them. If one of the Isthmian States attempted to exercise its sovereignty so as to give a foreign power control over a canal, that sovereignty must be traversed, and the State must be made to understand that its sovereignty was not superior to the rights and interests of 
the United States. Mark that Mr. Hayes did not talk about any American "privileges" on the Isthmus, but about our "rights." Of course, our control was to be established-if possible-through just and liberal negotiations; such, for example, as those which we essayed with Colombia in 1903. But suppose negotiations failed, and some country attempted to assert its property rights or rights of sovereignty, as superior to and inimical to the rights and interests and welfare of the United States? Nothing could be more clear and unmistakable than the answer implied in Mr. Hayes's message. No matter what happened, it would be "the right and the duty of the United States to assert and maintain supervision over any interoceanic canal across the Isthmus."

Strong doctrine, that. Put forward in these days, it would be denounced by some as "strenuous," "imperialistic," "big stick," and what not. But that was the doctrine of President Hayes, and of William M. Evarts, his Secretary of State, in March, 1880. It was a much-needed warning to De Lesseps and to France, that this country would not permit the canal to be under European control or under any European guarantee of neutrality, but that if Frenchmen built it with French capital, the United States would assume absolute control of it; French property rights to the contrary notwithstanding. It was also a much-needed warning to Colombia ta quit her secret dallyings with French intriguers. For De Lesseps was surreptitiously trying to persuade the Colombian Government to abrogate its Treaty of 1846 with the United States, or at least that part of it (Article 35) which gave to the Government of the United States "the right of way or transit across the Isthmus of Panama . . . free of all incumbrances or restrictions whatever," upon any railroad, canal, or other means of transportation which might ever be constructed. De Lesseps perceived that that treaty provision was as much in the way of his canal as the Clayton-Bulwer treaty was in our way at Nicaragua, and so he bent every effort to secure its abrogation, in which he might have succeeded had it not been for 
the prompt and energetic action of the United States. The President and the Secretary of State gave Colombia plainly to understand that she would not be permitted to exercise her sovereignty in the matter in a way displeasing to the United States. It will be well to keep that masterful precedent in mind hereafter, when considering American relations with Colombia at a later date. Nor was our Govern. ment in 1880 content with mere words. Under the old contract which President Lincoln had made in 1862 with the Chiriqui Company, it took possession of a coaling station at Boca del Toro, on the Chiriqui Lagoon, and also of another at Golfito, and Congress appropriated $\$ 200,000$ for the Secretary of the Navy to use in taking further steps to control the Panama route.

In the face of this resolute attitude of the American Government, De Lesseps changed his tactics. He nominally abandoned his "European control" scheme, and announced to his French supporters that President Hayes's message assured "the political security of the canal." Then he went to work in another way to get rid of the troublesome Colombian treaty, and also to kill off the rival Nicaragua scheme. He organised an "American Committee," at the head of which was the Hon. Richard IV. Thompson, who had been Secretary of the Navy under President Hayes; and he engaged as American fiscal agents of his company the great banking houses of J. \& W. Seligman, Drexel, Morgan \& Co., and Winslow, Lanier \& Co. The Committee and the bankers were supplied with vast sums of money, presumably to be used in influencing American opinion, subsidising the American press as that of France was subsidised, and affecting legislation.

Some of the activities of these agents were soon visible in the suggestion which was made by various public men and papers in America, that the United States ought not to oppose the abrogation of the Treaty of 1846 with Colombia, but should rather itself seek it and take the initiative to that end. Why? Because the treaty as it stood might presently 
involve us in some of those foreign entanglements which the "Fathers of the Constitution" had so deprecated and had so earnestly warned us against. That is to say, France was going to build and control the canal, anyway, and if we did not want trouble over it, we would better get out of the road. Some Americans, whose relations with De Lesseps's "American Committee" have not been fully disclosed but may be imagined, actually set forth in public prints that for the United States to insist upon and enforce the provisions of that treaty would be such a violation of the Colombian concession to the De Lesseps company that the French Government might be called upon to intervene for the protection of the latter, and so, if we did not wish to incur trouble with France, we would better abrogate the treaty and withdraw from our pretensions upon the Isthmus.

With this campaign of unparalleled impertinence set afoot in the United States, and with lobbyists working day and night at Washington to defeat the Nicaragua project, De Lesseps in April, 1880, returned to France with the air of a victor, to secure capital and organise a construction company. He reported that the construction of the Panama Canal would be a mere trifle compared with that at Suez, and that American opposition to it arose solely from Yankee jealousy of French glory. He also subsidised a large part of the French press and secured the active support of a number of influential French politicians.

Meantime there was a serious revival of interest in the Tehuantepec route. It had the obvious advantage of being much further north than either of the others. It was therefore closer to the coasts of the United States, and would afford a shorter line of communication between them. It would also give a shorter route from Europe to all points on the northern Pacific Ocean. Climatically, it was decidedly preferable to either Nicaragua or Panama. Politically, it was the best of the three, for it was entirely included within Mexico, a far larger, richer, and more powerful State than Colombia or any of the Central American republics, and one 
enjoying under the masterful statesmanship of Porfirio Diaz a far more stable and enlightened government. The one grave objection to Tehuantepec as a canal route was the greater width and elevation of the Isthmus, and the consequent necessity for so much more cutting. In 1880-81, however, it was proposed to construct not a canal but a ship railroad, by means of which the largest ocean steamship, fully laden, would be taken from the water, placed upon an enormous train of cars, conveyed overland, and put into the ocean at the other side. Colossal as this scheme was, there is no reason to think it was visionary or impracticable. It was conceived and elaborated in detail by one of the most competent engineers of his time. This was Captain James B. Eads, who designed and built the great steel railroad bridge across the Mississippi River at St. Louis, and who was the author of the system of jetties at the mouth of the Mississippi, by means of which the entrance to that river was made and kept deep enough for navigation. He was fully convinced of the practicability of his ship railroad scheme, and secured from the Mexican Government a concession on favourable terms for building it.

The summer and fall of 1880 were largely taken up in the United States with a Presidential campaign and election, but upon the reassembling of Congress in December the various Isthmian transit schemes were taken under consideration, and in that winter and the ensuing spring much time was devoted to discussion of them. Captain Eads estimated the cost of his railroad at only $\$ 18,750,000$, but Congress declined to give him any financial guarantee, and he was ultimately compelled to abandon the splendid enterprise. Neither was any aid given to the Nicaragua and Panama undertakings. Therefore the tactical victory remained with De Lesseps, since his venture was the only one which did not seek nor need aid from the American Government. It was felt in Congress, however, that the Clayton-Bulwer treaty was a barrier against American action on any of the Isthmuses, whether for building a canal of our own or for 
thwarting the unwelcome schemes of France. Accordingly, on April 16, 1881, a joint resolution was adopted, requesting the President to proceed immediately with steps for the formal and final abrogation of that treaty.

James A. Garfield had then become President, and had made James G. Blaine his Secretary of State. The latter, who had long cherished a marked suspicion of and antagonism toward Great Britain, and who was inclined toward what was called a "vigorous and aggressive" foreign policy, obeyed the instructions of Congress with promptness and avidity, and with rather more zeal than discretion. He began his negotiations against the Clayton-Bulwer treaty by sending a circular letter to the American Ministers to all the great powers, to be repeated by them to the governments to which they were accredited, strongly-and rightlydeprecating the proposal to establish a European guarantee over an American canal. Such a guarantee, he argued, would be superfluous, since the United States had already "positively and efficaciously" guaranteed the neutrality of the route in question, to wit, at Panama, and this guarantee did not require reinforcement, accession, or assent from any other power.

The proposed European guarantee would, moreover, he argued, be offensive to the United States, since it would be an uncalled-for intrusion into a field which this country properly considered its own and in which the interests of the United States were to be considered before those of any other country, save Colombia. Quoting the words of his predecessor, Mr. Evarts, he added that the United States would insist upon its right to take all needful precautions against the canal's ever being used offensively against American interests. He pointed out that if the proposed canal were in or near Europe, it would be proper for the European powers to safeguard it in their own interest, and that, conversely, as it would form practically a part of the American coast line, remote from Europe, it was similarly proper for the United States to safeguard it, and to do so without any 
European aid or intervention. Finally he roundly served notice that any attempt of European powers to guarantee the neutrality of the canal, and thus practically to establish political control over it, would be viewed by the United States with the gravest concern; and any attempt to supersede the American guarantee with an agreement among European military powers, would be regarded as a hostile alliance against the United States.

That was all perfectly sound doctrine, in line with precedents already well established by our Government. There was no reason to suppose, either, that it would be challenged or objected to by any of the powers of continental Europe. But Mr. Blaine made the mistake of reckoning without Great Britain. That kingdom stood in an entirely different relation to the American Isthmuses from that of any other power. It had territorial possessions there, and treaty rights there, recognised and solemnly guaranteed by the United States. This letter of Mr. Blaine's was practically an attempt to ignore the Clayton-Bulwer treaty, which was something he had no right to do, and which from a tactical point of view was a fatal mistake. He was putting the cart before the horse. He should have first secured the abrogation of the Clayton-Bulwer treaty, which could easily have been done. Then this circular note would have been appropriate and effective. His mistake was in issuing first the note, which should have come second, and of postponing to the second place that which should have come first.

Realising the special interests of Great Britain in Central America, and anticipating British resistance to his policy, Mr. Blaine strove to fortify his position by rallying the Central American States to his side. He first suggested to those States the desirability of their reunion into a confederacy, as of old. This was found impracticable, whereupon he changed his tactics and invited them to send delegates to a "Pan-American Congress," to be held under his management at Washington in November, 1882. This scheme appeared to some like a revival of the old Panama 
Congress of 1826, which the United States had treated with scant courtesy, and was more favourably received by the Central American States than his first suggestion had been. Indeed it was approved by all excepting Costa Rica, which was just then under French influence, and preparations were made for the holding of the Congress.

British diplomacy, however, was not to be caught napping. On the contrary, it got to work more quickly and more effectively than Mr. Blaine's. At the first hint of American action against the Clayton-Bulwer treaty, the British Government confirmed its hold upon the Nicaragua route. This was done by complaining of what was quite true, that Nicaragua had failed to pay the promised indemnity to the Mosquito Indians and had otherwise disregarded the treaty of Managua (of 1860 - see Chapter IV), and by demanding that the case thus established be submitted to the arbitration of the Emperor of Austria. Now, Nicaragua had ignored her treaty obligations because of American encouragement and expectations of American aid. But when Great Britain thus called her to account, American aid was not forthcoming, and she was accordingly compelled to acquiesce in the British proposals. The dispute was arbitrated by the Austrian Emperor, and in July, 1881, his decision was rendered. As might have been expected, it was unfavourable to Nicaragua. It declared that "Mosquitia" was autonomous; that Nicaragua had no right to regulate trade, levy duties, or grant concessions in Mosquitia; that the indemnity or subvention provided in the treaty of Managua must be paid by Nicaragua; and that in case of Nicaragua's failure strictly to observe the treaty, Great Britain had a right to intervene, for the protection of her own special interests. Thus, with Nicaragua's assent, the British claim to control of the Caribbean terminus of the Nicaragua canal was re-established.

It was only when this had been done that Mr. Blaine made his belated move for the abrogation of the Clayton-Bulwer treaty-a move, in the circumstances, very much like trying 
to lock the stable door after the horse had been stolen, for it was an attempt to prevent Great Britain from doing something after she had done it. The secret of this blundering was, doubtless, the same that had been banefully operative in Buchanan's time. The American Government wanted to eat its cake and have it too. It wanted to get rid of the Clayton-Bulwer treaty, and yet keep that instrument still in force. It wanted to free itself of restrictions under it, and yet keep Great Britain bound by those restrictions. And it hesitated to abrogate the treaty, as it could have done at any time, for fear of the consequences which might ensue when Great Britain was freed from its suppositious trammels. This was an attitude all the more weak and unworthy on our part, because as a matter of fact Great Britain had never been bound by the treaty in a more than nominal way, but had, whenever she pleased, been able to find in it a loophole big enough to permit the passage of a coach and four.

So it was not until four months after the re-establishment of practical British sovereignty over the Mosquito Coast, to wit, on November 19, 1881, that Mr. Blaine definitely moved for abrogation of the Clayton-Bulwer treaty. He then wrote a long letter to the British Government, through the American Minister in London, James Russell Lowell, elaborately reviewing the history of the treaty and analysing the changed conditions. He pointed out that the United States was now able and ready to build the canal, but that while under the treaty this country would be forbidden to send a - single soldier to guard it, Great Britain would be free to send warships thither to control it. This, he rightly argued, was unjust. A European guarantee of neutrality would be ineffective, because a European war, between two of the guaranteeing powers, would instantly convert the canal into a scene of hostilities. Again, the existence of that treaty prevented the United States from asserting its own treaty rights against France in Panama. For these and other reasons, he insisted that the Isthmuses should be placed under the sole protection of the United States, in return for which 
this country would guarantee absolute neutrality of the canal to all European powers. He therefore hoped the British Government would assent to a modification of the treaty in accordance with American demands-that is, that America should be released from the treaty, while Great Britain should still be bound by it.

Before this weak and impotent communication reached England or was known to the British Government, the British Foreign Secretary, Lord Granville-a statesman always conspicuous for his friendliness to America-had despatched a note to Washington, commenting with some expression of surprise upon Mr. Blaine's circular letter of June 24, reminding the American Government of the provisions of the Clayton-Bulwer treaty, and saying bluntly that the British Government expected all the provisions of that treaty to be fulfilled. This note was dated November 10, 1881. On November $29 \mathrm{Mr}$. Blaine sent to Mr. Lowell a second note, elaborately trying to reopen the phases of the case which had been definitely closed by Mr. Buchanan twenty-five years before. He argued, as Mr. Buchanan had argued, that the treaty engagements had been entered into misunderstandingly, comprehended imperfectly, and interpreted contradictorily. But instead of concluding, as Mr. Buchanan had done, that in spite of these things the treaty might stand, he insisted that it should be revised or abrogated. Mr. Buchanan in 1859 declared himself "entirely satisfied." Mr. Blaine in 1881, on precisely the same grounds and no others, declared himself entirely dissatisfied. Had Mr. Blaine based his dissatisfaction and his demand for revision upon occurrences subsequent to Mr. Buchanan's closure of the case, his argument might have been effective. Failing to do so, he subjected himself to Lord Granville's curt reply, that his contentions were "novel in international law."

The British diplomat continued, on January 7, 1882, with a long historical and legal argument, effectively traversing Mr. Blaine's two letters. He reminded the American Gov- 
ernment that Great Britain had at one time offered to abrogate the Clayton-Bulwer treaty on condition that there should then be a reversion to the status quo ante, but that the United States had declined; and in fine he refused to let the treaty be made over to suit the United States without regard to British interests.

Meantime, in the summer of 1881, President Garfield had been murdered, and had been succeeded by Chester $A$. Arthur. In time there was a reorganisation of the Cabinet, and Frederick T. Frelinghuysen took Mr. Blaine's place as Secretary of State. It fell to his lot to reply to Lord Granville's note and to continue the controversy, and while he did so to no substantial effect, he somewhat improved upon the controversial standard of his predecessor. Writing to Mr. Lowell, he set down as the corner-stone of his policy the principle of the Monroe doctrine, that the American Government could not assent to any intervention of European powers in the political affairs of the American republics, and therefore, he continued, European guarantee of the neutrality of an American canal was inadmissible.

Proceeding from this general principle to a consideration of the Clayton-Bulwer treaty, he argued that the objects of that instrument were three in number. One was the construction of a Nicaragua Canal. It had failed, after many years, to effect that object, and therefore in that respect was to be considered as having lapsed. The second object was to prevent Great Britain from extending or establishing settlements and sovereignty in Central America, under whatever guise. This object also had failed, he said, through Great Britain's flagrant disregard and violation of the treaty; and he denied the right of Great Britain to erect the timber-cutting camps in Honduras into a colony. The third object was the co-operation of the two governments in the control of any canal that might be built, at Tehuantepec, Nicaragua, or Panama. But this, argued Mr. Frelinghuysen, obviously applied to only the projects at that time under consideration, all of which had long since lapsed; and it could not be 
regarded as applying to entirely new projects which had originated since that time. Finally he argued, with much cogency, that the United States treaty with Colombia, of 1846, giving this country exclusive rights over the Isthmus of Panama, had been concluded before the Clayton-Bulwer treaty, and was not superseded by the latter; and therefore, whether or not the United States was to remain bound by the Clayton-Bulwer treaty in Nicaragua, it certainly was not so bound at Panama, but had a free hand under the Colombian treaty of 1846.

Lord Granville replied by denying that Great Britain had violated the Clayton-Bulwer treaty. He pointed out that that treaty was by its own terms applicable not only to then existing canal schemes but also "to any other" which might at any time be put forward, and especially to any at Tehuantepec or Panama. As to the colony of British Honduras, he defended it with Mr. Frelinghuysen's own argument of priority, on the ground that it had been established before the negotiation of the treaty. He would not even concede that the treaty had lapsed in respect to its first object, of securing a canal at Nicaragua, because no time had been stipulated in which that canal was to be built. Finally, he neatly argued that the United States ought not to bring up the Monroe Doctrine as a reason for abrogating the Clayton-Bulwer treaty, since that doctrine had not been regarded as a bar to the making of that treaty. The correspondence between Mr. Frelinghuysen and Lord Granville finally ceased, leaving the whole controversy about where it had been before. The United States was hopelessly handicapped by the blunderings of Mr. Buchanan's time, and by Mr. Blaine's inept attempt to reopen them, and settlement of the vexatious matter was deferred to a later date and to the hands of a more diplomatic statesman.

From these fruitless debates American attention was turned back to the schemes and operations of De Lesseps. That ambitious and resourceful promoter went rapidly and resolutely forward with his great undertaking. Actual 
construction work was begun on February 1, 1881, and announcement was made that within a year thousands of men would be busy all along the line, and that the canal would be open to commerce in 1888 . So well did he succeed in arousing interest, enthusiasm, and confidence in the enterprise that when the first subscriptions for $\$ 60,000,000$ capital were called for, $\$ 120,660,900$ was promptly offered. Of these offerings, $\$ 99,450,800$ were from French people, mostly in small lots. The original share-holders were 102,230 in number, about 16,000 of them being women in their own names. Of them, 80,839 had from one to five shares each, 19,143 from six to twenty shares, and 3,028 from twenty-one to fifty shares.

The work was "inaugurated" on February 1, 1881. In emulation of the gala performance of Verdi's "Aida" at the opening of the Suez Canal, Sarah Bernhardt went to Panama and presented a drama in the wretched little box of a playhouse which was then the only theatre of the city. In October of that year about three hundred Europeans went to the Isthmus to prepare for extensive operations, and in 1882 thousands of men were at work from Colon to Panama. Money was spent lavishly. Enormous salaries were paid to directors and engineers. Thousands of buildings were erected, for hospitals, hotels, warehouses, and what not. Elegant private mansions were built for the directors of the work. Machinery and other supplies were purchased in vast quantities, largely untried and unsuited to the work. An army of gamblers and harlots invaded the Isthmus. Neglect of sanitation' gave opportunity for pestilences to run riot and to sweep off thousands of victims. A great amount of effective work was done, but at far too great a cost. The general state of affairs was scarcely exaggerated by Froude, when he wrote that "in all the world there is perhaps not now concentrated in any single spot so much swindling and villainy, so much foul disease, such a hideous dungheap of moral and physical abomination." Meantime, De Lesseps remained in France, probably unconscious of half that was 
going on at Panama. Glowing reports came of what was being done, and his fame steadily rose to the climax of heroworship. In 1884 he was elected to the French Academy as the successor of Henri Martin, who had been the successor of Adolphe Thiers, and was saluted by Léon Gambetta with the title of "Le Grand Français," which ever afterward clung to him. On April 23, 1885, he was formally seated among the "Immortals," Victor Hugo being his sponsor and Ernest Renan delivering the oration of welcome.

Behind all this brilliance, the shadows were gathering. In 1885 a serious insurrection occurred on the Isthmus, largely promoted, if not incited, by French intrigues. The city of Colon was looted and burned, and Panama was saved from a like fate only by the intervention of a United States naval force, which went thither under the provisions of the Treaty of 1846. Against this perfectly lawful action of the American Government the French consul bitterly protested, and French sympathy with the insurgents was further shown by the asylum given to the insurgent chief, Aizpuru, on board the French flagship. Two years later came the beginning of the end. Far more money had been spent than the total original estimates, yet the work was scarcely twofifths done. The Congress of 1879 had reckoned a tide-level canal twenty-eight feet deep could be completed for $\$ 114$,000,000 , in seven or eight years. By 1887 it was concluded that a lock canal, only fifteen feet deep, would cost $\$ 351$,000,000 and would take twenty years to build. The seven construction companies which had been working under contracts withdrew from the field, and in November, 1887, the whole job was turned over to M. Eiffel, the French engineer, who had had the contract for building the locks. Efforts were made to raise more money, which met with little success. Government aid was sought, through the wholesale bribing of Ministers, Senators, and Deputies. A popular petition, signed with 158,000 names, asked for the licensing of a national lottery for the raising of funds. This was granted, but proved ineffectual. 
The crash came on December 13, 1888, when the company suspended payments and went into bankruptcy, and on February 4, 1889, was put into the hands of a receiver. The Congress had estimated the cost of the canal at $\$ 114,000,000$. The company had promised to finish it for $\$ 120,000,000$. At the end of 1888 the work was scarcely two-fifths done, while nearly $\$ 400,000,000$ had been disposed of. This colossal sum was said, not altogether untruthfully, to have been one-third spent on the canal, one-third wasted, and onethird stolen. Here are the amounts of the various subscriptions:

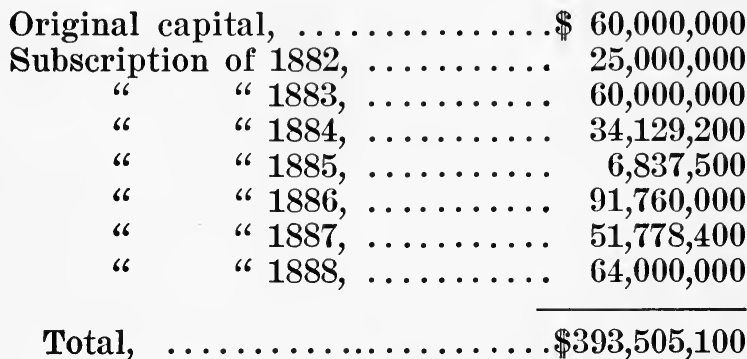

Which produced in cash, .....\$201,546,740

Losing in discounts, etc., ...... 191,958,360

This was an appalling showing. It opened the eyes of the world, even of France, to the monstrous futility of the enterprise as it had been conducted. There was no salvation for it in the patronage which the pinchbeck conspirator Boulanger, then in the height of his brief popularity, gave it, in proclaiming himself the protector and promoter of the enterprise, and subscribing for twenty-five of its bonds. The United States Government promptly took advantage of its opportunity to complete the discomfiture of the concern that had flouted and defied it. A few days after the company's suspension of payments, Senator Edmunds proposed a resolution expressing American disapproval of any connection of any European government with any canal across any American Isthmus, which, on January 7, 1889, was 
adopted by an all but unanimous vote. A few weeks later, in February, Congress adopted another resolution, protesting against French control of the Panama Canal, and appropriating $\$ 250,000$ to be used by the President in the protection of American rights and interests on that Isthmus. On February 7, the Maritime Canal Company of Nicaragua, an American organisation, chiefly of New York capitalists, was incorporated by act of Congress.

The remaining history of the De Lesseps enterprise, partly pathetic, partly tragic, and wholly unsavoury and disgraceful, may be briefly dismissed. Humanity forbids us long to dwell upon such a theme. Judicial proceedings and Parliamentary investigations and trials were conducted at Paris in 1892-93, and there was disclosed to the horrified world such an orgy of corruption as history had never before recorded. A hundred Senators and Deputies were accused of having taken bribes. The Ministry and the Police department were under the same charge. Ten Senators and Deputies, including five former Ministers, were brought to trial, together with the Directors of the Company. Baron Jacques Reinach, the financial agent of the company, who had done much of the bribing, committed suicide. Arton, a banker, who had been associated with him in the dirty work, fled into exile, and long afterward, in 1905, also killed himself. Cornelius Herz, the third member of the triumvirate of corruption, went to England, and either fell or pretended to fall ill, so that he could not be extradited, and thus spent the rest of his life. Ferdinand de Lesseps collapsed, physically and mentally, and probably never fully realised what had happened or what afterward happened. On January 10, 1893, these sentences were pronounced:" Ferdinand de Lesseps, five years' imprisonment and $\$ 600$ fine, and his son, Charles de Lesseps, the same; Baron Cottu, and Marius Fontane, each two years' imprisonment and $\$ 600$ fine; M. Eiffel, two years' imprisonment, and $\$ 4,000$ fine. The sentence against the elder De Lesseps was never executed, and that against his son was annulled by the Court of Appeals. The 
judgment of the world was that both Ferdinand and Charles de Lesseps had been accused and condemned without cause, and that they were guiltless of the iniquities which had been perpetrated in their names. Ferdinand de Lesseps died on December 7, 1894, without ever rallying from his prostration, and his fame will be immortal despite the melancholy ending of his career.

In the United States it became clear that extravagant sums of money had been used in secret if not illicit measures to promote the interests of Panama and to hamper and defeat the rival enterprise at Nicaragua. It was proved that combinations for trade monopoly had been formed by the Panama railroad, then owned by the French canal company, the Pacific Mail Steamship Company, and certain transcontinental railroads; all of which strengthened the resolution to enforce the established principle of an American canal under American control. The De Lesseps scheme had been conceived and elaborated in defiance and denial of that principle, and in its hopeless collapse it left that principle triumphant above all danger of future challenge. 


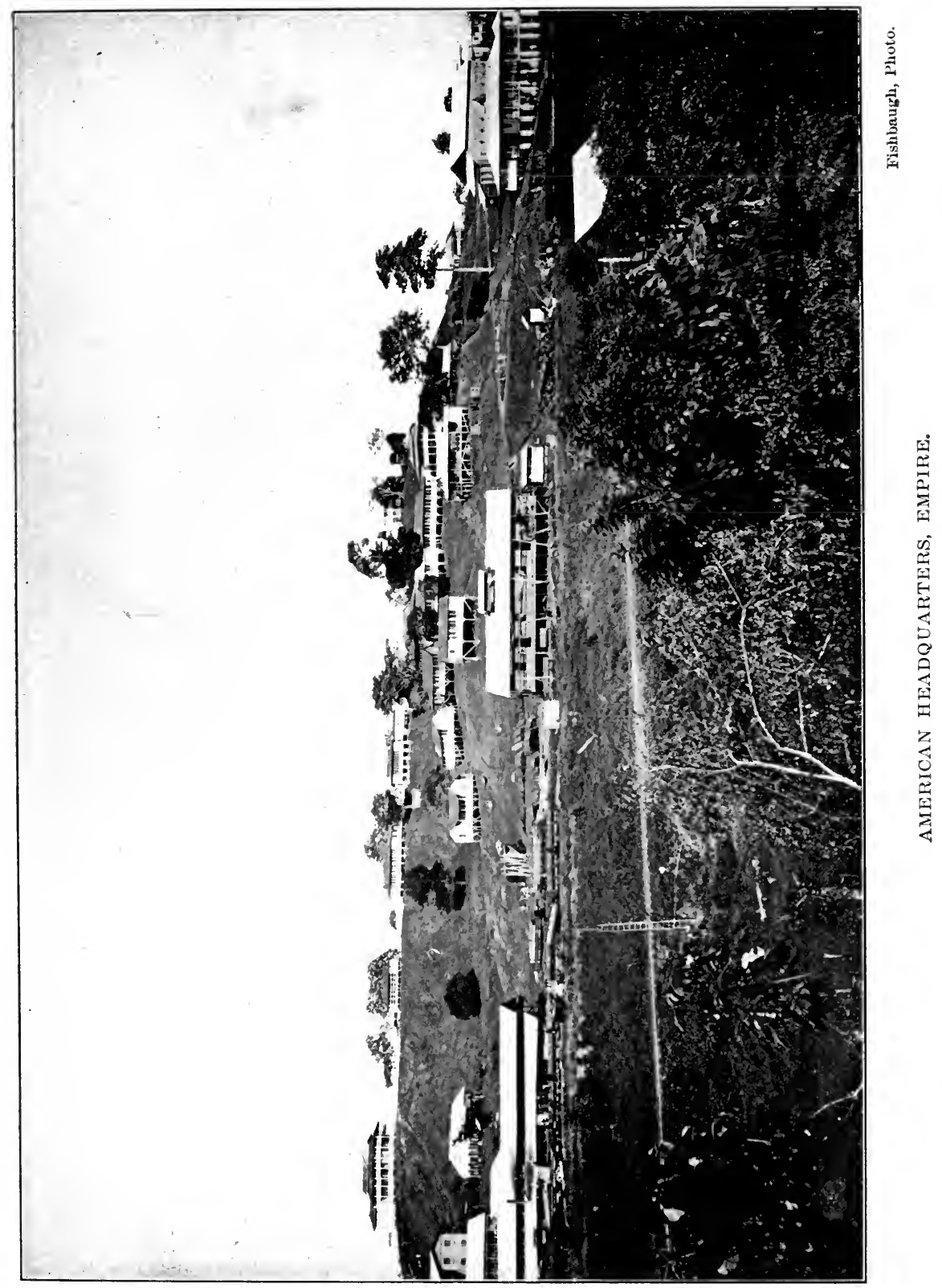




$$
\text { . }
$$




\section{GHAPTER VII}

\section{WHY THE FRENCH FAILED}

There is a familiar story of a lawyer who told a judge there were twelve good and sufficient reasons why his client had not obeyed a summons to appear in court. "In the first place," he began in recounting them, "he is dead." "Never mind the other eleven reasons," said the judge. Perhaps it will be risking a similar interruption for me to attempt to tell the reasons why the French under De Lesseps so signally and disastrously failed at Panama, after even the brief mention which I have already made of their financial wastefulness and corruption. Nevertheless, some of the reasons are so instructive that they deserve more than passing notice; some of them apply not only to the original De Lesseps Company but also to its successor, the New French Canal Company; and some of them were such as were not realised by the world at large at the time, but have only now become apparent to those who have visited the Isthmus and have studied the records and the situation there.

Let me begin with the matter of finances, since I have already referred to it. The extent of the profligacy of the De Lesseps régime was not bounded by the bribery of French officials, the subsidising of the French press, and the exercise of secret and sinister influences in the United States. "The trail of the serpent is over it all," on the Isthmus as well as at Paris, New York, and Washington. We were standing one day on the wind-swept veranda of Major Le Jeune's cottage at Empire, that sightly and salubrious hill where camp the United States troops which guarantee the order of the Canal Zone and also, indirectly, of the Republic of Panama. It was one of the highest points on the Isthmus 
along the line of the canal, and as we could see almost from sea to sea we fell to likening it to that "peak in Darien" whereon stout Cortez-alias Balboa-stood and gazed on the Pacific; in the midst of which, reverting to the topic we had been discussing on our way thither, I asked a man who knew, "What was the real cause of the French failure, and how can we hope to succeed where De Lesseps failed ?" For answer, he persisted in the lighter fancies of our vision, and pointing to the splendid vistas, toward the Pacific and toward the Caribbean, he said: "You see all that?" "Yes." "Forty-seven miles from Colon to Panama?" "Yes." "Well, in De Lesseps's time, it was forty-seven miles of 'graft."" "Yes ; and what is it now?" "Oh, now it is an American Canal Zone!"

Nor was his answer altogether obscure, to one who had seen what had already been pointed out to me. There was the house which had been built for the Director-General, at stockholders' expense, at a cost of $\$ 100,000$. There was also his summer house, at La Boca, which cost $\$ 150,000$ of stockholders' money. He drew a salary of $\$ 50,000$ a year, and got an extra allowance of $\$ 50$ for every day-or fraction of a day-in which he travelled along the line in that sumptuous private car which had been provided for him at a cost of $\$ 42,000$ of stockholders' money. Stables cost $\$ 600,000$; the hospitals at Ancon cost $\$ 5,600,000$, and those at Colon $\$ 1$, 400,000 - they were needed, but they cost three times as much to the stockholders as they did to the builders. Office buildings, etc., cost-the stockholders-\$5,250,000. Everywhere the grossest extravagance prevailed, and in addition to the extravagance there was invariably an enormous "rakeoff." Where a $\$ 50,000$ building was needed, a $\$ 100,000$ building was erected, at a corrupt cost of $\$ 200,000$.

The same conditions prevailed in the purchase of "supplies." In one place I saw where there had been stored a huge consignment of snow-shovels-thousands of them. Snow-shovels in Panama! In another place there had been received and stored some 15,000 kerosene torches, such as 
are used in torchlight processions. They were sent to the Isthmus at the beginning of operations, for use in the grand celebration which was to mark the completion of the canal ! Away up in the hills of Culebra, in the almost impenetrable jungle, miles from navigable water, I saw a number of sectional and portable iron steamboats. They had been sent from France, and carted up thither, overland, to await the time, years afterward, when the canal should be constructed up to them and they could be floated in it. Such examples might be repeated a thousand times.

Apparently, agents were sent all over France, asking manufacturers if they had any surplus stocks of goods of which they wished to get rid. If the answer was in the affirmative, as of course it usually was, they were told to ship the goods to Panama. But they were nothing that was wanted or could be used there. No matter; ship them along. So they sent cargo after cargo, of the most useless things, from hairpins to grand pianos. Almost every week the men at Colon were surprised by the arrival of a shipload of things they had not ordered, did not want, and could not use. But protest and demur were vain. They were told to take the things off and store them somewhere, anywhere, so that the ships could go back to France for more. The system was simple and effective. The manufacturers got rid of surplus, outof-date and almost worthless stock, at top prices. The purchasing agents got large commissions. The railroad and steamship companies got high freight rates. The managers, in France and on the Isthmus, got a rich "rake-off," and the stockholders paid the bills.

So much for the "graft," which consumed tens of millions of dollars and which was alone sufficient to cause the failure of the enterprise. What was suggested in the next place, by my informant's reference to the "American Canal Zone"? This: That the French did not secure control of such a zone, but tried to build a canal on Colombian soil, under Colombian control and jurisdiction. That was not their fault; it was their misfortune; since the United States cer- 
tainly would not have permitted them to obtain, or Colombia to grant, control of such a zone. But what did it mean to the French? It meant that they were left at the mercy of the Colombian police and of the Colombian courts. What that meant, in turn, let a single example, one of many, indicate.

There was a man of Panama, who owned some thirty acres of about the most worthless land on the whole Isthmus. It might have been used as a breeding place for malarial mosquitoes, or as a playground for baby alligators, but scarcely for anything else. It was, however, exactly in the path of the canal builders. They needed it. It was absolutely necessary that they should have it, and have it at once. So they went to the man with an offer of purchase. Ten dollars an acre would have been a fair price. But the Frenchmen wanted to be liberal so as to ingratiate the natives, and also were willing to pay a large price for the sake of closing the bargain at once, so they offered him a hundred dollars an acre. He flatly declined it. How much, then, did he want? Would he be satisfied with a thousand dollars an acre? Oh, no; he could not think of accepting $\$ 30,000$ for his land. Why? Because it was too much, and he did not wish to rob the generous Frenchmen? Oh, no; because it was too little. Well, then, how much would he accept? He answered, without the quiver of a nerve, $\$ 300,000$.

Of course, they appealed to the courts-Colombian courts. Elsewhere it would have been for a writ de lunatico inquirendo. There it was simply for condemnation proceedings and judicial assessment of value. They presented their case. They showed that the land was necessary for the construction of the canal, but they proved, by abundant testimony, that for any other purposes it was practically worthless, and that ten dollars an acre would be a fair price for it. All that was, however, quite superfluous, for the man did not dispute it. He frankly admitted that his land was not worth ten dollars an acre, and that in other circumstances he would have been glad to sell it at that price. But, he added 
in substance, an all-wise Providence had made him the owner of that land, possession of which was essential to this rich canal company, and had thus put it into his power to exact for it whatever price he saw fit to name; and who was he, a humble but, he trusted, a pious man, that he should slight the opportunity which Providence had placed before him?

That was all. The case was closed. The court deliberated for a moment, and then it awarded to the man the full $\$ 300,000$ which he had demanded. In similar fashion, in great things and small, the French company was bled by Colombian rapacity, and that is the sort of thing which was abolished and thereafter prevented by the establishment of American administration, jurisdiction, and control over the Canal Zone. That is something which might well be considered by some of those critics who have condemned our acquisition of the zone as an invasion of Colombian sovereignty and as a measure calculated to involve us in unpleasant and dangerous entanglements. The fact is, it was essential to the construction of the canal.

Another reason for the French failure had to do with sanitation, and was partly the misfortune and partly the fault of the De Lesseps company. It was their misfortune that science had not then discovered that malaria and yellow fever, the most serious of the Isthmian plagues, are propagated and spread chiefly, if not entirely, by the bites of certain varieties of mosquitoes, and that therefore the most effective means of extirpating and preventing those diseases are to be found in the destruction of the mosquitoes, and in guarding both sick and well against their bites-the sick, that the insects may not become charged with virus from them, and the well, that they may not become infected by mosquitoes which previously have bitten the sick. But if this was the misfortune of the French, their faults were no less marked. They neglected to begin their enterprise, as the Americans have done, with a complete sanitary renovation of the Isthmus. They were content to go on with the unspeakably vile conditions then prevailing, with the worse 
than unpaved streets, covered with the filth of ages, with the total absence of sewers or of a water supply, and in general with sanitary arrangements which would have been discreditable in Dahomey. It is true, they built fine hospitals. But they were for the cure of diseases which were permitted to run riot, unchecked. Far better would it have been to have sought prevention of the diseases.

A grave fault lay, too, in the management of the hospitals. The sites selected for the hospitals, especially at Ancon, were admirable. The buildings, too, were well planned and well constructed. They are now being used by the Americans, with little change, and with much satisfaction. It would be difficult to find a better operating room than that at Ancon, the delight of every surgeon who sees it. The equipment, of medicines, instruments, etc., was also as good as was possible at that time. But the management was hopelessly defective. The doctors and surgeons were competent. But they left most of the practical details of administration during the day, and everything at night, to the nurses. The latter were Sisters of Charity. Of those excellent and devoted women I would not say a word that savoured of disrespect or ingratitude. But a Sister of Charity is not necessarily a trained nurse. All her piety and devotion may give her no practical idea of sanitation, of hygiene, of the care of the sick. Nor, with all due reverence, can the saying of Aves and Paternosters supply the need of ventilation, of bathing, and of fresh dressings for wounds. To say a prayer in a hospital at evening is no doubt a pious and a commendable act. But we can scarcely consider it so all-sufficient as to warrant the physicians and nurses in thereupon going away for the night, shutting the wards up nearly air-tight, and leaving all the suffering inmates without care or comfort or attention, until it was time to say the morning prayers-and incidentally to carry out the bodies of those who had died during the night. Excellent sites, excellent buildings, excellent equipments, excellent physicians and surgeons, and excellent women-as women- 


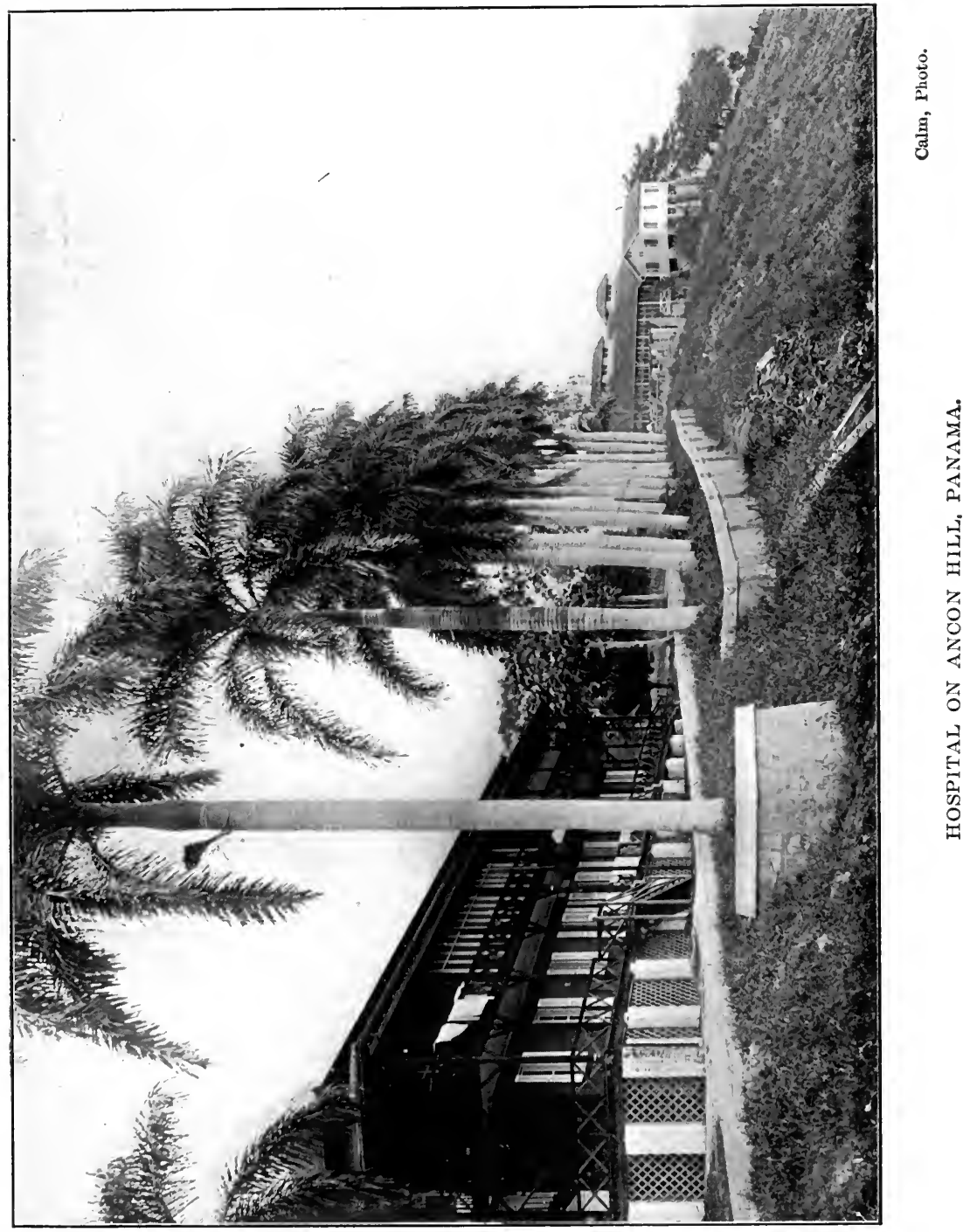


for nurses, but a practical administration which was a grim travesty of therapeutics and sanitation, and which would have been unworthy of the Ninth, not to mention the Nineteenth, Century.

Another serious error was made in the use of experimental machinery. Panama was the happy hunting ground of every mechanical inventor with a fad, where he could get his device practically tried at the expense of some one else. Pick and shovel were old and well tried, of course, but it was not alone with them that the canal was to be cut. Dredges and steam shovels were needed, and these and other machines were too often untried, impractical, and fantastic types, which, after experiments costly in both money and time, were found unsuitable or worthless. A single example, a minor one, will illustrate how the French were handicapped by imperfect utensils. The crux of the whole work, after the sea-level plan was abandoned for a canal with locks, was the monster dam at Bohio, and of course the crux of the dam-building was to find a secure foundation. There are those now who say there is no need of going down to bed-rock for the foundation, but that the great dam can be securely built upon clay or gravel. However that may be, the Frenchmen clung to the old theory that a rock base was necessary. In making their surveys and estimates, therefore, they made borings to ascertain the depth at which the bed-rock lay, so as to determine how great the excavation would have to be and how high the structure of masonry. They had, however, no diamond drills, though such implements were in common enough use elsewhere; and the result was that when they struck a boulder as big as a barrel, they supposed it to be bed-rock, and so reported it, when in fact the actual rock was fifty feet below.

Not to extend the catalogue of errors too far, another grave mistake lay in the manner and place of their disposal of the material excavated, especially at Culebra. Our present plan is to take it a long distance away, and indeed to cart most of it down to the coast at Colon, to raise the level 
of that city and to fill in the surrounding swamps. The French, however, dumped it close to the sides of the cuttings. Now the cuttings are not all through rock, but chiefly through clay, marl, and other comparatively soft and yielding soils. They are so soft that the sides of the cuttings cannot be left nearly as steep as they would be in a firmer soil. A steeper slope than one of forty-five degrees is likely to be marked with trouble, the side wall presently bulging and sliding down into the cut. That is why the canal must be made so wide at the surface in comparison with the width at the bottom. Now the French, not appreciating these conditions, and seeking to save time and labour as much as possible, did not cart the excavated earth away, but piled it up on the high ground at each side of the cutting, where, of course, its weight, superimposed upon the earth which belonged there, greatly increased the tendency of the sides to bulge and slip into the cutting, and thus greatly aggravated the natural conditions. It is to avoid this error and its consequent mischief that the American engineers have ruled that no earth shall be deposited within a certain and very considerable distance of the cutting. This rule necessitates the building of many miles of railroad, to carry the material away, but it will in the end greatly facilitate and expedite the completion of the canal.

With all these and various other errors to handicap them, we can but wonder that the French accomplished as much as they did. In fact, they really did a vast amount of admirable work, most of which is now being utilised by the American engineers. They also, with all their consignments of snow-shovels and petroleum torches, and with all their improvident experiments with untried and impractical devices, took to the Isthmus a vast amount of excellent machinery, tools, and hardware supplies, which is still, much of it, in first-rate condition. Our engineers, on taking possession of the works, found vast storehouses stocked with hardware of all kinds, practically as good as when it was shipped from France. Moreover, astounding as it may seem, in view 
of popular impressions of Isthmian climate and of its effect upon metal work of all kinds, they found locomotives and other steam engines, which had been standing neglected since De Lesseps's day, some of them actually in the open jungle, which needed only a little oiling and new leather belting to be set to work, as good as new. The dredges down in the submerged parts of the canal were chiefly rusty junk. But up on the highlands, around Culebra and Empire and Matachin, machinery has been preserved from ruin in a surprising and gratifying way.

It would be ungracious to dwell too long upon the errors of the French, and it would be vainglorious to exploit too highly the manner in which Americans are avoiding them. It was not strange, perhaps it was inevitable, that the French should make some serious blunders, in undertaking so vast a work, and a work so unlike, in some fundamental particulars, any they had ever undertaken before. It would be inexcusable for Americans to fall into the same errors. The French, too, as we have seen, suffered from certain unfortunate conditions beyond their control, to which we are not subject. We have the advantage of the great advance which has been made in the last score of years in medical science, and we were not prevented by the Monroe Doctrine from securing control of the Canal Zone. Much more, almost immeasurably more, is properly to be expected of us than of the French. That we shall meet those expectations in a satisfactory manner is to be hoped, but is yet to be proved. The first year and more of our work there, as we shall presently see in greater detail, was by no means free from errors, serious, though happily not disastrous. There are at the present time, moreover, potentialities and even menaces of further complications of an embarrassing and even discreditable character. The lesson of the French failure is, therefore, not one of vaunting on the part of Americans, but rather one of prudence, circumspection, and that eternal vigilance which is the price of honesty and efficiency as well as of liberty. 


\section{CHAPTER VIII}

\section{NICARAGUA OR PANAMA?}

The French did not propose, however, to lose all they had done and spent at Panama without a struggle. They realised as fully as the most censorious of their critics the blunders which had been made and the appalling corruption which had prevailed. They knew, however, that much good work had been done, and their confidence in the practicability of the enterprise was not diminished. Resolute and resourceful, they rose from the ruins of the De Lesseps company with splendid determination. The receiver of the bankrupt company, M. Brunet, promptly organised a committee to study the situation and to devise ways and means to rehabilitate the enterprise and to push it to completion. This committee was composed of nine Frenchmen, one Belgian, and one Dutchman. It met in October, 1889, and two months later five of its members visited Panama for personal observation and investigation. In May, 1890, it reported to M. Brunet that the canal could be completed, on the highlevel plan, with locks, and recommended the organisation of a new company to undertake the work. M. Brunet accepted the report and decided to act according to its recommendations. His first step was to send Lieutenant Wyse to Bogotá to secure an extension of the franchise. The original concession dated from May 28, 1878. On December 26, 1890, Lieutenant Wyse secured an extension of it for ten years, on condition that the new company should be fully organised by February, 1893. This condition it was found impossible to fulfil, but the Colombian Government complaisantly-for a substantial consideration-extended the time little by little, until on August 4, 1893, it gave a 
concession running until October, 1904, at which date the canal must be opened to commerce. Finally, in December, 1898, it added six years more to the time allowed, giving until October, 1910; though it was afterward said this last extension of time had not been legally made and was invalid.

Meantime, on October 21, 1893, the New Panama Canal Company was organised, under French laws. It had a capital of $\$ 13,000,000$, and expected to complete the canal for a total of $\$ 180,000,000$. Under its agreement with the receiver of the old De Lesseps company, it was to take as its own all the material assets of the latter, and when the canal was completed, forty per cent. of the profits was to be retained by the new company, and the remaining sixty per cent. was to go to the old company, for its liquidation. A Technical Committee was formed, of distinguished membership, consisting of one Colombian, one Russian, one Belgian, two German, two American, and seven French engineers. Work then proceeded, on the lines established by the original company, until in 1898 the Technical Committee estimated that ten years more would be sufficient to finish the canal, at a cost of $\$ 100,000,000$. By this time, however, the funds of the new company had been exhausted, and in accordance with its statutes a commission of five members-one American and four French engineers-was appointed to consider the question of further procedure. This committee canvassed the situation and prospects thoroughly, and in February, 1899, unequivocally approved the report of the Technical Committee and advised the continuation of the work. That course was thereupon adopted, and the work of constructing the canal was incessantly pushed.

The rivalry of Nicaragua was, however, by no means ended. It was indeed entering upon a new and more strenuous phase. A most important step toward the construction of a canal at Nicaragua was taken in 1884, when Mr. Frelinghuysen, the American Secretary of State, and General Joaquin Zavala, the Nicaraguan Minister at Washington, 
negotiated a treaty, which provided that the United States should construct such a canal, to be owned by it and Nicaragua jointly, that there should be a perpetual alliance between the two countries, and that the United States should guarantee the territorial integrity of Nicaragua. This was obviously a bold challenge to Great Britain. It violated the Clayton-Bulwer treaty, and was doubtless intended so to do, as an offset to Great Britain's former violations of it; and its probable result would have been to drive Great Britain to abrogation of that treaty, and then to precipitate a diplomatic struggle between the United States and Great Britain over control of the Mosquito Coast. The treaty would also have made the United States to some extent a partner of Nicaragua in the possible and not improbable wars of that country with its neighbours, or else, and more probably, would have established a practical American protectorate and control over Nicaragua.

The treaty was negotiated in the last months of President Arthur's administration, and was still before the Senate awaiting ratification when Mr. Cleveland succeeded to the Presidency. One of the early acts of the incoming administration was to withdraw several treaties from the Senate, this one among them, and so it failed of ratification. Mr. Cleveland made it plain that he withdrew and suppressed it, not because he was opposed to a canal, but because he was opposed to a purely American canal, and because he regarded the alliance with Nicaragua and the guarantee of that republic's territorial integrity as an entanglement contrary to the traditional policy of this country. He said:

"I do not favour a policy of acquisition of new and distant territory, or the incorporation of remote interests with our own. . . . I am unable to recommend propositions involving paramount privileges of ownership or right outside of our own territory, when coupled with absolute and unlimited engagements to defend the territorial integrity of the State where such interests lie. . . Whatever highway 
may be constructed across the barrier dividing the two greatest maritime areas of the world must be . . . removed from the chance of domination by any single power. . . An engagement combining the construction, ownership, and operation of such work by this Government, with an offensive and defensive alliance for its protection, with the foreign State whose responsibilities and rights we would share, is in my judgment inconsistent with such dedication to universal and neutral use."

In this utterance Mr. Cleveland did far more than to disapprove the Frelinghuysen-Zelaya treaty. He flatly reversed and repudiated the policy of his predecessors, Arthur, Hayes, and Grant, which was, as we have seen, for "a canal under American control." More than that, he repudiated the policy established in $\mathbf{1 8 4 6}$ by the treaty with New Granada, under which the United States did receive "paramount privileges of ownership or right outside of our own territory . . coupled with absolute and unlimited engagements to defend the territorial integrity of the State where such interests lie." There can be no doubt that $\mathrm{Mr}$. Cleveland's objections to the Frelinghuysen-Zelaya treaty would have been equally applicable to the Treaty of 1846 . Happily this divergence from the well-established course of the United States was not maintained. The Nicaragua treaty perished unratified, but the United States Government returned to and continued in the course indicated by President Polk in 1846 and so strongly confirmed by Presidents Grant and Hayes in later years.

The next step at Nicaragua was taken in 1887, when Lieutenant Menocal was sent thither at the head of an elaborate survey expedition, to determine the exact route of the proposed canal. Following this, on January 10, 1888, a bill was introduced into Congress for the chartering of the Provisional Canal Company under the new name of the Maritime Canal Company of the United States, and after more than a year's fighting, largely against the insidious opposition of the moribund Panama Company, the bill became a 
law on February 20, 1889. A necessary concession from Costa Rica was in the mean time secured, since the canal would for a part of the way traverse the territory of that republic. The company thus chartered was organised on May 9, 1889, with Hiram Hitchcock, of New York, as its President. Its capital was $\$ 150,000,000$, in preferred stock at five per cent., and $\$ 100,000,000$ in common stock. In March, 1890, a Construction Company was also organised, under the presidency of ex-Senator Warner Miller, of New York, with a capital stock of $\$ 12,000,000$, the shares of which were all sold at fifty per cent. discount, thus netting only $\$ 6,000,000$.

Work was actually begun at Greytown on June 8, 1890, and was pushed with considerable energy and discretion, chiefly in building a breakwater, wharves, warehouses, workshops, etc., at Greytown, a railroad, and a part of the canal; and large supplies of material, machinery, some steamboats, and other essential appliances, were purchased. In this way in the course of three years the whole of the $\$ 6,000,000$ capital of the Construction Company was exhausted. There would probably have been no difficulty in securing additional capital, to almost any amount; for the Nicaraguan project was popular in America, as an offset to the offensive French scheme at Panama, and there was full confidence not only in the practicability of it but also in the integrity and efficiency with which it was being promoted, and which formed a grateful and inspiring contrast to the blundering and plundering at Panama. But in 1893 occurred an almost unprecedented financial stringency in the United States, with widespread depression of business. In those circumstances it was impossible to get more capital, and in consequence, on August 30, 1893, the Construction Company was compelled to go into the hands of a receiver, and work on the Nicaragua Canal ceased, never to be resumed.

Thereafter for ten years a persistent campaign was waged in Congress, led conspicuously and with unsurpassed pertinacity and confidence by Senator Morgan of Alabama, for 
government aid for the Maritime Canal Company, or for government assumption of its enterprise at Nicaragua. Twice before 1893 Senator Sherman had introduced a bill for giving a government guarantee to the company's bonds, to the extent of $\$ 100,000,000$, but each time it had failed to reach a vote. In 1894 the measure was reintroduced, in the Senate, providing for a guarantee to the extent of $\$ 70,000$,000 , and was passed by the Senate, but failed of a vote in the House. The same thing occurred in 1895 , but on this occasion Congress provided for a commission of investigation. This commission was headed by General William Ludlow, a competent engineer, but it was able to do little, because the parsimony of Congress provided only $\$ 26,176$ for its expenses. It did some careful work, however, and reported that the company's plans were feasible. In this year a new Construction Company was organised, but lack of means and the lack of government encouragement prevented it from resuming work. During the next two years Congress devoted much time to futile debates upon the matter. In the session of 1897-98 it was proposed to purchase the Maritime Company's franchise and property and assume all its liabilities, paying its stock- and bond-holders and other creditors $\$ 4,500,000$ in bonds and $\$ 7,000,000$ in stock. Again, in 1898-99, a similar proposition was made; the Government to pay the company $\$ 5,000,000$ in bonds, and to assume all its indebtedness, in return for its franchise and property. Under these schemes the enterprise was to pass into the hands of the Government. Neither of these proposals, originating in the Senate, was enacted, nor was the one which originated in the House of Representatives in 1898-99, and which provided for the purchase outright of a strip of land from Nicaragua and Costa Rica, extending from sea to sea, and for the construction of a canal on it, at a cost of $\$ 115,000,000$.

Another Isthmian Canal Commission was constituted by Congress in June, 1897, headed by Rear-Admiral John G. Walker, U. S. N., and with an appropriation of $\$ 300,000-a$ 
liberal increase over the pittance given to the former commission under General Ludlow. It went to Nicaragua, partly to investigate matters and partly to gain time, for the ten years of the Maritime Company's concession expired in April, 1897, and it was necessary to make a brave show of activity, if the Nicaraguan Government was to be persuaded to extend the time. Nicaragua was, in fact, feeling anxious over the matter, was losing faith in the Maritime Company, if not in the United States, and was beginning to look elsewhither for some one to build her canal. She was, moreover, again quarrelling with Costa Rica, over the old boundary question. In June, 1897, she gave to an English steamship company exclusive privileges on and along the San Juan River and Lake Nicaragua, for navigation and railroad building, though it was stipulated that the rights of the Maritime Canal Company were to remain superior and unimpaired.

This was an ominous warning to the latter company, but it was followed by something worse. On October 31, 1898, the Nicaraguan Government formally declared that the Maritime Company's concession would become null and void on and after October 9, 1899, and would thereupon immediately be renewed in favour of a new combination of American capitalists, which was known as the Grace-Eyre-Cragin Syndicate, and which included among its members William $\mathbf{R}$. Grace, John D. Crimmins, John Jacob Astor, 'Darius O. Mills, Levi P. Morton, and other New York capitalists and promoters. Appeal was made by the Maritime Canal Company to the United States Government for protection, or for intervention in its behalf, and the whole matter was presently taken under consideration by Congress.

The aid of the Government had indeed been urgently sought, in the form of diplomatic intervention, early in 1898, but had necessarily, in the then existing circumstances, been denied. It was quite evident to judicious observers that nothing practical could be done by the United States without first securing abrogation or material modification of the 
Clayton-Bulwer treaty. But at the beginning of 1898 the United States was obviously within measurable distance of a war with Spain. In the spring of that year that war actually began. It was therefore deemed desirable to maintain perfectly cordial relations with Great Britain, instead of reopening an irritating, if not acrimonious, controversy with her; especially as Great Britain was the only important European power of whose sympathy and friendship this country felt entirely assured. The canal company's plans and requests were therefore put aside for the time. At the end of the war, however, the State Department made representations to Nicaragua in behalf of the Maritime Company, and in January, 1899, the war being ended, a general canal campaign was opened in Congress.

This campaign was the more earnestly and vigorously pushed, and indeed its prosecution was imperatively demanded by popular sentiment, because of a striking incident of that very war which had caused a postponement of canal activities. At the beginning of the war the battleship Oregon, perhaps the finest in the navy, was at San Francisco, where there was no probability of her being needed. She was therefore summoned to proceed at once to the West Indies, where she was urgently needed. To get from the Pacific to the Atlantic coast of the United States, she was compelled to make the long and perilous voyage by way of the Straits of Magellan, 13,400 miles, instead of the shortcut which the canal would have provided, of only 4,600 miles. Had the Oregon met with disaster on that long voyage, our victory over Spain would have been less certain and more difficult. Even the length of time consumed in the voyage might have been costly to us, had the Spaniards acted more promptly. Happily, thanks to the excellence of her construction and to the intrepidity and skill of her commander, Captain-afterward Rear-Admiral-Clark, the ship made the run in record-breaking time and in perfect safety, reaching the Florida coast in entire readiness for action. At that there was universal rejoicing, official and popular, but 
there was also a widespread resolution that there should be no more need of such a roundabout voyage from one part of our coast to another, but that the short-cut of the Isthmian canal should be provided at the earliest possible date.

There were now three competitors in the field, all earnest and exigent, and all well represented at Washington. These were the Maritime Canal Company, the Grace-Eyre-Cragin Syndicate, and the New Panama Canal Company. Each was hostile to each of the others, and each realised that the success of either of the others meant its own ruin. The result of the triangular contest was inconclusive. The Senate passed a bill for the construction of a canal at Nicaragua, as a national enterprise. This would have been a practical triumph for the Maritime Company, had it been enacted. But through the personal opposition of the Speaker, Thomas B. Reed, it failed to pass the House of Representatives. Meantime, Admiral Walker's Commission returned and presented a report which, while divided in opinion as to the cost of the canal, was unanimously and emphatically committed to the practicability and desirability of a canal at Nicaragua, following the Lull survey from the Caribbean Sea to Lake Nicaragua, and the Childs survey from that lake to the Pacific Coast at Brito.

Consideration of the Panama route as an alternative was, however, vigorously and persistently urged, and on March 3,1899 , the last day of the Congressional session, the President was authorised to send still another commission, to investigate both Nicaragua and Panama. An appropriation of $\$ 1,000,000$ was made for the purpose. On June 9, following, the new commission was appointed, Rear-Admiral Walker being at its head.

Congress thus having adjourned without affording relief to the Maritime Canal Company, that organisation saw its only hope of continued life in securing, through the diplomatic aid of the State Department, a reconsideration of the action of the Nicaraguan Government in forfeiting its concession. Before anything could be done, however, the fatal 
date, October 9, arrived. Without aid from Washington, the Maritime Canal Company would have been ruined. But the State Department intervened, with a request that Nicaragua would reopen the case. This request was granted, so far as to waive the technicality of the lapse of the concession through time limitation, and to refer the whole matter to arbitration. In pursuance of that scheme, the Nicaraguan Government appointed two arbitral commissioners, and invited the company to do the same. The company did so, selecting two of its own members. To such choice the Nicaraguan Government objected, and then it demanded that the company should select two Nicaraguans. To this the company in turn objected. Finally, a satisfactory tribunal was constituted, which took the whole case under advisement, and in the fall of 1900 rendered a decision, against the company. This the company refused to accept, and it protested against it to the United States Government, but the protest was ineffective.

Mean while the Grace-Eyre-Cragin Syndicate was becoming involved in embarrassments. The Nicaraguan Government had given it a concession under the mistaken notion, which seems to have been disingenuously fostered by somebody in the interest of the syndicate, that it was backed by the guarantee of the United States Government. When it found this was not the case, the Nicaraguan Government regarded the syndicate with suspicion and disfavour, and sought to cancel its engagement with it. This it finally did, on the ground that the syndicate had failed to pay its bonus of $\$ 500,000$ at the stipulated time.

When Congress met again, in the fall of 1899, it promptly took up again the canal question where it had laid it down in the preceding spring, and bills were introduced into both Senate and House for governmental construction of the Nicaragua Canal. The Senate also asked the President to secure abrogation or modification of the Clayton-Bulwer treaty, as an essential preliminary, but the House bill ignored the treaty and the rights of Great Britain under it, the 
author of the bill declaring that the treaty had been a dead letter since the day on which it was signed. This measure was passed by the House, by an overwhelming majority, but happily failed of passage in the Senate. However well meant, it was egregiously ill-timed, in view of the fact that diplomatic negotiations were at that very moment pending between the United States and Great Britain for an amicable disposal of the obstructive treaty.

These negotiations, conducted by the Secretary of State, John Hay, and the British Ambassador, Lord Pauncefote, culminated in a treaty which was laid before the Senate for ratification on February 5, 1900. It provided that an Isthmian canal might be constructed, operated, and regulated by the United States alone, but that it should be neutralised according to the principles of the Clayton-Bulwer treaty, so that in both peace and war it should be open to both the merchant ships and the warships of all nations, and should never be blockaded; that the United States should never erect fortifications commanding the canal or the adjacent waters; and that the other great powers should be invited to join in the guarantee.

This convention was doubtless well meant by both its makers. It was, however, received by the Senate and by the majority of the American nation with surprise, disappointment, and strong disapproval. It was objected that it did not abrogate nor supersede the Clayton-Bulwer treaty, but practically reaffirmed those features of that instrument which were most objectionable to America; that it required the United States to give free use of its own sanal to any power which might be at war with this country and which might wish to use the canal for this country's harm; and that it violated the Monroe Doctrine and reversed the established policy of this country by calling for European guarantees of American neutrality. Under the lead of Senator Cushman K. Davis, therefore, the Senate amended the treaty, by the insertion of declarations that none of the stipulations of neutrality should be interpreted so as to forbid the United 
States to take whatever measures it saw fit for its own protection and the maintenance of order. This would have permitted the United States to close the canal against an enemy in time of war. There were also adopted amendments proposed by Senator Joseph B. Foraker, specifically declaring the Clayton-Bulwer treaty to be superseded by this new one, and striking out the proposal to invite other powers to join in the guarantee of neutrality. All these amendments were in accord with the well-established policy of the American Government, and they must be regarded as having been desirable, if not essential to our welfare as a nation and to the success of the canal enterprise. With these amendments, the treaty was ratified by the Senate on December 20, 1900. The changes made were, however, unacceptable to the British Government, and the treaty was accordingly permitted to lapse.

Lord Lansdowne, the British Foreign Minister, was sincerely desirous of effecting a settlement of the old controversy on terms satisfactory to the United States, and with that end in view he made, on February 22, 1901, a statement of his reasons for not accepting the amended treaty, coupled with a suggestion that a new one be negotiated in its place. This suggestion was acted upon, the work being undertaken by the same patient and benevolent statesmen who had framed the former treaty, and on November 18, 1901, the second Hay-Pauncefote treaty was signed. It was laid before the Senate on December 5, and on December 16 it was ratified by that body without amendment. (See Appendix III.) This memorable convention, which in due time went into effect and has since been law, specifically abrogated and superseded the Clayton-Bulwer treaty; it gave the United States the sole power to construct, operate, and control the canal, without any co-operation or guarantee from Great Britain or any other country; and it gave to the United States practically a free hand over the canal in time of war. (On this latter point, it is true, the treaty is somewhat vague, and may be interpreted according to the 
requirements of the occasion. While it forbids the blockading of the canal it does not forbid the construction of forti. fications along it.) Thus happily the half-century's dispute over the inept Clayton-Bulwer treaty was peacefully and profitably ended, a cause of much misunderstanding and irritation between the United States and Great Britain was removed, and the chief diplomatic barrier to the construction of an Isthmian canal was swept away, and international sanction was given to, and indisputable opportunity was afforded for, the fulfilment of the policy enunciated by Grant and repeated and elaborated by Hayes, of an American canal under American control.

The report of the third Canal Commission was received by the President, and was transmitted to Congress on December 4, 1900. It discussed in detail the comparative merits and demerits of the Nicaragua and Panama routes. Its practical recommendation was for the construction of a canal at Nicaragua on the lines indicated by the preceding commission of 1897. The cost of the enterprise was estimated at $\$ 200,540,000$; or, by using only a single set of locks, and narrowing the bottom of the canal to 100 feet, at $\$ 163,913$, 000 . The time required for construction was set at ten years. The report estimated the cost of a canal at Panama at only $\$ 142,342,579$, or nearly $\$ 58,000,000$ less than at Nicaragua, but added that no way had been found by which the United States could secure complete ownership and control of the Panama Canal, unless at a cost that would make its total expense much higher than at Nicaragua. Therefore, in conclusion, it said:

"The estimated cost of building the Nicaragua Canal is about $\$ 58,000,000$ more than that of completing the Panama Canal, leaving out the cost of acquiring the latter property. This measures the difference in the magnitude of the obstacles to be overcome in the actual construction of the two canals, and covers all physical considerations. . . . The New Panama Canal Company has shown no disposition to sell its property to the United States. Should that company be able and willing to sell, there is reason to believe that the 
price would not be such as would make the total cost to the United States less than that of the Nicaragua Canal. The Panama Canal, after completion, would be shorter, have fewer locks, and less curvature than the Nicaragua Canal. The measure of these advantages is the time required for a vessel to pass through, which is estimated for an average ship at twelve hours for Panama and thirty-three hours for Nicaragua. On the other hand, the distance from San Francisco to New York is 377 miles, to New Orleans 579 miles, and to Liverpool 386 miles greater via Panama than via Nicaragua. . . . The Government of Colombia, in which lies the Panama Canal, has granted an exclusive concession, which still has many years to run. It is not free to grant the necessary rights to the United States, except upon condition that an agreement be reached with the New Panama Canal Company. The commission believes that such agreement is impracticable. . . . The governments of Nicaragua and Costa Rica, on the other hand, are untrammelled by concessions and are free to grant the United States such privileges as may be mutually agreed upon.

"In view of all the facts, and particularly in view of all the difficulties of obtaining the necessary rights, privileges, and franchises on the Panama route, and assuming that Nicaragua and Costa Rica recognise the value of the canal to themselves, and are prepared to grant concessions on terms which are reasonable and acceptable to the United States, the commission is of opinion that 'the most practicable and feasible route' for an isthmian canal to be 'under the control, management, and ownership of the United States' is that known as the Nicaragua route."

It was doubtless shrewd and wise for the Commission thus to report the apparent impracticability of making satisfactory terms with the New Panama Canal Company. Nothing could have been better calculated to bring that company to precisely such terms. Indeed, long before the date of this report, the directors of the New Panama Canal Company had begun to distrust their own ability to finish their job, to appreciate the force of American objections to an alien canal on American soil, and to realise that their only prudent course was to transfer their undertaking in some way to American control. Resort was first had to the expedient 
of reorganisation under an American charter. Early in $\mathbf{1 9 0 0}$ the "Panama Canal Company of America" was organised and incorporated in New Jersey, and it was planned to transfer the canal to it. But it was soon seen that that would not be sufficient to satisfy American demands. The ownership of the canal must be vested not in any private corporation, French or American, but in the United States Government. Nothing short of that would be acceptable to this country, despite President Cleveland's protest against such a policy, only a few years before.

The French company, at Panama, did not desire thus to sell out, and indeed, was prohibited by its charter from so doing. It began to see, nevertheless, that some such course was inevitable, and accordingly sought permission from the Colombian Government to make a transfer of its concession. The Colombian Government did not greatly care who constructed the canal, whether a French corporation or the American Government, nor indeed, did it display any consuming eagerness to have the canal constructed at all. What it did want was to extort as much profit from the enterprise as possible, in the shape of bonuses, not only for the original concession but for every extension of time that was granted, and for the transfer of ownership. The New Panama Canal Company at last secured, however, on certain conditions, from the Colombian Government, permission to sell its concession and unfinished works to the United States. That was in the spring of 1901. Thereupon, on May 8, Rear-Admiral Walker, the chairman of the United States Isthmian Canal Commission, categorically asked M. Hutin, the President of that company, if the company was willing, ready and able to sell, and if so, at what price. He inquired not only if Colombian permission had been fully granted, but also if the company had the right and power to sell in view of its agreement with the old De Lesseps company, and also of its terms of incorporation under the laws of France.

Much depended upon the answer to these questions, for, as 
we have seen, the report of the Canal Commission, which had been made in the fall of 1900 , favoured the Nicaragua route largely because of the assumed impossibility of securing complete ownership of the Panama route on satisfactory conditions and at an acceptable price. If now the Panama route could be acquired, that recommendation in favour of Nicaragua might be revised and reversed. The fact that the Commission had, on those grounds, reported in favour of Nicaragua was unquestionably what chiefly moved the Panama company to seek permission to sell, for it knew that if the United States once seriously entered upon the construction of a canal at Nicaragua, the Panama scheme would be ruined and dead beyond all hope. On the other hand, it was this move of the Panama company to get permission to sell that caused our Commission to suspect that after all it might be possible to secure the Panama route on terms that would make it preferable to Nicaragua.

M. Hutin replied promptly, on May 15. His company, he said, had unquestionable legal right and power to sell, subject to certain conditions imposed by Colombia: namely, that the United States should be the purchaser, and that the transfer should be effected on or before March 1, 1902. He was, however, unable to fix a definite price. That would have to be done by discussion, or by arbitration. Thus the matter stood in an indefinite state for some months, the American Canal Commission seeking and awaiting a statement of price from the French company, at any rate before Congress should reassemble in the fall, and the company hesitating to commit itself to any definite sum.

At last, on October 2, 1901, M. Hutin gave to RearAdmiral Walker not an offer of sale at a fixed price, but a memorandum of estimate of value, representing the maximum of the company's possible demands for its properties. It was not stated nor intimated that the sum named was the least the company would accept, or even that it would ask such an amount. The estimates, it was explained, were to serve as an indication of what the canal had thus far cost 
the French company, and as a basis of negotiation. The Canal Commission, however, chose to regard this statement of values as an offer of sale, or rather as a demand of price, and accordingly reported the lump sum total of the estimates as the price which the Panama company placed upon its property, and for which it would "sell and transfer its canal property to the United States." The sum was $\$ 109$,141,500. Now the Commission had already estimated the difference in cost between the two routes at only about $\$ 58,000,000$, aside from the cost of acquiring Panama, and had come to the conclusion that $\$ 40,000,000$ was the maximum price which the United States should pay for the Panama concession and unfinished works. It, therefore, regarded the sum above mentioned as more than twice too large for this country to pay, and repeated its recommendation in favour of Nicaragua. The statement of the French company it regarded as confirming its former anticipation that "the price would not be such as would make the total cost to the United States less than that of the Nicaragua Canal." In fact, the payment of the sum named would have made the cost of the Panama Canal the greater by more than $\$ 50,000,000$.

When this action and report of the Commission became known in Paris, a crisis occurred in the affairs of the company. Its President and most of its directors resigned their places in despair, seeing nothing but bankruptcy and ruin ahead. A general meeting of the stockholders was held on December 21, 1901, at which, after much debate, it was voted to negotiate for a sale of the canal to the United States on the best terms that could be secured-presumably the price already suggested by the Commission as the maximum which the United States should pay, $\$ 40,000,000$. At the same time it was earnestly protested that the Commission had misrepresented or misinterpreted the company's former statement of values, and had unjustly "forced the company's hand" by reporting that it demanded such a price for its property. A definite offer of sale of the entire 
property of the company for $\$ 40,000,000$ was made to the Commission by cable, on January 4, 1902, and was confirmed by later mail advices, whereupon the Commission, in a supplementary report, on January 18, revised and reversed its former judgment in accordance with the new conditions thus established, and recommended the adoption of the Panama route and the purchase of the unfinished French canal.

It was at this time pretty generally recognised throughout the world that the United States was at last in earnest, and would not only insist upon controlling whatever canal was constructed across any American isthmus, but also would itself promptly proceed with the construction of such a canal. The International Conference of the American States, commonly known as the Pan-American Congress, in January, 1902, unanimously adopted the following resolution :

"The Republics assembled at the International Conference of Mexico applaud the purpose of the United States Government to construct an interoceanic canal, and acknowledge that this work will not only be worthy of the American people, but also in the highest sense a work of civilisation and to the greatest degree beneficial to the development of commerce between the American States and the other countries of the world."

In this resolution the common sentiment of the American republics, and indeed of the world, was accurately expressed. It remained for the United States to justify that sentiment, and this was not done without one more struggle at Washington. It was now the turn of the advocates of Nicaragua and those interested in the Maritime Canal Company to be stricken with despair, since, if this latest report of the commission were acted upon favourably, the Nicaragua scheme would be killed. There accordingly arose in Congress the final and most vehement controversy over canal routes, the culmination of the age-long duel between Nicaragua and Panama. On January 8 , before the revised supplementary report of the Commission was presented, the 
House of Representatives adopted by the overwhelming vote of 223 to 25, Mr. Hepburn's bill authorising the President to proceed to the construction of a canal at Nicaragua, at a cost of $\$ 180,000,000$, and appropriating $\$ 10,000,000$ on account for immediate use. An amendment was proposed to this bill, leaving the choice of routes to the discretion of the President, but it was rejected by a vote of 120 ayes to 170 nays. Briefly stated, the argument against Panama and in favour of Nicaragua, which prevailed at this time and which brought about this vote, was that the Panama route was the further from the United States, making the voyage from our Atlantic to our Pacific coast much longer than by way of Nicaragua; that Panama was the less desirable for sailing vessels on account of the prevailing calms in the Bay of Panama; that the "Panama lobby" was not to be trusted; and that it would not be possible to make as satisfactory arrangements with Colombia as with Nicaragua and Costa Rica. There was also the general sentiment that Nicaragua was the "traditional American route," while Panama was a French route.

When this bill was reported from the House to the Senate, vigorous opposition was promptly manifested toward it. It is true, Senator Morgan had long been distinguished as the foremost advocate and champion of Nicaragua. But there were other Senators almost equally resolute in their advocacy of Panama, and their number was much increased and their position was greatly strengthened by the supplementary report of the Commission, showing how cheaply the Panama Canal could be purchased. An amendment to the Hepburn bill was therefore offered by Senator Spooner, which amounted practically to a substitute measure. It authorised the President to purchase the rights and property of the Panama company for not more than $\$ 40,000,000$, to secure by treaty with Colombia perpetual control of the strip of land, not less than six miles wide, through which the canal was to run; and then to proceed with the work of constructing the canal. If, however, he was unable in a 
reasonable time to make the necessary bargain with Colombia and with the Panama Canal Company, then he was to make terms with Nicaragua and construct the canal there.

A long and earnest debate followed, during which all the old arguments for and against each of the routes were rehearsed, while the lobbyists of both sides were indefatigable in their efforts to influence Senatorial votes. In addition, the old Darien route was once more brought forward. It was said that a site had been discovered at which a sea-level canal could be constructed with only twenty-nine and a half miles of cutting, or nearly twenty miles less than at Panama, and with no curves, dams, or locks. There would, it was true, have to be a tunnel nearly five miles long through the mountains, but the scheme of making a rock tunnel five miles long and three hundred feet in diameter, these ardent propagandists affected to regard as an inconsiderable trifle, nor did they fear the possible results of an earthquake shock upon such a passageway. It was shrewdly observed, however, that the most vehement advocates of this chimerical project were the very men who had been most opposed to the construction of any canal at all, to wit, the agents of certain transcontinental railroad lines. The game was quite obvious; too much so to delude any Senator or Representative who did not desire, for a consideration, to be deluded. It was, first, to oppose any canal at all; and then, failing that, to set the Government off on a wild-goose chase after some entirely impossible though at first sight plausible route. In this way, if the canal was not ultimately defeated, it would be greatly delayed, and every year's delay meant a year's profit to the railroad monopoly. It was actually proposed that if the Government would guarantee the bonds, a private corporation would supply the capital and do the whole work at Darien in four years at a cost of $\$ 100,000,000$. This precious lure was, however, disregarded or relegated to the limbo of fantastic follies.

There was a long fight over the so-called Spooner bill in the Senate, and there were many rumors of "abhorrent and 
forbidden forces" employed by lobbyists for and against it, most of which probably had their origin in nothing more than imagination or desire. The result was, however, generally regarded as doubtful until the vote was actually taken. That incident occurred on June 19, 1902, when the measure was adopted by the overwhelming vote of sixtyseven to six. It was supposed by many that the House of Representatives would offer strenuous objection to this complete transformation of its own measure, but such proved not to be the case. The very same House which only a few months before had voted overwhelmingly in favour of Nicaragua, and had strongly voted against giving the President any option in the matter, now, on June 26 , by a still more overwhelming vote-259 to 8-accepted the Spooner amendment, giving the President a certain discretion in the matter but directing him to make his first choice at Panama!

The measure thus passed by Congress was signed by President Roosevelt on June 28, and thus became law-the law under which the world's desire is now being fulfilled at Panama. (See Appendix IV.) It was the ending of a controversy which had lasted for nearly four hundred years. It was, in fact, the death warrant of the Nicaragua project, which had for so long and at so great expense been kept before American attention. It is true, the advocates of Nicaragua for a time regarded it, or affected to regard it, as a victory for them, on the ground that the President would find it impossible to make satisfactory terms with Colombia within the "reasonable time" prescribed by Congress, and would, therefore, eventually turn to the Nicaragua route; and indeed, this expectation came very near to fulfilment. The moment the Spooner bill became law, the tactics of the Nicaraguans, and of the enemies of any canal, were changed, and their energies were directed toward the creation of obstacles to a satisfactory agreement between the United States and Colombia. There is reason to believe, too, that some alien influences were exerted to the same end. In a measure these were successful. The United States and 
Colombia did not reach a satisfactory agreement. But, by a dramatic turn of events, which, however, was surprising to none but those who were wilfully or needlessly blind, the United States was enabled, with little delay, to attain its end without such an agreement, and on terms actually more advantageous to it than had been expected. 


\section{CHAPTER IX}

\section{NEGOTIATIONS WITH COLOMBIA}

A LAw for the construction of a canal was at last enacted and in force. It was next necessary, in fulfilment of the provisions of that law, to effect a valid purchase of the French canal company's rights and property, and to make a suitable treaty with Colombia. The first thing to be considered was whether the laws of France, under which the canal company was incorporated, would permit such a sale. The officers of the company, and the company's legal counsel in this country, were confident that they would. But some further assurance was necessary for the satisfaction of the United States Government, and this the Attorney-General of the United States, Philander C. Knox, undertook to secure. After a thorough investigation in France, he gave his opinion, on October 25, 1902, that the French laws would permit the sale, and that the French company could make the sale and give the United States a valid and indisputable title to the property thus conveyed-at least, so far as France was concerned; Colombia was to be reckoned with separately.

This opinion was based upon the revelations and results of legal proceedings in Paris. The offer of the stockholders of the company to sell to the United States had been referred for consideration to the Civil Tribunal of the Seine, which, under a special law enacted in 1893, had jurisdiction over the matter, and had been approved by it. From that approving decision a dissenting stockholder had made appeal to the Court of Cassation, the supreme tribunal of French justice, and the latter instead of reversing had affirmed it, on August 5, 1902. We need not here review, even in epitome, 
the intricate legal arguments, pro and contra, which were involved in the case. It is sufficient to say that after an elaborate and painstaking consideration of it the highest court in France decided that the transfer could legally be made; that after a detailed personal observation and investigation by the Attorney-General, the opinion above mentioned was given, and that no serious attempt was made thereafter to challenge the validity of the transaction.

The next step was much more difficult and more tedious. It was necessary to secure from Colombia a treaty giving to the United States perpetual control of a strip of territory, from sea to sea, and Colombia promptly exhibited an inclination not to make such a grant. It had long been the characteristic practice of both Colombia and Nicaragua to play a somewhat capricious part. Each was ready to offer all sorts of concessions in order to entice canal projectors to it and away from its rival, but the moment it felt pretty sure its route was to be chosen it would increase its demands to an extortionate degree. So it was with Colombia in 1902-3. During the long duel with Nicaragua, Colombia had been profuse in its invitations to the United States to go thither and build a canal. Now that the duel was practically ended in its favour, it began to demand terms which it should have known the United States would not and could not grant.

The terms proposed by the United States and accepted by Colombia in a preliminary protocol were in brief as follows: That Colombia should approve the sale of the French company's rights and property to the United States; that the United States should have the sole and exclusive right to construct, operate, and control the canal; that a Canal Zone five kilometers (3.105 miles) wide should be established, to be under Colombian sovereignty but under United States administration, its neutrality to be guaranteed by the United States, and the sanitary and police services to be jointly maintained by the two governments; that the United States should construct all necessary ports, light- 
houses, hospitals, etc., the ports to be free and the canal tolls to be equal to all nations; that damages arising from the construction of the canal should be appraised by a joint commission and be paid by the United States; that no taxes should be levied upon the canal property; that Colombia should not cede nor lease to any foreign power any lands or islands adjacent to the canal; that the canal should forever be neutral; that Colombia should provide the forces necessary for the policing and protection of the canal, but if she were unable to do so, she might call upon the United States for aid; that the United States should begin work upon the canal within two years after the ratification of the treaty, and should complete it within twenty-four years; and that the United States should pay to Colombia a bonus of $\$ 7,000,000$ in cash and after fourteen years a reasonable annuity, the amount of which, it was at first proposed, should be fixed by mutual agreement or by arbitration, but which was afterward set at $\$ 250,000$.

These terms were widely regarded in the United States as too liberal to Colombia, and as not sufficiently safeguarding the vast interests of the United States in the canal. It was thought that the Canal Zone should be wider, if indeed it did not include the whole State or Department of Panama, and that it should become outright the property of the United States. This latter idea was not perhaps held by a majority of the American people, but the feeling was practically universal that the terms proposed set forth the maximum of what the United States could afford to offer Colombia, and the minimum of what it could afford to accept in return. Colombia, however, affected to regard them as entirely too illiberal toward her, and on November 25, 1902, the Colombian Minister, Señor José V. Concha, informed Secretary Hay that he could not accept them in behalf of his government. Whether in assuming that attitude he was acting upon his own judgment and initiative, or in response to instructions from Bogotá, did not appear. Subsequent revelations, however, gave much colour to the belief that he 
was in entire accord with his home government, and that both were intent upon either the extortion of extreme terms from the United States or the defeat of the American project altogether in favour of some other interest.

The Colombian Republic was at that time in a bad way. Its government was of revolutionary origin and of disputed validity. Dr. Manuel Sanclemente, elected President on July 4, 1898, had been violently deposed and thrown into prison by a coup-d'état on July 31, 1900, and had been succeeded as "Acting President" by the Vice-President, Dr. José Manuel Marroquin, a man of fine literary and scientific attainments, but not gifted with the genius of government, who had established a dictatorship at once absolute and inefficient. The treasury was depleted, the silver peso was worth only 38 1-2 cents instead of 50 cents, and the paper currency, of which $350,000,000$ pesos were in circulation, was so debased that gold was at 2,500 per cent. premium. In 1901-2 revenues were less than 29,000,000 pesos, while expenses, swelled by the chronic state of war, were more than $40,000,000$ pesos. The public debt, both domestic and foreign, was large and was increasing rapidly, and could not be stayed by the activity of the printing presses, which were producing reams of depreciated paper currency.

In such circumstances, what must have been the covetousness with which the politicians of Bogotá regarded the $\$ 40$,000,000 which the United States proposed to pay in cash to the French Canal Company for its concession and unfinished works! It occurred to them that the canal was on Colombian soil, that the concession for its construction had been granted by the Colombian Government, that the whole enterprise thus naturally belonged to Colombia, and that, therefore, Colombia ought to have that money, or at least a large share of it. Why, indeed, should not Colombia have it all? Nothing could be simpler. The French company's concession had only until October, 1910, to run. Indeed, it had not so long, but only until October, 1904, for the extension of it beyond the latter date, though made by the Colombian 
President, had not been ratified by the Colombian Congress. If the Congress should refuse to ratify it, the concession would lapse in October, 1904, unless the canal were finished by that time. It was, of course, a physical impossibility for the company to finish the canal by that time, and so the concession would lapse, the franchise would be forfeited, and all the rights and property of the company would revert to the Colombian Government, which could then sell to the United States on its own terms and for its own profit, and the usufruct would go into the depleted Colombian treasury, to which it would be a veritable godsend. All that Colombia had to do, therefore, was to delay action for a couple of years, to "sit tight," and that $\$ 40,000,000$ would drop into its hands.

Nor was that potent consideration the only force at work. The German "colonial party" had for some time been deeply interested in Colombian affairs. This was natural, for a number of reasons. One was, that the Colombian foreign debt was largely held in Germany. Another was, that German commercial interests in Colombia were large and were steadily growing. A third was, that the Isthmian canal might be of practical use if not a necessity to Germany as an alternative route to her insular colonies in the Pacific and to the western countries of South America, with which she was developing a considerable commerce. Still another was, that it seemed eminently desirable for Germany to obtain, if possible, proprietary or at least leasehold rights in some lands somewhere about the Caribbean Sea. With the opening of the canal, and with the development of the West Indies and Central and South America, the Caribbean would become a centre of the world's commerce, and Germany, aspiring to commercial supremacy, could ill afford to forego the advantages enjoyed by her rivals. The United States was, of course, securely established upon the borders of the Caribbean. So was Great Britain, on mainland and on islands. So was France. So, too, was Holland. Even Denmark possessed a group of islands in those waters. It 
seemed intolerable, to the "forward" party in Germany, that the German empire alone should be denied such an advantage. If it could not have an extensive colony, it certainly should have a naval and coaling station.

Some aggressive German statesmen of the "colonial" school had for some time fixed their eyes on the Danish West Indies, the Dutch West Indies, and various Venezuelan and Colombian islands, as promising a convenient and commodious addition to German possessions. Now it occurred to them that control of, or even a share in the control of, an Isthmian canal would be a supremely felicitous realisation of their ambitions. True, the Monroe Doctrine might be regarded by some as an obstacle. But, they argued, America had already tolerated the French enterprise for twenty years, and apparently would have been willing for the French company to go on and finish the canal. Would not that complaisant attitude of the United States Government serve as an estoppel against any American protests against continuation of the work under German auspices? If America permitted the French to begin the canal, how could it logically forbid the Germans to complete it? The United States had not only acquiesced in the construction, or attempted construction, of the canal by the French company, but it had actually recognised the validity of the French company's title by negotiating for the purchase of it. Logically, then, it would have to acquiesce in the completion of the canal by a German company, and would have to concede the validity of the sale of the unfinished work to such a company. If, then, the French company could be prevented from selling to the United States, and persuaded to sell to a German company instead, the German scheme would be successful and the German position would be impregnable. Or if the whole matter could be delayed until the French's company's franchise had been forfeited to Colombia, and then Colombia should sell to a German company instead of to the United States, the same end would be gained. 
There was in this ingenious line of argument, however, one fatal flaw, or a flaw that would surely have proved fatal had the matter ever been put to the test. The United States could and doubtless would have objected, consistently and logically, to the transfer of the canal from a French to a German company, because it had long before laid down and maintained the principle that while European countries might possess property in the Americas, they could not transfer it from one to another, but upon relinquishing it must leave it independent or else surrender it to the United States or some other American power. It was on that ground that the United States had protested against any transfer of Cuba from the ownership of Spain to that of any other European power, and had announced its readiness to go to war, if necessary, to make that protest effective. On that principle the United States could and would have made effective objection to the transfer of the canal from French to any other European ownership. Happily, however, it was not necessary to take that stand. Diplomacy guards some of its secrets well, and it is not now possible to say with confidence to what extent, or indeed if to any extent at all, the German Government or any of its agents was responsible for or even cognisant of these designs and such efforts as were made for their fulfilment. It was quite notorious, however, that during much of the protracted period of negotiations between the United States and Colombia, and between these countries and the New Panama Canal Company, German agents, official or unofficial, were particularly busy at Bogotá and also in Paris, and seemed to be exceptionally influential with the Colombian Government and to enjoy its confidence and its favour to a remarkable degree. It was also observed that Señor Concha, the Colombian Minister to the United States, in both Washington and New York, was in close and frequent association with other German agents and apparently much under their influence. All this is to be recalled without offence, because it was, of course, quite legitimate for Germany to seek commercial, 
industrial, and political advantages in Colombia to whatever extent she could without traversing or infringing upon the rights of other nations. Moreover, given the scene of an enterprise which had been for four centuries the world's desire, and which was yearly growing of more and more importance to all commercial powers, and given the ownership and nominal control of that region by a State at once weak, disordered, and peculiarly susceptible to either political or pecuniary considerations, and we have an ideal situation for the exercise of diplomatic intrigue.

The year 1902 marked, moreover, the culmination of the latest of Colombia's many revolutionary movements. This widespread insurrection of the Liberal party against the oppressive Conservative and Clerical government had been maintained with varying success for several years, and early in 1902 it began to gather chiefly on and about the Isthmus. A new Governor of Panama-F. Mutis Duranwas appointed by the Bogotá Government in February. A few weeks later the danger of obstruction of commerce and travel over the Isthmus became so marked that the American Government deemed it essential to send a naval force thither to protect the rights and interests of this country, according to the provisions of the Treaty of 1846. On March 8 an American vessel reached Colon and thereafter commanded that city with its guns, thus exercising a most salutary influence over the belligerents. Six months later the situation grew more serious at the southern side of the Isthmus, and accordingly on September 12 another American vessel entered the harbour of Panama, and on September 19 American marines were landed. This action was taken under an order of the Secretary of the Navy, Mr. Moody, which ran in part as follows :

"The United States guarantees perfect neutrality of Isthmus, and that a free transit from sea to sea be not interrupted or embarrassed. . . . Any transportation of troops which might contravene provisions of treaty should not be sanctioned by you; nor should use of road be permitted 
which might convert the line of transit into a theatre of hostility."

This order, sent on September 12, was reasonable and logical, and intended simply to maintain our fixed policy and to fulfil our treaty rights and obligations. Against it the Governor of Panama protested, but without effect. The American authorities persisted in their intervention, in which they were clearly within their rights under the treaty. Indeed they were doing no more than they had done several times before with Colombian approval.

Nor was the American intervention confined to a mere show of force. Actual force was exercised to prevent either of the belligerents from interfering with traffic over the railway, or from using the railway as an engine of war. Colombian troops were disarmed on September 22, and three days later insurgent troops were prevented from using the railroad and were actually compelled to leave a train which they had seized and entered. There was, of course, no interference by Americans excepting to keep the railroad neutral and in peaceful operation. The principle was enunciated and maintained that no combatants under arms should be transported on the railroad, no matter to which party they belonged. That was because to permit such transportation would be to make the railroad an adjunct to that side in the war, and to subject it to attack by the other party. If the Colombian troops used the road, the insurgents would attack it, and the United States would either have to permit such attack, which might suspend the traffic on the road which this country was bound under the treaty to keep free and open, or to prevent it with force, which would make this country the ally of Colombia against the insurgents. If the insurgents were permitted to use it, the case would be, mutatis mutandis, precisely the same. The only logical and safe course was, then, that which was taken, to forbid the military use of the road by either party. This vigorous American policy had the desired effect. The road was kept 
open and undisturbed, and the belligerents, disappointed and discouraged in their efforts to involve the road, finally retired from that region, so that by November 19 it was deemed prudent to withdraw the United States forces.

Meantime, of course, diplomatic negotiations, both open and secret, had been going on. The first part of them came to an end at the beginning of December, 1902. At that time Señor Concha suddenly ceased to be the Colombian Minister to the United States, and was succeeded, as Chargé d'Affaires, by Dr. Tomas Herran. He denied the reports that he had been removed from his place by the Colombian Government, insisting that he had voluntarily resigned, and that, indeed, his resignation had for some months been in the hands of the government, he having presented it as a protest against the intervention of United States troops during the disturbances on the Isthmus. He added that the proposals of the United States for the canal were entirely unacceptable to him and to his government, on financial grounds, and that it would be far more profitable to Colombia to have matters remain as they were, than to make the proposed treaty, even with the payment of a bonus of $\$ 10$,000,000 instead of the $\$ 7,000,000$ first proposed-the United States having, during the negotiations, agreed to such increase of the bonus. He also emphasised the determination of Colombia not to surrender to any extent her sovereignty or administrative control of the Isthmus, and her irreversible opposition to the creation of a canal zone under American administration. Having thus delivered himself, from his hotel in New York, Señor Concha departed for Europe, in the company of a prominent German with whom his association had long been intimate.

This incident gave new hope to the advocates of the canal enterprise. It was felt that Señor Concha's departure from the scene removed a hostile influence, and that Dr. Herran's succession to him was of good omen. Dr. Herran was known to be favourably disposed toward the canal. He was at once a most loyal and efficient servant of Colombia, and a sincere 
friend of the United States. His capacity and integrity were of the highest order, and all his motives were above suspicion. He was earnestly desirous of effecting an arrangement whereby the United States should become the proprietor and builder of the canal, and he entered into negotiations with Secretary Hay, early in December, 1902, with that end in view. He laboured under some disadvantage, at first, in being not a full Minister but merely Chargé d'Affaires, and also in being much hampered by the hesitancy and unreasonableness of the Bogotá Government. His patience and tact triumphed in the end, however, and a convention, known as the Hay-Herran treaty, was signed on January 22, 1903.

Dr. Herran had delayed signing it much longer than he personally thought fit, under the constraint of the urgings of the Bogotá Government, which bade him to hold out with all possible tenacity for a more ample subsidy from the United States. Indeed, at the end Secretary Hay was practically compelled to deliver to him an ultimatum, telling him that if the treaty were not signed by a certain date, the United States would abandon Panama altogether and build a canal at Nicaragua. This menace, coupled with a reminder that the United States might so construe and enforce the Monroe Doctrine and the Treaty of 1846 as to prevent the construction of a canal at Panama by any other power or foreign corporation, brought the Bogotá Government to terms, and it gave Dr. Herran permission to sign the treaty. Nor was this reminder vain, for under the Treaty of $\mathbf{1 8 4 6}$ the United States indisputably had the exclusive right of control over any transportation route, whether railroad or canal, that might at any time be established across that Isthmus.

Under the Hay-Herran treaty, Colombia was to authorise the New Panama Canal Company to sell and transfer to the United States all its rights, privileges, concessions, and properties, including the Panama Railroad. The United States was to have perpetual administrative control, for canal pur- 
poses, of a strip of land 30 miles wide, extending across the Isthmus, the sovereignty of which was to remain vested in Colombia; police powers were, however, to be exercised by the United States. There were to be three sets of courts: One, Colombian, with jurisdiction over causes between Colombians and Colombians, or between Colombians and foreigners other than citizens of the United States; a second, American, with jurisdiction in cases between Americans, or between Americans and foreigners other than Colombians; and a third, jointly American and Colombian, with jurisdiction in cases between Americans and Colombians, and in general civil, criminal, and admiralty matters.

In return for the concession of territory and the canal franchise, the United States was to pay Colombia a cash bonus of $\$ 10,000,000$ immediately, and $\$ 100,000$ yearly, beginning nine years after the ratification of the treaty. These terms were decidedly more liberal to Colombia than those prescribed in the original protocol under which the negotiations were begun. Let us compare them. Under the protocol Colombia was to get a bonus of $\$ 7,000,000$ and an annuity of $\$ 250,000$ beginning after fourteen years. Under the treaty she was to have a bonus of $\$ 10,000,000$ and an annuity of $\$ 100,000$ beginning after nine years. If she had invested the bonus, say at five per cent., she would have had under the protocol an income of $\$ 350,000$ a year for fourteen years, and $\$ 600,000$ a year thereafter, while under the treaty she would have had $\$ 500,000$ a year for nine years and $\$ 600,000$ a year thereafter. Under the protocol she would have got in fourteen years an accumulated income of $\$ 4,900,000$, while under the treaty she would have got in the same time $\$ 7,500,000$, a difference of $\$ 2,600,000$ in her favour under the treaty. These points are to be borne in mind, in view of the fact that while Colombia assented to the original protocol, as a fair basis of negotiation, she objected to the treaty as not sufficiently generous to her in its financial provisions.

The treaty was ratified by the United States Senate on March 17,1903, and it was assumed that the Colombian Con- 
gress would also ratify it at an early date. The Acting President-and actual Dictator-of Colombia was understood to be favourable to it, but he either would not or could not exert any influence in behalf of the treaty. In view of his dictatorial conduct in other matters, and of the various circumstances already described, it seems not unjust to suspect that he was not unwilling to witness the failure of the convention which had been made under the direction of his administration. Such failure would, he might have reckoned, promote Colombian interests, for it would necessitate the negotiation of a new treaty, and by the time that was done the canal concession would lapse and Colombia would be able to sell the franchise and the unfinished work to the United States, and thus secure the coveted $\$ 40,000,000$ for itself.

The animus and aim of the Bogotá Government were, moreover, shown by a significant incident. During the negotiations over the Hay-Herran treaty, and before the signing of that document, President Marroquin ordered the New Panama Canal Company to appoint a special agent, who should come to Bogotá when Congress assembled, and who should have full power to transact any business which might come up between the company and the government. It was explained that the Colombian Government did not mean to oppose the transfer of the company's rights and property to the United States, but that the government would require of the company a "sum of money" in payment for permission to make the transfer, and would also "cancel every liability and obligation" which it had assumed in the original canal concession. This obviously meant that the Colombian Government would compel the company to surrender to it a part if not the whole of the $\$ 40,000,000$ paid by the United States, and then would practically abrogate the canal concession for which the United States had paid that sum. Never was there a more barefaced proposal to "eat a cake and have it, too"-or to get a purchase price without delivering the goods. 
Later it came out that the government intended to exact one-fourth of the $\$ 40,000,000$ from the company. The agent of the canal company at Bogotá, who had been appointed, but not with such power as President Marroquin had ordered, reported to the American Minister there, Mr. Beaupré, on June 20, that the Colombian Government had officially informed him that the Hay-Herran treaty would be ratified, if the company would pay the government $\$ 10$,000,000 - the intimation being, of course, that unless that sum was paid, the treaty would not be ratified. This was after the Congress which was to pass upon the treaty had been elected; indeed, on the very day on which it assembled. The government must have known, when it made that proposition, therefore, what the Congress would do, and must have felt sure of its ability to secure whatever action it desired from the Congress. In other words, the Congress would do whatever President Marroquin wanted it to do, and if the treaty failed of ratification, it would be because he was willing or desirous that it should fail.

A new Congress, which should act upon the treaty, was nominated and elected in Colombia after the treaty had been made and its terms were known. That body was, after the fashion of Colombian Congresses ever since the revolution of President Nuñez, practically selected through government dictation. Had President Marroquin so desired, he could have secured a Congress which would have ratified the treaty. Instead, he dictated the election of one that would reject it. Even in advance of its election it was openly announced that the Congress would be hostile to the treaty. In some cases, as we shall presently see, the government dictated the election of men conspicuously hostile to the treaty, if not to the whole canal scheme.

These facts were notorious, not only at Bogotá and Panama but in the United States, and the knowledge of them inspired the Washington Government to instruct its representatives in Colombia to warn the Colombian Government frankly of the sentiment of this country in the matter. Mr. 
Beaupré communicated to the Colombian Foreign Minister the substance of a despatch from Secretary Hay, which ran as follows:

"The Colombian Government apparently does not appreciate the gravity of the situation. The canal negotiations were initiated by Colombia, and were energetically pressed upon this Government for several years. The propositions presented by Colombia with slight modifications were finally accepted by us. In virtue of this agreement, our Congress reversed its previous judgment and decided upon the Panama route. If Colombia should now reject the treaty or unduly delay its ratification, the friendly understanding between the two countries would be so seriously compromised that action might be taken by Congress next winter which every friend of Colombia would regret."

This energetic "reading of the riot act" had, however, no restraining effect upon the Colombian zeal for delay, obstruction, and ultimate loot. The body which was to pass upon the treaty was made up in predetermined hostility to that instrument, or at any rate in complete servility to the will of the Acting-President. Thus constituted, the Congress met on June 20, 1903. It quickly showed that its reputation of hostility to the treaty was deserved. It was not only hostile to the treaty, but it was not willing to give the advocates of that measure a fair hearing. It made no secret of its bias and its intentions, and these were generally notorious at Bogotá. Just a week after the Congress met, the American Minister reported to the Washington Government that the friends and partisans of President Marroquin were in full control of both Houses, and that thus, he thought, the ratification of the treaty was assured, since President Marroquin was practically pledged to it. That report indicated only the unfortunate extent to which Mr. Beaupré had been deceived as to the real intentions of the Colombian Government. Other diplomats at Bogotá, who were taken more fully into the Acting-President's confidence, were bet- 
ter informed. The German Minister is said to have told his friends at an earlier date than this that the treaty was absolutely sure to be rejected.

A little later Mr. Beaupré began to see the light. He reported on July 2 that a majority of the Colombian Senate had expressed hostility to the treaty, and ten days later he added that the Colombian Government had informed him that the treaty would not be ratified unless the canal company would pay Colombia $\$ 10,000,000$ and the United States would pay $\$ 15,000,000$ instead of $\$ 10,000,000$ as its bonus. Thus were the intimations of the notice served by President Marroquin upon the canal company being fulfilled. Secretary Hay replied, of course, that such conditions were entirely unacceptable to the United States.

Meantime, great anxiety prevailed in Paris. The French company was little short of desperate. It knew its sale of its properties to the United States was contingent upon this country's making a satisfactory treaty with the sovereign of the Isthmus. It assumed, also, and with reason, that if it did not effect such a sale before October, 1904, its franchise would lapse and all its possessions would be forfeited. As time passed without Colombian ratification of the treaty, and as the prospects of such ratification waned, the company felt itself to be confronted by ruin. Naturally, therefore, it began to lend an eager ear to all suggestions of escape from its plight, even to other offers of purchase. If it could not sell to the United States for $\$ 40,000,000$, it would be better to sell for a smaller sum, to Germany, to Colombia, or to any purchaser, than to lose all. The situation was much intensified on August 12, when the Colombian Senate, in fulfilment of Mr. Beaupré's prognostications, rejected the treaty. There was still, of course, a possibility of reconsideration of that action, for there was yet a month, until September 12, before the treaty would expire by time limitation, but that possibility was little more than infinitesimal. Again and again the United States reminded Colombia that under the Spooner law the President could wait 
only "a reasonable time" for the conclusion of satisfactory arrangements with Colombia, and would then be bound to turn to Nicaragua, but these warnings were unheeded.

At the same time offers of purchase of the canal by other parties were renewed with redoubled zeal, and the pressure upon the unhappy company to accept one of them became almost irresistible. The American counsel for the company, William Nelson Cromwell, who had been most active and efficient in promoting negotiations thus far, was put almost at his wits' ends to restrain his clients from such action. The Atlantic cables were kept busy with appeals, arguments, remonstrances, and what not, and finally a hurried trip was made to Paris, with successful results. The company was persuaded to be patient and to expect, through some means, the consummation of its bargain with the United States. In pursuing this course it was justified by the event. What certain prescience of the coming event Mr. Cromwell had, is matter for conjecture. There is reason to believe that he had no part in the revolution which so soon thereafter occurred. Indeed, he is said on at least one occasion to have discouraged and opposed it. But he naturally shared the knowledge which many had, in New York, in Washington, at Panama, and at Bogotá, of the movement then in progress and of the warnings which had already been given to the Colombian Government of the inevitable result of its rejection of the treaty. So the company declined all other offers for its property, and patiently, though anxiously, awaited the result of the American negotiations with Colombia.

The Colombian Government persisted in its fatuous course. In accordance with its policy of delay, it proposed to the United States further negotiations, for the modification of the treaty, on the lines of the extortionate demands made by it and reported by Mr. Beaupré on July 12. As Secretary Hay had already with the utmost positiveness declared those conditions entirely inadmissible, he naturally 
declined this proposal. Strenuous warnings to Colombia were repeated. On August 5, Mr. Beaupré told the Colombian Foreign Minister that occurrences which had already taken place with respect to the canal treaty had been of such a character as fully to warrant the United States in considering any modification of the conditions stipulated in the treaty a violation of the compact between the two governments, which would produce most serious complications in the friendly relations which had thitherto existed between the United States and Colombia.

The only reply to this and other like utterances was a declaration that Colombia had a right to do as she pleased in the matter. Then, on September 8, 1903, the Colombian Government "confidentially" informed the Washington State Department that, despite its rejection of the proposal for further negotiations, it intended to propose a reopening of negotiations, upon bases which it judged would be acceptable "to the Congress of next July." That is to say, the HayHerran treaty was to be killed, and then Colombia would ask for the negotiation of a new treaty which would be acceptable to a new Congress the next year! This characteristic bit of jugglery did not meet with favour at Washington.

A few days later, on September 12, the treaty automatically lapsed, through the expiration of the time allotted for ratification. Still, a single, solitary, infinitesimal hope remained. The Colombian Congress was still in session, and it might yet reconsider its unfavourable action and ratify the treaty, and then request the United States Government to accept it, though ratified at technically too late a date. Whether the United States would or could have done so is an open question. But what is certain is that the Colombian Government had no thought of taking such action. On the contrary, it emphasised its intention of killing the HayHerran treaty, and of blocking the whole canal scheme until it could command success in its extortionate demands. On October 14 a committee of the Colombian Senate reported 
to the Senate a recommendation that Colombia should not negotiate any canal treaty with the United States until after the time granted in the concession to the French Company had expired and its franchise had lapsed. The object of this was obvious, and was two-fold. It would enable Colombia to secure the whole price paid by the United States, since she would then have confiscated the company's property, and it would enable Colombia to insist upon less favourable terms in her new concession to the United States than she had granted to the original De Lesseps Company. This recommendation was not acted upon by the Colombian Senate, but neither did that body direct or authorise the government to seek the negotiation of a new treaty. A show was made of generosity to the French company, in a proposal to ratify the prolongation of the time of its concession from 1904 to 1910 . This proposal is said to have met with the unanimous approval of the Senate when it was first presented. It was then, however, deftly inserted into a convenient pigeon-hole and was never heard of again and, of course, was never acted upon.

In the face of these things, the inexorable predetermination of President Marroquin's government to kill the treaty of its own making, unless extortionate and oppressive conditions were adopted, seems beyond question, and it is evident that there never was any real hope that the HayHerran treaty would become operative. The United States Government, however, was patient. The President interpreted the "reasonable time" provision of the Spooner law as permitting him to wait a little while, even after the time allowed for ratification had expired, before abandoning negotiations with Colombia for a canal at Panama and going to Nicaragua. So he waited patiently until the end of the Congressional session at Bogotá. That came on October 31. On that day the Colombian Congress adjourned without any favourable action upon the treaty, and the American Minister at Bogotá received a leave of absence, though he remained at Bogotá, or at least in Colombia, until 
November 24 following. On October 31, therefore, our relations with Colombia, in connection with an Isthmian canal, ceased. There was apparently nothing to do but to turn to Nicaragua. But before that could be done, there came a revolution. 


\section{CHAPTER $\mathrm{X}$}

\section{THE PANAMA REVOLUTION}

The Colombian Congress adjourned on October 31. On November 3, occurred the Panama Revolution. It was by no means unexpected. As I have said in the preceding chapter, the menace of it and the preparations for it had been known for months in New York, at Washington, at Panama, and at Bogotá. In order, however, to understand its causes and its justification perfectly, we must turn back to the time of Bolivar himself. Colombia, or New Granada, was one of the first Spanish provinces of South America to establish its independence from Spain, in 1819. At the same time it showed itself one of the least worthy of such a state. In the words of Quijano Otero, a historian of that time, "Colombia had lived so fast in her years of glory and great deeds that, though still a child, she was already entering a premature decrepitude." It was actually proposed to establish a monarchy, and the plans to that end were so strongly pushed that Bolivar was moved to seek for aid in preventing their consummation. With the monarchical scheme and with the general turbulence and lack of progress, the more orderly and enterprising people of Panama were disgusted. While Colombia, or, rather, the provinces of New Granada, Venezuela, and Quito, or Ecuador, became independent in 1819 , it was not until November 28,1821 , that the two Isthmian provinces of Panama and Veraguas made their Declaration of Independence. Thereupon they voluntarily allied themselves with New Granada. But in a few years much dissatisfaction arose, and in 1830 many of the foremost Isthmians regarded the union as a grievous mistake and began agitating for its repeal. 
It was in 1819 that Bolivar overthrew the Spanish power and, at the Congress of Angostura, established under its first Constitution the Republic of Colombia, consisting of the three provinces of Venezuela, Quito (now Ecuador), and New Granada, the last named corresponding with the Colombia of later years. In 1821, that Constitution, with some changes, was reënacted by the Colombian Constitutional Congress at Cucuta, and it was maintained until 1830. In that year the Republic was broken up into three parts, Venezuela, Ecuador, and New Granada, each becoming an independent state, and a Constitutional convention at Bogotá enacted and proclaimed a "fundamental law" for "the State of New Granada." This instrument was not fully sanctioned until 1832, wherefore it is known historically as the Constitution of 1832. Meantime, as we have said, discontent arose in Panama, and in 1830 a great mass meeting was held, presided over by the Governor of Panama, General J. D. Espinar, a distinguished veteran of the War of Independence, at which resolutions were adopted calling for "separation from the rest of the Republic, and especially from the government of Bogotá." It was proposed to establish an independent republic, and even, according to Otero, to seek the protection of, or annexation to, Great Britain, if freedom from Bogotan oppression and misgovernment could in no other way be assured. In the end, however, as a mark of personal deference to Bolivar, these plans were laid aside and Panama remained a member of the New Granadan federation, though against the better judgment of a large part of the Isthmian people.

Ten years later, the provocation being not alleviated but aggravated, Panama arose in determined revolt. On November 18, 1840, under the leadership of the famous Colonel Tomas Herrera, its independence was proclaimed and actually established, and on March 18, 1841, a fundamental law, preliminary to a Constitution, was adopted. which read in part as follows: 
"Article I.-The Cantons of the former provinces of Panama and Veraguas shall compose a sovereign and independent State, which shall be constituted under the title of State of the Isthmus.

"Article II.-Should the government of New Granada be organised according to the federal system and convenient to the interests of the Isthmus, the latter shall form a State of the Confederation.

"Special.-In no case shall the Isthmus be incorporated with the Republic of New Granada under the system of Central Government."

It is interesting to recall, by the way, that this fundamental law was signed by José de Obaldia, President; by Mariano Arosemena, Vice-President, and by Antonio Amador, a Deputy of the convention-family names which are to-day honourably conspicuous in the public life of Panama. It was also countersigned by the Secretary-General of the provisional government, José Agustin Arango, whose son, José Agustin Arango, Jr., was one of the foremost leaders in establishing the present Republic of Panama in 1903. Tomas Herrera was unanimously chosen "Chief of State."

Thus Panama became an independent republic in name and in fact. Presently Carthagena followed the example and declared its independence. But the government at Bogota, alarmed at this result of its own evil doings, and unable by force to undo the revolution, sent General Tomas C. de Mosquera to Panama to negotiate a return of the Isthmian State to the New Granadan federation. He made many promises, which were doubtless sincere so far as he was personally concerned, of decentralisation, reforms, and better times for all members of the federation, with the result that in 1842-3 Panama was induced to rejoin New Granada. Immediately thereafter, however, and unquestionably as a result of the action of Panama, Veraguas, and Carthagena, in 1843, a new Constitution was adopted at Bogotá, practically repudiating the promises which had been made by Mosquera, and making the government even more centralised than before. Under it the country was 
called the "Republic of New Granada" instead of "State of New Granada," and was divided into provinces, the provinces into cantons, and the cantons into parishes. Everything was subordinated to centralised power, and the attempt to secede or to withdraw from the union, as Panama had done in 1840, was made a penal offence against the common criminal law.

Against this constitution Panama protested vigorously, amid the various civil wars which followed, with the result that on May 28, 1853, the "Constitution of 1853" was promulgated in place of that of 1843 . Under it a federal system was established, giving the various provinces a considerable measure of autonomy. This was not, however, sufficient to satisfy the just demands of the Isthmians, and agitation was accordingly continued until, on February 27, 1855, the Congress at Bogotá enacted an amendment to the Constitution, specifically erecting "the territory which comprises the provinces of the Isthmus of Panama, to wit, Panama, Azuero, Veraguas, and Chiriqui"-the present Republic of Panama-into "a sovereign federal state, integral part of New Granada, under the name of the State of Panama." In addition, power was given to the other provinces to become such states also. This amendment was unanimously adopted. For six years then following peace and prosperity prevailed in Panama, under the presidential administration of Justo Arosemena, Francisco de Fabrega, Bartholome Calvo, Ramon Gamboa, Rafael Nuñez, and José de Obaldia. In 1856 Antioquia also became a state. In 1857 the other provinces were all made states, and in 1858 the federal system was extended throughout the whole of New Granada, which again changed its name and became known as the "Granadine Confederation."

The next year, however, a packed Congress enacted an election law and other measures greatly infringing upon the sovereignty of the states and aiming at the perpetuation of the power of the conservative party under President Ospina. Thereupon the State of Cauca rebelled, under the lead of 
General Mosquera, and declared its independence of Bogotá, and was followed by the States of Bolivar, Santander, Boyaca, and Magdalena, and a part of Cundinamarca, which last became known as the State of Tolima. These leagued themselves into "the United States of New Granada." A general civil war ensued, which ended with General Mosqueia's triumphal entry into Bogotá. In this war Panama was not involved, but it manifested in the strongest way its disapproval of the unconstitutional legislation of 1859, its opposition to the Bogotá Government, and its sympathy with General Mosquera's revolution. Before the overthrow of the Bogotá Government by General Mosquera, indeed, the President of Panama, José de Obaldia, issued a proclamation advising the final and complete separation of the Isthmus from the Granadine Confederation, on the ground that the latter was hopelessly unworthy of further confidence. This was enthusiastically received by the people, and steps were taken to fulfil the proposition, appealing, if necessary, to the United States of America for protection.

Before the thing could be completed, however, President Obaldia retired from office and was succeeded by Santiago de la Guardia. To him General Mosquera, who had become provisional President of the United States of New Granada, wrote on August 3, 1861, urging him to reconsider the matter and to use his influence to have Panama remain with the confederation, hinting that if it did so, the city of Panama would become probably the political capital and certainly the metropolis of the whole country. After due consideration of the matter, Señor de la Guardia signed an agreement with Dr. Manuel Murillo, the envoy of General Mosquera, making "the sovereign State of Panama" one of the federated members of the United States of New Granada. "But," it was added, "the State, in use of its sovereignty, reserves to itself the right to veto the new agreement and the constitution from which it receives authority, whenever, in its judgment, the principles embodied in the treaty of Carthagena are violated in detriment to the self-government 
of the States." Other stipulations emphasised the fact that Panama was to remain practically independent. There were to be no public officials in Panama appointed from Bogotá, but only those "created by the laws of the State." The courts of Panama were to be supreme and not subject to review by the courts of Bogotá. The federal government at Bogotá was not to send troops into Panama without the special permission of the Isthmian Government. This agreement was signed on September 6, 1861, and was ratified by the Panama legislature on October 15 following. On September 20,1861 , the name of the country was changed to "United States of Colombia," as it has ever since remained. In 1862, Mosquera's revolution was triumphant throughout every state.

Plenipotentiaries from the various states held a National Convention at Rio Negro, in the State of Antioquia, in 1863, the object of which was the reorganisation of the federal system. It repudiated and ignored the agreement under which Panama had reëntered the federation, and adopted a constitution of the United States of Colombia, creating what has been graphically and not inaccurately described as "organised anarchy." The states were made constitutionally independent, with absolute and unqualified sovereignty. The majority of them could nullify any act of the federal congress, and even defeat the acts of the general government in foreign relationships. Any state was free to indulge in revolutions ad libitum, the general government being forbidden to interfere and obliged to recognise any de facto government that might be established by force or fraud. A worse system was probably never devised. To counteract the powers of the states, the federal government promptly resorted to all sorts of extreme and violent measures. There was a series of insurrections, revolutions, and public scandals, provoked by the action of the Bogotá Government, in trying to control by military force the elections in the various States. Panama would have been justified in withdrawing from the confederation, under the terms of the agreement 
of 1861, but did not, hoping that better counsels would in time prevail at Bogotá.

A crisis came in October, 1875. At that time General Sergius Camergo, commander of the Colombian troops which had invaded Panama unconstitutionally, forcibly deposed and imprisoned Dr. Pablo Arosemena, the constitutional President of the State of Panama, for no other reason than that he would not give his support to the electoral plans of the President of the Confederation. Against this act of oppression Dr. Arosemena vigorously protested, and the Panama legislature adopted scathing resolutions of protest and suspended its session to mark its denunciation of Bogotan tyranny. Thereafter Panama, never ceasing to protest, but in vain, was at the mercy of the centralised government at Bogotá, and its interests were sacrificed to those of a sordid coterie of politicians who were practically as alien to the Isthmus as though they were natives of Kamchatka. Panama was made "the milch cow of the confederation," the profits accruing from its fortunate situation being diverted to the treasury at Bogotá. In 1885 conditions became intolerable and a desperate but fruitless insurrection occurred in Panama, Boyaca, Magdalena, Cundinamarca, and Santander. Immediately upon the suppression of these, in September, 1885, came a coup-d'état.

Dr. Rafael Nuñez had been elected President in 1884 for a term of two years. Under the Constitution he would be ineligible for a second term. But what was a little thing like the Constitution between a strenuous statesman and his ambitions? He simply issued a presidential decree, indefinitely suspending the Constitution. Then he appointed a new Governor, of his own arbitrary choice, for each state and instructed them each to appoint two delegates to a national convention "to reform the Constitution." This precious body met at Bogotá on November 11, 1885, to register its creator's will. Dr. Nuñez addressed to it a sententious and dictatorial message, containing many "resounding and glittering generalities" about freedom, justice, and prog- 
ress. The gist of it was, however, a denunciation of the federal system as the source of all evils and the sum of all villainies, and a practical command for the establishment of a strongly centralised government. The dictator also suggested the establishment of a large standing army, suggestively saying that "the State of Panama alone requires a numerous and well-paid garrison." The convention obeyed orders promptly. By the end of the month it had completed its task, and on December 1, Dr. Nuñez appended his approving signature to the new Constitution. That instrument was, by its own terms, to be ratified by the Colombian people before it should become effective, but the President was empowered to determine the manner of such ratification. He decided to have it done not by popular vote, but by vote of the various municipal Boards of Aldermen! In this way, of course, ratification was promptly secured, and in due time under the new Constitution Dr. Nuñez was re-elected President. It was provided, by way of guarding against any undoing of this work, that no amendment could be made to the Constitution unless it was asked for by a majority of the state legislatures and was unanimously voted by them all. Mr. King, the United States Minister to Colombia, appropriately described this Constitution as "an embodiment of precepts enjoining the obedience and submission of the former sovereigns to the will of their central agents, and bestowing all the prerogatives of Government upon an oligarchy of select individuals." This Constitution was ratified in 1886, and is consequently known in history by the name of that year.

The general quality of President Nuñez and his government may be appreciated when we remember that one of his first acts as dictator was to repudiate the foreign debt of the country, on the ground, as he himself expressed it, that "any one who pays a debt, unless he is forced to do so under pain of being hanged, is an imbecile." Under the delightful system thus established Panama, instead of enjoying the special favours it had formerly possessed, was made the 
object of most invidious discrimination. For the whole country an avowedly and intensely centralised system was adopted in place of federation, but under Article 201 of the Constitution Panama was deprived of even such remnants of local self-government as the other states were permitted to retain, and was "placed under the direct authority of the central government, to be ruled according to special laws." In brief, the once independent sovereign state was made a crown colony under the autocracy of Bogotá. Nor was this discrimination merely nominal. It was actual. That oppressive provision of the Constitution was enforced to the letter. Practically, the Isthmus had no rights which the politicians at Bogotá were bound to respect.

The two delegates from Panama to the Bogotá Congress were Miguel A. Caro and Felipe F. Paul. They voted for this arbitrary and tainted Constitution, of course, since they had been appointed at the dictation of President Nuñez, for that purpose. More noteworthy was the manner of ratification of the Constitution by the Cabildo or Council of the District of Panama in the "Department" (formerly State) of Panama. The Council met for the purpose on February 20, 1886. The Governor of the District was present, together with seven delegates. Two other delegates, Henry Ehrman and Ignacio Fuerth, were excused on the ground that they were foreigners. The new Constitution was read, and a vote was taken upon the question of ratification. According to the Official Gazette, of Panama, there were three votes given for ratification: namely, those of Francisco de la Guardia, Nicanor de Obarrio, and José Maria Vives Leon, the last named being the Secretary of the Council; and three votes against ratification: namely, those of Pablo Arosemena, Mateo Iturralde, and Pedro J. Sosa. Thereupon the deciding vote was cast in favour of ratification by the Chairman, Dr. Manuel Amador Guerrero. The act of ratification, thus adopted by the narrow margin of a single vote, was then signed by the Governor and by all the delegates excepting Dr. Pablo Arosemena. It is to be noted that 
Dr. Amador Guerrero, who cast the deciding vote for ratification, and Dr. Pablo Arosemena, who alone refused to sign the act, afterward became respectively the first President and First Designate of the Republic of Panama.

This ratification did not mean that Panama was satisfied with the new system, but merely that it considered itself unable at that time to offer effective resistance. Protest against discrimination and demands for at least equal rights with the other departments were vigorously continued, with the result that at length, on September 3, 1892, the Bogotá Government enacted a law nominally amending the Constitution by the elimination of the objectionable Article 201, and ordering Panama to be comprehended in the general legislation of the Republic. At the same time, however, it practically confirmed the offensive system by providing that "in fiscal matters, special legislative and executive ordinances may be enacted for the Department of Panama." Thus the discriminations against Panama were to be removed, excepting in respect to the most important of all matters, and in that respect they were to be retained. To what a deplorable condition the policies and practices of the Bogotá Government reduced Panama, and indeed the whole country, may be estimated from the official declaration of Dr. José Marroquin, in his inaugural address on becoming Vice-President at Bogotá, in August, 1898. He said :

"Hatred, envy, and ambition are elements of discord; in the political arena the battle rages fiercely, not so much with the idea of securing the triumph of principles as with that of humbling and elevating persons and parties; public tranquillity, indispensable to every citizen for the free enjoyment of what he possesses either by luck or as the fruit of his labour, is gradually getting unknown; we live in a sickly atmosphere; crisis is our normal state; commerce and all other industries are in urgent need of perfect calmness for their development and progress; poverty invades every home. The notion of mother country is mistaken or obliterated, owing to our political disturbances. The conception of mother country is so intimately associated with that of 
political disorders and with the afflictions and distrust which they engender that it is not unusual to hear from one of our countrymen what could not be heard from a native of any other country: 'I wish I had been born somewhere else.' Could many be found among us who would feel proud when exclaiming, 'I am a Colombian,' in the same way as a Frenchman does when exclaiming, 'I am a Frenchman'?"

It thus came naturally to pass that while the Colombian Government at Bogotá chose to play fast and loose with the American Canal proposition, and was willing to delay it indefinitely and even to threaten it with ultimate defeat, the people of Panama felt an intense interest in it and much eagerness to have.the great work begun. The prosperity of the Isthmus, and its peace and order, depended upon it. The contemplation of the possibility of an abandonment of the Panama route and of the building of the canal at Nicaragua was regarded with consternation and dismay, for such a turn of affairs would be an irremediable catastrophe. It would mean utter ruin. When, therefore, the Panamans saw the dilatory conduct of the Bogotá Government, and understood its purport and its possible if not its probable result, they became desperate, and the resolution began to arise among the foremost men to take things into their own hands for the promotion of their own welfare. Too long already the independence of Panama had been subverted and the state had been misgoverned and spoliated for the sordid gain of Bogotá. For Colombia now to deny Panama the opportunity of securing the long desired canal under the best possible auspices, would be more than the Isthmians could endure.

They gave Colombia fair warning. Early in 1903 they explicitly told the authorities at Bogotá that failure to ratify the canal treaty with the United States would be followed on the Isthmus by the most serious consequence. The Colombian Congress, which would pass upon the Hay-Herran treaty and either ratify or reject it, was to meet at Bogotá on June 20. Long before that date, indeed before the mem- 
bers of that Congress were elected or even nominated, a significant step was taken. Dr. Manuel Amador Guerrero had been, as already noted, chairman of the Council which ratified the Constitution of 1885, and had himself cast a deciding vote in favour of that instrument. He was therefore loyally affected toward the Colombian Government. He was at the same time one of the most eminent citizens of Panama, a physician of distinguished repute, a veteran statesman, a man of unblemished character, of large property interests, and of social leadership. There was probably no one on the Isthmus who could with better grace or with more authority have taken the step which he took. He wrote to the acting President of Colombia, Dr. Marroquin, who was his personal friend and former political associate and colleague, urging him for the sake of their common country to use his best efforts to secure the ratification of the treaty, and warning him that the consequence of failure to ratify it would be most serious.

To the surprise and consternation not only of Dr. Amador, but of all Panamans, the reply came in the form of a Congressional nomination. F. Mutis Duran, who was then Governor of Panama, under appointment of the Bogotá Government, nominated, as the government candidate for member of Congress from Panama, Señor Perez y Soto, one of the most implacable and outspoken opponents of the canal scheme, and a bitter enemy of the United States. There was only too good reason to suspect that this nomination was made in fulfilment of Dr. Marroquin's orders, and was practically his reply to the representations of Panama. It was obvious what the election of this candidate would mean. If this representative of Panama in Congress should leadas he doubtless would-the opposition to the Hay-Herran treaty, that convention would have no chance of ratification. There was an outburst of indignation, remonstrance, and protest, which availed nothing. Señor Perez y Soto was declared elected. J. Domingo de Obaldia, a distinguished citizen of Panama, of eminent public service, and unques- 
tioned loyalty to Colombia, hastened to Bogotá to remonstrate in person and to plead with Congress in favour of the treaty. He was received with so little courtesy, and the intent of Congress to disregard the sentiment and interests of Panama, and to kill the treaty, was so evident, that he soon left Bogotá in disgust, not pacified nor mollified, even by the appointment as Governor of Panama which Dr. Marroquin bestowed upon him-in September, to succeed F. Mutis Duran-in hope of placating him and confirming his allegiance.

One of the foremost leaders, if not indeed the foremost, in the practical organisation of the separatist movement in Panama was José Agustin Arango, son of the distinguished patriot of the same name who has already been mentioned as Secretary of the Provisional Government of 1841. He was in 1903 a Senator from Panama to the Colombian Congress at Bogotá, and was strongly in favour of ratification of the Hay-Herran canal treaty. When he perceived that the Colombian Government intended to defeat that measure, he revolted against what he justly deemed a sacrifice of Isthmian interests, and began to plot some means of averting the ruin which seemed to threaten Panama. While meditating upon this subject, he chanced to come into conference with Captain J. R. Beers, the freight agent of the Panama Railroad Company, and in the course of their conversation the suggestion arose that Panama might become independent of Colombia again, and then make for itself a treaty with the United States. Señor Arango became convinced that this was the only hope of Panama, and he requested Captain Beers, during a visit to the United States which he was about to make, to ascertain the sentiment of various representative men in this country upon the subject and to ascertain how such a movement would be regarded here. Meantime he proceeded with the enlistment of a working force of revolutionary propagandists. First of all he took into his confidence his own sons, Ricardo Manuel, Belisario, and José Agustin, and his sons-in-law, Samuel Lewis, 
Raoul Orillac, and Ernest T. Lefevre, and his close friend, Carlos Constantino Arosemena.

The next man to enter the conspiracy was the one destined to become the leader of it. This was Dr. Manuel Amador Guerrero, of whom I have already spoken, and who had already taken strong ground against the Colombian design to burke the canal treaty. He and Señor Arango, who were old and confidential friends, chanced to meet one day at the office of the Panama Railroad, and the conversation naturally turned upon the subject which was then heaviest upon their hearts and upon the hearts of the people of Panama. Señor Arango expressed to Dr. Amador his gloomy forebodings of the action of the Bogotá Government and its effect upon Panama, and his patriotic resentment thereat, and finally revealed to him the separatist plan which he had been cherishing and the mission to the United States which Captain Beers had undertaken. To his profound gratification, Dr. Amador not only sympathised with him in every detail, but also approved heartily the separatist plan and committed himself to it with enthusiasm. Captain Beers soon returned from the United States and made on the whole an encouraging report. It does not appear that he even attempted any negotiations with the United States Government, or any "sounding" of it, and he certainly made to the Panama revolutionists no promises in its behalf. But he reported truly, what every observant man in America knew at that time, that both popular and official sentiment in America was overwhelmingly in favour of the canal, was outraged at the tactics of Colombia, and would be inclined toward close relations with Panama if the latter should secure its independence.

Upon the strength of this, Señor Arango and Dr. Amador proceeded with the organisation of the revolution. They two and C. C. Arosemena constituted themselves into a Junta, which should assume both direction of and responsibility for the movement. Señor Arango's sons and sons-inlaw remained loyal to and active in the cause, but were left 
a little in the background in order that the revolution might not look too much like a family affair, and a goodly company of influential and representative Panamans were discreetly introduced into the conspiracy. Among these were Nicanor A. de Obarrio, who had been born in New York City but was the head of an old Panaman family and was prominently identified with the Isthmus; Federico Boyd, a Panaman banker, son of that American of Irish parentage, James Boyd, who was the founder of the Panama Star and Herald; Tomas Arias, formerly Minister of Finance, and his brother Ricardo Arias, members of a family that had been settled in Panama since Balboa's time; and Manuel Espinosa B., a brother-in-law of Dr. Amador and one of the foremost men of the city of Panama. These men met occasionally at Señor Boyd's house, but oftener at the electric lighting works of the city of Panama, the latter place-and the hour of midnight-being chosen for the sake of secrecy and security.

Other additions were rapidly made to the company, through the discreet invitation of trustworthy friends. Carlos A. Mendoza and Juan Antonio Henriquez joined the conspiracy, and undertook the task of preparing a formal declaration of independence and other documents which might be needed at a fitting time, in which work they were aided by Eusebio A. Morales. Gerardo Ortega, living on the Island of Taboga, was an enthusiastic and valuable recruit, as was Carlos Clement. Eduardo Ycaza not only joined the company but also undertook to bring into it General Domingo Diaz and Pedro A. Diaz. Ramon Valdez Lopez was commissioned to proceed to the interior of the country and organise the revolution there. Pastor Jimenez and Carlos R. Zachrisson V. undertook successfully to bring into line their friend General Esteban Huertas. Fernando Arango, nephew of J. A. Arango, was Chief of Police, but for sufficient reasons did not join the conspiracy and so, on the initiative of Tomas Arias, the manipulation of the police force in harmony with the revolution was intrusted to the deputy 


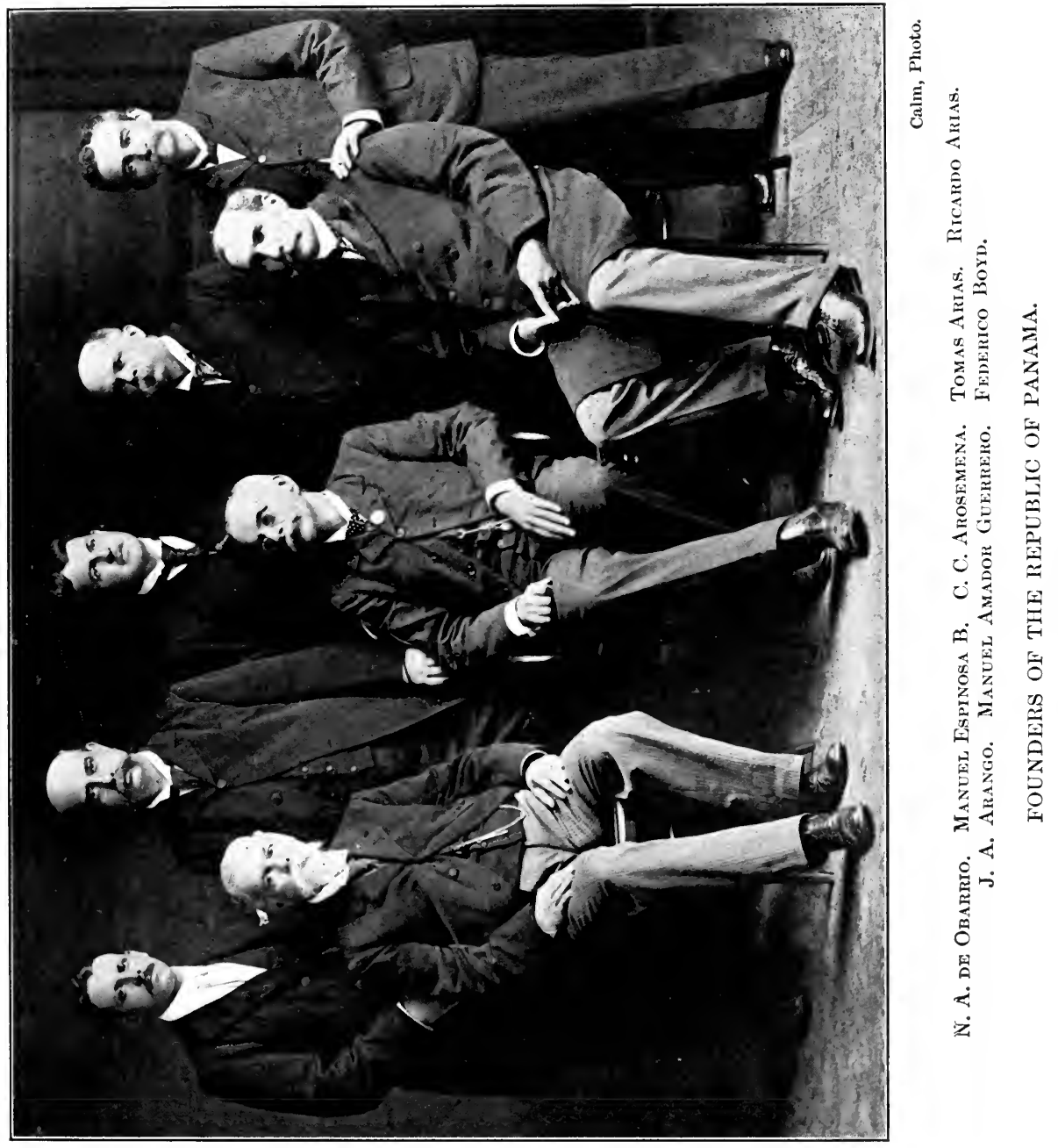




$$
\text { - }
$$


chief, Captain Felix Alvarez. Others who entered the move ment and did important work for it, at Colon and elsewhere, were Hector Valdez, General H. O. Jeffries, Porfirio Melen. dez, the Alcalde of Colon; General Ortiz, Chief of Police at Colon; Captain Achurra, Orondaste Martinez, and J. E. Lefevre. I recall all these names, partly in order to give them the historical credit due to them for their part in the revolution, and partly in order to show how largely-almost exclusively-the revolution was a native Panaman move. ment in inception, development, and execution, and how baseless is the imputation that it was an American conspiracy.

The sentiment of these men was practically unanimous in favour of a revolution which should restore Panama to its rightful place as an independent sovereign state-in case Colombia should fulfil its purpose of killing the canal treaty. To insure the success of such a revolution, however, two things were necessary. One was some fuller assurance concerning the attitude of the United States and its subsequent policy toward the new Republic, and the other, a certain amount of cash to serve as the "sinews of war." It was presently agreed that Dr. Amador and Ricardo Arias should visit the United States to secure, if possible, those ends. Domestic reasons at the last moment prevented Señor Arias from undertaking this mission, and Dr. Amador accordingly set out upon it alone. He sailed directly for New York. His only concealment of purpose was at the moment of leaving Panama. Knowing that he was watched by Government agents, and would probably be stopped if he attempted to leave the Isthmus without some urgent but non-political pretext, he caused the impression to be created that his son was seriously ill in New York and that he had been hastily summoned to see him. By that means he got away from Panama without interference. He was suspected, however, of having some revolutionary business in mind, and was therefore closely followed and watched by agents of the Colombian administration. At the same time, in view of 
his absence, the Junta was reorganised so as to consist of Federico Boyd, Nicanor A. de Obarrio, Ricardo Arias, Tomas Arias, and Manuel Espinosa B.

On reaching New York, Dr. Amador first called upon William Nelson Cromwell, the Counsel for the Panama Railroad Company, and for the French Panama Canal Company, who, of course, was deeply interested in securing the ratification of the treaty. To him he broached the plans of the revolutionists, and of him solicited aid. Mr. Cromwell, despite his earnest desire to see the United States secure the canal route and enter upon the undertaking, was strongly disinclined toward anything like a forcible revolution. He told Dr. Amador frankly that he could not and would not have anything to do with the scheme, and warned him that, in his opinion, the United States would not countenance anything of the sort. Nor was that the only discouragement with which Dr. Amador met. A zealous Panaman friend of the Bogotá Government had followed him from the Isthmus to America, to see what he was doing here, and, seeing him enter Mr. Cromwell's office, concluded that some revolutionary conspiracy was afoot, and hastened to Washington, to tell the Secretary of State what was going on, or what he imagined was going on. Mr. Hay properly replied that the United States Government was not concerned in it, that it could not deal with private conferences but only with overt acts against the neutrality laws, that it had no information of any such acts, and that he could not regard it as profitable to hear anything on the strength of mere hearsay and conjecture.

Then this Panaman went to Dr. Herran, the Colombian chargé d'affaires, and had a protracted conference with him, the character of which must be left to imagination. The quick sequel, however, was the sending of a long cable des. patch from Dr. Herran to President Marroquin, and the engagement of a detective by Dr. Herran to observe and report upon all Dr. Amador's doings. When, soon after, it was reported that Dr. Amador had again visited Mr. Crom- 
well, another despatch was sent to President Marroquin, and immediately thereafter a despatch came from the Colombian President to Mr. Cromwell, warning him that if he engaged in any conspiracy against the Colombian Government, or maintained any relations with revolutionists, the property of the railroad and canal companies, for which he was counsel, would under the law be subject to forfeiture. The result was a discontinuance of Dr. Amador's visits to his office, while Mr. Cromwell went to Paris, to look after the interests of the French Canal Company there, and did not return to America until the middle of November, some time after the Panama revolution had become an accomplished fact.

Thus disappointed, Dr. Amador was upon the verge of despair, and he cabled to his friends in Panama the one word "Desanimado"-“disappointed." He was still intent upon organising a revolution, but to his mind a revolution, of the old-fashioned kind, was impossible without material aid. It would be necessary not only to organise an army, but also to create a Panaman navy, by the purchase of several vessels capable of service as gunboats, and to such ends it would be necessary to secure funds. More for the sake of consolation in sympathetic talk than in the hope of material advantage, he went, immediately after his last call at $\mathrm{Mr}$. Cromwell's, to the office of a Panaman friend and sympathiser,-Joshua Lindo, of the firm of Piza, Nephews \& Co., in New York. To him he related the failure of his errand and bewailed the apparent hopelessness of the Panaman cause.

"There is one man would help us, I am sure," he said, "and that is Bunau-Varilla. But he is in Paris, and I cannot go thither and see him in time to do anything. It would then be too late."

His reference was to Philippe Bunau-Varilla, the distinguished French engineer who had long been identified with the canal scheme, who had been chief engineer for the French Canal Company, who was a capitalist as well as an engineer, 
and who was devoted, with all the strength of his ardent nature, to the promotion of the enterprise. (It is of agreeable interest to recall, also, though it is not pertinent to the present subject, that M. Bunau-Varilla had been in youth a fellow-student with Alfred Dreyfus, and had later played a leading part in securing justice for that much-wronged man. It was he, more, perhaps, than any other one man, who fixed responsibility for the forgery of the "bordereau" upon the infamous Esterhazy, and thus led the way to the vindication of Captain Dreyfus.) While the two were speaking of him and deploring his absence from America at that critical time, the telephone in the office rang. Señor Lindo answered the call; and then uttered an ejaculation of amaze. ment and delight.

"Santa Maria! Amador!" he cried, turning to his guest, "it's Bunau-Varilla, now !"

It was quite true. The French engineer had just arrived in New York from Paris, and had telephoned down to the office from his hotel to ask what had been happening at Panama and at Washington while he was on shipboard. Dr. Amador sprang to the telephone:

"Is that really you, Bunau-Varilla? For Heaven's sake, wait right there until I come up!"

Within half an hour they were closeted together, and M. Bunau-Varilla was committing himself to the revolutionary cause-should such a step be made necessary by the Colombian Government's rejection of the canal treaty-and was pledging to it the financial support which it might need. The Frenchman-he was a French citizen and not a Panaman or Colombian-gave himself zealously to the enterprise, asking in return for whatever he might do only one thing by way of recompense: namely, that as soon as the independence of Panama was established, he should be appointed its Minister to the United States just long enough to negotiate with this country a treaty for the construction of the canal. This was promised him by Dr. Amador, and, as we shall see, the promise was fulfilled. 
Raised from despair to exultant confidence by his interview with M. Bunau-Varilla, Dr. Amador cabled to the Junta at Panama the one word "Esperanzas"-_hopes." He then presently revisited Washington, and sought a conference with the Secretary of State, which had been suggested by his fellow conspirators at the electric light works. His aim was to learn what the United States Government would do, in case of a revolution on the Isthmus. Would it give the new Republic aid? Would it recognise its independence? Would it make with it a treaty for the construction of the canal? This last point was perhaps the most important of all, for the whole matter hinged upon it. There would be no use in a revolution, unless the United States would then proceed with the canal enterprise. There was, however, really no need of asking these questions, for the policy of the United States was already well established and known to the world, and from its record it was quite easy to forecast the action of this Government in any given circumstances. The replies given by Mr. Hay were diplomatically discreet and guarded. He told Dr. Amador that, however much the United States might sympathise with Panaman aspirations for liberty and independence, and however much it might regret or even resent Colombia's rejection of the canal treaty, it would be manifestly impossible for this Government to give any aid to a revolutionary enterprise, or to commit itself with any promises in advance. It would scrupulously fulfil its duties as a neutral, and would inflexibly maintain its rights and privileges under the Treaty of 1846 with New Granada. Those rights and privileges included the protection of free neutral transit across the Isthmus, and the guarantee of the sovereignty of land against alien aggression, though, of course, it did not guarantee Colombian possession of the Isthmus against local and domestic revolution. But the United States could give no promises to, and make no treaties with, a government which was not yet in existence.

Dr. Amador made only a few calls at the State Department. He was then told, kindly but firmly and plainly, that 
as he was confessedly and notoriously the would-be organiser of a revolution against a power with which the United States was at peace, any further visits to that office would not be proper. At that, he gracefully took his leave, with the proverbial "mingled emotions." He had received no direct encouragement or promise of aid, but on the other hand he had been assured of the benevolent neutrality of the United States, and that, he thought, would be sufficient for the purpose. It also dawned upon him that, as the United States was bound by the Treaty of 1846 to guarantee the Isthmus against alien attack, and as the United States was concerned only with the existing local government and not with any domestic revolutions or rivalries in Colombia, if Panama should actually win its independence, Colombia would ipso facto become an alien power, and the United States might, therefore, feel itself called upon to guarantee and maintain Panaman independence against Colombian attack. He also felt assured that the United States would negotiate a canal treaty with Panama, should the latter's independence be achieved. He further realised that two things were eminently desirable, if not absolutely necessary, for the success of the revolution. One was, that the revolution should be effected quickly and, if possible, without bloodshed or violence, since fighting would excite unpleasant and unfavourable sentiments in America. The other was, that a provisional government should be fully organised in advance, so as to become the de facto government and begin the discharge of its administrative duties the moment the Colombian Government on the Isthmus was overthrown.

He at once returned to Panama, to complete preparations for the revolution, and to report to his associates the result of his mission. (He had not been able to communicate with them while in America beyond those two messages of one word each, because of the strict censorship and surveillance which the Colombian Government maintained over the mails and telegraphs.) The other revolutionists were at first inclined to be skeptical, doubting the intentions of the 
United States, and fearing this country would use them merely as tools, with which to force Colombia to revivify and ratify the treaty. It was not until the United States gunboat Nashrille appeared off Colon, on November 2, that they were sufficiently reassured to proceed with the revolution. The reason for the Nashville's arrival at that time was simple and sufficient. Talk of revolution was in the air. It was common talk, at Panama and elsewhere, that a revolution had been planned and would be put into effect as soon as all hope of Colombian ratification of the treaty was dead. November 4 had been openly proclaimed as the day on which the blow would be struck. The general public knew these things, and of course the Washington Government was not ignorant of them.

Moreover, experience had taught the United States that an Isthmian revolution or insurrection was practically certain to imperil American lives and property, and also to menace that free transit across the Isthmus which the United States, under the Treaty of 1846, was bound to maintain. On more than one former occasion, the latest just a year before, United States vessels had been sent to Colon or Panama, and United States troops had been landed, to protect the railroad line and the lives and property of Americans, and this had been done sometimes at the request of, and sometimes against the protest of, the Colombian authorities. The principle had been established that the United States might thus intervene at its own discretion. As soon, therefore, as it became evident that another revolt was impending, the Nashville was ordered to the scene so that intervention could be promptly effected if it should appear necessary. Indeed, in view of the warnings of impending revolt which it had received, the United States Government would have been neglectful of its obligations under the Treaty of 1846 and of its duties to its own citizens, if it had not taken precisely such a precaution.

November 4 had been appointed by the revolutionists for the uprising and the expulsion of the Colombian Govern- 
ment from the Isthmus. General Huertas was to command the Panaman troops, and the signal for action was to be the blowing of bugles by the firemen. But the crisis was precipitated a day sooner than had been expected, by the Colom. bians themselves. Alarmed by reports of what the Panamans were doing, the Bogotá Government, after extraordinary delay, sent an "army" of about 450 men to Colon. This force, under command of General Tovar, reached Colon on the steamer Carthagena, on the morning of November 3, and was promptly landed, without any interference on the part of the Nashville. General Tovar, accompanied by Generals Castro, Alban, and Amaya, at once took train for Panama, leaving word for the soldiers to follow as soon as a special train could be prepared for them, Colonel Torres remaining in charge of them, and the soldiers, many of them accompanied by their wives, "camping out" on the street corners of Colon. Colonel J. R. Shaler, the General Manager of the Panama Railroad, and his deputy, H. G. Prescott, immediately teiephoned to Panama the news of the arrival and landing of the troops and the coming of the officers to Panama, and this quickly convinced Dr. Amador and his associates that the blow for independence must be struck at once, without waiting for the time appointed.

It was nearly ten o'clock when Dr. Amador received the news, and the Colombian officers would reach Panama by eleven o'clock. If they were permitted to enter the city and visit the barracks, they might secure the support of some of the troops, and then some fighting might be necessary. This prospect struck Dr. Amador and the others with consternation. Some of the leaders are said to have hidden themselves in fear, and to have renounced the whole project. Even Dr. Amador and the most resolute of his comrades were much perplexed. It was not that they doubted the outcome, in case of a trial of strength. General Huertas had enough loyal Panamans at his command to deal with all the recreant ones and with the soldiers at Colon to boot. The commanders of the three Colombian gunboats in the 
harbour of Panama were also supposed to have been won over to the revolution, or at least to non-resistance-though that supposition was ill-founded, as soon appeared. But what Dr. Amador had learned in the United States had convinced him that any fighting and bloodshed would seriously alienate the sympathies of Americans.

For an hour there was some quick thinking done, and various plans of action were proposed. One scheme, which seems to have been suggested in all seriousness, though it was not carried out, was to receive the officers with all possible honour, and entertain them at luncheon. There their wine was to be drugged with "knockout drops" so as to render them insensible, when they could be locked up without resistance! Waiving this and other more fantastic schemes, Dr. Amador finally went to the military headquarters, on the Plaza Chiriqui, to confer with General Huertas. That officer had just started, with his staff, resplendent in full-dress uniform, to the railroad station, to meet the coming Generals, and Dr. Amador had no opportunity for a word with him. There was nothing to do, apparently, but to await the progress of events.

The train arrived at eleven o'clock, bearing the four Generals and their staffs, fifteen men in all, glittering in elaborate uniforms and bristling with all the arms it was permissible for officers to bear. General Huertas greeted them with courtesy, and escorted them to the headquarters, while the leaders of the revolutionary conspiracy looked on from a distance, wondering what would happen next. Arrived at headquarters, General Tovar asked General Huertas to conduct him and the other Colombians to the fortifications of the city, and especially to the sea wall. Now from the sea wall it would be easy to signal to the Colombian gunboats in the harbour. Moreover, there were mounted upon that wall several modern rapid-fire guns, commanding the whole city. A small body of resolute men, even these fifteen, armed to the teeth, might make much trouble if they got possession of those guns. So the wily General Huertas determined not 
to gratify their desire. He put them off in characteristic Spanish-American fashion. He reminded them that it was already the hour of the siesta, when men should rest and not exert themselves. Moreover, he and they were dressed in their most elaborate uniforms, hot, closely buttoned, and blazing with medals. Surely, it would be wise to wait until the hour of the siesta was past and the day was a little cooler, and they had all had time to exchange full dress for more comfortable fatigue uniforms. Then he would with extreme pleasure conduct them to the sea wall, and facili. tate any disposition they might desire to make of their gallant soldiers, who would doubtless by that time have arrived from Colon.

Thus entreated, the Colombians yielded. They were entertained at lunch, and in one way or another their suspicions were lulled and inaction was maintained until late in the afternoon. Then the non-arrival of their troops alarmed them, and it is said that in some way an intimation was imparted to them that the troops were being detained at Colon and that they themselves were in danger of falling victims to a revolutionary plot. At any rate they suddenly demanded that without further delay the local troops be mustered and placed at their disposal, and that they be con. ducted to the batteries on the sea wall.

To this General Huertas assented. On some plausible pretext, however, he slipped from the room for a moment, and found Dr. Amador waiting, just outside the door, all anxiety and impatience. The contrast between these two men was most striking. The one was advanced in years, venerable and stately in aspect, and yet impetuous as youth. The other was only a boy in stature and scarcely more than a boy in years, yet at the time deliberate and dilatory. The latter, however, quickly responded to the zealous initiative of the former.

"Do it!" exhorted Dr. Amador, in an impassioned whisper. "Do it now!"

The little General needed no further incitement. He 
ordered out his faithful soldiers, under arms and with rifles loaded, as if to escort the Colombian officers and man for them the fortifications of Panama. Then, as the Colombians approached, he ordered the troops to level their rifles upon them, and announced to the astounded officers that they were his prisoners! Appeal and protest and menace were all in vain. At the muzzles of a hundred rifles the Colombians yielded, and were promptly disarmed and marched off to police headquarters and locked up for safe-keeping! At the same moment, Commandant Antonio A. Valdez and Colonel J. A. Arango J. arrested Señor Obaldia, the Governor of Panama, and conducted him to prison. He was immediately released, in their nominal custody, but was in fact set at entire liberty. His arrest was a mere matter of form, in which he acquiesced, for he was, and was well known to be, in full sympathy with the revolution; but it was deemed desirable to go through the form of deposing him as an appointee of the Bogotá Government.

A prearranged signal was now given to the three gunboats, that the revolution was effected, the expectation being that they would at once give their allegiance to the new government. That expectation was disappointed. Two of the vessels, the Padilla and Chucuito, remained silent and impassive. As for the third, the Bogotá, her commander, Man. uel Martinez, at eight o'clock sent word to the city that if the Colombian Generals were not released by ten o'clock he would bombard the city. To this threat no answer was made, and of course the Generals were not released. Accordingly, at about ten o'clock, the Bogotá fired three shells into the city. One of them hit and killed a Chinese coolie near the military barracks, and that was the only blood shed in the revolution. The Bogotá then steamed away toward Buenaventura.

The next morning, November 4, the gunboat Padilla, also known as the Twenty-First of December, steamed in to a station under the guns of the sea wall, anchored, and raised the Panaman flag in place of the Colombian. A report 
became current that the Bogotá was returning, whereupon the consular corps of the city, representing America, Great Britain, France, Germany, Italy, Spain, Holland, Ecuador, Guatemala, Salvador, Denmark, Belgium, Cuba, Mexico, Brazil, Honduras, and Peru, under the lead of the American Vice-Consul-General, united in a letter to her commander, protesting that the bombardment of a defenceless city, without notice to the consular corps, was contrary to the rights and practices of civilised nations. This letter was not delivered, however, as the Bogotá did not return to the harbour.

Dr. Amador had been strongly urged, when in the United States, to have the Provisional Government of the revolutionists so completely organised that it would be ready to take charge of the actual work of Government and be a de facto government without a moment's delay after the expulsion or deposition of the Colombian officers. This was done. The Municipal Council of the City of Panama met, of its own right, on November 4. There were present the President of the Council, Demetrio H. Brid, and Rafael Aizpuru, Ricardo M. Arango, F. Agustin Arias, Fabio Arosemena, R. José Maria Chiari, P. Cucalon, J. Manuel, Alcides Dominguez, Samuel Lewis, Enrique Linares, Oscar M. McKay, Manuel Maria Mendez, and Dario Vallarino. There was a free discussion of the existing crisis and of the train of historic incidents and circumstances which had led to it, after which it was unanimously voted that Panama should be declared a free and independent Republic, and that pending the organisation of a permanent government, all affairs should be placed in the hands of an Executive Board of three, consisting of José Agustin Arango, Federico Boyd, and Tomas Arias, together with the following Ministers: Eusebio A. Morales, Secretary of State; Manuel Amador, Secretary of the Treasury; C. A. Mendoza, Minister of Justice; F. V. de la Espriella, Secretary for Foreign Affairs; and Nicanor A. de Obarrio, Secretary of War and the Navy. This resolution was signed by the members of the Municipal Council, and 
then, at the call of the Council, it was ratified by a mass meeting of the people of Panama, held that afternoon in the Cathedral Plaza. The Junta at the same time issued a for. mal manifesto, constituting a declaration of independence and a vindication of the revolution. (See Appendix V.)

Meantime, what was happening at Colon, and where were the 450 Colombian soldiers who had come to prevent the revolution, and whom we left camping out upon the streets? Left in charge of the troops on the morning of November 3, Colonel Torres demanded that a special train should immediately be provided, to convey them to Panama. Certainly, replied the Superintendent of the railroad; a train would be provided as soon as possible. In the meantime, he respectfully called attention to the invariable rule of the company, which he had no authority to waive, that all transportation of passengers must be paid for in advance. He assumed that the Colonel in command would attend to that? The Colonel was nonplussed. The railroad fare for 450 men would amount to nearly $\$ 2,000$ in gold, and to twice as much in Colombian silver-depreciated stuff called in derision "monkey money" and "tin money." He had no such amount at command, nor any means of getting it. He at first tried to insist that the soldiers must be carried free, on govern. ment business, or at least on credit. But the railroad officials were resolute and inflexible. No money, no transportation; and that was all there was about it. In which unhappy circumstances, Colonel Torres and his warriors had no recourse but to remain bivouacked on the hospitable streets of Colon. Efforts to communicate with the officers who had gone on before to Panama were vain. Telegraph and telephone wires refused to serve them, for reasons under. stood by the revolutionists.

The next day, November 4, announcement was made that the revolution had occurred at Panama, and was successful, and that General Tovar and his comrades were in jail! At this some of the Colombian troops began to grow ugly and threatened to begin fighting and to seize the railroad by 
force and go to Panama. Colonel Torres was also said to have threatened to kill every American in Colon unless the Generals were promptly released. It has since been denied that such a threat was made. The Colombian General Ospina, who afterwards accompanied General Rafael Reyes to Panama on a futile mission of reunion, declared in a letter to the New York Evening Post (January 6, 1904) that he had heard a prominent Panaman statesman confess that the story of that threat was invented by the Prefect of Colon, and was reported to the Commander of the Nashville in order to move him to intervene in aid of the revolutionists. However that may be, there is no question that the Americans in Colon believed the threat had been made, and it is indisputable that the Colombians did threaten to seize the railroad. Thereupon the railroad officers made appeal to the captain of the Nashville, Commander John Hubbard, for protection, and he promptly landed fifty bluejackets, to serve as guardians of the peace. Their presence on shore effectually restrained the martial ardour of the Colombians, and no disturbance occurred. At the same time Commander Hubbard wrote to the Alcalde of Colon and to the Chief of Police the substance of an official order which he had received from Washington, to this effect: that affairs at Colon were in such a condition that the movement of the Colombian troops from Colon to Panama would precipitate a conflict which would interfere with that free and uninterrupted transit of the Isthmus which the United States was pledged to maintain, and that, therefore, he had directed the Superintendent of the Railroad not to transport the troops of either party. This was in exact accord with and continuation of the order already quoted, as given by the Secretary of the Navy, Mr. Moody, in September, 1902, forbidding "any transportation of troops which might contravene provisions of treaty."

So Colonel Torres and his men remained stranded on the streets of Colon. It was impossible to march across the Isthmus, the railroad would not carry them, and the ship 
which had brought them thither, the Carthagena, steamed away at full speed that very day, for home!

That same day the British consul at Colon suggested that if there were need of a stronger police force, British bluejackets might be landed from the cruiser Amphion, which lay at Panama. The suggestion was well meant, but was not accepted. The United States saw no need of any other intervention than its own, and was determined there should be none. Already, on November 3, the troop-ship Dixie had been ordered to join the Nashville at Colon, and the cruiser Boston had been ordered to Panama, and they arrived at those ports on November 5 and 7 respectively. Other vessels were.promptly despatched to join them, and within ten days the cruiser Atlanta, the battleship Maine, and the yacht Mayflower were at Colon, and the cruiser Marblehead, the gunboat Concord, and the monitor Wyoming were by the side of the Boston at Panama. Thus the United States had the whole situation perfectly in hand. It was announced on November 4 that the United States would allow no forces hostile to Panama to land within fifty miles of Panama, or anywhere on the Caribbean coast of the Isthmus, and on November 6 the Nashville set out from Colon for a cruise to Porto Bello and along the coast to prevent any such landing.

It was also desirable to get the $\mathbf{4 5 0}$ Colombian soldiers out of Colon and out of the Republic of Panama, as well as to keep others from getting in, and this consummation was expedited and facilitated by the commander of those troops. He offered to take the men away, by the first available ship, and in peace, if the Panama Government would "make it an object to him." Now there was at that time about $\$ 140$,000 in debased Colombian currency in the Panama treasury, worth about $\$ 56,000$ in gold. The Panamans concluded that it would be a cheap and easy way of getting rid of the Colombians, to accept his offer. So they gave him $\$ 8,000$ in gold, and he loyally kept his word. On November 5, the men . and their wives were hurried aboard the Royal Mail steam. 
ship Orinoco, and Colon knew them no more. The officer did not, of course, mean to go back to Colombia with them. That would have been inconvenient and probably dangerous for him, seeing the compact he had made with the Panamans. His scheme was to go to Jamaica, and enjoy his $\$ 8,000$ in that loveliest of the Antilles. But, alas for him! His precious soldiers found out what a bargain he had made, and came to the conclusion that the money belonged to them as much as to him, seeing that it was the price of their departure from the Isthmus. So they rose against him and took it from him, to the uttermost peso; and what became of him thereafter, deponent saith not!

Just as the Orinoco left Colon, the Dixie steamed into the roadstead. At the same time there arrived at the Colon station a special train from Panama, bearing General Tovar and his comrades, who had been released on condition that they would immediately leave the country, a condition they were glad enough to fulfil. They were too late to go on the Orinoco, so they had to wait at Colon until November 12, when they got away on the Spanish steamer Leon XIII.

Thereafter there were no military operations of significance. The United States authorities on November 9 formally announced that no landing of Colombian or any other alien troops would be permitted in any part of the territory of Panama. Three days later Esteban Huertas was made Commander in Chief of the Panaman army, but the functions of himself and his miniature army were chiefly ornamental.

There arose some rumors that a naval expedition was approaching Panama from Buenaventura, and the American ships in the Pacific were instructed to look out for it, but the rumors were baseless. Also there were tales of a great Colombian army being marched to Panama by land, which provoked only derision from those acquainted with the character of the country which such an army would have to traverse-the land of the San Blas Indians, which consists, as is supposed, chiefly of alternating mountains and morasses, but which in fact has never yet been fully surveyed 
or explored by white men. The object of such reports was, however, obvious. It was to create the impression that Colombia was sincerely and energetically striving to reduce the seceding State to subjection again, and was prevented from so doing only by the superior force of the United States. The truth was that Colombia made no serious effort in that direction, and was in no condition to make one, and that she would, in all probability, have failed to reconquer Panama even had the United States refrained from giving the latter any protection.

In the absence of military operations, political activities were abundant. The Provisional Government of Panama assumed the work of actual administration so promptly, energetically, and efficiently, that on November 7 it secured official recognition from the United States as the de facto government of the Isthmus. This recognition was conveyed to the Junta by Felix Ehrman, the American Vice-ConsulGeneral at Panama. The Junta had informed him on November 4 of the act of secession and the formation of the Provisional Government, and he had replied on November 5 simply acknowledging receipt of their communication. He, of course, made full reports to the government at Washington and in consequence presently received this note of instructions :

"The people of Panama have, by apparently unanimous movement, dissolved their political connection with the Republic of Colombia and resumed their independence. When you are satisfied that a de facto government, republican in form and without substantial opposition from its own people, has been established in the State of Panama, you will enter into relations with it as the responsible government of the territory, and look to it for all due action to protect the persons and property of citizens of the United States, and to keep open the Isthmian transit, in accordance with the obligations of existing treaties governing the relations of the United States to that territory."

In accordance with these instructions on November 7, Mr. Ehrman wrote to the Junta as follows: 
"As it appears that the people of Panama have, by unanimous movement, dissolved their political connection with the Republic of Colombia and resumed their independence, and as there is no opposition to the Provisional Government in the State of Panama, I have to inform you that the Provisional Government will be held responsible for the pro. tection of the persons and property of citizens of the United States, as well as to keep the Isthmian transit free, in accordance with obligations of existing treaties relative to the Isthmian territory."

To this the Secretary for Foreign Affairs, Señor de la Espriella, replied cordially on November 8, declaring that the Republic of Panama accepted fully the responsibility imposed upon it, and would regard it as a sacred and pleas. ant duty to fulfil all the duties required by the existing treaties which had been made by Colombia relative to the Isthmian territory. Meantime; on November 7, M. BunauVarilla was appointed Minister of Panama to the United States, in accordance with his request and the promise of Dr. Amador, and a Commission, consisting of Dr. Amador and Señors Boyd and C. C. Arosemena, was constituted to coöperate with him in framing and negotiating a canal treaty with the United States. The Commissioners set out on November 10 for the United States, the Minister being already here. Three days later M. Bunau-Varilla was formally received by President Roosevelt, and thus the new Republic was diplomatically recognised and received into the community of nations. The canal treaty was speedily negotiated, and on November 18 was signed at Washington by Secretary Hay and M. Bunau-Varilla. (See Appendix VI.)

Colombia also was busy with politics and diplomacy. The Bogotá Government was promptly informed of the attitude and intentions of the United States through the following despatch from our Government to Mr. Beaupré, who still remained at the Colombian capital :

"The people of Panama having, by an apparently unanimous movement dissolved their political connection with 
the Republic of Colombia and resumed their independence, and having adopted a government of their own, republican in form, with which the Government of the United States of America has entered into relations, the President of the United States, in accordance with the ties of friendship which have so long and so happily existed between the respective nations, most earnestly commends to the govern. ments of Colombia and of Panama the peaceful and equita. ble settlement of all questions at issue between them. He holds that he is bound not merely by treaty obligations, but by the interests of civilisation, to see that the peaceful traffic of the world across the Isthmus of Panama shall not longer be disturbed by a constant succession of unnecessary and wasteful civil wars."

In reply the Bogotá Government on November 8 formally but vainly protested against American recognition of Pan. aman independence, and appointed General Rafael Reyesone of the ablest and highest-minded statesmen in that Republic-a special commissioner to proceed to Panama and negotiate a return of that State to its former union with Colombia. Before he could get to the Isthmus, however, a company of five self-appointed commissioners from the Colombian state of Bolivar arrived at Colon on the Hamburg-American steamer Scotia, on a similar errand. They were not permitted to land, but were met on shipboard by a Panaman commission composed of Señors Arias, Espinosa, Morales, and Arosemena. A temperate and amicable interview ensued, but was entirely fruitless. That was on November 16. On the same day President Marroquin, of Colombia, took the extraordinary and most irregular step of cabling directly to the Senate of the United States an elaborate and vehement protest against American recognition of Panama. Both the Senate and the President and his Secretary of State would have been justified in resenting this performance, which can hardly have been inadvertent but must surely have been intended by Dr. Marroquin as a deliberate slight to the American Executive, but it was generously and good-naturedly decided to overlook it. of 
course the protest had no effect whatever at Washington, though it is possible it had and was intended to have some effect at home in Colombia, where the Government was in desperate straits to keep the states of Cauca and Antioquia from following the example of Panama and seceding.

General Reyes, accompanied by Generals Ospina, Holguin, and others, arrived at Colon on November 19, on the French steamer Canada. Like their predecessors from Bolivar, they were not permitted to go ashore, but they had a conference with the Panaman commissioners on shipboard. It, too, was without practical result, unless to demonstrate further the irrevocable nature of the step which Panama had taken. At its termination, General Reyes came on to the United States, having been commissioned to do so as a special envoy with extraordinary powers. He reached Washington on November 28, and was received with the courtesy and consideration to which his character and attainments, as well as the nature of his errand, entitled him. He pleaded, or argued, the cause of Colombia with consummate ability, and with frank integrity; and with the zeal of a double interest, for he was not only a loyal and patriotic representative of President Marroquin, but also, as he and all men then realised, he was practically designated to be President Marroquin's successor as the Chief of the Colombian State. He went so far as substantially to offer, if the United States would only compel the return of Panama to Colombian allegiance, to have the defunct Hay-Herran treaty resurrected, revivified, and ratified, with an amendment waiving the $\$ 10,000,000$ bonus and giving the United States the right of way across the Isthmus gratis. It does not appear to have occurred to him, though it should have done so, as it did to others, that this offer was a practical confirmation of the charges that the Marroquin government could have had the treaty ratified if it had wished, and that it deliberately strangled and killed that thing of its own creation.

This extraordinary proposition appears to have originated at Bogotá and to have been considered and approved by Dr. 
Marroquin, according to an authentic despatch from that capital quoted as follows by President Roosevelt in his annual message of December 7, 1903:

"Knowing that revolution has already commenced in Panama (an eminent Colombian) says that if the government of the United States will land troops to preserve Colombian sovereignty, and the transit, if requested by Colombian chargé d'affaires, this government will declare martial law; and, by virtue of vested constitutional authority, when public order is disturbed, will approve by decree the ratification of the canal treaty as signed;' or, if the government of the United States prefers, will call extra session of the Congress -with new and friendly members-next May to approve the treaty. (An eminent Colombian) has the perfect confidence of Vice-President, he says, and if it became necessary will go to the isthmus or send representative there to adjust matters along above lines to the satisfaction of the people there."

"This despatch," said President Roosevelt in that message, "is noteworthy from two standpoints. Its offer of immediately guaranteeing the treaty to us is in sharp contrast with the positive and contemptuous refusal of the Congress which had just closed its sessions to consider favourably such a treaty; it shows that the government which made the treaty really had absolute control over the situation, but did not choose to exercise this control. The despatch further calls on us to restore order and secure Colombian supremacy in the Isthmus, from which the Colombian Government has just by its action decided to bar us by preventing the construction of the canal."

The identity of "an eminent Colombian" will, of course, be obvious to the reader of the narrative. President Roosevelt was by official propriety and courtesy constrained thus to designate him with the bracketed phrase, but there was no secret and no doubt as to who he was.

The mission of General Reyes thus came to naught, and the American recognition and protection of Panama were properly maintained. In rapid succession many other gov- 
ernments also recognised the new Republic, until all had done so save Colombia itself. The dates of official recognition-which in most cases were delayed long after practical but informal recognition-were as follows: United States, November 7; France, November 16; China, November 22; Austria-Hungary, November 27; Germany, November 30; Russia, December 7; Denmark, December 8; Belgium, December 9 ; Peru, December 21; Sweden and Norway, December 22; Cuba, December 23; Great Britain, December 26 ; Switzerland, Japan, and Italy, December 28; Costa Rica, December 29; Nicaragua, January 1, 1904; Persia, January 11; Portugal, February 16; Corea, February 23; Mexico, Brazil, and Argentina, March 3; Siam, March 4; Ecuador, September 21. The long delay of Ecuador was doubtless due to the close and sympathetic relations between that country and Colombia. For a time Colombia refused to recognise Panama in any way, even to the extent of honouring Panaman postage stamps in the mails. After the accession of President Reyes at Bogotá, however, a more reasonable spirit began to be developed, in 1905 actual recognition of postal service between the two countries was effected, and the way to an ultimate establishment of amicable relations was opened.

Meantime the Provisional Government took prompt steps toward placing the Republic upon a permanent constitutional basis, and on December 13 it issued a call for a general election, to be held on January 15, 1904, for members of a National Constitutional Convention, by which the organic and fundamental law of the Republic would be formulated and decreed. 


\section{CHAPTER XI}

\section{AMERICAN POLICY IN PANAMA}

The policy of the American Government toward the Panama revolution was severely criticised in two quarters: to wit, by Colombians, and by a certain class of partisan opponents of the administration in the United States. By the world at large it was generally approved. That such approval was deserved should be evident to all who regard the matter impartially, logically, and with a proper historical perspective. The major part of criticism has been directed against the orders to our naval forces, which have been said to have prevented, and to have been intended to prevent, the Colombian Government from suppressing rebellion. (The charge that the revolution was conceived and planned in this country, "in the shadow of the Capitol at Washington," with the connivance of our Government, is too absurdly false to require attention. The indisputable facts of the record completely disprove it, and show it to have had its origin in nothing better than either ignorance or malignance.) The orders in question were, however, based upon long-established treaty rights and duties, and were consistent with the policy and practice of our Government for more than a half century before. I have already indicated that the sending of the Nashville to Colon on November 2 was a mere repetition of what had been done before several times, whenever there seemed to be need of protection to American interests there. It was perfectly well known, not only to the Government but to the general public, that a revolution was imminent on the Isthmus, and that Colombian troops were on their way thither to suppress it. In such a case, the lives and property of Americans were sure to be 
endangered, and free transit on the railroad to be interrupted. Certainly it was incumbent upon the Government to take prompt steps to prevent such wrongs, rather than to wait until they were committed and then vainly try to undo or savagely to avenge them. What was the order to the commander of the Nashville? It was identical with that sent on the same day, November 2, to the commanders of the Boston and the Dixie, and ran as follows:

"Maintain free and uninterrupted transit. If interruption threatened by armed force, occupy line of railroad. Prevent landing of any armed force with hostile intent, either Government or insurgent, either at Colon, Porto Bello, or other point."

That amounted simply to an order to maintain our treaty rights and to fulfil our treaty obligations, concerning transit on the Isthmus, and it was directed against the Panaman revolutionists as much as against the Colombians. Neither party was to be permitted to interfere with the free working of the railroad. Neither was to be permitted to land armed forces with hostile intent at the terminals of the railroad, where they would certainly convert the road into a theatre of hostilities, or at any other point-such as Porto Bellofrom which their sole purpose would be to march against the railroad and interrupt traffic. On the same day this order was sent to Rear-Admiral Glass at Acapulco, directing him to proceed at once to Panama with all available forces.

"Maintain free and uninterrupted transit. If interruption threatened by armed force, occupy line. Prevent land. ing of any armed force either government or insurgent, at any point within fifty miles of Panama. If doubtful as to the intent of any armed force, occupy Ancon Hill strongly with artillery. Government force reported approaching the isthmus in vessels. Prevent their landing, if in your judg. ment landing would precipitate a conflict."

As before, the object was to maintain our treaty rights and fulfil our treaty obligations. It is true, the order was 
calculated to prevent Colombia from sending troops to sup. press the insurrection. But if Colombia had exercised rea. sonable prudence, she would have sent an army thither many weeks before, when the revolution was first openly threatened. Then she would have had it on the ground, for ready use. But since she did not do so, but deliberately elected to wait until the revolution was an accomplished fact, the United States was not required to let her violate our treaty rights for the vindication of her own neglected and practically abandoned authority. Again, on November 4, the commander of the Nashville was ordered to send a battery across to Panama, to compel the Colombian gunboat to stop bombarding that city-an order which was perfectly proper, since such bombardment would have interrupted free transit of the Isthmus, but which it was not necessary to execute, since the Bogotá did not resume the bombardment after the firing of three shells the evening before. I have already mentioned the order not to permit the railroad to be used for military purposes. Nothing could have been more proper than that, for it was obvious that if either party were permitted to make such use of the road, the other party would have a right to attack it, and the free use of the road for peaceful transit, guaranteed by the United States in the Treaty of 1846, would have been interrupted. On November 9 this order was sent to the commander of the Boston at Panama:

"Sufficient force must be sent to watch movements closely of the British steamers seized at Buenaventura, and to prevent the landing of men with hostile intent within limits of the State of Panama."

At that time the Panaman revolution had been fully accomplished. The Provisional Government was at work, efficiently performing its functions, and had been recognised by the United States. Colombia had become a foreign power. Under the Treaty of 1846 the United States was bound to guarantee the Isthmus against oppression by any foreign 
Power. Therefore it ordered the protection of the Isthmus against Colombian invasion. It may be said-it has been said-that such construction of treaty obligations was strained and unreasonable, and that in forbidding Colombia to attempt the reconquest of Panama this country was acting without warrant in international law. That is not to be conceded. But even if, for sake of argument, it were to be conceded, what would it prove? Nations do not wait for warrants in international law when their own welfare is jeoparded. Self-preservation or self-defence is proverbially declared to be "nature's first law." It is that, for states as well as for individuals. There was no "warrant in international law" for our Declaration of Independence. There was none for the conduct of Jay, Adams, and Franklin in $\mathbf{1 7 8 3}$, in making a treaty in direct violation of the instructions under which they were commissioned. There was none for Jefferson's dictum, that if France would not sell Louisiana to us, we must take it from her by force; or for Monroe's similar policy toward Spain in Florida. There was none for our long-maintained policy forbidding Spain to do as she pleased with Cuba. There was none for John Quincy Adams's warning to the Russian Government to relinquish its holdings upon this continent, or for the Monroe Doctrine which logically followed. There was no legal sanction for the conduct of the United States in warning Great Britain and France to quit Hawaii and in ordering France out of Mexico. It may be, of course, that the United States sinned in all these things. If so, then it kept on sinning in the same way in Panama. But if it did not sin in them, neither did it when it pursued the same policy in Panama.

The question of our Government's policy in Panama is, as the term implies, a question of policy. It is not a question of executive details, because there were no such details concerning which, per se, any material question could be raised. There was no waging of war. There was no slaughter. There were no torturings nor imprisonments. There was no 
arbitrary overthrowing of an established government. All that was done was to exercise the moral influence of a definite and peaceful policy.

Our policy was justified, and indeed made necessary, by domestic obligations. Congress had directed the President to construct a canal at Panama, rather than at any other point. We need not stop to consider why Panama was chosen. That was a matter of congressional enactment, not of administrative policy. The question of route had been discussed, with . a wealth of investigation and detail, for many years. Whether wisely or not, and whether for adequate or inadequate reasons, Congress finally declared, explicitly and unequivocally, in favour of Panama. The President had to obey that mandate. There was no alternative, save in case of his inability to make satisfactory terms within a reasonable time. The President promptly proceeded to do the work prescribed by Congress. He made terms, which the Senate accepted as satisfactory, for the construction and control of the canal. He was himself the sole judge of what was a "reasonable time" in which to make such terms. That time proved to be something less than a year and a half, and it was approved as "reasonable" by the Senate. Thus far, then, the President scrupulously obeyed the law.

But it is said that the law directed him to make his terms with the Colombian Government, and that, instead, he made them with Panama. It is true that Congress mentioned the Colombian Government as the one with which he was to negotiate. Obviously, that was because it was at that time the sovereign of Panama. But it is equally obvious that Congress meant not that government, per se, but whatever lawful government the President might find in possession of the Isthmus. That is because (a) the Congress of the United States could not guarantee that President Marroquin's or any special Colombian Government would remain in power at Panama, nor give the President any assurance of what government he would find there when he made the treaty; 
and because (b) it did not say that if a change of government should occur upon the Isthmus before a treaty could be made, he should abandon Panama and go elsewhere. The prescription had reference to the place, rather than to the power. It was geographical rather than political. As the President himself wrote in his annual message of December 7, 1903 :

"When the Congress directed that we should take the Panama route under treaty with Colombia, the essence of the condition, of course, referred not to the government which controlled that route, but to the route itself; to the territory across which the route lay, not to the name which for the moment the territory bore on the map. The purpose of the law was to authorise the President to make a treaty with the power in actual control of the Isthmus of Panama. This purpose has been fulfilled."

The President then made satisfactory terms, within a reasonable time, and he made them with the actual government of the Isthmus of Panama. He obeyed the law of Congress in letter and in spirit. So far as domestic obligations were concerned, his policy was just and equitable.

Our policy was also justified by our legal obligations to Colombia. Our Treaty of 1846 with New Granada guaranteed to New Granada (or Colombia) "the perfect neutrality" of the Isthmus of Panama, "with the view that the free transit from the one to the other sea may not be interrupted or embarrassed," and also guaranteed "the rights of sovereignty and property which New Granada has and possesses over the said territory." It was perfectly understood, and was specifically and repeatedly declared, that this guarantee was solely against alien aggression, and was not to be interpreted as promising protection against domestic revolution or as assuring the perpetuity of the same domestic system of government that then existed. "The purpose of the stipulation," wrote Mr. Secretary Seward on November 9,1865 , "was to guarantee the Isthmus against seizure or invasion by a foreign Power only. It could not have 
been contemplated that we are to become a party to any civil war in that country by defending the Isthmus against another party." As a matter of fact, there were several revolutions in Colombia after the making of that treaty, to none of which was the United States a party, and none of which in any way affected the force of the treaty.

An impressive presentment of this phase of the case was made by President Roosevelt in his annual message of December 7, 1903. Writing of the Panama revolution and its incidents and the conduct of the United States, he said:

"When these events happened, fifty-seven years had elapsed since the United States had entered into its treaty with New Granada. During that time the governments of New Granada and of its successor, Colombia, have been in a constant state of flux. The following is a partial list of the disturbances on the Isthmus of Panama during the period in question as reported to us by our consuls. It is not possible to give a complete list, and some of the reports that speak of 'revolutions' must mean unsuccessful revolutions:

"May 22, 1850-Outbreak; two Americans killed; war vessel demanded to quell outbreak.

"October, 1850-Revolutionary plot to bring about independence of the isthmus.

"July 22, 1851-Revolution in four southern provinces.

"November 14, 1851-Outbreak at Chagres. Man-of-war requested for Chagres.

"June 27, 1853-Insurrection at Bogotá, and consequent disturbance on isthmus. War vessel demanded.

"May 23, 1854-Political disturbances; war vessel requested.

"June 28, 1854-Attempted revolution.

"October 24, 1854-Independence of isthmus demanded by provincial legislature.

"April, 1856-Riot, and massacre of Americans.

"May 4, 1856-Riot.

"May 18, 1856-Riot.

"October 2, 1856-Conflict between two native parties. United States forces landed.

"December 18, 1858-Attempted secession of Panama.

"April, 1859-Riots. 
"September, 1860-Outbreak.

"October 4, 1860-Landing of United States forces in consequence.

"May 23, 1861-Intervention of the United States forces required by Intendente.

"October 2, 1861-Insurrection and civil war.

"April 4, 1862-Measures to prevent rebels crossing isthmus.

"June 13, 1862-Mosquera's troops refused admittance to Panama.

"March, 1865-Revolution and United States troops landed.

"August, 1865-Riots; unsuccessful attempt to invade Panama.

"March, 1866-Unsuccessful revolution.

"April, 1867-Attempt to overthrow the government.

"August, 1867-Attempt at revolution.

"July 5, 1868-Revolution; provisional government inaugurated.

"August 29, 1868-Revolution; provisional government overthrown.

"April, 1871-Revolution; followed apparently by counterrevolution.

"April, 1873-Revolution and civil war which lasted to October, 1875.

"August, 1876-Civil war which lasted until April, 1877.

"July, 1878-Rebellion.

"December, 1878-Revolt.

"April, 1879-Revolution.

"June, 1879-Revolution.

"March, 1883-Riot.

"May, 1883-Riot.

"June, 1884-Revolutionary attempt.

"December, 1884-Revolutionary attempt.

"January, 1885-Revolutionary disturbances.

"March, 1885-Revolution.

"April, 1887-Disturbances on Panama Railroad.

"November, 1887-Disturbance on line of canal.

"January, 1889-Riot.

"January, 1895-Revolution which lasted until April.

"March, 1895-Incendiary attempt.

"October, 1899.-Revolution.

"February, 1900, to July, 1900-Revolution.

"January, 1901-Revolution. 
"July, 1901-Revolutionary disturbances.

"September, 1901-City of Colon taken by rebels.

"March, 1902-Revolutionary disturbances.

"July, 1902-Revolution.

"The above is only a partial list of the revolutions, rebellions, insurrections, riots, and other outbreaks that have occurred during the period in question; yet they number fifty-three for the fifty-seven years. It will be noted that one of them lasted for nearly three years before it was quelled; another for nearly a year. In short, the experience of over half a century has shown Colombia to be utterly incapable of keeping order on the isthmus. Only the active interference of the United States has enabled her to preserve so much as a semblance of sovereignty. Had it not been for the exercise by the United States of the police power in her interest, her connection with the isthmus would have been sundered long ago. In 1856, in 1860, in 1873 , in 1885 , in 1901, and again in 1902 , sailors and marines from United States warships were forced to land in order to patrol the isthmus, to protect life and property and to see that the transit across the isthmus was kept open. In 1861, in 1862, in 1885, and in 1900 the Colombian government asked that the United States Government would land troops to protect its interests and maintain order on the isthmus."

The United States held strictly aloof from all of these proceedings, so far as politics were concerned. The Treaty of 1846, however, gave this country the right to preserve peace and freedom of transit across the Isthmus, and was consistently interpreted and understood as giving us that right, even to the extent of intervening in local Colombian affairs and preventing either party in a domestic war from making belligerent use of the line of transit. Thus, to quote Mr. Seward again, while the United States would take no interest in any internal revolution in the State of Panama, it would hold itsetf ready "to protect the transit trade across the Isthmus against either foreign or domestic disturbance of the peace of the State of Panama." Note that it was not the sovereignty of the Bogotá Government, but "the transit trade across the Isthmus," that the United 
States was ready to protect against domestic disturbance; leaving it to the people of Colombia and Panama to determine whether Panama should be governed at Panama or at Bogotá.

Note also that the United States was to protect that transit trade "against domestic disturbance of the peace." How would it have been possible to do that if either of the domestic belligerents had been permitted to use the railroad as a base of military operations and thus to involve it in acts of war? The only effective fulfilment of the treaty was in protection of the road from attack, or even belligerent use, by either faction. Such protection was repeatedly given, to the extent of forbidding either the Colombian Government or the insurgents to use the railroad as an engine of war. That was what was done in November, 1903. The President protected the transit trade of the Isthmus against "domestic disturbance of the peace of the State of Panama," regardless of whether the menace of disturbance proceeded from Colon or from Bogotá.

It cannot justly be charged that the United States, while insisting upon free transit across the Isthmus for itself, prevented Colombia from enjoying it. The United States never but once--and that was not in November, 1903-forbade the Colombian Government to make non-belligerent use of the railroad, and it did so only through a subordinate functionary, who was promptly overruled by the Washington Government. All that it did prohibit was such conversion of the railroad into an engine of war as would interrupt free transit across the Isthmus and subject the road itself to destruction. That the intention of the Treaty of 1846 was to exempt the road from such belligerent use seems obvious and indisputable.

Mr. Secretary Hay set forth this phase of the case with epigrammatic force when he described the treaty as a covenant which "ran with the land." The application of the treaty was geographical rather than political. The United States had no right to say what government there should be 
in Colombia, save that the domestic government should not be oppressed or overthrown by a foreign power. But it had the right to say that whatever government there was should fulfil its treaty obligations in the maintenance of free transit across the Isthmus. It had the right to say that such freedom of transit should not be interrupted by rebellion arising at Panama or Colon, and equally that it should not be interrupted by government coercion from Bogotá. It had, finally, the right to say, as it did say, that after she had practically relinquished Panama to the control of its own people and they had restored peace and established an orderly government of their own, Colombia should not reinvade that state for the purpose of waging war and interrupting commerce.

If it be said that this barred Colombia from using her sovereign power and resources for the performance of some of the supreme functions of government: to wit, the suppression of rebellion and the maintenance of national integrity, the answer is that she should have thought of that before she made the treaty. Unquestionably she did, in making that treaty, to a certain extent abrogate and relinquish her sovereignty over the Isthmus of Panama. She did so in return for a quid pro quo, which then seemed to her adequate, and which, in the event, proved for many years not only to be adequate, but to put the balance of advantage upon her side of the account. Having thus enjoyed the benefits of the treaty for half a century, it was not lawful for her to evade its obligations or to repudiate its penalties. The United States, having fulfilled its duties toward her, in protecting her from alien oppression, was amply justified, legally, in exacting from her its full privileges. That was what our Government did at the beginning of November, 1903.

The United States was right, of course, in rejecting the Colombian proposal, that it should, in return for a canal concession, suppress for Colombia the already successful revolution in Panama, and restore that state to Colombian 
authority. The United States has never hired itself out as a mercenary, either for cash or for canal concessions. Equally right was it in recognising the de facto government at Panama. It is always lawful, and generally imperative, to recognise facts, and it was a fact that that was the only existing government on the Isthmus. The Colombian Government there had ceased to exist. It had been expelled. It had departed. The Colombian troops had not been driven out by us. They had gone because they found themselves alone and helpless amid a universally hostile population. They recognised the accomplished fact. The Panama Government was in entire and undisputed authority, and was ready to fulfil and was fulfilling the actual functions of government. The only possible procedure for the United States was to recognise that fact:

Nor is the rightfulness of our later recognition of the $d e$ jure independence of Panama to be impugned. It was done promptly a few dass after the Panaman Declaration of Independence. There seems, however, to be no ground for the characterisation of "indecent haste" which has been applied to it. There is no more generally accepted principle in international law than that every nation is its own judge of the time when it is fitting to recognise the independence of another. In our own revolution, France recognised our independence years before it was actually established, while Russia refused to recognise it until years after it had been established and had been rcognised by the very Power from which we had won it. Both acted well within their legal rights. The United States recognised the revolutionary Republic in Brazil, in 1889, more promptly than it did the Republic of Panama, although there was much less assurance of its stability. The long delay in recognising the independence of the South American republics in the early part of the last century has been cited as a precedent which should have been regarded in the case of Panama. There was little, if any, analogy between the cases. The contrast between South America then and Panama now is enormous. 
Considering the difference in speed of communication, and in extent and completeness of our knowledge of the countries concerned, it is scarcely too much to say that a day gives as ample time for deliberation now as a year did threequarters of a century ago.

In recognising the independence of Panama we were lawfully recognising an accomplished fact. If it be said it was a fact made possible only by our own conduct and attitude, the same may be said of other republics, which exist only because of our protection. Colombia herself would probably not have maintained her independence had it not been for the policy of the United States, especially as set forth and endowed with concrete force in the Treaty of 1846 . In the act of recognition, then, as in that of intervention, the United States fully observed its legal obligations to the Republic of Colombia.

Our policy was justified, moreover, on the ground of equity to Colombia. We must remember, what is too often overlooked, that while law is positive, equity is relative. We must fulfil legal obligations strictly and impartially,. even toward the least deserving and least worthy. But we are privileged to consider the character, the conduct, and the deserts of the applicant for equity. He who seeks equity must deal equitably. The very word itself implies that. It is an elementary justice, based not on legal prescription, but upon the mutual merits of the parties to the controversy. What, then, were Colombia's deserts? So far as Panama was concerned, they were slight indeed. She had treated Panama most inequitably. She had forcibly abrogated the Constitution of 1863, and had subverted Panama's undoubted rights thereunder without Panama's consentjust as though forty-four of our forty-five States should combine to deprive the forty-fifth of its equal representation in the Federal Senate without its consent. She had not only done that and persisted in it, but for many years she had systematically oppressed and plundered Panama, making the Isthmus the "milch cow of Colombia," as it used to be said 
Cuba was of Spain. Upon dispassionate and impartial review of the record, it was impossible to withhold sympathy from Panama in her controversy with the Bogotá Government.

If, however, we were to go by on the other side, saying that such matters were none of our business, we could not ignore the fact that Colombia had treated the United States badly in more than one important respect. In 1880 this Government found it necessary to warn Colombia against making the concessions which she then proposed to make to France, as-to quote Mr. Secretary Evarts, on July 31, 1880 - "introducing interests not compatible with the treaty relations which we maintain with Colombia." Colombia then proposed-I quote from President Arthur's message of 1881- "to the European powers to join in a guarantee which would be in direct contravention of our obligation as the sole guarantor of the integrity of Colombian territory." In other words, while enjoying, at her own request, our protection, Colombia was intriguing against our interests with the very Powers against which she had sought and was enjoying our protection.

We may justly complain also that she acted inequitably toward us in rejecting the canal treaty which her minister negotiated with us in 1902-3. Mark that she had a legal right to reject it. That is indisputable. Her legal right to reject it was as absolute as our right to reject other treaties which our Government has negotiated, but which have not met with the approval of the Senate. She had, let us say, the same right to reject it that we had to negotiate it, or that we had afterward to make another treaty with Panama. Her rejection was legal, but it was not equitable; or, at any rate, it was no more equitable than our subsequent recognition of, and negotiation with, Panama. If she stood upon her strict legal rights in rejecting the treaty, we had as good a title to stand upon our strict legal rights in recognising Panama.

But we may go beyond that, and say that her rejection 
of the treaty was positively inequitous-if I may coin that useful word, to express a slightly different shade of meaning from "iniquitous," though indeed "iniquitous" might serve as well. Two facts of record are sufficient to prove the indictment. One is the explicit and repeated offer made by General Reyes in behalf of the Bogotá Government, of which he was the prospective next chief, to resurrect and ratify the dead canal treaty, by martial law or dictatorship, in return for our resubjugation of Panama to the Colombian yoke. The other is the confessed, deliberate plan of the Bogotá Government to repudiate the concession lawfully given to the French Panama Canal Company and to confiscate that company's property, which it would then sell to the United States for a round sum.

Now the bearing of all that upon the question of our policy is simply to show upon how little ground Colombia could plead for better treatment as a matter of equity. Colombia, wearing the brand of a would-be spoliator, could not well come into court with a complaint that she had been despoiled. Upon the ground of equity she had nothing more to claim. She had been treated as well as she deserved, and better. Her only valid claim must be for legal justice, and in the making of that claim it might be well for her to take heed lest the court of civilisation should declare to her: "Thou shalt have justice, more than thou desirest." It will not serve to say we would not have treated a great, strong nation thus. I am not sure of that. The record of our dealings with some of the greatest Powers of the world suggests that we have been no less independent in our bearing toward them than toward the lesser ones. On the other hand, we might equally well ask if Colombia would have acted thus toward a nation that was not rich, that was not urgently desirous of building the canal, or that was a little more in the habit of using the "mailed fist." We must, it is said, have one law alike for all nations, great and small. That is quite true.

What, then, would we have done had England recognised 
the independence of the Confederacy in 1862? The cases are not analogous. The Confederacy was never, either physically or legally, in as strong a position as Panama. I say that advisedly. The United States never scuttled out of the Southern States and abandoned them to secession, as Colombia did out of Panama, but from the very beginning exerted its fullest possible power to suppress the rebellion and to restore and preserve the Union. The Confederate States had no such constitutional defence of secession as that which Panama had in the fact of former independence forcibly destroyed without her consent. The European Powers did promptly recognise the Confederate States as belligerents. In that they were simply recognising a fact, and, however distasteful it was to us, we had no cause for complaint.

There is another point which those who seek to raise this argument from analogy invariably overlook. It is this: that the United States had never, by treaty or otherwise, recognised international interests in the Southern States as Colombia had in Panama. In the Treaty of 1846, Colombia specifically recognised the fact that other nations, above all the United States, had natural and lawful interests in the Isthmus of Panama, which might in certain contingencies be paramount to Colombia's own interests there. Those interests were peculiar to the Isthmus, and did not extend to the rest of Colombia. For it is to be remembered that the provisions of that treaty, including our rights of intervention and our duty of protection and guarantee, did not apply to the whole of Colombia, but only to the State-that is, the Isthmus-of Panama. "The guarantee extends only to the Isthmus," wrote Mr. Bidlack, our Chargé d'Affaires who negotiated the treaty, to Mr. Secretary Buchanan in 1846. In that circumstance the separate status of Panama, as contrasted with the rest of Colombia, was recognised, and so were recognised the peculiar and even paramount interests of other countries in that territory. I quote from President Polk's message transmitting that treaty to the Senate for 
ratification: "The treaty does not propose to guarantee a territory to a foreign nation in which the United States will have no common interest with that nation. On the contrary, we are more deeply and directly interested in the subject of this guarantee than New Granada herself, or any other country."

Let us suppose, to make an analogy which does not now exist between our Civil War and the Panama revolution, that at some date prior to 1861 the United States had stipulated by treaty with England that the cotton trade from our Southern ports should never be interrupted or embarrassed, and that England should have the right to intervene whenever necessary to keep that trade free and open. In such case it seems to me that England would have had a legal and moral right to intervene in 1861-62, to break the blockade of our Southern ports and to prevent the United States from reëstablishing it. The United States never made such a treaty. It would never have made one. But Colombia did make the Treaty of 1846 . There is the radical difference between the two cases.

It is said that the application of the lex talionis does not indicate the loftiest motives. Granted. But there were other motives for our policy which were high and noble enough to satisfy the most exalted doctrinaire. At the present moment the argument is simply this, that neither law nor equity requires a nation to go out of its way to be generous to an unworthy object, even though that object be a weaker nation. Weakness gives no immunity, and is not a charter to license any more than strength is a charter to oppression. A strong nation should use its strength nobly. A weak nation should use its weakness no less nobly, seeking in morals the strength it lacks in material resources.

Our policy was justified, finally, under both law and equity to other nations. Our Government violated no item of international law. It invaded no rights of other countries or of their citizens. It dealt fairly, lawfully, even generously, 
with the French Canal Company. It patiently awaited and accepted the adjudication of the French courts in what. ever legal controversies arose over the transfer of the company's property. It showed a scrupulous regard for the letter and spirit of international law, and for international equities. It moreover fulfilled the implied duties which rested upon it as a result of its traditional policy. Under the Monroe Doctrine this country would not let other nations meddle in American affairs. It thus incurred a moral responsibility for those affairs. Thus it would not let European Powers guarantee neutrality and peace upon the Isthmus, and freedom of transit over that important route. Therefore it was morally bound itself to make such a guarantee, and to make it effective. It did so. It would not permit any other nation to construct a canal across the Isthmus. Therefore it incurred itself the moral obligation to construct one. It is now proceeding to do so. The United States thus shows itself to be no dog-in-the-manger, but a Power that is as ready itself to do as to forbid others to do.

Nor was it a new thing for the United States to forbid, or to threaten to forbid, Colombia to play the part of the dogin-the-manger. It did so long ago, in a formal declaration made by Lewis Cass, Secretary of State, in 1858:

"The progress of events has rendered the interoceanic route across the narrow portion of Central America vastly important to the commercial world and especially to the United States. . . . While the rights of sovereignty of the States occupying this region should always be respected, we shall expect that these rights be exercised in a spirit befitting the occasion and the wants and circumstances that have arisen. Sovereignty has its duties as well as its rights, and none of these local governments, even if administered with more regard to the just demands of other nations than they have been, would be permitted in a spirit of Eastern isolation to close the gates of intercourse to the great highways of the world and justify the act by the pretension that these avenues of trade and travel belong to them and that they choose to shut them, or, what is almost equivalent, to encum- 
ber them with such unjust relations as would prevent their general use."

This principle of "international eminent domain" has been adverted to many times in discussions of the Panama case. It is perhaps not altogether pertinent, for the reason that the United States was not compelled to resort to the application of such a principle. It is not to be denied, however, that such a principle exists, and that it has more than once been practically applied in the history of the world. Every "concert of the Powers" for the coercion of one or more nations involves its application. It was under that principle that Bosnia and Herzegovina, and Crete and Samos, and The Lebanon, were removed from unbridled Turkish rule. It was upon the same principle that the joint control and the international tribunals were established in Egypt. It would scarcely be an exaggeration to say that the same principle was involved in the opening of The Sound to free navigation. There need be no hesitation in saying that if there had been no other way to secure the Panama Canal, the Powers of the world, or the United States alone, would have been amply justified in proceeding under that principle. But the principle is so delicate a one, and so easily liable to perversion and misuse, that there is cause for gratitude in the accomplishment of the world's desire at Panama without resort to it. If that principle, or the contemplation of it as a possibility, did to any degree enter into the case in confirming the United States in its policy or in affording justification for that policy, then instead of condemning our Government, the world must give it commendation for having to that extent made use of so delicate and even perilous a principle with so much discretion, and with results so invariably beneficent.

For what is, after all, most clear in the whole business is this, that the United States acted unselfishly and for the good of the world. It acted unselfishly, because it sought no self-aggrandisement, no conquests, no acquisition of terri- 
tory, no extension of sovereignty. It sought, and secured, nothing but the privilege and power of constructing a canal which will be for the equal use and benefit of all nations. If it in doing so exacted a grant of perpetual control over a part of the territory of another state, it thus did only what was necessary for the safeguarding of the canal. It is inconceivable that any other nation on earth would have undertaken the construction of the canal and its protection and neutral maintenance on any basis of less authority. It also acted for the good of the world, because it assured fulfilment of the world's legitimate desire in the only way in which it could be satisfactorily fulfilled; because it assured the speedy opening of what will be one of the greatest highways of peaceful and beneficent commerce; and because it established a paramount influence for peace and justice in a land that for a century had known little of either peace or justice.

The sum of the matter was clearly and correctly set forth by President Roosevelt, in the message of December 7, 1903, from which I have already made several quotations. The simple recital of facts, he said, established beyond question:

"First-That the United States has for over half a century patiently and in good faith carried out its obligations under the Treaty of 1846 .

"Second-That when for the first time it became possible for Colombia to do anything in requital of the services thus repeatedly rendered to it for fifty-seven years by the United States, the Colombian Government peremptorily and offensively refused to do its part, even though to do so would have been to its advantage and immeasurably to the advantage of the State of Panama, at that time under its jurisdiction.

"Third-That throughout this period revolutions, riots, and factional disturbances of every kind have occurred one after the other in almost uninterrupted succession, some of them lasting for months and even for years, while the central government was unable to put them down or to make peace with the rebels.

"Fourth-That these disturbances, instead of showing any 
sign of abating, have tended to grow more numerous and more serious in the immediate past.

"Fifth-That the control of Colombia over the Isthmus of Panama could not be maintained without the armed intervention and assistance of the United States.

"In other words, the government of Colombia, though wholly unable to maintain order on the Isthmus, has nevertheless declined to ratify a treaty the conclusion of which opened the only chance to secure its own stability and to guarantee permanent peace on and the construction of a canal across the Isthmus.

"Under such circumstances the Government of the United States would have been guilty of folly and weakness amounting in their sum to a crime against the nation had it acted otherwise than it did when the revolution of November 3 last took place in Panama. This great enterprise of building the interoceanic canal cannot be held up to gratify the whims, or out of respect to the government impotence, or to the even more sinister and evil political peculiarities, of people, who, though they dwell afar off, yet, against the wish of the actual dwellers on the Isthmus, assert an unreal supremacy over the territory. The possession of a territory fraught with such peculiar capacities as the Isthmus in question carries with it obligations to mankind. The course of events has shown that this canal cannot be built by private enterprise, or by any other nation than our own, therefore it must be built by the United States.

"Every effort has been made by the Government of the United States to persuade Colombia to follow a course which was essentially not only to our interests and to the interests of the world, but to the interests of Colombia itself. These efforts have failed, and Colombia, by her persistence in repulsing the advances that have been made, has forced us, for the sake of our own honour, and of the interest and wellbeing, not merely of our own people, but of the people of the Isthmus of Panama and the people of the civilised countries of the world, to take decisive steps to bring to an end a con. dition of affairs which had become intolerable. The new Republic of Panama immediately offered to negotiate a treaty with us. By it our interests are better safeguarded than in the treaty with Colombia, which was ratified by the Senate at its last session. It is better in its terms than the treaties offered to us by the republics of Nicaragua and Costa Rica. At last the right to begin this great undertaking 
is made available. Panama has done her part. All that remains is for the American Congress to do its part, and forthwith this Republic will enter upon the execution of a project colossal in its size and of well-nigh incalculable possibilities for the good of this country and the nations of mankind." 


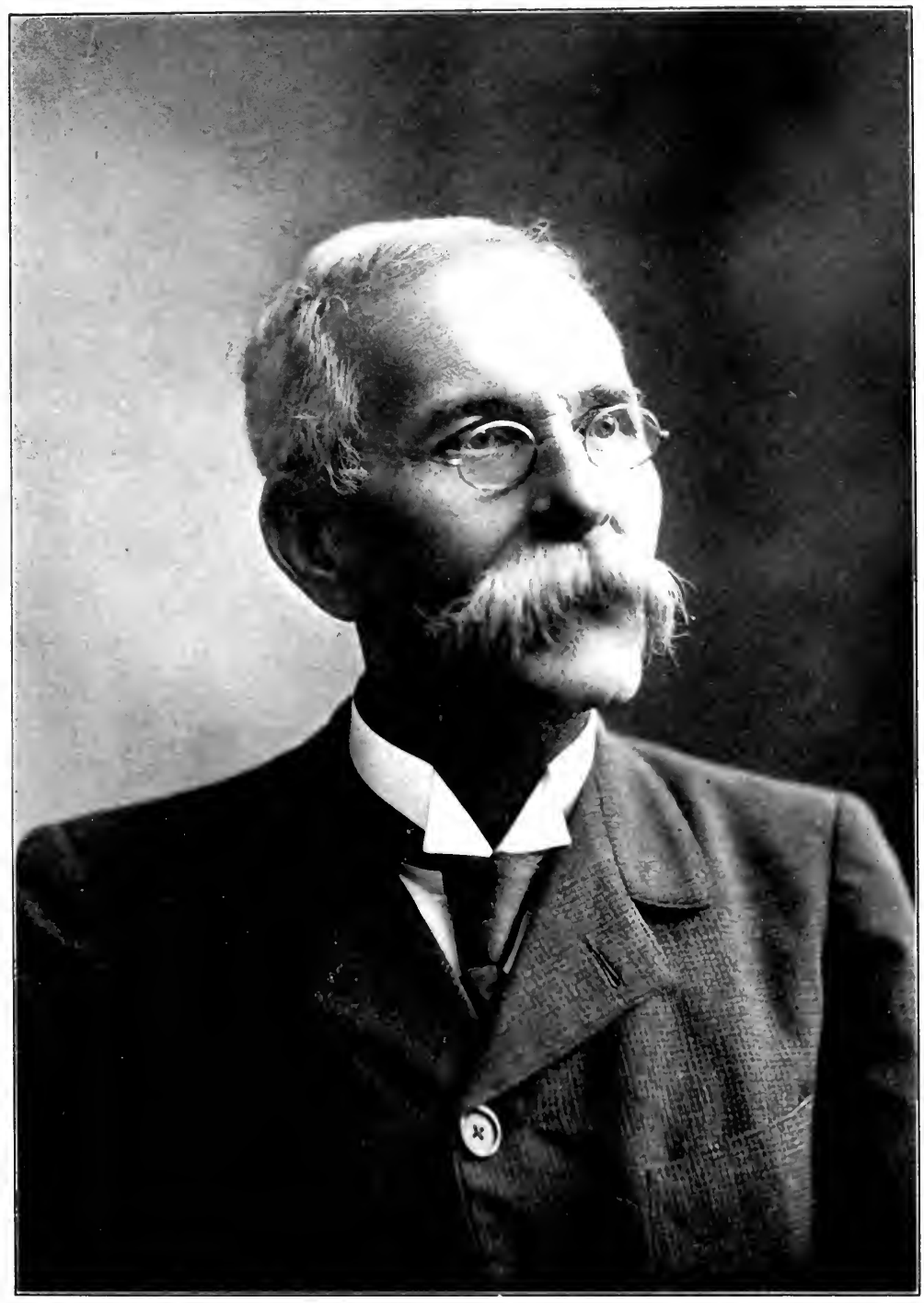

Scherer, Photo.

MANUEL AMADOR GUERRERO,

First President of Paxama. 


\section{CHAPTER XII \\ THE REPUBLIC OF PANAMA}

Panama promptly passed from the revolutionary stage into the status of a Constitutional Republic. Its Constitution was adopted by a National Constitutional Convention, which was elected on December 28, and met in the city of Panama on January 15, 1904, and practically completed its labours on February 13, following. Dr. Pablo Arosemena, formerly President or Governor of the State under the Colombian Government, and first First Designate of the Republic of Panama, was President of the Convention and a Deputy from the Province of Panama. Other deputies were Manuel Quintero V., Nicolas Victoria J., and Demetrio H. Brid. The completed instrument was signed by the thirtytwo deputies; by the Secretary, Juan Brin; by the Provisional Board, J. A. Arango, Federico Boyd, and Tomas Arias; and by the Minister of Government, Eusebio A. Morales; the Minister of Foreign Relations, F. V. de la Espriella; the Minister of Justice, Carlos A. Mendoza; the Minister of the Treasury, Manuel E. Amador; the Minister of War and Marine, Nicanor A. de Obarrio; and the Minister of Public Instruction, Julio J. Fabrega ; and it was published and enforced on February 15, 1904.

This Constitution is an elaborate instrument, generally accordant with that of the United States and other republican constitutions in its guarantee of personal and popular rights, and its general guarantee of a free democratic government. Some of its provisions are exceptional if not unique. Thus it is provided that (Art. 14) citizenship may be suspended for habitual intoxication; that (Art. 19) there shall be no slaves in Panama, but any slave who may step 
upon the territory of the Republic shall in that act become free; that (Art. 23) there shall be no arrest or imprisonment for debt or other purely civil obligations; that (Art. 25) no one shall be compelled to testify in a criminal proceeding against any member of his or her family, "within the fourth grade of consanguinity or the second of affinity;" that (Art. 29) any person may practise any profession or trade without the necessity of belonging to an association; that (Art. 37) games of chance shall not be permitted in the territory of the Republic; that (Art. 68) the National Assembly shall not pass votes of censure or approval relating to official acts; that (Art. 83) the President cannot be elected to succeed himself, nor can any relation of his within the fourth grade of consanguinity or the second of affinity be elected to succeed him; that (Art. 117) there can be no obligatory circulation of paper money; and that (Art. 127) the government alone can import or manufacture arms or implements of war.

The government of Panama is purely democratic in form, and is divided into three parts, the Legislative, the Executive, and the Judicial. The Legislative power is exercised by the National Assembly, consisting of a single chamber, elected by popular vote for a term of four years, and meets on September 1, of every second year. The session lasts ninety days, but in any case of necessity it may be extended thirty days more. Special sessions for special purposes may be called by the President of the Republic. Deputies are elected from districts at a ratio of one to every 10,000 inhabitants, or residue of not less than 5,000. The Deputies must be citizens at least twenty-five years of age. The Executive and the Judicial officers are ineligible for election as Deputies during their terms of office, and for six months thereafter. The Assembly has the customary legislative functions, including the trial of charges against the President of the Republic, the Attorney-General, the Secretaries of State, and the Justices of the Supreme Court; the election of three Designates or Vice-Presidents of the Republic for a 
term of two years; the election of the Judges of the Exchequer; and the granting of leave of absence to the President. There is also an equal number of Substitute Deputies, to take the place of the Deputies on the inability of any of the latter to serve.

The Executive power is exercised by the President of the Republic. He must be a Panaman by birth, and thirty-five years of age. He is elected by popular vote for a term of four years, beginning on the first of October following his election. He appoints the Secretaries of State or members of his Cabinet, the Governors of the Provinces, the AttorneyGeneral, the Judges of the Supreme Court, and some other officers. Every act of the President must be countersigned by that Secretary of State to whose department it properly appertains. In temporary or permanent absence his place is filled by one of the three Designates or Vice-Presidents, whose qualifications are the same as those of the President. The Secretaries of State have the same qualifications as the Deputies; they are the only regular mediums of communication between the Executive and the Legislative body, and they are permitted to propose laws and to take part in debates in the National Assembly.

The Judicial power is exercised by a Supreme Court, inferior courts, and justices of the peace. The Supreme Court consists of five magistrates, appointed by the President for a term of four years. Five substitutes are also appointed to take the place of the Justices in case of absence or disability of the latter. The Justices or their substitutes must be thirty years of age, and must have been residents of Panama for fifteen years, and practising lawyers for ten years. The same qualifications are required of the justices of the inferior courts.

A law to be valid must be approved by the National Assembly by an absolute majority after three debates on three separate days, and must also be approved by the President of the Republic. The second debate on a law cannot be closed, nor can a final vote be taken at the end of the third 
debate, without the attendance of an absolute majority of the Assembly. The President before signing a law may consider it for from six to fifteen days, according to the number of articles it contains. If he does not within this time either approve it or return it unsigned, with a statement of his objections, his approval of it then becomes compulsory. When he returns the measure with objections, it may be passed over his objections by a two-thirds vote of a quorum, whereupon he must sign it. If his objections are on the ground of alleged unconstitutionality, the measure may be sent by the Assembly to the Supreme Court for its decision, which must be rendered within six days, and if it is favourable to the measure, it is made compulsory upon the President to sign it.

The Republic is divided into seven provinces: namely, Boca del Toro, Coclé, Colon, Chiriqui, Los Santos, Panama, and Veraguas. Each province has a Governor, appointed by the President of the Republic and subject to removal by him. The provinces are divided into municipal districts, in each of which is a Municipal Council, elected by the people. There is also a Mayor appointed or elected according to law. Each municipality has almost unlimited powers of local selfgovernment, but cannot contract any indebtedness without the consent of the National Assembly. The administration of justice is free in all parts of the Republic. Public instruction is free, and in primary grades is compulsory. There is freedom of religion, but the Roman Catholic Church is recognised as that of the majority of the people and therefore receives a state subsidy. All property used for religious purposes is exempt from taxation, and all ministers of all religious creeds are excluded from public office. The Constitution may be amended by the National Assembly by a two-thirds vote.

Upon the completion of its work in framing the Constitution, the Convention resolved itself into a National Assembly (the first regularly elected National Assembly was not to be chosen until July 1906, and was not to meet until 
September, 1906), and it elected Dr. Manuel Amador Guerrero to be President of the Republic, and Pablo Arosemena, J. Domingo de Obaldia, and Carlos Mendoza to be respectively first, second, and third Designates. These gentlemen were chosen alternately from the two political parties, Dr. Amador and Señor Obaldia being Conservatives and Dr. Arosemena and Señor Mendoza being Liberals. The inauguration of President Amador occurred on February 20, 1904, and on that day a Cabinet was also appointed, consisting of Tomas Arias, Minister of Foreign Affairs and of War; F. V. de la Espriella, Minister of Finance; Julio Fabrega (soon succeeded by Nicolas Victoria), Minister of Justice and Public Instruction; and Manuel Quintero V., Minister of Public Works. These Cabinet Ministers were also equally divided between the two parties. The harmonious coöperation of the two political parties was further indicated in the design of the National Flag, which was made to consist of four equal fields-one blue, representing the Conservatives; one red, representing the Liberals; and two white, emblematic of peace, with a blue star in one white field, and a red star in the other.

Steps were promptly taken to rid Panama of the debased currency of Colombia. For a time it was necessary to use Colombian silver,_-"tin," "monkey," or "spicketty" money, as it was contemptuously called by the Panamans,- - though even then American coin and paper money was much preferred. As soon as possible several millions of Panaman gold and silver were coined, and thus a currency comparable with the best in the world was established. The monetary standard is the Balboa, a gold coin exactly equivalent to an American dollar. The silver coins are of 50, 25, 10, 5, and 2 1-2 cents' value, and, being exactly twice the size and weight of American silver coins of the same denominations, are worth their face value in gold. No paper money is used by the Republic.

In one important respect the Republic of Panama began its career in a unique fashion. Instead of having a national 
debt, it had a national endowment. This latter was provided by the bonus of $\$ 10,000,000$, which the United States paid to it for the right of way for the canal and for the lease of the Canal Zone. The Isthmian statesmen disposed of this sum with prudence. Nearly one-third was apportioned among the provinces for much-needed public works, as follows: to the Province of Panama, $\$ 1,000,000$; to Chiriqui and Boca del Toro, $\$ 450,000$ each; to Coclé, Los Santos, and Veraguas, $\$ 350,000$ each; and to Colon, $\$ 300,000$. The major part of the whole, $\$ 6,000,000$, was judiciously and profitably invested in real estate mortgages and similar securities in New York City; and the balance, $\$ 750,000$, was kept in hand as working capital.

Mention has already been made of the prompt negotiation of a canal treaty between the. United States and the Republic of Panama. That instrument, known as the Hay-BunauVarilla Treaty, was tersely but comprehensively summarised by President Roosevelt in his message of December 7, 1903, as follows:

"The United States guarantees and will maintain the independence of the Republic of Panama. There is granted to the United States in perpetuity the use, occupation, and control of a strip ten miles wide and extending three nautical miles into the sea at either terminal, with all lands lying outside of the zone necessary for the construction of the canal or for its auxiliary works, and with the islands in the Bay of Panama. The cities of Panama and Colon are not embraced in the canal zone, but the United States assumes their sanitation and, in case of need, the maintenance of order therein; the United States enjoys within the granted limits all the rights, power, and authority which it would possess were it the sovereign of the territory to the exclusion of the exercise of sovereign rights by the Republic. All railway and canal property rights belonging to Panama and needed for the canal pass to the United States, including any property of the respective companies in the cities of Panama and Colon; the works, property, and personnel of the canal and railways are exempted from taxation as well in the cities of Panama and Colon as in the 
canal zone and its dependencies. Free immigration of the personnel and importation of supplies for the construction and operation of the canal are granted. Provision is made for the use of military force and the building of fortifications by the United States for the protection of the transit. In other details, particularly as to the acquisition of the interests of the new Panama Canal Company and the Panama Railway by the United States, and the condemnation of private property for the uses of the canal, the stipulations of the Hay-Herran treaty are closely followed, while the compensation to be given for these enlarged grants remains the same, being $\$ 10,000,000$, payable on exchange of ratifications, and, beginning nine years from that date, an annual payment of $\$ 250,000$ during the life of the convention."

Diplomatic relations between the United States and Panama were fully established by the appointment of a Minister from each to the other. The first Panaman Minister to the United States, as already noted, was the distinguished French engineer, Philippe Bunau-Varilla, who was sent hither by the Junta immediately after the revolution. Soon after negotiating the canal treaty he retired, and was succeeded by J. Domingo de Obaldia, who had been Governor of Panama, under the Colombian Government, at the time of the revolution, and who was the Second Designate and one of the most distinguished statesmen of the Isthmus. The United States on its part appointed William I. Buchanan as Minister to Panama, on December 12, 1903, and he was received at Panama on December 25. He was succeeded in March, 1904, by John Barrett, who served-as we shall see presently-during a peculiarly trying period and rendered some invaluable services to both the United States and Panama, and who was in turn succeeded, in April, 1905, by Charles E. Magoon, who served until September, 1906.

The territory of the Republic of Panama lies well within the area bounded by the seventh and tenth parallels of latitude north of the equator, and the seventy-seventh and eighty-fourth meridians of longitude west from Greenwich. It is thus in the longitude of Virginia and North Carolina, 
and in the wholly tropical latitude of Sierra Leone, Ashan. tee, the Bahr-el-Ghazel, Somaliland, Ceylon, Lower Siam, and Mindanao. Its extreme length, from east to west, is 425 miles, and its width from north to south varies from 31 to 118 miles, the average being about 70 miles. Its area is between 32,000 and 33,000 square miles. At the east it abuts upon Colombia, and at the west upon Costa Rica, with a frontage in each case of about 175 miles, so that its total of land frontiers is only about 350 miles, against a sea frontage of 1,250 miles, of which 480 is on the Caribbean at the north, and 770 on the Pacific at the south. It is thus about the size of the State of Maine, smaller than Portugal, larger than Scotland or Ireland, nearly four times as large as Massachusetts, nearly three times the size of Belgium, and more than twice the size of Holland or Switzerland. It is sparsely settled, much of it being practically uninhabited, and the total population is less than 350,000 .

While it belonged to Colombia, Panama was considered a part of South America. It really belongs, geographically, however, to Central America, and is now thus to be reckoned. The territory is traversed from end to end, with a pretty complete break between Panama and Colon, by the Cordillera de Bando, which forms a connecting link between the Rocky Mountains of North America and the Andes of South America. This range is nowhere-in PanamaAlpine in elevation, and is seldom truly mountainous. The highest peaks are at the extreme west, and comprise several extinct volcanoes. Among these are Cerro Picacho, 7,054 feet, the highest in the Republic; Pico Robaldo, 7,012 feet; Volcan de Chiriqui, 6,480 feet; Cerro Santiago, 6,234 feet; and Cerro Horqueta, 6,234 feet. The mountains of San Blas, at the east, nowhere exceed 3,250 feet in height, and average not more than 2,000. In the central regions the hills are only from 500 to 1,000 feet high, and on the route of the canal the extreme elevation above tidewater, at Culebra, was only 290 feet, before the engineers began cutting it down. 


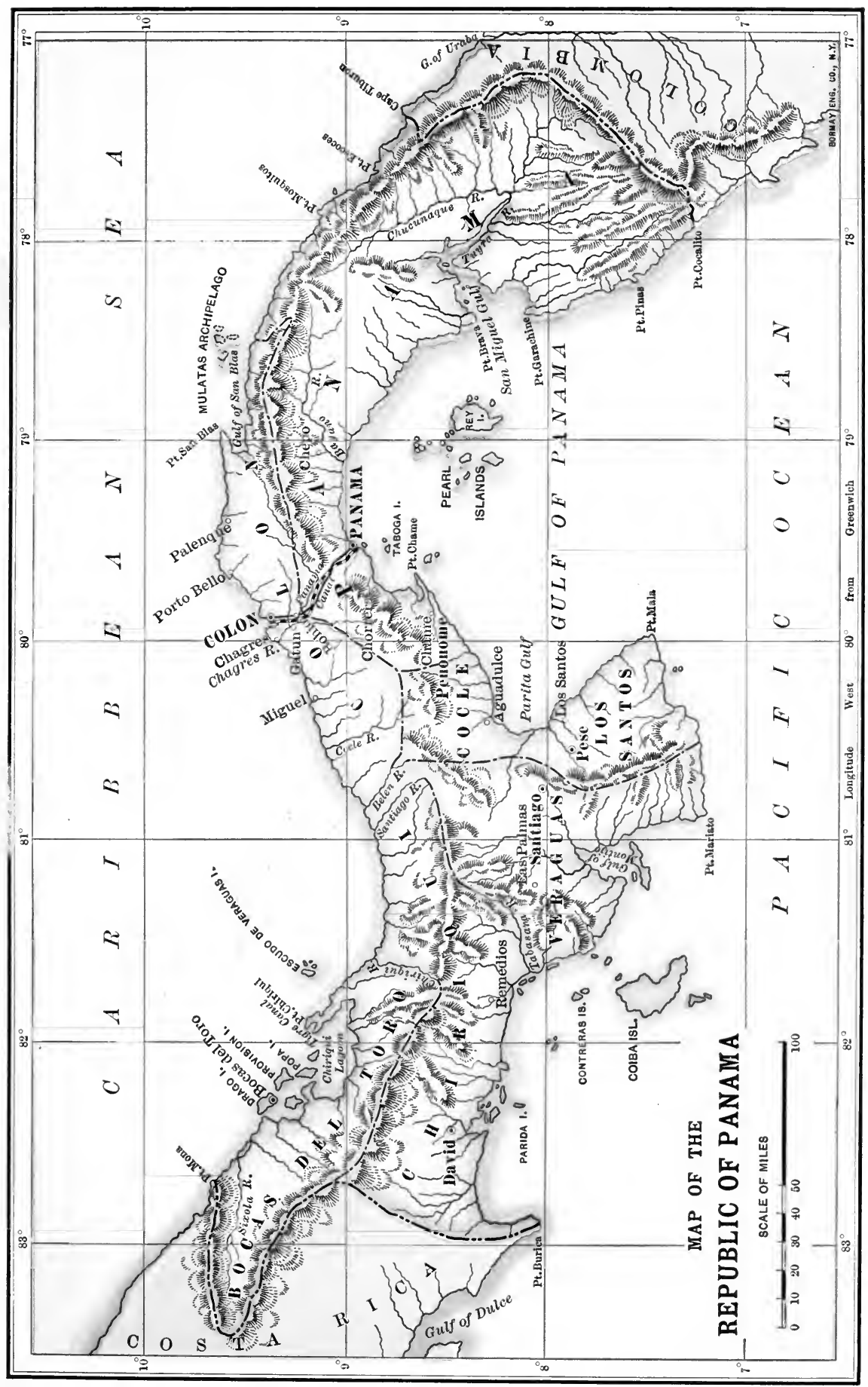


r 
In this narrow territory there are' no lakes worthy of the name, but along the coasts there are several extensive lagoons, or nearly landlocked sounds, of considerable extent. The rivers are necessarily short, but they are almost innumerable, traversing every part of the Republic. Most of them abound in rapids, and are not well adapted to navigation, the descent from the hills to the coast being sudden. Moreover, they are largely subject to great and rapid changes of volume, sometimes being transformed from brooks of a few inches in depth to torrents of several feet, in the course of a few hours, under the stress of tropical rains. The largest of the rivers is the Tuyra, in the southeastern part of the Republic. It is navigable by schooners and small steamers for about 100 miles, and has a large and also navigable tributary, called the Chucunaque. The famous and dreaded Chagres is in the north central part of the Republic, and flows into the Caribbean near Colon, after a course of 100 miles, more than half of which is navigable in the rainy season. Of all the considerable streams, it is subject to the most violent fluctuations, sometimes rising thirty feet in twenty hours. The Chepo, or Bayamo, is in the south central region, reaching the Pacific east of the city of Panama, and is $\mathbf{1 4 0}$ miles long and navigable by small craft for more than half its length. The Coclé, Calabebora, Tarire, and Los Indios rivers all flow into the Caribbean, are from 35 to 65 miles long, and are navigable for half their length. The San Pedro, Cambuta, Golfito, Chiriqui, Santiago, Fonseca, San Pablo, Santa Maria, Chiman, and Sambu, flow into the Pacific, and are navigable for some distance by small craft. The lack of good roads on land, and the great difficulty of constructing and maintaining them through the jungles, cause the rivers to be used as highways wherever possible. The Rio Grande, a comparatively small stream, flowing into the Pacific near Panama, is notable as the source of the excellent water supply of that city.

The great extent of the coasts of Panama, proportionately to the area of its territory, makes a survey of them perhaps 
the most instructive and essential of all conspectuses of the material republic. If we begin at the northwestern corner, we find Carreta Point marking the boundary between Costa Rica and Panama. A little to the eastward is the Tarire River, and then comes the first great feature of the littoral, in Almirante Bay. This landlocked lagoon is about thirteen miles in east to west extent, and almost as long from north to south, but its shores are most irregular in contour, and it contains a number of extensive islands, dividing it into a groups of sounds and harbours rather than a single sheet of water. The water is deep enough for the largest ships, and in many places these can approach close to the shore, so abrupt are the submerged banks. Much of the southern and western or mainland shore is a table-land, from 500 to 700 feet in elevation, gradually sloping upward to a height of from 1,500 to 2,000 feet at a distance of a couple of miles from the bay. This elevation makes the adjacent country agreeable for residence. Unfortunately it also makes the rivers which flow into the bay too rapid for navigation. At the north and east the Bay is shut in from the Caribbean by two large islands, Columbus Island, formerly called Isla del Drago, and Provision Island, or Isla de Bastimentos. The former lies at the northwest, and is about seven miles by four in extent, low and flat, and densely wooded. At the west it is separated from Terraba Point, on the mainland, by a strait three-fourths of a mile wide, known as Boca del Drago, or the Dragon's Mouth, which forms the westernmost entrance into Almirante Bay. This strait is nine fathoms deep, but tortuous and dangerous for navigation. Cauro Point and Lime Point are the principal headlands of the island on this strait, and at the latter there is a considerable settlement.

The chief settlement on Columbus Island, however, is Boca del Toro, at the southeastern extremity, fronting upon the strait of the same name (literally Bull's Mouth) which separates Columbus Island from Provision Island and which forms the central and chief entrance into Almirante Bay. 
The town of Boca del Toro has about 6,000 inhabitants, and is the capital of the province of the same name. It is one of the chief fruit-shipping ports of the whole coast, from five to seven steamships and many sailing craft leaving it daily during the fruit season. The trade is chiefly with American ports. There are coal mines near at hand producing coal of good quality, and the possibilities of an extensive and profitable trade in lumber and fish as well as in fruit are enormous. The strait of Boca del Toro is about threefourths of a mile wide, and is much preferable for navigation to Boca del Drago. At the east and south lies Provision Island, eight miles long but very irregular in shape. It consists chiefly of low land, well wooded, and enormously productive of tropical fruits, whence the name of the island. There are several small settlements on the island, but most of the commerce is conducted by way of Boca del Toro. At the south of Provision Island is Crawl Cay Channel, an eighth of a mile wide and dangerous for navigation, beyond which lies Popa Island, six miles long, rich in timber and containing some coal, and surmounted by Mount Popa, an isolated peak with a rounded summit rising 1,300 feet above the sea. At the southwest Popa Island is separated from the mainland by a narrow channel studded with islets, thus completing the chain which landlocks Almirante Bay.

Immediately south and east of Almirante Bay and separated from it by a long peninsula and by Popa Island, lies the great and well-known Chiriqui Lagoon. This body of water, its expanse quite unbroken by islands or reefs, is thirty-two miles long from east to west, and twelve miles in its greatest central width from north to south, and is almost everywhere deep and safe for navigation. It is well landlocked, mainland peninsulas embracing it at the northeast and northwest, and Popa Island and Water Cay filling much of the space between their extremities. Water Cay is several miles in extent, low, flat, and heavily wooded. Between it and Popa Island is a narrow, rock-studded chan. nel, difficult and dangerous for navigation, but at the east of 
it, between it and the mainland (Valiente Peninsula), is a broad, fine channel known as Boca de Chiriqui or Tiger Channel, forming the chief entrance into the lagoon. Numerous rivers and creeks flow into the lagoon, some of which are navigable by small vessels for a distance, and at their mouths are villages which do a considerable trade in fruit, lumber, turtles, fish, etc. Chief among these are Chirica Mola and Frenchman's Creek, on streams of the same names. From Frenchman's Creek a road runs overland to the city of David, near the Pacific coast, on which there is much travel, chiefly in connection with the trade in cattle and hides. At the northeast Chiriqui Lagoon is inclosed by the Valiente Peninsula, a crooked arm about twelve miles long and two miles wide, with Valiente Peak, 722 feet high, as a landmark near its extremity. The peninsula is largely rugged and hilly, and its outer shore is fringed with islets and rocks and coral reefs, making approach by sea dangerous. It has a beach of pure white sand, the only such beach between Colon and Greytown (Nicaragua), all the rest of the coast being lined with brown or reddish-black ironbearing sand. Although the fluctuation of the tide here is only a foot, there is generally a furious surf breaking along this coast, under the stress of the trade winds and "northers." A few miles to the northeast of the peninsula lies the island of Escudo de Veraguas, which is about a mile wide and two and a half miles long, densely wooded. Its shores consist largely of cliffs forty or fifty feet high, cut by the waves into caves and archways of the most fantastic design.

The seaward coast of the Valiente Peninsula runs toward the southeast, and that general direction is continued for many miles by a coast devoid of striking features, though with many river mouths and a few scattered towns. From the Province of Boca del Toro we pass to that of Chiriqui, and thence, at the Cana River, to that of Veraguas. From the Cana River there are many miles of low, sandy shore, until Buppan Bluff is reached, a promontory bearing several peaks 700 or 800 feet high. A little beyond are the Pedro 
and Chiriqui rivers, and a few miles beyond the latter a great spur of the Cordilleras, known as Tiger's Head, nearly 4,000 feet high, abuts upon the coast. The mouth of the Catalina River, just west of Coaita Point and at the foot of the Catalina Hills, is the southernmost point on the Caribbean coast. Thence the shore of Panama runs in almost a straight line about a hundred miles east by north, to Provision Point (Punta de Bastimentos) beyond Porto Bello. This stretch of coast is marked with the mouths of innumerable rivers and creeks. It is chiefly wooded, and much of the way is lined with dark-coloured cliffs. Perhaps its most striking landmark is Castle Choco, a square, flat-topped mountain, rising to the height of 6,342 feet, which at times is clearly visible from the Castle of San Lorenzo, at Chagres, 67 miles away. Eastward from Castle Choco the mountains-the Cordilleras of Veraguas-come down almost to the coast for a distance of more than thirty miles. Rincon Point is a rocky headland more than 500 feet high, and beyond it is the Coclé River, overshadowed by the Coclé Hills, nearly 1,500 feet high. The small Mangalee River marks the boundary between the provinces of Veraguas and Panama, and near it is the Pilon de Miguel de la Borda, an isolated peak nearly 1,700 feet high, standing fourteen miles inland but clearly visible from the sea. Fourteen miles eastward from the Mangalee is the Indios River, and about the same distance further on, the mouth of the Chagres is reached.

The Chagres enters the sea between a low, dark-coloured sandy beach at the southwest side and a steep bluff and table-land at the northeast, the former marked with the ruins of the ancient Castle of San Lorenzo. The town of Chagres is at the east, near the castle, and is a poor place of about 2,500 fishermen and their families. The entrance to the river is rendered difficult by a number of shifting sandbars and by some rocky ledges and reefs. The depth of water is, however, not less than eleven feet even in the dry season. Inside the bars there is a depth of twenty feet, with good anchorage. From the Chagres the coast is steep and 
rocky for three miles to Brujas Point, a bold, wooded headland; thence for two miles lower and sandy to Toro Point, which marks the western side of Limon Bay and which is a wooded hill 400 feet high, bearing a lighthouse, the flashing white light of which is visible for sixteen miles. Limon Bay, also known as Colon Bay and Navy Bay, is about three miles wide and three and a half miles deep from north to south. It is from three to seven fathoms deep, but seems to be steadily growing more shallow. This process is easily explained, when we remember that it is not landlocked but is an open roadstead, fully exposed to the trade winds and to the furious "northers" which sweep into it with tremendous force, doubtless driving into it a certain amount of detritus from the bottom of the Caribbean, while the torrential rains wash into it much matter from the shore. At the east side of the bay is the low, flat Manzanillo Island, a mile long and three-fourths of a mile broad, on which is the city of Colon. This was formerly known as Aspinwall, and was created as the Caribbean terminus of the Panama Railroad. As such it supplanted the once flourishing town of Chagres and reduced the latter to its present inferior estate. On the northern point of the island is a lighthouse with a fixed white light visible for ten miles. Colon has a population of about 6,000 and is the most important shipping port of the Republic, being visited by steamships from all parts of the world. The entrance to the Panama Canal is just west of Colon. Inland from Colon a couple of miles are the Mountains of Quebrancha. Northeast of Manzanillo Island is the small Bay of Manzanillo.

Thence the shore proceeds to the northeast, much broken with capes and bays and river mouths, to the ancient town of Porto Bello, where Columbus landed in 1502, which was the scene of one of the most hideous tragedies of Morgan the Buccaneer. It is one of the best harbours on the coast, being partly landlocked and reasonably safe, but the hills which inclose it shut off the breezes and it is hot and unhealthy. Once the chief Isthmian port, it has never recov- 
ered from the injury inflicted by Morgan, and is now an unimportant place of less than 3,000 inhabitants and little commerce. The irregular coast thence runs on to Bastimentos Point, beyond which lies Manzanillo Island (not to be confounded with Colon's island of the same name), the northern extremity of which, Manzanillo Point, is the northernmost land of Panama. Beyond this lies San Cristoval Bay, into which flows the Nombre de Dios River, and here was the old city of Nombre de Dios, famous in the days of the Spanish conquistadors, and of Francis Drake. The next striking coast feature is the Point of San Blas, partly inclosing the Gulf of San Blas, an extensive sheet of water affording some good harbourage. It lies, however, within the territory of the San Blas Indians, who, though amiable enough to well-disposed visitors, do not encourage intercourse, and permit no white man to remain on shore at night. A short distance off the entrance to this gulf lie the Mulatas Islands, an archipelago of islets and rocks, among which there is fine fishing, and where many large edible turtles are captured. Escoces Point, Escoces Harbour, Caledonian Bay, and Paterson's Hill, many miles further down the coast to the southeast, are reminiscent of the ill-fated attempt to plant a Scotch colony on the Isthmus and thus win "the keys of the universe" for Great Britain. At Cape Tiburon, a high, rocky point, we reach the entrance to the Gulf of Darien, and the boundary between Panama and Colombia.

Turning now to the Pacific coast, and again beginning at the west, the Costa Rican boundary is marked by Burica Point, a long and conspicuous cape jutting to the southward. From the point of the cape, the coast runs northward and then sweeps around in a third of a circle, to Boca San Pedro, one of the chief entrances to the delta of the David River, upon which, a few miles inland, lies the important city of David. This delta comprises an extensive group of islands, reaching along the coast for nearly twenty miles. The southernmost of them is Parida Island, which is about four miles by two in extent and is well provided with wood and 
fresh water. Venado Island is the easternmost of the group, and thence a clean coast runs eastward and a little southward to a similar but smaller archipelago at the mouth of the Santiago River. Thence the coast trends sharply southward, to Bahia Honda, off which lies Coiba or Quibo Island, the largest of all the islands of Panama. Coiba is about twelve by twenty-one miles in extent, of moderate elevation, well wooded and watered, and with extensive fertile plains. This island was visited by Lord Anson, in the middle of the eighteenth century, and was then said to be infested with flying serpents. Several smaller islands lie near Coiba, the chief of them being Jicaron, four miles to the southward. It is three and a half miles across, and has hills rising to a height of 1,400 feet.

Twenty miles east of Bahia Honda is Brava Point, at the western side of the Gulf of Montijo. This gulf is a fine, almost landlocked sheet of water, nine by fourteen miles in extent, with Cebaco and Gobernador Islands screening its entrance. Within the gulf, near its head, is the Island of Leones, three miles across. Cebaco Island, which serves as a breakwater across the entrance to the gulf, is nearly fourteen miles long, but only from one to two miles wide. Gobernador Island is only a mile or two in extent. The San Pablo and several other considerable rivers flow into this gulf. At the eastern side of the entrance is Duartis Point, and thence the coast runs south and a little east, with marked irregularities, nearly twenty miles, to Mariato Point, the southernmost land of Panama. Thence the coast line turns at a right angle, and runs, with some irregularities, little north of east, twenty-seven miles to Morro Puercos, or Puercos Point; thence it curves in a large bight northeastward to Guanico Point, about seven miles, and thence in a larger bight in the same direction ten miles to Raia Point. Near Raia Point is the mouth of the Juera River, a stream navigable for a mile or two by the largest vessels, its depth being more than fifty feet. Twelve miles to the east and a little north is Cape Mala, the western side of the entrance to 
the vast Bay of Panama. Here the coast turns sharply, at something less than a right angle, and runs in an almost straight line northwest by north about fifty-five miles to Point Lisa, at the southern side of the entrance to the Bay of Parita, an indentation at the extreme west of the Bay of Panama. The cities of Parita and Los Santos-in the province of Los Santos-are near the shore of the Bay of Parita, on rivers which are navigable for several miles. At the northeast side of the bay is Anton Point, whence the coast extends in an almost straight line northeast to Point Chamé, forty miles. At Point Chamé the line curves northwest and thence around to northeast in a semicircular bight about seventeen miles, to Batele Point. This bight is shallow and is not readily navigable. The Chorrera River, a considerable stream, enters it and is navigable for a couple of miles, as far as the city of Chorrera, an important place of about 6,000 inhabitants. Across the entrance to the bight lies a long chain of islands, extending from north to south for a distance of more than twenty miles. At the northern end of the chain are Naos, Perico, Flamingo, and Culebra islands, mere islets, a mile or two from the city of Panama. A few miles south of them lies the beautiful Taboga Island, nearly two miles in extent and rising to a height of 935 feet. Upon it is a large and attractive village, and the island is a favourite place of residence and resort for health and pleasure. Near by are the much smaller islands of Taboguilla, or Little Taboga, and Urava, and a number of rocky islets, all rising sheer and high above the water like abrupt mountain peaks. Still further south are the islets of Chamé and Valladolid, and at the southern end of the series are Otoque, Bona, and Estiva.

Passing Point Batelé and Changarni Island, the harbour of Panama is reached, the city itself being about five miles north by east from Batelé. Panama occupies a peninsula between two bays, that at the west being formed by the estuary of the Rio Grande and the little Rio San Juan, and that at the east, more than a mile wide from Panama to 
Point Paitillo, being a mere indentation in the coast. The view of Panama from the sea, as it stands upon its terraces of volcanic rock, with the huge mass of Ancon Hill, 630 feet high, rising as a background behind it, is one of rare and memorable beauty. Just west of the city is the Pacific terminal of the canal, known as La Boca, at which is a great wharf for ocean steamships. The anchorage off Panama is excellent, and although the harbour is open to the Pacific Ocean, calm weather almost constantly prevails, so that vessels are secure without any breakwater. The Bay of Panama was indeed once known as the Bay of Calms, and one serious disadvantage to commerce is that sailing vessels often have to be towed out of port for a hundred miles before they can find wind to fill their sails. There are numerous rocks and reefs off the Panama waterfront, and the fluctuation of the tide is about twenty feet, so that navigation has to be conducted with much care. Five miles east of Panama is the site of the original city of Panama, now marked by nothing but a single ruined tower, visible for miles. Thence the coast runs almost due east, for twenty miles, to the mouth of the Bayamo or Chepo River, a large and navigable stream, the lower twelve miles of which it was proposed to use as a part of the projected canal at the San Blas route. The lovely Chepillo Island lies off the mouth of this river.

Thirty miles southeast from the Chepo, the mouth of the Chiman River is reached, with Pelado Island near it. The village of Chiman, at the mouth of the river, is the point from which Pizarro sailed for Peru in $\mathbf{1 5 2 5}$ for the conquest of that empire. Directly southwest from the mouth of the Chiman, at a distance of more than twenty miles, lie the famous Pearl Islands, a large and numerous archipelago thirty miles in extent from north to south and twenty miles in width from east to west. These exquisite islands have also been called Islands of the King, Islands of the Isthmus, and Islands of Colombia. There are sixteen of them, beside a score or more of mere rocks. Isla del Rey is by far the 
largest, being more than ten miles long, and having an area greater than that of all the rest put together. It has also been called the Island of St. Michael (San Miguel). San José and Pedro Gonzalez are also considerable islands. Bayoneta, Casaya, Saboga, Pacheca, and Contadora are much smaller, though Saboga has a large village and perhaps the best anchorage in the group. Nearly all the islands are hilly, some of them rising 600 feet above the water. They are well wooded and watered, and fertile, and present a singularly beautiful panorama of mingled landscape and seascape.

Returning to the Chiman River and going south by east twenty miles, Brava Point is reached, at the northern side of the entrance to the great gulf of San Miguel, or Darien del Sur, Point Garachine, twelve miles south, marking the other side. This gulf is very irregular in shape and is dotted with small islands. It extends inland about fifteen miles, where it is reached and entered by the huge estuary of the Tuyra and Sabana rivers, the former the largest in the republic and a part of several of the Darien canal routes. The large Sambu River also flows into this gulf near its southern extremity. From Point Garachine the coast runs generally about southsoutheast for fifty miles to the Colombian border, without noteworthy features. A high mountain range rises almost directly from the shore, and there are no rivers or towns of importance in that region.

Of the city of Panama I shall speak in detail in another place. It remains to mention briefly the other cities and towns of importance. Colon, already mentioned, dates from 1849 only, and is essentially a modern commercial city. Everything in it is subordinated to the railroad and steamships. It is largely built of wood and sheet iron, and is periodically ravaged by extensive conflagrations. Elevated only a few feet above tide level, adequate sewerage is impossible. The sanitary conditions have accordingly been bad, and the task of improving them is proving most diffcult. Exposed to the trade winds, however, Colon is some- 
what cooler than Panama, and has thus been regarded by some as a more desirable place of residence. Such judgment seems strange, to one who has contrasted the dripping, reeking climate of swamp-girt Colon, and the turbid, yellow waves of Limon Bay, with the vastly dryer climate and crystalline air of rock-founded Panama, fronted with the fathomless azure of the Pacific. There has been talk of establishing the Caribbean terminus of the canal at a distance of some miles from Colon, and removing that city to the new site. "Tis a consummation devoutly to be wished." Wherever the new site, it must be better than the old.

Boca del Toro, with its great fruit trade and its up-to-date wireless telegraphy, I have already mentioned; and also Porto Bello, with its record of being sacked and burned five times. Chagres, too, has been described, as having fallen from the estate of a walled and castled city to that of a fishing village of thatched huts. Agua Dulce, on the Bay of Parita, provides the whole Republic with salt, and is a great centre of grain and cattle growing. David, the capital of the province of Chiriqui, is the largest of the inland cities, having about 8,000 inhabitants, and being the chief grain and cattle market of the Republic. It has also some gold mines. Its trade is conducted by way of both the Pacific and the Caribbean. Los Santos, the capital of the province of that name, has 7,500 inhabitants, and is beautiful for situation. Santiago, capital of the province of Veraguas, has 7,000 inhabitants, and is the seat of iron and steel, sugar, cotton, and woollen factories, and has gold, silver, and copper mines.

The visitor to the Isthmus from the United States lands, of course, at Colon. In the outskirts of that city the train passes the unspeakably squalid settlement of Cristobal, founded by the French in 1880, and Monkey Hill, with its cemetery. Beyond several miles of swamp Mindi, an insig. nificant place, is reached, and beyond it is Gatun, a village of 900 inhabitants, the first station of importance after leav- 


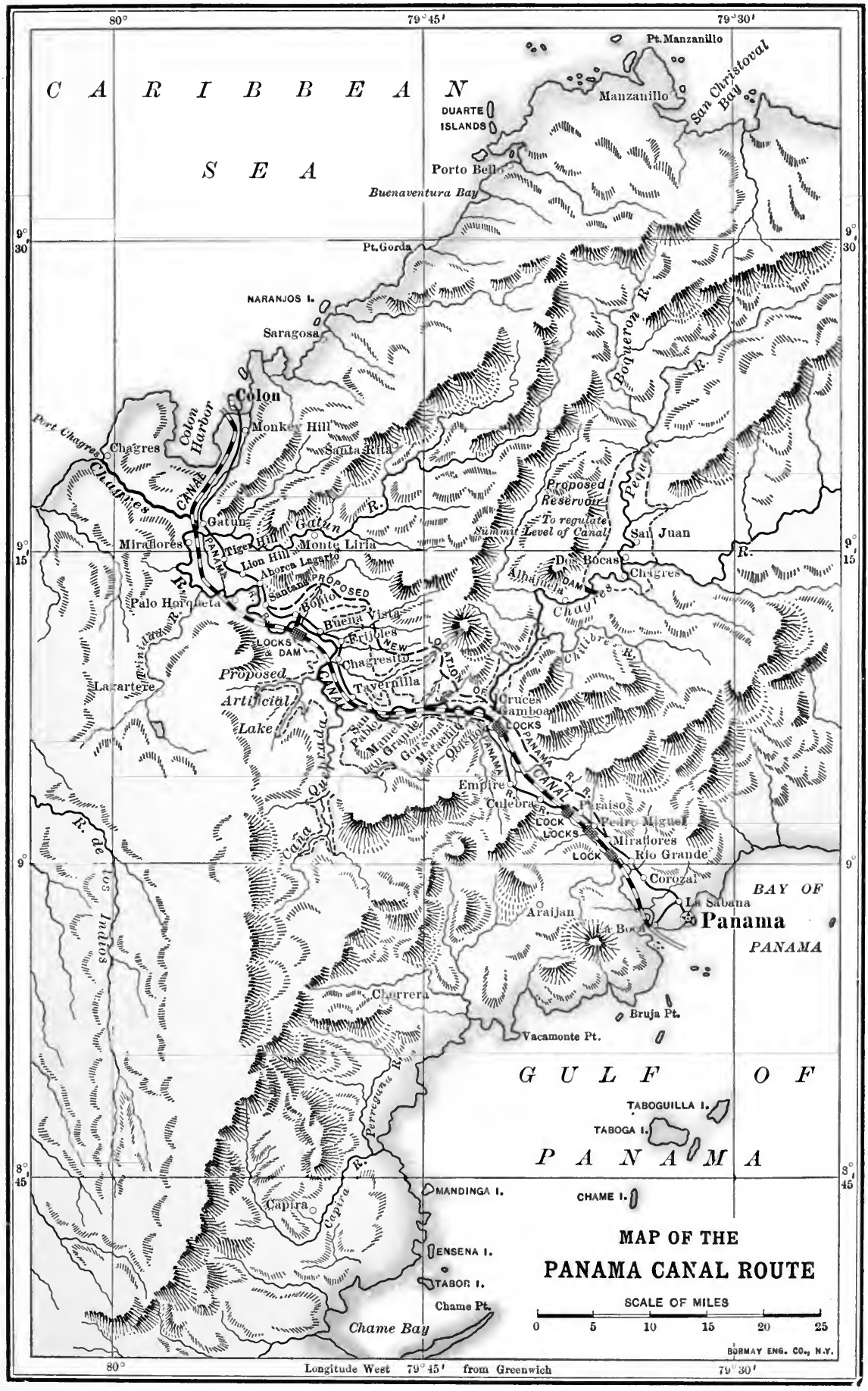




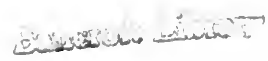


ing Colon, and about seven miles from the latter. Gatun stands on the banks of the Chagres River, which is navigable to that point by steamers, and is the proposed site of a dam for the control of that stream. Three miles further on, across the swamps bordering the Quebrancha River (a tributary of the Chagres), the negro village of Lion Hill, or Tiger Hill, is reached, a poor place, with about 200 inhabitants. Five miles further, after passing the insignificant hamlets of Ahorca Lagarto, Carmen Messias, and Santana, the negro and Chinese village of Bohio Soldado is reached, where it has been proposed to construct the gigantic Bohio Dam, to transform the valley of the Chagres for miles into a lake, for a high-level canal. The village has fewer than 500 inhabitants. A little beyond is Buena Vista, and three and a half miles from Bohio is Frijoles, where the French built important machine shops and storehouses. Tavernilla, with 200 inhabitants, is three miles further on, Mamei is five miles beyond it, and two miles beyond Mamei is Gorgona, a town of more than 3,000 people. Matachin, two and a half miles from Gorgona, is the site of machine shops and warehouses. Under the French company, in 1887, it was the scene of an outbreak of yellow fever, which killed more than 2,000 Chinamen. Its present population is less than 1,000, chiefly negroes and Chinese. Obispo, a mile beyond, is a village of 250 inhabitants. It is close to Gamboa, the site of another proposed dam for the control of the Chagres. Las Cascades, two miles further on, has 400 black and yellow inhabitants.

The important station of Emperador, or Empire, comes next, two miles beyond Las Cascades. It has more than 4,000 population, and is attractively situated. Just east of the railroad station is a hill, 250 feet high, which was fortified and used with effect in more than one of the Isthmian wars, and is now occupied by the barracks of the United States troops which guard the Canal Zone. That sightly and breezy hilltop is a comfortable and most attractive place of residence, commanding one of the finest panoramas to be 
seen on the Isthmus. A mile and a half from Empire is the village of Culebra, on the "continental divide," and near the great Culebra Cut, the crux of the canal construction. Paraiso comes next, only eight miles from Panama, with three hundred negro and Chinese inhabitants; a mile and a half beyond is Pedro Miguel; a mile beyond that is Miraflores, on the Rio Grande River, whence Panama draws its water supply ; the insignificant hamlet of Rio Grande is just beyond; and finally comes Corozal, on the edge of a mangrove swamp, three miles outside of the city of Panama. A short distance before reaching the Panama terminal of the railroad, a spur branches off and runs around the city to the great steamship wharf at La Boca, at the other side.

The Isthmus of Panama is the only part of the American continents where there is a distinct break in and indeed an abandonment of the mighty continental backbone of mountains which extend from Alaska to Patagonia. There that chain, known variously as the Rocky Mountains, the Cordilleras, and the Andes, gives place for some miles to irregular scattered hills, solitary or grouped, of no considerable height. Few rise as high as 1,500 feet, and many no higher than 500 or 600 feet. Along the line chosen for the canal there is no elevation as great as 300 feet, and most of the route is much lower. Upon the interesting and plausible theory that at one time there was a gap in the Isthmus, and an open waterway between the two seas, which has been filled up by volcanic action, it is not necessary here to dwell. But it seems quite inconceivable that any intelligent observer can personally inspect and examine the Panama route without being quickly convinced that it is peculiarly and preëminently fitted by nature for the purpose of canal construction, and of a canal at tide level.

Beginning at the flat, swampy coast near Colon, the route of the canal proceeds practically at tide level through an alluvial plain, for a distance of six miles, to Gatun, where the first hills are reached, and where there have been proposals to construct a dam-provided any one is willing to 
go two hundred feet below sea level for a bed-rock foundation. Passing through a gap in the hills, scarcely elevated above the sea, the line follows the valley of the Chagres River for nine miles more, with a scarcely perceptible ascent, to Bohio. At this point the valley of the Chagres is narrow, and to the superficial observer the place seems well fitted for the building of a dam, to impound the waters of the Chagres in what has been called in advance "Lake Bohio"-an essential feature of the high-level canal scheme. But on careful examination it is found that the bed rock is nearly as far below sea level as at Gatun, a circumstance which has caused many engineers to regard the plan for a dam there as problematic. Beyond Bohio lies the extensive Plain of Tavernilla, which rises gradually and slightly toward Obispo, thirteen miles further on. The proposed dam at Bohio would transform that entire plain, from Bohio to Obispo, into a lake.

At Obispo the "continental divide" is reached, the ridge of earth and rock which in diminutive fashion corresponds with the Rocky Mountains and the Andes as the watershed between the Atlantic and the Pacific. As the vast width of the North American Continent is to the narrow Isthmus of Panama, so are the Rocky Mountains to the little hill of Culebra, south of Obispo, through which the famous and dreaded Culebra cut is being made. At its extreme summit, before the French engineers removed a spadeful of earth, it was less than 300 feet above tide level. The length of this cut, from Obispo to Pedro Miguel, is less than eight miles, and, of course, it is not all as deep as at the centre. At Pedro Miguel the foot of the hill is reached, and thence there is a very slight descent along the valley of the Rio Grande, to the Pacific Ocean, eight miles away, at La Boca, or "The Mouth," just west of the city of Panama. There it will be necessary to dredge a channel for the canal for three miles in the Bay of Panama, out to the island of Naos.

Most of the way this route runs through a tropical wilderness of profuse vegetation. The geology of the region is 
peculiar. Bed rock lies generally far below the surface, so far below that it need not be touched in canal cutting, until the city of Panama itself is reached, which stands upon a terrace of volcanic rock. The cuttings at Culebra and elsewhere are chiefly through red clay, a greenish marl-like deposit, and various rocks abounding in quartz which when dry are hard as granite but when saturated with waterwhich they take in as does a sponge-are as easily disintegrated as so much loaf sugar. I remember that on my first visit to the Culebra cut I saw innumerable masses of glittering quartz crystal from the size of a walnut to that of a barrel, apparently as strong as New England granite, and reminding me of masses of Herkimer County rock crystals of exaggerated size. My first thought was that it would be difficult for me to break off such specimens as I might want to carry away. But when I made the attempt I found that my real difficulty was to keep the pieces which I gathered from crumbling into atoms in my hand or in my pocket. The rain of the night before had saturated the rock, and had made it as friable and perishable as so much confectionery. This peculiarity of the rock, of course, greatly facilitates excavation.

A less agreeable peculiarity is possessed by the red clay and other earths at Culebra: to wit, the property or tendency of slipping and sliding and refusing to "stay put." These earths are in horizontal or nearly horizontal strata, among which there is little or no cohesion. Our French predecessors were much troubled by the frequent landslides which brought the sides of the cuts tumbling and bulging in upon them and filling up the space which had been excavated. This trouble they themselves aggravated, as I have told in a former chapter, by the ill-advised system of piling up the excavated material at the sides of the cuttings and thus adding to the pressure upon the lower strata of the banks. Our own engineers have more wisely decided to remove all material to a greater distance, and also to make the cuttings wider and the slope of the sides at a much lower angle. Thus 
that trouble will be avoided. It may be that torrential rains will wash some earth down the banks into the canal, though it is probable that in a short time the banks will be so covered with masses of vegetation as to prevent any serious erosion. If not, it may be necessary to cover the slopes with rip-rap.

The volcanic character of the Isthmus has already been mentioned. The region is not now altogether free from slight earthquake shocks, but there are no active volcanoes, and severe shocks have been unknown for centuries. Such seismic disturbances as do occur must now be regarded as nothing more than the results of more severe shocks in fardistant places. The fact that the lofty tower of the cathedral of Old Panama is still standing, intact, indicates that there has been no destructive tremor of the earth for the best part of four centuries. Careful records are made at Panama, with the most sensitive and accurate seismometers and seismographs, from which I noted that in the three years 1901-1903, there was not one real shock, and there were only eight tremors, of which probably not more than one was perceptible save to the delicate instruments. In the same years at San José, in Costa Rica, there were about 150 shocks, more than thirty of them being very strong. We may, therefore, dismiss all fears of city-destroying earthquakes at Panama, though, of course, there is always a possibility that a comparatively slight shock might gravely damage the masonry locks of a high-level canal, while it would do no harm to one at sea-level.

The climate of Panama is strongly affected by several circumstances. One is that the Isthmus lies about nine degrees north of the equator, and scarcely one degree north of the thermal equator. Another is that the Isthmus is so narrow a strip of land between two oceans. These circumstances give Panama a particularly moist climate. Another feature of the climate, especially at Colon and along the northern shore, is the prevalence of the Caribbean trade winds, and this, with the altitude of the sun, conduces to remarkable 
uniformity of temperature. From April 13 to August 29 the sun at noon is north of the zenith, on June 21 being only 75 deg. $41 \mathrm{~min}$. above the northern horizon, while on December 21 it is $57 \mathrm{deg} .24 \mathrm{~min}$. above the southern horizon. There is thus an extreme variation of $46 \mathrm{deg}$. $55 \mathrm{~min}$. Generally speaking, 55 per cent. of the time the wind at Colon is blowing from northerly quarters: that is, from some point between northeast and northwest; 35 per cent. of the time it is from the corresponding southerly quarters; nine per cent. of the time it is from easterly or westerly quarters; and one per cent. of the time there is a dead calm. These percentages vary with the seasons, of which there are twothe dry season, comprising January, February, March, and April, and the wet season, including all the rest of the year. During the dry season more than 90 per cent. of the wind is from between north and northeast, and during the rainy season more than 50 per cent. is from southerly quarters. As these winds blow from the sea upon the land, the temperature of the water is an important factor in climatic problems. The temperature of the Caribbean has a yearly average of 79.3 deg., Fahrenheit, ranging from 75.8 in February to 81.9 in September. The temperature of the Pacific, or of the Bay of Panama, has a yearly average of only 76.1, ranging from 67.8 in February to 80.0 in October. Thus the Pacific is 3.2 degrees cooler than the Caribbean, and has just twice as great a range of variation as the latter. At this point I may perhaps appropriately mention the tides, though they have probably no bearing upon the climate. At Colon the total range from low to high water is from $\mathbf{7 . 4 4}$ to 24.84 inches, the average being 17.208 inches. At Panama the range is from $\mathbf{1 6 . 4 0}$ to 20.93 feet, the average being $\mathbf{1 8 . 7 5}$ feet, or more than thirteen times as great in the Pacific as in the Caribbean.

The uniformity of the climate of Panama is most notable, when we observe the temperature of the air and its slight variations. At Panama the hottest time of the day is from two to four o'clock p. m., when the average temperature 
ranges from 81.6, Fahrenheit, in November, to 86.1 in March. The coolest hour is from six to seven o'clock a. m., when the average temperature ranges from $\mathbf{7 4 . 0}$ in January to 76.6 in June. The general average of highest temperature is 84.0, and of lowest, 75.1. The average daily temperature ranges from 77.9 in November to 81.1 in April, the yearly average being 79.6. Thus the variation of monthly averages during the year is at most only 3.2 degrees. I know of no other place where it is so slight, and where, therefore, the temperature is so uniform. At Barbados there is a variation in monthly averages of 3.5 degrees; at San Juan, Porto Rico, of 5.8; at Kingston, Jamaica-that land of comfort and of beauty-of 6.5; at Havana, Cuba, of 12.1; at New Orleans, of 29.1; and at Washington, D. C., of 43.7. The first four of the places named have a yearly average from a fraction of a degree to 4.1 degrees cooler than Panama. But Kingston, San Juan, and Havana all have hotter weather as well as cooler weather than Panama, and on the whole the temperature of the Isthmus is more agreeable than theirs. It is an impressive fact that there is no record of the thermometer's ever having risen as high as $\mathbf{1 0 0}$ deg., Fahrenheit, at Panama. It has been observed at 101 at Havana and at San Juan, and at 104 in Washington.

So much for the dry bulb thermometer. I am sorry to say that the record concerning humidity is less favourable.at Panama than elsewhere. I do not think the Isthmians ever suffer as much from excessive humidity as we do at times in New York, in August, but they suffer from it for a much longer time. Even in the dry season, from January to April, there is an average humidity of about 80 degrees, and in the rainy season this rises to about 87.7. Probably $85 \mathrm{deg}$. would be a fair average for the year. That is a record which speaks for itself. I shall not attempt to defend it or to extenuate it. I should add, however, in passing, that up at Empire and other places on the highlands, at an elevation of only from 100 to 500 feet, the humidity is much less than at Panama, while the range of variation of temperature is 
greater, the maximum of heat being higher and the minimum lower than on the coast. The wind at Colon blows almost incessantly, at an average velocity of from five to eight miles an hour, seldom rising above twenty miles, save in the destructive "northers."

The rainfall on the Isthmus is heavy, but varies much according to place. At Colon it is heaviest, averaging about 140 inches a year. At Matachin and Empire, on the "divide," it is from 90 to 95 inches. In the city of Panama it is not more than 60 inches. The average number of rainy days in a year is 246 at Bohio, 196 at Colon, and 141 at Panama. At Bohio there is not nearly as much contrast between the wet and dry seasons as at Panama, the four dry months at Bohio having an average of twelve rainy days each, while at Panama they have less than five each. At Panama the rainy season is by no means a time of incessant downpour. When it does rain, it rains hard, as hard as we ever see it in the north in the most torrential summer thunderstorms and "cloudbursts." But at least one day in three is fine, and generally one day, in two. The rainiest month is October, in which there is an average of twenty rainy days and eleven fine ones. In November the average is eighteen rainy, in August and September seventeen each, in July fifteen, in June thirteen, in May twelve, and in December eleven rainy days. In the dry season the average number of rainy days is seven in April, six in January, four in March, and one in February.

It is not my purpose, however, to attempt a technical scientific treatise upon climatic or other conditions in the Isthmian Republic, but to give the general impression which the country makes upon the observant layman who visits it, not in quest of special facts to bolster up some longcherished prejudice, but with an open mind in quest of truth. To such, Panama must seem a land where tropical conditions present their best phases, and where their evil phases are minimised. It is a land which is not only tolerable but even comfortable and enjoyable to those who have been accus- 
tomed to the capricious, uncertain, and intemperate regions which we contradictorily call temperate, and it is one whose political constitution, whose geographical position, and whose topography, geology, meteorology, and all other natural conditions, not only permit but favour and facilitate the development of a high civilisation and great prosperity for a numerous population of the Caucasian race. 


\section{CHAPTER XIII}

\section{AN ANTI-REVOLUTIONARY EPISODE}

The Republic of Panama was scarcely a year old when it was first called upon to determine the fundamental question whether it should have a stable and constitutional civil government, or should, after the fashion of some neighbouring states, be subject to military revolutions. At the beginning of the Republic's life the former choice was made. Instead of forming a military government, a government of civilians was organised. For President was chosen not a general of the army, but the leading physician of Panama; for First Designate the foremost lawyer and jurist; and so on all through the Cabinet. It was, in a measure, a coalition government, comprising men of all parties. But in time, as already related, party antagonisms were developed, both in and out of the government. The Liberals believed themselves to be in the majority in the country at large, but were in the minority in the government. Agitation therefore arose, in public prints and speeches and in addresses to the President, for a reorganisation of the government, and especially for the removal from the Cabinet of Tomas Arias, the Minister of Foreign Affairs and War, and of Nicolas Victoria, the Minister of Public Instruction and Justice. At last, failing to effect their end by other means, the opposition leaderslargely the friends and partisans of Belisario Porras, of whom I shall speak more at length, in another chaptersought and secured the coöperation of Esteban Huertas, the commander-in-chief of the army. Now, General Huertas was the idol of the army. He was highly esteemed by the general public for his very important services in the revolu. tion of November 3, 1903. He was, moreover, a man of decided ability, and of peculiarly attractive and engaging 
personality. I trust I shall not offend, however, in saying that he was too much flattered by not altogether disinterested friends. It is not good to tell a man, and especially a young man, that henceforth Washington and Napoleon must be ranked second to him.

Matters approached a crisis on October 29, when, under date of the preceding day, General Huertas sent to President Amador a letter couched in the most extraordinary terms, commingling almost inconceivable egotism, extravagant affection for the President whom he was trying to bully, and bitter hatred of the two Ministers already mentioned. As a curiosity of correspondence I must quote the letter in full, with a few italicised passages of my own marking. Here it is :

"Dr. Manuel Amador Guerrero, (Confidential.)

Esteemed Companion and Friend:-

I have thought much and deeply before sending you the present lines. They do not, then, embody an accusation, but an explanation and a sane statement of what it has become necessary to carry into effect if we do not wish that History should set a stigma upon our acts and on our names.

You and I, joined by indissoluble bonds of honest methods, together formed the Isthmian Fatherland. Now it remains for us to maintain and improve it. Even at the risk of our lives must we uphold it. Do not let us separate, Doctor; let us continue united in the same work which we have taken up. My acts may be separate from all your civil authority, but your civil authority will be always upheld by the unquestionable loyalty of the Army. We are in truth the fathers of the Isthmian people. Let us show by our acts our wisdom and probity. Let us give heed to the errors which are pointed out to us by the opposition; correct the vices and support the Administrative Edifice with an honourable personnel, which will shed lustre upon the country, which notwithstanding its youth, suffers tortures already from a choking iron collar.

Neither you nor I are disliked by the people. I have sounded all hearts, and I can assure you that none contains rancour; that which they hold is sentiment and the desire to 
see affairs move forward in a clear way. And this is most natural. A great portion of the people, among whom exist brave elements which can apportion splendour and wealth to this beloved Fatherland, because it possesses vast resources, find themselves removed from the direction of Public Affairs in order that rapacious spirits, which gobble up everything, may be sustained in office to the disgrace of the National dignity and to your disgrace as Chief Magistrate and to my disgrace as faithful Executor of the Divine Will coöperating with you in the formation of our Nation. We must find sane elements, Doctor, we must not surround ourselves with enemies. We must consider that the interests of all are more precious than the interests of those favoured ones who, fully counted, do not number THReE.

It matters not what those two may suffer so that the Nation may save itself from the sorrowful road upon which it moves.

Let us mutually work together to restore order, dignity, and honour in all that relates to our nation and to our life. Let us make a holocaust if possible of all that is most precious to us, in order to make sure, when God wills, the happiness of this land for its children. Let us cast away from us the impure rubbish which surrounds us. May our acts of morality shine with splendour from our period of life and power. In fact, Doctor, I am resolved that when History analyses my deeds, it will be said without circumlocution or illusion, that notwithstanding my immense sum of power I was a Goop man and that I worked tenaciously to gain such a name. In the name, then, of these sentiments, springing from the bottom of my heart, I beg of you, my friend, to be good, as I intend to be.

Observe, Doctor, that all delay in excusing the evil which to-day affects the country will only diminish our honour and affect above all the moral and material honour with which God and man have invested us.

You are, I judge, an honourable man, and, with a wellfounded reputation as a great reasoner, I am confident that you will stand by me to make great the Nation which we have formed, so I infer that you will not wish that I alone, with my weak soldiers, shall take up the labour alone. But, if it be necessary that the step shall be taken by my deficient force, I shall do so without hesitation, or die in the attempt.

So, then, Companion and Friend, let us work together, let us clear the way of all obstruction and confide in God and 
in this people, who, with reason, show themselves cold; with our firm propositions of grandeur and prosperity let us offer them our help.

In virtue of the above I reiterate to you, that which I said at night, viva voce, and that which I said in the conference we had to-day.

In order that you may better meditate upon it I have written these lines, a genuine exposition of my way of thinking, so that if the necessity which they set forth arises, you can judge me impartially.

I possess copious testimony which I do not care to publish, of what has been plotted against me during my absence; but as it concerns me, only, personally, I cross my arms and let them do what they wish, when they wish.

To-day it is different; the future of our country is involved and $I$ cannot see, with indifference, its ruin without raising a preventing hand. Thercfore $I$ recommend and I demand the removal of Don Tomas Arias and Don Nicolas Victoria $J$., who by their methods are affecting the country's interests; lessening your authority and mine, and accumulating the hate of the people upon us, with grave detriment to our National and personal dignity.

By right, by reason, and in justice, all cannot be sacrificed to a part. Let it be, then, that the guidance of the Ship of State be intrusted to those who will direct its course along a true course of light, of progress, and of civilisation; indispensable factors to a safe arrival at the Port of Safety.

From to-day forward, all my forces and abilities shall be devoted to this end.

In the name, then, of the friendship which unites us, of the Morals and the Future of this country, it is demanded, Doctor, that the reorganisation of existing conditions shall be undertaken.

Where can there be happiness for us if the country is not happy?

I have a soul, Doctor, which knows how to feel, and therefore I preoccupy myself with the conditions of others.

It is not enough for me to live well, knowing that those whom we have liberated are longing for the benefits not accorded them.

The ambition of my soul will be fulfilled if only, with your consent, there is brought into existence a relative happy selection of your Associates, and this is not possible, while 
certain posts are occupied by individuals of the moral complexion of Arias and Victoria.

My heart embraces you because I want you.

Your affectionate friend and companion,

E. Huertas."

Nothing could have been more insubordinate than the sentence, "I demand the removal of Don Tomas Arias and Don Nicolas Victoria J." The significance of this demand was made clear by the additional intimation that if the President did not comply with it General Huertas would undertake the enforcement of it with his army: "I infer that you will not wish that I, with my weak soldiers, shall take up the labour alone. But, if it be necessary that the step shall be taken by my deficient force, I shall do so without hesitation, or die in the attempt." That was a plain threat of insurrection. President Amador made known the contents of this letter to his colleagues, whereupon the two Ministers named, desiring to free him from all embarrassment, offered their resignations. In addition, the President conferred promptly with Joseph Lee, the Secretary of the American Legation and Chargé d'Affaires in the absence of the Minister.

Mr. Lee, with admirable discretion, reminded him of his proper authority as President, and pointed out that it would be deplorable-indeed, disastrous to the good name of Panama-to have the approaching first anniversary of the Republic, on November 3, marred with a revolution, marking the lapse of the young Republic into the evil conditions from which it had freed itself and from which the world hoped it would remain free. President Amador thereupon bent his energies toward keeping the peace until the national festival should have been celebrated, and two days later two of the foremost Liberal leaders-one of them was Belisario Porras - called upon Mr. Lee with the assurance that there would be no disturbance or untoward demonstration during the celebrations of November 3 ; adding, however, that President Amador would be expected to accept the resignations 


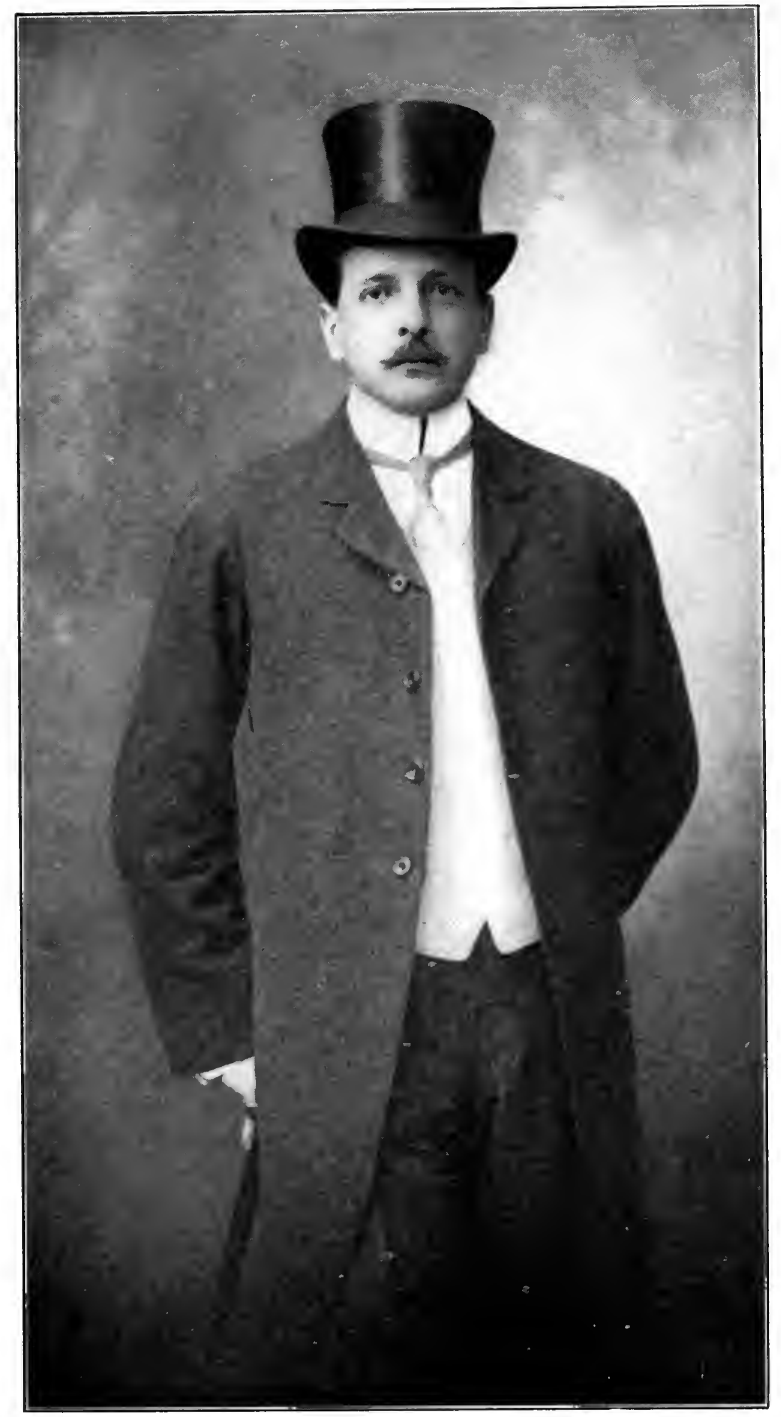

Scherer, Photo.

JOSEPH LEE,

Secretary of American Legation. Panama, in 1904-5. 
.

\section{1}

. 
of the two Ministers as soon as the anniversary was past.

The American Chargé d'Affaires received this information discreetly, but plainly perceived that their real purpose in visiting him was to ascertain if possible, without asking him directly, what would be the attitude and action of the United States in case of a forcible attempt at revolution. $\mathrm{He}$, therefore, took occasion in the course of the ensuing conversation to point out very clearly the bearing of Article 136 of the Panaman Constitution upon the matter. That article provides that "the government of the United States of America can intervene in any part of the Republic of Panama for the purpose of establishing the public peace and constitutional order in event of the same having been disturbed." It was also brought to mind that Article 7 of the American treaty with Panama declares that "in case the government of Panama is unable or fails in its duty to enforce compliance by the cities of Panama and Colon with the sanitary ordinances of the United States, the Republic of Panama grants to the United States the right and authority to enforce the same. The same right and authority are granted to the United States for the maintenance of public order in the cities of Panama and Colon and the territories and harbours adjacent thereto, in case the Republic of Panama should not be, in the judgment of the United States, able to maintain such order." This reminder produced a profound impression upon the Panaman Liberal leaders, and doubtless had much to do toward determining the subsequent progress of affairs.

That was on October 31. The next day Santiago de la Guardia was named as the successor of Señor Arias as Foreign Minister. Señor Guardia was at that time in Costa Rica, where he was Panaman Minister. Although a nátive of Panama, he had spent most of his life in Costa Rica, and had at one time been a member of the Cabinet of that country. In Panaman politics he was a Conservative, and his high character, great ability, and wide experience added 
materially to the strength of the Panaman Government. Two days later the festival of Panaman independence began, and lasted four days. The whole city was given up to rejoicings and merrymaking, and the utmost good-feeling seemed to prevail on all hands. On November 3 there was a solemn Te Deum in the great cathedral, attended by President Amador and his Cabinet, the diplomatic and consular corps, the Governor of the Canal Zone, and the commanderin-chief of the army, General Huertas, and his staff. On that day also General Huertas issued "to the Isthmian army and people" a most flamboyant proclamation, in the form of an "Order of the Day," which is worthy of reproduction in full, as a sequel to the letter to President Amador, already quoted. The italics are mine:

\section{"Official Order:}

by General Esteban Huertas, Commander-in-Chief of the Army of the Republic of Panama to the Isthmian Army and people on the Great Day of the Fatherland;

\section{Compatriots :}

To-day is the first Anniversary of our glorious Emancipation! The Fatherland figures with refulgent brightness on the Roll of free and civilised Nations. The ominous yoke, which oppressed our rights with its heavy weight, was cast off in a second by the sovereign grandeur of the Isthmian people, impelled to proclaim their liberty!

The Isthmian Ship of State, well-nigh wrecked in a bitter sea of trouble, required the hand of an expert Pilot in order that she should not be swallowed up in the frightful waves eager to devour her!

Where was such a one to be found?

Bolivar exists no more; no more does Washington live. The memories of these men of genius is implanted in the hearts of their fellow citizens. The Ship of State then seemed bound to certain disaster and with her ruin would go our last hope of salvation. But God was with us and those who are true to Him enjoy His infinite Mercy!

Behold the key of all great success !

The tablet of Fame is inscribed with all the most notable deeds of History, but it is not enough to be wise nor to be 
powerful, it is always necessary to count upon the protection of God.

And it was the protection of God which spread snowy wings over the Isthmus and gave it life and being and the greatness which clothes it to-day, and the just praises which are heard in its honour.

All this without lamentable sacrifice and cruel disgraces ! The high designs of Providence are inscrutable. The mathematical precision with which they are fulfilled, as well as the greatness of their accomplishment, are the unquestionable signs of $\mathrm{His}$ omnipotence, either to reward us or to punish us according to our merits or faults.

Hence the admirable portents which cause admiration and are the foundation of mundane results.

Hence it was, that I, a weeak bit of chaff in the desert of life, possessed, at the moment of our emancipation, the efficiency indispensable to the solution of the great problem so necessary to the Isthmian Family!

Completely in ignorance of the high mission which I should have to fulfil, I occupied myself solely with the discharge of my duties, which has been, from my tenderest infancy, the unique ambition of my whole life. Indefatigable in the fulfilment of my obligations, I devoted myself to them alone; all else that went on around me appeared to me to be foreign and apart.

So, step by step, confident ever of the goodness of the Supreme Being, I have risen in the glorious career of Arms, by a rigorous path, until my career is crowned with the grade of General after so many fatigues and setbacks.

What merits I possessed in the eyes of God in order to be chosen to bring about the wished for fruition and to be the instrument of the Most High to redeem a people, I cannot and do not want to know.

It is enough for me to know that the mission fulfilled by me was in obedience to the Divine Impulse of the Omnipotent Will.

But if neither my right nor my illustriousness is enough to explain to me the portentous result achieved by me and the Army with the decisive consent of the Isthmian people, however, I succeeded in comprehending the high moral and material responsibility which has fallen to my lot, so as to know how to preserve that which the Maker has given to us, and to that end were directed all my forces, in the hope that those who collaborated in the beginning would know how to 
sacrifice themselves upon the altars of the most exalted Patriotism in order that our beloved Country should never run the risk of being involved in the indignity of bastard ambitions nor vile and ruinous methods.

And as the formation of our Republic owes itself to the concord and amity between the people and the Army, forgetting misunderstandings and resentments, which to-day seem to have disappeared, I exhort Als on the solemn day of the first Anniversary of our Republican existence, that everything may be in harmony with this great day, and let us all rejoice together in the celebration of this glorious event.

Let us not forget that we have worked together and have crowned our efforts with success, and that we should still work together to the end that no parties may be established in the Isthmian Family to the detriment of some and the benefit of others.

May it be, however, for the present generation, entirely sacred how much and how firmly is established the love of country, and united together let us raise our voices in Unison in the magnificent cry of:

Viva the Republic of Panama,

Viva the 3d of November, 1903.

Viva Isthmian Brotherhood,

Viva the Army and the valiant Isthmian people!

The Commander-in-Chief, Esteban Huertas."

Such expressions might more easily be pardoned on the ground of temperament, were it not that they indicated an exaggerated estimate of the importance of the military power and an inclination to make it paramount to the civil authority. Precisely that mistake was made a few years ago in France, in connection with the Dreyfus case, when army officers of undoubted patriotism were inclined to exalt the army above the state. Such a misconception would, of course, have been all the more dangerous in Panama, because of the inclination of South and Central American states toward military despotisms. Granted, for sake of argument, that a change of Ministry was desirable, it would have been deplorable to have it effected by means of military pressure. 
It was, moreover, an obvious impropriety, if nothing more, for the commanding general to address an order of the day not merely to the army but to the whole nation, as if he were dictator and superior to the civil government.

Happily, thanks to President Amador's tactful disposition and to Mr. Lee's judicious warning that a revolution would not be countenanced by the United States, trouble was averted at that time. Nearly all the army remained within the barracks during the four days' fiesta, and the peace of Panama remained unbroken. A few days later came the news of President Roosevelt's reëlection in the United States, which caused general rejoicing in Panama, and which also strengthened the hands of the Isthmian Government by assuring it of a continuance of the policy which Mr. Lee had indicated through his reasonable interpretation of the Panaman Constitution and the canal treaty. The announcement that Secretary Taft was about to visit the Isthmus also had a salutary effect.

But the roused spirit of military revolution would not down. The fiesta closed on November 6 with the promise of peace unbroken. Just a week later, however, General Huertas addressed another letter to President Amador, more amazing in terms than that which I have already quoted. He was not satisfied with the appointment of Señor Guardia, a Conservative, to succeed Señor Arias. Still more was he displeased that Señor Victoria's resignation had not been accepted. In this second letter he literally railed against Señor Victoria, whom he denounced as "a stranger to all dignity and honour; a stranger to gratefulness and decency . . Señor Victoria is a fraud. Hypocrisy and perfidy can be clearly seen in his jaundiced features." Astounding language, surely, to be addressed by the commanding general of the army to the President of the Republic concerning a member of the latter's Cabinet! We need not wonder that a few hours after its utterance there was disclosed a plot, led by General Huertas, forcibly to seize President Amador and Secretary Guardia when they should attend the military 
review in honour of Señor Guardia early the next morning; at which review, by the way, General Huertas in his letter peremptorily demanded President Amador should be present. Naturally, President Amador turned again to the American Chargé d'Affaires for counsel. At midnight $\mathrm{Mr}$. Lee was visited by the Alcalde of Panama and Raoul A. Amador, son of the President, who told him of the plot organised by General Huertas and Belisario Porras. Mr. Lee advised that President Amador should ignore the summons of General Huertas, and should not attend the review. This counsel was accepted and acted upon, though with some misgivings lest General Huertas should send and seize the President by force. At five o'clock in the morning Mr. Lee was again approached by the President's private secretary, with a request that he would summon a force of United States marines from the camp at Empire. This request $\mathrm{Mr}$. Lee refused, but he sent a very plain warning to General Huertas, or his partisans, that the United States was ready to enforce Article 136 of the Constitution and Article 7 of the treaty, and that it was high time for all revolutionary tactics to cease. So the review of the troops that morning passed off quietly, Secretary Guardia attending it alone and without molestation, and that day the American warships New York, Boston, and Bennington, commanded by RearAdmiral Goodrich, arrived in the Bay of Panama, an incident of salutary moral effect.

Two days later the American Minister, John Barrett, arrived in Panama, and learned what had happened and was happening. He at once went to the Government House to pay his respects to President Amador, and naturally the existing crisis in Panaman affairs formed the topic of some conversation. It was evident to both Dr. Amador and Mr. Barrett that if the Panaman Government was to be maintained and was to vindicate its authority, General Huertas must be got rid of by resignation or retirement, and it seemed advisable that the army, or the bulk of it, should also be disposed of. In the end, President Amador and his Cab- 


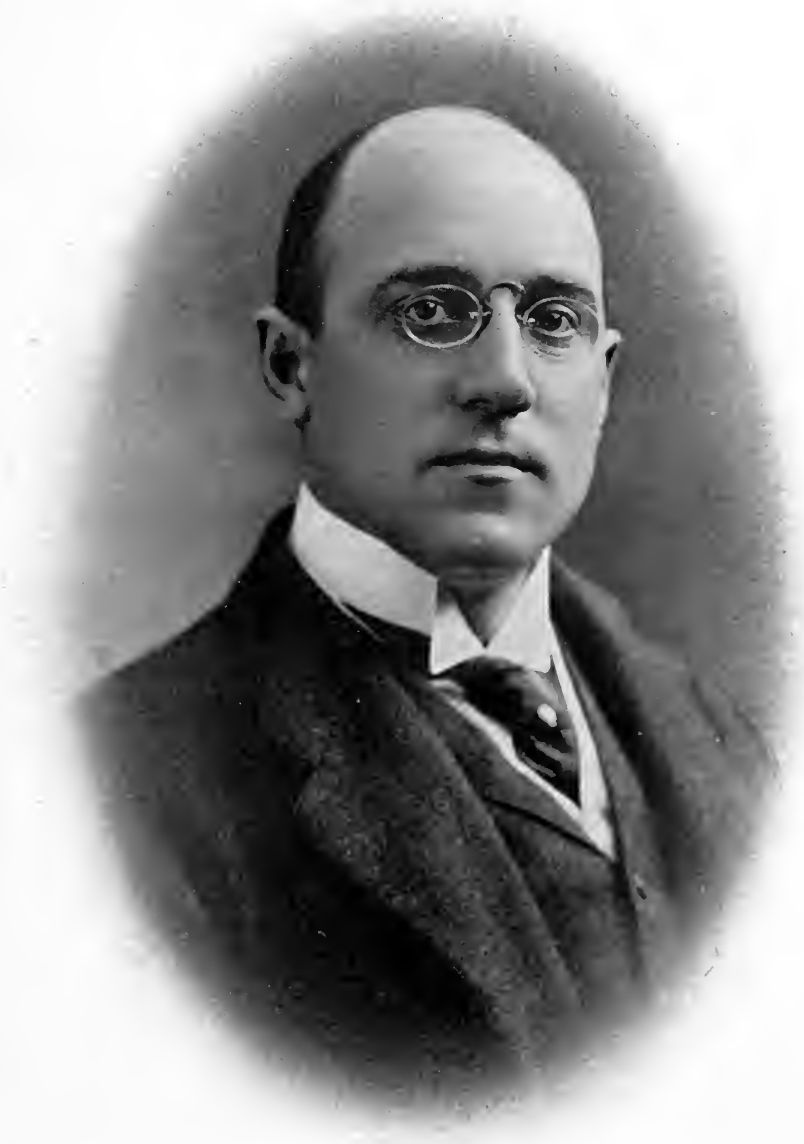

Chandler, Photo.

JOHN BARRETT,

American Minister to Panama in 1904-5. 

inet decided to require the resignation of General Huertas and the disbandment and abolition of the army, excepting a handful of officers and men just sufficient to meet the statutory requirements of a standing army. The army consisted of only 250 men, anyway; just enough to cause trouble but not enough to do any real good. It was felt that the police force and the American marines at Empire would be sufficient for the maintenance of order and the protection of the Republic. An earnest request was also made that at least one of the American warships should remain in the harbour until the crisis was past.

Accordingly, the next day, November 17, President Amador called for General Huertas's resignation, warning him that if he refused to give it or resisted the civil authority, the American marines would support the government. In this course President Amador was encouraged by Mr. Barrett and Rear-Admiral Goodrich, who called upon him and assured him that at least one American ship would stay there as long as he considered it desirable, and that the marines from Empire would be ready for service if needed. Under Rear-Admiral Goodrich's order, Major Le Jeune brought one company of marines down from Empire to Ancon Hill, just outside the city of Panama.

That afternoon General Huertas called upon the President, protested against the demand for his resignation and the impending disbandment of the army, "my poor soldiers," but promised to obey the mandate. A further hint from Mr. Barrett to General Huertas, through the medium of a mutual friend, Señor Obarrio, that the American Government hoped no indiscretion would be committed, but that the Constitution of Panama would be respected, doubtless went far toward assuring the fulfilment of this promise. That night some of his friends tried to persuade General Huertas not to resign, but to fight the matter out, but the general's own better judgment prevailed. He had been too deeply impressed by the hint conveyed from Mr. Barrett by Señor Obarrio. The next day he resigned, in a long letter addressed 
to President Amador. This letter was entitled "Irrevocable Resignation," and was written in the flamboyant style of his former utterances. After denouncing the government's action as dictated by "foreign and interested designs," and declaring his own ability and natural inclination to oppose it with force, he said he would abstain from such procedure, and would bow to the government's will, for two reasons:

"First, because as I have not learned to be dazed by exaltation, preserving at all times my inherent modesty or humility; neither do I, in misfortune, desire to sound the discordant or comic note which will dash to pieces in a moment all that honest endeavour on my part has created; and second, my goodness of heart forbids me to sacrifice the lives of my poor soldiers, true republican soldiers, after by their efforts, and those of this noble people, we obtained our independence; for they suffer fully enough, and will continue to suffer in the destitution in which they will be left, notwithstanding that the allowance of one additional month's salary will alleviate their necessities for a few days.

"It, therefore, being impossible, from what I have stated, that myself, my chiefs, officers, and soldiers should remain at the front of a Government whose want of confidence in us is notoriously visible, I present to you in my own name, and in that of the entire army, the irrevocable resignation of our positions, in the certainty that not a single member desires to tarnish his glorious career as a warrior by accepting the same position that through and for them, and for companionship, their commander-in-chief resigns, considering himself offended.

"I swear before God and to History, that all my actions have been governed by patriotism, that my love for this soil, and respect for the legitimate government, have always been sincere; and that this step has been caused by this same patriotism, which no one nor anything can belittle."

The resignation, thus tendered in terms at once amazing and amusing, was accepted and publicly announced in a government decree, and General Huertas was placed upon the retired list of the army, on a salary, or pension, of five hundred dollars a month. At the same time President Amador wrote him a cordial personal letter, saying: 
"I was informed by a friend that on resigning the position of commander-in-chief your only wish was that your honour should remain unharmed. I have not entertained any intentions to the contrary, and as a proof of this, you can see that the decree accepting your resignation could not be more honorary. This letter is further testimony of what you desire; but you must comprehend that, notwithstanding the affection which I have for you, of which I have given and shall give you proofs, your retirement is indispensable so that my Government may exist with all the independence that the Constitution and the Law concede it, and that it cannot be subject to the control of the military hierarchy, no matter how much I may esteem and like you personally."

The decree granting him a salary, in retirement, of $\$ 500$ a month, provoked from General Huertas another characteristic outburst, in the guise of a very formal letter to the new Secretary of War, in which he scornfully declined the pension, and insisted that his resignation involved also the resignation of the entire army ; adding a threat of a violent demonstration if it was not thus accepted. He wrote:

"Deeply grateful for the liberality of His Excellency the President of the Republic and for the great honour done to me by assigning a salary of five hundred dollars monthly as a recompense for the services lent by me to the cause of independence, I beg to decline such distinguished honour, not accepting same, as the enormous weight which would rest on my dignity would be an indelible stigma. My profound patriotism, and my love for this country, contributed to the glorious event of the Third of November, 1903. I cannot accept a salary which I do not earn; my honour scorns it. When I earned it, I had a right to it; to-day when I do not, I have not.

"In conclusion, I beg to state to His Excellency, the President of the Republic, through the worthy conduct of Your Excellency, that my resignation is solidary with that of the Arny, which fact should have been taken into consideration, not supposing that I take upon myself unwarranted faculties; because in this case, and as a proof of my assertion, if it be desired, I shall go in conjunction with my army to solicit same, with the object of leaving no doubt." 
The Secretary of War, Señor Guardia, fortunately was quite competent to deal with so extraordinary a communication. He was now commander-in-chief of the army, having been made so by the same decree which accepted General Huertas's resignation. He accordingly wrote to General Huertas on that same day, November 18, as follows:

"The Government, at present, does not intend to disband the army. The chiefs and officers that may not be satisfied with the new state of affairs may retire through the channels indicated by the law, but under no circumstances by insubordination, nor by conjointly making any demonstrations, and much less under your orders, as you are no longer their commanding officer.

"The troops have no voice in their resignation, and you should be aware of this better than anybody else, since you are a veteran military man and a man of honour.

"With regard to your salary, you have wrongly interpreted an act of justice and magnanimity on the part of the Government. The decree continues in force in all its parts."

To this the retired commander made no reply. He quietly accepted the salary which he had declined, and retired to his hacienda at Agua Dulce, on the western part of the Pacific coast of the republic, remote from the capital, there ostensibly to devote his attention entirely to cattle-raising. There were those, however, who doubted that he would permanently refrain from further revolutionary efforts, and some who even questioned whether he had ever really left the city of Panama. In fact he did go to Agua Dulce, but there is reason to suspect that he kept in close touch with some dissatisfied politicians at the capital. In the following spring, of 1905, there were threats of a mutiny among the Panama police, which happily came to nothing. General Huertas was believed to be responsible for the attempt at revolution, however, and it was doubtless on that account that the Panaman Secretary of War made a visit to Agua Dulce at that time. On that occasion the United States marines were moved from their usual camp at Empire down to Ancon, just outside the city of Panama, and a guard for 
the Canal Commission's offices was taken into the city; with most salutary effect.

To return, however, to the incidents of November, 1904. There was the army to be disposed of. General Huertas had written to the President that the soldiers were unwilling to serve after his retirement, and Dr. Amador naturally welcomed the statement as suggesting a good opportunity for getting rid of the army. He, therefore, announced that the army would be disbanded, the soldiers receiving sixty days' pay as a bonus. This would be paid to them-I think on Mr. Barrett's very judicious suggestion-one half down upon disbandment and the remainder at the end of a week. This was to insure their good behaviour, and, with the same end in view, it was ordered that all barrooms be closed for the three days after their disbandment. To fulfil this plan the army was ordered to assemble at the Government House, at one o'clock on Saturday afternoon, November 19, to be mustered out and paid off. Now, one o'clock is the hour of the siesta, when even revolutionists must rest! So at that time not a soldier appeared. Two o'clock came, and not one arrived. President Amador was uneasy, fearing the army had decided to resist his order, but after a conference with Mr. Barrett he determined to wait a little longer. (Imagine a "hustling" Yankee advising a Panaman to wait!) At 2.30 o'clock, just as Señor Guardia and Mr. Lee were on the point of going to the barracks to see what the delay was about, fifty soldiers came to the scratch, followed by a great mass of the populace. They had left their weapons at the barracks, but they sent in word to the President that they wanted their whole sixty days' pay in a lump, at once. President Amador, conferring with the American Minister, refused their demand. It is probable that, mindful of the slipshod methods of the old Colombian Government, they doubted whether they would ever get the deferred half of the bonus if they agreed to the postponement, and held with the Texas philosopher that "a bird in the hand is the noblest work of God." 
The deadlock was ended, however, when Mr. Barrett, accompanied by Secretary Guardia as his interpreter, went down to the sidewalk, addressed the soldiers, assured them that they would be fully paid, and warned them that the American Government would fully sustain President Amador, and that if they were insubordinate they would be dealt with sternly by the American marines. Upon this the soldiers promptly agreed to the government's terms. Within two hours the entire army presented itself at the Government House, received thirty days' pay and was disbanded, all excepting three men and twenty officers, who were entirely loyal to the civil government, and who were retained as a nominal force to meet the technical requirements of the Constitution. That night there were some slight popular demonstrations of sympathy with the soldiers, but these amounted to little. A week later the second thirty days' pay was given to the soldiers in full, as promised, and thus the episode was ended.

There were other details of the affair, more picturesque than important. The gist of it was this: That it was a struggle to determine whether changes of administration should be effected only by peaceful and constitutional means or by military force; that it was decided in favour of the former, very largely through and because of the benevolent offices of the United States, exercised or at least offered in strict accordance with the Panaman Constitution and the Panaman-American treaty; and that it was thus decided not only for the time being but, as there is ground for belief, for a long time, if not for all time. It may be that some features of the case will cause amusement-the small size of the Panaman army as it was, and the practical absence of any army at all at the present time. It will not be well, however, to scoff at our sister republic on such grounds. There are sovereign states in Europe which are smaller than Panama and as destitute of military force; yet their independence is respected, and any attempt to override it might provoke a Continental war. Neither is the attitude of the United 
States, as a practical protector of Panama, to be unfavourably criticised. There is more than one "guaranteed" state in Europe. Moreover, such guarantees in Europe are largely for selfish purposes and for the maintenance of a "balance of power," while ours over Panama is made with the disinterested design of maintaining peace and order and of facilitating the commerce of the world. If, in the episode I have described, the United States exercised a strong, perhaps a paramount, influence in the affairs of another sovereign state, at least it did so with the fullest regard for the liberties and the susceptibilities of the people of that country, and for the rights and interests of all nations. 


\section{CHAPTER XIV}

\section{A MISSION OF READJUSTMENT}

Close upon the heels of General Huertas's vain attempt at revolution came another important episode. This was the visit of the Secretary of War of the United States, William H. Taft, to Panama, upon what may be called a mission of readjustment. Dissatisfaction had arisen in Panama, not with the Hay-Bunau-Varilla Treaty but with some features of the American construction and application of it, especially concerning the tariff and the postal service. For such dissatisfaction there was ample ground. In response to an unthinking demand in the United States, the full tariff rates of the United States were by executive order (see Appendix VIII.) on June 24, 1904, applied to the Canal Zone, not only against all foreign countries but also against Panama itself, and two collection districts were established. A Canal Zone port was also established at Ancon, adjoining the city of Panama. This resulted in little or no gain to the United States, but in a great hardship to Panama, depriving it of an all but indispensable market and also of a large part of its import trade. Again, the domestic postal rate of two cents was established between the Canal Zone and the United States, and nine United States post offices were opened in the Zone, while the old five-cent rate was maintained between Panama and the United States. The result was that the business men of Panama carried all their mail over into the Zone and deposited it in the American post office there, thus depriving the Panama post office of the bulk of its business. In doing this they not only got the sixty per cent. lower rates of postage, but also got far more trustworthy service. For the Panama post office had not yet been redeemed from the old Colombian methods, under which it 
was necessary to mail a letter two or three days in advance to make sure of its being despatched by a certain steamer, and even then there was no assurance that the postmaster would not tear off the stamp, to resell to some one else, and throw the letter into the waste-paper basket. It used to be notorious that there was no use in inquiring for letters at a post office if you found the postmaster sitting down, for he would not get up to see if there were any for you, but would declare there were none, and remain seated!

In order to adjust these and some other minor matters, which had been for some time the subject of diplomatic correspondence (see Appendix IX), President Roosevelt decided to send Secretary Taft to Panama, as his personal representative. This mission set out from the ancient port of Pensacola, Florida, on November 22, 1904, for Colon. It was conveyed in impressive state by the two cruisers Columbia and Dolphin, of the United States Navy, and its members and their companions included Secretary Taft and Mrs. Taft; Rear-Admiral Walker, U. S. N., the chairman of the Canal Commission; Charles E. Magoon, the legal adviser of the Commission; William Nelson Cromwell, the legal adviser of the old Canal Company and railroad company, and of the Panama Government; and Domingo de Obaldia, the Panaman Minister to the United States.

Pensacola was an appropriate starting point for the mission. It would have been such had the errand been one of war, of aggresion, of militant expansion. Above all places in the United States that quaint old Spanish city, the very names of its streets still echoing the voices of Leon and Castile, is reminiscent of the strenuous forward movement of the American nation. It was there that an American army first invaded alien soil. From the Perdido to the Escambia is a short distance, but in marching it, ninety-odd years ago, a distinguished Democratic expansionist set for all time a most important precedent. In maintaining "the immutable principle of self-defence"-the self-defence of the republicJackson marched an American army for warlike purposes 
into the territory of a foreign Power with which America was at peace. Approved at the time by the "fathers of the Constitution," and confirmed by the experience and practice of four score and ten succeeding years, that epoch-marking precedent returns vividly to mind to-day, as the sanctioning authority of more than one subsequent act which the forgetful have in late years all too heedlessly challenged.

Not now, however, was it necessary to follow that precedent, with force and arms. Though led by the Secretary of War, and transported in ships of war, this errand to and from Pensacola was one of peace. It was, no less than Jackson's, meant for the self-defence of the Republic; but it sought that end by means of conciliation and good will. It was to maintain "the immutable principle of self-defence," not only against foreign intrigues and whatever might to any extent menace the achievement of the great work of "an American canal under American control," but also against the insidious peril of misunderstandings between the United States and a sister republic, and against the possibility of reproach for having dealt ungenerously with a weaker and halfdependent nation. Nor was the port of departure less fitting in that view of the case. Peace and good will mean social and commercial intercourse; and the superb harbour of Pensacola may well become the great gateway of the Eastern Gulf and South Atlantic States opening upon the Gulf and Caribbean Sea, and leading to that world's gateway of commerce and travel at Panama. It was auspicious and appropriate, too, that the departure of the mission should have been effected under a sunny sky and upon a smooth sea, and that similar conditions, to an extent seldom experienced in these capricious regions, should have accompanied it all the way. The "stormy Caribbean" was, to the Columbia and the Dolphin, as calm and placid as the devotions of a universal peace congress.

The reception of Secretary Taft and his party at Panama by the Panaman Government and people was unmistakably marked with cordiality and friendly expectation. There 
seemed to be none of the extravagant illusion which had been cherished; or which the Panamans had been reported to cherish. The Panamans were not looking for any radical reversal of American policy. Indeed, some things had recently happened which were well calculated to dispel such visions, if they had ever been cherished. General Huertas had made, only a short time before, his fatuous attempt at what would have been a revolution, and had been effectively suppressed through the good offices of the United States; and that episode had given much food for thought for all thoughtful men in Panama. More than anything else, since the revolution of a year before, it revealed with convincing emphasis the purpose of the United States to stand firm for both its rights and its duties under the existing treaty, to respect and to maintain the independence of the Isthmian republic, but equally to maintain, whenever necessary, the constitutional order of that country. The conduct of the United States in that crisis had, on the one hand, reassured the Panaman Government and had inspired it with feelings of confidence and gratitude, and had, on the other hand, given a stern but salutary and effective lesson of warning to whatever discordant and revolutionary elements there might be in the community. From such point of view we might almost say it was a good thing that the abortive conspiracy had occurred. There can be no doubt that because of it and its firm suppression the fulfilment of Secretary Taft's mission was materially facilitated through the formation in the minds of the Panamans of a more just and accurate appreciation of the United States and of its relations to Isthmian affairs.

Secretary Taft did not delay to sound what we may call the dual keynote of his mission: to wit, that justice should be done to Panama, and that, in return, justice, order, and stability would be required of Panama. It was at noon of Sunday, November 27, that he reached the city of Panama, and an hour or two later he was received by President Amador at the Government House. In his address to the Presi- 
dent, the Secretary congratulated him and the Republic of Panama upon the auspicious beginning of a long and prosperous life, and-most significantly-upon the fact that "this life is to be a peaceable life, to be a life of government that shall know no changes, except those according to the rules of law and the Constitution." There should have been no uncertainty or mistake as to the purport of those words. There was none. They were received in the spirit in which they were uttered, and no less graciously and gratefully than was the further declaration of the speaker, that the United States "has no intention, in being on this Isthmus, to do other than to build a canal, and no desire to exercise any power except that which it deems necessary under the treaty to insure the building, maintenance, and protection of the canal." That brief but pregnant speech was applauded with equal vigor and sincerity by Americans and Panamans, and was a happy prelude to the diplomatic negotiations which began the next day and which were continued until the end of the week.

The conferences were held in private, as was fitting. Townmeeting diplomacy is never admirable. Least of all would it have been well to attempt it between two nations-such as these-of widely different temperaments. Each of them was proud and sensitive in its own peculiar way, and when, as in this case, the susceptibilities of each were directly and deeply involved, it was essential that the negotiations should not, during their progress, be the theme of common knowledge and of more or less passionate popular discussion. The public was ignorant of what was going on, lacking even those newspaper surmises and rumours which would have been an inevitable accompaniment of such conferences in the United States. There was also a marked absence of popular speculation upon the result. That was not, however, because of any lack of interest, but rather because of a serene confidence in the wisdom and justice of the conferrees and an assurance that in the end a satisfactory arrangement would be reached. As day after day passed without 
announcement of such a conclusion there was no anxiety nor impatience manifested. Panamans are not given to worrying or hurrying. The end might come on the morrow, or not until the next week. What did that matter? It was sure to come and to be good when it did come.

The first certain intimation that it was near at hand came from Secretary Taft himself. It was made in his speech at a great banquet given to him and his party by the Panaman Government at the Grand Central Hotel, on Thursday evening, December 1-a banquet, by the way, which, in its appointments and general conduct, was highly enjoyable, and would have been creditable to a city of greater size and more opulent resources than Panama. There was much applause when, at the very beginning of his speech, he said that justice had not been done to the people and to the country of Panama, and again when he referred directly to the negotiations as having led to a point at which there was every reason to expect a solution of all difficulties which would be honourable to both countries alike. There was no hint of any retrocession, or even of consideration of retrocession, from the existing treaty. But the Panamans greeted his declaration with applause which bore no resemblance to mere perfunctoriness. Nor was that all. Again the Secretary referred, in even stronger terms than before, to the imperative necessity of ordered and stable government and to cessation from revolutionary movements. "Stability of government," he said, "is absolutely impossible unless there is implanted in the breasts of all your people who take part in the government as voters a profound respect for the laws and constitution which you yourselves have founded." At that there was again applause. The Secretary continued:

"You must have a government in which the minority shall enjoy equal rights with the majority. A government in which the minority, upon the election by the majority, retires from the borders of the country in exile, only to await the result of the next successful revolution, is not a government at all. It is a tyranny. You can have a despotism as 
complete by a majority of the people as by one man, and unless you respect the rights of each individual in your community you will have no government worth the supporting."

That was plain talk. I do no injustice to Panama when I say-in view of the experience of neighbouring South and Central American states, and in view of the then recent incident in Panama itself-that it was salutary talk. Best of all, it was not unwelcome talk, but it was applauded and cheered three times in the last four sentences which $I$ have quoted, with as much spontaneity and manifest earnestness of approval as were shown for the vehement and torrential eloquence of the First Designate, Pablo Arosemena, which preceded it, or to the rhetorical periods of Belisario Porras, the opposition leader, which followed it. Additional and very practical emphasis was given to this same point by William Nelson Cromwell-of all men persona gratissima in Panama-when in his tactful speech at the same banquet he referred to the perfect security which New York afforded to the $\$ 6,000,000$ which Panama had invested there, and then demanded that in return Panama should give equal security to the $\$ 300,000,000$ which the United States proposed to invest in the Isthmian canal.

It will be worth while to recall, as a matter of record and as an indication of the spirit of the Panamans, a part of the speech of Dr. Arosemena, already referred to; bearing in mind that while he was First Designate of the Republic he was also one of the foremost leaders of the Liberal party, in opposition to the government of President Amador. $\mathrm{He}$ said :

"In the speech delivered by our distinguished guest when he was received by the President of the Republic in solemn audience, he stated that our National Life had to be pacific; the life of a government in which only the anticipated changes in the Constitution will occur; he affirmed that in said existence we should have the aid of the United States and that the Government of those States only desired to construct an interoceanic canal for the benefit of the uni- 
verse; that it would only exercise on the Isthmus the authority necessary to carry the work to an end, maintain, and protect it. In conclusion he manifested that he, within a short time, would hold conferences with the President regarding these affairs, and hoped to arrive at honourable and equitable conclusions. I think it superfluous to say that the declarations of the Secretary of War-frank and truehave given us consummate satisfaction. He is an ambassador who brings in the folds of his mantle conciliation with honour and equity.

"Referring to those declarations, I affirm, with the certainty of being the true echo of the Isthmian people, that in the Republic of Panama only those changes that are determined by the natural course of events shall occur. We have definitely closed the period of blood-so prolonged and so distressing-and opened the era of peace that requires the consolidation and prosperity of the Republic.

"We must justify the achievement of independence-so grave and transcendental-and that end can only be reached by basing peace on law, which is justice, and preserving order, which is liberty and civilisation. We will discuss, but let us not quarrel. The recourse to arms so costly and fruitless shall not be made by either party of the young nation which came into existence the Third of November of 1903. Instead of the weapon that kills, we shall employ the word that enlivens; instead of the sword, the press, the tribune, and suffrage. We shall render to reason the efforts that we have given to force, and we shall strive to win, not the victories of the bloody battle, but the triumphs of peace, legitimate and fruitful, that do not leave in our conscience the thorn of remorse.

"We have not, it is true, the means of being on the morrow rich and powerful; but we have of being sound and honest, and of meriting the respect and esteem of other peoples, practising without vacillations the policy of honesty, which is the best policy. That policy is condensed in these words: -in the interior, the Constitution; and in the exterior, religious respect for international agreements."

It was thus made known at this memorable banquet that the agreement was in sight and was practically assured, and that it was an honourable, just, and mutually satisfactory agreement. On Saturday evening, at the smaller dinner given to Secretary Taft at the American Legation, it was 
known that the agreement had actually been concluded and that an executive order putting it into effect had been issued. A delightful interlude occurred on Sunday, in the form of an excursion to the Pearl Islands, given by the Panaman Government to the American visitors and two or three hundred representative Panamans, upon which there was little talk of anything so serious as politics or diplomacy, though it became generally known that the business of the mission was, in Yankee parlance, "all over except the shouting."

We returned from the Pearl Islands on Sunday evening to find a newspaper "extra" had been printed for gratuitous distribution, giving the full text of the executive order. (See Appendix X.) And then on Monday night, December 5, came the shouting! By word of mouth and by placards posted all over the city the people of Panama were summoned to the Cathedral Plaza to pay a tribute of respect to Secretary Taft. They came. Estimates of their number vary. But they filled nearly all the space from the Canal Building, at the one end, to the Bishop's palace, at the other, and from the Grand Central Hotel, on the one side, to the Cathedral, on the other. The aristocracy and the rabble, rich and poor, white and black, Conservative and Liberal, were all there. Upon the decorated and illuminated balcony of the hotel were the President and other high officials of the Republic, Secretary Taft and his party, and various representative men and women of Panama. A brief introduction was given by the popular Alcalde, who had held office ten years and was a candidate for ten years more, and seemed likely to get them. Then Dr. Pablo Arosemena roused the enthusiasm of the throng with another of his passionate orations, in which the words flowed so swiftly that even the trained Panaman ear was taxed to catch them all.

Finally Secretary Taft arose, his stalwart figure dominating the whole scene and his resonant voice reaching to the farthest confines of the square. It was his last speech to the people of Panama, and his best. Particularly was it the most forcible of all upon the point to which I have most 
referred, the necessity for orderly, constitutional government in the new Republic. Speaking in the very place in which the revolutionary junta of thirteen months before had been organised, he began his address by congratulating the people upon the facts that that junta did not establish a dictatorship, but opened the way to a constitutional government, elected by the people, and that in electing that government the people chose not soldiers but civilians as its members. "In a republic, and in a peaceful republic," he said, "the army must always be the instrument of the civil power. . . and you have, therefore, indicated that you do not propose that this community shall be governed by the sword, but by reason and by law."

I know not whether that was meant to be, what to many it seemed, a bold reference to the Huertas episode. I have little doubt that many, if not all, of the Panamans regarded it as such, and there had been rumours earlier in the day that the friends of General Huertas meant to disturb the meeting with a hostile counter-demonstration. What I know is that not a hand nor a voice was raised in hostile demonstration, but the words I have quoted were acclaimed with a universal frenzy of enthusiasm, until the fronds of the towering palms and the gray façade of. the old Cathedral seemed to vibrate together with its tumultuous stress. There was a like outburst of applause at the straightforward and manly acknowledgment that a mistake had been madewhich had now been rectified-in the executive order applying the Dingley tariff to the Canal Zone against the rest of the territory of Panama, a mistake for which the speaker did not hesitate to assume responsibility. And, finally, for the third time, "the cheering rose with a mighty swell" to a supreme climax of enthusiasm when the Secretary ended his speech with the vibrant cry of "Viva la Republica de Panama!"

That was the end. The business was done, and even the shouting was over. If it be asked what had been accomplished, the answer is, much. The new agreement was not 
a treaty, nor a revision or modification of the Hay-BunauVarilla Treaty, which remained intact. It was an agreement relating to some details of interpretation of the treaty, chiefly concerning customs and postal service, put into effect by an executive order of the American Government. But there was something more important than even that executive order; that was, the impression produced upon the government and people of Panama and the sentiments and relations established between the two countries. I have said Secretary Taft and his party were received with cordiality and with confidence, and that is quite true. It is equally true that before he was commissioned to go thither there were widespread feelings of suspicion of American motives and purposes and a discontent with American relations. Those feelings were doubtless unfounded, or were founded upon misapprehension, misunderstanding, and misrepresentation; the last, I am afraid, too often wilful: Men in the United States, as well as in Panama, for factional, sordid, or other unworthy motives, had maligned the American Government and had represented it as seeking not merely to construct a canal but to plant a colony and to achieve a forcible conquest. Those tales were false, but how were the Panamans to be assured of the truth?

There was only one way, and it was wisely and opportunely adopted by President Roosevelt in sending Secretary Taft upon this mission of explanation and reassurance. The mere announcement of that appointment effected a marked change. The Panamans were quickly convinced that the policy of the United States was one of reason and justice, and not of arrogance and force. This conviction was strengthened by the attitude of the American authorities in the Huertas episode, for, while there were those who wildly declared that the retirement of General Huertas and the disbanding of the Panaman army would be quickly followed by American conquest and annexation, and that the American Government was intriguing to that end, most men of thought and discretion realised the absurdity of such 
views. They saw that if the United States were bent upon the conquest of Panama, General Huertas and his 250 soldiers would be scarcely so much as a straw in the way. More than that, however, they saw that the United States was aiming at the support, and not the suppression, of Panaman independence, and they presently testified, as did President Amador himself, that American intervention, or the promise of it, was not the spoliation but the strengthening, not the destruction but the salvation, of the young Republic.

There were, I remember, some reports extant in the United States that the news of President Roosevelt's reëlection had not produced a favourable impression in Panama. They were entirely untrue. The fact is that the news of the result of the election was received there-not only by Americans but by the Panamans-with enthusiastic and practically universal rejoicing. The American Legation was literally overwhelmed by the multitude who thronged thither to express in person their congratulations and their joy, while the city was given up to music, fireworks, parades, and speechmaking. This was the more significant, coming, as it did, upon the very heels of the Huertas incident. Panamans saw that the Roosevelt administration had saved their republic from revolution and was sending a distinguished mission to assure it of justice. Why should they not exult in the retention of that administration in power? Thus favourably disposed were the Panamans toward Secretary Taft upon his arrival. His every word and act during his stay confirmed them in that disposition. Finally, the terms of the executive order issued by him as the result of the conferences between him and President Amador vindicated their confdence and satisfied their expectations. Before he came and before that order was issued they did not know how the United States would execute the canal treaty. After that, they did know, and they were well pleased. It is not too much to say that 90 per cent. of the intelligent people of Panama were not only satisfied, but profoundly gratified with the result of Secretary Taft's mission. 
Thus the differences between the United States and Panama were settled. Will they remain settled? Prophecies are rash. We must remember the temptations and the opportunities of party politics. In the United States we have, in all ages of the Republic, seen men unworthily ready and eager to compromise oụr foreign relations for the sake of factional advantages in domestic affairs. We cannot expect Panamans to be better in that respect than we. The relations of the Isthmian republic with the United States afford an easy issue of factional dissension, and it is possible that they will be thus used. Time, however, is on our side, and on the side of the existing status. Every month that passes will reveal more clearly to the Panamans the hollowness of their fears and suspicions and the substantial reality of the benefits arising from their connections with the United States. It has been said of some communities that they did not care for and did not appreciate the sanitary and other improvements introduced by American administrators. That must not be said of Panama. The people realised their need of a water-supply, of a sewer system, of better paved and cleaner streets, and of the other works which American administrators have now performed or upon which they are now engaged. They wanted these things. They appreciate them, and their enjoyment of them will confirm their approval of and adherence to the compact under which they have been provided. If to these things we add the consideration and the sympathy which are the due of each nation to and from each other, if we keep it continually clear to the Panaman mind that we are building a canal and not a colony, a highway of commerce and not a wall of exclusion, it will not be difficult to maintain the relations of mutual confidence and mutual benefit which so happily were established. 


\section{CHAPTER XV}

\section{ISTHMIAN POLITICS}

Although auspiciously begun, the career of the Isthmian republic was not destined to be one of unmarred harmony. Within its first year there arose the two serious crises in its affairs which I have already described; one of them an attempt at military revolution and the other a controversy with the United States. There also came a deplorable rise or revival of partisanship and factional animosities in the Republic. At first these were held in abeyance, and were vainly supposed by some to have been extinguished. The stress of the revolution and the fervour of patriotic enthusiasm moved men to sink all party differences, and, as I have said, the composition of the government and the design of the flag indicated a union of hearts and minds. That era of harmony did not long endure, however; nor was it reasonably to be supposed it would. "Colum, non animum, mutant, qui trans mare currunt." How little do they change their minds, then, who do not even cross the sea and change their scene, but merely pull down one flag and raise another in its place! The people of Panama had for years been subject to the partisan passions which were so marked a feature of Colombian political life. It was simply impossible that they should be intellectually, morally, and spiritually transformed by the act of establishing their independence. A revolution could be effected in a day. Complete conversion of national character would be a matter of years or generations, if, indeed, it were ever effected. Nor should we, the proud, impute to them the fault. Note our own experience. Even in the throes of our Revolution, partisan rivalries and animosities were implacable, savage, and mischievous, and with the return of peace and the complete 
establishment of independence they rose and raged with a fury unsurpassed in the history of hatreds.

Special reasons for this were not lacking in Panama. There was, for one, the customary ambition of political leaders, and especially of those who at first had made the mistake of taking the wrong side. Let me mention a single example, perbaps the most conspicuous. Dr. Belisario Porras, of whom I have already spoken, was a native of the Isthmus, and a lawyer of ability and standing, who had long been ambitious of political distinction and had been identified with several revolutionary movements. In July, 1900, he was one of the three Liberals who, under General Herrera, led the revolutionary forces to Panama, besieged that city for a time, and inflicted heavy losses upon its defenders. Soon after that incident, however, the Liberal cause collapsed, and Dr. Porras thereafter spent much of his time out of the country. At the occurrence of the final revolution of 1903 he was in Central America, and though notified of what was going on, and strongly urged to return home and aid in the establishment of Panaman independence, he refused to do so. On the contrary, he opposed the revolution, and denounced the separation from Colombia as a violation of "sacred patriotism." He wrote a number of letters to the press to that effect, and especially showed distrust of and animosity against the United States. It is not improbable, indeed, that his opposition to the revolution was based, half upon the fact that the new republic was to enter into close relations with the United States, and half upon the prominence which Dr. Amador and other Conservatives had in the movement.

In time, however, Dr. Porras perceived that despite his opposition the revolution had been successfully effected. Thereupon he accepted the accomplished fact, returned to Panama, and became one of the chief leaders of the Liberal party. In that capacity he showed more hostility toward the administration of President Amador than did any of his colleagues, and was regarded as the most strenuous spirit 
in the whole Opposition-for despite the fact that the government was formed by a coalition of Conservatives and Liberals, the more extreme Liberals soon formed themselves into what was virtually an opposition party. The government seems to have done its utmost to placate Dr. Porras. It made him a member of its Law Committee, and sanctioned his election as President of the Municipal Council of Panama. He was, however, implacable in his opposition to Conservative policies, and thus became more and more persona non grata to the government. Finally, in 1905, his citizenship was impeached. It was pointed out that under Article 7 of the Constitution citizenship in Panama was forfeited by "being born a Panaman and not accepting the movement for independence of the Nation," and it was argued that by his opposition to the revolution he had incurred this penalty. True, he had afterward repented of his opposition and had accepted the new order of affairs, and so the penalty might properly be remitted. But the same article of the Constitution also provided that "nationality can only be regained by an Act of the National Assembly." Therefore, it was argued, he was not and could not be a citizen until his citizenship had been restored to him by legislative enactment, and that, of course, could not be done until the National Assembly should be elected in July, 1906, and should meet in September of that year.

All this was vigorously contested by Dr. Porras and his friends, and the point was raised with some logical force that by accepting him as a member of its Law Committee and as President of the Municipal Council of Panama, the government had virtually recognised him as a citizen. The case was finally submitted to the Supreme Court of the Republic, and it, on November 15, 1905, rendered its decision against Dr. Porras, the conclusion of its detailed review of the case being as follows:

"In view of all hereinbefore expressed and adjudicated, the Court, administering justice in the name of the Republic 
of Panama and by authority of the law, decides: That Doctor Belisario Porras has forfeited the right to be a Panamanian citizen which is conceded by Article 6 of the Constitution, in virtue of the provision made in paragraph three of Article 7 of the same document, a right which he has not recovered by not having solicited rehabilitation through the National Assembly."

This decision was fiercely resented by Dr. Porras and his friends, and some deplorable utterances were made in the press and at public meetings. Not only was the action against him described as "malicious persecution," but the court's decision was denounced in savage terms. Thus the Diario de Panama-the organ of the Liberal party, controlled by Dr. Arosemena, First Designate of the Republic, said :

"To the lasting disgrace and eternal shame of this new Republic, and the absolute discredit of its institutions, the Supreme Court of Justice, composed of Judges Fabrega, Guardia, Lombardi, and Villareal-the fifth judge, Benites, withholding his vote-has finally handed down the infamous decision, steeped in political rancour and inspired by personal hatred, which declares Dr. Belisario Porras an alien to his native soil."

A great mass meeting of the Liberal party was held in Santa Anna Park, in Panama, to express disapproval of the court's decision and sympathy with Dr. Porras, at which impassioned addresses were made by Dr. Arosemena and Dr. Mendoza, the First and Third Designates of the Republic, condemning the decision of the court and the action of the government in pressing the case against Dr. Porras.

The reply of the government party was, logically, that the decision of the Court ought to be respected, and that relief should be sought through appeal to the National Assembly to restore Dr. Porras to citizenship as provided by the Constitution. The Liberal retort was to express lack of confidence in the National Assembly as it was to be constituted, on the ground that the government was preparing to carry 
the elections, which would occur in July, 1906, by force or fraud. So strenuous were they in this contention that they actually made appeal to the United States Government concerning it, asking whether it proposed to countenance government control of the elections. This appeal was addressed to William H. Taft, the United States Secretary of War, on November 7, 1905, at which time he was visiting the Isthmus. On that day Secretary Taft was visited by Dr. Arosemena, First Designate of the Republic; Belisario Porras, President of the Municipal Council of the city of Panama; General Domingo Diaz, Eusebio A. Morales, and F. Filos, composing the National Directorate of the Liberal party of Panama. They laid before him an elaborate document signed by themselves, which reviewed the relations of the United States to Panama and the protectorate of the former over the latter; arraigned the Panaman Government for all manner of force and fraud, both past and prospective; and then demanded to know what the United States proposed to do about it. Their memorial ran in part as follows:

"The Diplomatic correspondence which, toward the end of 1903, was exchanged in Washington between Secretary Hay and General Rafael Reyes, Envoy Extraordinary of Colombia, on account of the attitude assumed by the Government of the United States with regard to the separation of the Department of Panama and its transformation into an independent republic, demonstrates that the American Government considered itself bound to maintain the established order of things and to prevent that interoceanic traffic should be suspended or impeded by military operations, which might convert the territory of the Isthmus into a battlefield. . . .

"The treaty, celebrated on November 18 of that year [1903], contains the above doctrine, although in a more concrete form. The United States thereby guarantee the sovereignty and independence of Panama. This treaty, whose principal object is to facilitate the construction of a canal across the Isthmus, was also bound to make provision for the preservation of public order, so that the universal traffic might not suffer disturbances; and, in fact, this faculty was 
not allotted to the United States, as shown in the latter part of Article 7 of said treaty. . . .

"Public order in a country is the harmonious working of its institutions; it is the normal state which results from the respect shown by the government to the individual rights of the people and from the submission of the latter to the existing laws. A government which violates the constitution or the laws, which attacks or ignores the rights of the citizens, or which, in any manner, directly or indirectly, favours or tolerates such violation on the part of unscrupulous underlings, is not within the bounds of constitutional order. If, therefore, to-morrow, it should happen that a government should violate in a flagrant manner the free suffrage, is this, or is it not, an act which constitutes an infraction against lawful and constitutional order? Should, in the opinion of the illustrious Government of the United States, the violation of free suffrage on the part of the Panama Government not be considered an attempt against constitutional order, what remedy remains there for the people of the Isthmus to protect their rights and to prevent usurpation of their sovereignty?

"The present government of the country was formed most auspiciously, with a Cabinet composed of members of both political parties, but since then the Liberal members of the Cabinet have joined the ranks of the other party, so that the government to-day is solely in the hands of the Conservatives. Following Colombian customs, the government is getting itself in readiness to take a hand in the coming elections for Congressmen, and through agents and its own employees it is circulating in the towns of the interior the threat that it will stop at nothing and spare no means in order to gain the elections; that it has the support of the United States; and that it will, if necessary, use high-handed means and force in order to attain its ends. On the other hand, it has also given notice that if the people of Panama should resist this usurpation, American troops will come to maintain order and to shoot them down without mercy.

"Thus the government wants to place the people of Panama before an alternative: Either they permit the coming elections to be a farce, or they offer resistance and thus provoke the intervention of the United States to maintain order.

"We represent the Liberal party, which has an overwhelming majority all through the country, and as its leaders, we deem the time opportune to state to the Government 
which your excellency represents that we do not approve of the recourse to arms as a remedy for political wrongs; but still less do we approve of that system of violation of free suffrage which it is intended to impose upon us, invoking the support of the great American nation for this purpose.

"Already in the last elections, held on December 16, last, which were only of minor importance, we realised to what lengths the agents of the government would go. There are fifty-five precincts in the republic. In some of them no vote was cast because the mayors (alcaldes) prevented the notices of the appointment of election judges from reaching their destination; in others the Liberals were attacked, and shot at to prevent them from casting their ballots; in others the lists of voters were altered on the night preceding the elections, and the names of the Liberals were stricken out therefrom; in others, the people of the rural districts were intimidated by the police and forced to cast a vote contrary to their convictions. . . .

"If the agents of the government made use of all kinds of artifices, deceits, violence, and frauds in order to triumph or to undo our triumph in municipal elections in which only minor interests were at stake, what would they not be capable of doing when it comes to the election of Congressmen to the National Assembly - the only body that has the power to pass upon the acts of the ruling government? . . .

"The several questions which we hereby present to your excellency may be summarised as follows:

"First-Does the American Government guarantee public order and constitutional succession in office in this republic?

"Second-Is a government which violates constitution and laws, and attacks the first right of the citizen-the right of free suffrage-within the pale of such a protection?

"Third-Granted the possibility, and to us it is an absolute certainty, that in the coming elections all manner of outrages will be committed against the people, will the government of the United States look on with indifference at the spectacle of a defenceless people being cast on the mercy of those who trample on their rights?

"Fourth-Will it not be preferable for the United States to adopt, in time, such a course as would prevent their appearing before the eyes of the world as the champions of abuse and oppression?

"The directorate of the Liberal party request your excellency to favour them with a frank answer to these questions, 
and beg respectfully to point out that a reply expressing the repugnance of the United States to meddle in the internal affairs of a friendly nation could not be considered by us in the light of an answer, since our Constitution confers upon your government the right to intervene for purposes of maintaining constitutional order, and if such faculty is given to avoid the evils of war it is natural that it also should be used to suppress the causes which, even contrary to our wishes, might produce them."

The casual reader of this manifesto might think matters in Panama were in a desperate plight. But much allowance must be made for two things. One is, the heat of partisan passions, which, as we well know, even in the United States often leads, in political "campaign documents," to gross exaggerations. To "point with pride" to their own party, and to "view with alarm" the doings of the other party, are the stock-in-trade of political "spellbinders" and platform-makers, and their vision is often monstrously distorted, and is had through glasses of couleur de rose or of jaundiced yellow. There is no reason to suppose the politicians of Panama were or are exceptions to this rule. The other thing to be remembered is, that the Latin races everywhere, and most of all in the tropics, are given to a vivacity of imagination and to a florid exuberance of speech to which the Anglo-Saxons and Teutons of the north are strangers. The extremes of speech in this memorial must, therefore, be largely discounted. When a Spaniard tells you that his house and all it contains are yours, he means no more than an American does when he invites you to come in and make yourself at home. So this memorial really indicated nothing more than many a party platform in the United States has meant, and portrayed a situation no more alarming.

Concerning the complaint made by the Liberals, that the Government, originally representative of both parties, had become exclusively Conservative, the following reply was made by F. V. de la Espriella, a member of the Cabinet of President Amador: 
"The waters of Lethe have, without doubt, bathed the brow of Dr. Arosemena, when he fails to recall the fact, that the President of the Republic tendered him a Legation of the first-class in Europe, which he did not accept; and that, later, he was offered an elevated position as AttorneyGeneral in the Government, which he also refused; that, Doctors Patino and Morales were offered cabinet positions and both declined them, and that, later, Morales was made a member of the Fiscal Commission sent to the United States to place the $\$ 6,000,000$ gold invested by Panama in different American securities, where he was occupied several months, being also employed, under additional salary, as Legal Adviser of the Panama Legation at Washington; and, that, upon his return here, he was named Attorney-General-a position which he decorously resigned two or three days after he had accepted it, on account of the appearance in a local paper of an article by him attacking the Judiciary. Also, that when Dr. Porras returned to the Isthmus, he was courteously and benevolently received in official circles and tendered an appointment to codify the laws of the Republic, at a salary then exceeding that received by members of the Cabinet, and which he afterwards declined for reasons until now unknown to me. As to General Domingo Diaz, the President assures me that, when assuming office, he offered to leave him in the same place that he held at that time; but Diaz declined, stating that while Mr. Tomas Arias was Secretary of Government he could accept nothing from the Administration. Thus, all persons prominent in the Liberal Directorate have been requested to coöperate in the Government. If they have refused to do so, it is not the fault of the Government. Indeed, even the Secretary of the Directorate, who will probably, we believe, hesitate to abandon his law office for an official post of any kind, was distinguished by an appointment as Second Judge-Advocate-General of the Republic. I do not recall at this moment whether, besides the gentlemen aforementioned, there exists in the opposition Liberal Party another personage of the prominence of Dr. Carlos A. Mendoza, who was appointed a Magistrate of the Supreme Court, but declined to serve. The foregoing statement, to which I now give publicity, brings out absolute facts-truths that cannot be questioned or denied.

"The Government has no other means within its reach by which to demonstrate its impartial character and concilia- 
tory spirit than to tender positions to gentlemen of the opposition party. If these reject its overtures for concord why, then, complain?"

Secretary Taft received the Liberals' memorial with his accustomed suavity and discretion, and according to request, communicated it to President Amador and, on his return to Washington, to President Roosevelt. It called for no specific action by our Government, and was followed by none; though perhaps it led to an added manifestation of the desire and determination of the United States that the Isthmian Government shall be conducted in a just and orderly manner.

Still another effort was made by the Liberal leaders to secure the intervention of the United States in the Panaman election. Early in June, 1906, four of them visited Washington for the purpose of laying their case before the President in person. These were Dr. Pablo Arosemena, Dr. Belisario Porras, General Domingo Diaz, and Señor Eusebio A. Morales. They were courteously received, and they discussed the Isthmian situation fully with Secretary Taft and Secretary Root. Their first proposition was that the United States should send agents to supervise the Panaman elections. This, it was pointed out to them, the United States had no right to do, unless at the formal request of the Panaman Government. As an alternative, they then suggested that a confidential agent should be sent, who should carefully observe the electoral practices of the Isthmian Government and report upon them to Washington. To this the Secretary of State, Mr. Root, made the adroit and conclusive reply, that the United States already had a particularly competent and observant confidential agent at Panama, in the person of the American Minister, Mr. Magoon, to whose reports upon the election, as well as upon all matters, it would pay attention, and who would, if a fitting opportunity arose, make such representations to the Panaman Government as would comport with diplomatic usage. 
That was the American Government's last word upon the subject. Mr. Magoon at Panama, however, continued to exert his very considerable personal influence in favour of justice and order at the elections, with gratifying results. On June 24 municipal elections were held in the cities, and save for one or two drunken brawls, in which two lives were lost and several men were injured, order prevailed. A week later, on July 1, the elections for members of the National Assembly were held. In order to avoid any repetition of the affrays of the week before, the government forbade the sale of intoxicants on that day. Consequently, profound peace prevailed. Moreover, Mr. Magoon persuaded the two rival parties to unite in the province of Panama, on a coalition ticket. The government party was generally successful, though Pablo Arosemena and Eusebio A. Morales were elected on the coalition ticket, and the result was accepted as honestly attained. The first National Assembly, elected on July 1, met on September 1, as provided in the Constitution, and elected Domingo de Obaldia, Federico Boyd, and Domingo Diaz, to be respectively First, Second, and Third Designates. Thus the menaces of disorder were dispelled, and the Isthmian republic demonstrated its disposition to conduct its elections in a manner befitting a free and enlightened people. 


\section{CHAPTER XVI \\ BEGINNING THE WORK}

The canal, after all, is the thing. The ancient history, the diplomacy, the politics, and what not of the Isthmus, are not void of interest, but interest in the canal is paramount. It was for a canal that we first went to the Isthmus, generations ago, and it is for the canal that we are there at the present time. It is to the canal that the American mind instinctively turns at mention of Panama. What of the canal? Are we really to have one at last? What kind of a canal is it to be? What hope have we of succeeding where De Lesseps so disastrously failed? What is actually being done upon the great work at the present time? These and a host of other questions naturally arise. There are many which time alone can answer. But there are some fundamental facts concerning the canal which may now be stated with confidence, and which those who have personally gone over the line and investigated all its conditions at first hand and at close range see in a far different light from that of those who look upon the work from afar, through a mist of prejudice and more or less fantastic legends.

We are, then, to have a canal. That is assured to us, and in the near future, as much as any great human achievement can be assured. So far as diplomacy and legislation are concerned, it is well known to the world that complete arrangements have been made for the canal. The statesmanship of Theodore Roosevelt and John Hay has compassed the end which Columbus and Cortez vainly sought. It may be added that upon the engineering and material side the canal is no less assured to us. The skill and energy of American engineers are moving toward success where Ferdinand de 


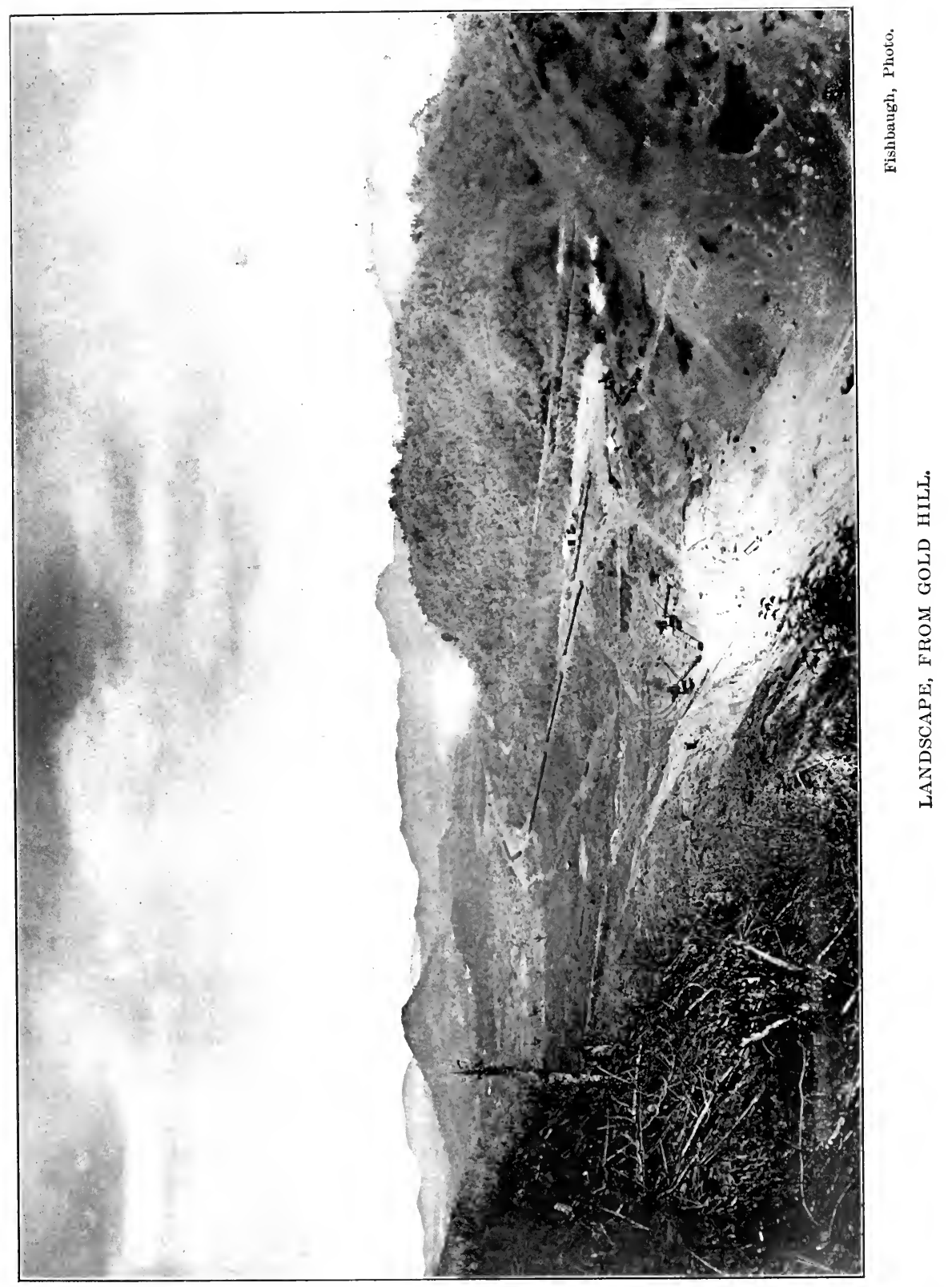



Lesseps met with egregious failure. It would be difficult for any one to visit Panama and see what has been done, what is being done, and what can be done, without being converted to the belief that it is, of all places, the place for a gateway between the oceans. We used to hear much about the great Cordillera, the "mighty mountain wall of the Andes," the "backbone of the continent," which must be broken through or passed over. De Lesseps once talked of a ship tunnel through the mountain as a feature of his proposed sea-level canal, and I remember seeing seriously meant sketches of a tall-masted ship entering a huge bore, with a cloudcapped Andean peak towering far above. Now, the fact is, that if a tunnel were made, its roof would be so thin that we should have to put in rafters to hold it up! I went one day to the top of the highest peak on the whole line of the canal, climbing thither upon the back of one of Uncle Samuel's little army ponies. It was worth while. The outlook was extended and inspiring; a vast amphitheatre of mountains sweeping almost around the horizon. Some one in the party murmured a reminiscence of Church's "Heart of the Andes," which was not altogether inappropriate, considering the vast expanse of wilderness before us, and imagining the ever-present vultures on their untiring wings to be their greater cousins, the condors. But if truth must be confessed, the Andean peak upon which we stood, the loftiest elevation between the Caribbean and the Pacific, was little more than three hundred feet above sea level! I do not suppose that was the very "peak in Darien" upon which stout Cortez-or Balboa-stood, when his men "looked at each other with a wild surmise." It could not have been, for Balboa crossed at St. Michael's Gulf. But I doubt if their amazement could have been more marked and grateful than that of those who, after those fairy tales of mountain walls, realised that this was all there was of it, and that a ridge of soft earth and friable rock, nowhere as much as three hundred feet high, was the only barrier to a sea-level canal between the oceans! To say that such a 
barrier is insuperable would be to discredit engineering science.

The French companies failed, it is true. Why they failed I have already tried to make clear. But they did not labour in vain. They did a great deal of work, and provided a great deal of material which can now be used in our completion of the canal. Practically all their excavation work can thus be utilised, whether in the great cut at Culebra or on the tidal flats where the canal is already navigable. No less to the purpose is it to observe that much of the machinery taken thither by them, even by the original De Lesseps company, was found by our engineers, on taking possession, still in serviceable condition. There were, of course, some things which could not be used. I doubt if it would have been worth while to furbish up the sectional steamboats which were lying around on the hilltops, and I am quite sure that the consignments of snow-shovels which were received there in the days of De Lesseps will never be needed. But in purchasing the title and plant of the French company we secured something far more than the proverbial "right of way and two streaks of rust." We secured millions of dollars' worth of useful machinery and materials and of work well done.

Under the authority of the Spooner bill, as the law for the construction of the canal was termed, the President went forward with promptness and energy. He waited for nothing but for the canal treaty with Panama to be ratified by our deliberate Senate. He submitted that convention to the Senate on December 7, 1903. It was not ratified until February 23, 1904. Six days later, on February 29, 1904, he. appointed an Isthmian Canal Commission of seven members, who were duly confirmed by the Senate on March 3 . The Commissioners were John G. Walker, a Rear-Admiral of the United States Navy, on the retired list, who had been at the head of former canal commissions for the purpose of investigation and report; George W. Davis, a Major-General of the United States Army, on the retired list; William B. 
Parsons, an eminent civil engineer, of New York; William H. Burr, Professor of Civil Engineering in Columbia University, New York; Benjamin M. Harrod, formerly City and State Civil Engineer, of New Orleans, Louisiana; Carl E. Grunsky, civil engineer, of San Francisco, California; and Frank T. Hecker, a civil engineer, of Detroit, Michigan. Rear-Admiral Walker was made Chairman of the Commission and General Davis was appointed Governor of the Canal Zone. Dominic I. Murphy, of Washington, D. C., was engaged as Secretary to the Commission, and Charles E. Magoon, an eminent jurist, of Lincoln, Nebraska, as General Counsel.

On May 9, 1904, the President issued these instructions to the Commission:

"Subject to the limitations of law and the conditions herein contained, the Isthmian Canal Commission are authorised and directed: First-To make all needful rules and regulations for the government of the Zone and for the correct administration of the military, civil, and judicial affairs of its possessions until the close of the LVIIIth session of Congress. Second-To establish a civil service for the government of the strip and construction of the canal, appointments to which shall be secured as nearly as practicable by a merit system. Third-To make, or cause to be made, all needful surveys, borings, designs, plans, and specifications of the engineering, hydraulic, and sanitary works required, and to supervise the execution of the same. Fourth - To make, and cause to be executed after due advertisement, all necessary contracts for any and all kinds of engineering and construction works. Fifth-To acquire by purchase or through proper and uniform expropriation proceedings, to be prescribed by the Commission, any private lands or other real property whose ownership by the United States is essential to the excavation and completion of the canal. Sixth-To make all needful rules and regulations respecting an economical and correct disbursement and an accounting for all funds that may be appropriated by Congress for the construction of the canal, its auxiliary works, and the government of the Canal Zone; and to establish a proper and comprehensive system of bookkeeping showing 
the state of the work, the expenditures by classes, and the amounts still available. Seventh-To make requisition on the Secretary of War for funds needed from time to time in the proper prosecution of the work, and to designate the disbursing officers authorised to receipt for the same.

"The inhabitants of the Isthmian Canal Zone are entitled to security in their persons, property, and religion, and in all their private rights and relations. They should be so informed by public announcement. The people should be disturbed as little as possible in their customs and avocations that are in harmony with principles of well ordered and decent living.

"The municipal laws of the Canal Zone are to be administered by the ordinary tribunals substantially as they were before the change. Police magistrates and justices of the peace and other officers discharging duties usually devolving upon these officers of the law will be continued in office if they are suitable persons. The Governor of the Zone, subject to the approval of the Commission, is authorised to appoint temporarily a judge for the Canal Zone, who shall have the authority equivalent to that usually exercised in Latin countries by a judge of a court of first instance; but the Isthmian Canal Commission shall fix his salary and may legislate respecting his powers and authority, increasing or diminishing them in their discretion, and also making provision for additional or appellate judges, should the public interest require.

"The laws of the land with which the inhabitants are familiar and which were in force on February 26, 1904, will continue in force in the Canal Zone and in other places on the Isthmus over which the United States has jurisdiction, until altered or annulled by the Commission; but there are certain great principles of government which have been made the basis of our existence as a nation which we deem essential to the rule of law and the maintenance of order, and which shall have force in said Zone.

"The Commission may legislate on all rightful subjects of legislation not inconsistent with the laws and treaties of the United States so far as they apply to said zone and other places; and the said power shall include the enactment of sanitary ordinances of a preventive or curative character to be enforced in the cities of Colon and Panama. Such legislative power shall also include the power to raise and 
appropriate revenues. All taxes, judicial fines, custom duties, and other revenues levied and collected in said zone by, or under the authority of the Commission, shall be retained, accounted for, and disbursed by the Commission for its proper purposes. All laws, rules, and regulations of a governmental character enacted by the Commission are to be submitted to the Secretary of War for approval. Gambling is prohibited in the canal strip."

The Commissioners promptly proceeded to organise the great enterprise which had been committed to them. General Davis reached Panama on May 17th to assume the duties of the Governorship, and two days later was formally received by President Amador with much ceremony. He made on that day an inaugural proclamation to the inhabitants of the Canal Zone (see Appendix VII.), announcing that the United States had taken possession of it and outlining, according to the President's instructions to the Commission, the governmental and administrative policy which would be pursued. Announcement was also made of the appointment of the following officers: Secretary, Ernest Lagarde, Jr.; Treasurer, E. C. Tobey, a Paymaster of the United States Navy; Captain of Police, G. R. Shanton; Sanitary Officer, Dr. I. W. Sprattling, U. S. N. The last named was presently succeeded by Dr. W. C. Gorgas, a Colonel of the United States Army. The work of delimiting the Zone, preparing maps, etc., was pushed to completion by June 16, while the actual transfer of the archives and authority of the Zone was made on June 1 .

Four engineering parties were organised, to begin work on the canal. One, under the lead of Charles List, was to survey and study the harbour of Colon, or the roadstead where a harbour was to be created, and the route of the canal as far as Gatun, where the first hills were reached and where it was proposed to construct a dam and locks. The second, under A. B. Nichols, was to give its attention to Gatun and investigate the practicability of constructing the dam. The third, under H. F. Dosé, was to investigate the proposed 
dam site at Bohio. The fourth, under Boyd Ehle, was commissioned to examine and report upon the proposed dam sites at Gamboa and Alhajuela. From this it will be perceived that the Commission at that time took it for granted that a high-level canal, with locks, was to be constructed. Major W. M. Black, U. S. A., was put in temporary charge of actual excavation work, and with Lieutenant Brooke, U. S. A., and A. C. Harper, maintained a small showing of activity in the Culebra cut, where such excavation would need to be done, no matter what type of canal was finally adopted.

These various companies were scarcely at work, however, before an important change occurred in the direction of affairs. On June 1, John F. Wallace, an eminent civil engineer of Chicago, Illinois, was appointed Chief Engineer of the whole enterprise. He arrived at Panama on June 28, and soon suggested to the Commission a new programme of work, which it adopted. He did not accept the high-level plan as a foregone conclusion. On the contrary, he was decidedly in favour of a sea-level canal, if it were found possible to make one. In any event, the first thing to do, in his mind, was to survey carefully the whole route, with a view to securing perfectly trustworthy data from which the practicability and comparative desirability of the various plans of construction could be determined. At the same time he proposed to proceed with the work of actual construction experimentally at Culebra; with the work of rehabilitating the existing machinery, supplies, and buildings, and of securing such new machinery as would be needed; and with the sanitation of the Canal Zone.

How much need there was of such work and how untrustworthy former surveys were may be seen from my promised recurrence to the Bohio-Obispo section of the canal. In most discussions of the high-level canal plan the great Bohio dam has figured as the crux of the whole situation. In surveying for that dam the French engineers chose the narrowest part of the valley, where there would be the smallest amount of 
dam to build above the surface of the ground. The early American surveyors-before our purchase of the unfinished canal-chose another place, where the valley was wider but where, as they thought, the bed rock was nearest to the surface of the ground and there would thus have to be the least excavations for the foundations. Both parties did their work very imperfectly. They had, as I have said before, no diamond drills, and such drills as they had were put down at too great and irregular intervals. They would strike a bowlder as big as a barrel, and exclaim with joy, "Voilà! le bed rock!" Now our later engineers, after our purchase of the property, sent down diamond drills which did not stop at bowlders, and they sent them down fifty feet apart all the way across the valley. The result was that the bed rock was found to be thirty-five feet or more below the former measurements and to have a very irregular contour. This one example indicates the imperative necessity of doing just what was done as soon as we got possession of the canal route: namely, making a complete and accurate survey of the whole course of the canal. An inch on the end of a man's nose, we are told, makes a great difference. So does an increase of thirty-five feet in excavating for the foundations of a dam, especially when you are a hundred and sixty-five feet below sea level.

In the pursuance of his admirable plans, Mr. Wallace reorganised the enterprise on a more elaborate and comprehensive scale. He divided it into seven bureaus: to wit, Supplies ; Personnel, and Quarters ; Buildings and Architecture; Machinery; Maps, Printing, and Lithography; Climatic Conditions and River Hydraulics; and Communications. The titles of these departments indicate sufficiently the character of the work committed to each. Each was essential to the satisfactory and successful conduct of so vast and varied an undertaking. The work of the four engineering parties previously mentioned was continued, with A. C. Harper in charge of excavation at Culebra; W. E. Dauchy succeeding him as resident engineer there in November, 1904. 
C. F. Bertoncini, formerly an employee of the French Company, was put in charge of engineering records and drafting. E. C. Tobey, already named as Treasurer of the Zone, became the head of the department of accounting and of materials and supplies. Charles J. Strom, a mechanical engineer, was charged with the task of examining and rehabilitating the machinery and supplies left by the French. M. O. Johnson became supervising architect. Carleton E. Davis was chosen to direct the work of providing the cities with water and sewers. All told, there were about 1,000 men at work under the Commission in various capacities, on July 1, 1904.

Mr. Wallace was at the very outset, however, confronted with a difficulty, or with a dilemma, which proved serious and embarrassing. The first necessities of the situation were to ascertain the best way of doing the work and to make the Zone fit for men to live in while doing the work-in brief, surveys and sanitation. But the Government and people of the United States were in a hurry to "see the dirt fly" in the construction of the canal itself. It was evident that if work was begun on the canal on a great scale at once, before proper preparations were made, disaster would result. Yet, if at least a great showing of work were not made, there would be discontent and grumblings at the slowness of the Commission and its Chief Engineer. Confronted with this dilemma, Mr. Wallace did what seemed to him the best. He set a host of men at work at the Culebra cut, and ordered a number of huge steam shovels, so as to be able to report much actual excavation, and at the same time he essayed the work of sanitation.

Colonel Gorgas went to Panama with Mr. Wallace, and assumed charge as chief sanitary officer, with headquarters in the fine hospital built by the French at Ancon, just out of Panama, and began, against some local prejudice and opposition, and with a melancholy meagreness and slowness of support from the Commission, the tremendous task of extirpating yellow fever and at least of keeping malaria in 
check. The construction of water supply and sewer systems for Panama and Colon was also begun, but the work was much delayed. Water was to be provided for Panama by damming the Rio Grande to form a reservoir, 235 feet above sea level. Thence a sixteen-inch iron conduit was to convey the water to a high-level distributing reservoir at Ancon, from which, at an elevation of 200 feet, giving ample pressure, mains would conduct it to all parts of the city. The system was designed to give a supply of $2,000,000$ gallons a day, or more than 66 gallons per capita of the population. The plans for this indispensable and most urgent work were submitted by Mr. Wallace to the Commission on August 9, 1904, and were in due time approved. Much energy was displayed in building the dam across the Rio Grande, and in preparing the route of the conduit and in building the reservoir at Ancon. But there was painful and apparently inexcusable delay in shipping the iron pipes from the United States. The last lot of them was not sent until May, 1905, eight months after they had been asked for! Despite this delay, however, water was turned into the mains and was drawn from some hydrants in the city of Panama on July 4,1905 . Work on the sewers was begun in the fall of 1904 , and the system was nearly completed in a year. The repaving of the streets could not, of course, be begun until the water mains and sewers were laid, and so had to be postponed until late in 1905 , when it was pushed with much energy, the streets in the heart of the city being paved with vitrified brick, and those in the outskirts with stone macadam. In February, 1905, authority was granted to $\mathrm{Mr}$. Wallace for the construction of eight new hotels, and by June 1, two of them, at Culebra and at Corozal, were finished and occupied, though the supervising architect, M. O. Johnson, died of yellow fever in April of that year. By July 1, 1905, Mr. Wallace had increased the working force tenfold, to a total of 10,000 men. In a subsequent chapter we shall see what a penalty was paid for the delay in sanitation, and how much better it would have been had the demand to 
"make the dirt fly" been held in abeyance until the Isthmus had been redeemed from pestilence.

For the present, let us turn back to the engineering and surveying work which Mr. Wallace so elaborately organised. The investigations at Gatun showed conclusively that a dam there would be extremely difficult if not impossible to construct. For a dam of such dimensions, a foundation of bed rock was regarded as necessary, and that was not to be found nearer the surface than two hundred feet below sea level. It was thereupon assumed by the engineers that a dam at that point was outside the limits of practical consideration. At Bohio another gigantic dam had been proposed, such as would need a bed-rock foundation. But that was nowhere found in that region at a less depth than 167 feet below the sea, which was also regarded by many engineers as too deep. At Gamboa, on the other hand, undoubted bed rock was found at about sea level, and therefore, in Mr. Wallace's opinion, that was decidedly the best point for a dam. The Gamboa dam would not be needed if the highest level plan, 90 feet, were adopted, but it would form an essential feature of any lower level, or of the sea-level plan. If the last named were adopted, the Gamboa dam would shut the waters of the Chagres from the canal altogether, and would divert them, through a tunnel and the San Juan River, to the Pacific Ocean, or, perhaps preferably, through an open cutting to the Caribbean.

Work in the great Culebra cut was, as I have said, necessary no matter what plan of canal was adopted. Mr. Wallace conducted it largely, however, in experimental fashion, and for the sake of determining the best method of doing it and the lowest cost at which it could be done. He began with the old-fashioned machinery left by the French, but in November, 1904, began the use of enormous steam shovels of American design and make, of which he secured and introduced more than a dozen. Each of these machines, manned-with its appurtenant trains of cars for carting away the dirt-by fifty men, did the work of 500 men under 


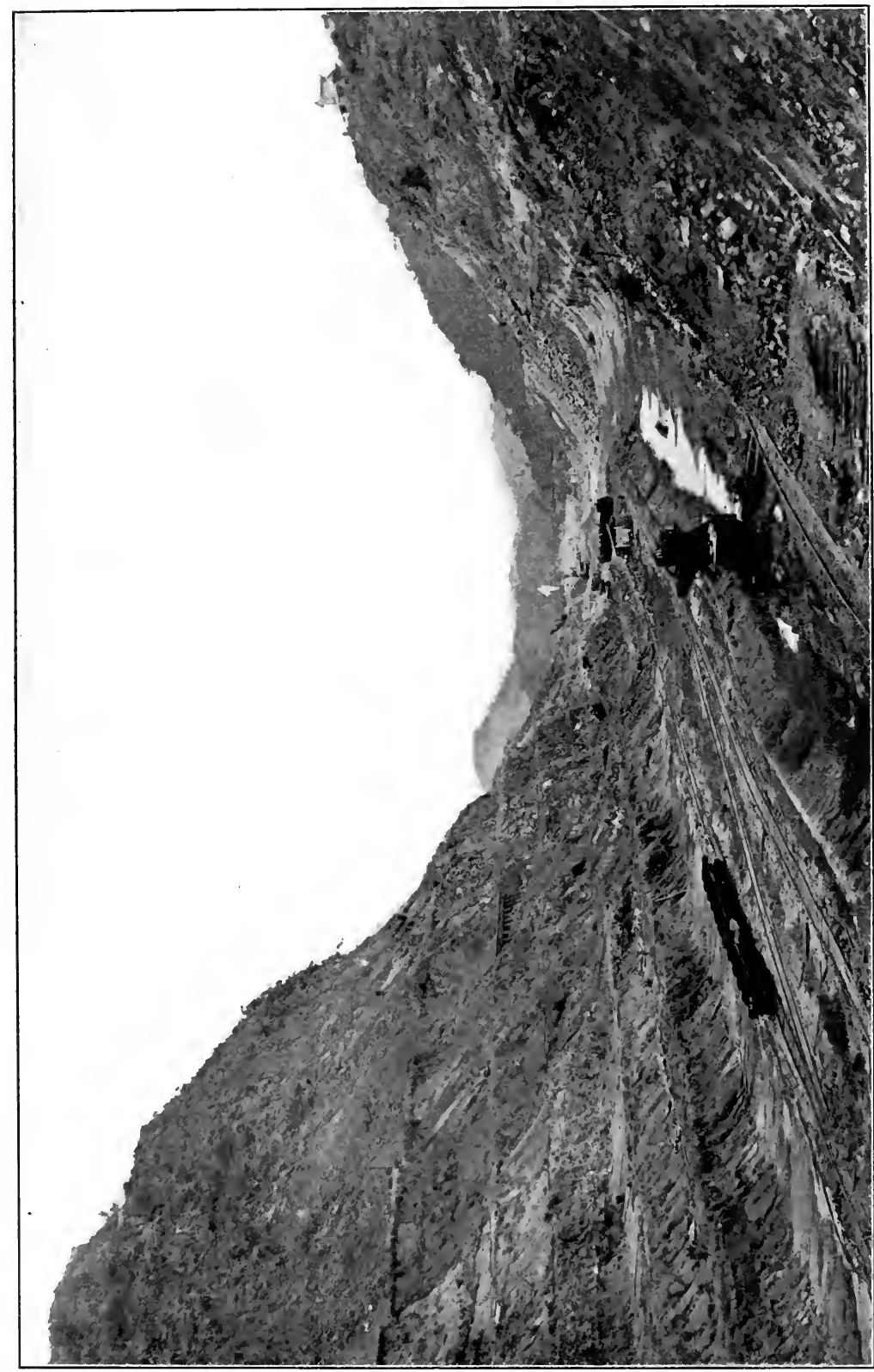

官 


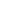


the old system. Mr. Wallace was thus enabled to reduce the cost of excavation much below the eighty cents a cubic yard estimated by the former Canal Commission and used by it as the basis of computation of the cost of the canal. From May 4, 1904, to January 1, 1905, largely under the old methods, there were excavated 243,472 cubic yards, at an average cost of 55 cents a yard. From January 1 to April 1, 1905, under Mr. Wallace's direction and largely with improved methods, there were excavated 278,680 cubic yards, at an average cost of 45 cents. Seeing that there were from $100,000,000$ to $200,000,000$ cubic yards to be excavated, according to the plan adopted, a saving of from 25 to 35 cents a yard meant, Mr. Wallace held, a considerable reduction of cost from the estimates of the former Commission. Moreover, he believed that with the further introduction of improved machinery, and with the provision of better cars and engines for hauling away the excavated matter, the cost could be still further reduced. On the other hand, it is only fair to state, other engineers insisted that Mr. Wallace was doing the very easiest and cheapest of the work, and that the cost thus incurred by him was no criterion by which to judge the whole job.

Four plans of canal construction were, in general, considered by Mr. Wallace, in his surveys and investigations. These were as follows:

1. The high-level plan of the former Canal Commission, involving an enormous dam at Bohio and a number of locks, the level of the lake at the summit of the canal being ninety feet above the sea. Under this plan there would be no dam at Gamboa to divert the waters of the Chagres, but the entire flow of that stream would enter the lake which would form the central part of the canal. The former Commission had estimated the canal could thus be opened for use in eight years and finished in ten years, at a cost of $\$ 200,000,000$ (including the purchase price from the French Company). Mr. Wallace, on the basis of his reduced cost of excavation, was inclined to reduce the estimate of cost to $\$ 145,000,000$. 
2. The sixty-foot level plan, comprising a dam and two locks at Bohio or Gatun, and a dam at Gamboa to divert so much of the Chagres water as was needed to fill the canal; the summit of the canal to be 60 feet above tide-level. This, according to the Commission's figures, would take ten years to open and twelve to finish, and would cost $\$ 225,000,000$; which latter figures Mr. Wallace thought might be reduced to $\$ 178,000,000$.

3. The thirty-foot level plan, involving a dam and a single lock at Bohio, and another lock at Miraflores on the Pacific slope, with a dam at Gamboa as in the preceding plan. The Commission's estimate was that such a canal could be opened for use in twelve years and finished in fifteen, at a cost of $\$ 250,000,000$. Mr. Wallace put the cost at $\$ 195,000,000$.

4. The sea-level plan, originally proposed by Ferdinand de Lesseps, with no locks whatever, but a dam at Gamboa to divert all the waters of the Chagres into some other channel and rid the canal of that troublesome stream. Some have held, and still hold, that in such a canal a "tidal lock" at Miraflores would be necessary, to control the flow of the tides, seeing that the Pacific rises and falls ten feet above and below the mean, against only as many inches in the Caribbean. This argument does not seem convincing. With the Pacific ten feet above or below the Caribbean, there would be a fall in the canal of only ten feet in forty-seven miles, or a trifle more than two and one-half inches to the mile. That is the fall of a slow-flowing river, and would cause nothing more than a gentle current through the canal, half the time in one direction and half the time in the other, which would do no harm and would serve the excellent purpose of flushing the canal and keeping its water pure. Of course, it would be necessary to cut the canal at the Pacific end ten feet deeper than would be necessary with a tidal lock, so as to keep it navigable at low tide, but that would be preferable to the lock. According to the Commission's data, such a canal would require fifteen years to open, and twenty years to finish, and would cost $\$ 300,000,000$. Mr. 
Wallace was disposed to reduce that estimate of cost to about $\$ 230,000,000$. He thought the time estimates of this plan, as well as of the other plans, might also be correspondingly reduced.

As a result of these investigations and computations, Mr. Wallace was strongly inclined toward a sea-level canal. For such preference there were and are, indeed, strong reasons. Even the most of those who for one cause or another favour a lock canal at some elevation concede that in time we must cut down to sea level. Well, if that is ultimately to be done, it would seem to be the part of wisdom to do it at the outset. That is partly because it would probably be cheaper, quicker, and easier to do it at once than to postpone it. Alterations of completed works are usually costly and troublesome, making the works in the end much more expensive than they would have been had the final plan been executed at the beginning. Also, there is a grave question whether it would be possible to cut a high-level canal down to tide level without for the time suspending navigation through it. I believe Mr. Wallace was pretty strongly of opinion that while such cutting down without interruption of traffic might be possible on a twenty or thirty-foot level canal, it was impracticable on one at ninety feet elevation. Obviously, it would be a very bad thing to be compelled to suspend traffic on the canal for a term of years, some years after it had been opened and lines of commerce and travel had been adapted to its use.

Before leaving this phase of the subject, however, I must add that at least one eminent and authoritative engineer has unequivocally and aggressively committed himself to a view exactly contrary to that which I have just described. That is M. Bunau-Varilla, of whose distinguished career something has already been said-sufficient to indicate that his opinions upon any matter connected with Panama and the canal are to be regarded with respectful consideration. I shall not here attempt to give even a synopsis of his plans of canal construction, which he has himself publicly set forth 
in a most lucid manner. It will suffice, without entering into technical details, to say that he is strongly in favour of a sea-level canal. Indeed, he would make it and call it not a canal but the "Straits of Panama." He holds, however, that the easiest, quickest, and cheapest way of constructing such a seaway is first to make and put into use a lock canal at high level, and then cut it down to tide level. This, he is sure, could be done without interruption of traffic, and he shrewdly argues that it is more economical of time, labour, and money to dredge or pump out mud than to dig and haul dry earth.

Two other plans should also be noted in passing, for full accounts of which, however, I must refer the reader to the publications of them made by their respective authors. Lindon W. Bates, an engineer of distinguished attainments and achievements, proposed in 1905 what has been called a "lake canal." Instead of merely damming the Chagres River at Gatun or Bohio, he would construct an extended barrage, or huge dyke, along the sea front at and west of Colon, and another at the Pacific side of the Isthmus, so as to form a broad lake, reaching nearly or quite across the Isthmus, at a moderate elevation above sea level. In such a body of water, he cogently argues, navigation would be much more rapid and safer than in a narrow canal with some pretty sharp curves. Major Cassius E. Gillette, of the United States Army, also an engineer of distinction and authority, proposed a canal with locks, and urged that the difficulty of dam building at Bohio, Gatun, or elsewhere should be overcome by constructing not a masonry dam resting on bed rock, but one of sheet steel piling, driven down to the required depth, backed with concrete forced into place under hydraulic pressure. His plan, as did that of Mr. Bates, received careful consideration and was highly appreciated for the valuable suggestions which it gave to those engaged in the laborious and responsible task of determining what plan should be officially adopted.

If anything which has been said above appears to indicate 
a preference on the part of the present writer for a sea-level canal, it is by no means misleading. A sea-level canal is surely the ideal highway between the two oceans. It is the only one that would be secure, or reasonably secure, against damage by earthquake shocks; and we must remember that Panama is a volcanic region, where seismic disturbances have at times been severe and where they are now by no means things of the past. Granted that, as I have elsewhere pointed out, they have long been so slight as to do no material harm, I know of no guarantee that science can give against the recurrence of destructive tremblings. A comparatively slight shock might wreck the masonry and machinery of a costly lock to such an extent that it would take months of time and cost hundreds of thousands if not millions of dollars to repair it; all use of the canal being for the time suspended. It would take an almost unprecedentedly severe shock to do real damage to a tide-level canal. Again, there is the Chagres River. In any high-level plan that capricious and formidable stream must be depended upon to supply the canal with water and not to overflood it or to wash away its banks. Perhaps it would be possible to control it, so as to make it as useful a servant as it has been destructive, obstructive, and generally undesirable; though those who have seen its antics under the stress of a characteristic Isthmian rain must be pardoned if they regard the harnessing of the Chagres to the canal as something much like the harnessing of a mad elephant to a family carriage. Better far to put a barrier between that raging monster and the canal, make an opening for it at the other side, and bid it rush as madly as it pleases to the sea, but to keep away from the canal.

There is the question of cost, too, in both money and time. Beyond doubt, the sea-level canal would cost more than any other, at the beginning. But that is a partial and most inadequate and misleading basis of judgment. The first cost of a canal, the cost of construction, is not the whole cost. It is only one, and not the most important, of four items, 
the sum of all which must be considered in estimating the cost of the work. The second item is the cost of maintenance. The third is the cost of operation. The fourth is the cost of transit, determined by the value of a ship's time consumed in passing through. That canal will be cheapest which costs the least not for any one of these items, but for all four of them added together. Now, the first item is a temporary one. It must be paid once for all. But the others are continuing and perpetual. They will be charges against the canal as long as it exists. If we were going to build a canal for temporary use or for a few years only, we might do well to select the plan that would cost least for original construction. But this is to be $a^{\prime}$ canal for all time, and we must have regard for the fixed charges against it, which will continue for all time. It would be poor economy to build a canal for $\$ 200,000,000$ which would cost $\$ 5,000,000$ a year for maintenance and operation, when we could build one for $\$ 300,000,000$ which would cost only $\$ 1,000,000$ a year. The canal which at the beginning cost $\$ 100,000,000$ the less would at the end of fifty years have cost $\$ 100,000,000$ the more. (Of course, I do not mention these sums as even approximate estimates of yearly cost, but merely as illustrations.) We must, as Cartier said, "regard the future." We and the world have already waited long for this canal, but that is no reason why we should now hurry ourselves into adopting an inferior and unsatisfactory plan. Better take a little more time and have the best possible plan for all time to come. 


\section{CHAPTER XVII}

\section{REORGANISATION}

The work thus begun was not destined long to continue under the same direction. As early as the summer of 1904, complaints arose of delay on the part of the Canal Commission in supplying urgent needs of the men on the Isthmus, of an excess of red tape, and of a general lack of flexibility, adaptiveness, and responsiveness. The members of the Com. mission spent little time at Panama. Their office was in Washington, and there they transacted their business. Requisitions for supplies, even for things urgently needed in the hospitals and by the sanitary squad, in cases where every hour was precious, had to be sent to Washington, deliberated upon by the Commissioners, approved or rejected with little or no knowledge of the circumstances, and then, if approved, advertised, awarded, and finally filled weeks or months after date. In such fashion it took several months to get an X-ray apparatus for the Ancon hospital. It took many weeks to get mosquito-netting for the windows of the canal office building, and then not enough was supplied; and in the mean time some of the most valuable men of the staff were prostrated by the bites of malarial mosquitoes. The chief sanitary officer wanted netting for all the official buildings in the Canal Zone. This request was refused as extravagant and unnecessary. Then he asked for at least enough to inclose the verandas of the hospitals. This, too, was refused, and he was told that there was no need of inclosing more than half the verandas, and that even then a part of the space should be solidly boarded up instead of screened! In June, 1904, Colonel Gorgas, Mr. Wallace, and others urged the immediate assumption of sanitary control over the cities of Panama and Colon, in order to prevent an out- 
break of yellow fever, but the Commission would not permit this until some months thereafter, when the dreaded disease had appeared and was threatening to become epidemic. The need of a proper water supply for Panama was urgent. Mr. Wallace pushed the work of constructing a reservoir and digging ditches for the iron conduit pipe, and expected and promised to have the water turned on in the city by the end of 1904. This promise he could and would have fulfilled had his requisition for iron piping been promptly granted. But it was not. Months passed, and no pipe came. Mr. Wallace cabled to Washington, urging that it be sent, and the only answer was a reminder that "cabling cost money" -practically a reprimand for wasting money on cable tolls ! Finally, in February, 1905, small quantities of pipe began to reach the Isthmus, and the water was turned on in Panama on July 4, six months later than it should have been. It was also complained, and truly, that the workmen on the canal were ill-housed, and ill-fed, at extortionate prices.

The effect of such a policy, partly exasperating and partly discouraging upon the men at the front, who were waging a life-and-death war with pestilences, may be imagined. There was, no doubt, an explanation of it, if not an excuse or a justification. The Commissioners were mindful of the profligacy and corruption which had run riot in De Lesseps's time, and they were determined to avoid all possibility of a repetition of it. But in fulfilling that praiseworthy resolution they ran into the opposite extreme. It became evident, therefore, that a radical reorganisation of affairs must be made. The Commissioners must either spend most of their time on the Isthmus, where they would be constantly in touch with the work and would appreciate its needs, or they must give place to others who would do so. The President became convinced of this necessity soon after Secretary Taft's return to Washington from Panama in December, 1904, and asked Congress to enact legislation to that end. In a message on January 13, transmitting to Congress a letter of Secretary Taft's upon the subject, he suggested that 
authority should be given to him to form a new Commission of five, or, better still, of only three members. The desirability of such a change was widely recognised. There was no disposition to condemn the existing Commission, or to belittle its achievements. It had done a most valuable and important work. But now its work was done. The whole enterprise was entering a new stage. Diplomacy, and the preliminary negotiations and tentative explorations, were to be laid aside for the most intense and active execution. The Commissioners had been well adapted to the former tasks. They were, most of them, not suited to the latter. The old system of organisation and procedure had served the old purposes well-with such exceptions as I have noted. They would not and could not serve the new purposes. There must be a less complicated, more flexible, and more direct administration.

Already, indeed, a week before this message of the President's, acting upon knowledge of what the President and the Secretary of War had in mind, proposals of reorganisation had been made in Congress. One was for the abolition of the existing Commission and the substitution of a new one consisting of only three members, all engineers-not a desirable thing, for some other than purely engineering ability was needed. Another was for the simple abolition of the Commission; and the bestowal upon the President of power to replace it in any manner he saw fit. These proposals were made in the House of Representatives, and after some debate that body enacted a bill in accord with the President's views. The Senate, however, failed to pass it. Then the President decided to take matters into his own hands. He could not change the Commission from one of seven members to one of only three, as he wished, but he could practically compel the existing Commissioners to resign, and he could fill their places with new men, and organise the new Commission on a now plan. This was what he did.

Already one of the Commissioners, Colonel Hecker, had resigned, on November 18, 1904. In March, 1905, the other 
Commissioners also resigned, and on April 1 a new Com mission was appointed, consisting of Theodore P. Shonts, of Illinois, a civil engineer and railroad president; Charles E. Magoon, of Nebraska, a distinguished jurist, who had been general legal counsel to the old Commission and, before that, law officer of the Bureau of Insular Affairs of the War Department; John F. Wallace, a civil engineer, who had been Chief Engineer under the old Commission, and who had had much experience in railroad and canal work; Mordecai $T$. Endicott, a Rear-Admiral of the United States Navy on the retired list, who had been Chief of the Bureau of Yards and Docks in the Navy Department, and had been a civil engineer before entering the Navy; Peter C. Hains, a BrigadierGeneral of the United States Army on the retired list, who had been educated at West Point, had served with distinction in the Civil War, and had been identified with many important harbour works and other engineering undertakings of the Government; Oswald H. Ernst, a Colonel in the United States Army, who had been educated at West Point and had served with distinction in the Engineering Corps; and Benjamin M. Harrod, of Louisiana, an accomplished civil engineer, who had been a member of the former Canal Commission. Thus all the members of the new Commission were engineers save one, Judge Magoon, and he was meant for administrative and diplomatic work as Governor of the Canal Zone and also as United States Minister to Panama. Mr. Shonts was made Chairman of the Commission, with headquarters in Washington, and Mr. Magoon was made Governor of the Zone, and Mr. Wallace was made Chief Engineer, with their offices at Panama. These three formed an Executive Committee, with general charge of the work; the other members of the Commission acting chiefly in an advisory capacity. The President embodied the suggestions of Secretary Taft in a detailed bill of instructions and rules for the guidance of the Commission, and the new Commissioners promptly entered upon their duties.

The President ordered that the Commission should meet at 
Panama quarterly, four members constituting a quorum for all purposes; and that meetings of the Executive Committee, two being a quorum, should be held at Panama on Monday and Wednesday of every week. The rules continued:

"For the convenience of executing the work to be done, there shall be constituted three executive departments.

"(a) The head of the first department shall be the chairman of the commission, who shall have direct and immediate charge of-

"First-The fiscal affairs of the commission.

"Second-The purchase and delivery of all materials and supplies.

"Third-The accounts, bookkeeping, and audits.

"Fourth-The commercial operations in the United States of the Panama railroad and steamship lines.

"Fifth-He shall have charge of the general concerns of the commission, subject to the supervision and direction of the Secretary of War, and shall perform such other duties as may be placed upon him from time to time by the Secretary of War.

"The head of the second department shall be the Governor of the Zone, with the duties and powers indicated in the executive order of May 9, 1904, which includes in general-

"First-The administration and enforcement of law in the Zone.

"Second-All matters of sanitation within the Canal Zone, and also in the cities of Panama and Colon, and the harbours, etc., so far as authorised by the treaty, the execu. tive orders and decrees of December 3, 1904, between the United States and the Republic of Panama relating thereto.

"Third-The custody of all supplies needed for sanitary purposes and such construction necessary for sanitary purposes as may be assigned to this department by the commission.

"Fourth-Such other duties as he may be charged with from time to time by the Secretary of War.

"Fifth-He shall reside on the Isthmus and devote his entire time to the service, except when granted leave of absence by the Secretary of War.

"The head of the third department shall be the chief engineer. He shall have full charge on the Isthmus-

"First-Of all the actual work of construction carried on by the commission on the Isthmus. 
"Second-The custody of all the supplies and plant of the commission upon the Isthmus.

"Third-The practical operation of the railroad on the Isthmus with the special view to its utilisation in canal con. struction work.

"Fourth-He shall reside on the Isthmus and devote his entire time to the service, except when granted leave of absence by the Secretary of War.

"All officers and employees shall be appointed and their salaries shall be fixed by the head of the department in which they are engaged. Their appointment and salary shall be subject to the approval either of the commission or, if the commission is not in session, of the executive committee. The employment of labourers where the contract of employment is made in the United States or outside of the Isthmus, shall be negotiated and concluded by the chairman of the commission, subject to the approval of the executive com. mittee. Where the employment of labourers is effected upon the Isthmus, it shall be conducted under the supervision of the chief engineer, subject to the approval of the executive committee.

"Contracts for the purchase of supplies or for construction involving an estimated expenditure exceeding $\$ 10,000$, shall only be made after due public advertisement in newspapers of general circulation, and shall be awarded to the lowest responsible bidder, except in case of emergency, when, with the approval of the Secretary of War, advertising may be dispensed with. In the making of contracts for supplies or construction involving an estimated expenditure of more than $\$ 1,000$ and less than $\$ 10,000$, competitive bids should be secured by invitation or advertisement whenever practicable.

"The commission under the supervision and direction of the Secretary of War, and subject to the approval of the President, is charged with the general duty of the adoption of the plans for the construction and maintenance of the canal and with the execution of the work of the same; with the purchase and delivery of supplies, machinery and necessary plant, the employment of the necessary officers, employees, and labourers, and with the fixing their salaries and wages; with the commercial operation of the Panama Railroad Company and its steamship lines, as common carriers; with the utilisation of the railroad as a means of constructing the canal; with the making of contracts for construction 
and excavation, and with all other matters incident and necessary to the building of a waterway across the Isthmus of Panama, as provided by the act of Congress of June 28, 1902."

If this was not in all respects an ideal administration for the canal, it was at least a great improvement upon the former one, and it was probably the best the President could do in the absence of the new legislation which Congress had declined to grant. The constitution of the Executive Committee, whose members would be at Panama practically all the time, was regarded as a most auspicious thing. Mr. Shonts was known as a competent executive in important undertakings. Mr. Magoon was admirably qualified by training, by temperament, and by ingratiation with the people of Panama, to fill the two offices of Governor and Minis: ter-a union of functions which had been recommended to the President by his predecessor in the Ministry to Panama, John Barrett. Mr. Wallace's appointment as a member of the Commission was universally recognised as most appropriate. It was believed that through such organisation the evils complained of under the former Commission would be avoided, and such proved to be the case.

Another important and commendable step was taken on May 15, 1905, when Secretary Taft approved a decision of the Executive Committee to the effect that supplies for the canal should be purchased not necessarily in the United States but wherever they could be most advantageously secured. Lowness of price, promptness of delivery, and all other essential details, were to be taken into account. This was no sudden nor unexpected decision. Months before, at the beginning of December, 1904, in his annual report, Secretary Taft had suggested such a policy, and had asked the will of Congress in the matter. He had at that time said:

"An important question of policy is yet to be determined. If the Isthmian Canal Commission are not bound by any restriction of Congress as to where they shall purchase 
machinery, material, and supplies, then it would seem to be their duty to construct the canal as cheaply as possible, and so to buy what they need where they can get it cheapest. This, however, is certain to produce, every time that a large contract is awarded to a foreign manufacturer or dealer, an outcry on the part of the American unsuccessful competitors. If Congress approves the policy of favouring American manufacturers and dealers, even if it increases the cost of the construction of the canal, then it seems to me only just that it should declare this policy by law and lay down a rule which the commission can exactly follow."

Congress having, from December to May, declined or failed to take any action upon the matter, but having left it entirely to the discretion of the President, the Secretary of War, and the Canal Commission, it was proper and indeed necessary that a decision should be made, which should remain in force until Congress, at some future time, might otherwise enact. Mr. Shonts, the Chairman of the Commission, truly said, in vindication of the action :

"As sworn officers of this Government and of the Isthmian Canal Commission, it is our bounden duty to purchase machinery and supplies necessary for the construction of the canal wherever they can be most advantageously obtained, whether in foreign or domestic markets. I do not mean to say that it necessarily follows that these supplies must be purchased where they can be obtained the cheapest, but where they can be obtained most advantageously, all matters being considered."

The propriety, economy, necessity, and wisdom of the order were widely recognised, although bitter attacks were instantly made upon it by the representatives of some protected monopolies, and by those so-called "stand-patters" in Congress who were opposed to anything even remotely looking to a revision of the tariff. Such attacks upon it were illogical and ill-founded. The principle of the protective tariff was not and is not to be effectively invoked against the order, for the reason that protection is intended to preserve the home market for the home producer, and the Pan- 
ama Canal is not a home market. The Canal Zone is not a part of the United States, and the canal which we are constructing there is not to be a domestic institution, such as, let us say, the Erie Canal or one of the Pacific railroads. The canal will be owned by this country, and will be operated and controlled by this country. Perhaps in time it will also be used by this country more than by any other. But, nevertheless, it will be in a foreign land, and it will be, by the most sacred guarantees, open impartially for international and universal use. It does not appear, then, that it is properly to be regarded as under the rule of the protective system. There are, on the other hand, strong arguments in favour of precisely such a system as that which was adopted by the Commission. It is on all hands agreed that-provided, in the first place, that it be the best possible canal in plan and workmanship-it is eminently desirable that the canal shall be constructed as quickly and as cheaply as possible. There is reason to believe that much time, perhaps a year or two, and much money, amounting perhaps to tens of millions of dollars, could be saved through the policy adopted by the Commission.

In at least two important particulars the Government had long been committed to this very policy. In purchasing the unfinished canal from the French company it purchased millions of dollars' worth of foreign machinery and other supplies. Having done that at the beginning, it would seem to be logical for it to continue so doing whenever it is to its material advantage to do so. Again, the principle of employing alien labour has been well established. Natives of Panama, imported workmen from Jamaica, and other nonAmericans are employed and are to be employed. This is necessary, since it would probably be impossible to get labour in this country to do the work. If, then, we are to employ foreign workmen, there would seem to be no reason why they should not use foreign machinery.

There was no real expectation, however, that under this order many supplies would be purchased abroad. That was 
not the purpose of the order, and it was realised, by even the "stand-patters," that it would not be its effect. It would simply compel American manufacturers to sell to their own government as cheaply as to foreign customers, and to continue selling at Panama at such prices as they had hitherto been glad to get. Before the United States acquired the Canal Zone, American manufacturers and merchants had enjoyed almost a monopoly of the hardware, machinery, and other trades at Panama, and had found them highly profitable, although they had no tariff protection but were compelled to compete in open market with their rivals of England and Germany. Secretary Taft rightly held, therefore, that they should continue to do business in that same way under American control of the Canal Zone, and should not be permitted under the shelter of the American tariff to raise their prices far above what they had thitherto been glad to get. It is true there were threats that as soon as Congress met in the fall the order would be annulled by it, and the Commission would be compelled by law to purchase all supplies in the American market, at no matter how high a price. So strenuous was the opposition to the order, indeed, that it seemed for a time doubtful whether it would be executed. But it was put into effect, and when Congress met the next fall it was not rescinded. Not until June, 1906, did Congress take any action whatever upon it, and then it adopted a shifty and unworthy resolution which did not deal decisively with the matter, but merely directed that supplies for the canal should be purchased in the American market unless, in the President's opinion, the prices demanded here were unreasonable or extortionate. Even with this unsatisfactory action of Congress, the incident will doubtless prove to have a salutary effect, in keeping down the cost of the canal to within reasonable limits.

Another step of reorganisation was taken in January, 1905, when Secretary Taft recommended the acquisition by the United States of the few shares of Panama Railroad stock which were held by individuals. The great majority 
of the stock had been purchased by the United States along with the unfinished canal, but a small minority of it was still in private hands. This recommendation was approved and executed, and the United States thus became the sole owner of the Isthmian railroad and of its steamship line from Colon to New York. The result of that transaction was-in time-a breaking of the monopoly which the Pacific Mail Steamship Company had enjoyed by virtue of a compact with the old Panama Railroad Company, and a consequent great improvement of traffic conditions. Concerning this matter an important report was made in $\mathrm{July,} \mathrm{1905,} \mathrm{to}$ the Secretary of War, by Joseph L. Bristow, who had been specially commissioned for the purpose, and who, as the result of exhaustive investigations, recommended:

"That the Panama Railway be double tracked and provided with all possible facilities for handling business, such as increased wharves, etc.; that it charge a rate for transportation based on improved facilities for handling traffic, plus a moderate amount with which to pay dividends; that the policy of charging a per cent. of the rates on through business, subject to certain minima, be adhered to; that the steamship line between New York and Colon be retained; that contracts with the Pacific Mail Steamship Company and with South American lines be cancelled, and the traffic be thrown open to all steamship lines on equal terms; that, unless a private steamship line be established between Colon and the Gulf ports of the United States within a reasonable time, the Panama Railway establish such line; that if the Pacific Mail Steamship Company withdraws its present service, some other company be induced to establish a line between Panama and all important Pacific ports of the United States, and that if this cannot be done the Panama Railway itself establish such line; and, finally, that American vessels be favoured where that can be done without violating the treaty obligations of the United States."

Now came one of the most unexpected and most unpleasant incidents in thr history of the American canal enterprise at Panama. This was the resignation or dismissal of Mr. Wallace from his place as a member of the Commission 
and as Chief Engineer of the canal. There was no doubt that he had been much dissatisfied with the conduct of the former Commission, but he was supposed to be not only content but highly gratified with the new order of things. He was receiving a salary of $\$ 25,000$ a year, and was living in the finest house in Panama. Under the reorganisation of the Commission he would have almost absolute authority over the engineering features of the work. The enterprise was one, to be identified with the successful completion of which might well satisfy the ambition of any man. It was, therefore, assumed that he would remain in his place to the end. When in June, 1905, rumours arose that he was coming home to resign his place and to engage in some business enterprise in the United States at a higher salary, they were regarded with incredulity; and when he actually did come, it was confidently assumed that he would speedily return to the Isthmus.

Immediately upon his arrival, however, on Sunday, June 26, Messrs. Taft, Wallace, and Cromwell had a more or less stormy conference in New York. The details of it were not at once revealed, but it was made known that Mr. Wallace's connection with the canal was terminated, either by his resignation or his dismissal. A few days later, Secretary Taft made public what had occurred. He quoted Mr. Wallace's letters of December 20, 1904, and March 15, 1905, asking that he be appointed a commissioner, and suggesting the new organisation of the Commission, including the appointment of an executive committee of three members. He said that Mr. Wallace's suggestions were followed out, and quoted Mr. Wallace as expressing unequivocal approval of all that had been done under a date as late as May 26, 1905, two days before the chief engineer last reached the Isthmus and twelve days before he determined to resign. The Secretary's report of the conference of June 26 was, in brief, as follows:

"Mr. Wallace said that a few days before he sent his cable to the Secretary he had received a cable from prom- 
inent business men in New York, asking if he would consider an offer to accept an important position in New York, and that he had cabled in reply that it was simply a question of terms and conditions, and that he had requested particulars; that the particulars came, and it proved to be a definite offer of a position as president of a large holding company, controlling several other corporations, with certain stock benefits and other advantages to himself, which, with the salary, made it equivalent to $\$ 50,000$ a year; that he did not at once accept the offer, but delayed it for a few days in order to cable the Secretary of War, during which the parties increased their proposals between $\$ 10,000$ and $\$ 15,000$ a year, making it equivalent to $\$ 60,000$ or $\$ 65,000$.

"Mr. Wallace stated that the position was an especially attractive one; that the duties of the new position were especially agreeable and afforded opportunities to make money through investments, etc.; further, that the position was such a good one that he did not consider that he could decline it. Concluding, he stated that while he was severing his connection with the canal work, he was willing to make up his annual report, and he would, if desired by the Government, continue to serve as a commissioner, but not as chief engineer in charge of the construction work on the Isthmus."

At this, Secretary Taft's usually equable temperament was much disturbed, and he expressed his indignation in no uncertain tones. Addressing Mr. Wallace, he said:

"I am inexpressibly disappointed, not only because you have taken this step, but because you seem so utterly insensible of the significance of your conduct. You come with the bald announcement that you quit your task at a critical moment, on the eve of important work and in the midst of reorganisation plans under which you accepted your position, with your department unperfected in organisation. ... When the President found it necessary to make a reorganisation of the former Commission, you were consulted in the frankest manner about every feature of the reorganisation and were encouraged freely to express your opinions. Indeed, vour voluntary suggestions from the Isthmus embraced the proposal that you yourself be made a member of 
the Commission and Chief Engineer on the Isthmus. The substance of the plan of reorganisation, as afterward embodied in the President's executive order of April 1, was cabled to you by me, and you cabled me your fullest approval of it, and your thanks; for it included the appointment of yourself as a Commissioner, as you had solicited, and a member of the Executive Committee.

"The new plan of organisation was warmly accepted and indorsed by you when you arrived in Washington, and you expressed your hearty approval of it in the most unequivocal manner, not only to the President and myself, but to the members of the Commission and its counsel, and just before sailing for the Isthmus you called upon us and voluntarily thanked me in the warmest terms for what had been done in the reorganisation of the canal work and in the positions which had been given you. . . .

"Now, within twelve days after your arrival upon the Isthmus, you send me a cable which, read in the light of what you say to-day, signifies your practical acceptance of an offer of another position inconsistent with the performance of your duties on the Isthmus. I am astonished that you should be so disregardful of the splendid opportunities of the position which would have made you famous the world over by the honourable performance of your duties of chief engineer. For mere lucre you change your position over night, without thought of the embarrassing position in which you place your Government by this action, when the engineering forces on the Isthmus are left without a real head and your department is not perfected in organisation, when the Advisory Board of Engineers is to assemble under call of the President within two months, and when I am departing for the Philippines on public duty. I consider that by every principle of honour and duty you were bound to treat the subject differently. You have permitted the President and all of us to proceed in full confidence that you would perform the functions of Chief Engineer, and now in an hour you drop your great duties and throw them back upon us as if it were a matter of no consequence, and all this for your personal advantage solely. . . .

"Under the circumstances, Mr. Wallace, and with great personal pain and disappointment, I am bound to say that I consider the public interests require that you tender your resignation at this moment and turn over the records of your office to the chairman of the Commission." 
Mr. Wallace thereupon tendered his resignation, both as Commissioner and as Chief Engineer, and it was, on June 28, accepted by the President, to take effect immediately. On June 30, Mr. Wallace made a public statement in reply to Secretary Taft's strictures upon him, in which he said:

"The primary causes which led me to tender my resignation as Chief Engineer of the Isthmian Canal Commission were underlying and fundamental, and I must emphatically resent the charge that my motive in leaving the work was a financial one. A careful consideration of the entire subject had brought me to the decision that I should disconnect myself with the work at the earliest possible date that it could be done without embarrassment to the administration or injury to the work. It is unnecessary to state the reasons for this decision, except that in fairness I should say that they involve no criticism of any act of the President or the Secretary of War. My final decision was arrived at as the result of the six days' uninterrupted thought which I was able to give the subject in all its bearings during my voyage from New York to Colon, in May. Furthermore, I had pledged myself to my family to give the matter of my resignation as Chief Engineer, or of any position which would require my continuous residence on the Isthmus, serious consideration.

"It was at this psychological moment that I received a cable message from New York offering me a business opportunity which I was bound to consider. I, therefore, immediately cabled the Secretary of War requesting a conference and arrived in New York for that purpose on Thursday, June 22. In the meantime I had addressed a letter to the Secretary, in which I confirmed the request for an interview, and also requested my annual leave of absence, which was part of my original understanding with the Isthmian Canal Commission, and which I had requested from Admiral Walker in March, to take effect at our mutual convenience some time later in the season, which request, however, was not complied with or answered, owing, probably, to a sudden change made in the Commission on April 1.

"On my arrival in New York I was met by Mr. William Nelson Cromwell, who stated that he was delegated by the Secretary to arrange for a personal interview with me, and asked me if I would meet him at the Manhattan Hotel at 
10 a. m., Sunday, June 25. While Mr. Cromwell treated me with the suavity and courtesy for which he is noted, he endeavoured to draw from me my reasons for desiring to see the Secretary. I told him frankly that I did not consider it would be proper for me to discuss the matter in advance of my interview, and I also requested him to arrange for me with the Secretary that the interview should be absolutely private, and that no one but the Secretary and myself should be present.

"On arriving at the Manhattan on Sunday, I was met by Mr. Cromwell, who ushered me into the Secretary's private apartment, accompanied by my son. Assuming that arrangements had been made for a strictly private interview, my son withdrew, expecting Mr. Cromwell to do the same. However, the Secretary, in a rather peremptory manner, directed Mr. Cromwell to remain. This action, of course, caused irritation and apprehension on my part that the interview would be unpleasant and unsatisfactory, and the irritation under which the Secretary was evidently labouring had a tendency to prevent that calm and dignified consideration of the question in all its bearings which should have been given it.

"If the Secretary understood me to say that I had accepted a position in New York, he laboured under a misapprehension. I did state to him that I desired to accept one, but under such circumstances and conditions and at such time as would cause the least embarrassment to the administration and the least injury to the work, and that I was even willing to go to the extent of remaining for an indefinite time on the Commission, should he desire my counsel and advice in arranging for the change, assisting in preparing plans for submission to the Advisory Board of Engineers in September, or in the further consideration of the question by the administration or Congress during its next session.

"Much to my surprise he indignantly spurned my suggestion and took the position that I was compelled under what he called my contract to remain in charge of the Isthmian canal, regardless of circumstances or conditions, until the completion of the work, and spoke in such a manner as to outrage my feeling to such an extent that further discussion of the reasons for my action was out of the question.

"I did not seek the position of chief engineer of the Isthmian Canal Commission, and, considering my salary as general manager of the Illinois Central Railroad Company and 
my other sources of earnings, my financial condition was not improved by my acceptance of the position, and it was with the greatest reluctance that I did so.

"While it was my own expectation that I should continue my connection with the work, it did not occur to me that I was not free to withdraw if justice to myself and my family and to my reputation as an engineer required me to do so. It was not only my right, but my duty, to give the matter most careful consideration in all its bearings, considering not only the general situation as it affected the work, but my family, personal and business relations, and all the various factors entering into the problem, and I could not concede the right to the Secretary of War or any one to dictate my decision. The only debatable questions were the details as to putting my decision into effect, and, while I stated to the Secretary what my desires were, I told him that I was perfectly willing to conform to his wishes as far as possible as to the time and manner of my withdrawal.

"I have made no criticism of personnel or individuals, but do believe that the obstacles due to the government methods required by existing laws are so serious that they will have to be eliminated if the American people are to see the Panama Canal constructed in a reasonable time and at a moderate cost."

Upon one point there was universal agreement: namely, that this episode was a most painful and regrettable one. The most general opinion was that Secretary Taft had acted in a justifiable and, indeed, necessary manner, and that $\mathrm{Mr}$. Wallace had sacrificed a splendid fame for sordid considerations. There were those, however, who while holding this general opinion thought the Secretary had been needlessly severe with Mr. Wallace. The minority opinion was that Mr. Wallace had been unjustly forced out of his place, or else was justifiable in his act of resigning. But even those who held this view, and even his warm friends and supporters, regretted that he did not more clearly state the reasons for his action. He spoke of the "primary causes" as "underlying and fundamental," but he did not say what they were. He spoke of "obstacles due to the governmental methods required by existing laws" as "serious," but he did not 
say what they were. Such vagueness was disappointing and discouraging to his friends, who, had he spoken more explicitly, would have been glad to rush to his defence and vindication. There were those who ventured to assume that they knew his reasons, and who gave public intimation of what they believed to be their nature. One was, that he was unwilling longer to inflict upon his family the distress and anxiety they suffered during his stay in a plague-smitten place. A second was, that he was disgusted with the red tape and delay which had formerly prevailed, and feared their continuance. A third was, that his heart was set upon a sea-level canal and he was unwilling to be identified with any other; that he knew it would be impossible to construct such a canal at a cost which Congress would sanction unless supplies could be bought in the cheapest market, as Secretary Taft had ordered; and that he believed Congress would rescind that order and thus so increase the cost of work that a sea-level canal would be out of the question.

All this, however, was conjecture, and Mr. Wallace made no further explanation of his course for some time. But in February, 1906, he was called as a witness before a committee of the United States Senate which was investigating canal affairs, and was asked to explain the causes of his resignation. In reply he made it appear that he had been largely, perhaps chiefly, moved by personal incompatibility with or antagonism to Mr. Shonts, his colleague on the Commission, and Mr. Cromwell. Concerning the former, he said :

"I told Secretary Taft that I did not want to go back to the Isthmus as Chief Engineer. My reason was, that I was made jointly responsible with Mr. Shonts and Mr. Magoon for work on the canal, while Mr. Shonts had a verbal agreement with the President that he should have a free hand in the management of all matters. I felt Mr. Shonts was not as well qualified as I was either as a business man or an administrator, and he was not an engineer. I thought I was to be director-general of the canal work. I thought it 
better to sacrifice my ambitions regarding this work, which was to be the crowning event of my life, than remain to be humiliated, forced to disobey orders, or create friction."

His objections to Mr. Cromwell were, chiefly, that he had too much influence with the President and Secretary of War, and was interested in too many things:

"I thought about him as being the man who brought about the sale of the canal to the government; who brought about the revolution in Panama; who assisted the government of Panama in making its investments; who is carried on the diplomatic list of that government, and who is interested in public utilities on the Isthmus. I felt that a man mixed up in so many things might have his mind perverted, and at some time he might give the wrong advice, and the result would be a scandal."

With this, we may take leave of this regrettable incident, with sincere gratification, however, that it had no mischievous effect upon the canal enterprise. Mr. Wallace's place on the Commission was not at once filled, but his successor as Chief Engineer was selected and announced almost simultaneously with his resignation. This was John F. Stevens, who was at that time supervising the Government's plans for a thousand miles of railroads in the Philippine Islands, and who had formerly been chief engineer and general manager of some of the most important railroads in the United States. He had been about to start for the Philippines. Instead, he went straight to Panama. In the summer of 1905, Joseph Bucklin Bishop, of New York, an experienced journalist, was made Secretary to the Commission, and in December following was appointed by the President a member of the Canal Commission. His nomination was not acted upon by the Senate, however, and at the end of the Congressional session, in June, 1906, it was withdrawn, or permitted to lapse, and Mr. Bishop was returned to his former place as Secretary to the Commission. At the same time Colonel Ernst, who had been placed upon the retired list 
of the army, retired from the Commission, and Mr. Stevens, the Chief Engineer, was appointed a Commissioner in his place.

Another important feature of the reorganisation effected in 1905 was the appointment of a Board of Consulting or Advisory Engineers, chiefly for the purpose of considering and recommending a plan for the canal-whether at high level or sea level. The creation of such a Board had been recommended by Secretary Taft in a letter to the President on March 30, 1905, and the President, in his instructions and directions to the reorganised Commission, had promised that it should be done. The Board was made to consist of the following members; five of them being appointed by European governments on request of the President: Major-General George W. Davis, U. S. A. (retired), formerly Canal Commissioner and Governor of the Canal Zone, and an engineer of long and wide experience, chairman; Brigadier-General Henry L. Abbot, U. S. A. (retired), a distinguished engineer, long intimately conversant with and connected with the Panama Canal enterprise; Eugen Tincauzer, chief engineer of the Kiel Canal, appointed by the German Government; Edouard Quellennec, consulting engineer of the Suez Canal, and J. W. Welcker, an eminent engineer, director of the State Waterways of Holland, appointed by the government of the Netherlands; Adolph Guérard, a leading official engineer of France, inspector-general of bridges and highways, appointed by the French Government; Henry W. Hunter, chief engineer of the Manchester Ship Canal, appointed by the British Government; Isham Randolph, of Illinois, engineer of the Chicago Drainage Canal; Frederick P. Stearns, of Massachusetts, the hydraulic engineer of the city of Boston; William H. Burr, of New York, Professor of Engineering in Columbia University; Joseph Ripley, of Illinois, chief engineer of the Sault Ste. Marie Canal; William Barclay Parsons, the chief engineer of the New York City Subway; and Alfred Noble, chief engineer of a division of the Pennsyl- 
vania Railroad. Captain John C. Oakes, U. S. A., was made secretary of the Board. To this Board, the President had ordered, there should be submitted by the Isthmian Canal Commission for its consideration and advice the important engineering questions arising in the selection of the best plan for the construction of the canal. "The recommendation of the Board of Consulting Engineers shall be considered by the Isthmian Canal Commission, and, with the recommendations of the Commission, shall finally be submitted, through the Secretary of War, to the President for his decision."

This Board-obviously one of exceptional distinction and authority-was organised and began its work early in September, 1905. The instructions given to it by President Roosevelt were general in terms, outlining the spirit and purpose of its undertaking, rather than its details of execution. He said:

"There are two or three considerations which I trust you will steadily keep before your minds in coming to a conclusion as to the proper type of canal. I hope that ultimately it will prove possible to build a sea-level canal. Such a canal would undoubtedly be best in the end, if feasible; and I feel that one of the chief advantages of the Panama route is that ultimately a sea-level canal will be a possibility. But, while paying due heed to the ideal perfectibility of the scheme from an engineer's standpoint, remember the need of having a plan which shall provide for the immediate building of a canal on the safest terms and in the shortest possible time. If to build a sea-level canal will but slightly increase the risk, then, of course, it is preferable. But if to adopt the plan of a sea-level canal means to incur a hazard, and to insure indefinite delay, then it is not preferable. If the advantages and disadvantages are closely balanced, I expect you to say so. I desire also to know whether, if you recommend a high-level multi-lock canal, it will be possible, after it is completed, to turn it into or substitute for it, in time, a sea-level canal, without interrupting the traffic upon it. Two of the prime considerations to be kept steadily in mind are:

"First-The utmost practicable speed of construction. 
"Second-Practical certainty that the plan proposed will be feasible; that it can be carried out with the minimum risk.

"The quantity of work and the amount of work should be minimised so far as possible.

"There may be good reason why the delay incident to the adoption of a plan for an ideal canal should be incurred; but if there is not, then I hope to see the canal constructed on a system which will bring to the nearest possible date in the future the time when it is practicable to take the first ship across the Isthmus; that is, which will in the shortest time possible secure a Panama waterway between the oceans of such a character as to guarantee permanent and ample communication for the greatest ships of our navy and for the larger steamers on either the Atlantic or the Pacific. The delay in transit of the vessels owing to additional locks would be of small consequence when compared with shortening the time for the construction of the canal or diminishing the risks in its construction.

"In short, I desire your best judgment on all the various questions to be considered in choosing among the various plans for a comparatively high-level multi-lock canal, for a lower level, with fewer locks, and for a sea-level canal. Finally, I urge upon you the necessity of as great expedition in coming to a decision as is compatible with thoroughness in considering the conditions."

The President's policy was, in brief, to construct the best canal in the shortest time. The two supremely desirable qualities were promptness and efficiency, and they were coördinate. Neither was to be sacrified to the other, and if not to the other, certainly not to any or to all other considerations in the world. As for these two, they were to go harmoniously hand in hand, and everything else was to make way for them and adapt itself to their requirements. That was precisely as it should be. This nation does not want to wait a single day unnecessarily for the canal for which it and the world have waited so long and which they need so much; but neither does it want, however speedily it might be provided, a canal which will prove unsafe or unsatisfactory, or of which men will say it might have been made better had a little more time been given it. 
The Board proceeded to the Isthmus and made a careful study of the canal route. At first the majority had been opposed to the sea-level plan, but the views of several were quickly changed by personal inspection of the route, and on November 18, at a meeting of the Board in Washington, after its return from Panama, it was decided by a vote of 8 to 5 to recommend a canal at sea level. The report of the majority of the Board, on January 10, 1906, was signed by Messrs. Davis, Parsons, Burr, Hunter, Guérard, Tincauzer, Welcker, and Quellennec. It was largely technical in character, entering into minute engineering details. Its gist was that all plans involving lift-locks, whether few or many, should be rejected and that a sea-level plan should be adopted "as the only one giving reasonable assurance of safe and uninterrupted navigation." In conclusion this report said :

"It is the belief of the Board that the essential and indispensable features of a convenient and safe ship canal at the American Isthmus are now known; that such a canal can be constructed in twelve or thirteen years' time; that the cost will be less than $\$ 250,000,000$; that it will endure for all time.

"The Board does not believe that a provisional treatment of this great question would yield results which would be satisfactory to the American nation or advantageous to American commerce, or that such treatment would be in consonance with the increase of population, of trade, and of wealth which will surely take place during the next half century in the Western Hemisphere."

The report of the minority of the Board was signed by Messrs. Abbot, Noble, Stearns, Ripley, and Randolph. It traversed largely the same ground as the other, but differed from it in estimates of cost and time, and concluded as follows :

"In view of the unquestioned fact that the lock canal herein advocated will cost about $\$ 100,000,000$ less than the proposed sea-level canal; believing that it can be built in 
much less time; that it will afford a better navigation; that it will be adequate for all its uses for a longer time, and can be enlarged, if need should arise, with greater facility and less cost, we recommend the lock canal at elevation 85 for adoption by the United States."

Exception may properly be taken to the phrase "unquestioned fact," applied to the estimate of $\$ 100,000,000$ difference in cost between the two plans, seeing that the majority report estimated that difference at not more than about $\$ 71,000,000$.

A report was also made by the Chief Engineer, Mr. Stevens, strongly in favour of a lock canal at high level; going to such an extreme as to declare a preference for such a canal even if one at sea level could be made as quickly and as cheaply. Mr. Stevens said:

"The sum of my conclusions is, that, all things considered, the lock or high-level canal is preferable to the sealevel type, so called, for the following reasons:

"It will provide as safe and a quicker passage for ships, and, therefore, will be of greater capacity.

"It will provide, beyond question, the best solution of the vital problem of how safely to care for the flood waters of the Chagres and other streams.

"Provision is made for enlarging its capacity to almost any extent at very much less expense of time and money than can be provided for by any sea-level plan.

"Its cost of operation, maintenance, and fixed charges will be very much less than any sea-level canal.

"The time and cost of its construction will be not onehalf that of a canal of the sea-level type.

"The element of time might become, in case of war, actual or threatened, one of such importance that measured, not by years, by months, or even days, the entire cost of the canal would seem trivial in comparison.

"Finally, even at the same cost in time and money for each type, I would favour the adoption of the high-level lockcanal plan in preference to that of the proposed sea-level canal."

These three reports were submitted to the Canal Commissioners, all of whom met in Washington to consider them, 
in February, 1906. After due deliberation the Commissioners made two reports, that of the majority agreeing with the minority report of the consulting engineers, and the minority report of the Commission agreeing with the majority report of the engineers. The majority report was signed by Messrs. Shonts, Magoon, Hains, Ernst, and Harrod. It admitted that the ideal canal would be one at sea level, provided it were made of sufficient width; but it declared that the cost of making a canal of such dimensions would be prohibitive. It, therefore, favoured a canal with locks, at 85 feet level above the sea, saying:

"It appears that the canal proposed by the minority of the Board of Consulting Engineers can be built in half the time and a little more than half the cost of the canal proposed by the majority of the board, and that when completed it will be a better canal for the following reasons:

"(1) It provides greater safety for ships and less danger of interruption to traffic by reason of its wider and deeper channels.

"(2) It provides quicker passage across the Isthmus for large ships or a large traffic.

"(3) It is in much less danger of damage to itself or of delays to ships from the flood waters of the Chagres and other streams.

"(4) Its cost of operation and maintenance, including fixed charges, will be less by some $\$ 2,000,000$ or more per annum.

"(5) It can be enlarged hereafter much more easily and cheaply than can a sea-level canal.

"(6) Its military defence can be effected with as little or, perhaps, less difficulty than the sea-level canal.

"(7) It is our opinion that the plan proposed by the minority of the Board of Consulting Engineers is a most satisfactory solution of the problem of an Isthmian canal, and, therefore, we recommend that the plan of the minority be adopted."

The minority report was signed by only one Commissioner, Rear-Admiral Endicott, and its conclusions were as follows: 
"The undersigned does not concur in the preference for a lock canal, expressed by the Commission, but regards a sealevel canal, as proposed by the majority of the Board of Consulting Engineers, a better canal for commercial and military purposes.

“(1) Because, while for exceptionally large vessels, such as built for Atlantic liners, the time of transit might be as long as, or longer than, in the lock canal, the average time of transit of the class of vessels which will use the canal for a long term of years will be less than in the lock canal.

"(2) Because the risks of interruption to traffic from accident are deemed greater in a high-level canal with six locks than in a sea-level canal with a tidal lock, notwithstanding the greater distance in the latter canal, which might be obstructed by a sunken vessel.

"(3) Because the cost of maintenance and operation of the sea-level canal will be less.

"(4) Because in the enlargements to accommodate increase in traffic the relative advantages of the sea-level canal will increase.

"(5) Because it is a better, safer, and more capacious canal from a military standpoint."

All these reports were laid before the Secretary of War, who considered them carefully and then transmitted them to the President, with a letter of recommendation. In that letter he recalled the fact that the existing act of Congress practically fixed the minimum dimensions of the locks (if any) and the width and depth of the canal, by the requirement that the canal should be of sufficient capacity for the largest vessels afloat: to wit, ships 800 feet long, 88 feet beam, and 38 feet draught. The locks proposed in the highlevel plan would accommodate such vessels, and so would the entire canal. But the proposed sea-level plan would not meet the requirements. Said Mr. Taft:

"In the high-level canal a vessel of the dimensions noted would have, with the exception of the 4.7 miles where the width is only 200 feet, ample lee-way for safe navigation and good speed, without objectionable currents and without difficulties at the points where changes in course are necessary. 
"With the proposed sea-level canal conditions are different. The depth is but two feet greater than the draught of the ship, not sufficient to permit her to proceed under her own steam, except at great risk; twenty-one miles of the canal is not sufficiently wide for two such ships to pass; currents caused by the regulation of the Chagres and by the flow of other streams into the canal, and its many curves, combine to increase the difficulties and dangers of navigation. In short the sea-level canal recommended is 'not of sufficient capacity and depth' to 'afford convenient passage for vessels of the largest tonnage and greatest depth' and can be made so only by materially increasing the depth and width, and at a considerable increase of time and money. If the suggested width of 150 to 200 feet is the greatest width economically permissible for a sea-level canal, the cost of the enlargement required must be prohibitive.

"It, therefore, follows that the high-level canal more fully meets the requirements of Congress."

The Secretary further discussed the questions of locks, of speed and safety of navigation, of time and cost of construction, and others, finally recommending the adoption-with some modifications-of the high-level plans of the minority of the engineers and the majority of the commissioners. He said:

"When I visited the Isthmus a year and a half ago and went over the site and talked with the then Chief Engineer, I received a strong impression that the work of construction upon which the United States was about to enter was of such world-wide importance and so likely to continue in active use for centuries to come that it was wise for the government not to be impatient of the time to be taken or of the treasure to be spent. It seemed to me that the sea-level canal was necessarily so much more certain to satisfy the demands of the world's commerce than a lock canal that both time and money might well be sacrificed to achieve the best form, and this feeling was emphasized by reading the very able report of the majority. But the report of the minority, in showing the actual result of the use of the locks in ship canals, in pointing out the dangers of so narrow and contracted a canal prism as that which the majority proposes, and in making clear the great additional cost in time 
and money of a sea-level canal, has led me to a different conclusion."

The next word was spoken by the President. On February 19, 1906, he referred the whole matter to Congress for its final decision, accompanying the mass of reports and documents with a brief message, in which he declared his concurrence with the recommendation of the Secretary of War. In the message he said:

"It must be borne in mind that there is no question of building what has been picturesquely termed 'the Straits of Panama;' that is, a waterway through which the largest vessels could go with safety at uninterrupted high speed. Both the sea-level canal and the proposed lock canal would be too narrow and shallow to be called with any truthfulness a strait, or to have any of the properties of a wide, deep water strip. Both of them would be canals, pure and simple. Each type has certain disadvantages and certain advantages. But, in my judgment, the disadvantages are fewer and the advantages very much greater in the case of a lock canal substantially as proposed in the papers forwarded herewith; and a careful study of the reports seems to establish a strong probability that the following are the facts: The sea-level canal would be slightly less exposed to damage in the event of war; the running expenses, apart from the heavy cost of interest on the amount employed to build it, would be less; and for small ships the time of transit would probably be less. On the other hand, the lock canal, at a level of 80 feet or thereabouts, would not cost much more than half as much to build, and could be built in about half the time, while there would be very much less risk connected with building it, and for large ships the transit would be quicker; while, taking into account the interest on the amount saved in building, the actual cost of maintenance would be less. After being built, it would be easier to enlarge the lock canal than the sea-level canal.

"The law now on our statute books seems to contemplate a lock canal. In my judgment a lock canal, as herein recommended, is advisable. If the Congress directs that a sealevel canal be constructed its direction will, of course, be carried out. Otherwise, the canal will be built on substantially the plan for a lock canal outlined in the accompanying 
papers, such changes being made, of course, as may be found actually necessary."

The question of the plan of the canal was thus left with Congress for final determination, and that body, at the close of its session in June, 1906, decided in favour of a high-level lock canal, substantially on the lines suggested by the minority of the Advisory Board and by the majority of the Canal Commission. 


\section{CHAPTER XVIII}

\section{THE FIGHT WITH FEVER}

IT was realised by judicious observers at the outset of the Isthmian canal enterprise that the work of sanitation was of supreme importance, and especially the elimination of yellow fever, which, if not the most destructive of diseases there, was decidedly the most terrifying and demoralising. Nearly a century before, Humboldt had written that yellow fever and other diseases at Panama were due to the marine plants, mollusks, etc., on the beach at low tide, exposed to the heat of the sun, while on the Caribbean coast, at Porto Bello and elsewhere, bilious fever was due to putrescent emanations from rank vegetation. The world knows better than that now, having learned of the bacterial nature of those diseases and of the part played by certain varieties of mosquitoes in propagating them-the Stegomyia yellow fever and the Anopheles malaria. The attention of sanitarians at Panama was, therefore, given largely to the destruction of those insects, and to the guarding of non-immune people against their bites. In his address to the members of the Canal Commission, on their entrance upon their duties in the spring of 1904, President Roosevelt said:

"There is one matter to which I wish to ask your special attention-the question of sanitation and hygiene. You will take measures to secure the best medical experts for this purpose whom you can obtain, and you will, of course, make the contractors submit as implicitly as your own employees to all the rules and regulations of the medical department under you."

It was remembered that epidemic diseases had been among the most formidable of the difficulties which the French 
companies had encountered on the Isthmus, though there was encouragement in the fact that conditions had generally improved since the beginning of De Lesseps's enterprise. To that effect some statistics may be cited from Dr. Lacroisade, who was for many years director of the great French hospital at Ancon Hill, Panama. From 1881 to 1888 under the original company the number of employees averaged 10,854, and the mean yearly percentage of disease was 62.58 , and of mortality 5.97 (though for a time there was the appalling death rate of 60 per cent. a year). From 1889 to 1894, under the receivership, the average number of men was only 971 and the percentage of disease was 49.68, and of mortality 2.88. Under the new French company, from 1895 to 1901 the number of men averaged 2,703, and the percentage of disease was 37.17, and of mortality 2.61. Moreover, of this last mortality percentage, 2.61, European diseases amounted to 2.10, and characteristic tropical diseases to only 0.51. From 1892 to 1897 there was no yellow fever on the Isthmus. With these figures before them, it behooved the American administrators to improve, if possible, upon the record.

As early as January 7, 1904, Mr. Buchanan, the American Minister to Panama, conferred with Rear-Admiral Glass, in command of the United States ships at Panama, concerning measures to prevent the importation of disease from Ecuadorean or other South American ports, and two days later he wrote to Señor Espriella, the Panaman Minister for Foreign Affairs, congratulating him upon the fact that there then existed upon the Isthmus no case of yellow fever, smallpox, or bubonic plague, and suggesting an active and intimate coöperation of Panaman and American authorities for the preservation of that immunity. To this Señor Espriella responded cordially, and the practical work of hospital reorganisation and quarantine improvement was promptly begun. The Provisional Board of Government of Panama on January 21 issued a decree imposing severe penalties upon all physicians and pharmacists who should fail at once to report to the National Board of Hygiene any cases of con- 
tagious diseases coming under their notice. Nevertheless, a few cases of yellow fever presently appeared. Two deaths from that disease occurred in the hospital of San Tomas, Panama, on January 15, and other cases occurred at intervals during the year. On July 1, 1904, the American sanitary officers assumed charge of the Canal Zone, and from that date to December 20 following there were ten cases of yellow fever, of which two resulted fatally. Four of these cases occurred in the first two weeks of December, and two of them were known to Secretary Taft and his party on their visit to Panama at that time. Secretary Taft was, indeed, greeted on his arrival with the fearsome whisper that a case or two had just occurred. No public proclamation was made of the fact, for fear of creating a panic, but the fact was perfectly well known to the visitors, and was variously regarded. Some were frightened, while others pooh-poohed and scorned the idea that yellow fever could make any serious headway under American administration. But it did make headway. Week by week new cases occurred, steadily increasing in numbers. The rainy season came on, making almost every square foot of the wretched cobblestone pavements a breeding ground for the Stegomyia. To make the situation worse, many of the streets were torn up for the laying of sewers and water-mains, and, under the torrential tropic rains, were transformed into sluggish rivers of mud. Meantime demoralisation grew apace in the minds of the American colony. Among many fear and fright developed into absolute panic. As for those who had formerly scoffed, they assumed a cynical bravado and fatalism. The refrain of their daily song was the old

"One cup for the dead already, And hurrah for the next that dies!"

They professed contempt for the mosquito theory, and ostentatiously tore holes in the nettings which had been placed over the windows of the canal building, or removed them altogether, and disregarded all the sanitary precau- 
tions and regulations which had been prescribed by the health officers.

It would be ungracious to dwell in too great detail or with too much emphasis upon responsibility for this state of affairs. Careful investigation and conservative consideration warrant, however, the charging of it chiefly to two causes. One was, the failure of the Canal Commission to support the efforts of the sanitary officers with the promptness and liberality which were required if those efforts were to be in the highest degree successful. There was too much "red tape." Those sanitary officers were in the positions of army officers on the firing line. It was necessary that they should have all the arms and munitions of sanitary warfare that they wanted, and should have them right away. The enforced waiting for weeks or months sometimes meant disaster. It is not for a moment to be supposed the Canal Commissioners were careless in the matter. They were as desirous as anybody that the fever should be suppressed and the sanitary conditions of the Isthmus should be improved. But at Washington they did not and could not realise the urgency of the case as fully as did the men at Colon and Panama. Moreover, they were under the restraint of caution lest they should be charged with looseness of business methods and with opening the door to "graft." In former years the name of Panama had been synonymous with scandal and corruption. These men proposed to avoid a repetition of that state of affairs, and if in doing so they erred, they erred on the side of caution.

The other cause of trouble was, the haste of the American nation to have the canal built. Because of that heedless haste, the cart was put before the horse. The canal work was begun before essential preparations for it were complete. This should have been realised at the outset. In its original bargain with the new-born Republic of Panama for the construction of the canal, the United States Government contracted to do a vast work of sanitation in the cities of Panama and Colon and in the whole stretch of country between 
them. It undertook to create in them a sewer system, a water supply system, and civilised street pavements, and to do its utmost to destroy the Anopheles and Stegomyia mosquitoes, so as to banish malarial and yellow fevers. It was not through pure benevolence to Panama that the United States undertook such tasks, but in order to facilitate and expedite the construction of the canal; for it was seen that, if the canal was to be built, the Isthmus must be rendered fit for the builders to live in. There were those then who thought this preparatory work of sanitation should be done first, and that nobody should be set to work on the canal until yellow fever had been completely stamped out, as it had been years before in Cuba-under the direction of the same health officer, Colonel Gorgas, who is now in charge at Panama. But the popular impatience for the canal, and the President's desire "to make the dirt fly," were too strong to be at once resisted. The work of sanitation was begun, but without waiting for it to be completed several thousand men were also set at work upon the canal. The result was not exactly disastrous, but it was deplorable and demoralising.

The state of affairs in May, 1905, when Governor Magoon arrived upon the scene, may be summed up in three wordspanic, lethargy, bravado; and the three together meant demoralisation. In that month there were thirty-eight cases of fever on the Isthmus, with a threat of a large increase in June. Governor Magoon arrived on May 25, and it did not take him long to perceive two things. One was that the first supreme and necessitous duty of the administration was to get rid of yellow fever, whether a single spadeful of earth was dug on the canal or not. The other was that the first step toward getting rid of the fever must be to restore the public mind-that of the non-immune Americans, especially -to sanity. He began by frankly and publicly declaring that he, personally, was afraid of the fever, and that in his opinion all non-immunes who professed not to be afraid were "talking rot!" Then he ordered all the window screens to 


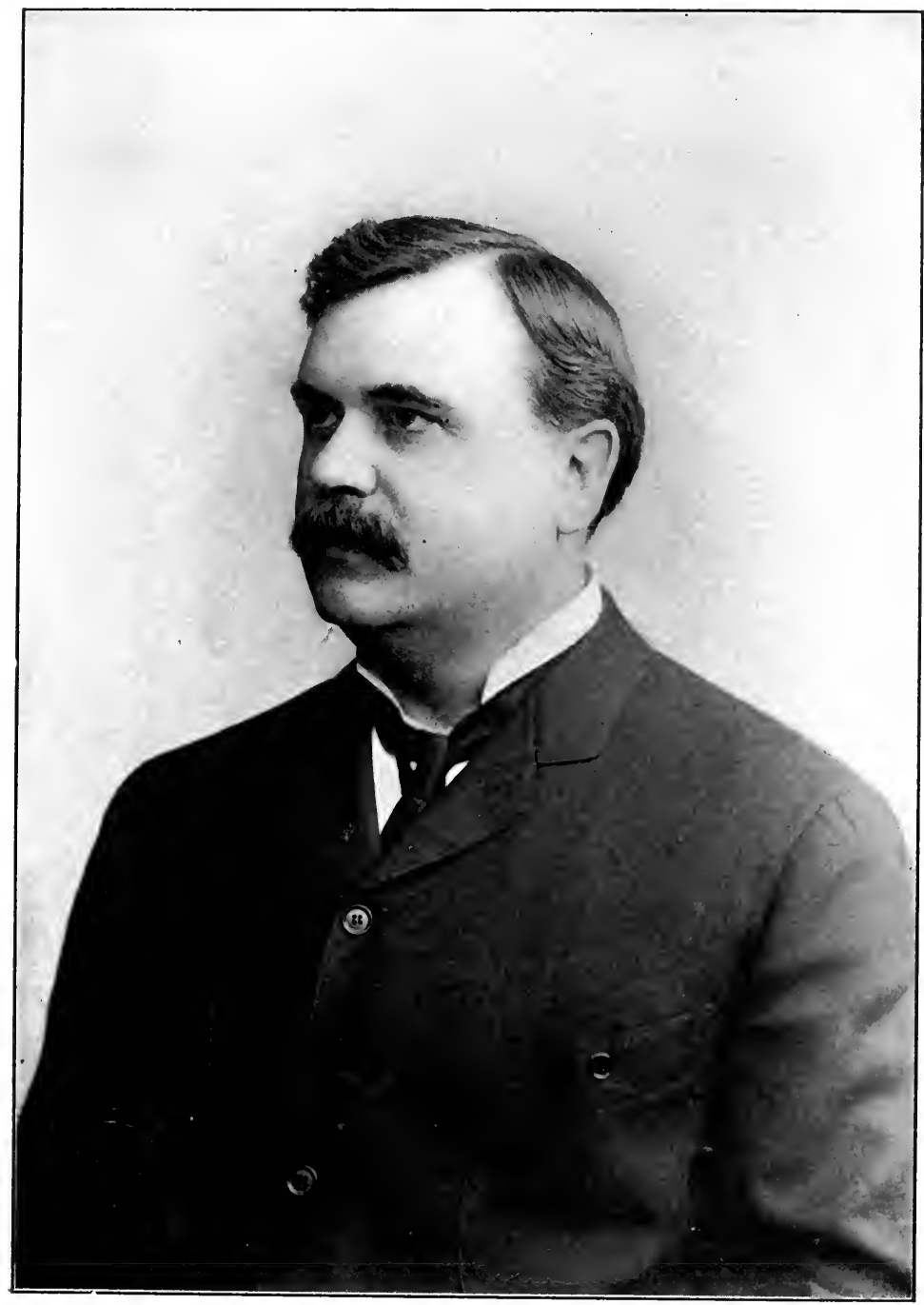

West, Photo.

CHARLES E. MAGOON,

Governor of the Canal Zone and American Minister to Panama in 1905-6. 
- 
be repaired and replaced and kept in place, and announced that if any man was caught leaving them open or tearing holes in them, something uncommonly unpleasant would happen to him. Now, when a man of Judge Magoon's mental and physical stature admits that he is afraid, any lesser man is a fool to say he isn't; and when a man of Judge Magoon's resolution gives an order and prescribes a penalty for its violation, that order is very likely to be obeyed. In this case it was, and there was an end to the cheap bravado that had proved so costly.

The next step, promptly taken, was destruction of all mosquitoes possible by fumigation. They began with the canal building in Panama. It was thoroughly fumigated on the first Sunday after the Governor's arrival, and every second Sunday thereafter for some months, when the interval was increased to three weeks. But that was not enough. There were probably many infected mosquitoes in other buildings throughout the city, which must be destroyed. In Havana, Colonel Gorgas had followed the rule of disinfecting three houses for every case of fever: to wit, the house in which it had occurred and the house on each side of it. That practice was effective there. But Havana is a thousand miles further north than Panama, and has a winter climate which is fatal to the delicate Stegomyia. No such aid from nature was possible on the Isthmus, wherefore artifice must be more energetic. The heroic plan was, therefore, conceived of fumigating and disinfecting every building in the city of Panama! It was at first hoped to do this enormous work within twelve days, the period of yellow fever's incubation in the Stegomyia, but this was found to be impossible, and the time actually required was more than thirty days; but it seems probable that the work was just as effective as though it had been accomplished in the shorter time. As an illustration of the energy and expedition with which Isthmian affairs were then administered, it may be recalled that Governor Magoon had to send to Washington for material and appliances for the work. He did so by tele- 
graph, and within forty-eight hours after the filing of his despatch the supplies were shipped and on their way to Panama. There was a time when it would have taken nearer forty-eight days.

It was evident to Governor Magoon, also, that the efforts of the Health Department had been for some reason not as effective as they should have been under so admirable a staff as that of Colonel Gorgas and with so excellent a hospital equipment, and he set about discovering where the fault lay. It was found in the system of reporting cases of fever. In a majority of cases the patients were ill four or five days before they were taken to the hospital or isolated and screened. Now, the first three or four days of the fever are the very time in which mosquitoes are most surely infected through biting the patient. Immediate isolation is, therefore, of the utmost importance. . But here these patients had been left exposed to the bites of mosquitoes during that critical period, the time of all times when they should have been under screens. What was the cause of such laxity? It appeared that the health officers had not sufficient means at their disposal to employ expert inspectors, and were, therefore, compelled to depend for information upon voluntary reports of patients or their families, and upon reports from ordinary inexpert workmen who were engaged in cleansing water tanks and similar work. No wonder, under these conditions, that the fever was constantly spreading. Governor Magoon changed all that in a twinkling. He employed eight native Panaman physicians as sanitary inspectors, selecting, with the valuable aid of President Amador, who is a distinguished authority on yellow fever and other tropical diseases, those who were most familiar with yellow fever and who would be most likely to recognise it in its earliest stages. Then he divided the whole city of Panama into eight districts, and assigned one of these physicians to each district, with orders to make a thorough inspection of every house in it every day. That was thorough inspection with a vengeance! In addition, these physicians were directed to 
act as missionaries and teachers, explaining to the people the mosquito theory, and impressing upon them the importance of hearty and constant coöperation with the American authorities in sanitation. The employment of native Pan. aman physicians for this purpose was a tactful device and obviated friction and opposition on the part of the people.

Colonel Gorgas also organised a practical school of sanitation for the employees of his department, both inspectors and workmen, to teach them what was to be done and why it must be done, and to enable them in turn to explain matters to the people. Then the whole city was thoroughly gone over, with a view to destroying all Stegomyia larræ which might be found in water tanks or other vessels, and either abolishing the receptacles or screening them so thoroughly that no more mosquitoes could get access to them. The Panamans are generally immune against yellow fever, and many of them had no faith in, if even knowledge of, the mosquito theory; and so they were disinclined to take the trouble to screen the tanks and to replace the screens carefully every time they were removed to get at the water. Tact and patience, however, in time overcame this difficulty and secured the hearty and efficient coöperation of the people of Panama. This achievement was, of course, greatly promoted by the introduction of a new water supply and the consequent abolition of the old tanks and cisterns. Governor Magoon at an early date withdrew the workmen from the canal and concentrated all efforts upon the waterworks and sewers, with happy results. By July 4, the principal water main was extendea as far as the Cathedral Plaza, in the very heart of the city, and on that day the water was turned on for public use. It was supplied freely from street hydrants until plumbing connections were made with the houses. In addition, as a temporary measure, until the mains could be extended to all parts of the city, ten large "water wagons" were employed to go about the city, distributing water freely to all who could not get it from the hydrants. With such facilities afforded to the people, it was possible to proceed 
vigorously with the work of destroying water barrels and tanks and filling up wells and underground cisterns. Before the end of the year fully nineteen-twentieths of such water receptacles which had existed in Panama had been destroyed. Meantime, a careful watch was kept on all the streets of the city for the immediate removal and destruction of all empty cans, bottles, etc., which, holding a little water, might serve as mosquito nests, and the filling up, drainage, or treating with oil or disinfectants of all pools and puddles of water. In this way it was made practically impossible for the Stegomyia to be propagated in Panama. A similar work was performed in Colon and in the various villages along the line of the railroad and canal.

Statistics show the results of this policy. I have said that in May, 1905, there were thirty-eight cases and more were expected in June. They came, of course, because the results of former neglect were then to be reaped, and there was not time for the results of the new policy, which dates from Governor Magoon's arrival on May 25, to appear. In June there were sixty-two cases and Governor Magoon, without losing faith in the ultimate triumph of his and Colonel Gorgas's policy, seriously considered the question of temporarily removing the entire non-immune population of Panama from the city, and placing it upon the beautiful and salubrious island of Taboga, in the bay. It is probable that the whole clerical force of the canal administration, at least, would thus have been transferred had the buildings on Taboga been in proper condition to receive it. As it was, this step was not taken and was soon seen not to be needed. In July the number of cases decreased to forty-two, and a general feeling of encouragement arose. In August the number fell to twenty-seven and victory was within sight. In September the disease came to an end, with a total of only six cases. The last case in Colon occurred on August 27, and the last case in the city of Panama on September 14. The last case anywhere in the Canal Zone occurred at the village of Matachin, on September 29, where I think the 
fever had never been known before. The case was obviously an adventitious one, imported by some remote chance, but to guard against even the slightest danger of its duplication, the whole village was literally saturated with disinfectants, so that a stegomyia flying over it would probably have dropped dead.

Thus "Finis" was written to the story of yellow fever in Panama. For some weeks Colonel Gorgas with Governor Magoon's sanction publicly and conspicuously advertised a reward of $\$ 50$ in gold to any one not connected with the Health Department who should report a case of the fever in the Canal Zone or in the cities of Panama and Colon, but nobody claimed the reward. The offer, was not, of course, made in any spirit of bravado or vainglory. It was intended to serve two exceedingly important and practical purposes. One was to reassure the minds of all non-immunes and put a final quietus upon the demoralisation which had recently existed. The other was to inspire the utmost vigilance among all people, to transform every member of the poulation into an amateur sanitary detective, and thus to secure for the health officers the earliest possible information of any suspicious case of illness; for now that yellow fever is actually suppressed every sanitarian will appreciate the supreme necessity of guarding against the spread of infection from any solitary sporadic case which may occur.

The completeness of the triumph of sanitation may be estimated from the fact that in August, 1905, the month in which yellow fever was practically subdued, the death rate in the Canal Zone was only 25 to the thousand yearly, which is little more than that of many of our northern cities, and vastly less than that of many tropical and semi-tropical communities. The death rate of Alexandria, Egypt, is about 35, that of Cairo is nearly 38, that of Calcutta is 30, that of Madras is 38, and that of Bombay is 55. Panama is a sanitarium compared with those places. In 1904 the death rate of Dublin and its suburbs was 23.3, of Breslau 23.5, of Moscow 27.6, of Rio de Janeiro 22, of St. Petersburg 23.7, of 
Trieste 25.8, of Venice 22.2, of Liverpool 22.6, of New Orleans 21.5, and of New York 22.6. Compared with these the rate of 25 at Panama is highly creditable. In that same month of August, 1905, out of 12,000 workmen in the Canal Zone, only 301 entered the hospitals. That fact compares well with conditions in almost any industrial community.

Nor is the work of sanitation by any means complete, nor is the death rate reduced as low as we may hope it will soon be. Down to the beginning of 1906 there had been, in the Canal Zone, less than an acre of swamp actually filled in, and about 145 acres drained; three and a half miles of new ditches dug, and less than 30 miles of old ditches cleaned and paved; and about 412 acres of grass and jungle cut and burned. These achievements were only a scratching of the surface, only a beginning of the work which is to redeem Panama from pestilence and make it as healthful as it is beautiful.

Much was promptly done by the reorganised Commission in 1905 for the general welfare of the staff, employees, and residents of the Canal Zone, apart from, and in addition to, the works of sanitation. Reading rooms, club rooms, gymnasiums, and other places of social entertainment and recreation were provided. They had been much needed, for the Zone was formerly quite destitute of such things. Still more important was the supplying of food. Governor Magoon, upon his arrival at the Isthmus, quickly perceived that this was a matter of supreme and vital interest, and he quickly set about the task of dealing with it. There was no hope of getting satisfactory supplies, at reasonable prices, on the Isthmus. Owing to the fact that the natives never look beyond their present necessities, no surplus food supply ever accumulates. This normal condition of no surplus was greatly intensified by the almost total failure of the crops for the two preceding years, by the abandonment by agricultural labourers of their farms back in the hills for work on the canal, where they received higher pay for shorter hours, and by quarantine against the port of Panama on account 
of bubonic plague, which prevented the arrival of foodstuff from neighbouring provinces. The Commission was thus brought face to face with the problem of feeding 17,000 men with the base of supplies 2,000 miles away.

Governor Magoon soon arranged to open local commissary stores at every important labour camp, to provide mess houses, and to furnish food, both cooked and uncooked, to all employees at cost. Orders were sent by cable to have the Commission's steamers equipped with refrigerating plants, arrangements were made for the erection of a temporary cold storage plant at Colon, and refrigerator cars were purchased for immediate shipment to the Isthmus, thus establishing a line of refrigeration from the markets of the United States to the commissary stations of the Isthmus. The equipment in existing hotels was also purchased from individuals lessees and their management assumed by the Commission. The net result of these efforts is that to-day all employees have an opportunity to obtain an abundant supply of wholesome food, cooked and uncooked, at reasonable prices. The silver men-that is, the common labourers -are being fed for 30 cents a day, and the gold employees -that is, those of the higher class-at 90 cents per day, and they get good food in place of bad.

I have related the story of the commissaries thus briefly, chiefly in the words of the Commission's own report. It should be added that the people of Panama at first strongly protested against the arrangement, fearing it would deprive them of a profitable market for their wares; but Governor Magoon diplomatically argued the point with them and reconciled them to the new order of things, on the ground that it would be better for them to have the canal constructed promptly than to have it delayed in order to retain a market for their produce at exorbitant prices. Mr. Shonts then made a contract with a leading railroad and hotel caterer of the United States to undertake the work of feeding all the employees in the Zone; but before anything material was done to execute it the contract was cancelled and the com- 
missary department remained under the direct charge of the Commission.

A victory was won for morals and thrift in the Canal Zone, in September, 1905, when the first decision of the Supreme Court of the Zone was rendered. The purport of that decision was to confirm the validity of Act No. 4 of the Canal Zone laws, under which the conducting of a public gambling place is made a penal offence. A man was charged with running a roulette table. He did not deny the fact, but claimed a right to maintain the place under a concession from the Republic of Panama. The Circuit Court overruled his plea and found him guilty, sentencing him to a fine of $\$ 100$ and thirty days' imprisonment. He made appeal to the Supreme Court, which unanimously affirmed the decree of the lower court, with a modification of the sentence. It was held by this decision that under the treaty between the United States and the Republic of Panama, the United States has full control of the Canal Zone, just as though it were the actual sovereign of that territory, free from all anterior obligations or concessions of any kind, and has also full power to legislate for the Zone. If any concession holder is aggrieved by such exercise of authority by the United States, his remedy is in action against the Republic of Panama, and not against the United States. The prohibition of gambling within the Zone was within the legal power of the Isthmian Canal Commission, under the treaty and under the act of Congress constituting the Commission, and is therefore valid. The effect of this decision was most salutary. Gambling had long been one of the chief vices of Panama. It was one of the worst features of the régime of the French canal companies. The purveyor of lottery tickets and the tout for gambling dens dogged the heels of the paymaster, and a large share of the wages paid went quickly into the pockets of professional gamblers. It is now determined that there shall be no more gambling within the limits of the Canal Zone, and that means that there will be none within reach of the vast majority of the canal employees. 
This is a gratifying assurance for morals, for industry, and for thrift, and it will serve as another of those valuable object lessons which Americans are giving to the Panamans, and which the latter, it is encouraging to observe, appreciate and use to their own profit.

Early in 1906 two more decisions were made with a view to facilitating and expediting the work of canal construction. One was made on January 8 , by the President, the Secretary of War, the Chairman of the Canal Commission, the Chief Engineer, and the United States Civil Service Commission, to the effect that the civil service rules and regulations, devised for use in the United States, should not apply in Panama, in the employment of what were termed in a general way "ontside men,"-that is, track layers, skilled labourers, foremen, etc. To other classes of employees, stenographers, clerks, bookkeepers, and other "inside men," the rules were to continue to apply. The other decision was made by Congress, a month later; to the effect that the eighthour labour law should no longer be enforced upon the Isthmus. It was recognised that that law, devised for the benefit of American labourers in America, was not suited to the conditions at Panama, where the labourers were nearly all aliens, who had never even heard of the eight-hour law before and who had no desire for its application. The enforcement of that law would, therefore, benefit nobody and please nobody, but would greatly delay the completion of the canal and increase its cost. 


\section{CHAPTER XIX}

\section{STULTILOQUENTIA}

THE progeny of Gifted Hopkins is numerous and vociferous. There is no important subject upon which much nonsense is not spoken, and there is no great work concerning which there are not counsels of folly. In most cases we may perhaps concede these to have been the output of honest ignorance, or of that intrepidity and precipitancy of judg. ment to which the human mind is too often prone. When the Quarterly Review declared a man might as well ride upon a Congreve rocket as upon a railroad train at twenty miles an hour, it was doubtless sincere, and not moved by malice against Stephenson. We may say the same of Thiers, with his cocksure pronouncement that, however useful railroads might be for some purposes, they could never be of value for transporting freight. Lardner was doubtless animated by a purely scientific spirit when he argued that no steamship could carry enough coal to feed its engines on a voyage across the Atlantic. The railings against the Erie Canal were perhaps less honest, having a strong tincture of partisan politics; and the British prophecies that the Suez Canal would never pay its cost were probably in part inspired by jealousy of the French builders of that great highway. In the case of Panama, there has been more folly emitted than in any of these others, and it has been of a distinctly lower type, marked chiefly either with deliberate malice or with a crass ineptitude most urgently requiring the fool-killer's attention. It would require a large volume to contain even a synopsis of the half-foolish and half-malicious stuff which has been spoken, written, and printed about various phases of the Panama enterprise in the last three years. The compass of this chapter would not 
suffice for a mere catalogue of it. But it may serve the purpose to cite just a few samples of its chief types. Ex pedeThersitem!

One of the first propagandists of folly, in point of time, was employed by a political organisation in the United States, to go into a foreign land and there lampoon and libel his own country and its government for the sake of hoped-for partisan advantages in a political campaign. He went to Colombia in December, 1903, right after the Panaman revolution, and sought to cultivate the acquaintance of the President, Dr. Marroquin. He represented himself as the agent of the newspaper press of one of the great political parties of this country, which was strongly opposed to President Roosevelt's administration and especially to his policy toward Colombia and Panama. He had come, he said, to investigate and to report upon the "situation of Colombia with regard to the painful occurrences upon the Isthmus of Panama." "There prevails in my country, with respect to this matter," he said, " a great sentiment of sympathy for Colombia; and the acts and attitude of the Roosevelt government are regarded with profound repugnance." He, therefore, sought "such information and opinions as shall enable the American people to make a decision in favour of your excellency's government and the people of Colombia." That is to say, he was confessedly seeking, in a foreign land, mud to throw at his own government! The political ethics of Colombia have not always been of the highest type, but they were far too high for such a scheme as that, and Dr. Marroquin pretty promptly and curtly declined to lend himself to the tainted scheme. He answered the applicant with a few words which produced "the most painful impression." Thereupon this precious propagandist betook himself to Panama, as the accredited agent of a political organisation, and there, in September and October, 1904, during the Presidential campaign in the United States, busied himself with trying to prove that Dr. Marroquin-who by this time was dead and unable to defend 
himself against such attacks-had been a perjured and sordid knave, who had conspired with President Roosevelt to betray Colombia for American gold! The astounding fiction was evolved that President Roosevelt, through Secretary Hay, had bribed Dr. Marroquin, with $\$ 250,000$, himself to foment the Panaman revolution and so turn the Canal Zone over to the United States. Cipher despatches were actually sent by this accomplished discoverer of mare's nests from Panama to his political employers in the United States, declaring that if he were supplied with sufficient funds he could secure documentary proofs of such a bargain! Doubtless he could have done so. The supply of fiction is always adequate to the demand, especially under the potent inspiration of "Culebra cocktails." I do not think the slightest perceptible result was produced upon the United States election by this fantastic folly, but I do know that the joy of Panama was materially enhanced by it. For many a week thereafter the very mention of that versatile propagandist's name, whether in a club on the Cathedral Plaza or in the less conventional purlieus of the road to "Section," was an unfailing and irresistible provocation to something more than Homeric mirth.

Another outbreak occurred a year later. At the beginning of September, 1905, the corner stone of a new school building was laid at La Trinchera, in the presence of the President of Panama and his Cabinet, and an oration was pronounced by a prominent young member of the Opposition party. Immediately it was announced, and bruited over the world, that the speaker had bitterly referred to the impending spoliation of Panama by the United States, and impassioned homilies were published upon the wickedness of America's thus oppressing the little republic, and we were warned-all this stuff in our own American press, of course-that when the Liberals came into power in Panama there would be resistance to the bitter end against our confiscatory schemes. It is quite true that he did speak of the Republic of Panama as being about to be "rent in twain by the iron hand of Amer- 
ica," but there was scarcely a person in the audience who did not understand what was, of course, his meaning-that America was going to cut a big ditch across the Isthmus ! $\mathrm{He}$, in fact, welcomed that prospect, as assuring the future greatness of Panama.

I remember, too, another case, in which a probably wellmeaning descendant of the illustrious Hopkins, in an important magazine article, dolefully descanted upon the primitive and barbarous conditions which prevailed along the line of the canal. When this pious pilgrim visited the labourers' camp at Culebra, he found there actually no pavements on the sidewalks. Neither were there electric lights. He could find no resorts of entertainment and social culture, excepting a reading room and a café, the latter, by the way, deserted! Beside all of which, it rained! Men familiar with similar camps in the United States will appreciate the unrelieved horror of the situation, and will join with that scribe in condemning the American Government for trying to dig a canal without first establishing squash courts and automobile garages all along the line, and changing the climate so that it could be depended upon not to rain when distinguished visitors were in town.

At the risk of tediousness, I must quote somewhat at length a really notable gem of anti-Panaman literature, which has recently been widely current. Here it is:

"A land as feverish to the imagination as to the body is Panama. It is a land making a fitting environment to the deeds of conspiracy, piracy, loot, cruelty, and blood that have principally made its history for centuries. This gloomy, God-forsaken Isthmus is a nightmare region. One descriptive writer has truly said of it that it is a land where the flowers have no odour, the birds no song; where the men are without honour, and the women without virtue. He is not far wrong. The birds, brilliant as is their plumage, have no musical notes. The dense forests teem with bright-hued parrots, parroquets, and other birds, which squeak and scream but do not sing. There are beautiful orchids to be found in the swamps and jungles, fair to look upon, but they have no odour. The oranges have green skins, instead of 
golden, the plantains must be fried to make them fit to eat, the reptiles and insects are often venomous, and myriads of parasites are ever ready to invade the human body and bring disease and death. In the atmosphere itself is something suggestive of the days of the old pirates and their fiendish cruelties and orgies. There is no life in the air; it is depressing, damp, miasmatic, and intensely hot. For a great part of the year thunder showers succeed each other all day long and half the night, with sheet lightning all around the horizon after dark. There is practically no twilight, day passing almost instantly into night. It is no wonder that this uncanny land has made its residents degenerate into plotters, revolutionists, murderers, and thieves. Its aspect is one of darkness, treachery, and curse."

Now I wonder if the author of that precious twaddle really regards a land of exceptionally brilliant and profuse sunshine as "gloomy." I wonder if he is really ignorant of the fact that it is the rule in all tropical lands, and indeed to a considerable extent in all the world, that the most brilliantly coloured birds are songless and the singers are of plain and inconspicuous dress; and that the gaudiest flowers are destitute of sweet perfume. Did he never compare a blue-jay with a cat-bird, or a wood-duck with a nightingale? Did he never observe the differences between a peony and a violet? It is quite true that at Panama the oranges have green skins. So they do everywhere, before they are ripe! It is true that plantains are better fried than raw, as they are in Jamaica, and New York, and everywhere; though they are better raw in Panama than in almost any other part of the world, and are eaten raw there as often as anywhere else. Of course, there is little twilight; but does anybody suppose that is a condition peculiar to Panama and unknown in other tropical lands? As for the monstrous fling at the people of Panama, it could not-save in an ignorance scarcely removed from criminality-have been made by any one capable of appreciating either the honour of men or the virtue of women. I should not have quoted the offensive stuff, save for the purpose which is sometimes served of putting a bit of carrion in the pillory. 
One more example of stultiloquentia running amuck, and I leave this unpleasant phase of my subject. I refer to Mr. Poultney Bigelow's screed on "Our Mismanagement at Panama," in the New York Independent, of January 4, 1906, chiefly for two reasons. One is, that its writer's name is somewhat more conspicuous than the names of most of the other purveyors of misinformation and malice who have expended their ignorance or spleen upon Panama, and the other is, that it was deemed of sufficient interest to be the subject of Executive inquiry and Congressional investigation. But $I$ am at a loss to know whether to regard it as the more malicious or absurd. Certainly nothing could be more preposterous than the pretensions to encyclopædic wisdom which are put forth in the article, when contrasted with the meagreness of the writer's information and of his opportunity for acquiring information.

"I have had," says Mr. Bigelow, "abundant opportunity to hear the views of opposing witnesses, but I have also been in a position to examine on the spot many things which have so far been conspicuous by their absence in so-called 'official' and authoritative reports. ... I made a houseto-house visitation throughout the best part of a blazing hot day. . . . One day I stopped to chat with a well-dressed, intelligent, and energetic negro. . . . Next day I came to the same place for another chat. He was not there. . . ."

The facts are that $\mathrm{Mr}$. Bigelow reached Colon on the steamer Trent, at 10 a. m. on November 30, went across to Panama, returned to Colon the same evening, and sailed away at $2.10 \mathrm{p}$. m. on December 1 . Thus he spent precisely twenty-eight hours and ten minutes on the Isthmus, half of that time being a holiday when no work was done. The "abundant opportunity" was all within that brief period. The "best part of a blazing hot day" was presumably the forenoon of December 1 , just before he sailed. The "one day" and the "next day" were the only days he spent at Panama. Note, also, that his article, which was published in New York, on January 4, 1906, was dated, as a letter, at 
"Panama, December, 1905," as though it had been written at Panama and sent on from that place where he was still remaining; when, as a matter of fact, it was not and could not have been written there, for it bears intrinsic and confessed evidence of having been written at least some days later, at some place remote from Panama.

The specific charges against the canal management which Mr. Bigelow made were specifically answered by Mr. Stevens, the Chief Engineer. Mr. Bigelow's information as to the awful unhealthfulness of Colon seems to have been derived largely from a man who had lived there for more than forty years and had all that time been in splendid health! The "vast hordes" of negroes whom Mr. Bigelow saw fleeing from the Isthmus had been employed there for the best part of a year, and were going home to spend the Christmas holidays. The quarter-mile awning which Mr. Bigelow saw stretched over a ditch, which he was told was "to protect the workmen from the sun," and which tale he believed because "no one could invent such midsummer madness," was really put there to protect the concrete lining of the drain from rain until it had hardened. Concerning the new hotel at Corozal, said Mr. Stevens, "Mr. Bigelow's statement that it is deserted is absolutely false. Every room is occupied, and has been since it was opened." The "big new dredges at the Culebra cut" were not dredges at all but steam shovels. "The statement that there is no water supply at Colon is absolutely and unqualifiedly false." In such manner, with citations of facts, figures, and indisputable evidence, Mr. Stevens traversed and refuted practically every serious accusation made by Mr. Bigelow. On some essential points further refutation was provided by Governor Magoon. In summing the matter up in an official report to the President, Secretary Taft said:

"I learn from the isthmus that the writer arrived in Panama on the Royal Mail steamer Trent from Jamaica, and left by the same steamer. The steamer docked at 10 o'clock on the morning of November 30, and sailed at 2 o'clock on the 
afternoon of December 1. Assuming that after landing and docking the writer at once began work, it is not unfair to say that his opportunities for observation were limited to twenty-eight hours, including daytime and nighttime. It would seem not to be a very long period in which to look carefully into and determine the character of the engineering difficulties of the greatest constructive enterprise yet undertaken by man, the efficiency of tropical negro labour, the healthfulness of a city, the proper place to put dredges, the proper amount of capacity to obtain from steam shovels, the character of the administration of justice, the proper position of hotels along the line of the road, the question whether a sewer system should be adapted to Panama at all, or whether the sewer system as established was sufficient for the purpose. Nor does it seem to offer the abundant opportunity for examining opposing witnesses on controverted issues which the writer of the article assures us that he had. The 'many things on the spot' which he says he was able to examine must, therefore, be taken with some qualification. In view of the time which this critic-a man with no knowledge of engineering whatever-took to decide all the questions which arise in the construction of the canal and pronounce them of altogether vanishing difficulty, he should not take exception to the seven or eight days which twelve of the most distinguished engineers in the world in canal construction devoted to the same task.

"The writer of the article says that he proposes to state the truth from the standpoint 'neither of an officeholder nor an office seeker, much less that of a disappointed contractor or an invalided labourer ;' that 'he has had abundant opportunity to hear the views of opposing witnesses' and was in a position 'to examine on the spot many things so far conspicuous for their absence in so-called "official" and authoritative reports.' It will be observed that from the beginning to the end of the article the writer shows that instead of seeking evidence from the officials responsible for the work on the Isthmus he deliberately avoided consulting them or giving them any opportunity whatever to state their knowledge or explanation of the facts which he says had attracted his attention. When the actual facts are compared with the statements in this article it gives rise to doubt what the real explanation of the article is-whether it was written from such a wanton motive as actuates a pure sensation monger or whether it arises from the exaggerated eccentric- 
ity of mind which furnishes both an excuse and an explanation."

If I have thus devoted more space to Mr. Bigelow's attack upon the canal administration than the importance of it may seem to some to warrant, it is because of all such attacks his was apparently the most studied and detailed, and of all who have made such attacks he was the best known and the most likely to command attention and credence. If, therefore, his attack was not important, it was at any rate the least unimportant of them all. In one respect it was highly important, and that was, as an exposure of the weakness of the enemy. It was with reason said on every hand that if that was the most destructive criticism that could be directed against the canal administration, then that administration must be pretty nearly sans peur et sans reproche, and the net result unquestionably was to discredit all other attacks upon the administration and to confirm it more strongly than ever before in public confidence.

Nevertheless, even though good be thus brought out of it, evil remains evil still; and it would be difficult to find a way of absolving Mr. Bigelow-or his article-from the imputation either of evil intent or of evil ignorance. If his misstatements were made knowingly, Mr. Stevens's characterisations of them, in stronger terms than any I have quoted, must be deemed well deserved. If they were made ignorantly, what is to be said of the ignorance that assumes omniscience? It is just possible, however, that there is a third explanation, beside the two suppositious ones already named, and that it is the true one, to wit, habit. Account must be taken of idiosyncrasies. Almost simultaneously with the publication of this diatribe in New York there appeared from Mr. Bigelow's pen in a leading London journal-The Outlook-an attack upon the American army administration which I can scarcely describe with a milder word than malignant. Taking for his text some statements of Secretary Taft-whom he repeatedly called "my illus- 
trious friend"-in defence of the American army against some German criticisms, this American writer in a foreign journal assured his foreign readers that "during the Spanish war of 1898 the military authorities at Washington treated the army mainly as a means of political jobbery;" that "the commanders of brigades, divisions, and army corps were as a rule profoundly ignorant of elementary military matters;"-to wit, Generals Miles, Wheeler, Shafter, Lee, Chaffee, Lawton, Brooke, Merritt, Grant, Wilson, Stone, MacArthur, et al.; that "our generals are mainly conspicuous for not having been educated at West Point;" that "the American army is not fit to take the field to-day. The same spirit which made it the tool of political jobbers during the Spanish war is dominant to-day," et cetera. If these strictures and railings had been true, the publication of them in an American paper might have been entirely justifiable, and commendable. But to select a foreign medium and a foreign constituency for the publication of such a belittlement of one's own country, might well be regarded as indicating a mental habit as much at variance with patriotic manners and morals as that shown in the Panama article was at variance with truth.

It was in reviewing such utterances as those which $I$ have cited in this chapter, of which the name, all through the year 1905, was legion, that President Roosevelt, on January 8,1906 , wrote in a message to Congress:

"From time to time various publications have been made, and from time to time in the future various similar publications, doubtless, will be made, purporting to give an account of jobbing or immorality or inefficiency or misery as obtaining on the Isthmuśs. I have carefully examined into each of these accusations which seemed worthy of attention. In every instance the accusations have proved to be without foundation in any shape or form. They spring from several sources. Sometimes they take the shape of statements by irresponsible investigators of a sensational habit of mind, incapable of observing or repeating with accuracy what they see, and desirous of obtaining notoriety, by wide-spread slan- 
der. More often they originate with or are given currency by individuals with a personal grievance. The sensation mongers, both those who stay at home and those who visit the Isthmus, may ground their accusations on false statements by some engineer, who, having applied for service on the Commission and been refused such service, now endeavours to discredit his successful competitors, or by some lessee or owner of real estate who has sought action or inaction by the Commission to increase the value of his lots, and is bitter because the Commission cannot be used for such purposes, or on the tales of disappointed bidders for contracts, or of officeholders who have proved incompetent or who have been suspected of corruption and dismissed, or who have been overcome by panic and have fled from the Isthmus. Every specific charge relating to jobbery, to immorality, or to inefficiency, from whatever source it has come, has been immediately investigated and in no single instance have the statements of these sensation mongers and the interested complainants behind them proved true. The only discredit inhering in these false accusations is to those who originate and give them currency, and who, to the extent of their abilities, thereby hamper and obstruct the completion of the great work in which both the honour and the interest of America are so deeply involved. It matters not whether those guilty of these false accusations utter them in mere wanton recklessness and folly, or in a spirit of sinister malice to gratify some personal or political grudge."

To that, we may well add that it is high time we were at an end of this flood of folly and worse than folly, and were at least within measurable distance of an end of the discussions and investigations of Panaman affairs which have been so copious for most of the time since the great enterprise was undertaken. That view of the case was well expressed by Secretary Taft, in a public address at Detroit, Michigan, in February, 1906. He had been speaking of the then current investigation into canal affairs, and had made it clear that neither he nor the President nor anybody else in authority shrank from the most searching scrutiny of everything that had been done. But, he continued:

"After one thorough investigation has been completed and every truthful man and every liar has been heard, then let 
the work go on. You can't be answering questions and building a canal at the same time. You can't have the chief engineer and the other constructing officers engaged in that work both in Washington and on the Isthmus. Therefore, I say that all those who wish to be heard ought to be heard now, or ever after hold their peace."

There spoke the voice of common sense and justice. Discussion and investigation have doubtless been necessary. But some day there should be an end of them, and that day should be somewhere this side of the Greek Kalends. 


\section{CHAPTER XX \\ THE NEXT THINĞ}

Tue task before us at Panama is well begun. Despite the proverb, however, it is not half done, and it will not be done years hence when the canal is opened to the commerce of the world. It is a never-ending task which we have undertaken, a perpetual responsibility which we have assumed. That is a fact which should be well borne in mind. "Do the next thing" is a wise counsel; and we may supplement it with many others to the same effect, from the divine "sufficient unto the day is the evil thereof," to the homely adjuration not to cross a bridge until we reach it. But there is an equal marshalling of authorities to the contrary effect, that it is not wise to begin building a house until the plans are drawn and the cost is counted. Assuredly it would not be wise to engage in a permanent undertaking upon a temporary basis. In every detail of our work at Panama, therefore, it is to be remembered that we are doing a work for all time; whether in engineering, or in sanitation, or in the establishment of political and social relationships with the Isthmian people.

That was one powerful argument in favour of a sea-level canal, as I have already tried to show. If we were constructing a canal for ten or twenty years, one at high level might be preferable, and would certainly be the less expensive. But we are making a canal for all time, to be in $u$ : as long as the trade winds sweep the Caribbean and the tides of the Pacific rise and fall. The plan of it should, therefore, be determined and adopted with such destiny in view. And there are still those who hold that, despite the contrary decision now made and the high-level plan now adopted, we 


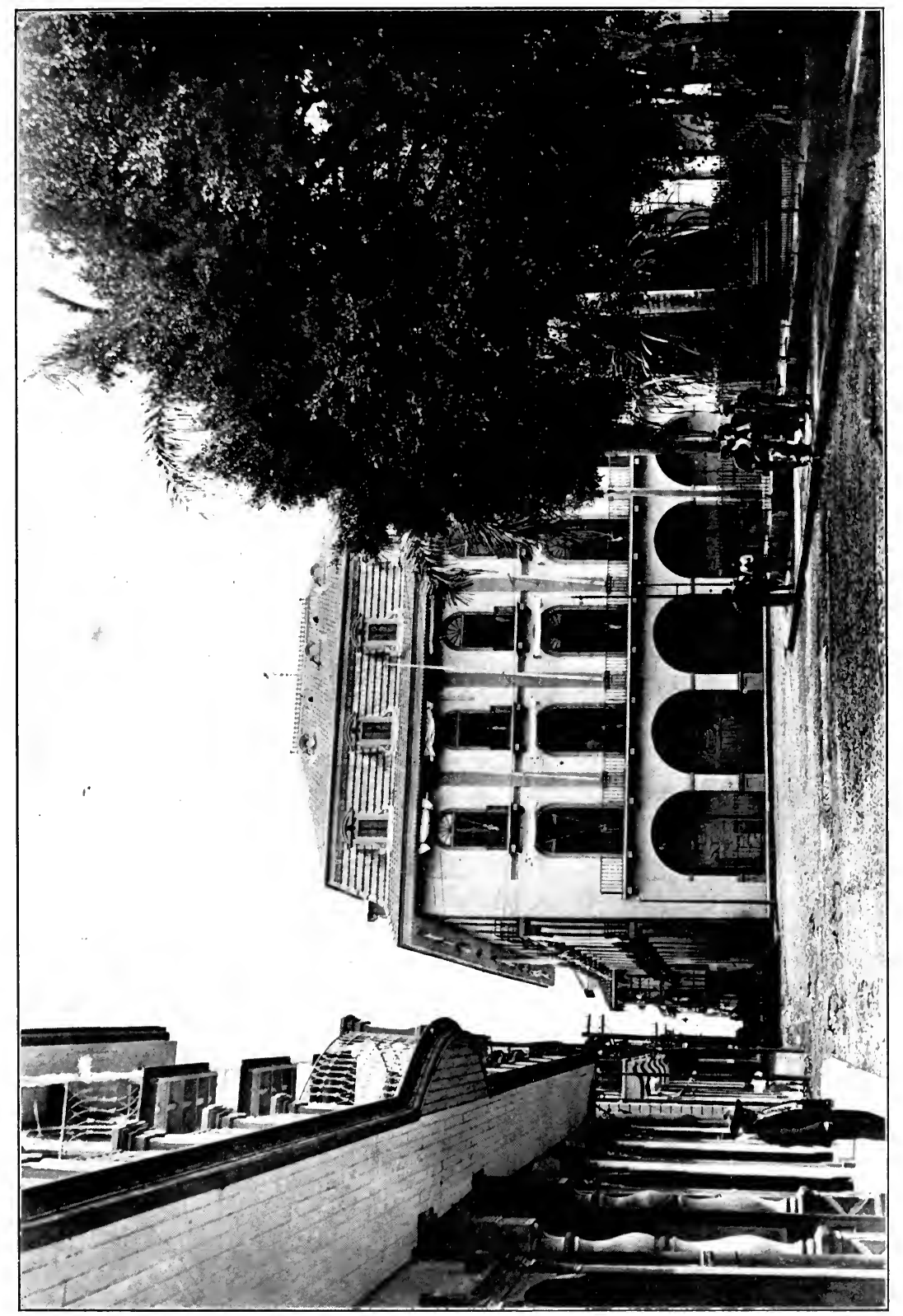

S 

shall in time have to come to the sea-level plan. The question is whether we shall secure for ourselves and for posterity the advantage and the reward of a wise forethought, or shall incur the inexorable penalty of cowardice and delay. Surely it would seem that the fulfilment of the world's desire of four centuries in the completion of an equatorial waterway around the globe is an enterprise more worthily to be achieved in a Promethean than in an Epimethean spirit.

The same is to be said of the adjunct and auxiliary works. There are harbours to construct; perhaps, on the Caribbean, a new terminal city to build; the appurtenances of civilisation to supply throughout the Canal Zone. These are not simply to be done for the construction of the canal, during the next five or ten or fifteen years, but for the perpetual maintenance of the canal for uncounted centuries to come. It was a heroic task to get rid of yellow fever in the summer of 1905. But what is it going to be, to keep the Isthmus free from that and other pestilences "far on, in summers that we shall not see," in 1955, and 2005? Is that looking too far? We must respect the future, said Jacques Cartier. There are those who would interpret that to mean that we should not overtax ourselves with efforts and expenditures for the remote future, but should leave a share of the burden for the future itself to bear. That in a measure is true. But a no less true interpretation is that we are not to impose upon the future the handicap of our weakness and cowardice, nor to compel it to undo the ill-devised deeds of our shortsighted blundering. It might be well to leave the pecuniary cost of the canal to be paid little by little through the next century, or the next five centuries. It would not be well to turn a single spadeful of soil or to lay a single stone for some future generation to undo. "Sufficient unto the day is the evil thereof," and sufficient unto the future days will be the tasks of that time, without a legacy of our ineptitude.

This principle applies with peculiar force to the question of labour on the canal. There is a vast amount of work to be done, and of manual work despite our utmost introduc- 
tion of machinery. It is reckoned that as many as 25,000 workmen, efficient according to the American standard, will need to be employed, if the canal is to be constructed with all possible expedition. Now the efficiency of labour in the United States is about three times as great as that in Panama. To secure such a working energy, therefore, it will be necessary to employ something like 75,000 men. That will be a formidable army, equal in numbers to the entire adult male population of the republic. It will be no easy task to secure such hosts of workingmen, and from the political and social point of view it will be no light thing to introduce them into the Zone and into the Republic of Panama.

There arises at once the question whether they are to be introduced for the temporary purposes of canal construction, or as permanent residents of the Isthmus. Beyond doubt, I think, the latter would be preferable, provided they were of proper character. Panama needs more men. The population of the state is not more than a tithe of what it should be. Belgium, scarcely more than one-third as extensive in area, has twenty-two times as many people. Bulgaria, only a little larger than Panama, has ten times its population. Switzerland, only half as large as Panama, and with so much of its area uninhabitable, has ten times as many people as the Isthmian republic. Nor need we confine ourselves to comparisons with distant lands in another zone. The neighbouring Republic of Salvador has scarcely a quarter of Panama's area, yet has more than three times its population. Hayti has only a third of Panama's area, yet has four times its population. Nor is there any natural inhibition against the increase of population on the Isthmus. Climate and soil and products are all well calculated for the prosperous maintenance of ten times the present number of inhabitants. We need not here enter elaborately into the causes which have retarded growth. They have been sufficiently indicated in the story of Panama's misgovernment at the hands of Colombia, with all the attendant wars and revolutions, the neglect of sanitation and other public interests, and the general 
prostitution of Isthmian interests and welfare to the passions and greed of Bogotá. With the new era that was established in 1903, a marked change in the Isthmian census should be effected.

It would be desirable, then, to increase the population of Panama by introducing an army of workmen for the canal who would remain as permanent residents after the completion of the canal. But in that case, as I have already hinted, they must be men of desirable character, from both the Panaman and the American point of view. They must be such as would be congenial and acceptable to the present people of Panama, and would be worthy citizens of that republic; and they must be also well disposed toward the United States and its administration of the Canal Zone and its protectorate of Panama. It would be criminal to introduce an element which would be antagonistic to the Panamans, and it would be one of those blunders which are worse than crimes to plant upon the Isthmus a numerous colony hostile to the United States. From what source, then, could we secure a permanent industrial army answering these requirements?

The answer, I fear, must be that there is no adequate source. Workmen can doubtless be secured, but not enough of them of a kind desirable for citizenship in Panama. For to be thus desirable, or even acceptable, they must be of the Caucasian race. This is to be said without the slightest prejudice against either the black or the yellow race, but with the fullest sympathy with them and the fullest appreciation of their excellent qualities. But even those who-like myself-most strongly condemn the savage proscription and persecution of Chinamen which was begun by the hoodlums and criminals of the Pacific Coast and which-through agencies too well understood to require elucidation-have now become potent throughout the land, even we, I say, would shrink from the prospect of introducing say ten million Chinese coolies into the United States. Well, proportionally, it would be as bad as that to introduce fifty thou- 
sand of them into Panama. There are already, I think, more Chinese in Panama than in the United States, proportionally; and the Panaman government is certainly as much justified as our own in prohibiting their further immigration. Those who are already there are treated with a degree of courtesy and justice which makes the American observer blush at the contrast it presents to the savagery of New York, San Francisco, and Rock Springs. But to the increase of their number to an extent which would make them oneseventh the population of the whole republic, Panama not unreasonably nor unrighteously objects.

Neither would it be well to plant there so large a permanent colony of the negro race. In saying this there is no thought of prejudice against the negro. But it is not well to transform a white man's country into a black man's country; and especially it is not well to plant the seeds of racial antagonisms in a country where that noxious plant has hitherto been unknown. At the present time, the white race is the dominant race in Panama, though there is no discrimination whatever against the coloured race. A negro is as good as a Spaniard in Panama, provided his character and capacity are equal to the Spaniard's. Or if there is any disposition to treat the negro as an inferior, it has been introduced there by Americans. As to numbers, I believe the negroes equal and perhaps outnumber the whites, and might be able to outvote them and control the government if they were so disposed. But they are not so disposed, but amicably acquiesce in an almost purely white government. That is partly because the whites treat the blacks with so much friendliness and equity that the blacks feel their interests to be quite safe in white men's hands without any need of their own self-assertion; and partly because the negroes have no particular taste or aptitude for politics, while the white Panamans are born politicians and possess the genius of government in an eminent degree. So long as matters remain in their present general condition, therefore, we need fear for Panama none of the brutal race conflicts which have 
disgraced America from New York to Texas. But if from fifty to seventy-five thousand negro labourers were permanently colonised in Panama, and were made citizens of the state, Panama would be made a "black republic" almost as much as Hayti is to-day. With negro voters outnumbering the whites more than two to one, the opportunity for illadvised or unscrupulous ambition would be dangerously great, and we should probably soon see there a political and social war of races which would be disastrous to the property and progress of Panama, and embarrassing in a great degree to our own administration of the Canal Zone.

If then we rule out the yellow and black races from extensive colonisation in Panama, whence are the tens of thousands of recruits to be drawn? There have been various suggestions, chiefly futile. I have heard it gravely proposed that colonies of Russian refugees, Jews or others, should be planted there. Some Russians have, I believe, settled in Mexico and are reported to be doing well. But the idea of transplanting extensive communities from sub-arctic to tropical latitudes does not commend itself to reason. Another suggestion was that Boers should be brought from South Africa. From the climatic point of view that seems not impracticable, for the Transvaal lies within the semitropical zone. But the Boers are, of course, not sufficiently numerous to provide the labour needed at Panama without depopulating their own land of all save those whom they used to call Outlanders; they indicate no desire to emigrate in any considerable numbers; and they would certainly prove irreconcilably antagonistic to the Panamans, and uncommonly difficult for American administrators to deal with. The hosts of emigrants from Europe who now come to our shores are, with the exception of the Italians, unsuited for labour in the tropics. For the same reason, of course, we must rule out our own people, the white men of the United States. I have been confronted with the inquiry why, if we are eliminating yellow fever and making the Isthmus healthful, an army of American labourers cannot safely go 
thither and do the work. The answer is easy. We can make Panama sanitary, but we cannot make it temperate in climate. Tropical it is and tropical it will remain; and Americans will not and cannot successfully engage in habitual and severe manual exertion in the tropics. Moreover, Americans who can earn high wages at home will not go to Panama to work for low wages. Engineers, foremen, draughtsmen, and the large clerical force, can, of course, be taken from the United States, and in such capacities there are and will be many desirable opportunities for young Americans of ability and character, and of common sense enough to live in proper fashion in the tropics and not get hobnails on their livers through recklessness in food and drink. But American workingmen have no call to Panama, any more than English workingmen have to the plains of India.

There remain the peoples of the two great southern peninsulas of Europe. Spain is not commonly thought of as a land of considerable emigration. Its less than $19,000,000$ people do not overcrowd it. Nor do we regard the Spanish as a conspicuously industrial race. Yet, in fact, many Spaniards do go abroad each year, and they are capable of splendid efficiency in industrial pursuits, even in the hardest forms of manual labour. It might not be possible to get anything like a sufficient number of workingmen from Spain. If it were possible it would be a most advantageous thing to do, and it would be well in any case to encourage as large an immigration to Panama from Spain as maý be secured; because such colonists would be in admirable accord with the existing population of Panama, and would make a homogeneous and harmonious addition thereto.

The Italians have already been mentioned. Their splendid physical efficiency is amply known in the United States, as are also their devotion to duty, their ambition, their frugality, and their adaptability to new modes of life. They would probably get along well with the Panamans, and would form a valuable addition to the permanent population of the Isthmus. Of their ability to endure the climate there need be 
little question. Each year now sees hundreds of thousands of them go abroad, chiefly to the United States and to Argentina and Brazil. It would be an admirable stroke of policy, from every point of view, to divert a part of that great stream of migration from our own shores to Panama. We do not need so many Italians here, and we do need them in Panama, and Panama needs them to cultivate her waste places and to transform the jungles into gardens.

Such are the possible-and impossible-sources of labour, if that labour is to remain permanently in Panama. There remains the other course, less desirable, of securing a sufficient force of workmen for the construction of the canal, with the understanding that when that task is done they will depart from the Isthmus. That plan must be adopted if suitable permanent colonists cannot be found, and in that case it will probably be best to look to China for a supply. It is true that Panama has a strict Chinese exclusion law, which it will probably be necessary to maintain. But even with that law in force it would be easy to make a contract with some of the great Chinese companies, for the supplying of so many thousand labourers, who would live at Panama within a certain pale, and when their work there was done would return to China. Precisely such an arrangement has been effected in South Africa for the working of mines, and, despite the political campaign clamour which has been raised against it, it seems to be reasonably successful and satisfactory. I can see no convincing argument against the adoption of such a system at Panama, while the arguments in its favour are many, obvious, and strong. There can be no doubt of the ability of the Chinese to endure the climate and to do the work with marked efficiency. Their labour would be inexpensive, and they would be exceptionally trustworthy and easy to govern; while their return home could be much more readily and certainly assured than that of any other temporary levy.

We must remember, too, that we are not merely doing at Panama an immense physical work that is to endure, under 
our control and responsibility, for all time. We are also entering into political and social relations with an alien people, and those relations, in some form, are to endure for all time. Concerning that feature of the case, of unsurpassed interest and importance, three things may be asserted with confidence. One is, that we do not wish to annex Panama, nor to subvert nor interfere with its autonomy further than is provided in our treaty with that republic and in its own Constitution. The second is, that we do intend to maintain our protectorate over Panama and our special and exclusive privileges-and responsibilities-there. The third is, that we desire these relations to be maintained in a spirit of mutual amity, confidence, and contentment. It would be a most unwelcome-I might almost say, an abhorrent-thing to be compelled for any reason to reduce Panama to the condition of a subject province, or to add it to the category of those alien possessions which were forced upon us by the logic of an unsought war, and which are to us to-day a "white man's burden" which is heavy and costly to bearthough we shall doubtless bear it unflinchingly as long as necessity or duty may require. It would be no less unpropitious for us to lose our hold upon the Isthmus in any way; the hold which we have had, for its profit and our own, not merely since the treaty of 1904 , but since the treaty of 1846 was signed. Assuredly, it would be intolerable to have our permanent relations with Panama incessantly or even periodically marked with friction and irritation.

How, then, are we to insure the permanence of pleasant relations between America and Panama? I would answer, first of all, that we must treat Panama with justice. The Panaman sense of justice is as highly cultivated, and the Panaman sensitiveness to and resentment of injustice are as keen, as our own. I shall never forget an incident of Secretary Taft's visit to Panama in 1904-to which I have already devoted a chapter. At the state banquet in his honour on the evening of December 1, at which were present the representative men of Panama, of all parties, he said in the 
course of his address that since his arrival there he had become convinced "that justice had not been done to Panama." The approving applause was instantaneous, spontaneous, electric, universal, tremendous. The whole heart of Panama, without regard to party, responded to that sentiment, nor was there a whisper of dissent from any of the well-informed Americans present. There were two possible interpretations of those words. One was, that justice had not been done to the climate, the resources, and the attractiveness of Panama. The other was, that Panama had not been justly treated in the customs and postal arrangements between it and the United States. There was some doubt, among some, as to which of these things the speaker meant. I have purposely refrained from asking him. But I think that it may safely be assumed that, whichever thought may for the moment have been uppermost in his mind,-for he spoke entirely ex tempore,-upon mature reflection he would have meant and did mean both. Indeed, only four days later, speaking again from almost the same place, he made it quite clear that he did mean both those things.

There can be no question, however, of the interpretation of his words which instantly sprang uppermost in the mind of every one of his Panaman hearers. It was the latter of the two. They had felt for months past that they were being unjustly treated-as they were. They had been divided in opinion, some holding that the injustice was intentional and would be arrogantly persisted in by the irresistible northern power, and others declaring that it was unintentional and would be abated as soon as the state of affairs was made clear to the American government. Secretary Taft's visit, therefore, was crucial. It was to determine and to demonstrate which of these views was correct. Until he arose to speak that night, he had given no intimation as to what he thought of the matter. But in almost the opening sentence of his address he made the unequivocal declaration which I have quoted. That settled it. In that instant he won the loyalty and the affection and the confidence of Pan- 
ama as America had never had it before. The Panamans, some to their pleased surprise and some to the welcome confirmation of their hopes, realised that the injustice they had suffered had been unintentional, and that the American government was great enough and brave enough to admit and to repair its inadvertent fault. I doubt if in all the story of our dealings with Panama there is an utterance or a deed more auspicious of good, or more significant of the true policy to be pursued, than was that pregnant sentence in an after-dinner speech.

We must, in the next place, act with firmness, and with consistent firmness. We must do that, for the maintenance of our own rights and privileges, and also for the protection of Panama alike from external foes-which are little to be feared-and from intestine disorder-which is not beyond the bounds of reasonable apprehension. Let me revert again to that speech of Mr. Taft's to say again that some of the very heartiest and most universal applause-I am convinced it was as sincere as it was tumultuous-was given to his declaration that the United States would countenance no political revolutions in Panama other than those constitutionally effected at the polls. The approval of that declaration was, indeed, no less positive than that which greeted his statement concerning the doing of justice to Panama. The people of the Isthmus want justice. But equally they are willing to submit themselves to such American authority as they have in their Constitution formally accepted. They realise the inexorable force of the familiar principle, that authority and responsibility must be commensurate and inseparable. They have accepted with gratitude the guardianship of the United States, and they have in equal measure accepted its control.

We must act, moreover, with discretion and with tact. The first part of oratory, said Demosthenes, is action; the second part is action; and the third part is action. Danton, prescribing or describing political success, said "De l'audace, encore de l'audace, toujours de l'audace!" I would that 
some voice of similar authority might impress upon all Americans, official and unofficial, the necessity and the supreme utility, first, of tact; second, of tact; and third, of tact. It would not hurt us to cultivate that quality in our domestic operations. In our dealings with foreign peoples, it is simply indispensable; if our car of progress is not always to be at least a potential powder cart. Nor are there any people in the world toward whom the exercise of tact is more desirable than our Latin-American or SpanishAmerican neighbours at the south. It was all very well for Pinckney to read the riot act to Godoy, and for John Quincy Adams to treat Onis and Vives with New England brusqueness. That was the particular type of tact which those Spanish statesmen needed to have applied to them; and, moreover, we were quite ready and not at all reluctant to accept the consequences, even though they had been militant. Nor should we forget that a great power, such as Spain then still professed to be, can endure bullying much more easily than can a small one. The great power can yield to a peremptory demand as a matter of magnanimous grace, where a small power would feel and would seem coerced and humiliated.

Now Panamans are weak, but they are also proud and sensitive. It would be in our power, of course, to drive them whithersoever we pleased; but they would greatly and properly resent it. It is in our power to lead them in certain desirable and beneficent ways, and for our doing so they will be grateful. But even in leading them instead of driving them, we should exercise tact and discretion. It is not desirable to lead them into all the ways which we ourselves might properly and profitably pursue. For they are Panamans and we are Americans, and there is a difference between us. I do not mean that there is a difference which is significant of superiority on the one hand and of inferiority on the other. Peers differ among themselves. The antecedents of the Spanish people for many centuries have been radically different from those of the Anglo-Saxons. 
Their temperaments and dispositions, their ambitions, their whole mental and spiritual make-up, are different from ours. There could be nothing more foolish and more fruitless than to try to make them like ourselves. Between them and us there are and there will be some things in common, but there also are and will always be some decided differences; and the sooner and the more fully we realise, accept, and act upon that fact, the better it will be for all concerned.

Improvement, not transformation, is needed. We could not make Panama wholly American if we should try, and we could not transform the Panamans into Americans. To attempt it would be both futile and impertinent. Instead, we should seek to promote the development of all that is best in Panama and the Panamans, as Panamans and not as pseudo-Americans. As the latter they would be our inferiors, while as the former they are our equals. We cannot make ourselves Panamans, no matter how hard we try. No matter how long we live there, no matter how well we learn their language, no matter how much we strive to adopt their customs, we remain aliens, awkward and absurd, until the second or third generation. If any American wants to make of himself a butt of merited ridicule, all he has to do is to go to Panama and try to pose as a Panaman. He will find himself inferior to the poorest and most ignorant native. But if he goes thither and remains confessedly an American, he will command respect. Now it is precisely the same with Panamans. They cannot rival us as Americans. But if they remain Panamans, and make the best of themselves as such, they will be entitled to our respect.

What is incumbent upon us, then, is to regard Panama from the Panaman point of view, just as we demand that Panamans and other aliens shall regard America from the American point of view. That is not easy to do, I know. It is not easy, perhaps not always possible, to see ourselves as others see us; and it is no less difficult to see others as they see themselves. But this latter ability is just as much to be desired as the former, and is just as necessary to a 
correct judgment of our neighbours. To each, his own standard. Judged by the standard of New York, Panama would seem a contemptible place. Judged by the standard of Panama, New York would be intolerable. Judged by its own standard, Panama is the equal and perhaps the superior of New York. It has probably more nearly attained its ideal than has the American metropolis. Perhaps the New York standard is the higher and better, in some respects-for New Yorkers, not for Panamans. But that is not the essential point. What we need to recognise is the equality of Panama with America-its equal rights to live its own life and develop its own destiny. No matter if Panama is not America's equal, measured by our rule. No two men in the world are exactly equal; yet we have agreed to regard them as so, for purposes of business and politics and social intercourse. Upon such foundation of equality must we build our permanent relationship with Panama, if the structure is to be enduring and is to be a temple of peace.

Such tactful policy is, moreover, as necessary in private and individual as in official and public affairs. At home we may lay the flattering unction to our souls that we are The People, as much as we please. But that will not work well abroad. The American who goes to Panama and regards the Panamans as "damned Greasers"-as I have known only too many to do-sets himself down at once as a boor and a fool. $\mathrm{He}$ is a boor, thus to treat those upon whose hospitality he has intruded himself; and he is a fool, because he shows himself incapable of appreciating people who in manners and learning are decidedly his superiors. He is and does something still worse. He brings reproach upon his country, and engenders ill-feeling between it and the land he thus maligns. For, generally speaking, a nation is estimated not according to its constitution or its government or its abstract rank in the scale of civilisation, but according to the concrete, individual specimens of its people with whom we come into contact. If a lot of individual Americans go to Panama and call the Panamans "damned Greasers," the 
Panamans will not say-as they might, truly-"These are only a few unworthy Americans, who have left their country for their country's good. The mass of the American people and the American Government are just and courteous." No, but they will say-as we should do in their place-"So! The Americans regard us as 'damned Greas. ers,' do they? Well, who cares what the damned Yankees think, anyway?" Seriously, it is in such fashion that half the international animosities in the world are generated.

There is need, too, that we shall study Panama and the Panamans. Certainly we ought to know as much about them as they do about us. At present we certainly do not. Few things impressed me more at Panama than the perfect familiarity of Panamans with America and American affairs, as contrasted with the ignorance of Americans of Panama and Panaman affairs. The Panamans have visited America. They have studied in our schools and colleges. They are familiar with our social customs. But what do we know of them? It will not do to say that America is worth but Panama is not worth studying. Our own conduct gives that excuse the lie. If Panama is worth going to, as we are going to it, it is worth studying. If the Panamans are worthy of the relationships with them which we, at our own initiative, have sought, they are worthy of study. We have much to teach them, but they have also much to teach us. Especially have they to teach us a lesson of tactful adaptation. The Panaman endeavours to treat his American guest as that American wants to be treated. He studies his tastes, sus. ceptibilities, prejudices, national idiosyncrasies. He says, in effect, "Your ways are not my ways, and I would not like them for myself; but they are yours, and therefore I respect them and cater to them to the best of my ability." Do Americans treat Panamans thus? Some do, and some do not; but it is in proportion as they do so that they establish mutually satisfactory relations with them.

This is a lesson which Americans greatly need to learn in commercial matters, not only in Panama but in all the lands 
of Central and South America. It is a matter of surprise and regret to many that our European rivals so far outstrip us in the markets of those countries. To those who have studied and compared the methods of Americans and Europeans in pushing trade, it is a matter of no surprise at all. A Panaman merchant expressed it to me epigrammatically but most comprehensively, when he said, "The American brings samples, but the European gets samples." That is precisely it. The American commercial agent goes to Central or South America with a case full of samples of goods such as we use at home and such as are not at all designed for use in the tropics, and tries to persuade the people that these are the things they ought to buy and to use, instead of the things they have long been accustomed to and which are especially suited to their needs. "You poor, benighted heathen," he says, in effect, "you ought to give up your ways and manners, your tools and clothes, and adopt such as we Superior People have. You don't know what is best for you. We do. Behold, here are the things you ought to buy!" The German, or the Frenchman, or the Englishman, on the other hand, goes to them with an empty bag, and asks "What kind of clothes do you like to wear? And what kind of tools do you prefer to use? And what are your tastes in this and that and the other thing?" He gets samples of all the things they use, and takes home a bag full of them. Then his employers at home manufacture exactly the sorts of things which he has found out the people want, and they send those goods to them, and sell them at a handsome profit, and get a practical monopoly of the market.

Now that is what we must do, if we are to win the place in the Central and South American market which we desire. We must cater to our customers. We must give them the things they want, and not try to force upon them the things they don't want but which we think they ought to want. In Europe there are vast manufacturing establishments whose wares are never seen in European markets, but are all shipped abroad, for the supplying of foreign demands. And 
the foreign order is faithfully filled, no matter how strange or outlandish it may seem. As a widely and shrewdly observant friend of mine said one day, "It is no business of ours what they want. Our business is to supply it. No matter if it is razors without edges, or guns without triggers, or shoes without soles-if they want such things and are willing to pay for them, in the name of Mercury, god of trade, let them have them!" As a matter of fact, our Panaman friends know what they want and what is good for them a great deal better than we do. They have been settled on that tropical Isthmus for a hundred years longer than we have been settled here, and they understand their natural environment not only better than we do but, I am inclined to think, actually better in some respects than we understand our own.

All this, however, is not to say that we are not to introduce any of our ways and manners at Panama. On the contrary, we must do so, promptly and resolutely, if our enterprise there is to prove successful. Americans cannot live at Panama as the Panamans live, and cannot do in all things as the Panamans do. There must be special laws and customs and institutions provided for the benefit of the Americans who are now there and who will be and must be there in increasing numbers in future. For example, Panamans are largely immune against yellow fever, while Americans are not. Panamans could therefore afford to neglect sanitary precautions which are necessary for the safety of Americans. But for the sake of Americans, it is necessary that the Panamans shall adopt and maintain regulations which seem to them unnecessary. They are willing, of course, to do so. But even with their voluntary and efficient coöperation, the task of keeping Panama free from pestilence is not going to be an easy one. That is not because the place itself is essentially unhealthful, or must remain so, for it can be made almost a tropical sanitarium, but because it is and will be increasingly subject to invasion from all parts of the world. It is to-day a cosmopolitan spot. But when the canal is 
opened it will be a veritable world centre, the resort of trade and travel from every continent and from all the islands of the seas. With every plague of every clime making insidious approaches to it, Panama will need, and needs to-day and from this day forward unremittingly, a sanitary guardianship surpassed by none in the world for intelligence, for vigilance, and for inflexible authority. 


\section{CHAPTER XXI}

\section{PANAMA}

I hesitate to write of Panama. I mean not only Panama the country, but also and more especially Panama the city, and its environs, and its people. I mean Panama, with its faults and frailties, and also with its beauties and its virtues, and with its unique and ineffable charm. One may well hesitate to write about his host, save with unfailing courtesy. Yet at least equally one must hesitate to write aught but the truth. Let me hope that in writing the truth, both pleasant and unpleasant, unfailing courtesy may prevail, and the net balance may be on the side which is not only agreeable but welcome to my friends in Panama. The memory of that place is one of blue skies, seen through a fairy tracery of palm-fronds; of quaint old streets that made me dream a composite dream of Seville, Naples, and Hong Kong; of a sea more blue and more calm than ever is seen on our boisterous Atlantic coasts; of a strange mingling of the fifteenth century with the twentieth; of pearl-roofed spires and clangorous bells; of a riot of rich colours and sweet sounds; of a hospitality at once stately and inviting, dignified and cordial, which made the stranger to feel at home and the wanderer to realise that he had won the goal of his desire. Because of such memories I have deferred writing of Panama until I have written of all else that I may write about upon the Isthmus, and now I shall try to write of Panama as it was, but as it will be no more. It was then trembling upon the verge of a great and strange transition. The Panama of Philip of Hapsburg still remained, and the Panama of Theodore Roosevelt was dawning into existence. No more suggestive contrast has been seen in all the world than 


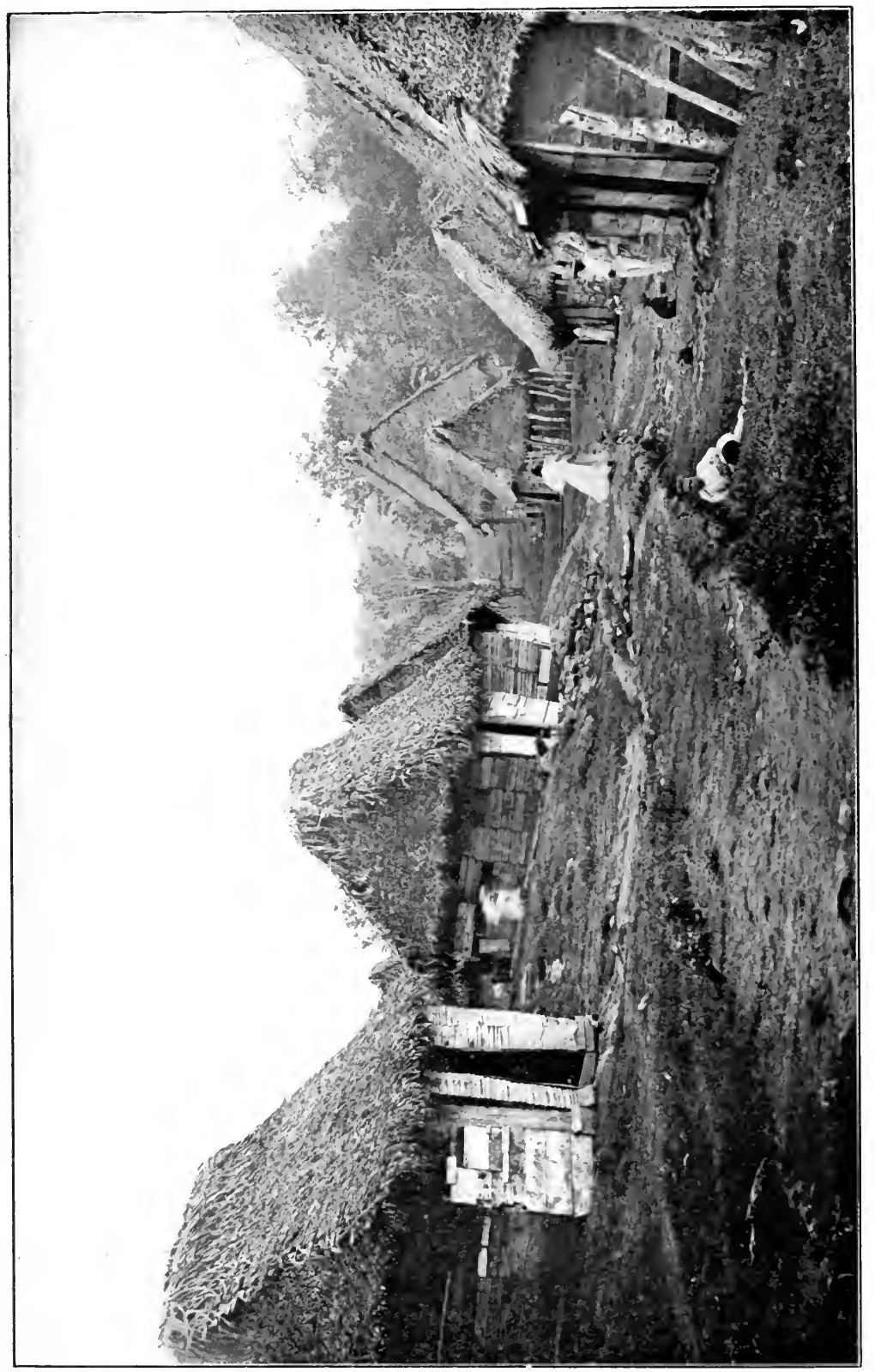



告 


$$
\text { • }
$$

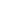


was there and then presented, and none more worthy of commemoration.

The approach was, of course, by way of Colon-the Aspinwall of earlier years-and it must be confessed it was not impressive. The translucent ultramarine of the Caribbean was changed as we approached the coast to turbid, tawny yellow, due partly to the muddy outflow of the Chagres and partly to the all but insistent trade-winds which beat upon that coast and so disturb the waters of the open roadstead as constantly to stir up the mud from the shallower bottoms. Yet the coast itself was not unattractive. Low and flat as Manzanillo Island itself is, at each side and at the inland background the eye found grateful variety in swelling hills and jutting headlands, while everywhere was a riotous profusion of verdure, both low and lofty. The rows of graceful, towering palms, all leaning at a uniform angle before the trade-winds, gave even the squalid streets of Colon an air of distinction at a distance. But it must be confessed that the enchantment of the view was in great measure lent by distance. It needed only a short time ashore to persuade me that Colon was a wretched blunder. The site is all but hopeless. It is wind-swept, and therefore not as hot as some other places on the Isthmus. But it lies at only the slightest elevation above an almost tideless sea, in one of the rainiest climates of the world. The result is such humidity as not even the Ganges Delta knows, and an almost hopeless lack of drainage. The elevation is scarcely sufficient to permit sewerage into the sea, though we have been building a sewer system there; and such sewage as does find its way into the sea is not swept away into the depths, but is beaten back upon the shore, or churned about in the shore waters. We used to say of certain lands that they would be delightful if only they could be submerged in the sea for an hour, until all the inhabitants were drowned beyond resuscitation, and then be raised again for a new population. Colon would be an attractive place if, on the other hand, it could be elevated in a mass ten or twenty feet, and sustained there. If enough 
earth for that purpose can be brought down from Culebra, well and good. Colon may be redeemed. Otherwise, it would be best to abandon it altogether and rebuild elsewhere.

When, however, we got away from the reeking coast swamps, and reached solid ground, and began to wind our way among the hills, the prospect was charmingly trans. formed. The general landscape varied from the beautiful to the sublime, while detailed bits on every hand presented an exquisite loveliness beyond the power of words to describe. There were impenetrable jungles of vines and fern and brake, and there were stately open woodlands of palm and cedar and mahogany and ceiba and a hundred other woods. There were near the coast some sluggish waters, from which alligators leered at us with half-human, half-reptilian eyes, but elsewhere the swift-flowing streams were clear as crystal. Orchids and innumerable other flowers glowed and blazed with colours which would be the despair of a painter's palette, but of course, as is the rule in tropic lands, mostnot all-of them were without perfume. (Is not, by the way, the same to be said of our flowers in the north? The majority of the showy ones are odourless, or have unpleasant odours.) Monkeys chattered in the treetops, and there was assuredly no "loneliness of wings," with the countless multitudes of birds, from the humming-birds, scarcely bigger than a bumble bee, to parrots and cockatoos as big as barnyard fowls-and, of course, the omnipresent black vulture, sailing and circling on motionless wings far up the sky. Again, according to the rule of tropic lands, the most brilliantly coloured birds were songless. (But why say the rule of tropic lands? With few exceptions the same is true elsewhere. One little brown house wren can outsing a whole flock of your brilliant jays and tanagers, and even bluebirds and orioles, while the greatest of all our feathered choir, the catbird, the mocking-bird, and the veery, are very Quakers and nuns for plainness of garb.)

The stretches of open and cultivated country were by no 


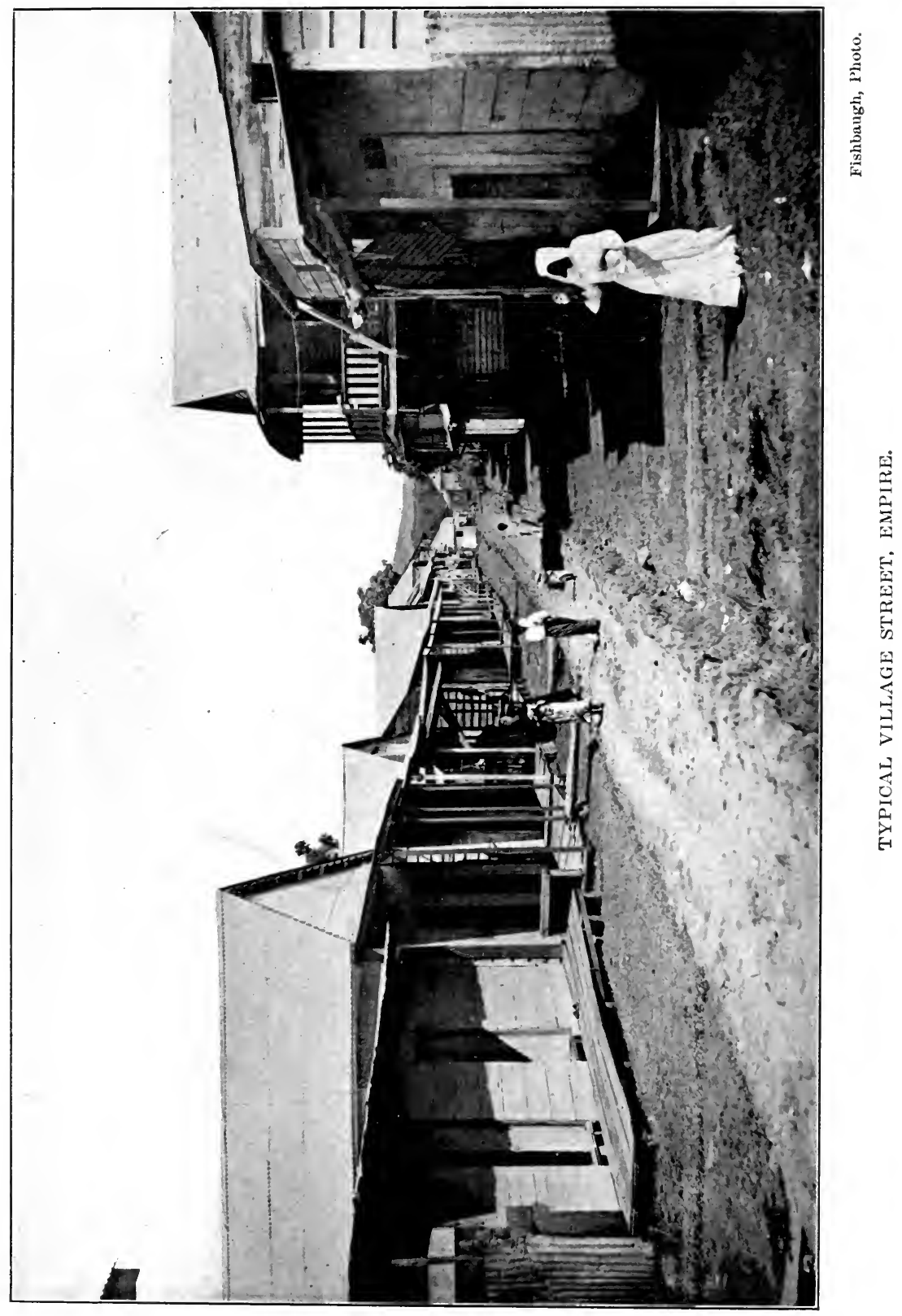


$$
\text { - }
$$ 
means unattractive. There was not, of course, the thrift of a New England farm, nor were there the magnificent expanses of tillage which our western prairies and plains afford. But there were fine corn-fields and creditable gardens, and the rich pasture lands showed herds of cattle, and nowhere did I see the piteous neglect of some of our "abandoned farms," or the dreary shiftlessness of the poorer regions of our Southern States. Jerrold said that in Australia "Earth is so kind, that just tickle her with a hoe and she laughs with a harvest." In Panama she does not need so much as the tickling. If ever there was a land of natural plenty, "flowing with milk and honey," it is Panama. Unhappily, such profusion of nature's bounty, and the consequent ease of sustenance, in the absence of commercial and industrial stimulus, have greatly induced neglect and sloth. There is nothing more impressive on the Isthmus than the magnitude of the opportunities and the completeness with which they are neglected. Corn grows as well there as in Georgia or Illinois, and you can grow three crops of it in a year. Yet it is a neglected industry. Some cattle are raised, with much success. But what would not be possible in a land where the rich guinea grass produces the equivalent of from 20 to 30 tons of hay to the acre, and of course cattle can be at pasture the whole year round? There are, I am told, some 300 acres planted with india rubber trees, in Panama. Yet there are hundreds of square miles on which some of them-notably the fine Castilloa elastica-would flourish. You may plant a hundred trees on the acre, at a cost of only thirty dollars, and in a few years each tree will be yielding from two to ten pounds of rubber a year, worth nearly a dollar a pound. The San Blas Indians raise some of the finest coffee in the world, and its culture might be general throughout much of the republic. As for cocoanuts, bananas, all the citrus fruits, vanilla, sarsaparilla, ipecacuanha, indigo, and what not else, the Isthmus is their chosen home.

Amid all this luxuriance and these unbounded possibili- 
ties a large proportion of the people lead an indolent, unambitious life. Cabins built of logs and thatch form their homes, surrounded by banana and cocoanut trees, with perhaps an acre or two of cultivated ground. Scarcely less primitive, and much more squalid, are the homes in the villages. The "native" streets of the villages along the railroad, and practically the entire villages remote from that line, are composed of thatched cabins of one or two rooms each. The main streets of the railroad villages, built largely by foreigners, have two-storied houses of dressed lumber, which are really far more squalid and vastly less picturesque than the thatched cabins. These villages are not lovely to look at or to smell of. Squalid and savage, most visitors would say. Yes, but in that genial clime life in such quarters is not physically uncomfortable, and really its conditions even at the worst are not nearly as shocking, not as squalid, not as repulsive to see, as are those of tens of thousands of both blacks and whites in our own Southern States, and in some parts of some of our Northern States, or of the denizens of the overcrowded, reeking, rotting slums of our great cities. I have seen within an hour or two of New York, and even in the immediate suburbs of that city, in rural villages, families of white Americans, of several generations of American ancestry, living in worse squalor than any in Panama; while as for some of the metropolitan tenements, which still exist in this Twentieth Century, by the side of them the hovels of Panama appear like sanitariums and pleasure resorts.

The city of Panama is unfortunate in its entrance-way, by land; the railroad delivering you in one of its very poorest quarters. In that respect it does not differ from many other places of greater pretensions. Some parts of Newark (New Jersey), for example, and of Atlanta (Georgia), are exceptionally handsome and attractive; yet it would be difficult to imagine anything more dreary and uninviting than the aspect of those really splendid cities from a railroad train. At the time of our advent in Panama, the roadways of the 
streets were mud, dust, and cobblestones, varied with cobblestones, mud, and dust. Perhaps there were worse paved streets, somewhere. Of course we used to have in New York and Brooklyn streets paved with cobblestones, in all respects but one probably as bad as those of Panama. But the Panaman streets were unique in having a sort of fret-work, or diaper work, composed of rows of bigger stones, rising above the general cobble-level two or three inches, and crossing the streets at all sorts of angles, a few feet or yards apart. It is all changed now; and you may ride about the town, from the Chiriqui Plaza to the Savannahs, on smooth pavements of vitrified brick, and macadam. But never, till osteopathy is a lost art, shall I forget the sensations of riding along those fretted-cobblestone streets, in a cabriolet without rubber tires, and with the most inflexible of springs, and with the little horses always at a gallop!

The streets were-and are-generally narrow, many of them little if any wider than some of the narrowest in New York and Boston and Philadelphia. Their narrowness is accentuated, too, by the overhanging balconies which run along the second stories of many of the houses, from one to the other of which an agile man might leap across some streets. Yet none of the streets seem quite as narrow as some in New York, for the reason that the buildings seldom exceed three stories in height. Panama contains no such canyon of gloom and hideousness as Nassau Street or Exchange Place, in New York. Some Panaman streets are crooked, though as a rule they are straighter and more regular than those of some parts of New York and Boston-not to mention many European cities. Some of them are steep, too, so that the sidewalks are built like flights of stairs, but these are very few. The sidewalks are narrow, and the buildings abut directly upon them, without any intervening area, bringing the passer-by into a somewhat startling proximity to the interiors, with the doors and windows wide open, at sidewalk-level. As a rule, however, the ground floors are not used for dwelling purposes, save by the poorer 
classes. All the better residences are upstairs, sometimes with shops or business offices below, and sometimes with the ground floor a vacant court-yard. The typical house of the best class is built of stone, brick, or concrete, with thick walls through which the heat of the sun never penetrates. It is built around an open central court, and has a shaded balcony along the street front of the second story. The roof is of heavy, heat-resisting tiles. Often the windows are void of glass, slatted blinds taking the place of sashes.

The city contains a number of parks, the most important being the Plaza de la Cathedral and the Plaza Santa Anna. These are small, mere squares, but of much beauty. The Plaza de la Cathedral is the real centre of the city. Upon it face the stately old Cathedral, with its towers roofed with mother-of-pearl; the Bishop's palace, with the office of the Panama Lottery Company on the ground floor; the Grand Central Hotel, the City Hall, the handsome Canal Administration Building, and several important banking houses and stores, while close by are the fine mansion of the American Minister and the attractive quarters of the Commercial Club. In the park is a band stand, where an excellent band discourses music every Sunday evening and on various other occasions. The Government House is a few squares away. It is a stately and sumptuously furnished mansion, fronting eastward upon the Bay of Panama; and commanding from its spacious balconies a landscape and seascape of singular beauty. The ancient sea wall which extends along the waterfront at the southwest part of the city affords a charming promenade, at an elevation, from which one can overlook on the one hand the red-tiled roofs of the city interspersed with masses of palm fronds, with the great mass of Ancon Hill in the background, and on the other the serene azure expanse of the Pacific, with the islands of Taboga, Naos, Perico, and Flamengo jutting up "like peaks of some sunk continent."

There is, of course, a seamy side to Panama. I found some streets given over to filth and squalor, but none worse, 


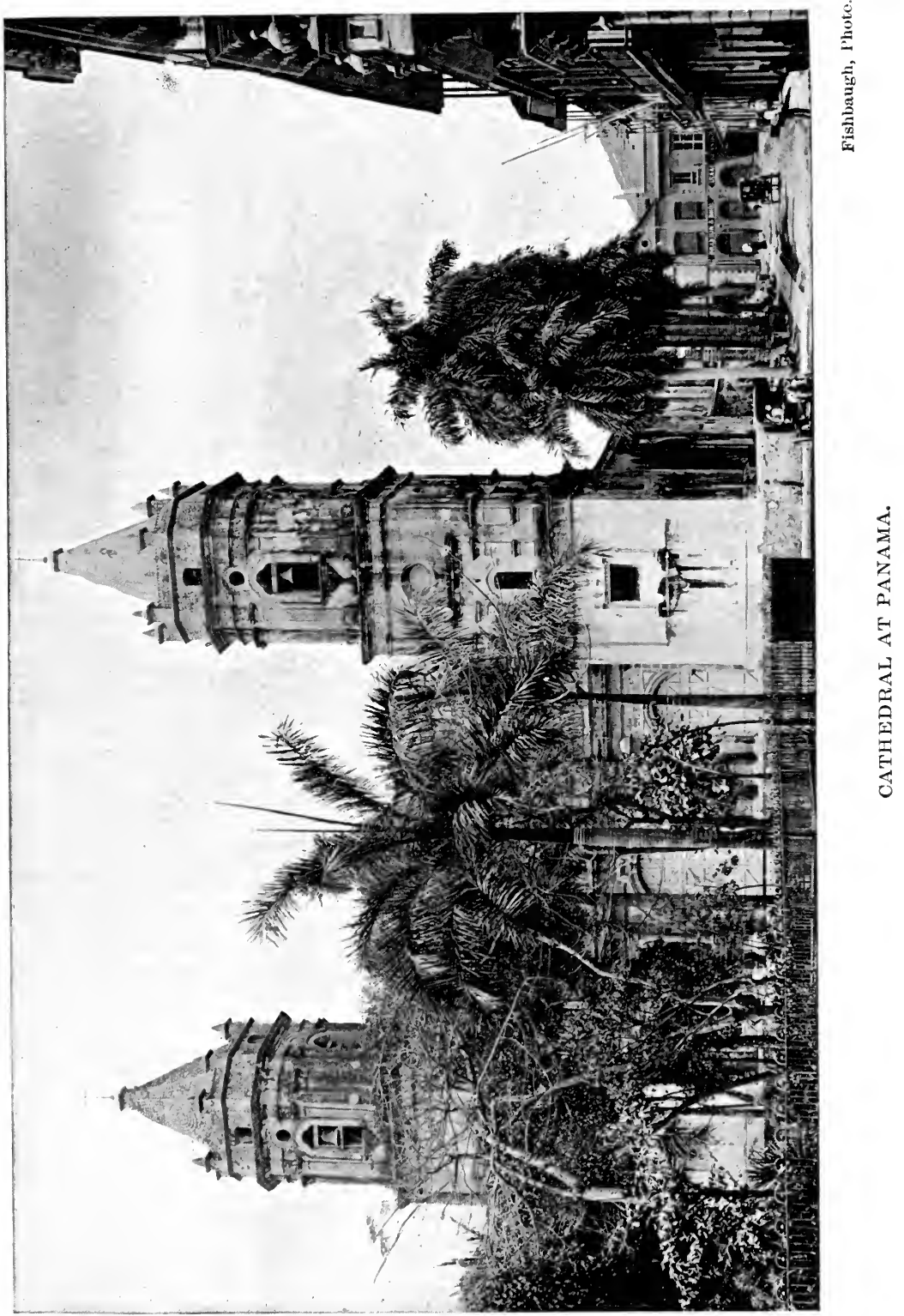


on the whole, than some I have seen in New York. Indeed, I should say that nowhere did I find conditions quite as depressing and repulsive as some in the American metropolis. However poor the place, and however ragged the clothing, house and people still had a certain artistic air, or at least an air of joyousness and content. There was none of the sordid sullenness and black despair which are so ominous a feature of the denizens of our northern slums. The place at its poorest reminded me of the Spanish caballero of ruined fortune who discovered that he had not enough money to buy a breakfast, and so must go hungry, but at least had enough to buy a bunch of violets! To pick one's steps among a dozen quite naked babies, sunning themselves on a sidewalk in Panama, was not half as unpleasant to humane susceptibilities as to see a single barefoot newsboy in the streets of New York. No doubt there is vice, too, in Panama. The American colony there would assure that. And vice is vice, the world over. But at least it does not flaunt itself in Panama as openly as in many cities of the United States; and while the native morals of Panama are doubtless open to much reproach, it is, I believe, a fact that the chief purveyors of vice and the chief patronage of their establishments are of North American origin.

One thing that greatly impressed me at Panama was the sobriety of the people. There was much drinking, no doubt, and it was drinking of strong liquors, too. Whiskey and rum and brandy and gin flowed freely. Yet there was no drunkenness, save among the American element. I cannot remember that I saw a single Panaman intoxicated, though I was compelled to blush for shame at the condition of several of my own countrymen. One evening-it was the evening when, as I have related in a former chapter, Secretary Taft made his memorable speech to the people of Panama from the balcony of the Grand Central Hotel-it was announced that for two hours, from six to eight o'clock, every barroom on the Cathedral Plaza would serve free drinks to all comers at government expense. A shocking way for a 
national government to celebrate a great occasion, some will say. Doubtless it was, from some points of view. But, as I have already tried to make plain, there are other points of view than ours, which perhaps are no less entitled to respect from us than ours is from others. I remembered, that night, the saloon I had noticed one day on the road to "Section," with its hospitable sign: "Café of All Nations: All Nations Welcome, except Carrie!" and I wondered how such a festival would be regarded by the strenuous hatchet-wielder whose name was thus taken in vain. At about the height of the orgy I went over to the barroom of the Grand Central Hotel, the biggest and most frequented in the city, and watched the proceedings from the coign of vantage afforded by the top of a large up-ended cask. The scene was not unlike the Brooklyn Bridge entrance in rush hours. At one end of the big room there poured in a tumultuous throng of men and boys of all ages, colours, and present conditions of thirstiness, literally climbing over each other in their eagerness to reach the bar. Before the bar they were crowded like massed players in a football rush. Behind the bar were half a dozen active and agile men, handing out drinks with both hands. But not drinks by the glass. Oh, no! A full bottle was placed in every outstretched hand, whiskey or wine or beer, as the taste might be. And then at the other end of the room there poured out a halfreluctant throng, each man or boy with at least one bottle snugly held beneath his arm.

Now, suppose that had been tried in New York, or Washington, or any North American city? I do not care whether it had been on Fifth Avenue or on the Bowery-in five minutes there would have been a dozen fights, and a hurry call for police reserves and ambulances, and it would have required an expert census-taker to enumerate the "drunks." But in Panama there was not a man intoxicated, not a blow struck, not a hard word spoken; and all the police had to do was to stand around and watch the fun! Of course, it was a hideous orgy, a degrading debauch, and all that. Yet it 
was as good-natured, and as free from ruffianism, and as sober, as a Sunday School picnic. And somehow I could not help contrasting it, and not to the disadvantage of Panama, with some particularly fashionable and aristocratic "social functions" in Washington and Philadelphia and New York, from which many of the guests went away maudlin. Nay, a contrast was presented later that same evening, when I personally assisted, with physical force, in restraining two of my fellow Americans, who had become hopelessly drunk, from creating a public scandal.

On Sunday evenings all Panama went to the promenade concert in the Cathedral Plaza. The fashion and the beauty of the city were there, strolling to and fro beneath the palm fronds, now in the full blaze of the electric lights, and now under only the softer lustre of the tropical constellations. It suggested a scene in a great conservatory adjoining some fashionable New York ballroom, save that the men were in white duck instead of black broadcloth. Moreover, there were plebeians as well as patricians-the twenty thousand as well as the Four Hundred of Panama. But in what city of the United States, at an open-air evening concert in a park, would it be fitting, as in Panama, for girls and women of refinement to stroll about without chaperons or male escorts; and where, if they did so, would they be secure against insult or annoyance? Where, indeed, would such a gathering be exempt from an amount of "hoodlumism" requiring frequent activity of the police?

It was a queer Sunday, that of Panama; at least to any one possessed of even a fragment of the traditional "New England conscience." In the forenoon we went to church, if we were so disposed; and noticed the multitudes of mosquito "wigglers" in the holy water in the Cathedral font. At noon we went to the Bishop's palace, to attend the weekly drawing of the lottery, and to assure ourselves that we had nothing better than blanks. Most of the afternoon was given up to the siesta. In the evening there was the promenade concert; and after that there was, for the select few, a ball 
at the Commercial Club, where the youth and beauty of Panama danced until well on into Monday morning. Most of it was very reprehensible and shocking, no doubt, from the orthodox United States point of view; and yet it was all very orderly and quiet and well disposed, and not nearly as offensive to the thoughtful mind as the furtive sneaking in and out of saloon side doors in a city where reputedly rigid "Sunday laws" prevail. Of course, I am not arguing that these Panaman customs should be adopted in New York. That would be incongruous and indeed impossible-as much so as to enforce our customs in Panama. The point to be kept in mind is that which I have already expressed, that Panama is Panama and not the United States, and is properly to remain so, and not be dragooned into the alien ways of the alien folk who have now come into so close relations with it.

Business in Panama is business, as it is the world over. There are handsome and well-stocked "department stores," or bazaars as they are called; some conducted by Panamans and some by Chinese merchants. The transaction of business is more quiet and deliberate than in American cities, but certainly not less satisfactory. Prices rule much lower than in New York, whether for American or for European goods. In some lines of goods, particularly for men's wear, it was somewhat disappointing to American pride to find the European goods of by far the better quality, at the same or actually less price. In other lines, however, notably hardware, American goods easily dominated the market.

The Panama landlord is much like his brethren elsewhere. His rule is to get as much and spend as little as he can. A friend of mine wanted to lease a house in the city. The landlord positively refused to give him a year's lease, and was with the utmost difficulty at last prevailed upon to give him a lease for as long as two months. Why? Because, he frankly said, he might want to increase the rental before a year had passed. And he did. The house contained no bathroom and no plumbing, and as the landlord would not supply 
such things, my American friend, who regarded them as necessities, had them put in at his own expense. I believe he spent about $\$ 500$, in permanent improvements on the house, which, of course, would remain there for the landlord's benefit. Thereupon, at the end of the two months, the landlord promptly and very materially raised the rent; because, he naively explained, the house was worth a great deal more, since all those improvements had been made in it?

Hotel rates were high. My friends told me that when they paid their weekly bills, they felt that they ought to get in return title deeds for the building and ground! I know that when, occasionally, I was compelled to patronise a hotel, it impressed me unpleasantly to have to pay two or three dollars for a breakfast which I could easily equal in New York or Washington for less than a dollar. In the matter of cab fares, however, Panama had an advantage over all American cities of my acquaintance. Ten cents was the uniform rate, for any distance within the city limits. It was, however, necessary to make it a "continuous passage." If the cab was halted for even an instant, to speak to a friend, to take a snap-shot photograph, or for any other purpose, a second fare was charged. Thus a ride of ten minutes, with five stops of a minute each, would cost fifty cents, while a ride of half an hour with no stops would cost only ten cents. On the whole, even with frequent stoppings, it was cheap riding. And there was no extra charge for the osteopathic treatment we got from the combination of cobblestones, steel tires, and stiff springs.

If some Panaman business men, especially landlords and hotel proprietors, do seem a bit rapacious, there is no cause for wonder and little cause for blame. They are merely living up to the traditions of the land. We were talking one day with some Panamans, whose family names are on the rolls of Columbus's and Balboa's and Cortez's companies. “Did your ancestors come hither with Balboa?" I asked one. Before he could reply, an audacious American broke in with "No! with Harry Morgan!" The Panamans roared with 
laughter, and confessed the hit well made. I have never felt inclined greatly to blame our Southern negroes for sometimes disregarding the law of meum et tuum, especially when chickens or watermelons are in question, because for generations, in slavery days, that law was practically made a dead letter to them. Well, so it is with the Panamanswith a distinction, of course. In the old Spanish days, from Pedrarias Davila, through the days of Drake, in the dark time of Morgan, and all the way down to Sharpe and Paterson, they were so frequently the victims of spoliation that they began to apply to all life

$$
\text { “. . . the good old rule }
$$

That they should take who have the power, And they should keep who can."

Nor did their three-fourths of a century of connection with Colombia do aught to change their view or practice. The rule in the days of the "Forty-Niners" was to exact all possible tribute from the gold-seekers and gold-bearers who crossed the Isthmus, and the mad profligacy of the De Lessepsian régime confirmed them in whatever grasping proclivities heredity had given them. Some of them are probably disappointed and grieved, to find that the American advent does not mean a renewal and perpetuation of the extravagance and "graft" of the French. Yet, on the whole, I fancy that the business men of Panama are no less honest and no more selfish or rapacious than those of other cities, the world around.

Above all, as I said at the beginning of this chapter, I hesitate to write of the people of Panama, as I met them and knew them, and of their social and domestic life, into which I was permitted to enter. I shall probably not be able to do so without incurring the imputation of partiality, which, however, I feel certain I do not deserve. To me, the Panamans were almost wholly charming. I had not been prepossessed in their favour. For many years I had come 
into occasional contact, here in the United States, with people from Latin America, and I had not learned to like them. Perhaps that was because they were here removed from their native and harmonious environment. But when I got among them in their own land and city, the whole impression was one of charm. In the first place, there was a fine cosmopolitanism of knowledge and interest, such as not more than one or two American cities-and not New York-could rival. I found that they knew a great deal more about us than we about them. They knew at least as much, too, about Europe and the world at large as the best informed and most widely travelled Americans. Why not? Here was one who had spent four years in one of the largest American universities and four more in a New York medical college. Here was one who was graduated from a New England college and from a great German university. Here was one who had travelled three times around the world, by three different routes. Here was a jurist who could make arguments or render decisions with equal readiness in Spanish, English, French, or Latin. Here were half a dozen pretty girls, chattering away in a medley of tongues, as in a boudoir at Babel ; and when I ventured to compliment one upon her perfect English accent, they cried in chorus, "What's the matter with the rest of us? We all studied in New York and Baltimore!" If there is as high an average of intellectual acumen and of cosmopolitan culture in a fashionable New York reception as $I$ found in gatherings in the salon of President Amador, then the groves of Academia are nearer to the banks of the Hudson than I have supposed.

This cosmopolitanism of Panama has been, of course, much promoted by the advantage of situation. Mohammed has not had to go to the mountain; the mountain has come to him. All the world has crossed the Isthmus and has passed through the streets of Panama. We were at a great state banquet given by the government one evening and I was admiring-as they well deserved to be admired-its general appointments, which would have been highly cred- 
itable to the best New York hotel. "Panama has certainly 'done herself proud,' to-night," I said. "Yes," said my Panaman neighbour, "but she has drawn upon the whole world to enable her to do it. This fish, and some of these fruits, are from Panama. These olives and these vegetables are from the United States. This butter is from Denmark. This wine is from France, and Italy. This whiskey is from Scotland. This mineral water is from Germany." And so he went through the entire menu; and what was true of that banquet is largely true of the whole life of Panama.

So will it be henceforward, in the great new era which is dawning upon Panama. Through the canal which we are cutting the tides of the world's travel and trade will flow in floods such as have scarcely been dreamed of in former days. Half the people of the world live in lands fronting upon the Pacific, and this canal will be the gateway of that ocean. That fact alone is of ample significance. Couple with it the fact that the canal will be an integral part of our own coast line, giving for the first time direct navigation between our Atlantic and Gulf ports on the one hand and our Pacific ports on the other. Once more, observe that by way of Panama we shall have for the first time direct water communication with the rich western coast of South America. Let us note a few comparative distances. From New York to San Francisco by way of the Strait of Magellan is 13,107 miles, and by way of Panama it will be only 5,294, a saving of 7,813 miles. From New York to Callao (Peru), by way of Cape Horn is 9,700 miles, and by way of Panama it will be only 3,359 miles, or a little more than one-third as far. From New York to Auckland by way of Cape Horn is 11,771 miles, and by way of Panama it will be only 8,610 miles, a saving of 3,161 miles. From New York to Sydney by way of Cape Horn is 13,051 miles and by way of Panama it will be only 9,709 miles, a saving of 3,342. Marked, too, is the contrast against the Suez route. From New York to Shanghai by way of Suez is 13,324 miles, while by way of Panama it will be only 10,689 miles. From New York to Yoko- 


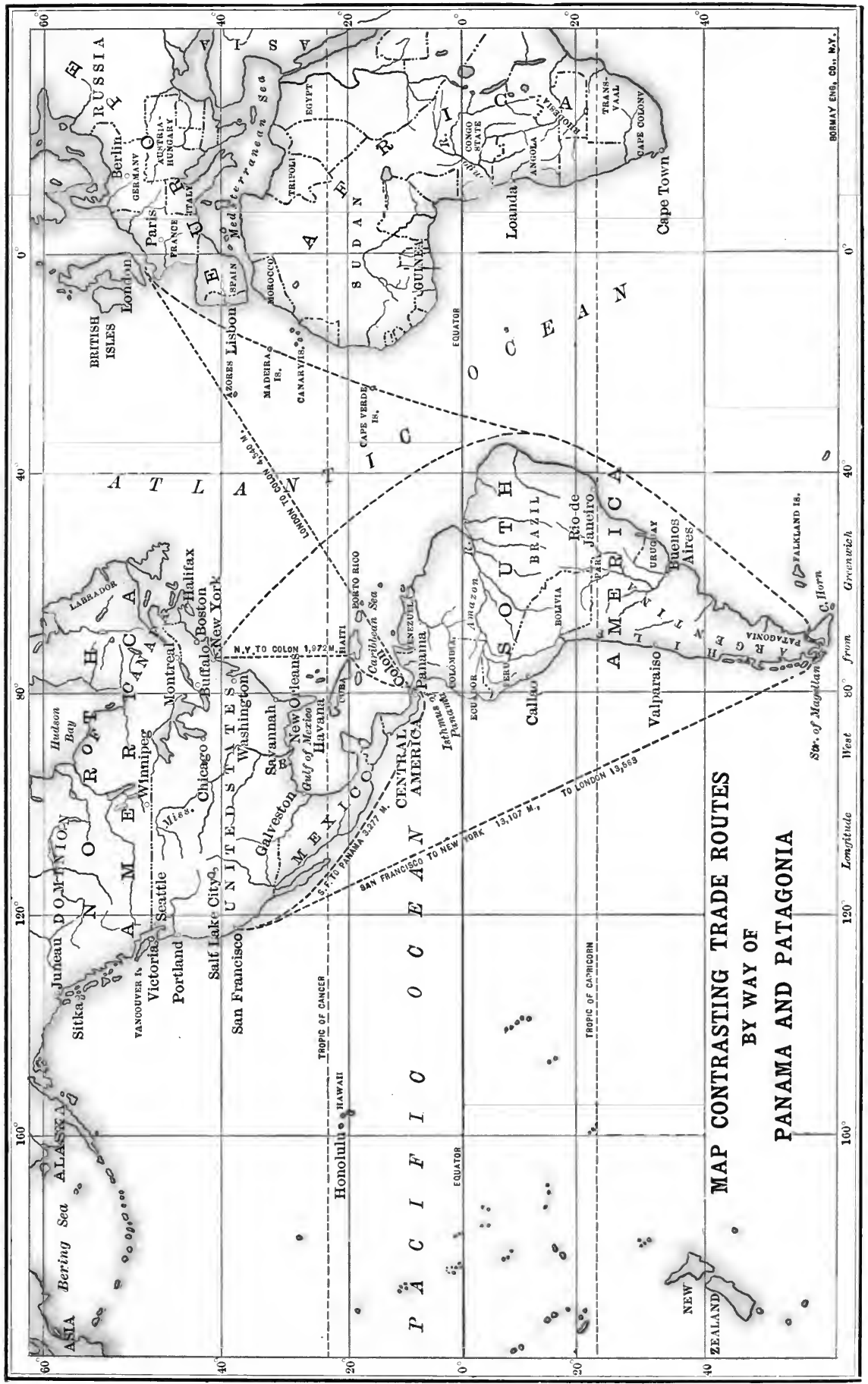


2

Bancroft Librars 
hama by way of Suez is 13,042 miles, and by way of Panama it will be only 9,719 miles. Nor will New York be the only gainer. All our Atlantic and Gulf ports will profit, some in even more notable degree. Thus from New Orleans to San Francisco by way of Cape Horn is 13,650 miles, while by way of Panama it will be only 4,700 miles. From New Orleans to Callao by way of Cape Horn is 10,100 miles, and by way of Panama it will be only 2,750 miles.

If we reckon Panama the centre of the Pacific Coast of the American continents, as indeed it is, for it lies almost exactly equidistant between Sitka and Cape Horn, we may measure the gain of the canal to Atlantic commerce by the difference in distance to Panama by way of the Strait of Magellan, now the shortest existing water route, and by the canal. Let us regard such distances from both American and European ports, in tabular form: .

\begin{tabular}{|c|c|c|c|c|c|c|}
\hline $\begin{array}{l}\text { To Panama } \\
\text { from }\end{array}$ & \multicolumn{2}{|c|}{$\begin{array}{l}\text { By Strait of } \\
\text { Magellan }\end{array}$} & \multicolumn{2}{|c|}{$\begin{array}{l}\text { By the } \\
\text { Canal }\end{array}$} & \multicolumn{2}{|c|}{$\begin{array}{c}\text { Saving by } \\
\text { Canal }\end{array}$} \\
\hline Antwerp & 11,383 & miles & 4,463 & miles & 6,920 & miles \\
\hline Charleston & 10,803 & “ & 1,611 & 66 & 9,192 & " \\
\hline Galveston & 11,391 & 6 & 1,545 & “6 & 9,846 & “ \\
\hline Genoa & 11,143 & 6 & 5,229 & “6 & 5,914 & “ \\
\hline Hamburg & 11,614 & "6 & 5,054 & " & 6,560 & “ \\
\hline Havana & 10,682 & 66 & 1,425 & “6 & 9,257 & “ \\
\hline Havre & 11,156 & 6 & 4,648 & “ & 6,508 & 6 \\
\hline Liverpool & 11,261 & “ & 4,575 & “6 & 6,686 & “ \\
\hline Marseilles & 10,985 & 66 & 5,071 & “6 & 5,914 & “ \\
\hline New Orleans & 10,286 & 66 & 1,425 & “ & 8,861 & “ \\
\hline New York & 10,851 & "6 & 2,017 & "6 & 8,834 & " \\
\hline Southampton & 11,137 & 66 & 4,608 & 6 & 6,529 & “ \\
\hline
\end{tabular}

These figures tell their own story and they speak with convincing eloquence of the future of Panama. The two ports of Panama and Colon are now visited by 1,000 vessels a year, landing 1,000,000 tons of merchandise, and the Isthmus is crossed by 100,000 travellers. What will those figures be when the canal is opened, and there goes thither all the traffic that now passes around Cape Horn and through 
the Strait of Magellan and much that goes by way of Suez? Nor will it do to say the canal will be a mere passageway, and that the city and republic of Panama will profit from it no more than the Isthmus of Suez has locally profited from its canal. There is an immeasurable difference between the two. The climate, the people, the scenery, the resources, and all the conditions and circumstances of Panama are as attractive, opulent, and promising as those of Suez are abominable, squalid, and depressing. No rational man desires at Suez anything more than the utmost speed in passing through and getting away, and his memory of it, in sight and smell and sound and taste and feeling is altogether one which he would gladly erase from the tortured tablets of the mind. But those who pass by way of Panama will wish to linger long in sheer delight amid its scenes of beauty; and, taking at last a reluctant leave, will cherish forever a memory of emerald shores and sapphire seas, of feathery palm fronds and pearl-roofed spires, of lovely women and of courteous, hospitable men, of a fascinating cosmoculus of all times and places, manners and customs, tribes and nations, of nature's very masterpiece of riotous luxuriance-

"Larger constellations burning, mellow moons and happy skies,

Breadths of tropic shade and palms in cluster, knots of Paradise."

On one never-to-be-forgotten Sunday at Panama we visited the Pearl Islands-that wondrous cluster of summer isles of Eden lying not in dark purple spheres of sea but in a sea that differs from the overarching sky only in being a deeper, purer blue. We had trailed the daring divers through the deeps by their long wakes of opalescent bubbles; we had spied out the nestling villages beneath the palm trees on the cliffs; we had feasted, and danced, and drunk deep of the beauty and mystery of the sea-of that storied South Sea where Drake had mingled crimson with the blue and blended thus the purple of world-wide empire; we had even organised, some favoured few of us, such a joyous Junta as surely not even that realm of Juntas had known before; 


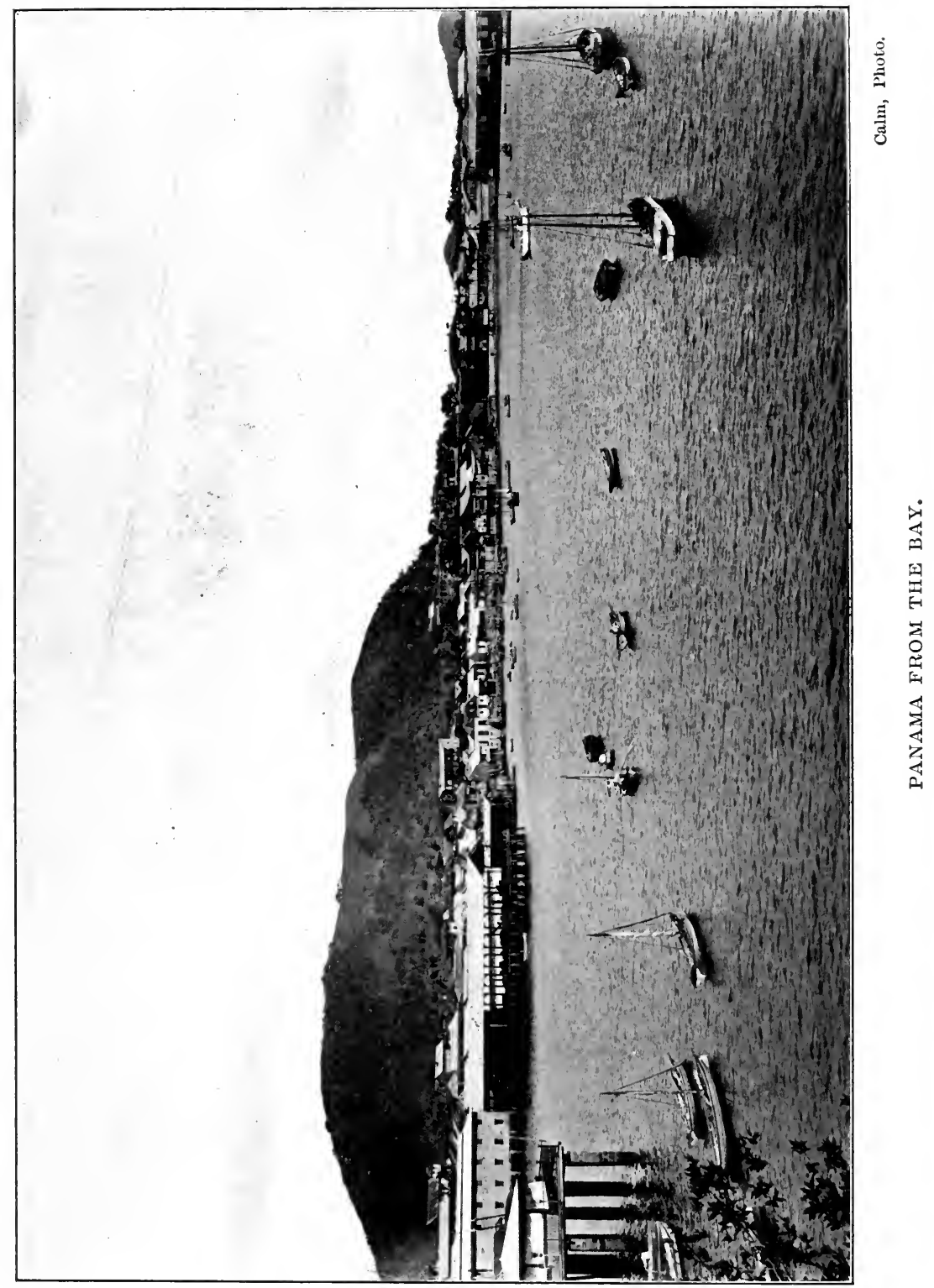


and then at last, we were returning, with reluctance to leave the Fortunate Isles and the Sea of Peace, though with gladness to regain the gardens and the palm groves that lay in the shadow of Ancon Hill. Then, as we neared the city, as the sun was setting, and the rich colouring of sea and sky and land gave to the scene an air of unreal and unearthly beauty, a strange thing appeared. Upon the crest of Ancon, and upon the summits and shoulders and ledges of the more distant amphitheatre of hills that girt the fair city round, from beyond the ruined tower of Old Panama in the darkening east to Chorrera in the still glowing west, we saw what seemed like drifts of snow, pure, glittering white amid the dark green of the hillside forests. I marvelled, for I knew that in that tropic latitude snow never fell. Yet there the drifts lay, white, spectral, motionless, precisely as I had seen them upon the peaks and ledges of our own White Hills. But as we drew nearer and nearer, I saw they were not snow, nor any solid thing, but only masses of mist and floating cloud, which presently faded from our view and vanished. Then, as from the full golden glow of day we rushed through the brief tropic twilight into the purple solemnities of night, and the Southern Cross and all the luminous constellations of the Equatorial heavens shone out in splendour, I fell to likening those seeming snowdrifts and glaciers to the difficulties and dangers which the fainthearted and the hostile have conjured up as besetting our way in our great enterprise at Panama, and it seemed to me that the worst of them, the most chilling and oppressive and ominous, might in the end prove to be as tenuous and as evanescent as those fugitive cloud-wraiths, so that we might cry to it in confident defiance,

"Thou art a phantom,

A shape of the sea-mist,

A shape of the brumal

Rain, and the darkness

Fearful and formless;

Day dawns, and thou art not!" 
We have only to be true to our opportunities, true to our principles, true to our destiny, true to ourselves, to make the obstacles before us flee as the clouds from the mountains; to fulfil the great designs of Columbus and Cortez; to make, to our own honour and the inestimable profit of the whole world, the Panama canal an accomplished fact; to open up a highway of peaceful commerce between the two great oceans; and, after four centuries have their full cycles turned, to achieve at last the triumphant fulfilment of the world's agelong desire. 
APPENDICES 


\section{APPENDICES}

\section{APPENDIX I}

\section{The United States-New Granada (Colombia) Treaty of 1846 (In part).}

\section{Ratified June 10, 1846}

The United States of America and the Republic of New Granada, desiring to make as durable as possible the relations which are to be established between the two parties by virtue of this treaty, have declared solemnly and do agree to the following points:...

For the better understanding of the preceding articles, it is and has been stipulated between the high contracting parties that the citizens, vessels, and merchandise of the United States shall enjoy in the ports of New Granada, including those of the part of the Granadian territory generally denominated Isthmus of Panama, from its southernmost extremity until the boundary of Costa Rica, all the exemptions, privileges, and immunities concerning commerce and navigation which are now or may hereafter be enjoyed by Granadian citizens, their vessels, and merchandise; and that this equality of favours shall be made to extend to the passengers, correspondence, and merchandise of the United States in their transit across the said territory from one sea to the other. The government of New Granada guarantees to the government of the United States that the right of way or transit across the Isthmus of Panama, upon any modes of communication that now exist or that may be hereafter constructed, shall be open and free to the government and citizens of the United States, and for the transportation of any articles of produce, manufactures or merchandise, of lawful commerce, belonging to the citizens of the United States; that no other tolls or charges shall be levied or collected upon the citizens of the United States, or their said merchandise thus passing over any road or canal that may be made by the government of New Granada, or by the 
authority of the same, than is, under like circumstances, levied upon and collected from the Granadian citizens; that any lawful produce, manufactures, or merchandise belonging to the citizens of the United States thus passing from one sea to the other, in either direction, for the purpose of exportation to any other foreign country, shall not be liable to any import duties whatever, or, having paid such duties, they shall be entitled to drawback upon their exportation; nor shall the citizens of the United States be liable to any duties, tolls, or charges of any kind to which native citizens are not subjected for thus passing the said Isthmus. And, in order to secure to themselves the tranquil and constant enjoyment of these advantages, and as an especial compensation for the said advantages, and for the favours they have acquired by the 4 th, 5 th, and 6 th articles of this treaty, the United States guarantee positively and efficaciously to New Granada, by the present stipulation, the perfect neutrality of the before-mentioned Isthmus, with the view that the free transit from the one to the other sea may not be interrupted or embarrassed in any future time while this treaty exists; and, in consequence, the United States also guarantee, in the same manner, the rights of sovereignty and property which New Granda has and possesses over the said territory. 


\section{APPENDIX II}

\section{The Clayton-Bulwer Treaty}

\section{Ratified July 5, 1850}

The United States of America and Her Britannic Majesty, being desirous of consolidating the relations of amity which so happily subsist between them, by setting forth and fixing in a convention their views and intentions with reference to any means of communication by ship-canal which may be constructed between the Atlantic and Pacific Oceans by the way of the river San Juan de Nicaragua and either or both of the Lakes of Nicaragua or Managua, to any port or place on the Pacific Ocean, the President of the United States has conferred full powers on John M. Clayton, Secretary of State of the United States, and Her Britannic Majesty on the Right Honourable Sir Henry Lytton Bulwer, a member of Her Majesty's most honourable Privy Council, Knight Commander of the most honourable Order of the Bath, and Envoy Extraordinary and Minister Plenipotentiary of Her Britannic Majesty to the United States, for the aforesaid purpose; and the said plenipotentiaries having exchanged their full powers, which were found to be in proper form, have agreed to the following articles:

\section{ARTICLE I}

The governments of the United States and Great Britain hereby declare that neither the one nor the other will ever obtain or maintain for itself any exclusive control over the said ship-canal; agreeing that neither will ever erect or maintain any fortifications commanding the same or in the vicinity thereof, or occupy, or fortify, or colonise, or assume, or exercise any dominion over Nicaragua, Costa Rica, the Mosquito Coast, or any part of Central America ; nor will either make use of any protection which either affords or may afford, or any alliance which either has or may have to or with any state or people, for the purpose of erecting or maintaining any such fortification, or of occupying, fortifying, 
or colonising Nicaragua, Costa Rica, the Mosquito Coast, or any part of Central America, or of assuming or exercising dominion over the same; nor will the United States or Great Britain take advantage of any intimacy, or use any alliance, connection, or influence that either may possess with any state or government through whose territory the said canal may pass, for the purpose of acquiring or holding, directly or indirectly, for the citizens or subjects of the one, any rights or advantages in regard to commerce or navigation through the said canal which shall not be offered on the same terms to the citizens or subjects of the other.

\section{ARTICLE II}

Vessels of the United States or Great Britain traversing the said canal shall, in case of war between the contracting parties, be exempted from blockade, detention, or capture by either of the belligerents; and this provision shall extend to such a distance from the two ends of the said canal as may hereafter be found expedient to establish.

\section{ARTICLE III}

In order to secure the construction of the said canal, the contracting parties engage that if any such canal shall be undertaken upon fair and equitable terms by any parties having the authority of the local government or governments through whose territory the same may pass, then the persons employed in making the said canal, and their property used, or to be used for that object, shall be protected, from the commencement of the said canal to its completion, by the governments of the United States and Great Britain, from unjust detention, confiscation, seizure, or any violence whatsoever.

\section{ARTICLE IV}

The contracting parties will use whatever influence they respectively exercise with any state, states, or governments possessing or claiming to possess any jurisdiction or right over the territory which the said canal shall traverse, or which shall be near the waters applicable thereto, in order to induce such states or governments to facilitate the construction of the said canal by every means in their power. 
And furthermore, the United States and Great Britain agree to use their good offices, wherever or however it may be most expedient, in order to procure the establishment of two free ports, one at each end of the canal.

\section{ARTICLE V}

The contracting parties further engage, that when the said canal shall have been completed, they will protect it from interruption, seizure, or unjust confiscation, and that they will guarantee the neutrality thereof, so that the said canal may forever be open and free, and the capital invested therein secure. Nevertheless, the governments of the United States and Great Britain, in according their protection to the construction of the said canal, and guaranteeing its neutrality and security when completed, always understand that this protection and guaranty are granted conditionally, and may be withdrawn by both governments, or either government, if both governments, or either government, should deem that the persons or company undertaking or managing the same adopt or establish such regulations concerning the traffic thereupon as are contrary to the spirit and intention of this convention, either by making unfair discriminations in favour of the commerce of one of the contracting parties over the commerce of the other, or by imposing oppressive exactions or unreasonable tolls upon passengers, vessels, goods, wares, merchandise, or other articles. Neither party, however, shall withdraw the aforesaid protection and guaranty without first giving six months' notice to the other.

\section{ARTICLE VI}

The contracting parties in this convention engage to invite every state with which both or either have friendly intercourse to enter into stipulations with them similar to those which they have entered into with each other, to the end that all other states may share in the honour and advantage of having contributed to a work of such general interest and importance as the canal herein contemplated. And the contracting parties likewise agree that each shall enter into treaty stipulations with such of the Central American states as they may deem advisable, for the purpose of more effectually carrying out the great design of this convention: 
namely, that of constructing and maintaining the said canal as a ship communication between the two oceans for the benefit of mankind, on equal terms to all, and of protecting the same; and they also agree, that the good offices of either shall be employed, when requested by the other, in aiding and assisting the negotiation of such treaty stipulations; and should any differences arise as to right or property over the territory through which the said canal shall pass between the states or governments of Central America, and such differences should in any way impede or obstruct the execution of the said canal, the governments of the United States and Great Britain will use their good offices to settle such differences in the manner best suited to promote the interests of the said canal, and to strengthen the bonds of friendship and alliance which exist between the contracting parties.

\section{ARTICLE VII}

It being desirable that no time should be unnecessarily lost in commencing and constructing the said canal, the governments of the United States and Great Britain determine to give their support and encouragement to such persons or company as may first offer to commence the same, with the necessary capital, the consent of the local authorities, and on such principles as accord with the spirit and intention of this convention; and if any persons or company should already have, with any state through which the proposed ship canal may pass, a contract for the construction of such a canal as that specified in this convention, to the stipulations of which contract neither of the contracting parties in this convention have any just cause to object, and the said persons or company shall moreover have made preparations, and expended time, money, and trouble, on the faith of such contract, it is hereby agreed that such persons or company shall have a priority of claim over every other person, persons, or company to the protection of the governments of the United States and Great Britain, and be allowed a year from the date of the exchange of the ratifications of this convention for concluding their arrangements, and preventing evidence of sufficient capital subscribed to accomplish the contemplated undertaking; it being understood that if, at the expiration of the aforesaid period, such persons or company be not able to commence and carry out the proposed enterprise, then the governments of the United 
States and Great Britain shall be free to afford their protection to any other persons or company that shall be prepared to commence and proceed with the construction of the canal.

\section{ARTICLE VIII}

The governments of the United States and Great Britain having not only desired, in entering into this convention, to accomplish a particular object, but also to establish a general principle, they hereby agree to extend their protection, by treaty stipulations, to any other practicable com. munications, whether by canal or railway, across the isthmus which connects North and South America, and especially to the interoceanic communications, should the same prove to be practicable, whether by canal or railway, which are now proposed to be established by the way of Tehuantepec or Panama. In granting, however, their joint protection to any such canals or railways as are by this article specified, it is always understood by the United States and Great Britain that the parties constructing or owning the same shall impose no other charges or conditions of traffic thereupon than the aforesaid governments shall approve of as just and equitable; and that the same canals or railways, being open to the citizens and subjects of the United States and Great Britain on equal terms, shall also, be open on like terms to the citizens and subjects of every other state which is willing to grant thereto such protection as the United States and Great Britain engage to afford.

\section{ARTICLE IX}

The ratifications of this convention shall be exchanged at Washington within six months from this day, or sooner if possible.

In faith whereof, we, the respective plenipotentiaries, have signed this convention, and have hereunto affixed our seals.

Done at Washington, the nineteenth day of April, anno Domini one thousand eight hundred and fifty.

John M. Clayton (L. S.)

Henry Lytton Bulwer (L. S.) 


\title{
APPENDIX III
}

\author{
The Isthiman Canal Convention \\ (Commonly called the Hay-Pauncefote Treaty)
}

\author{
Signed, November 18, 1901 \\ Submitted to the Senate, December 5, 1901 \\ Ratified by the Senate, December 16, 1901
}

I. The high contracting parties agree that the present treaty shall supersede the afore-mentioned (Clayton-Bulwer) convention of April 19, 1850.

II. It is agreed that the canal may be constructed under the auspices of the government of the United States either directly at its own cost, or by gift or loan of money to individuals or corporations, or through subscription to or purchase of stock or shares, and that, subject to the provisions of the present treaty, the said government shall have and enjoy all the rights incident to such construction, as well as the exclusive right of providing for the regulation, and management of the canal.

III. The United States adopts as the basis of the neutralisation of such ship canal the following rules substantially as embodied in the Convention of Constantinople, signed the 28th October, 1888, for the free navigation of the Suez Canal; that is to say:

First-The canal shall be free and open to the vessels of commerce and of war of all nations observing these rules, on terms of entire equality, so that there shall be no discrimination against any such nation or its citizens or subjects in respect of the conditions or charges of traffic, or otherwise. Such conditions and charges of traffic shall be just and equitable.

Second-The canal shall never be blockaded, nor shall any right of war be exercised nor any act of hostility be committed within it. The United States, however, shall be at liberty to maintain such military police along the canal as may be necessary to protect it against lawlessness and disorder. 
Third-Vessels of war of a belligerent shall not revictual nor take any stores in the canal except so far as may be strictly necessary; and the transit of such vessels through the canal shall be effected with the least possible delay in accordance with the regulations in force, and with only such intermission as may result from the necessities of the service.

Prizes shall be in all respects subject to the same rules as vessels of war of the belligerents.

Fourth-No belligerent shall embark or disembark troops, munitions of war or warlike materials in the canal except in case of accidental hindrance of the transit and in such case the transit shall be resumed with all possible despatch.

Fifth-The provisions of this article shall apply to waters adjacent to the canal, within three marine miles of either end. Vessels of war of a belligerent shall not remain in such waters longer than twenty-four hours at any one time except in case of distress, and in such case shall depart as soon as possible, but a vessel of war of one belligerent shall not depart within twenty-four hours from the departure of a vessel of war of the other belligerent.

Sixth-The plant, establishments, buildings and all works necessary to the construction, maintenance and operation of the canal shall be deemed to be parts thereof for the purpose of this treaty, and in time of war, as in time of peace, shall enjoy complete immunity from attack or injury by belligerents, and from acts calculated to impair their usefulness as part of the canal.

IV. It is agreed that no change of territorial sovereignty or of international relations of the country or countries traversed by the before mentioned canal shall affect the general principle of neutralisation or the obligation of the high contracting parties under the present treaty.

V. The present treaty shall be ratified by the President of the United States by and with the advice and consent of the Senate thereof, and by His Britannic Majesty; and the ratifications shall be exchanged at Washington or at London at the earliest possible time within six months from the date hereof. 


\section{APPENDIX IV. \\ The Isthmian Canal Law (Commonly called the Spooner Bill)}

Approved, June 28, 1902

$\mathrm{B}_{\mathrm{E}}$ it enacted, etc. That the President of the United States is hereby authorised to acquire, for and on behalf of the United States, at a cost not exceeding $\$ 40,000,000$, all of the rights, privileges, franchises, concessions, grants of land, right of way, unfinished work, plants and other property, real, personal and mixed, of every name and nature, owned by the New Panama Canal Company, of France, on the Isthmus of Panama, and all its maps, plans, drawings, records, on the Isthmus of Panama and in Paris, including ail the capital stock, not less, however, than 68,863 shares of the Panama Railroad Company, owned by or held for the use of said canal company, provided a satisfactory title to all of said property can be obtained.

Sec. 2. That the President is hereby authorised to acquire from the Republic of Colombia, for and on behalf of the United States, upon such terms as he may deem reasonable, exclusive and perpetual control in perpetuity of a strip of land from the territory of the Republic of Colombia, not less than 6 miles in width, extending from the Caribbean sea to the Pacific Ocean, and the right to use and dispose of the waters thereon, and to excavate, construct and to perpetually maintain, operate and protect thereon a canal, of such depth and capacity as will afford convenient passage of ships of the greatest tonnage and draught now in use, from the Caribbean Sea to the Pacific Ocean, which control shall include the right to perpetually maintain and operate the Panama Railroad, if the ownership thereof or a controlling interest therein shall have been acquired by the United States, and also jurisdiction over said strip and the ports at the ends thereof; to make such police and sanitary rules and regulations as shall be necessary to preserve order and pre- 
serve the public health thereon, and to establish such judicial tribunals thereon as may be necessary to enforce such rules and regulations. The President may acquire such additional territory and rights from Colombia as in his judgment will facilitate the general purposes hereof.

Sec. 3. That when the President shall have arranged to secure a satisfactory title to the property of the New Pan ama Canal Company, as provided in Section 1 hereof, and shall have obtained by treaty control of the necessary territory from the Republic of Colombia, as provided in Section 2 hereof, he is authorised to pay for the property of the New Panama Canal Company $\$ 40,000,000$, and to the Republic of Colombia such sums as shall have been agreed upon and a sum sufficient for both said purposes is hereby appropriated out of any money in the Treasury not otherwise appropriated, to be paid on warrant or warrants drawn by the President.

The President shall then cause to be excavated, constructed and completed, utilising to that end as far as practicable the work heretofore done by the New Panama Canal Company, of France, and its predecessor company, a ship canal from the Caribbean Sea to the Pacific Ocean. Such canal shall be of sufficient capacity and depth as shall afford convenient passage for vessels of the largest tonnage and greatest draught now in use, and such as may be rea. sonably anticipated and shall be supplied with all necessary locks and other appliances to meet the necessities of vessels passing through the same from ocean to ocean; and he shall also cause to be constructed such safe and commodious harbours at the terminals of said canal, and make such provisions for defence as may be necessary for the safety and protection of said canal and harbours. That the President is authorised for the purposes aforesaid to employ such persons as he may deem necessary, and to fix their compensation.

Sec. 4. That should the President be unable to obtain for the United States a satisfactory title to the property of the New Panama Canal Company, and the control of the necessary territory of the Republic of Colombia, and the rights mentioned in Sections 1 and 2 of this act, within a reasonable time and upon reasonable terms, then the President, having first obtained for the United States exclusive and perpetual control, by treaty, of the necessary territory from Costa Rica and Nicaragua, upon terms which he may con- 
sider reasonable, for the construction, perpetual maintenance, operation and protection of a canal connecting the Caribbean Sea with the Pacific Ocean by what is commonly known as the Nicaragua route, shall cause to be excavated and constructed a ship canal and waterway from a point on the shore of the Caribbean Sea near Greytown, by way of Lake Nicaragua, to a point near Brito, on the Pacific Ocean. Said canal shall be of sufficient capacity and depth to afford convenient passage for vessels of the largest tonnage and greatest draught now in use, and such as may be reasonably expected, and shall be supplied with all necessary locks and other appliances to meet the necessities of vessels passing through the same from ocean to ocean; and he shall also construct such safe and commodious harbours at the terminal of such canal as shall be necessary for the safe and conven. ient use thereof, and shall make such provisions for defence as may be necessary for the safety and protection of said harbours and canal; and such sum or sums of money as may be agreed upon by such treaty as compensation to be paid Nicaragua and Costa Rica for the concessions and rights hereunder provided to be acquired by the United States are hereby appropriated out of any money in the Treasury not otherwise appropriated, to be paid on warrant or warrants drawn by the President.

The President shall cause such surveys as may be necessary for said canal and harbours to be made, and in making such surveys, and in the construction of said canal, may employ such persons as he may deem necessary, and may fix their compensation.

In the excavation and construction of said canal the San Juan River and Lake Nicaragua, or such parts of each as may be made available, shall be used.

Sec. 5. That the sum of $\$ 10,000,000$ is hereby appropriated out of any money in the Treasury not otherwise appropriated, toward the project herein contemplated, by either route so selected.

And the President is hereby authorised to cause to be entered into such contract or contracts as may be deemed necessary for the proper excavation, construction, completion and defence of said canal, harbours and defences, by the route finally determined upon under the provisions of this act. Appropriations therefor shall from time to time be hereafter made, not to exceed in the aggregate the additional sum of $\$ 135,000,000$, should the Panama route be 
adopted, or $\$ 180,000,000$, should the Nicaragua route be adopted.

Sec. 6. That in any agreement with the Republic of Colombia or with the States of Nicaragua and Costa Rica, the President is authorised to guarantee to said republic or said States the use of said canal and harbours, upon such terms as may be agreed upon, for all vessels owned by said States or by citizens thereof.

Sec. 7. That to enable the President to construct the canal and works appurtenant thereto, as provided in this act, there is hereby created the Isthmian Canal Commission, the same to be composed of seven members, who shall be nominated and appointed by the President, by and with the advice and consent of the Senate, and who shall serve during the pleasure of the President, and one of whom shall be named as the chairman of said commission.

Of the seven members of said commission, at least four shall be persons learned and skilled in the practice of engineering, and of the four at least one shall be an officer of the United States Army, and at least one other shall be an officer of the United States Navy, the said officers respectively being either upon the active or the retired list of the army or of the navy. Said commissioners shall each receive such compensation as the President shall prescribe until the same shall have been otherwise fixed by Congress. In addition to the members of said Isthmian Canal Commission, the President is hereby authorised, through said commission, to employ in said service any of the engineers of the United States Army at his discretion, and likewise to employ any engineers in civil life, at his discretion, and any other persons necessary for the proper and expeditious prosecution of said work. The compensation of all such engineers and other persons employed under this act shall be fixed by said commission, subject to the approval of the President. The official salary of any officer appointed or employed under this act shall be deducted from the amount of salary or compensation provided by or which shall be fixed under the terms of this act.

Said commission shall in all matters be subject to the direction and control of the President, and shall make to the President annually and at such other periods as may be required either by law or by the order of the President full and complete reports of all their actings and doings and of all moneys received and expended in the construction of said 
work, and in the performance of their duties in connection therewith, which said reports shall be by the President transmitted to Congress.

And the said commission shall furthermore give to Congress, or either House of Congress, such information as may at any time be required either by act of Congress or by the order of either House of Congress. The President shall cause to be provided and assigned for the use of the commission such offices as may, with the suitable equipment of the same, be necessary and proper, in his discretion, for the proper discharge of the duties thereof.

Sec. 8. That the Secretary of the Treasury is hereby authorised to borrow on the credit of the United States from time to time, as the proceeds may be required to defray expenditures authorised by this act (such proceeds when received to be used only for the purpose of meeting such expenditures) the sum of $\$ 130,000,000$, or so much thereof as may be necessary, and to prepare and issue therefor coupon or registered bonds of the United States in such form as he may prescribe, and in denominations of $\$ 20$ or some multiple of that sum, redeemable in gold coin at the pleasure of the United States after ten years from the date of their issue, and payable twenty years from such date, and bearing interest payable quarterly in gold coin at the rate of 2 per cent. per annum; and the bonds herein authorised shall be exempt from all taxes or duties of the United States, as well as from taxation in any form by or under State, municipal or local authority.

Provided, That said bonds may be disposed of by the Secretary of the Treasury at not less than par, under such regulations as he may prescribe, giving to all citizens of the United States an equal opportunity to subscribe therefor, but no commissions shall be allowed or paid thereon; and a sum not exceeding one-tenth of 1 per cent. of the amount of the bonds herein authorised is hereby appropriated, out of any money in the Treasury not otherwise appropriated, to pay the expense of preparing, advertising and issuing the same.

And provided further, that none of the said bonds shall be sold to pay the sums appropriated in Sections 1 and 2 of this act, or to pay the sum of $\$ 10,000,000$ appropriated in Section 5 of this act. 


\section{APPENDIX V \\ The Panaman Declaration of Independence}

\section{Signed and Promulgated on November 4, 1903}

THe transcendental act that by a spontaneous movement the inhabitants of the Isthmus of Panama have just executed is the inevitable consequence of a situation which has become graver daily.

Long is the recital of the grievances that the inhabitants of the Isthmus have suffered from their Colombian brothers; but those grievances would have been withstood with resignation for the sake of harmony and national union had its separation been possible and if we could have entertained well-founded hopes of improvement and of effective progress under the system to which we were submitted by that Republic. We have to solemnly declare that we have the sincere and profound conviction that all the hopes were futile and useless, all the sacrifices on our part.

The Isthmus of Panama has been governed by the Republic of Colombia with the narrow-mindedness that in past times was applied to their colonies by the European nations-the Isthmian people and territory were a source of fiscal resources and nothing more. The contracts and negotiations regarding the railroad and the Panama Canal and the national taxes collected in the Isthmus have netted to Colombia tremendous sums which we will not detail, not wishing to appear in this exposition which will go down to posterity as being moved by a mercenary spirit, which has never been nor is our purpose; and of these large sums the Isthmus has not received the benefit of a bridge for any of its numerous rivers, nor the construction of a single road between its towns, nor of any public building nor of a single college, and has neither seen any interest displayed in advancing her industries, nor has a most infinite part of those sums been applied toward her prosperity. 
A very recent example of what we have related above is what has occurred with the negotiations of the Panama Canal, which, when taken under consideration by Congress, was rejected in a summary manner. There were a few public men who expressed their adverse opinion, on the ground that the Isthmus of Panama alone was to be favoured by the opening of the canal by virtue of a treaty with the United States, and that the rest of Colombia would not receive any direct benefits of any sort by that work, as if that way of reasoning, even though it be correct, would justify the irreparable and perpetual damage which would be caused to the Isthmus by the rejection of the treaty in the manner in which it was done, which was equivalent to the closing of the doors to future negotiations.

The people of the Isthmus, in view of such notorious causes, have decided to recover their sovereignty and begin to form a part of the society of the free and independent nations, in order to work out its own destiny, to insure its future in a stable manner, and discharge the duties which it is called on to do by the situation of its territory and its immense richness.

To that we, the initiators of the movement effected, aspire and have obtained a unanimous approval.

We aspire to the formation of a true republic, where tolerance will prevail, where the law shall be the invariable guide of those governing and those governed, where effective peace be established, which consists in the frequent and harmonious play of all interests and all activities, and where, finally, civilisation and progress will find perpetual stability.

At the commencement of the life of an independent nation we fully appreciate the responsibilities that state means, but we have profound faith in the good sense and patriotism of the Istlimian people, and we possess sufficient energy to open our way by means of labour to a happy future without any worry or any danger.

At separating from our brothers of Colombia we do it without hatred and without any joy. Just as a son withdraws from his paternal roof, the Isthmian people in adopting the lot it has chosen have done it with grief, but in compliance with the supreme and inevitable duty it owes to itself-that of its own preservation and of working for its own welfare.

We therefore begin to form a part among the free nations 
of the world, considering Colombia as a sister nation, with which we shall be whenever circumstances may require it, and for whose prosperity we have the most fervent and sincere wishes.

José Agustin Arango,

Federico Boyd,

Tomas Arias. 


\section{APPENDIX VI}

\section{The Panama Canal Convention (Commonly called the Hay-Bunau Varilla Treaty)}

Signed at Washington, November 18, 1903

Transmitted to the Senate, December \%, 1903

Ratification advised by the Senate, February 23, 1904

Ratified by the President, February 25, 1904

Ratified by Panama, December 2, 1903

Ratifications exchanged at Washington, February 26,1904

Proclaimed, February 26, 1904

The United States of America and the Republic of Panama being desirous to insure the construction of a ship-canal across the Isthmus of Panama to connect the Atlantic and Pacific oceans, and the Congress of the United States of America having passed an act approved June 28, 1902, in furtherance of that object, by which the President of the United States is authorised to acquire within a reasonable time the control of the necessary territory of the Republic of Colombia, and the sovereignty of such territory being actually vested in the Republic of Panama, the high contracting parties have resolved for that purpose to conclude a convention and have accordingly appointed as their plenipotentiaries,-

The President of the United States of America, John Hay, Secretary of State, and the Government of the Republic of Panama, Philippe Bunau Varilla, Envoy Extraordinary and Minister Plenipotentiary of the Republic of Panama, thereunto specially empowered by said government, who after communicating with each other their respective full powers found to be in good and due form, have agreed upon and concluded the following articles:

\section{ARTICLE I}

The United States guarantees and will maintain the independence of the Republic of Panama. 


\section{ARTICLE II}

The Republic of Panama grants to the United States in perpetuity the use, occupation and control of a zone of land and land under water for the construction, maintenance, operation, sanitation and protection of said Canal of the width of ten miles extending to the distance of five miles on each side of the centre line of the route of the Canal to be constructed; the said zone beginning in the Caribbean Sea three marine miles from mean low water mark and extending to and across the Isthmus of Panama into the Pacific Ocean to a distance of three marine miles from mean low water mark with the proviso that the cities of Panama and Colon and the harbours adjacent to said cities, which are included within the boundaries of the zone above described, shall not be included within this grant. The Republic of Panama further grants to the United States in perpetuity the use, occupation and control of any other lands and waters outside of the zone above described which may be necessary and convenient for the construction, maintenance, operation, sanitation and protection of the said Canal or of any auxiliary canal or other works necessary and convenient for the construction, maintenance, operation, sanitation and protection of the said enterprise.

The Republic of Panama further grants in like manner to the United States in perpetuity all islands within the limits of the zone above described and in addition thereto the group of small islands in the Bay of Panama, named Perico, Naos, Culebra and Flamenco.

\section{ARTICLE III}

The Republic of Panama grants to the United States all the rights, power and authority within the zone mentioned and described in Article II of this agreement and within the limits of all auxiliary lands and waters mentioned and described in said Article II which the United States would possess and exercise if it were the sovereign of the territory within which said lands and waters are located to the entire exclusion of the exercise by the Republic of Panama of any such sovereign rights, power or authority.

ARTICLE IV

As rights subsidiary to the above grants the Republic of Panama grants in perpetuity to the United States the right 
to use the rivers, streams, lakes and other bodies of water within its limits for navigation, the supply of water or water-power or other purposes, so far as the use of said rivers, streams, lakes and bodies of water and the waters thereof may be necessary and convenient for the construction, maintenance, operation, sanitation and protection of the said Canal.

\section{ARTICLE V}

The Republic of Panama grants to the United States in perpetuity a monopoly for the construction, maintenance and operation of any system of communication by means of canal or railroad across its territory between the Caribbean Sea and the Pacific Ocean.

\section{ARTICLE VI}

The grants herein contained shall in no manner invalidate the titles or rights of private land holders or owners of private property in the said zone or in or to any of the lands or waters granted to the United States by the provisions of any Article of this treaty, nor shall they interfere with the rights of way over the public roads passing through the said zone or over any of the said lands or waters unless said rights of way or private rights shall conflict with rights herein granted to the United States, in which case the rights of the United States shall be superior. All damages caused to the owners of private lands or private property of any kind by reason of the grants contained in this treaty or by reason of the operations of the United States, its agents or employees, or by reason of the construction, maintenance, operation, sanitation and protection of the said Canal or of the works of sanitation and protection herein provided for, shall be appraised and settled by a joint Commission appointed by the Governments of the United States and the Republic of Panama, whose decisions as to such damages shall be final and whose awards as to such damages shall be paid solely by the United States. No part of the work on said Canal or the Panama railroad or on any auxiliary works relating thereto and authorised by the terms of this treaty shall be prevented, delayed or impeded by or pending such proceedings to ascertain such damages. The appraisal of the said private lands and private property and the assess- 
meilt of damages to them shall be based upon their value before the date of this convention.

\section{ARTICLE VII}

The Republic of Panama grants to the United States within the limits of the cities of Panama and Colon and their adjacent harbours and within the territory adjacent thereto the right to acquire by purchase or by the exercise of the right of eminent domain, any lands, buildings, water rights or other properties necessary and convenient for the construction, maintenance, operation and protection of the Canal and of any works of sanitation, such as the collection and disposition of sewage and the distribution of water in the said cities of Panama and Colon, which, in the discretion of the United States, may be necessary and convenient for the construction, maintenance, operation, sanitation and protection of the said Canal and railroad. All such works of sanitation, collection and disposition of sewage and distribution of water in the cities of Panama and Colon shall be made at the expense of the United States, and the Government of the United States, its agents or nominees shall be authorised to impose and collect water rates and sewerage rates which shall be sufficient to provide for the payment of interest and the amortisation of the principal of the cost of said works within a period of fifty years and upon the expiration of said term of fifty years the system of sewers and water works shall revert to and become the properties of the cities of Panama and Colon respectively; and the use of the water shall be free to the inhabitants of Panama and Colon, except to the extent that water rates may be necessary for the operation and maintenance of said system of sewers and water.

The Republic of Panama agrees that the cities of Panama and Colon shall comply in perpetuity with the sanitary ordinances whether of a preventive or curative character prescribed by the United States, and in case the Government of Panama is unable or fails in its duty to enforce this compliance by the cities of Panama and Colon with the sanitary ordinances of the United States the Republic of Panama grants to the United States the right and authority to enforce the same.

The same right and authority are granted to the United States for the maintenance of public order in the cities of Panama and Colon and the territories and harbours adjacent 
thereto in case the Republic of Panama should not be, in the judgment of the United States, able to maintain such order.

\section{ARTICLE VIII}

The Republic of Panama grants to the United States all rights which it now has or hereafter may acquire to the property of the New Panama Canal Company and the Panama Railroad Company as a result of the transfer of sovereignty from the Republic of Colombia to the Republic of Panama over the Isthmus of Panama, and authorises the New Panama Canal Company to sell and transfer to the United States its rights, privileges, properties and concessions as well as the Panama Railroad and all the shares or part of the shares of that company; but the public lands situated outside of the zone described in Article II of this treaty now included in the concessions to both said enterprises and not required in the construction or operation of the Canal shall revert to the Republic of Panama except any property now owned by or in the possession of said companies within Panama or Colon or the ports or terminals thereof.

\section{ARTICLE IX}

The United States agrees that the ports at either entrance of the Canal and the waters thereof, and the Republic of Panama agrees that the towns of Panama and Colon, shall be free for all time, so that there shall not be imposed or collected customhouse tolls, tonnage, anchorage, lighthouse, wharf, pilot, or quarantine dues or any other charges or taxes of any kind upon any vessel using or passing through the Canal or belonging to or employed by the United States, directly or indirectly, in connection with the construction, maintenance, operation, sanitation and protection of the main Canal, or auxiliary works, or upon the cargo, officers, crew, or passengers of any such vessels, except such tolls and charges as may be imposed by the United States for the use of the Canal and other works, and except tolls and charges imposed by the Republic of Panama upon merchandise destined to be introduced for the consumption of the rest of the Republic of Panama, and upon vessels touching at the ports of Colon and Panama and which do not cross the Canal. 
The Government of the Republic of Panama shall have the right to establish in such ports and in the towns of Panama and Colon such houses and guards as it may deem necessary to collect duties on importations destined to other portions of Panama and to prevent contraband trade. The United States shall have the right to make use of the towns and harbours of Panama and Colon as places of anchorage, and for making repairs, for loading, unloading, depositing, or transshipping cargoes either in transit or destined for the service of the Canal and for other works pertaining to the Canal.

\section{ARTICLE $\mathbf{x}$}

The Republic of Panama agrees that there shall not be imposed any taxes, national, municipal, departmental, or of any other class, upon the Canal, the railways and auxiliary works, tugs and other vessels employed in the service of the Canal, storehouses, workshops, offices, quarters for labourers, factories of all kinds, warehouses, wharves, machinery and other works, property, and effects appertaining to the Canal or railroad and auxiliary works, or their officers or employees, situated within the cities of Panama and Colon, and that there shall not be imposed contributions or charges of a personal character of any kind upon officers, employees, labourers, and other individuals in the service of the Canal and railroad and auxiliary works.

\section{ARTICLE XI}

The United States agrees that the official despatches of the Government of the Republic of Panama shall be transmitted over any telegraph and telephone lines established for canal purposes and used for public and private business at rates not higher than those required from officials in the service of the United States.

\section{ARTICLE XII}

The Government of the Republic of Panama shall permit the immigration and free access to the lands and workshops of the Canal and its auxiliary works of all employees and workmen of whatever nationality under contract to work upon or seeking employment upon or in any wise connected 
with the said Canal and its auxiliary works, with their respective families, and all such persons shall be free and exempt from the military service of the Republic of Panama.

\section{ARTICLE XIII}

The United States may import at any time into the said zone and auxiliary lands, free of custom duties, imposts, taxes, or other charges, and without any restrictions, any and all vessels, dredges, engines, cars, machinery, tools, explosives, materials, supplies, and other articles necessary and convenient in the construction, maintenance, operation, sanitation and protection of the Canal and auxiliary works, and all provisions, medicines, clothing, supplies and other things necessary and convenient for the officers, employees, workmen and labourers in the service and employ of the United States and for their families. If any such articles are disposed of for use outside of the zone and auxiliary lands granted to the United States and within the territory of the Republic, they shall be subject to the same import or other duties as like articles imported under the laws of the Republic of Panama.

\section{ARTICLE XIV}

As the price or compensation for the rights, powers and privileges granted in this convention by the Republic of Panama to the United States, the Government of the United States agrees to pay to the Republic of Panama the sum of ten million dollars $(\$ 10,000,000)$ in gold coin of the United States on the exchange of the ratification of this convention and also an annual payment during the life of this convention of two hundred and fifty thousand dollars $(\$ 250,000)$ in like gold coin, beginning nine years after the date aforesaid.

The provisions of this Article shall be in addition to all other benefits assured to the Republic of Panama under this convention. But no delay or difference of opinion under this Article or any other provisions of this treaty shall affect or interrupt the full operation and effect of this convention in all other respects.

\section{ARTICLE XV}

The joint commission referred to in Article VI shall be established as follows: 
The President of the United States shall nominate two persons and the President of the Republic of Panama shall nominate two persons and they shall proceed to a decision; but in case of disagreement of the Commission (by reason of their being equally divided in conclusion) an umpire shall be appointed by the two Governments who shall render the decision. In the event of the death, absence, or incapacity of a commissioner or umpire, or of his omitting, declining or ceasing to act, his place shall be filled by the appointment of another person in the manner above indicated. All decisions by a majority of the Commission or by the umpire shall be final.

\section{ARTICLE XVI}

The two Governments shall make adequate provision by mutual agreement for the pursuit, capture, imprisonment, detention and delivery within said zone and auxiliary lands to the authorities of the Republic of Panama of persons charged with the commitment of crimes, felonies or misdemeanours without said zone and for the pursuit, capture, imprisonment, detention and delivery without said zone to the authorities of the United States of persons charged with the commitment of crimes, felonies and misdemeanours within said zone and auxiliary lands.

\section{ARTICLE XVII}

The Republic of Panama grants to the United States the use of all the ports of the Republic open to commerce as places of refuge for any vessels employed in the Canal enterprise, and for all vessels passing or bound to pass through the Canal which may be in distress and be driven to seek refuge in said ports. Such vessels shall be exempt from anchorage and tonnage dues on the part of the Republic of Panama.

\section{ARTICLE XVIII}

The Canal, when constructed, and the entrances thereto shall be neutral in perpetuity, and shall be opened upon the terms provided for by Section I of Article Three of, and in conformity with all the stipulations of, the treaty entered into by the Governments of the United States and Great Britain on November 18, 1901. 


\section{ARTICLE XIX}

The Government of the Republic of Panama shall have the right to transport over the Canal its vessels and its troops and munitions of war in such vessels at all times without paying charges of any kind. The exemption is to be extended to the auxiliary railway for the transportation of persons in the service of the Republic of Panama, or of the police force charged with the preservation of public order outside of said zone, as well as to their baggage, munitions of war and supplies.

\section{ARTICLE XX}

If by virtue of any existing treaty in relation to the territory of the Isthmus of Panama, whereof the obligations shall descend or be assumed by the Republic of Panama, there may be any privilege or concession in favour of the Government or the citizens and subjects of a third power relative to an interoceanic means of communication which in any of its terms may be incompatible with the terms of the present convention, the Republic of Panama agrees to cancel or modify such treaty in due form, for which purpose it shall give to the said third power the requisite notification within the term of four months from the date of the present convention, and in case the existing treaty contains no clause permitting its modification or annulment, the Republic of Panama agrees to procure its modification or annulment in such form that there shall not exist any conflict with the stipulations of the present convention.

\section{ARTICLE XXI}

The rights and privileges granted by the Republic of Panama to the United States in the preceding Articles are understood to be free of all anterior debts, liens, trusts, or liabilities, or concessions or privileges to other Governments, corporations, syndicates or individuals; and consequently, if there should arise any claims on account of the present concessions and privileges or otherwise, the claimant shall resort to the Government of the Republic of Panama and not to the United States for any indemnity or compromise which may be required. 


\section{ARTICLE XXII}

The Republic of Panama renounces and grants to the United States the participation to which it might be entitled in the future earnings of the Canal under Article XV of the concessionary contract with Lucien N. B. Wyse now owned by the New Panama Canal Company and any and all other rights or claims of a pecuniary nature arising under or relating to said concession, or arising under or relating to the concessions to the Panama Railroad Company or any extension or modification thereof; and it likewise renounces, confirms and grants to the United States, now and hereafter, all the rights and property reserved in the said concessions which otherwise would belong to Panama at or before the expiration of the terms of ninety-nine years of the concessions granted to or held by the above mentioned party and companies, and all right, title and interest which it now has or may hereafter have, in and to the lands, canal, works, property and rights held by the said companies under said concessions or otherwise, and acquired or to be acquired by the United States from or through the New Panama Canal Company, including any property and rights which might or may in the future either by lapse of time, forfeiture or otherwise, revert to the Republic of Panama under any contracts or concessions, with said Wyse, the Universal Panama Canal Company, the Panama Railroad Company and the New Panama Canal Company.

The aforesaid rights and property shall be and are free and released from any present or reversionary interest in or claims of Panama and the title of the United States thereto upon consummation of the contemplated purchase by the United States from the New Panama Canal Company shall be absolute, so far as concerns the Republic of Panama, excepting always the rights of the Republic specifically secured under this treaty.

\section{ARTICLE XXIII}

If it should become necessary at any time to employ armed forces for the safety or protection of the Canal, or of the ships that make use of the same, or the railways and auxiliary works, the United States shall have the right, at all times and in its discretion, to use its police and its land and naval forces or to establish fortifications for these purposes. 


\section{ARTICLE XXIV}

No change either in the Government or in the laws and treaties of the Republic of Panama shall, without the consent of the United States, affect any right of the United States under the present convention, or under any treaty stipulation between the two countries that now exists or may hereafter exist touching the subject matter of this convention.

If the Republic of Panama shall hereafter enter as a constituent into any other Government or into any union or confederation of states, so as to merge her sovereignty or independence in such Government, union or confederation, the rights of the United States under this convention shall not be in any respect lessened or impaired.

\section{ARTICLE XXV}

For the better performance of the engagements of this convention and to the end of the efficient protection of the Canal and the preservation of its neutrality, the Government of the Republic of Panama will sell or lease to the United States lands adequate and necessary for naval or coaling stations on the Pacific coast and on the western Caribbean coast of the Republic at certain points to be agreed upon with the President of the United States.

\section{ARTICLE XXVI}

This convention when signed by the Plenipotentiaries of the Contracting Parties shall be ratified by the respective Governments and the ratifications shall be exchanged at Washington at the earliest date possible.

In faith whereof the respective Plenipotentiaries have signed the present convention in duplicate and have hereunto affixed their respective seals.

Done at the City of Washington the 18th day of November in the year of our Lord nineteen hundred and three.

JoHN HaY

(Seal)

P. Bunau Varilla (Seal) 


\section{APPENDIX VII}

Proclamation of the Governor of the Canal Zone Issued at Culebra, Panama, May 19, 1904

To the Inhabitants of the Isthmian Canal Zone:

In pursuance of the terms of the canal convention between the United States and the Republic of Panama, the ratifications of which were exchanged on the 26th day of February, 1904, the Republic of Panama granted to the United States, on the Isthmus of Panama, the perpetual use, occupation, and control of a certain zone of land 10 miles in width, and land under water, including the islands within said zone, and also the islands of Perico, Naos, Culebra, and Flamenco, situated on the Bay of Panama, and the use, occupation, and control of certain other lands and waters outside said zone, which may be found to be necessary and convenient, all to be utilised for and in connection with the construction, maintenance, operation, sanitation, and protection of the ship canal which the United States is to construct, and which will extend from the Caribbean Sea, near Colon, to the Pacific Ocean, near the City of Panama.

In addition to the perpetual use, occupation, and control of the lands and waters referred to, the Republic of Panama has also granted to the United States all the rights, powers, and authority within said zone, auxiliary canals, islands, and lands under water which the United States would possess and exercise if it were the sovereign of the territory granted, to the entire exclusion of the exercise by the Republic of Panama of any such sovereign rights, power, and authority.

The canal zone, and all the real and movable property situated within it, that formerly belonged to the New Panama Canal Company have been purchased and taken possession of and are now occupied or controlled by or on behalf of the United States of America.

For the maintenance of order within the territory above described, the use, occupation, and control of which have been granted to the United States, and in order that the 
inhabitants may be protected in the full enjoyment of their liberty, property, and religion, the President of the United States has been empowered by the Congress to establish a temporary government for the canal zone, to which end he has been authorised to delegate to such person or persons as he may designate, and to control the manner of their exercise, all the military, civil, and judicial powers and authority granted to the United States by the Republic of Panama as well as the power to make all needful rules and regulations.

With respect to the government and administration of the canal zone, the President has delegated to the undersigned, as governor of the zone, all necessary executive and administrative attributes, with power to appoint the officials and organise the police force necessary to preserve order and to carry out the purposes of government on the Isthmus. The power to make rules and regulations-in short, all matters of legislation for the zone and its inhabitants-have been delegated to the members of the Isthmian Canal Commission, of whom four constitute a quorum for legislative purposes; but it is provided that the governor of the zone and the legislative commission shall exercise their powers and authority and carry on their work always under the supervision and direction of the Secretary of War.

The President has ordered that the laws of the land which were in force on the 27th of February, 1904, shall continue in force in all places on the Isthmus of Panama over which the United States has jurisdiction until said laws are altered or annulled by the canal commission, and the people are entitled to security in their persons, property, and religion, and in all their private rights and relations. They will be disturbed as little as possible in their customs and avocations that are in harmony with the principles of well ordered and decent living, but there are certain great principles of government that have been made the basis of our existence as a nation which are deemed essential to the rule of law and the maintenance of order, and will have force within the canal zone and within other lands on the Isthmus that are controlled by the United States. The principles referred to may be generally stated as follows:

That no person shall be deprived of life, liberty, or property without due process of law; that private property shall not be taken for public use without just compensation; that in all criminal prosecutions the accused shall enjoy the right 
of a speedy and public trial, to be informed of the nature and cause of the accusation, to be confronted with the witnesses against him, to have compulsory process for obtaining witnesses in his favour, and to have the assistance of counsel in his defence; that excessive bail shall not be required nor excessive fines imposed, nor cruel or unusual punishment inflicted; that no person shall be put twice in jeopardy for the same offence, or be compelled in any criminal case to be a witness against himself ; that the right to be secure against unreasonable searches and seizures shall not be violated; that neither slavery nor involuntary servitude shall exist, except as a punishment for crime; that no bill of attainder or ex-post facto law shall be passed; that no law shall be passed abridging the freedom of speech or of the press, or of the rights of the people to peaceably assemble and petition the Government for a redress of grievances; that no law shall be made respecting the establishment of religion, or prohibiting the free exercise thereof. Provided, however, that the commission shall have power to exclude from time to time from the canal zone and other places on the Isthmus over which the United States has jurisdiction, persons of the following classes who were not actually domiciled within the zone on the 26th of February, 1904, viz.: idiots, the insane, epileptics, paupers, criminals, professional beggars, persons afflicted with loathsome or dangerous contagious diseases, those who have been convicted of felony, anarchists, those whose purpose it is to incite insurrection, and others whose presence it is believed by the commission would tend to create public disorder, endanger the public health, or in any manner impede the prosecution of the work of opening the canal; and may cause any and all such newly arrived persons, or those of the same classes alien to the zone, to be expelled and deported from the territory controlled by the United States, and the commission may defray from the canal appropriation the cost of such deportation, as necessary expenses of the sanitation, the police protection of the canal route, and the preservation of good order among the inhabitants.

The President has further directed notification to the inhabitants of the canal zone that the establishment and maintenance of lotteries and the holding of lottery drawings, or sale of lottery tickets, or the conduct of gambling methods and devices of a character that is prohibited by the laws of the United States are to be strictly forbidden by the canal 
commission, within the canal zone, and that any violation of the law respecting lotteries and gambling, to be enacted, will subject the offender to severe punishment.

The municipal laws of the canal zone are to be administered by the ordinary tribunals substantially as they were before the change of government. Alcaldes, comisarios de barrios, and other persons in lawful discharge of official duties in the zone that are in harmony with the principles of government herein set forth will be continued in office for the present. A judge of a superior court will soon be appointed, and as soon as practicable the limits of the zone will be defined.

The following announcements are made of heads of departments in the government of the zone:

Secretary : Mr. Ernest Legarde, Jr.

Treasurer: Paymaster E. C. Tobey, United States Navy. Xaptain of police: Mr. G. R. Shanton.

Sanitary officer: Dr. L. W. Sprattling, United States Navy. Geo. W. Davis, Governor. 


\section{APPENDIX VIII}

\section{The First Administrative Order}

The following is the text of the first Administrative Order, the enforcement of which was regarded by the Panama Government as an oppressive hardship:

War Department,

Washington, June 24, 1904.

To the Chairman of the Isthmian Canal Commission:

By direction of the President it is ordered:

Section 1. The territory of the canal zone of the Isthmus of Panama is hereby declared open to the commerce of all friendly nations. All articles, goods, and wares, not included in the prohibited list, entering at the established customs ports, will be admitted upon payment of such customs duties and other charges as are in force at the time and place of their importation.

Sec. 2. For the purposes of customs administration in said canal zone, there are hereby established two collection districts, as follows:

First. The district of Ancon, comprising the southern half of said canal zone, more particularly described as follows :

The port of entry in said district shall be Ancon.

Second. The district of Cristobal, comprising the northern half of said canal zone, more particularly described as follows :

The port of entry in said district shall be Cristobal.

Sec. 3. There is hereby created and shall be maintained in the government of the canal zone a subdivision of the executive branch to be known as the customs service; the general duties, powers and jurisdiction of the customs service shall be to administer the customs laws and tariff regulations in force in said zone. The governor of the canal zone shall be the head of the customs service. There shall be a collector of customs for each collection district, who shall receive an annual salary of $\$ 2,500$ in gold, payable in monthly instal- 
ments. It shall be the duty of the collector to collect all revenues derived from the enforcement of the customs laws and tariff regulations in the district subject to his jurisdiction and to perform such other service in the administration of such laws as is ordinarily performed by a collector of customs or as he may be required to perform by the governor of the canal zone. The collector of customs shall be appointed by the governor, with the advice and consent of the Isthmian Commission. The governor of the canal zone is hereby authorised to appoint and fix the compensation of deputy collectors, surveyors of customs, and such other subordinates and employees as may be necessary for the efficient administration of the customs laws and service.

Sec. 4. The governor of the canal zone is hereby authorised and empowered to prescribe and enforce rules and regulations for the administration of the customs laws and service of said zone, and report the same to the chairman of the Commission, and said rules and regulations shall have the force and effect of law until annulled or modified by legislative act of the Isthmian Canal Commission or other competent authority.

Sec. 5. Until otherwise provided by competent authority duties on importations into the canal zone are to be levied in conformity with such duties as Congress has imposed upon foreign merchandise imported into other ports of the United States.

Sec. 6. Goods or merchandise entering the canal zone from ports of the United States or insular possessions of the United States shall be admitted on the same terms as at the ports of the States of this Union.

Sec. 7. All goods or merchandise, whether free or dutiable, entering the canal zone by water, by rail, or otherwise, for transportation across said zone must be entered at the custom house of the collection district wherein the point of entrance is situated. Violation of this requirement shall subject the goods to seizure and forfeiture by the customs officials.

Sec. 8. The governor of the canal zone is authorised to enter and carry out an agreement with the President of the Republic of Panama for coöperation between the customs service of the canal zone and that of the Republic of Panama to protect the customs revenues of both Governments and to prevent frauds and smuggling.

Sec. 9. The governor of the canal zone is hereby authorised 
to enter upon negotiations and make a tentative agreement with the President of the Republic of Panama respecting reciprocal trade relations between the territory and inhabitants of the canal zone and appurtenant territory and the Republic of Panama; also a readjustment of customs duties and tariff regulations so as to secure uniformity of rates and privileges and avoid the disadvantages resulting from different schedules, duties, and administrative measures in limited territory subject to the same conditions and not separated by natural obstacles. The governor shall report as to such negotiations and proposed agreement to the chairman of the Isthmian Canal Commission for submission and consideration by the Commission and such action by competent authority as may be necessary to render said agreement effective in the canal zone.

This order will be proclaimed and enforced in the canal zone at Panama.

(Signed)

WM. H. TAFT, Secretary of War. 


\section{APPENDIX IX}

\section{The Panaman Protest}

THE following is the text of the Panaman Government's official representation, against the Administrative Order. It was addressed by the Panaman Secretary for Foreign Affairs to the American Minister at Panama:

Mr. Arias to Mr. Barrett.

\section{Memorandum.}

Office of the Secretary of Government and Foreign Affairs,

Panama, July 27, 1904.

The undersigned, secretary of government and foreign affairs of the Republic of Panama, has received instructions from the President of the aforesaid Republic to submit to his excellency the envoy extraordinary and minister plenipotentiary of the United States the following:

Pursuant to orders given by the President of the United States of America for the creation of ports and establishment of customs regulations in the canal zone, the governor of said zone has forthwith declared as ports of entry the section denominated La Boca, wherein he has, in consequence, thought fit to assume, disregarding the Republic of Panama, the prerogatives of sovereign of the port, entering and clearing vessels, establishing and collecting port dues and, finally, adopting measures tending to the establishment in the canal zone of the customs system of the United States. In a similar fashion the postal tariff and postage stamps of the United States have been made obligatory within the limits of the canal zone, and it appears the belief was entertained that the United States could, at its option, establish in the canal zone a monetary system different from any adopted by the Republic of Panama.

Such proceeding and intentions are, undoubtedly, the result of the interpretation given by the United States of America to the treaty concluded with Panama on the 18th 
of November, 1903, on points such as those of vital importance for the growing Republic and as said interpretation clashes with the opinion of the government of Panama in what concerns the treaty itself and points at issue, the undersigned, in the name of the President of the Republic, respectfully invites his excellency the envoy extraordinary and minister plenipotentiary of the United States to exchange views in connection with the measures recently adopted in the canal zone, so as to convey to the treaty, by mutual accord, such interpretation as is found more to conform to the spirit and letter of its stipulations.

Although the Republic of Panama when negotiating with the United States the treaty of the 18th of November, 1903, could not offer any obstacle whatsoever to the wishes and convenience of the United States, it did observe, nevertheless, with pleasure, when approving without restrictions said treaty, that the United States had waived in favour of the Republic of Panama that which was neither needed by the United States nor by the canal enterprise, but which for the Republic constitutes the most effective guaranty of its existence-in other words, fiscal and economical sovereignty within and without the canal zone.

This point is of great importance because it is really a fact that a nation can cede part of its territory and sovereign rights in connection therewith, without materially affecting its proper existence, in surrendering life itself, and this very life, without the corresponding nourishment, is thereby doomed to sure death. From this it follows that the treaty concluded with the United States amply provides, on the one hand, for all requirements of the canal enterprise, and, on the other hand, it fully provides for the perpetual existence of the Republic of Panama.

The said Republic thus agreed to surrender a strip of land of the required size, and boundaries to be excavated for a canal and to be eventually used by the shipping communi. cating the Atlantic and Pacific oceans, and the zone thus surrendered was ceded to the government of the United States, in perpetuity for "the construction, maintenance, operation, sanitation, and protection of said canal." (Article II of the treaty.)

Whatever was considered indispensable by the United States to secure perpetually the canal enterprise was readily granted by the Republic of Panama. By such concession the canal zone, properly speaking, was comprised in the grant, 
and such lands and waters without the zone as would be found necessary, the islands of Perico, Naos, Culebra, and Flamenco, and moreover, the rights, power, and authority (as per Article III of the treaty) which the United States "shall have and exercise as if it were sovereign of the territory wherein said land and waters are located," entirely precluding the Republic of Panama in the exercise of such sovereign rights, power, or authority.

But the general, and so to speak, the universal phase of these concessions of sovereignty, has, to judge from the treaty, two conceptions, one conditional and the other exceptional, both indispensable to the existence of the Republic of Panania.

These two points are those which the undersigned believes have been disregarded by the authorities of the canal zone, by means of the measures set forth at the commencement of this memorandum.

According to the clause in question, referred to in Article II of the treaty, "the cities of Panama and Colon and adjacent ports which are included in the described zone shall not be considered as comprised in this concession."

This provision has an object further than that of indicating the material possession of said cities and ports. The evident object of that provision tends to insure and safeguard the very existence of the Republic of Panama, reserving to it in perpetuity the aforesaid cities and ports as fiscal resources, wherefrom to derive the most effective means of subsistence.

The canal zone, before being ceded to the United States and subsequent to its cession, forms part of the region wherefrom importation and exportation take place and is the central spot between the two seas. The very existence of the Republic is derived from there; hence it was necessary to reserve that spot, although in other respects ceded to the United States.

Such is, in the opinion of the undersigned, the reason and the object why from the canal zone the cities of Panama and Colon are set apart and the ports adjacent thereto, virtually leaving the zone without jurisdictional ports.

Hence the right of levying and collecting maritime taxes, etc. (without regard to the exceptions provided in the treaty referring to all shipping and otherwise everything connected with the canal enterprise,) has invariably been a prerogative of the Republic of Panama, and the Republic claims it by 
virtue of the spirit and letter of the treaty concluded on the 18th of November, 1903.

Not only that, the Republic claims the acknowledgment to the full extent of its economical and fiscal sovereignty within the canal zone, not only because it considers it has a right according to the treaty, but that its very existence and future depend on it. The fact stands, therefore, that Panama, being the original owner of the canal zone, clearly reserved what it did not expressly surrender.

The sovereign right of levying taxes within the zone does not appear by any of the stipulations of the treaty to have been expressly surrendered to the United States. On the contrary, the right is implicitly acknowledged by Clauses $\mathbf{X}$ and XIII, wherein are specified the effects that cannot be subject to taxes. It follows therefore, that other effects are liable to taxation. In other words, national taxes and contribution take effect in the canal zone in so far as not expressly excepted by said Articles X and XIII.

This being the case, the fact of excluding from the canal zone, by order of the authorities there, the postal tariff and postage stamps of the Republic of Panama, is, to say the least, improper, inasmuch as such proceedings affect, in a marked manner, a source of revenue from which it expects brilliant results in the near future.

Finally, and as logical understanding of the meaning of a treaty whereby the fiscal and economical sovereignty is assured to the Republic, it considers that the rights which it so clearly and expressly reserved to itself have not been taken into proper consideration.

The foregoing are the ideas which have been considered as proper to submit to his excellency the envoy extraordinary and minister plenipotentiary of the United States of America as a true expression of the feeling of the national government in order to serve as the basis of interpretation of the treaty of the 18th of November, 1903, in a matter of such vital importance for the Republic of Panama.

Tomas Arias. 


\section{APPENDIX X}

\section{The Revised Executive Order}

The following is the text of the new administrative or executive order, made by the United States Secretary of War as a result of a long controversy with the Panaman Government, during his visit to Panama in 1904.

Panama, December 3, 1904.

By the direction of the President it is ordered, that, subject to the action of the Fifty-eighth Congress, as contemplated by the act of Congress approved April 28, 1904 :

Section 1. No importation of goods, wares, and merchandise shall be entered at Ancon or Cristobal, the terminal ports of the canal, except such goods, wares, and merchandise as are described in Article XIII of the treaty between the Republic of Panama and the United States, the ratifications of which were exchanged on the 26th day of February, 1904, and except goods, wares and merchandise in transit across the Isthmus for a destination without the limits of said Isthmus, and except coal, and crude mineral oil for fuel purposes to be sold at Ancon or Cristobal, to sea-going vessels, said coal and oil to be admitted to those ports free of duties for said purposes :

Provided, however, that this order shall be inoperative, first, unless the Republic of Panama shall reduce the ad valorem duty on imported articles described in the class 2 of the act of the National Convention of Panama, passed Juiy 5, 1904, and taking effect October 12, 1904, from 15 per centum to 10 per centum and shall not increase the rates of duty on the imported articles described in the other sched. ules of said act except on all forms of imported wines, liquors, alcohol, and opium, on which the Republic may fix higher rates; second, unless Article 38 of the Constitution of the Republic of Panama as modified by Article 146 thereof, shall remain in full force and unchanged, so far as the importation and sale of all kinds of merchandise are concerned; third, unless the consular fees and charges of the 
Republic of Panama in respect to entry of all vessels and importations into said ports of Panama and Colon shall be reduced to 60 per cent. of the rates now in force; and, fourth, unless goods imported into the ports of Panama and Colon, consigned to and destined for any part of the canal zone shall not be subjected in the Republic of Panama to any other direct or indirect impost or tax whatever.

Section 2. In view of the proximity of the port of Ancon to the port of Panama and of the port of Cristobal to the port of Colon, the proper customs or port official of the canal zone shall, when not inconsistent with the interest of the United States at the instance of proper authority of the Republic of Panama, permit any vessel entered at or cleared from the ports of Panama and Colon together with its cargo and passengers under suitable regulations for the transit of the imported merchandise and passengers to and from the territory of the Republic of Panama to use and enjoy the dockage and other facilities of the ports of Ancon and Cristobal respectively, upon payment of proper dockage dues to the owners of said dock.

Provided, however, that reciprocal privileges as to dockage and other facilities at Panama and Colon, together with suitable arrangement for transit of imported merchandise and passengers to and from the territory of the canal zone, shall be granted by the authorities of the Republic of Panama when not inconsistent with its interests, to any vessel, together with its cargo and passengers, entered at or cleared from the ports of Ancon and Cristobal; provided, however, that nothing herein contained shall affect the complete administrative, police and judicial jurisdiction of the two governments over their respective ports and harbours, except - as hereinafter provided in Section 6.

Provided, also that vessels entering or clearing at the port of Panama shall have the absolute right freely to anchor and lade and discharge their cargoes by lighterage from and to Panama at the usual anchorage in the neighbourhood of the islands of Perico, Flamenco, Naos, and Culebra, though included in the harbour of Ancon under the provisional delimitation as amended under Section 5 hereinafter, and in use the said waters of said harbour for all lawful com. mercial purposes.

Section 3. All manifests and invoices and other documents in respect to vessels or cargoes cleared or consigned for or from the ports of Panama and Colon shall, as hereto- 
fore, be made by the officials of the Republic of Panama. All manifests, invoices, and other documents in respect to the vessels and cargoes cleared or consigned for or from the ports of Ancon or Cristobal shall be made by officials of the United States.

Section 4. No import duties, tolls, or charges of any kind whatsoever shall be imposed by the authorities of the canal zone upon goods, wares, and merchandise imported, or upon persons passing from the territory of the Republic of Panama into the canal zone; and Section 5 of the Executive Order of June 24, 1904, providing that duties on importations into the canal zone are to be levied in conformity with such duties as Congress has imposed upon foreign merchandise imported into ports of the United States, is hereby revoked; but this order shall be inoperative unless the authority of the Republic of Panama shall grant by proper order, reciprocal free importations of goods, wares, and merchandise and free passage of persons from the territory of the canal zone into that of the Republic of Panama.

Section 5. The provisions of this order also shall not be operative except upon the condition that the delimitation of the cities and harbours of Colon and Panama, signed on the 15th day of June, 1904, by the proper representatives of the governments of the Republic of Panama and of the canal zone, shall be provisionally in force; and while the same shall remain in force, with the consent of both parties thereto, the provisional delimitation shall include not only the terms set forth in writing thereof, but also the following, viz.: that the harbour of Panama shall include the maritime waters in front of said city to the south and east thereof, extending 3 marine miles from mean low-water mark, except the maritime waters lying westerly of a line drawn from a stake or post set on Punta Mala through the middle island of the three islands known as Las Tres Hermanas, and extending 3 marine miles from mean low-water mark on Punta Mala, which waters shall be considered in the harbour of Ancon.

Section 6. This order also shall be inoperative unless the proper governmental authorities of the Republic of Panama shall grant power to the authorities of the canal zone to exercise immediate and complete jurisdiction in matters of sanitation and quarantine in the maritime waters of the ports of Panama and Colon.

Section 7. The Executive Order of June 24, 1904, concern- 
ing the establishment of post offices and postal service in the canal zone, is modified and supplemented by the following provisions:

All mail matter carried in the territory of the canal zone, to or through the Republic of Panama, to the United States and to foreign countries, shall bear the stamps of the Republic of Panama, properly crossed by a printed mark of the canal zone government, and at rates the same as those imposed by the government of the United States upon its domestic and foreign mail matter, exactly as if the United States and the Republic of Panama for this purpose were common territory. The authorities of the canal zone shall purchase from the Republic of Panama such stamps as the authorities of the canal zone desire to use in the canal zone at 40 per centum of their face value; but this order shall be inoperative unless the proper authorities of the Republic of Panama shall by suitable arrangement with the postal authorities of the United States provide for the transportation of mail matter between post offices on the Isthmus of Panama and post offices in the United States at the same rates as are now charged for domestic postage in the United States, except all mail matter lawfully franked and inclosed in the so-called penalty envelopes of the United States government, concerning the public business of the United States, which shall be carried free, both by the governments of Panama and of the canal zone; provided, however, that the zone authorities may, for the purpose of facilitating the transportation of through mail between the zone and the United States in either direction, inclose such through mail, properly stamped or lawfully franked, in sealed mail pouches, which shall not be opened by the authorities of the Republic of Panama in transit, on condition that the cost of transportation of such mail pouches shall be paid by the zone government.

Section 8 . This order also shall not be operative unless the currency agreement made at Washington June 20, 1904, by the representatives of the Republic of Panama and the Secretary of War of the United States, acting with the approval of the President of the United States, for the establishment of a gold standard of value in the Republic of Panama and proper coinage, shall be approved and put into execution by the President of the Republic of Panama, pursuant to the authority conferred upon him by law of the Republic of Panama No. 84, approved June 20, 1904; and 
unless the President of the Republic of Panama, in order that the operation of the said currency agreement in securing and maintaining a gold standard of value in the Republic of Panama may not be obstructed thereby, shall, by virtue of his authority, conferred by law No. 65, enacted by the National Assembly of Panama on June 6, 1904, abolish the tax of 1 per cent. on gold coin exported from the Republic of Panama.

Section 9. Citizens of the Republic of Panama at any time residing in the canal zone shall have, so far as concerns the United States, entire freedom of voting at elections held in the Republic of Panama and its provinces or municipalities, at such places outside of the canal zone as may be fixed by the Republic and under such conditions as the Republic may determine; but nothing herein is to be construed as intending to limit the power of the Republic to exclude or restrict the right of such citizens to vote as it may be deemed judicious.

Section 10. The highway extending from the eastern limits of the city of Panama, as fixed in the above mentioned provisional delimitation agreement of June 10, 1904, to the point still farther to the eastward where the road to the Savannahs crosses the zone line (which is 5 miles to eastward of the centre axis of the canal), shall be repaired and maintained in a serviceable condition at the cost and expense of the authorities of the canal zone; and also in like manner the said road from the said eastern limits of the city of Panama to the railroad bridge in the city of Panama shall be repaired at the cost of the authorities of the canal zone. But this order shall not be operative unless the Republic of Panama shall waive its claim for compensation for the use in perpetuity of the municipal buildings located in the canal zone.

Section 11. The United States will construct, maintain, and conduct a hospital or hospitals, either in the canal zone or in the territory of the Republic, at its option, for the treatment of persons insane or afflicted with the disease of leprosy, and the indigent sick, and the United States will accept for treatment therein such persons of said classes as the Republic may request; but this order shall not be operative unless, first, the Republic of Panama shall furnish without cost the requisite lands for said purposes if the United States shall locate such hospital or hospitals in the territory of the Republic, and, second, unless the Republic 
shall contribute and pay to the United States a reasonable daily per capita charge in respect of each patient entering upon the request of the Republic, to be fixed by the Secretary of War of the United States.

Section 12. The operation of this executive order and its enforcement by officials of the United States on the one hand, or a compliance with and performance of the conditions of its operation by the Republic of Panama and its officials on the other, shall not be taken as a delimitation, definition, restriction, or restrictive construction of the rights of either party under the treaty between the United States and the Republic of Panama. 1904.

This order is to take effect on the 12th day of December, (Signed)

WM. H. TAFт, Secretary of War. 


\section{APPENDIX XI}

\section{Data of Existing Ship Canals}

\section{SUEZ}

The Suez Canal connects the Mediterranean and Red seas, extending from Port Said on the former to Suez on the latter, and is at sea level, without locks of any kind. Its total length is $\mathbf{1 0 4 . 0 8}$ miles, as follows: Channel of roadstead at Port Said, 1.86 miles; Entrance channel of outer harbour, 1.24 ; Port Said Harbour, 2.48; Lake Timsah, 1.24; Large Bitter Lake, 9.32; Channel of Suez Roadstead, 1.55; Canal proper, including Small Bitter Lake, 86.37. The canal was authorised by the Egyptian government in 1856, and confirmed by the Sultan of Turkey in 1866. The concession runs to November, 1968. Work was begun on the canal in 1860 , and it was opened to commerce in 1869. The original excavation amounted to $80,000,000$ cubic yards, chiefly of sand but with some strata of rock two or three feet thick. The original depth was 25 feet, the bottom width 72 feet, and the surface width from 196 to 328 feet, according to the character of the soil composing the walls. The deepest cutting was about 80 feet, to the bottom of the canal. In 1895 it was enlarged to a depth of 31 feet, and to a width of 108 feet at the bottom and 420 feet at the top. This work increased the total excavation to $98,000,000$ cubic yards. The original cost was about $\$ 90$,000,000 , which was increased by the work of enlargement to $\$ 102,500,000$. At the present time the canal is being further enlarged, so as to have a depth of a little more than 34 feet. The authorised draught of vessels passing through it is, however, only 27 feet. The speed of vessels is limited to 10 kilo. metres, or 5.4 knots, an hour. The average time of passage is 18 hours. The entire canal is lighted with electricity, and vessels pass through at night as well as by day. A current is caused by the tides, sometimes in one direction and sometimes in the other, seldom exceeding a knot an hour. Statistics of traffic through the canal in the years stated are as follows: 


$\begin{array}{lrrr}\text { Year } & \text { No. of Vessels } & \text { Net Tonnage } & \begin{array}{r}\text { Receipts } \\ \text { from Tolls }\end{array} \\ 1869 & 10 & 6,576 & £ \quad 2,178 \\ 1870 & 486 & 436,609 & 206,273 \\ 1895 & 3,434 & 8,448,383 & 3,124,148 \\ 1900 & 3,441 & 9,738,152 & 3,624,944 \\ 1904 & 4,237 & 13,401,835 & 4,616,034\end{array}$

The British Government purchased shares in the canal amounting to $f 4,000,000$, the value of which in March, 1905, was $£ 30,857,755$. Despite repeated reductions of tolls, the yearly dividends on the shares show a tendency to exceed the maximum permitted, of 25 per cent. In 1904 they were 141 francs on each ordinary share of 500 francs, and 117.50 francs on the Actions de Jouissance. In 1893 tolls were reduced to 9 francs a ton, in 1903 to 8.50 francs a ton, and in 1905 to 7.75 francs a ton.

\section{KAISER WILHELM (KIEL)}

The Kaiser Wilhelm or Kiel Canal, constructed by the German Government, begun in 1887 and completed in 1895, connects the Baltic and North seas, across the northern part of Germany. It is a sea-level canal, with locks at the ends to control the influx of the tides. It is 61 miles long, 29.5 feet deep, and 72 feet wide at the bottom, with a number of much wider "turn-outs" at which vessels may pass each other. The total excavation was 100,000,000 cubic yards, and the cost was $\$ 40,000,000$. Statistics of traffic follow:

$\begin{array}{rccr}\text { Year } & \text { No. of Vessels } & \text { Total Tonnage } & \begin{array}{c}\text { Tom Tolls } \\ \text { and Towing }\end{array} \\ 1896 & 16,834 & \mathbf{1 , 5 0 5 , 9 8 3} & \$ 213,356 \\ 1900 & 26,279 & 3,488,767 & 430,768 \\ 1904 & 32,038 & 4,990,287 & 574,651\end{array}$

\section{AMSTERDAM}

The Amsterdam or North Sea Canal, giving access to the inland city of Amsterdam from the North Sea, was constructed by the private North Sea Canal Company, and afterward purchased and enlarged by the government of the Netherlands. It is a sea-level canal, or really 14 inches below sea level, with tide locks at the ends, and is $\mathbf{1 5 . 5}$ miles long. 
Its depth is 27.9 feet, which is now being increased to 32.2 feet. The width at the bottom is $\mathbf{1 1 5}$ feet and at the surface 164 feet. It was begun in 1865 and opened in 1876 . The cost was $\$ 15,000,000$, but this was reduced to $\$ 10,000$,000 by the sale of lands filled in and reclaimed from the sea.

\section{MANCHESTER}

The Manchester Ship Canal, connecting the inland city of Manchester, England, with the Atlantic Ocean by way of the Mersey River and the harbour of Liverpool, was constructed by a private company, and was begun in 1887 and was opened to traffic on January 1, 1894. It is a lock canal, 35 1-2 miles long, with five reaches at various levels. Beginning at tidewater, there is a tidal reach of 21 miles. The second reach, of 7 1-2 miles, is at an elevation of 16 1-2 feet; the third, of 2 miles, is 16 feet higher; the fourth, of $31-4$ miles, is 15 feet above the third; and the fifth, of $13-4$ miles, is $\mathbf{1 3}$ feet above the fourth. Thus the elevation of the Manchester terminal above the outlet at Liverpool is 60 1-2 feet. The depth of the canal is 26 feet. The width varies. For 28 miles the bottom width is 120 feet, with occasional "turnouts" of 180 feet. For 4 miles the bottom width is 170 feet and is now being increased to 200 feet. The surface width varies from 175 to 230 feet. The total amount of excavation was about 45,000,000 cubic yards, of which one-fourth was sandstone. The cost was $\$ 75,000,000$. The time required for passage is from five to eight hours. Statistics of traffic are as follows:

\begin{tabular}{rrrrr} 
Year & No. of Vessels & \multicolumn{1}{c}{ Tonnage } & Tons of Freight & \multicolumn{1}{c}{ Receipts } \\
1894 & 4,551 & 720,425 & 925,659 & $£ 94,656$ \\
1895 & 4,761 & 879,204 & $1,358,875$ & 136,759 \\
1896 & 5,156 & $1,094,837$ & $1,826,237$ & 179,834 \\
1900 & 5,362 & $1,492,320$ & $3,060,516$ & $.290,474$
\end{tabular}

\section{CORINTH}

The Corinth Canal, connecting the Gulf of Corinth with the Gulf of Ægina and affording a short cut from the Adriatic and Mediterranean seas to the Ægean Sea and the Dardanelles, was begun by a private company in 1884 and was opened for traffic in 1893. It is a perfectly straight canal, at sea level, without locks. It lacks 100 yards of being four 
miles long, and is $261-4$ feet deep. At the bottom it is 69 feet wide, and at the surface of the water only $801-4$ feet, the banks being much steeper than those of any other canal. The total excavation was $15,000,000$ cubic yards, a large part of which was granite, and clay so hard as to require blasting. For 2 1-2 miles there is a cut of great depth, measuring at the centre, to the bottom of the canal, 286 feet, or about the depth that would be required at Culebra to make the Panama canal at sea level. The cost of the Corinth Canal was about $\$ 5,000,000$. There are strong currents in the canal, and steamers not under the best of control frequently graze the side walls, sometimes with much force.

\section{CRONSTADT}

A ship canal connects Cronstadt, on the Gulf of Finland, with St. Petersburg. It is about six miles long, with a bay channel of ten miles. Its depth is 20 feet and its width from 220 to 350 feet. Its cost was about $\$ 10,000,000$.

\section{WELLAND}

The Welland Canal, connecting Lake Erie with Lake Ontario, was constructed in 1883, and was enlarged in 1871 and again in 1900 . It is 27 miles long, and has twenty-five locks, with a total elevation of 327 feet. It is 27 feet deep, and has cost $\$ 24,000,000$.

\section{ST. MARY'S FALLS}

The St. Mary's Falls (Sault Sainte Marie) canals connect Lake Superior with Lake Huron, around the falls of the St. Mary's River, and are two in number, one belonging to the United States and one to Canada. The United States canal was built in 1853-55 by the State of Michigan, at a cost of $\$ 1,000,000$. It was enlarged in $1870-81$ by the United States Government, and in 1882 was transferred entirely from State to Federal control. In 1887-96 it was again enlarged. It is now a little more than a mile long, 160 feet wide, and 25 feet deep, but the depth of the two locks is only 17 and 22 feet respectively. The lift of the locks varies from 16 to 20 feet. The total cost of the canal and locks to 1904 was more than $\$ 6,000,000$. Statistics of traffic follow: 


$\begin{array}{rrr}\text { Year } & \text { No. of Vessels } & \begin{array}{c}\text { Tonnage of } \\ \text { Vessels }\end{array} \\ 1855 & \text { Not reported } & 106,296 \\ 1860 & \text { “ } & 403,657 \\ 1865 & 997 & 409,062 \\ 1870 & 1,828 & 690,826 \\ 1875 & 2,033 & 1,259,534 \\ 1880 & 3,503 & 1,734,890 \\ 1885 & 5,380 & 3,035,937 \\ 1890 & 10,557 & 8,454,435 \\ 1895 & 17,956 & 16,806,781 \\ 1900 & 19,452 & 22,315,834 \\ 1904 & 16,120 & 24,364,138\end{array}$

The Canadian Canal at St. Mary's Falls was built by the Canadian government in 1888-95. It is a mile and one-eighth long, 22 feet deep, and 150 feet wide. Its total cost has been nearly $\$ 4,000,000$. Statistics of traffic follow:

$\begin{array}{lccc}\text { Year } & \text { No. of Vessels } & \text { Registered Tonnage } & \begin{array}{c}\text { Freight } \\ \text { Tonnage }\end{array} \\ 1900 & 3,003 & 2,160,490 & 2,018,999 \\ 1903 & 4,353 & 4,737,580 & 5,502,185\end{array}$




\section{INDEX}

Аввот, Gen. Henry L., member of Board of Advisory or Consulting Engineers, 316, 319.

Achurra, Captain, 165.

Acosta, José de, 33.

Adams, Charles Francis, 72.

Africa, circumnavigated by Menelaus, 2.

Agua Dulce, 228; Gen. Huertas at, 252.

Ahorca Lagarto, 229.

Airian. M., on Caledonian Bay route, 70 .

Aizpuru, Rafael, 176.

Aizpuru, revolutionist, 95.

Albemarle, Duke of, Governor of Jamaica, 52.

Alceda, Dionysius, quoted, 34.

Alfonso V, King of Portugal, 6.

Allen, Horatio. Nicaragua canal promoter, 47.

Almirante Bay, 218.

Alvarez, Felix, 165.

Amador, Antonio, 152.

Amador, Manuel, (Guerrero), Chairman of Panama Council, 158; appeals to Colombian government, 161; plans revolution, 163; member of Junta, 163; mission to United States, 165; calls on W. N. Cromwell and John Hay, 166; "Desanimado," 167; calls on Lindo, 167; finds BunauVarilla, 168; "Esperanzas," 169; second visit to Hay, 169; returns to Panama, 170; Secretary of Treasury, 176, 209; Commissioner to United States, 182; first President of Panama, 213; Huertas's letter to, 239; consults Lee, 242, 248; consults Barrett, 248; demands Huertas's resignation, 249; letter to Huertas, 251; disbands army, 253; receives Secretary Taft, 259; aids in sanitation of Panama, 332; portrait, $164,209$.

Amador, Raoul A., 248.

America, early voyages to, 1 ; mistaken for Asia, 2; legendary map of, 4; eliminated by Toscanelli, 9; believed by Columbus to be Asia, 10.

America, Central, visited by Columbus, 13; becomes independent of Spain, 44; seeks construction of canal, 44, 47; union dissolved, 47; origin of British claims in, 51; British aggressions upon, 53, 56.

America, South, discovered by Columbus, 12 ; becomes independent of Spain, 43.

"American Committee," organized by De Lesseps, 84; its activities, 84.

American Policy on the Isthmus, 72; established by Grant and Hayes, 73; strongly stated by Hayes, 81; Edmunds's resolution concerning, 96; confirmed in Hay-Pauncefote Treaty, 119; policy toward Panama revolution, 187; precedents for, 190; justified by domestic obligations, 191; by legal obligations to Colombia, 192; by equity to Colombia, 199; by law and equity to other nations, 203; unselfish and benevolent, 205; policy toward Huertas's revolutionary attempt, 254; controversy with Panama, 256; Secretary Taft's mission of readjustment, 256, 268; appealed to, by Liberal Directorate, 273; questions concerning, 275; Secre- 
tary Root's statement, 278; vicious libels upon, 341; future duties and responsibilities, 352 ; labour problems, 353; justice required, 360; firmness, 362, and tact, 362.

Amerigo Vespucci, calls America the "New World," 15; clings to Columbus's errors, 15; explorations, 16; America named for him, 17; first European to reach mainland of America, 17; accompanies Ojeda, 18; explores Atrato River, 19.

Ammen, Daniel, Rear Admiral, Canal Commissioner, 73; at international Engineering Congress, 78.

Amphion, British cruiser, 179.

Amsterdam ship canal, data of, 437. Ancon Hill, 226.

Andagoya,Governor of Panama, 33. Anson, Lord, at Panama, 224.

Antigua, Nuestra Senora de, founded by Ojeda, 21 .

Antilles, discovered by Carthaginians, 3; explored and named by Columbus, 11.

Antioquia, province of, 153.

Anton Point, 225.

Antonelli, Batista, 33.

Appleton, Nathan, 78.

Arango, Belisario, 162.

Arango, Fernando, 164.

Arango, José Agustin, 152.

Arango, José Agustin, Jr., 152; leader of revolution, 162 ; member of Junta, 163; member of Executive Board of Republic, 176, 209; portrait, 164 .

Arango, José Agustin, 3rd, 162, 175.

Arango, Ricardo Manuel, 162, 176.

Argentina, recognizes Panama, 186.

Arias, F. Agustin, 176.

Arias, Ricardo, joins revolution, 164; member of Junta, 166; portrait, 164 .

Arias, Tomas, joins revolution, 164; member of Junta, 166; member of Executive Board of Republic, 176, 209; Minister for Foreign Affairs, 213; removal demanded by Huertas, 238; offers resignation, 242; succeeded by Guardia, 243; portrait, 164.
Aristotle, geographical theories of, 2,8 ; on discovery of Antilles and Mexico, 3.

Army of Panama, disbandment upon, 248; terms of disbandment, 253; disbandment effected, 254 .

Arosemena, Antonio, 152.

Arosemena, Carlos C., 163; member of Junta, 163; Commissioner to United States, 182; portrait, 164.

Arosemena, Fabio, 176.

Arosemena, Justo, 153.

Arosemena, Pablo, President of State of Panama, deposed and imprisoned, 156; votes against ratifying treaty, 158; President of Constitutional Convention, 209; First Designate, 213; speech at State banquet to Taft, 262; speech at Cathedral Plaza, 264; supports Dr. Porras, 272; appeals to United States, 273; visits Washington, 278.

Arthur, Chester A., President, 92, $110,200$.

Arton, Panama corruptionist, 97.

Asia, sought by Columbus, 1; ancient theories of, 2; Toscanelli's map of, 6; errors concerning, 8,9 .

Aspinwall, see Colon.

Astor, John Jacob, 114.

Atlanta, U. S. cruiser, at Colon, 179.

Atlantic Ocean, "Sea of Darkness," 1; highway from Europe to Asia, 1; early theories of, 2.

Atrato River, discovered by Bastidas, 19; explored by Amerigo Vespucci and La Cosa, 19; canal route forbidden by Philip II, 34; alleged natural waterway, 34 ; canal routes surveyed, 69 , 70; Selfridge's survey, 74.

Austria, Emperor of, arbitrator, 89.

Austria-Hungary, recognizes Panama, 186.

Avila, Gil Gonzalez de, exploits of, 27; treaty with Nicarao, 28; seized by Christopher de Olid, 30 . Avila, Juan Arias de, son of Pedrarias, 27.

Avila, Pedro Arias de, see Pedrarias. 
Azores, 6, 8.

Azua River, 13.

Azuero, province of, 153.

Badajos, Gonsalvo de, 26.

Bahamas, mistaken by Columbus for Philippines, 10.

Bahia Honda, 224.

Bailey and Bates survey, 47.

Bailey, Stephen, 62.

Balboa, Vasco Nuñez de, first visits Isthmus with Bastidas, 21; flight from Hispaniola to Golden Castile, 21; quarrel with Enciso, 22; Governor of Golden Castile, 22; crosses Isthmus and discovers Pacific Ocean, 23; explorations, 23; made Adelantado, 24; builds first ships on Pacific, 25; arrested by Pizarro, 25 ; judicially murdered by $\mathrm{Pe}-$ drarias, 25.

Barrett, John, American Minister to Panama, 215; discusses attempted revolution with Amador, 248; encourages Amador, 249; warns Huertas, 249; advises and aids in disbandment of army, 253; dinner to Taft at Panama, 263.

Bastidas, Rodrigo, at Darien, 18; explorations, 19.

Bastimentos, Isla de, see Provision Island.

Bastimentos Point, 223.

Batele Point, 225.

Bates, Lindon W., plans for canal, 294.

Bayamo River, 217, 226.

Bay Islands, visited by Columbus, 13.

Bayoneta Island, 227.

Beaupré, A.M., American Minister at Bogota, 143; dispatch to Hay, 144; deceived by Colombian Government, 144; reports American recognition of Panama, 182.

Beers, J. R., aids Panaman revolution, 162.

Belcher, Edward, canal plans, 47.

Belen River, 14.

Belgium, recognizes Panama, 186.

Belize, occupied by England, 35, 51, 54; called "British Honduras," 56.
Belly, Felix, canal promoter, 65 .

Beniski, canal promoter, 45.

Bennington, gunboat, at Panama, 248.

Berosius, quoted by Galvano, 2.

Bertoncini, C. F., 288.

Biddle, Nicholas, at Nicaragua and Panama, 47.

Bidlack, B.A., on Treaty of 1846 , 202.

Bigelow, Poultney, on "Our Mismanagement at Panama," 345; his meagre opportunities for investigation, 345; answered by Chief Engineer Stevens, Secretary Taft, and Governor Magoon, 346; his lampoon upon the American army, 348.

Bishop, Joseph Bucklin, Secretary to Canal Commission, 315 .

Black, W. M., 286.

Blaine, James G., Secretary of State, opposes De Lesseps's schemes, 87; proposes PanAmerican Congress, 88; his tactical blunder, 88; moves for abrogation of Clayton-Bulwer Treaty, 89; his letter to Lowell, 90.

Blanco, Cape, 27.

Bluefields, 56.

Boca de Chiriqui, 220.

Boca del Drago, 218.

Boca del Toro, United States takes possession of, 84; province of, 212 ; strait and town of, 218.

Boca San Pedro, 223.

Bogota, gunboat, fires on Panama, 175.

Bogotá, negotiations at, 130-149; Mosquera's entry into. 154; relations of Panama with, 155; oppression of Panama, 158; new law for Panama enacted, 159.

Bohio Dam, site of, 229, 231, 290; proposed lake, 231.

Bohio Soldado, 229.

Bolivar, province of, 154 ; commissioners from, to Panama, 183.

Bolivar, Simon, frees Colombia from Spain, 44, 150; canal plan, 45.

Bona Island, 225.

Bona Speranza, see Cape of Good Hope. 
Borico Point, 27.

Borland, Solon, mission to Central America, 63.

Boston, cruiser, at Panama, 179; orders to commander of, 188189; second visit to Panama, 248.

Bourdiol, M., on Caledonian Bay route, 70 .

Boyaca, province of, 154, 156.

Boyd, Federico, joins revolution, 164; member of Junta, 166; member of Executive Board of Republic, 176; Commissioner to United States, 182, 209; Second Designate, 279; portrait, 164.

Brava Point, 224, 227.

Brazil, recognizes Panama, 186.

Brid, Demetrius H., 176, 209.

Brin, Juan, 209.

Bristow, Joseph L., report on Panama Railroad, 307.

British Honduras, see Belize.

Brito, proposed canal terminus, 62.

Brooke, Lieutenant, 286.

Brujas Point, 222.

Brunet, M., receiver of Panama Company, 108.

Buccaneers on Isthmus, 34; Walker, 63.

Buchanan, James, on British claims in Central America, 55; sends Hise to Nicaragua, 58; mission to England, 63; alarmed at British plans at Panama, 68; sends surveyors to Isthmus, 70.

Buchanan, William I., American Minister to Panama, 215; action for sanitation, 327.

Buena Vista, 229.

Bulwer, Sir Henry, negotiates treaty with J. M. Clayton, 60.

Bunau-Varilla, Philippe, his career, 167; joins revolution at Amador's request, 168; wishes to negotiate treaty, 168; Panaman Minister to United States, 182, 215; makes treaty, 182; plans for "Straits of Panama," 293.

Buppan Bluff, 220.

Burica Point, 223.

Burr, William H., Canal Commissioner, 283; member of Board of
Advisory or Consulting Engineers, 316, 319.

Cabesa Cattiva, Gulf of, 13.

Cab fares in Panama, 381.

Calabebora River, 217.

Caledonian Bay, 35; Wafer's report, 36; Paterson's colony, 36; failure of, 37; survey by Milla, 38 ; various schemes, 68-71; survey by Selfridge, 74; site of, 223; description, 227, 371 .

Calvo, Bartholome, 153.

Cambuta River, 217.

Camergo, Sergius, 156.

Cana River, 220.

Canal, see Nicaragua, Panama, Ship, etc.

Canal Commission, appointed by Grant, 73; Ludlow's, 113; Admiral Walker's first, 113; Walker's second, 116; report of 1900,120; third commission appointed, 282; President's instructions to, 283; organization of work, 285; need of reorganization, 297; reorganization effected, 299; President's orders to new Commission, 300; further changes, 315; reports on plan of canal, 321; delay in sanitation, 329; improved conditions in Canal Zone, 336339.

Canal Zone, first proposed by W. H. Seward, 73 ; value of, 101 ; asked of Colombia by United States, 151; acquired from Panama, 182, 214; Panaman dissatisfaction over, 256; General Davis appointed Governor, 283; government organized, 285; Magoon made Governor, 300; sanitation, 328-336 (see Sanitation); improved conditions of life and work, 336; reading rooms, clubs, etc., established, 336; commissary stores, 337; gambling abolished, 338; Civil Service rules, 339; eight-hour law, 339; Governor's proclamation, 419; first Administrative Order, 423; Panaman protest, 426; revised Executive Order, 430. 
Canary Islands, discovered by Lewis of Cerda, 3.

Canaz, José, 44.

Cape of Good Hope, early reports of, 4 .

Caperosa, islands of, 13.

Cape Verde, discovered by Hesperus, 2; by Henry the Navigator, 8.

Caribbean Sea, navigated by Columbus, 11.

Carmen Messias, 229.

Caro, Miguel A., 158.

Carreta Point, 218.

Carthagena, founded by Ojeda, 20; province declares independence, 152.

Carthagena, steamship, brings Colombian troops to Colon, 172; abandons them there, 178 .

Cartier, Jacques, 28.

Casaya Island, 227.

Cass, Lewis, Secretary of State, warns France from Nicaragua, 66; on American rights in Panama, 204.

Castellon, Francisco, seeks French aid at Nicaragua, 49.

Castilla del Oro, see Golden Castile.

Castle Choco, 221.

Catalina River and Hills, 221.

Cathay, see China.

Cauca, province rebels, 153.

Cauro Point, 218.

Cebaco Island, 224.

Ceron, Alvaro de Saavedra, proposes Panama Canal, 31 ; voyage to the Moluccas, 31 ; death, 32 .

Cerro Horquita, 216.

Cerro Picacho, 216.

Cerro Santiago, 216.

Ceylon, identified with Taprobane, 7.

Chagres River, visited by Columbus, 13; surveyed for canal, 33; Lull and Menocal report on, 74; description, 217, 221; menace to canal, 295.

Chagres, town of, 221.

Chamé Point, 225; Island, 225.

Changarni Island, 225.

Charles II and Mosquito King, 52.

Charles V, orders search for Strait, 29 ; orders canal built, 32 .
Chepo River, 217, 226

Chevalier, Michael, 67.

Chiapes, native chief of Panama, 23,26 .

Chiari, R. José Maria, 176.

Childs, O. W., surveys Nicaragua route, 62 .

Chiman River, 217, 226; village, 226.

China, sought by Columbus, 2; missionaries to, 4; Toscanelli's map, 6; sought by Columbus, 10; recognizes Panama, 186.

Chinese labour, 355 .

Chirica Mola, 220.

Chiriqui Lagoon, visited by Columbus, 14 ; canal survey at, 71 ; Chiriqui Improvement Company, 71 ; United States takes possession of, 84; description, 219.

Chiriqui, Province of, 153, 212.

Chiriqui River, 217.

Chorrera, river and city, 225.

Chucuito, gunboat, 175 .

Chucunaque River, 217.

Church, Roman Catholic, at Pana$\mathrm{ma}, 212$.

"Churchill's Voyages," quoted, 52.

Cibao, mistaken by Columbus for Japan, 11.

Cipango, see Japan.

Circuit of the globe, reckoned by Toscanelli, 8 ; by Galvano, 9 .

Civil Service rules in Panama, 339.

Clarendon, Earl of, 55; denies American demands, 63 .

Clark, Aaron, 47.

Clark, Captain, of Oregon, 115.

Clay, Henry, Secretary of State, sympathizes with canal project, 44.

Clayton-Bulwer Treaty, negotiated, 61 ; ratified, 62 ; abrogation threatened, 63, 75, 87; Blaine's negotiations over, 87-92; his tactical blunder, 88; Granville's reply, 91; Frelinghuysen's argument, 92; Granville's reply, 93; challenged by FrelinghuysenZavala Treaty, 110; Senate asks President to abrogate or modify, 117; first Hay-Pauncefote Treaty dealing with, 118; abrogated and superseded by second Hay- 
Pauncefote Treaty, 119; text, 393.

Clayton, John M., Secretary of State, sends Squier to Nicaragua, 59; negotiations with Great Britain, 60.

Clement, Carlos, 164.

Clement VI, Pope, 3.

Cleveland, Grover, President, withdraws Frelinghuysen - Zavala Treaty, 110; repudiates American canal policy, 110.

Climate of Panama, 233.

Clinton, DeWitt, 45.

Coaita Point, 221.

Coatzocoalcos River, explored by Cortez, 29.

Cocle, Province of, 212; River, 217, 221 ; Hills, 221.

Coiba Island, 224.

Colombia, becomes independent of Spain, 44; gives Gorgoza canal concession, 76; De Lesseps's intrigues, 83; warned by United States, 84; extortionate practices on French, 103; extends canal concession, 108; United States canal negotiations with, 130-149; terms of protocol, 131; republic in a bad way, 133; covets canal purchase price, 133; German influences in, 134; revolution, 137; double dealing toward United States, 142; Congress meets, 144; extortionate demands, 146; juggling proposals, 147; lets treaty lapse, 147; negotiations with United States ended, 149; early history of Republic, 150; first Constitution, 151; Constitution of 1832, 151; Constitution of 1843, 152; Constitution of 1853, 153; amended Constitution, 153; Mosquera's revolution, 154; present name adopted, 155; Constitution of 1863, 155; coup d'état by Nuñez, 156; condition described by Marroquin, 159; inability to deal with Panama revolution, 180; no serious effort made, 181; protests against American policy in Panama, 183; relations with Panama, 186; General Reyes becomes President, 186; list of revolutions in, 193; limits of power under Treaty of 1846 , 197; inequity of conduct toward Panama, 199, and toward United States, 200; Treaty of 1846, 391.

Colon, city of, railroad terminal, 57; looted and burned, 95.

Colon Bay, 222.

Colon, Province of, 212.

Colonization in Panama, needed, 354; Chinese, 355; negroes, 356; Russians, Jews, Boers, Americans, 357; Spanish and Italians, 358.

Columbia, cruiser, at Colon, 257.

Columbus, Christopher, founder of Isthmian canal enterprise, 1; geographical theories, 2; correspondence with Toscanelli, 5; recent researches concerning, 5; estimates of distance from Europe to China and Japan, 9; discovery of and delusions concerning America, 10; reports visit to India, 11; among the Antilles, 11; seeking the Golden Chersonesus, 12; visits Trinidad and Gulf of Paria, 12; seeks "Secret of the Strait," 12; explores Central America, Panama, and Darien, 13-15; persists in errors, 15.

Columbus, Diego, ill treated by King of Spain, 20.

Columbus Island, 218.

Commissary Stores in Canal Zone, 336.

Companies: Central America and United States Atlantic and $\mathrm{Pa}$ cific Canal, 45; "Compania de Transito de Nicaragua," 58; American Atlantic and Pacific Canal, 58; Accessory Transit, 58; Honduras Interoceanic, 63; Central American Transit, 66; Maritime Canal, 67, 97, 111; Chiriqui Improvement, 71; "La Société Civile Internationale du Canal Interoceanique," 76; Universal Interoceanic Canal, 80; Provisional Interoceanic Canal, 80; New Panama Canal, 109; Nicaragua Construction, 112, 113; Grace-Eyre-Cragin Syndicate, 
114; Panama Canal Company of America, 122.

Concha, José V., opposes American canal plan, 132; under German influence, 136; quits office and goes to Europe, 139.

Concord, gunboat, at Panama, 179.

Condamine, Charles M. de la, advocates Nicaragua canal, 38 .

Congress, International Engineering, or Scientific, organized by De Lesseps, 77; its composition, 78; Committee on Route, 79; adopts Panama scheme, 80.

Congress of Panama, 40.

Congress, Pan-American, see PanAmerican Congress.

Congress, United States, non-committal resolutions on canal, 47; resents De Lesseps's scheme, 80; appropriation for control of Panama route, 84; declines to aid Eads's scheme, 86; requests abrogation of Clayton-Bulwer Treaty, 87; action against De Lesseps company, 97; charters Maritime Canal Company, 111; great canal controversy in, 112; provides canal commissions, 112; attitude toward Clayton-Bulwer Treaty, 117; final canal debate, 125; Spooner bill adopted, 128; Marroquin's letter to Senate, 183; controversy over purchase of canal supplies, 303; adopts lock plan for canal, 325; text of Isthmian Canal Law or Spooner bill, 400.

Constitution of Panama, provisions of, 209; on Legislature, 210; on Executive, 211; on Judiciary, 211; on Enactment of Laws, 211.

Consuls at Panama protest against bombardment, 176.

Contadora Island, 227.

Contreras, Alonzo de, 30.

Cordillera de Bando, 216; of Veraguas, 221.

Cordova, Francisco Hernandez de, 28.

Corea recognizes Panama, 186.

Corinth canal, data of, 438 .

Corozal, 230.

Corral, Miguel de, 38.

Cortez, Hernando, in Mexico, 29; seeks "Secret of the Strait," 29; explores Tehuantepec, 29; letter to Charles V, 29; writes of California, 30 ; thorough exploration of coasts, 30 .

Cosa, Juan de, 18; death, 20.

Costa Rica, visited by Columbus, 14 ; acquiescence in British agressio.ss, 56; plans for canal, 62; gives concession to Maritime Cana' Company, 112; recognizes Panama, 186.

Cottu, Baron, 97.

Cramer, Augustin, 38.

Craven, T. A., surveys Atrato region, 70.

Crawl Cay Channel, 219.

Crimmins, John D., 114.

Cristobal, port of, 228.

Crocodiles, River of, see Chagres.

Cromwell, William Nelson, counsel for New Panama Canal Company, 146; Amador's visit to, 166; disapproves revolution, 166; goes to Paris, 167; visits Panama with Taft, 257; address at State banquet, 262; relations to Wallace's retirement, 308.

Cronstadt canal, data of, 439.

Cuba, mistaken for Japan, 10; recognizes Panama, 186.

Cubanacan, mistaken for Kublai Khan, 11.

Cucalon, P., 176.

Culebra Cut, 231; work in, 290; Island, 225; village, 230 .

Cundinamarca, Province of, 154, 156.

Currency, of Colombia, depreciated, 213; new, of Panama, 213.

DAMs, see Bohio, Gamboa, Gatun.

Darien canal route, first proposed, 32 ; surveys, 74,75 ; last desperate proposal of, 127.

Darien del Sur, Gulf of, 227.

Darien, Gulf of, visited by Columbus, 14; River of, 18; Ojeda's explorations, 18.

Dauchy, W. E., 287.

David, City of, 220, 223, 228; River, 223.

David, Edward, raid at Nicaragua, 35.

Davila, see Avila and Pedrarias. 
Davis, Carlton E., 288.

Davis, C. H., Rear-Admiral, on Nicaragua and Panama routes, 71.

Davis, C. K., Senator, on first HayPauncefote Treaty, 118.

Davis, George W., General, Canal Commissioner, 282; Governor of Canal Zone, 283; inaugural proclamation, 285, 419; member and chairman Board of Advisory or Consulting Engineers, 316, 319.

Denmark, recognizes Panama, 186.

De Soto, Hernando, 28.

Diaz, Domingo, General, joins revolution, 164; appeals to United States, 273; visits Washington, 278; Third Designate, 279.

Diaz, Pedro A., joins revolution, 164.

Dixie, troopship, at Colon, 179.

Dolphin, dispatch boat, at Colon, 257.

Dominguez, Alcides, 176.

Dose, H. F., 285.

Drake, Francis, in South Sea, 34.

Drexel, Morgan \& Co., 84.

Dreyfus case, 168.

Duartis Point, 224.

Duran, F. Mutis, Governor of Panama, 137, 161.

Earthquakes, 233; possible effect on canal, 295.

Ecuador, recognizes Panama, 186.

Edmunds, George F., Senator, canal policy, 96.

Ehle, Boyd, 285.

Ehrman, Felix, reports on revolution, 181.

Ehrman, Henry, 158.

Eiffel, G., contractor at Panama, 95; fined and imprisoned, 97.

Eight Hour law, 339.

Eminent Domain, international. 205.

Emperador, see Empire.

Empire, United States headquarters at, 99, 229.

Enciso, Martin Ferdinand de, 20; first Spanish book about America, 21; Governor of Golden Castile, 22; quarrel with Balboa, 22.

Endicott, Mordecai T., Rear-Ad- miral, Canal Commissioner, 300; favours sea-level plan, 321 .

Engineering, see Panama Canal

Engineers, Board of Advisory or Consulting, appointed, 316; President's instructions to, 317 ; report of majority, for sea-level canal, 319 ; report of minority, for lock canal, 319.

Ernst, Oswald H., Colonel, Canal Commissioner, 300; resigns, 315.

Escobedo, Fernando de, 35.

Escoces Point and Harbor, 223.

Escudo de Veraguas, 220.

Espinar, J. D., Governor of Panama, 151.

Espinosa, Gaspar de, acquits Balboa, 25.

Espinosa, Gonzalez Gomez, 27.

Espinosa, Manuel, B., joins revolution, 164; member of Junta, 166; portrait, 164.

Espriella, F. V. de la, Minister for Foreign Affairs, 176, 209; Minister of Finance, 213; replies to Liberal Directorate, 276; consulted on sanitation, 327 .

Estiva Island, 225.

Europe, early attitude of, toward world, 1.

Evarts, William M., Secretary of State, 82, 200.

Evening Post, New York, letter in, quoted, 178.

Excavation, French errors in, 106.

Executive of Panama, 211.

Fabrega, Francisco de, 153.

Fabrega, Julio J., Minister of Public Instruction, 209; Minister of Justice, 213.

Falcmar's survey at Panama, 45.

Fever, see Sanitation.

Field, Cyrus W., 78.

Filos, F., 273.

Fish, Hamilton, Secretary of State, negotiations with Great Britain and Nicaragua, 75.

Flag of Panama, 213.

Flamenco or Flamingo Island, 225.

Fonseca, Bay of, 28; BritishAmerican rivalry for, 60 .

Fonseca River, 217.

Fontane, Marius, 97. 
Foraker, J. B., Senator, on first Hay-Pauncefote Treaty, 119.

Formosa, 6.

France, recognizes Panama, 186.

Frelinghuysen, Frederick 'T., Secretary of State, succeeds Blaine, 92; reply to Lord Granville, 92; argument against Clayton-Bulwer Treaty, 92; negotiates treaty with Nicaragua, 109.

French schemes in Nicaragua, 65; at Panama, 75; "Old Imperialists," 76; American warnings against, 83; causes of failure at Panama, 99-107. See also Lesseps.

Frenchman's Creek, 220.

Frijoles, 229.

Froude, J. A., description of Panama, under De Lesseps, 94.

Fruit Trade at Boca del Toro, 219.

Fuerth, Ignacio, 158.

Galisteo, Manuel, surveys Nicaragua route, 38 .

Gallinas, Cape, 18.

Galvano, Antonio, history of early voyages and discoveries, 2 ; geographical theories, 9; account of Columbus's last voyage, 13; Ojeda's and Bastidas's discoveries, 18, 20; Pedrarias, 24, 26; Cortez, 30; Ceron and the canal routes, 32 .

Gama, Vasco da, 2.

Gambling in Canal Zone prohibited, 339.

Gamboa, 229; dam at, 290.

Gamboa, Ramon, 153.

Ganges River, Columbus's quest of, 14.

Garachine, Point, 227.

Garay, José de, canal promoter, 67.

Garella, Napoleon, 48.

Garfield, James A., President, 87; death, 92.

Gatun, 228; proposed dam, 230, 290.

George, Frederick, Mosquito Prince, 55.

Germary, interested and influential in Colombia, 134; recognizes Panama, 186.

Gillette, Cassius W., plan for canal, 294.
Gisborne, Lionel, at Caledonian Bay and Panama, 68.

Glass, Henry, Rear-Admiral, orders to, 188; action for sanitation, 327 .

Gobernador Island, 224.

Goethe, J. W., on Humboldt's canal schemes, 42; prophesies construction of canal by United States, 42; on England at Suez, 43.

Golden Castile, governed by $\mathrm{Ni}$ cuesa, 20; by Balboa, 22; by Pedrarias, 24.

Golden Chersonesus, 7.

Golfito, United States coaling station, 84; River, 217.

Gomara, F. L. de, on Columbus's last voyage, 13; on Ojeda's and Bastidas's discoveries, 18 ; on Gil Gonzalez de Avila's exploits, 27 ; on Cortez, 30; on Ceron and the canal routes, 32 ; appeal to Charles V for canal, 33.

Goodrich, C. F., Rear-Admiral, 248, 249.

Gorgas, W. C., Sanitary Officer of Canal Zone, 285; begins work, 288; methods of dealing with yellow fever, 331 ; school of sanitation, 333; success achieved, 334; offers reward for case of fever, 335. See Sanitation.

Gorgona, 229.

Gorgoza, canal promoter, 75; gets concession, 76 .

Grace, William R., 114.

Grace-Eyre-Cragin Syndicate, 114; concession cancelled, 117.

Gracias à Dios, Cape, 13.

"Graft" at Panama, 100.

Granada sacked by L'Olonnais, 35 .

Granadine Confederation, see Colombia.

Grant, U.S., President, canal policy, 73; appoints Canal Commission, 73.

Granville, Lord, effective reply to Blaine, 91; reply to Frelinghuysen, 93 .

Great Britain, interested in Honduras and Nicaragua, 51; practical seizure of Mosquito Coast, 53; scheme to acquire all Central America, 56; seizure of Tigre 
Island and Bay of Fonseca, 60; treaty with Nicaragua, 64; arbitration with Nicaragua, 89; reply to Blaine, 91; first HayPauncefote Treaty, 118; second Hay-Pauncefote Treaty, 119; offer of aid at Colon, 179; recognizes Panama, 186; text of Clayton-Bulwer Treaty, 393; of Hıy-Pauncefote Treaty, 398.

Great Khan, missions to, 4; Columbus accredited to, 10; Columbus's errors concerning, 11 .

Greytown, bombarded by United States, 63; work on canal there, 112.

Grijalva, Juan de, 28.

Grunsky, Carl E., Canal Commissioner, 283.

Guanico Point, 224.

Guardia, Francisco de la, 158.

Guardia, Santiago de la, Minister for Foreign Affairs and War, 243; plot against, 247; attends review, 248; letter to Huertas, 252.

Guardia, Santiago de la, President of State of Panama, 154.

Guatemala, asks Pope to build canal, 48.

Guerard, Adolph, member of Board of Advisory or Consulting Engineers, 316, 319 .

Guerrero, see Amador.

Guizot's advocacy of canal at Panama, 48.

Gulf of Mexico, 7; explored by Pineda, 28.

Hains, Peter C., General, Canal Commissioner, 300.

Hanno of Carthage, voyage to Arabia, 2.

Harper, A. C., 286, 287.

Harrisse, H., Columbian researches, 5.

Harrod, Benjamin, Canal Commissioner, 283, 300 .

Hatfield, Chester, canal surveys, 74 .

Hay, John, Secretary of State, negotiates treaty with Great Britain, 118, 119; negotiates treaty with Colombia, 140; warns Colombian government, 146; Amador's visit to, 166, 169;
American policy stated, 169; declines dealings with revolutionists, 169; negotiates treaty with Panama, 182; describes Treaty of 1846 as a covenant which "runs with the land," 196.

Hay-Bunau Varilla Treaty, made, 182 ; text, 408.

Hay-Herran Treaty, 140; opposed to Bogotá, 142; lapses, 147.

Hay-Pauncefote Treaty, made, 118, 119 ; text, 398.

Hayes, Rutherford B., President, canal policy, 73 ; rebuffs De Lesseps, 81; message on canal, 81 ; his strenuous policy, 82 .

Hecker, Frank T., Canal Commissioner, 283; resigns, 299.

Henry III of Castile, 4.

Henry the Navigator, 2, 8.

Hepburn bill, 126.

Herodotus, geographical theories of, 7 .

Herran, Tomas, Colombian chargé d'affaires at Washington, 139; negotiates treaty for canal, 140; reports Amador's doings, 167. Herrera, Tomas, Panaman patriot, 151; "Chief of State," 152.

Herz, Cornelius, 97.

Hesperides, West Indies so called, 2.

Hesperus, King of Spain, discoveries of, 2 .

Heuer, W. H., 75.

Hiemra, 13.

Higueras, Cape, 13.

Hise, Elijah, mission to Nicaragua, 58 ; work repudiated, 62 .

Hispaniola, Columbus at, 13.

Hitchcock, Hiram, 112.

Honduras, British aggressions upon, 59.

Honduras, British, see Belize.

Honduras, Cape, 13.

Hospitals, French management of, 104.

Hotel rates in Panama, 381.

Huasacualco, see Coatzacoalcos.

Hubbard, John, keeps peace at Colon, 178.

Huertas, Esteban, in revolution, 164; receives Colombian officers, 173; arrests them, 174; commander in chief of Panaman army, 180; attempts revolution, 
238; letter to Amador demanding resignations of Ministers, 239; "Order of the Day," 244; rails against Victoria, 247; plans to seize Amador and Guardia, 247; retirement determined upon, 248; resignation demanded, 249 ; protests, 249; letter of resignation, 249; letter to Guardia refusing pension, 251; accepts pension and retires, 252; under suspicion, 252 .

Humboldt, Alexander von, visits the Isthmus, 39; proposes nine canal routes, 39 ; on Nicaragua, 40; on Panama, 40; on plan of canal, 41 ; on Darien route, 41 ; credits "legend of the Strait," 41 ; on tidal levels, 46 ; on effect of canal on Gulf Stream, 46; letter to Salomon, 48.

Humidity at Panama, 235.

Humphreys, A. A., 73.

Hunter, Henry W., member of Board of Advisory or Consulting Engineers, 316, 319.

Hutin, M., President of New French Canal Company, correspondence with Admiral Walker, 122.

Hylacomylus, see Waldseemüller.

Ilacomilus, see Waldseemüller.

Independent, New York, P. Bigelow's article in, 345.

India, early voyages to, 2 ; Ptolemy's theories of, 7; Columbus's quest of, 10.

Indian Ocean, supposed by Ptolemy to be land bound, 7 .

Indies, West, called Hesperides, 2; discovered by Hesperus, 2; by Carthaginians, 3.

Innocent IV, Pope, 4.

Isidore of Seville, geographical theory, 2.

Isla del Rey, 227.

Islands of Colombia, of the Isthmus, or of the King, 227.

Italy, recognizes Panama, 186.

Iturralde, Mateo, 158.

JACkson, ANDrew, President, orders canal surveys at Nicaragua, 47.
Jamaica, Columbus at, 13; seized by English, 35.

Japan, called Cipango, 6; sought by Columbus, 10; recognizes Panama, 186.

Jeffries, H. O., 165.

Jeremy, Mosquito King, 52 .

Jewett, Hugh J., 80.

Jicaro Island, 224.

Jiminez, Pastor, joins revolution, 164.

John, Friar, of Plano Carpini, 8.

Johnson, M. O., 288, 289.

Juan, George, 38, 46.

Judiciary of Panama, 211.

Juera River, 224.

Junta, revolutionary, formed, 163; reorganized, 166.

Kaiser Wilhelm canal, data of, 437.

Kelly, Frederick, directs canal route surveys, 69.

Kiel canal, data of, 437 .

King, Y. P., United States Minister to Colombia, quoted, 157.

Knox, Philander C., AttorneyGeneral, investigations in Paris, 130.

Kublai Khan, Columbus's error concerning, 11.

LA BocA, 226.

Labour Problems at Panama, 353; Chinese considered, 355.

Lacroisade, Dr., health statistics, 327.

Lagarde, Ernest, 285.

Landlords in Panama, 380.

Lansdowne, Lord, 119.

Las Cascades, 229.

La Trinchera, 342.

Lawrence, Abbott, denounces British claims on Mosquito Coast, 60 .

Lee, Joseph, Secretary of American Legation at Panama, consulted by Amador, 242; warns revolutionists, 243; effect of his warning, 247; midnight appeal to him, 248; renews warnings, 248; aids in disbanding army, 253.

Lefevre Ernest T., 163.

Legislature of Panama, 210.

Le Jeune, Major, brings troops to Ancon, 249. 
Leon, city of, sacked, 35 .

Leon, José Maria Vives, 158.

Leon XIII, steamship, 180.

Leones, Island of, 224.

Lesseps, Charles de, 97.

Lesseps, Ferdinand de, seeks concession at Nicaragua, 72 ; sends Wyse to Panama, 76; organizes International Engineering Congress, 77; inaugurates work at Panama, 80; at Washington ard New York, 81; intrigues witn Colombia, 83; change of tone, 84; organizes "American Committee," 84; returns to France, 85; begins work on canal, 94; "Le Grand Français," 95; overwhelmed with disaster, 97; death, 98.

Lewis of Cerda, voyage to the Canaries, 3.

Lewis, Samuel, 162, 176.

Lime Point, 218.

Limon Bay, 14, 222.

Linares, Enrique, 176.

Lindo, Joshua, 167.

Lion Hill, 229.

Lisa, Point, 225.

List, Charles, 285.

Lloyd's survey at Panama, 45.

L'Olonnais, raids Granada, 35.

Lopez, Ramon Valdez, joins revolution, 164.

Los Indios River, 217, 221.

Los Santos, Province of, 212; City of, 225, 228.

Louis, St., King of France, 4.

Lowell, James Russell, Blaine's letter to, 90 .

Ludlow, William, Canal Commissioner, 113.

Lull, E. P., surveys at Nicaragua, 72,74 ; Panama, 74; San Blas, 75.

McClellan, George B., 80.

MacFarland, Walter, 75 .

Macham, adventures and discoveries of, in Madeira, 3.

Machico, haven of, 3.

Machinery, experimental and imperfect, used by French, 105; preservation of, 106.

McKay, Oscar M., 176.

Madeira, discovered by Macham, 3.
Magdalena, Province of, 154, 156.

Magellan, Strait of, called "Dragon's Tail," 4, 9; discovered, 28.

Magoon, Charles E., United States Minister to Panama, 215; visits Isthmus with Taft, 257; influence in Panama politics, 279; Counsel to Canal Commission, 283; Canal Commissioner and Governor of Canal Zone, 300; Minister to Panama, 300; admirable qualifications for place, 303; undertakes sanitation of Canal Zone, 330; success of his policy, 334 ; improves conditions of life and work in Canal Zone, 336; refutes P. Bigelow's charges, 346.

Maine, battleship at Panama, 179 .

Mala, Cape, 224.

Malaria, see Sanitation.

Mamei, 229.

Managua, Lake, 28.

Manchester Ship Canal, data of, 438.

Mandeville, Sir John, 7.

Mandingo route, 34 .

Mangalee River, 221.

Mangi or Mangu, see China.

Manuel, J., 176.

Manzanillo Island and Bay, 222, 223; Point, 223.

Map, of America, seen by Don Peter, 4; Toscanelli's, 5; Ptolemy's, 7; Columbus's, 10; on globe of Orontius Finæus, 16; Humboldt on early maps, 16; Waldseemüller's, 16; Central American Canal Routes, 41; Republic of Panama, 216; Panama Canal Route, 228; Trade Routes compared, 385 .

Marble, Cape of, 13.

Marco Polo, reports of, followed by Toscanelli, 6, 7 .

Marcy, William L., negotiations with Great Britain, 63.

Mariato Point, 224.

Marroquin, José Manuel, acting President of Colombia, 133; attitude toward Hay-Herran Treaty, 142; describes state of Colombia, 159; extraordinary letter to United States Senate, 183, repels American intriguer, 341. 
Martinez, Ferdinand, 6.

Martinez, Manuel, 175.

Martinez, Orondaste, 165.

Martins, see Martinez, Ferdinand.

Matachin, 229.

Mayflower, naval yacht, at Panama, 179.

Melendez, Porfirio, 165.

Mendez, Manuel M., 176.

Mendoza, Carlos A., joins revolutionists, 164; Minister of Justice, 176, 209; Third Designate, 213; supports Dr. Porras, 272. Mendoza, Diego Hurtado de, 30.

Menelaus, legendary voyage to India, 2.

Menocal, A. G., surveys at Nicaragua, 72, 74; at Panama, 74; at San Blas, 75; at International Engineering Congress, 78; in Nicaragua Company, 80; surveys Nicaragua route, 111 .

Mercado, Louis de, 26.

Maxico, recognizes Panama, 186.

Michler, Nathaniel, surveys Atrato region, 70 .

Milla, Manuel, surveys Caledonian Bay route, 38 .

Miller, Warner, 112.

Mills, D. O., 114.

Mindi, 228.

Miraflores, 230.

Mitchell, Henry, 75.

Monkey Hill, 228.

Monroe Doctrine, disputed by Great Britain, 63; enforced against France, 67; defied by De Lesseps, 80; discussed by Frelinghuysen, 92; and by Granville, 93; violated by first Hay-Pauncefote Treaty, 118.

Montezuma, aids in search for Strait, 29.

Montijo, Gulf of, 224.

Moody, W. H., Secretary of Navy, orders intervention in Panama, 137; orders concerning revolution, 178.

Morales, Eusebio A. joins revolution, 164; Secretary of State, 176, 209; appeals to United States, 273; visits Washington, 278.

Morales, Gaspar, 26.

Morantes, Christopher, 28.
Morazan, President of Central America, orders canal survey, 47.

Morgan the Buccaneer, sacks Panama, 26, 35; and Porto Bello, 35.

Morgan, John T., Senator, 112, 126. Moro, Gaetano, survey at Tehuantepec, 67.

Morro Puercos, 224.

Morton, Levi P., 80, 114.

Moscoes, see Mosquito Indians.

Mosquera, Tomas C. de, negotiates with Panama, 152; leads revolution, 154; President of United States of New Granada, 154.

Mosquitia, see Mosquito Coast.

Mosquito Coast, visited by Columbus, 14; first war on, 47; British relations with, 51; practical British seizure of, 53; declared autonomous by Emperor of Austria, 89.

Mosquito Indians, origin of, 51 .

Mosquitoes, see Sanitation.

Mulatas Islands, visited by Columbus, 14; description, 223.

Murillo, Manuel, 154.

Murphy, Dominic I., 283.

NaOs IsLAND, 225.

Napoleon, Louis, plans Nicaragua canal, 49; pamphlet on the subject, 49; plans renewed, 65; final defeat, 67 .

Nashville, gunboat, at Colon 171; lands marines, 178; cruise to Porto Bello, 179, orders to commander of, 188.

National Assembly of Panama, 210. Navy Bay, 222.

Nelson, Lord, at Nicaragua, 38, 54. New Andalusia, governed by Ojeda, 20.

New Granada, gives canal concession to French speculator, 48; Treaty of 1846,391 . See also Colombia.

New Spain, discovered by Carthaginians, 3 . See Mexico.

"New World," origin of phrase, 15

New York, cruiser, at Panama, 248.

Nicaragua, described by Louis Napoleon as ceritre of New World, 49; relations with Mos- 
quito Indians, 51; British aggressions in, 53; treaty with Great Britain, 64; French intrigues in, 66; refuses De Lesseps a concession, 72 ; arbitration with Great Britain, 89; negotiations over canal, 114; arbitration with canal company, 117; recognizes Panama, 186.

Nicaragua Canal: Route proposed, 32; advocated by Condamine, 38; surveyed by Galisteo, 38; canal ordered by Congress of Central American States, 45; United States orders survey, 47; Louis Napoleon's pamphlet on, 49; Oersted's route, 62; Childs's survey, 62; Belly's scheme, 65; De Lesseps seeks concession, 72; Hatfield's surveys, 74; Lull and Menocal's, 74; MacFarland and others, 75 ; unanimously favoured by President Grant's commission, 75; rivalry with Panama, 109; survey by Menocal, 111; work begun in 1890,112 ; failure of enterprise, 112; efforts at resuscitation, 113; arbitration results adversely to Maritime Company, 117; cost estimated by third Canal Commission, 120; route favoured by third Canal Commission, 121; Hepburn bill approving route, 126 ; final defeat, 128 .

Nicaragua, Lake, first heard of by Pedrarias, 26; discovered by Gil Gonzalez de Avila, 27; explored by Edward David, 35; visited by Lord Nelson, 38 .

Nicarao, chief of Nicaragua, 28.

Nichols, A. B., 285.

Nicuesa, or Niquesa, Diego de, Governor of Golden Castile, 20; at Darien and Veraguas, 21; death, 21.

Niño. Andrea, 28.

Noble, Alfred, member of Board of Advisory or Consulting Engineers, 316, 319.

Nombre de Dios, visited by Columbus, 13; by Ojeda, 21; site of city, 223

North American Review, quoted, 73. North Sea, Caribbean so called, 13.
North Sea Canal, data of, 437.

Nueva Andalusia, see New Andalusia.

Nuñez, Rafael, Governor of Panama, 153; President of Colombia, 156; coup d'état, 156; repudiates debts, 157.

OAKes, John C., 317.

Obaldia, José de, 152-154.

Obaldia, J. Domingo, mission to Bogotá, 161; Governor of Pana$\mathrm{ma}, 162$; arrested by revolutionists, 175; Second Designate, 213; Minister to United States, 215; at Panama with Taft, 257; First Designate, 279.

Obarrio, Nicanor de, 158; joins revolution, 164; member of Junta, 166; Secretary of War and Navy, 176, 209, 249; portrait, 164.

Obispo, 229.

Oceans, supposed difference in levels, 46.

Ochoa, Lopez, 28.

Oersted, Andreas, surveys of, 62 .

Official Gazette, Panama, quoted, 158.

Ojeda, Alfonso, or Alonzo, visits Venezuela or Darien, 18; Governor of New Andalusia, 20; Galvano's account of, 20; disaster at Carthagena, 20; builds first town on mainland, 21; death, 21.

Oldman, Mosquito King, 52.

Olid, Christopher de, treason against Cortez, 30.

Ordaz, Diego, 29.

Oregon, battleship, voyage of, in 1898, 115.

Orillac, Raoul, 163.

Orinoco, steamship, 180.

Orontius Finæus, 16.

Ortega, Gerardo, joins revolution, 164.

Ortiz, General, 165.

Ospina, General, quoted, 178.

Ospina, President of Colombia, 153.

Otero, Quijano, quoted, 150.

Otoque Island, 225.

Outlook, The, London, P. Bigelow's article in, lampooning American army, 348. 
Oviedo, Gonsalvo Ferdinand de, quoted by Galvano, 2.

Pacheca Island, 227.

Pacific Ocean, Thinae placed in, 7; eliminated by Toscanelli, 9; discovered by Balboa, 23.

Padilla, gunboat, 175 .

Paitillo Point, 226.

Palmer, A H., 45.

Palmerston, Lord, policy in Central America, 57.

Panama, Bay of, 225, 226.

Panama, Canal: First proposed by Cortez and Ceron, 31; ordered by Charles V, 32 ; forbidden by Philip II, 33; routes surveyed, $68,70,71,74$; Wyse's concession, 76; adopted by French company, 77; inaugurated by De Lesseps, 80; work begun, 94; story of, 94-96; final disaster, 96; efforts at reorganization, 108; new company formed, 109; cost estimated by American commission, $120 ;$ disapproved by American commission, 121; negotiations of New Panama Canal Company with American commission, 122; crisis in affairs, 124; company offers to sell for $\$ 40,000,000,125$; purchase recommended, 125 ; route prescribed by Spooner bill, 126; finally adopted, 128; right of French company to sell, 130; company's anxiety over Colombia's conduct, 145; description of route, 230; work begun by Americans, 280; appointment of Commission, 282; organization of work, 285; Wallace chief engineer, 286; engineering problems, 290; four plans considered, 291; Wallace favours sea-level, 293; plans of Bunau Varilla, 293; plans of Bates and Gillette, 294; advantages of sea-level plan, 295; reorganization of commission, 299; controversy over purchase of supplies, 303; retirement of Wallace, 308; Stevens appointed chief engineer, 315; changes in commission, 315; Board of Advisory or Con- sulting Engineers appointed, 316; instructions to, 317 ; reports, 319 ; report of Stevens, 320; reports of commission, 321; Taft's recommendations, 322; President's recommendations, 324; lock-canal plan adopted by Congress, 325; lampoons and libels, 340; Poultney Bigelow's attack, 345 ; labour problems, 353 ; commercial importance of canal, 384; text of canal law, 400; text of canal treaty, 408.

Panama, City of, old, founded by Pedrarias, 26; destroyed by Morgan, 26, 35.

Panama, City of: site, 225; water supply, 289; sewers, 289; impressions of, 370; approach to, 374 ; streets, 375 ; parks, 376 ; slums, 376 ; buildings, 376 ; drinking habits of people, 377; Sunday in, 379 ; shops and shopping, 380; landlords and their ways, 380 ; hotel rates, 381 ; cab fares, 381 ; society, 382; commercial importance, 384 .

Panama, geographical and physical features of, 215; extent and situation, 215; boundaries, 216; population, 216; mountains, 216; rivers, 217; coasts, 217; geology, 231; earthquakes, 233; climate, 233; seasons, 234; temperature, 234; humidity, 235; rainfall, 236; lampoons and libels upon, 343; general impressions of, 370 .

Panama, Isthmus of: Visited by Columbus, 14; crossed by Balboa, 23 ; route to California, 57 ; Louis Napoleon's description of, 77; insurrections and revolutions on, 193; protection of transit across, 195; topography of, 230; geological peculiarities, 232; lampoons upon, 343; colonists needed, 354.

Panama, Province of, 212.

Panama Railroad, on LloydFalcmar route, 46; construction of, 57; use denied to belligerents, 177, 196; shares purchased by United States, 306.

Panama, Republic of: Organized. 
176; Executive Board and Ministry, 176; Declaration of Independence, 177; recognized by United States, 182; recognized by other nations, 186 ; Constitutional Convention, 186; American policy toward, 187; constitutional government organized, 209; salient features of Constitution, 209; Legislature, or National Assembly, 210; Executive, or President, 211; Judiciary, 211; lawmaking, 211; division and organization of Provinces, 212; Roman Catholic church in, 212; first Administration, 213; flag, 213; new currency, 213; endowment instead of debt, 214; diplomatic relations with United States, 215; attempted revolution, 238; controversy with United States, 256; Taft's mission and its results, 256-268; political dissensions, 269 (see also Politics in Panama); general elections of 1906, 279; Magoon, Minister to, 300; action for sanitation, 327; colonists needed, 354; not to be "Americanized," 364 ; worthy of study, 366; trade methods in, 366; agricultural and other resources, 373; commercial importance, 384 ; text of Declaration of Indepe dence, 405; text of First Administrative Order of United States in Canal Zone, 423; Panaman protest, 426; revised Executive Order, 430.

Panama Revolution, 150-186; warnings of, 150,160 ; planned by Arango, 162, and Amador, 163; Junta formed, 163; many recruits, 164; a Panaman and not an American movement, 165; need of expcdition and absence of violence, 170 ; crisis precipitated, 172; Colombian generals arrested, 174; Provisional Government organized, 176; Colombian troops baffled, 177; shipped for home, 180; American policy, 187; crazy fictions about, 341 ; Declaration of Independence, text, 405.
Panama, State of: F. Mutis Duran, governor, 137; insurrection in, 137; United States intervention, 137; original union with Colombia, 151; declares independence, 151; rejoins Colombia, 152; "sovereign federal State," 153; relations with Bogotá, 155; betrayed and oppressed by Colombia, 156; ratifies new constitution, 158; continued protests, 159; new law at Bogotá, 159; insurrections and revolutions in, 193.

Pan-American Congress, first, 44; second, called by Blaine, 88; third, approves American canal policy, 125.

Paraiso, 230.

Paria, Gulf of, discovered by Columbus, 12.

Parida Island, 223.

Parisa, native chief, 27.

Parita, bay and city, 225.

Parsons, William Barclay, Canal Commissioner, 282; member of Board of Advisory or Consulting Engineers, 316, 319.

Paterson, William, plants colony in Darien, 36; canal scheme, 37; failure of enterprise, 37.

Paterson's Point, 223.

Patterson, C. P., 73.

Paul, Felipe F., 158.

Pauncefote, Lord, 118.

Pearl Islands, discovered by Balboa, 23; riches of, 26; description, 226; Taft's party visits, 264; memorable visit to, 386 .

Pearson, Sir Weetman, builds railroad at Tehuantepec, 68.

Pedrarias, "Timour of the Indies," 24; Governor of Golden Castile, 24; cruelties, 24; murders Balboa, 25; founds city of Panama, 26 ; explorations and conquests, 26; plans canal at Nicaragua, 32 ; death, 32 .

Pedro Gonzalez Island, 227.

Pedro Miguel, 230.

Pedro River, 220.

Pelado River, 226.

Pensacola, Taft starts from, 257; historic significance of, 257.

Perez y Soto, Panaman representa- 
tive in Colombian Congress, 161.

Perico Island, 225.

Persia, recognizes Panama, 186.

Peru, recognizes Panama, 186.

Peter, King of Aragon, 3.

Peter Martyr, speaks of "New World," 15; on Pedrarias, 24, 26.

Peter, Prince of Portugal, travels of, 4.

Phelps, S. L., 80.

Philip II, orders surveys for canal, 33; forbids canal, 33 .

Philip III, orders surveys of Atrato River route, 34 .

Philippine Islands, indicated by Toscanelli, 6.

Pico Robaldo, 216.

Pierce, Franklin, negotiations with Great Britain, 63.

Pillars of Hercules, 2, 4.

Pilon de Miguel de la Borda, 221.

Pineda, Alvarez, 28.

Pinzon, Arias Perez, 6.

Pinzon, Martin Alonzo, 6.

Pinzon, Vincente Yañez, explorations, 19.

Pizarro, Francisco, at Uraba with Ojeda, 21; succeeds Ojeda, 21; arrests Balboa, 25.

Pliny, geographical theories of, 2, 8.

Politics in Panama, 269; Dr. Porras, 270; Liberal Directorate appeals to United States, 273; bitter attack upon Panaman government, 274; Espriella's reply, 276 ; Liberal leaders visit Washington, 278; Secretary Root's reply to their appeal, 278; Governor Magoon's influence, 279.

Polk, James K., President, sends Hise to Nicaragua, 58; makes offer for Tehuantepec route, 67; on Treaty of 1846, 202.

Ponce, Fernando, 27.

Popo Island and mountain, 219.

Population of Panama, 216, 354.

Porras, Belisario, friends plan revolution, 238; calls on Lee, 242; receives warning, 243 ; speaks at State banquet, 262; record as a revolutionist, 270; opposed revolution of 1903, 270; anti-American sentiments, 270; Liberal leader, 270; declared not to be a citizen, 271; denounces court's decision, 272; appeals to United States, 273; visits Washington, 278.

Porto Bello, visited by Columbus, 13; by Bastidas, 19; sacked by Morgan, 35; description, 222.

Portugal, recognizes Panama, 186.

Prescott, H. G., 172.

Press, subsidizing of, 84 .

Provinces of Panama, 212; funds for public works apportioned to, 214.

Provision Island, 218; Point, 221.

Ptolemy, geographical theories of, followed by Toscanelli, 5; location of Thinae, 7; errors of, 7 ; followed by Waldseemüller, 16 .

Puercos Point, 224.

Quebrancha, Mountains of, 222; River, 229.

Quellennec, Eugen, member of Board of Advisory or Consulting Engineers, 316, 319.

Quibo Island, 224 (see Coiba).

Quintero, Manuel, V,, 209; Minister of Public Works, 213.

Quisai, 9, 11.

Quisqueya, 11.

Raia Point, 224.

Rainfall at Panama, 236.

Randolph, Isham, member of Board of Advisory or Consulting Engineers, 316,319 .

Raspadura, Ravine of, 41, 69 .

Reading Rooms established in Canal Zone, 336.

Reclus, Armand, surveys on Isthmus, 76 .

Recognition of Panama, by United States, 182 ; by other governents, 186; principles involved, 198; contrasted with recognition of Confederate States, 201.

Reed, Thomas B., Speaker, opposes canal legislation, 116.

Reinach, Baron Jacques, 97.

Retreat, Haven of, visited by Columbus, 13.

Revolutions, see Colombia, and Panama Revolution.

Reyes, Rafael, Colombian Commis- 
sioner to Panama, 183; fruitless efforts, 184; visits United States, 184; extraordinary offer to United States, 184; President of Colombia, 186.

Riggs, George W., 80.

Rincon Point, 221.

Rio Colorado, opened, 35.

Rio Francisco, visited by Columbus, 13.

Rio Grande (Caribbean), visited by Columbus, 13.

Rio Grande (Pacific), 217, 225.

Ripley, Joseph, member of Board of Advisory or Consulting Engineers, 316, 319.

Roatan, visited by Columbus, 13 .

Robert, Charles Frederick, Mosquito King, 56.

Robert, Mosquito Prince, 55.

Robinson, Monroe, 45.

Roosevelt, Theodore, President: Completing Columbus's work, 1; signs Spooner bill, 128; receives Panaman Minister, 182; comments on Colombian offer, 185; on Hay-Bunau Varilla Treaty, 192,214 ; on insurrections in Panama under Colombian rule, 193; on American policy in Panama, 206; news of his reelection received at Panama, 247; energetic work for canal, 282; appoints third Canal Commission, 282; instructions to Commission, 283; reorganizes Commission, 299; orders to Commission, 300; appoints Board of Advisory or Consulting Engineers, 316; instructions to, 317; recommends lock canal, 324 ; on gossip and libels, 349 .

Root, Elihu, Secretary of State, replies to appeal of Liberals, 278.

Royal Geographical Society, 68.

Rubruquis, William of, 4.

Russia, recognizes Panama, 186.

Ruysch's map of the world, 16.

Sabana River, 227.

Saboga Island, and village, 227.

St. Lorenzo, Castle of, 221.

St. Mary's Falls canal, data of, 439.

St. Michael, Gulf of, 23, 227; Island of, 227.
St. Thomas, Island of, discovered by Hesperus, 2.

Salomon \& Co., 48.

Sambu River, 217.

San Blas canal route, 70,75 .

San Blas, Mountains, 216; Point, 223; Gulf, 223; Indians, 223.

San Carlos, Fort, stormed and rebuilt, 35 .

Sanclemente, President, deposed, 133.

San Cristoval Bay, 223.

Sandoval, Gonzalo de, 29.

Sanitation, French neglect of, 103; need of, 288; Gorgas begins work, 288; delays and obstructions, 297; the fight with fever, 326; Humboldt's errors, 326; President Roosevelt's orders, 326; French mortality statistics, 327; outbreak of yellow fever in Canal Zone, 328; causes of the trouble, 329 ; Magoon's vigorous action, 330 ; methods of work, 331; success, 334 ; offer of reward for case of fever, 335; favourable vital statistics of Panama, 335. San José Island, 227.

San Juan River Nicaragua, 28; diverted by Escobedo, 35.

San Juan River, Panama 225.

San Miguel, Gulf of, 23, 227.

San Pablo River, 217, 224.

San Pedro River, 217.

San Salvador, Island of, mistaken by Columbus for East Indies, 10.

Santa Maria River, 217.

Santana, 229.

Santander, Province of, 154, 156.

Santiago River, 217, 224; City of, 228.

Santo Domingo, Columbus's errors about, 11.

Sault Ste. Marie canals, data of, 439. Scruggs, William L., history quoted, 34 .

Seasons, see Climate, 234.

"Secret of the Strait," sought by Columbus, 12; by Bastidas, 19; by Gil Gonzalez de Avila, 27; by De Cordova, De Soto, Morantes, Pineda, Ochoa, De GrijalvaVerrazzano, Cartier, and Magel, lan, 28; by Cortez, ‘9; doubts of 
its existence, 30 ; revived by Gorgoza, 75.

Selfridge, T. O., surveys, 74 ; at International Engineering Congress, 78.

Seligman, J. \& W., 84.

Seneca, geographical theories, 2,8 . Seward, William H., Secretary of State, policy toward Isthmus, 72, 192, 195.

Sewers in Panama, 289.

Shaler, J. R., 172.

Shanton, G. R., 285.

Sharpe, Captain, freebooter at Panama, 35.

Sherman, John, 113.

Ship Canals, data of, 436 .

Shonts, Theodore P., Canal Commissioner, 300; Chairman of Commission, 300; on purchase of supplies, 304 .

Shops and shopping in Panama, 380.

Shufeldt, R. W., surveys, 74 .

Siam, recognizes Panama, 186.

Sloane, Sir Hans, quoted, 52.

Snow shovels at Panama, 100.

Society in Panama, 382.

Solis, Juan Diaz de, explorations, 19.

Sosa, Pedro J., 158.

South Sea, 13 (see Pacific Ocean).

Spain, first interested in discoveries, 3; seeks to construct canal, 43; loses American colonies, 43; American war with, delays canal, 115.

Spooner bill, 126; becomes law, 128; text of, 400 .

Spooner, John C., Senator, 126.

Sprattling, L. W., 285.

Squier. E. G., mission to Nicaragua, 59; his work disavowed, 61 .

Stearns, Frederick P., member of Board of Advisory o: Consulting Engineers, 316, 319.

Stephens, John L., recommends Nicaragua route, 48.

Stevens, John F., chief engineer, 315; Canal Commissioner, 316; favours lock canal, 317; refutes P. Bigelow's charges, 346 .

Strabo, geographical theories, 2.

Strain, Isaa.c C., surveys, 69.

"Straits of Panama" proposed, 294.
Strom, C. J., 288.

"Stultiloquentia," 340.

Suez Canal, data of, 436.

Sunday in Panama, 379.

Sweden and Norway, recognize Panama, 186.

Switzerland, recognizes Panama, 186.

TABOGA IsLAND, 225.

Taboguilla Island, 225.

Taft, William H., Secretary of War: Mission to Panama in 1904, 256; starts from Pensacola, 257; cordial reception at Panama, 258; significant address to President Amador, 259; conferences with Panama government, 260; address at State banquet, 261; warning against revolutions, 261; success of mission announced, 264; reception and address at Cathedral Plaza, 264; apparent reference to Huertas episode, 265; results of mission, 265; second visit to Panama, 273; receives Liberal Directorate, 273; suggestions concerning Canal Commission, 298; embodied in President's orders, 300; order concerning purchase of supplies, 303; recommends purchase of railroad shares, 306; interview with Wallace, 308; demands his resignation, 310; recommends appointment of Board on Advisory or Consulting Engineers, 316; recommends lock canal, 322 ; scathing reply to P. Bigelow, 346 ; protests against campaign of lies, 350 ; on justice to Panama, 360; text of first Administrative Order, 423; of $\mathrm{Re}-$ vised Executive Order, 430.

Taprobane, identified with Ceylon, 7.

Tararequi, Island of, discovered, 26.

Tavernilla, village of, 229; Plain of, 231.

Taylor, Zachary President sends Squier to Nicaragua, 59.

Tehuantepec, canal route proposed, 32; surveyed by Cramer and Corral, 38; Mexican scheme, 67; 
offer of United States, 67; surveyed by Shufeldt, 74 .

Tehuantepec, Isthmus of, discovered, 28; explored by Cortez, 2

Tehuantepec railroad, proposed by J. B. Eads, 68, 85; built by Pearson, 68.

Temperature, 234.

Terraba Point, 218.

Thierry, Baron, 45.

Thinae, 6-9.

Thompson, Richard W., 84 .

Tiburon, Cape, 223.

Tides, delusions concerning, 46.

Tiger Channel, 220.

Tiger Hill, 229.

Tiger's Head, 221.

Tigre Island, British-American rivalry for, 60 .

Tincuazer, Eugen, member of Board of Advisory or Consulting Engineers, 316, 319.

Tobey, E. C., 285, 288.

Tolima, State of, 154 .

Toro Point, 222.

Torres, Colonel, at Colon, 172; efforts to reach Panama, 177.

Toscanelli, Paolo, map and letter, 5, 6; geographical theories, 5-7; reckons circuit of globe, 8 .

Totten, Colonel, report on Panama canal route, 70 .

Tovar, General, at Panama, 172.

Trade routes compared, 384 .

Trautwine, J. C., surveys Atrato region, 69.

Treaties: Anglo-Spanish of 1670, 51; Aix-la-Chapelle, 53, Paris, 1763, 53; Versailles, 54; A gloSpanish of 1786, 54; United States-New Granada, 57; Hise's with Nicaragua, 58; Squier's with Nicaragua, 59; ClaytonBulwer, 61; British-Nicaraguan, 64; United States-Colombian, 71; Dickinson-Ayon, 72; Frelinghuysen-Zavala, 109; first HayPauncefote, 118; second HayPauncefote, 119; Hay-Herran, 140; Hay-Bunau Varilla, 182. (For texts, see Appendices, pp. 391, 393, 398 408.)

Trenı, steamship. 345.
Trinidad, discovered by Columbus, 12.

Tumaco, or Tumaccus, friend of Balboa, 24.

Turr, Etienne, 76.

Tuyra River, discovered by $\mathrm{Pe}$ drarias, 26; described, 217.

Ulloa, ANtonio DE, 38.

United States, Goethe's prophecy concerning, 42; interest in Isthmian canal, 47; resolution by Congress, 47; terms proposed to Colombia for canal, 131; attitude toward German schemes, 136; knowledge of impending revolution, 171; preparations to fulfil treaty obligations, 171; recognizes Panama, 182; policy toward Colombia and Panama, 187. See also American Policy and Congress.

Uraba, Gulf of, discovered by Ojeda and Bastidas, 18; town, built by Ojeda, 21.

Urava Island, 225.

Valdez, Antonio A., 175.

Valdez, Hector, 165.

Valiente Point, 220; Peak, 220.

Valladolid Island, 225.

Vallarino, Dario, 176.

Vanderbilt, Cornelius, organizes company at Nicaragua, 58 .

Van Rensselaer, Stephen, 45.

Vatican Library, legendary manuscript in, 6 .

Vela, Cabo de la, 18.

Velasco, Ferdinand de, Governor of Golden Castile, surveys Atrato River route, 34 .

Velasquez, Diego, 30.

Venado Island, 224.

Venezuela, mistaken by Columbus for Garden of Eden, 12; visited by Ojeda, 18.

Veraguas, visited by Columbus, 13; by Nicuesa, 21; Province of, united with Panama, 152; Panaman Province of, 212.

Verrazzano, Giovanni da, 28.

Vespucci see Amerigo.

Victoria, Nicolas, J., 209; Minister of Justice and Public Instruction, 213; removal demanded by 
Huertas, 238; offers resignation, 242; denounced by Huertas. 247. Vignaud, Henry, Columbian researches, 5.

Volcan de Chiriqui, 216.

WAFER, Lionel, reports on Caledonian Bay route, 36 .

Waldseemüller, Martin, map of world, 16; suggests name of America, 16.

Walker, John G., Rear-Admiral, head of Canal Commission, 113; makes report, 116; head of second Commission, 116; visits Panama with Taft, 257; Chairman of third Commission, 282.

Walker, the Filibuster, 63.

Walker, Patrick, Regent of "Mosquitia," 56.

Wallace, John F., Chief Engineer of canal, 286; plans of work, 286; organization of staff, 287; early embarrassments, 288; engineering problems, 290; four plans considered, 291; favours sea level. 293; Canal Commissioner, 300; retirement from Commission, 307 ; interview with Taft, 308; Taft's criticism of him, 309; his reply, 311; statement to Congress 314; objections to Cromwell, 315 .
Water Cay, 219.

Water Supply, 289; delay in, 298.

Webb, William H., gets concession in Nicaragua, 66.

Welcker, J. W., member of Board of Advisory or Consulting Engineers, 316, 319.

Welland Canal, data of, 439.

Werweer, General, 45.

West Indies, see Indies.

William of Rubruquis, 4,8 .

Winslow, Lanier \& Co., 84.

Wyoming, monitor, at Panama, 179.

Wyse, Lucien N. B., explor s Isthmus, 76; gets concession from Colombia at Panama, 76; negotiations in Nicaragua and New York, 77; sent to Colombia in $1890,108$.

Xaquator River, 32.

YCAZA, Eduardo, joins revolution, 164.

Yellow Fever, see Sanitation.

Zachrisson, Carlos R., V, joins revolution, 164.

Zavala, General Joaquin, 109.

Zipangu, see Japan. 



\section{-}

$>$ 


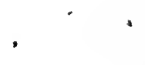




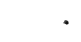





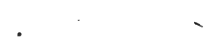


